Portland State University

PDXScholar

Summer 8-11-2015

\title{
Caring for the Land, Serving People: Creating a Multicultural Forest Service in the Civil Rights Era
}

Donna Lynn Sinclair

Portland State University

Follow this and additional works at: https://pdxscholar.library.pdx.edu/open_access_etds

Part of the Civil Rights and Discrimination Commons, Recreation, Parks and Tourism Administration Commons, and the Urban Studies Commons

Let us know how access to this document benefits you.

\section{Recommended Citation}

Sinclair, Donna Lynn, "Caring for the Land, Serving People: Creating a Multicultural Forest Service in the Civil Rights Era" (2015). Dissertations and Theses. Paper 2463.

https://doi.org/10.15760/etd.2461

This Dissertation is brought to you for free and open access. It has been accepted for inclusion in Dissertations and Theses by an authorized administrator of PDXScholar. Please contact us if we can make this document more accessible: pdxscholar@pdx.edu. 
Caring for the Land, Serving People:

Creating a Multicultural Forest Service in the Civil Rights Era

$$
\text { by }
$$

Donna Lynn Sinclair

\begin{abstract}
A dissertation submitted in partial fulfillment of the requirements for the degree of
\end{abstract}

\author{
Doctor of Philosophy \\ in \\ Urban Studies
}
Dissertation Committee:
Carl Abbott, Chair
Sy Adler
Charles Heying
Katrine Barber
William Lang

\title{
Portland State University
}

2015 
(C) 2015 Donna Lynn Sinclair 


\begin{abstract}
This qualitative study of representative bureaucracy examines the extension and limitations of liberal democratic rights by connecting environmental and social history with policy, individual decision making, gender, race, and class in American history. It documents major cultural shifts in a homogeneous patriarchal organization, constraints, advancement, and the historical agency of women and minorities. "Creating a Multicultural Forest Service" identifies a relationship between natural and human resources and tells a story of expanding and contracting civil liberties that shifted over time from women and people of color to include the differently-abled and LGBT communities. It includes oral history as a key to uncovering individual decision points, relational networks, organizational activism, and human/nature relations to shape meaningful explanations of historical institutional change. With gender and race as primary categories, this inquiry forms a history that is critical to understanding federal bureaucratic efforts to meet workforce diversity goals in natural resource organizations.
\end{abstract}




\section{Acknowledgements}

Although writing a dissertation appears solitary, it truly takes a community to birth a project like this. In my case, multiple communities contributed over a very long time. From the women historians at Washington State University Vancouver (Jacqueline Peterson, Sue Peabody, and Laurie Mercier) who let me peek into the challenges of scholarly life while modeling the possibilities, to Bill Lang who turned me over to the Urban Studies Department soon after I finished a Master's in History, I give thanks. Their belief in my potential and the opportunities they offered gave me the confidence to pursue graduate studies. They have cheered me on since my undergraduate years and their faith in me has fueled my own. My committee, too, provided significant support. Thanks to Charles Heying for introducing me to the policy process, for sharing his experiences as a non-traditional academic, and for the many good discussions inside and outside of class. I thank Sy Adler for introducing me to the literature of policy studies, for his piercing insights about politics and society, and for engaging me in outside community work. Carl Abbott's rapid turnaround on reviewing my work was admirable. I have appreciated both his discernments about structure and the questions that prompted me to rethink my approach. His wit in the midst of track changes was unexpected and delightful, always making revision more fun. Thank you, Carl, for shepherding my work through, despite retirement, and for doing it so very cheerfully. I feel fortunate to be among your final graduate students and proud to list you as my chair.

Words cannot describe my gratitude toward Bill Lang, who first sent me on the graduate path and then guided me until I was ready to be on my own. Thank you, Bill, for 
agreeing to serve on my committee despite your retirement. As always, your feedback strengthened my work and your presence centered me. My thanks to Katy Barber also extend beyond this work. Thank you, Katy, for helping to shape my social consciousness. Your ability to peel back the veneer of racism and sexism in society is unmatched. You, too, went well beyond your obligations in the midst of sabbatical to serve on my committee. As in so much else, I can't imagine having done it without you.

This project would not have happened without David Gross, who first brought the oral history proposal to PSU. Like so many of the public employees I've met in the Forest Service, David's commitment to his work extends far beyond the requirements. His added passion for civil rights made this project possible. Thank you, David, for sharing an insider's view of the Forest Service, for introducing me to this topic, and especially for your friendship. It has enriched my life. Gloria Brown, too, has provided me with greater understanding through many hours of interviewing and discussion. I thank you, Gloria, for sharing your life story, past and present, with me. Thanks to Mary Albertson for sharing her perspective, and for reading and commenting on chapter six. John Kusano also deserves special thanks. He demonstrated the significance of this subject by allowing me a second interview during his final retirement week, and made possible my access to previously unavailable agency reports at his own inconvenience. His assistance provided systematic data and ensured the accuracy of my statistics. Many other Forest Service employees, retired and active, have helped me. They have taken the time for interviews, made materials available, and shared their personal and professional stories. I wish I could have told each person's story, as they are the key to this work. I 
have instead listed their names and brief biographies in Appendix B and I thank them formally here. Thanks, too, to the many students who participated in this project from 2004 to 2007. Thanks to Lincoln Bramwell and the Grey Towers Scholar-in-Residence Program for providing a quiet space to write and for bringing me to Washington, D.C. Thanks also to Kathy Wahlgren for giving me space to stay longer and familiarizing me with the city. That experience introduced me to many of the most significant stories I've told and added to the significant body of materials I collected at the Forest History Society under the Bell Travel Fellowship. Thanks to Cheryl Oakes, Steve Anderson and James Lewis for making me feel at home in the archives. The Coordinating Council for Women in History deserves significant credit for granting me the Catherine Prelinger Award. The funds made possible a second trip to D.C., paid for some transcription, and allowed me to take a term off of teaching to finish writing this dissertation. The Prelinger Award also affirmed my scholarship, my journey as a non-traditional student, and pushed me to think about the centrality of women to my work.

I am forever grateful to the support provided by my "History Sista" with whom I've shared challenges and successes for many years now. Jan, Eliza, Jo, and Katy, may we continue to sustain one another personally and professionally for years to come.

My family deserves the heartiest thanks of all. They have experienced the intensity of my study and writing more closely than anyone, having spent years with an absentee or too-busy mother, spouse, and daughter. I thank you Bud, Mom, Dad, Joe, Jacob, Danielle, Christopher, Madi, and Mylee for your unwavering support and encouragement. 


\section{Table of Contents}

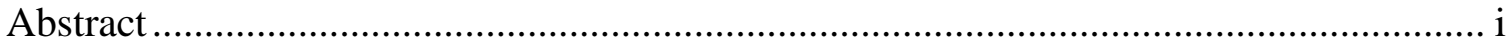

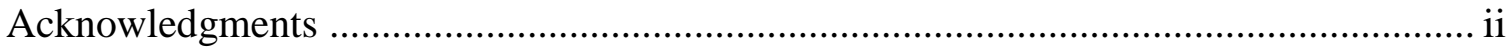

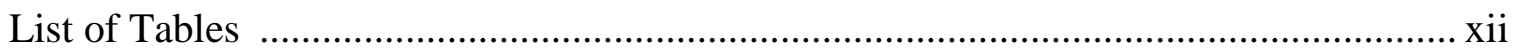

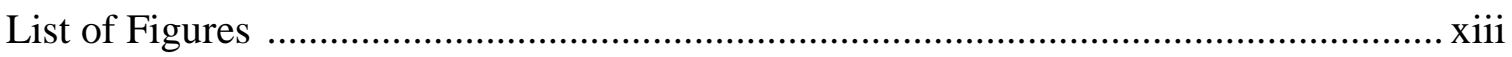

List of Acronyms . .......................................................................................... xiv

Chapter 1: Multicultural Mandates in the USDA Forest Service, An Introduction .............1

Introducing Entwined Diversification in the U.S. Forest Service ..........................

Historical Background of USDA Forest Service ..............................................12

From Tree Farming to Ecosystems ....................................................................12

Agency Organization and Structure ..................................................................17

The Forest Service in the Pacific Northwest ............................................................18

The Historic Forest Service Work Force............................................................22

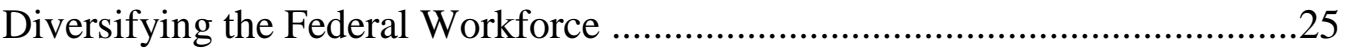

Legal Mandates and the Evolution of Workforce Diversity .......................................25

Diversifying the USDA Forest Service Workforce ………………………................30

Cultural Transformation in the Civil Rights Era ........................................................

Women, Minorities, and the Pacific Northwest ................................................42

Region 6 as a Proving Ground for Agency Employees .............................................42

Overlapping Connections - Entwined Systems and the Pacific Northwest ...............43

Chapter 2: Theoretical and Historical Underpinnings of Workforce Diversity in the USDA Forest Service .46

Framing Workforce Diversity - the Literature …………………………….......47

Organizational Theory, Hierarchy, and the Individual Decision-Maker....................49

Representative Bureaucracy: Theoretical and Historical Foundations of

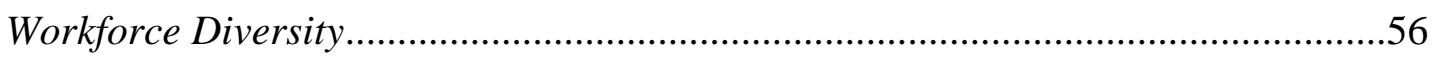

Empirical Studies of Representative Bureaucracy …………………………....62

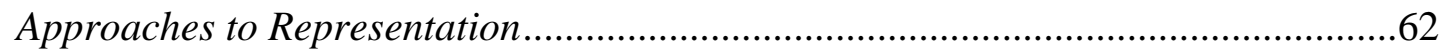

Social Origins and the Civil Service - Passive and Active Representation ................65 
Studying the USDA Forest Service .69

A Bureaucratic Superstar - Changing Values

Revisiting Herbert Kaufman's Forest Ranger.... .71

Forest Service History and non-traditional employees ...........................................75

Assumptions, Methodologies, and Research Design .......................................77

Historical Institutionalism, Representative Bureaucracy, and Research

Questions .77

Representative Bureaucracy, Biographical Research, and Historical

Methods .80

Environmental History and Narrative. .81

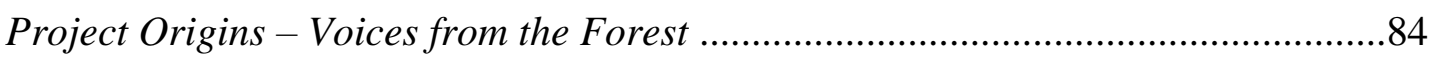

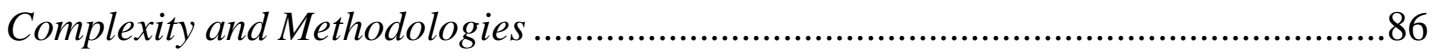

The Research Process and Interview Methods .....................................................90

Chapter 3: Workforce Diversification and the U.S. Forest Service, The Early Years .....95

Unequal Opportunities in the Mid-twentieth Century...................................97

Separation and Equality, the Roots of Affirmative Action .....................................99

Representative Bureaucracy, the New Deal, and Racial Liberalism ......................101

Representation: Women, Minorities and Public Forestry, the Early Years .............104

The Civilian Conservation Corps, Minorities, and the She-She-She .....................106

Hispanos and American Indians in the CCC ......................................................110

Policy Implementation and Representation - African Americans in the

$C C C$

African Americans and Public Forestry in World War II, the Triple Nickles..........118

The Foundations of Affirmative Action ....................................................122

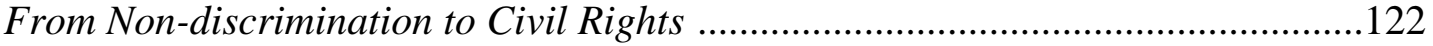

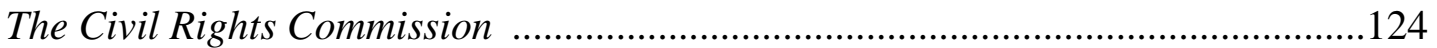

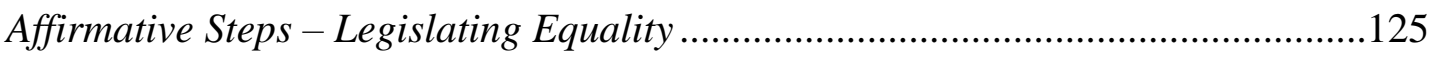

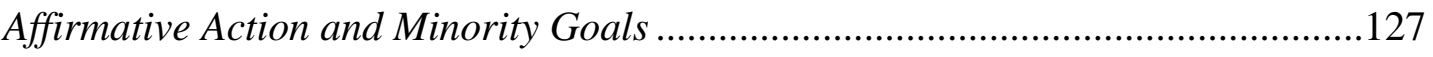

Bringing Equal Opportunity to the U.S. Forest Service ...............................128 
Equal Employment Opportunity and USFS - the Civil Rights Act of 1964 128

Employment Outreach and Job Corps

Discussion: The Ironies of Opportunity

Chapter 4: An Agency in Flux: Muddling Through, 1968-1976 ...................................145

Law, Policy, and Definitive Action ...........................................................147

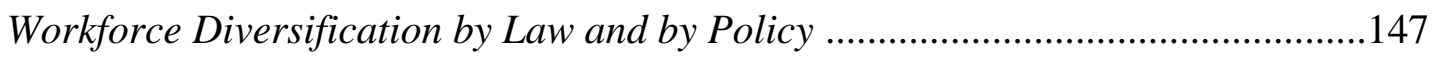

Reporting, Training, and "Definitive Action" ........................................................150

The Forest Service and American Indians ...................................................155

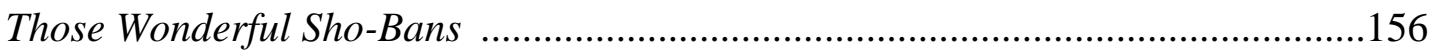

Native Americans and Manpower Programs .......................................................159

Diversification in the Pacific Northwest (Region 6) .....................................160

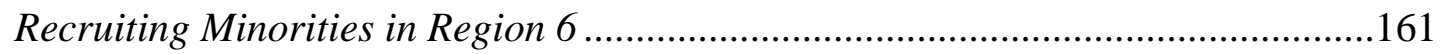

Recruitment Challenges in Region 6 - "Good Action!" ..........................................163

Civil Rights Development in USFS ........................................................167

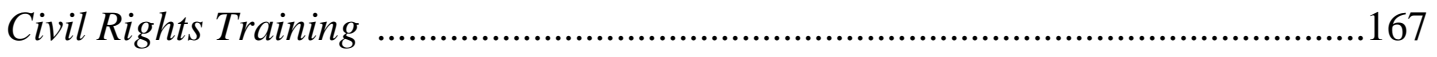

Jetie Wilds, Civil Rights and the U.S. Forest Service ....................................... 171

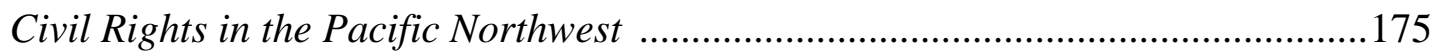

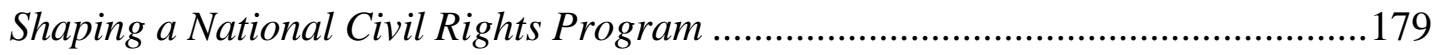

Discussion: Muddling Through the Turbulent Times ...................................183

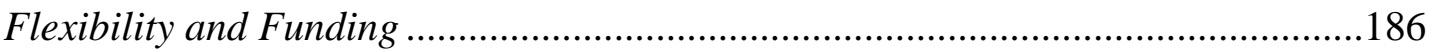

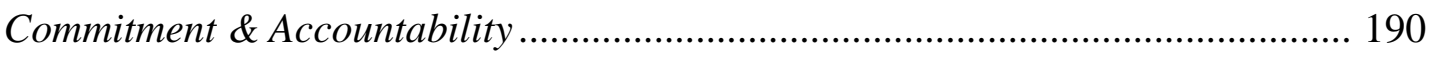

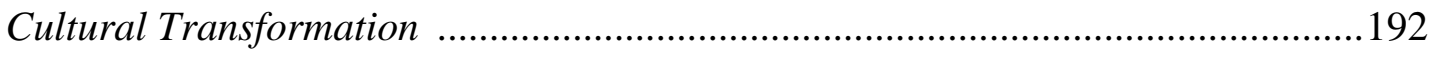

Chapter 5: "Black Foresters Needed" - Professionalizing the Minority Workforce.......195

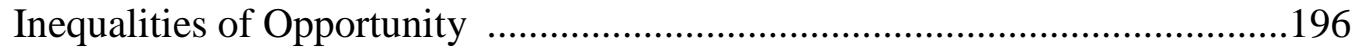

Forestry Education and the Land Grant Institutions ............................................199

African Americans and Professional Forestry ....................................................201

Agricultural Education in White and Black - the HBCUs ....................................204

Seeking Equal Opportunity ..............................................................208 
Developing the Tuskegee Pre-Forestry Program ……………………...............208

Tuskegee Pre-forestry Program - the Early Years .................................................211

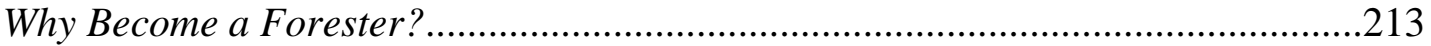

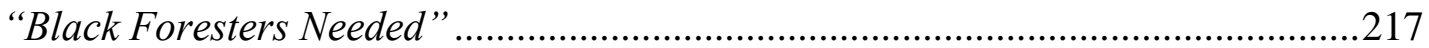

Finding Opportunity in the U.S. Forest Service................................................221

The Tuskegee Graduates ..............................................................................221

Entwined Diversification and Occupation - USFS in the 1970s ....................226

African Americans, Soil Science, and the USFS ................................................... 229

An Alternative Path in the Era of the "Ologists".................................................235

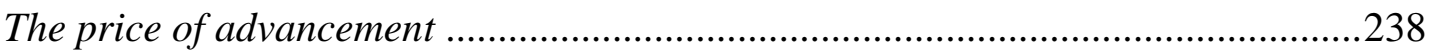

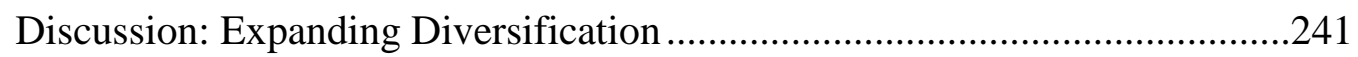

Extending Opportunity - Beyond African Americans ............................................ 244

Stereotypes, Stories, and Diversified Conformity..................................................248

Chapter 6: Re-gendering the Forest Service - Paving the Way in Region 6 ……...........254

Women's Work in the U.S. Forest Service ..................................................257

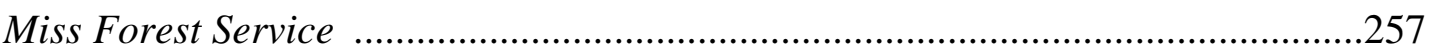

Recruiting Women for USFS ...........................................................................262

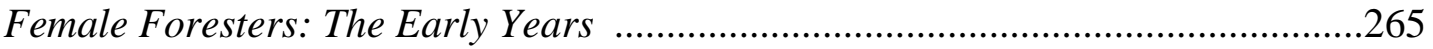

Re-gendering the Forest Service by Law and Policy .....................................268

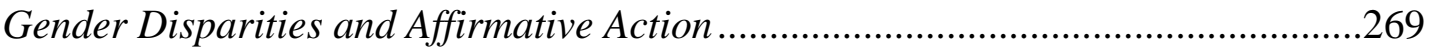

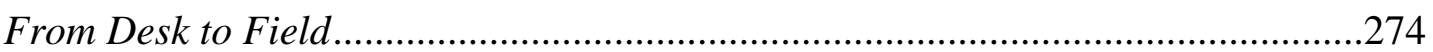

Women Foresters and the Timber Beasts: "Rangerettes" and "Nature Fakers" ...278

Federal Women's Program in Region 6 .......................................................282

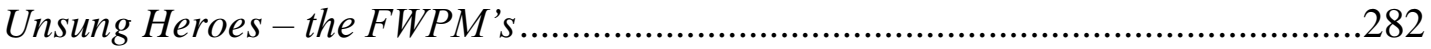

Changing Roles of Men and Women ............................................................... 288

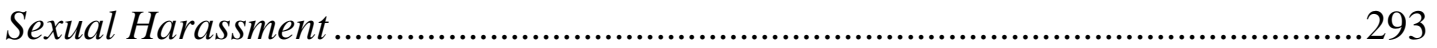

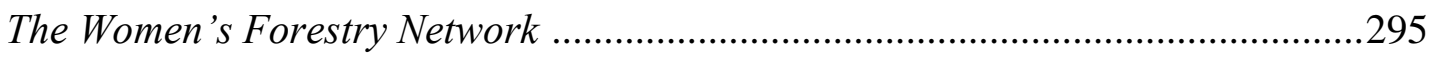

Discussion: Expanding Representation in Region 6 .......................................300

Civil Service Reform, 1978 ................................................................................... 301 
Upward Mobility - Law, Policy, and Representation .303

Women and Bears

Chapter 7: "Go West Young Woman" - Upward Mobility and the Pacific Northwest .310

Upward Mobility in Region 6 .................................................................. 314

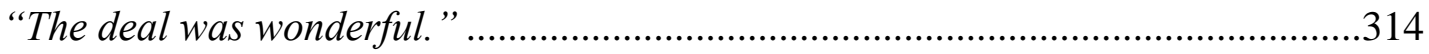

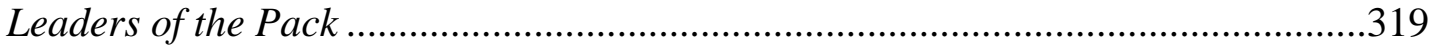

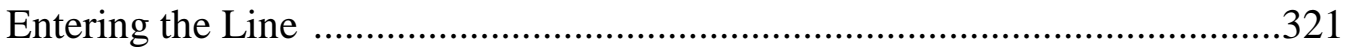

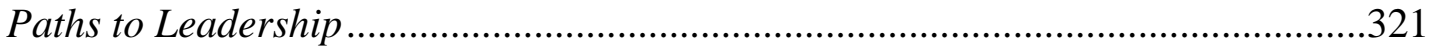

Structural and Informal Barriers to Line Positions ...............................................328

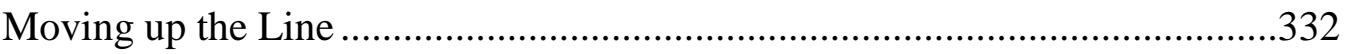

High Level Line Leaders - The Women's Trail Through Region 6 .........................332

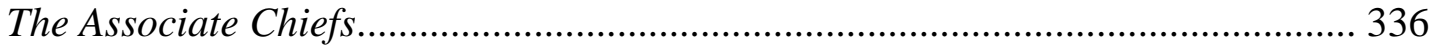

Entwined Diversification, the Line, and Women of Color........................................340

Becoming One of Nine - “Go West Young Woman” ..............................................347

Discussion: Revisiting Herbert Kaufman...................................................352

You have to "be" Forest Service to Lead Forest Service .................................... 352

Occupational Diversification and Diversified Conformity ....................................356

Chapter 8: Moving Toward a Multicultural Organization, 1986-1993..........................364

A Workforce Reflective of the Nation's Diversity ..................................... 366

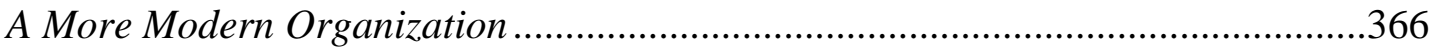

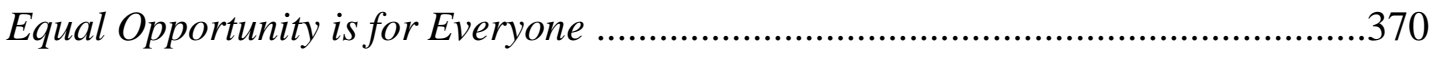

The Forest Service, Service-wide Civil Rights Committee (SCRC) .........................377

Entwined Diversification and the Pacific Northwest ....................................381

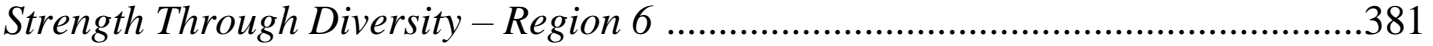

The "first one there" - Civil Rights and Region 6 ................................................ 384

A "Hammer" in the Courts - the Northern Spotted Owl .......................................388

New Forestry, New Perspectives and the Advent of Ecosystem Management ........394

National Diversity Efforts .......................................................................400 
All Together Now Conference ……………........................................................... 400

Toward a Multicultural Organization ....................................................................403

Changing Paradigms: What is a Multicultural Organization?.................................407

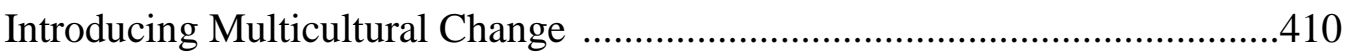

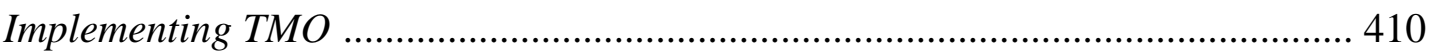

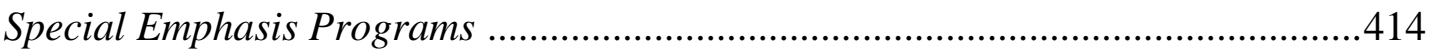

A Watershed for Entwined Diversification ……………………………………....418

Discussion: Turning Points .............................................................................422

The "Same Bottom Line" ............................................................................... 423

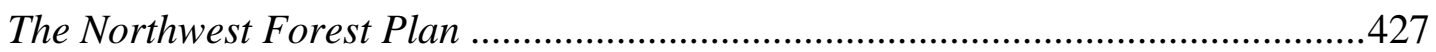

Chapter 9: Strength Through Diversity....................................................................429

The Aftermath of TMO ............................................................................... 433

Orientation, Preference, and Policy ...................................................................435

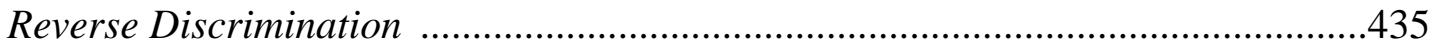

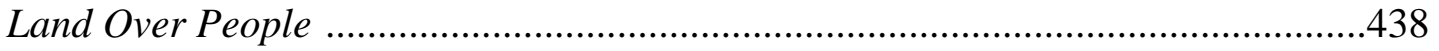

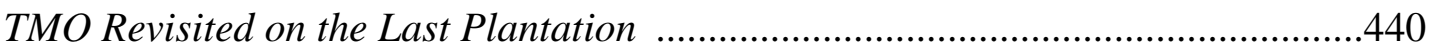

Caring for the Land, Serving People under Entwined Diversification .......... 450

Shaping Unequal and Equal Opportunity ...................................................... 450

Entwined Diversification and Expanding Opportunity .........................................455

Entwined Diversification in a Multicultural Organization .......................................456

Reflections and Conclusions: Representation and Narrative ...........................460

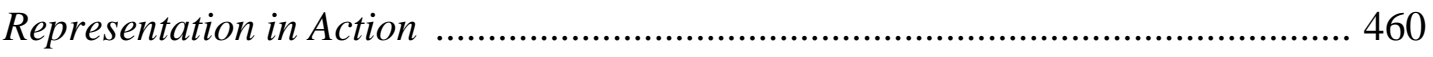

Representation and Diversification ...................................................................463

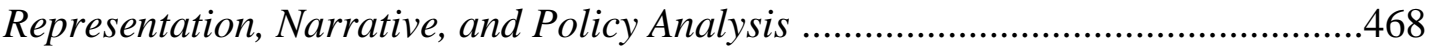

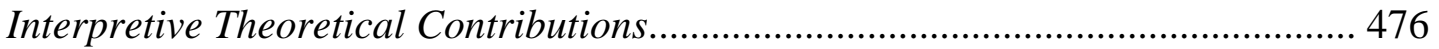

Workforce Diversity at Century's End: Nature and Storytelling .............................488

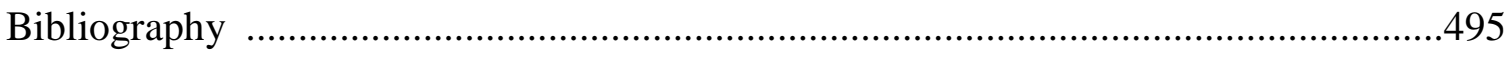


Appendices .509

Appendix A: Summary of Henry Fayol's General Principles of Management 510

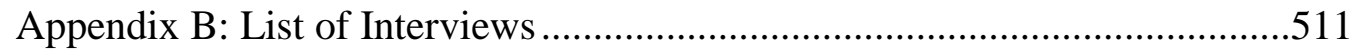

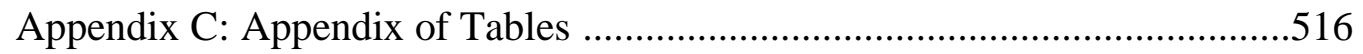

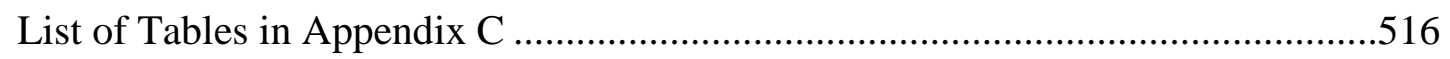

Appendix D: TMO Goals and Strategies ................................................530 


\section{List of Tables}

Table 1: Environmental and Social Legislation and Forest Service Policy, 19601993.

Table 2: Civilian Labor Force (CLF) and Forest Service - Women and Minorities, 19762011 .11

Table 3: On Board Strength - from Civil Rights Update December 10, 1980 .31

Table 4: Professionals on Board - from Civil Rights Update December 10, 1980 .32

Table 5: Number of Employees, 1984-2011 .33

Table 6: FY2011 Diversity Demographics By Agency - Department of Agriculture .38

Table 7: Forest Service Demographics June 30, 1962, 1963, and 1964. 128

Table 8: Human Resource Programs, FY 1976 150

Table 9: Forest Service programs that employed American Indians, 1970.

Table 10: Definitive Action - R-6, June 10, 1970 Reporting period .166

Table 11: Women in the Forest Service Workforce, 1976 and 1992. .320

Table 12: Female Regional Foresters, USFS, by date of appointment, 19982013

Table 13: Time in Grade before entering the line. Kaufman, 1957, in Carroll, et. al., 1996 .361

Table 14: Number of years spent by women line officers in federal service, 1992 .361

Table 15: Distribution of EEO Groups and Comparison by PATCO (Professional, Administrative, Technical, Clerical, and Other, i.e., wage grade). 373

Table 16: Changes in the number of Minority and Women Line Officers, 19861990 


\section{List of Figures}

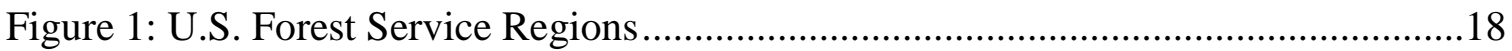

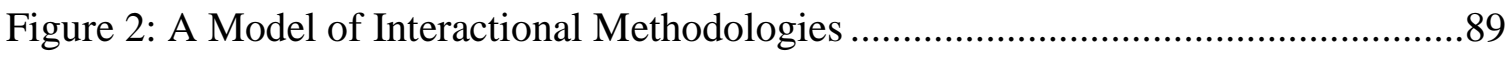

Figure 3: Chip Cartwright at Carson Elementary ......................................................250

Figure 4: W.O. Clerical Staff employment brochure ............................................259

Figure 5: "Careers for Women in Conservation” Images, 1969 .................................261

Figure 6: Erma Kirk, Miss Forest Service ................................................................262

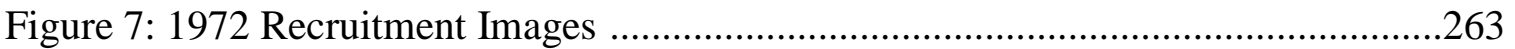

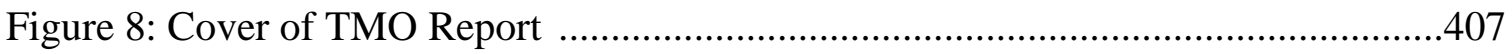




\section{List of Acronyms}

ADA - Americans with Disabilities Act

APHIS - Animal/Plant Health Services

BLM - Bureau of Land Management

BLS - Bureau of Labor Statistics

CIP - Continuous Improvement Process

CLF - Civilian Labor Force

Co-op Ed - Cooperative Education Program

CRAG - Civil Rights Action Group

CRAT - Civil Rights Action Team

EEO - Equal Employment Opportunity

EEOC - Equal Employment Opportunity Commission

EIS - Environmental Impact Statement

EO - Executive Order

ESA - Endangered Species Act

FEPC - Fair Employment Practices Commission

FSH-FSM - Forest Service Handbook-Forest Service Manual

FWP - Federal Women's Program

FWPM - Federal Women's Program Manager

HEP - Hispanic Employment Program

MUSY - Multiple Use Sustained Yield Act

NEPA - National Environmental Policy Act

NFMA - National Forest Management Act

NPS - National Park Service

NRCS - National Resource and Conservation Service

OPM - Office of Personnel Management

PNW - Pacific Northwest

PSW - Pacific Southwest

RIF - Reduction in Force

$\mathrm{RO}$ - Regional Office

RPA - Resources Protection Act

SCS - Soil Conservation Service

SES - Senior Executive Service

$\mathrm{SO}$ - Supervisor's Office

TMO - Toward a Multicultural Organization

USDA - U.S. Department of Agriculture

USFS - U.S. Forest Service

USFWS - U.S. Fish \& Wildlife Service

WO - Washington Office 


\section{Chapter 1: Multicultural Mandates in the USDA Forest Service, An Introduction}

In September 1993, a group of disgruntled U.S. Department of Agriculture Forest Service employees, identifying themselves as the "Steering Group for a Servicewide Association of European-American Employees" from "Some Ranger District," "Any National Forest" wrote a memo to agency chief, F. Dale Robertson. The group cited progress toward a multicultural organization as their primary purpose and envisioned modeling themselves after "the recently endorsed Hispanic Employees Association and Asian Pacific Islander Association” groups. Replicating the exact language of the agency's sanctioned special emphasis groups, the employees sought the following: to promote a sense of community among European-American and other employees; to serve as a resource to the agency in carrying out its mission; to provide a forum for EuropeanAmerican employees to discuss issues for agency-wide presentation; and to contribute "to more and better training, provide support for career development and provide mentoring for European-American employees so that they can reach their highest potential." To carry out these objectives, the association sought official endorsement, use of agency resources, facilities, and equipment, approval to meet during "reasonable official time," authority to travel, and funding as identified in annual work plans. They also requested regular meetings with the Chief and Staff, and asked to weigh in on decisions that could affect European-American employees. Finally, they wanted to announce their 
organization on February 12, 1994, the birthday "of one of the most significant European-American contributors to American culture, Abraham Lincoln.",

Like others in the organization, these employees resented concerted and effective efforts to increase workforce diversity, and took offense at what they considered exclusive privileges awarded to women and minorities. Special emphasis groups not only created cultural networks, they also engaged in seemingly extraneous and costly activities like newsletter production and organizing diversity conferences—on the agency's dime. Recruiters from the Federal Women's Program (FWP) and special emphasis groups also conducted outreach to strengthen female and minority employee candidate pools, activities that seemingly removed them from work "on the ground." Some employees also alleged that the Forest Service had created a hostile work environment for white males and Christians, and besieged "traditional" American values. Meanwhile, the Forest Service had begun commemorating Black History Month and promoting other special events to recognize women and minorities. Worse yet for those who opposed organizational change, identifying sexual orientation as a matter of workforce diversity simply took inclusion too far. ${ }^{2}$ That these groups had the ear of the chief may have been most galling of all.

$1 \quad$ Memo from Steering Group for a Servicewide Association of European American Employees to F. Dale Robertson, re: "Request for Approval of a Servicewide European-American Employees Association," September 6, 1993. Forest History Society, Durham, North Carolina (Hereafter FHS), Collection F13.2, File, Personnel - Asian Pacific Islander ; The memo was sent to Chief F. Dale Robertson and copied to Luther Burse, WO-CR, J. Lamar Beasley, WO-ADM, Christine Pytel, WO-ADM, and William J. Riley, Jr., WO-PM.

2 Washington Office Civil Rights Action Group Issue Form, Issue: "Creating a Hostile Work Environment for Christians,” November 10, 1993. FHS Coll. F5\&F5.2, File, Civil Rights - Forest Service Civil Rights Program. 


\section{Introducing Entwined Diversification}

As awareness of diversity issues and the status of minorities and women became more widely known, understood, and addressed in the late 1980s and early 1990s, backlash emerged in multiple forms. The European-American Employees Association serves as a prime example of emergent bitterness against changes that had occurred over the previous twenty-five years, inside and outside the Forest Service. The satirical memo highlights rising tensions, as the U.S. Forest Service pushed to incorporate non-traditional employees into the agency. For many long term employees, such groups represented all that had gone wrong in the agency, and implicitly, in society at large in the interests of “multiculturalism.” This term, coined as government policy in Canada in 1971, and adopted elsewhere over the next two decades, meant equality, recognition and appreciation of difference, and maintenance of separate cultural identity within a national context. Like Herbert Kallen's early twentieth century notions of ethnic pluralism, multiculturalism rejected the inevitability of full assimilation into American society. ${ }^{3}$ In the 1970s and 1980s, multiculturalism as an educational and/or employment philosophy emerged in nations like Canada, Australia, South Africa, and the United States and quickly came under fire politically and socially. Reactions to "multiculturalism" and the

3 Horace M. Kallen, "Democracy versus the Melting-Pot: A Study of American Nationality," The Nation, February 25, 1915. As Kallen saw it, Americanization involved preservation of every ethnic group's heritage - language, art, literature, and customs, rather than destruction of all but those traits associated with Anglo Saxons. Preserving unique cultural characteristics would occur within the overarching framework of American language use, and adherence to the prevailing economic and political system as outlined in the Declaration of Independence, with equality at the fore. Instead of the melting pot, Kallen offered the metaphor of an orchestra, with each instrument likened to a cultural group making a unique contribution to the symphony. Kallen's work, however, failed to recognize the historical political and social position of ethnic minorities, nor did it recognize the unique positions of African Americans and American Indians, although his later work included these groups. 
reality of "managing diversity" extended beyond the Forest Service as debates raged about multicultural education. In the workforce, white male "reverse discrimination" suits also pushed the courts to enlarge possible challenges to affirmative action. ${ }^{4}$

Still, well into the next century most Forest Service employees were and are European American, despite legal mandates to incorporate women and people of color into the agency workforce. ${ }^{5}$ Notwithstanding efforts to achieve demographic parity with the nation's civilian labor force (CLF) in keeping with the 1978 Civil Service Act, by 1994 white males still held "almost all of the top positions in the Forest Service."6 Complaints about workforce diversification within the agency stemmed from external social changes and increased efforts by agency leadership to reconstitute the workforce to "represent the diversity of American society as a whole," by 1995. This goal, which some viewed as unnecessary by virtue of liberal democratic equal employment policy, seemingly pitted minorities and women against the Caucasian workforce, and prompted many white men - and some white women - to feel threatened. ${ }^{7}$ While "hard-core multiculturalists," those who supported diversity and inclusion policies, saw the value of maintaining group identity in American culture, others critiqued multiculturalism as a separatist policy that would facilitate dissension. Although women and minorities did not

$4 \quad$ "New Blow to Racial Bias Plans," San Francisco Chronicle, June 13, 1989, FHS Collection 13.3. $5 \quad$ In 2011, White males constituted $51.2 \%$ of the workforce and white females were $31.63 \%$. The civilian labor force is respectively $39 \%$ and $33.7 \%$. United States Department of Agriculture, FY 20122015 Department-wide Diversity and Inclusion Plan," available at http://www.dm.usda.gov/employ/diversity/docs/DiversityandInclusionPlanFY11-15.pdf [accessed January $2013]$.

USDA Forest Service, Toward a Multicultural Organization: Report of th
Task Force on Work Force Diversity (March 1991): 6. Hereafter, TMO Report.

Ibid, 6, 20. 
"get all the jobs," as some claimed, or fill most positions for that matter, it is true that by the late 1980s the Forest Service had begun to hire more women and people of color than ever before. ${ }^{8}$ Although not stated explicitly in terms of "representative bureaucracy" even as the agency tried to implement the principle of representation, efforts to create a diverse workforce were both written into law (Kennedy's EO 10925) and related to the founding tenets of representative government. While legal mandates meant that creating representation in government would not be a choice made by leadership, an agency's level of investment in workforce diversification very much depended on those in charge. The idea of representative bureaucracy is that in a democratic society broad social groups should have spokespersons and officeholders in administrative as well as political [emphasis added] positions. Thus, the personnel who administer public functions should come from all social sectors. ${ }^{9}$ Some theorists believe that with broadly representative bureaucracies in place, public administrators are more likely to "produce policy outputs that reflect the political will of the populace" ${ }^{10}$ and to function democratically. Others view the idea of representation in a more cynical light, as a smokescreen for assimilation in the interest of shaping homogeneous social norms. ${ }^{11}$

8 Ibid, 2. The 1980 CLF was used to identify goals in this report because 1990 CLF had not yet been released. The 1980 CLF was $43 \%$ women and $18 \%$ minorities.

$9 \quad$ Samuel Krislov, Representative Bureaucracy (Englewood Cliffs, NJ: Prentice-Hall, Inc., 1974); Margo Bailey, "Representative Bureaucracy: Understanding its past to Address its Future." Public Administration Review, 64, no. 2 (March/April, 2004).

$10 \quad$ Julie Dolan, "Representative Bureaucracy in the Federal Executive: Gender and Spending Priorities, Journal of Public Administration Research and Theory, 12, no.3 (2007): 355; Dolan and Rosenbloom, eds. Representative Bureaucracy: Classic Readings and Continuing Controversies. New York: M.E. Sharpe, 2003): 31.

$11 \quad$ Francis R. McKenna, "the Myth of Multiculturalism and the Reality of the American Indian in Contemporary America," Journal of American Indian Education, 21, no 1 (October 1981). 
At a pragmatic level, those who believed multicultural policies could serve as social equalizers tried to increase government diversity through a variety of efforts. To that end, in 1990 Chief, F. Dale Robertson commissioned a National Work Force Diversity Task Force to identify strategies for achieving demographic parity with the civilian workforce by 1995 . The resulting report titled "Toward a Multicultural Organization" (TMO) identified diversification as more than a matter of law. Rather, the agency sought clear policy to expand demographic inclusion to guide the Forest Service into the next century. Defining workforce diversity became the first charge for the task force and provided an ideal to shape the future, one that mirrored the multicultural tenor of the 1990s:

In a culturally diverse work force, employees of differing race, color, age, sex, national origin, religion, marital status, and people with disabilities contribute effectively at all levels of the organization. Employees are given every opportunity to develop, advance, and contribute to the organization's mission. The organization understands, embraces, and effectively uses the diverse values, beliefs, and behavior of its employees. ${ }^{12}$

In addition, the TMO report, also known as the "Blue Book," outlined diversification goals and identified a vision for the Forest Service "in which leadership, power, and influence are shared." This idealistic management approach, grounded in social change and shifting land management philosophies, constituted the antithesis to existing agency culture and reflected the basic tension of multiculturalism as policy - functionally balancing difference and sameness. Consequently, shared authority suggested a new set of values that, while not completely altering organizational culture, would make the

$12 \quad$ TMO Report, 2. 
Forest Service rethink its identity, reshape its philosophies, and at times shake the agency to its core. ${ }^{13}$

Impacts to Forest Service culture and operations from the outside world occurred in overlapping stages from the late 1960s into the twenty-first century, as law and policy intersected to reflect broader social and scientific trends in the United States. For much of its first century, the Forest Service focused on three primary activities - forest administration, research, and cooperation with state and private forests. Its role has since expanded to include international forestry cooperation, global warming research, disaster relief, urban forestry, and a host of other issues as needed. By the 1970s, external relations became increasingly complex for the agency, as environmental legislation shaped operational change. Between 1960 and 1976, new forest management laws moved the Forest Service toward an ecosystem management model that would heavily impact both land management practices and the agency workforce. At the same time, civil rights legislation directed recruitment of minorities and women into the federal government, leading to social diversification policies meant to fulfill the law (see Table 1 below).

This time period, known to employees as the era of the "ologists," unarguably altered the Forest Service and shaped what I call entwined diversification, with ecological, occupational, and social shifts rooted in junctures between the human and natural worlds. The elements of entwined diversification include: the ecological expansion of land management policies that transpired through the meeting of law and

13 Paul Hirt, A Conspiracy of Optimism: Management of the National Forests Since World War II (United States: University of Nebraska Press, 1994). 
environmental exigencies like the spotted owl crisis; the occupational diversification that occurred in tandem with ecological shifts, as the agency altered its focus from timber to meeting ecosystem needs; and the ways in which these transformations combined with social diversification mandates to incorporate race, gender, and other types of difference with agency policy and organizational change. For three quarters of a century foresters alone served as agency leaders, but because of the temporal intersection in the 1970s between environmental and social legislation, large numbers of scientific professionals joined the agency. There were wildlife and fisheries biologists, soil scientists, landscape architects, hydrologists, archaeologists and others who addressed increasingly complex natural resource questions that often required public consultation. Due to newly enacted equal employment legislation, many of the scientists and even the field going foresters and firefighters who joined the agency during this era were women and people of color. By the 1990s, the Americans with Disabilities Act also directed people with disabilities into natural resource agencies, and shaped a trajectory of inclusion and conflict into the next century. 
Table 1: Environmental and Social Legislation and Forest Service Policy, 1960-1993

\begin{tabular}{|c|c|c|}
\hline Environmental Legislation & Social Legislation & Forest Service Policy \\
\hline $\begin{array}{l}1960 \text { - Multiple Use Sustained } \\
\text { Yield Act } \\
1969 \text { - National } \\
\text { Environmental Policy Act } \\
1970 \text { - Clean Air Act } \\
1972 \text { - Clean Water Act } \\
1973 \text { - Endangered Species } \\
\text { Act } \\
1974 \text { - Resources Protection } \\
\text { Act } \\
1976 \text { - National Forest } \\
\text { Management Act } \\
1992 \text { - Spotted Owl listed as } \\
\text { threatened under ESA } \\
1994 \text { - Northwest Forest Plan }\end{array}$ & $\begin{array}{l}1964 \text { - Civil Rights Act (Title VI } \\
\text { and Title VII) } \\
1967 \text { - Federal Women's Program } \\
1969 \text { - Equal Opportunity \& } \\
\text { Affirmative Action (EO 11478) } \\
1970 \text { - Hispanic Employment } \\
\text { Program } \\
1972 \text { - Title VII (Equal } \\
\text { Employment Opportunity Act) } \\
1973 \text { - Rehabilitation Act } \\
1978 \text { - Civil Service Reform Act } \\
1990 \text { - Americans with Disabilities } \\
\text { Act } \\
1993 \text { - Government Performance } \\
\text { and Results Act }\end{array}$ & $\begin{array}{l}1968 \text { - Memo } 1662 \text { - outreach to } \\
\text { minority communities begins } \\
1976 \text { - U.S. Forest Service } \\
\text { establishes civil rights policy and } \\
\text { line officers establish numerical } \\
\text { targets } \\
1978 \text { - Agency creates Service- } \\
\text { wide Civil Rights Committee and } \\
\text { regional action groups } \\
\text { 1987 - F. Dale Robertson initiates } \\
\text { "Work Force 1995" initiative } \\
\text { 1990 - F. Dale Robertson forms } \\
\text { National Civil Rights Task Force } \\
\text { 1991 - TMO Report issued } \\
1993 \text { - USDA sanctions special } \\
\text { emphasis programs }\end{array}$ \\
\hline
\end{tabular}

Although some employees responded positively to workforce diversity initiatives, many an old time forester resisted incorporating the female and male "ologists" into the workforce. Their very existence in the agency reflected mandated shifts from "getting the cut out" to alternate land management methods that reduced timber outputs. These nontraditional employees of the late twentieth century not only differed from the existing workforce in terms of race or gender, but many also held world views that challenged the power and position of white males in society at large. On the heels of the civil rights movements of the 1950s came demands for equality, inclusion, and fairness all around. Returning veterans had learned to question the establishment. Women sought gender equality in the workplace and at home. Environmentalists wanted complexity rather than simplicity in land management practices. People with disabilities expected access to the 
public sphere. Gays and lesbians requested public acceptance and equivalent rights, while people of color continued fights for rights begun long before.

Holistic ideals of ecological land management, collaboration, and power sharing also threatened the efficiency and esprit de corps of an agency lauded in 1985 as a "bureaucratic superstar" because of its internal stability (i.e., homogeneity) and power to realign under outside pressures. The agency's fame had stemmed from its prodevelopment, multiple-use mission, utilitarian ideology, clear beginning and mission, recruitment from within, external support, and sense of purpose. ${ }^{14}$ Additionally, the Forest Service was all but self-supporting due to timber revenues that had increased in the post-World War II era. Although funding allocations came from Congress, the fact that the agency helped to fill government coffers added to its status, and in turn, provided the funds for operational efficiency. By the early 1990s, alongside ecosystem management policies in which diversity and complexity overlapped, occupational and social diversification shifted the agency away from the very qualities that had created governmental prominence. Reduced timber outputs meant less funding, while mandated variation muddied the mission, replaced inside with outside recruitment, and often substituted process for outcome as agency employees engaged with the public more than ever before.

Still, the Forest Service remained relatively homogenous, male, timber-oriented, and White into the 1990s. When the USFS instituted its civil rights policy in 1976,

\footnotetext{
14 Jeannie Nienaber and Daniel C. McCool, Staking Out the Terrain: Power and Performance Among Natural Resource Agencies (Albany: State University of New York, 1995).
} 
women constituted 22 percent and minorities eight percent of employees, including those with disabilities. Foresters constituted the bulk of professional employees. In 1992, European-American employees constituted 85 percent and women 40 percent of the workforce (see table below). ${ }^{15}$ Yet, twenty years later, the agency had reduced female employment slightly and increased minority employment by only two percent. These shifts occurred as the nation's 2010 minority civilian labor force increased to 33 percent, its overall population swelled from 248.7 million people to 308.7 million, and women composed nearly half of the workforce. ${ }^{16}$ The following table provides an overview of female and minority employment from 1976 - 2011. More information on employment patterns will follow later in this chapter.

Table 2: Civilian Labor Force (CLF) and Forest Service - Women and Minorities, 1976-2011 ${ }^{17}$

\begin{tabular}{|l|c|c|c|c|c|c|c|c|c|c|c|}
\hline & $\mathbf{1 9 7 6}$ & $\mathbf{1 9 8 0}$ & $\mathbf{1 9 8 4}$ & $\mathbf{1 9 8 8}$ & $\mathbf{1 9 9 2}$ & $\mathbf{1 9 9 6}$ & $\mathbf{2 0 0 0}$ & $\mathbf{2 0 0 4}$ & $\mathbf{2 0 0 8}$ & $\mathbf{2 0 1 0}$ & $\mathbf{2 0 1 1}$ \\
\hline $\begin{array}{l}\text { Women's } \\
\text { CLF }\end{array}$ & --- & -- & -- & -- & $46 \%$ & $46 \%$ & $47 \%$ & $47 \%$ & $47 \%$ & $47 \%$ & $47 \%$ \\
\hline FS Women & $22 \%$ & $28 \%$ & $30 \%$ & $33 \%$ & $40 \%$ & $39.5 \%$ & $39.5 \%$ & $38.5 \%$ & -- & -- & $38.5 \%$ \\
\hline $\begin{array}{l}\text { Minority } \\
\text { CLF }\end{array}$ & -- & -- & -- & -- & $22 \%$ & $22 \%$ & $27 \%$ & $27 \%$ & $27 \%$ & $33 \%$ & $33 \%$ \\
\hline $\begin{array}{l}\text { FS } \\
\text { Minorities }\end{array}$ & $8 \%$ & $10 \%$ & $11 \%$ & $13 \%$ & $15 \%$ & $16 \%$ & $16 \%$ & $16 \%$ & -- & -- & $17 \%$ \\
\hline
\end{tabular}

\footnotetext{
15 TMO report, iii, 2-3.

16 FS 2012 Diversity and Inclusion Plan; Gov Central, 2011; United States Department of Commerce, U.S. Census Bureau, http://www.census.gov/main/www/cen2000.html [accessed March 18, 2013]. The population rose to 281.4 million in $2000,308.7$ million in 2010 and is expected to reach 341.4 million in 2020. The Bureau of Labor projects a 38\% minority workforce by the year 2020 .

17 Table compiled from FS Diversity, 1976-2005, information from John Kusano in Human Resources/WO \& Monthly Labor Review, January 2012, http://www.bls.gov/opub/mlr/2012/01/art3full.pdf \& U.S. Department of Agriculture, FY 2012-2015 Department-wide Diversity and Inclusion Plan, 17. Hereafter "Cultural Transformation Report." CLF is based on ten-year census intervals. The data provided by J. Kusano showed numbers based only on the 1990 CLF. I have included 2000 and 2010 CLF from BLS report. See also, Civilian Labor Force (CLF) and Forest Service - Women and Minorities, 1978-2005 in Appendix C, Table C.3.
} 
The agency that had pushed so hard to diversify in the late 1970s and 1980s changed its demographics only slightly between 1992 and 2011, and the main question is why? How did the Forest Service bring women and minorities into the agency in the first place and what can we learn from those efforts?

\section{Historical Background of USDA Forest Service}

From Tree Farming to Ecosystems

Examining workforce diversity in the U.S. Forest Service requires understanding the agency's historical purpose, culture and fluctuating commitment to change.

Throughout the twentieth century the Forest Service functioned clearly as the offspring of the Progressive era reform that shaped its birth. From its inception in 1905, and led by the Use Book of 1906 the U.S. Forest Service developed confidence in its mission clarity. The agency's foundational values came from the idea of esprit de corps, i.e. "union is strength," rooted in the philosophies of its founder, Gifford Pinchot, who studied forestry in France in the 1890s. Pinchot's organization of the agency applied basic standards espoused by the primary contributor to the concept of scientific management, Henry Fayol: clear planning, organization, and execution through coordination and control. It also mirrored Fayol's principles of good administration. ${ }^{18}$ Division of work lacked specialization in the early years, but became more concentrated over time. Authority and

18 Henri Fayol's principles of management are as follows: 1) Division of work; 2) Authority and responsibility; 3) Discipline; 4: Unity of command; 5) Unity of direction; 6) Subordination of individual interest to the general interest; 7) Remuneration of personnel; 8) Centralization; 9) Scalar chain (line of authority); 10) Order; 11) Equity; 12) Stability of tenure of personnel; 13: Initiative; 14) Esprit de corps. Henri Fayol, General and Industrial Management, trans. Constance Storrs (London: Pittman, 1949): 19-42; original work published in 1916; in Jay M. Shafritz, J. Steven Ott, and Yong Suk Jang, Classics of Organization Theory, Sixth Edition (Belmont, CA: Wadsworth, Cengage Learning, 2005): 48. 
responsibility rested mainly on the individual. Foresters worked alone much of the time, making discipline imperative; however unity of command, direction, and subordination of individual interest to the general welfare facilitated self-discipline, as did the remuneration, which included intangibles like working in the woods and material goods like housing. Although decentralized, the Forest Service used a clear scalar chain (line of authority) to maintain communication and order. The agency promoted from within, fostered initiative, and valued unity. Fayol would have identified Gifford Pinchot, who became an agency icon, as a good leader. His personal authority and perceived morality informed official authority, and despite leaving the Forest Service abruptly in $1910,{ }^{19}$ his foundation and ethics produced cooperation and stability well into the twentieth century. Pinchot articulated the agency's guiding motto, found in the utilitarian principles identified by Jeremy Bentham and John Stuart Mill in the late eighteenth and early nineteenth centuries: "the greatest good for the greatest amount of people in the long run."

Pinchot's adoption of this conservation ethic directed agency action for much of its history. The basic mission, sustaining "the health, diversity, and productivity of the nation's forests and grasslands to meet the needs of present and future generations,"20 is what has distinguished the Forest Service, a branch of the Department of Agriculture, from its cousin in the Interior Department - the National Park Service (NPS). This

\footnotetext{
19 Pinchot's dismissal by President William Howard Taft as a result of conflict with Secretary of Interior Richard Ballinger over several aspects of the conservation movement has been well-documented. 20 Mission, Motto, Vision, and Guiding Principles," USDA Forest Service Website, www.fs.fed.us/aboutus/mission.shtml, [accessed December 28, 2012].
} 
distinction is important because the Agriculture Department secured forest lands for use by the nation's populace to secure a "permanent supply of timber for the people and insuring conditions favorable to continuous water flow" as indicated in the agency's Organic Act. ${ }^{21}$ National parks, on the other hand, preserve natural and cultural resources. NPS interaction with the public has always been recreational and educational, while the history of commerce and production on national forestlands is longer and stronger than its recreational focus.

National forests are "public," meaning they belong to the nation and all of its citizens; thus, individual Americans and corporations have benefited through forest use. In the late nineteenth century, this meant that a person could harvest enough timber to build a home, and could access firewood and other special products for private use and to supplement income. The public aspect of Forest Service lands also meant lucrative partnerships with timber companies. In the early twentieth century, the agency sold timber to individual operators, many of whom thus built fortunes. In addition to generating wealth for some and providing jobs for others, timber sales had other advantages. They provided tax revenues so that public lands benefited communities. They also helped the Forest Service contribute to the nation's assets, a key to Congressional allocations for the agency and a significant element in recruitment and diversification programs of the twentieth century.

\footnotetext{
21 USDA Forest Service Website, "Forest Management," http://www.fs.fed.us/forestmanagement/aboutus/histperspective.shtml [accessed February 9, 2013]; Rules and Regulations Governing Forest Reserves Established Under Section 24 OF THE ACT OF MARCH 3 , 1891. (26 STATS., 1095.), Organic Act of 1897 [Public No. 2]. Washington: GPO.
} 
By mid-century, a housing boom rapidly increased lumber production on public and private lands. Post-war chainsaw technologies facilitated efficiency, timber outputs rose and the Forest Service and big timber worked to harvest billions of board feet annually. Together, they provided wood for the expansion of suburbia in the decades following World War II, so that engineers eventually built hundreds of thousands of miles of roads into forests for recreation and to "get the cut out." As these incursions expanded access to previously closed areas, the affluent, typically Caucasian Americans of the 1950s, increasingly used national forests for recreation, while poorer urbanites, especially minorities, did not. By then, the Forest Service had entered into what environmental historian Paul Hirt calls a "conspiracy of optimism," the misplaced confidence of both the agency and timber operators that even as harvests increased, supplies would remain perpetually available.

In 1989, U.S. timber harvests peaked at 18.8 billion board feet, with the Pacific Northwest in the lead throughout the decade. ${ }^{22}$ Because of its rich lumber supply, the Northwest historically and intermittently also supported the largest Forest Service workforce in the nation. Declining timber harvests after 1990 created employee reductions that hit the region hard and cut back on funding connected to social diversification. Overall, Region 6 (Oregon and Washington) lost more than 40 percent of its workforce at that time, stalling parity for women and with significant impacts to minority employment.

22 Darius Adams, Richard Haynes, and Adam Daigneault, "Estimated Timber Harvest by Region and Ownership, 1950-2002," USDA Forest Service, PNW Research Station, General Technical Report, PNWGTR-659 (January 2006): 17. 
By the end of the twentieth century, forest use had gone through a number of transitions shaped by a combination of conservation ideals and environmental law, public demand, and the need for financial self-sustenance. Key legislation of the 1960s and 1970s changed how the agency operated and dramatically impacted land management practices. In 1960, the Multiple Use Sustained Yield Act (MUSY) directed the Forest Service to consider all aspects of land use, from recreation to timber to special forest products, while the National Environmental Policy Act (NEPA) of 1969 mandated that the agency publicly disclose environmental effects of any disturbance to land or water and make informed decisions. This meant the agency had to prepare Environmental Impact Statements (EIS's) for timber sales and had to consider public input in land management shifts. ${ }^{23}$ The Clean Air and Clean Water Acts of the early 1970s changed management practices in national forests by increasing timber harvest buffers near streams. The Resources Protection Act (RPA) of 1974 and the 1976 Forest Management Act (NFMA) added to the complexity of operations through increased planning requirements. NFMA required management plans for just about everything and, like NEPA, resulted in public consultation that further altered land management decision processes. These laws, in addition to the 1973 Endangered Species Act (ESA) would take the Forest Service into the courtroom nearly as often as the woods by the 1990s, and contributed to the entwinement of ecological and social diversification in the Forest Service workforce.

23 "Background on Forest Service NEPA Procedures," U.S. Forest Service Website, NEPA Projects, http://www.fs.fed.us/nepa/nepa_home.php [accessed February 9, 2013]. 


\section{Agency Organization and Structure}

The Forest Service is headed by the Chief, a career Forest Service employee selected by the Secretary of Agriculture, usually in consultation with the existing Chief, and is based out of the agency's national headquarters in Washington, D.C., the "WO." The agency is organized into nine regional offices each of which includes two or more states, except Region 10, Alaska. The regions vary in size from 12 to 32 million acres of the 193 million acres of national forests and grasslands in the National Forest System. A regional forester leads each region out of the "RO" or Regional Office, while national forest units operate under a forest supervisor who coordinates activities between districts, allocates budgets, and provides technical support out of the "SO" or Supervisor's Office. Each national forest is divided into districts and run by a district ranger. There are over 600 ranger districts in the nation, with staff ranging in size from ten to a hundred.

District rangers are "line-staff officers," and until recently have always been trained foresters. Line officers have explicit supervisory authority and responsibility for one or more assigned functions and "they are said to act "in the name of their chiefs." 24 District staff officers hold supervisory positions, typically in natural resource specialty areas and/or recreation. They supervise staff programs and coordinate action and outcomes with the district ranger. The agency also hosts a large Research and Development Branch, including offices for Forest Health Protection, Technology Enterprise, and other Forest Health Protection issues, as well as an International Institute

$24 \quad$ Herbert Kaufman. The Forest Ranger: A Study in Administrative Behavior (Baltimore: Johns Hopkins Press, 1960): 45. 
of Tropical Forestry in Puerto Rico. In addition, most regions host research stations that play a significant role in what has become one of the largest natural resource Research and Development organizations in the world. ${ }^{25}$

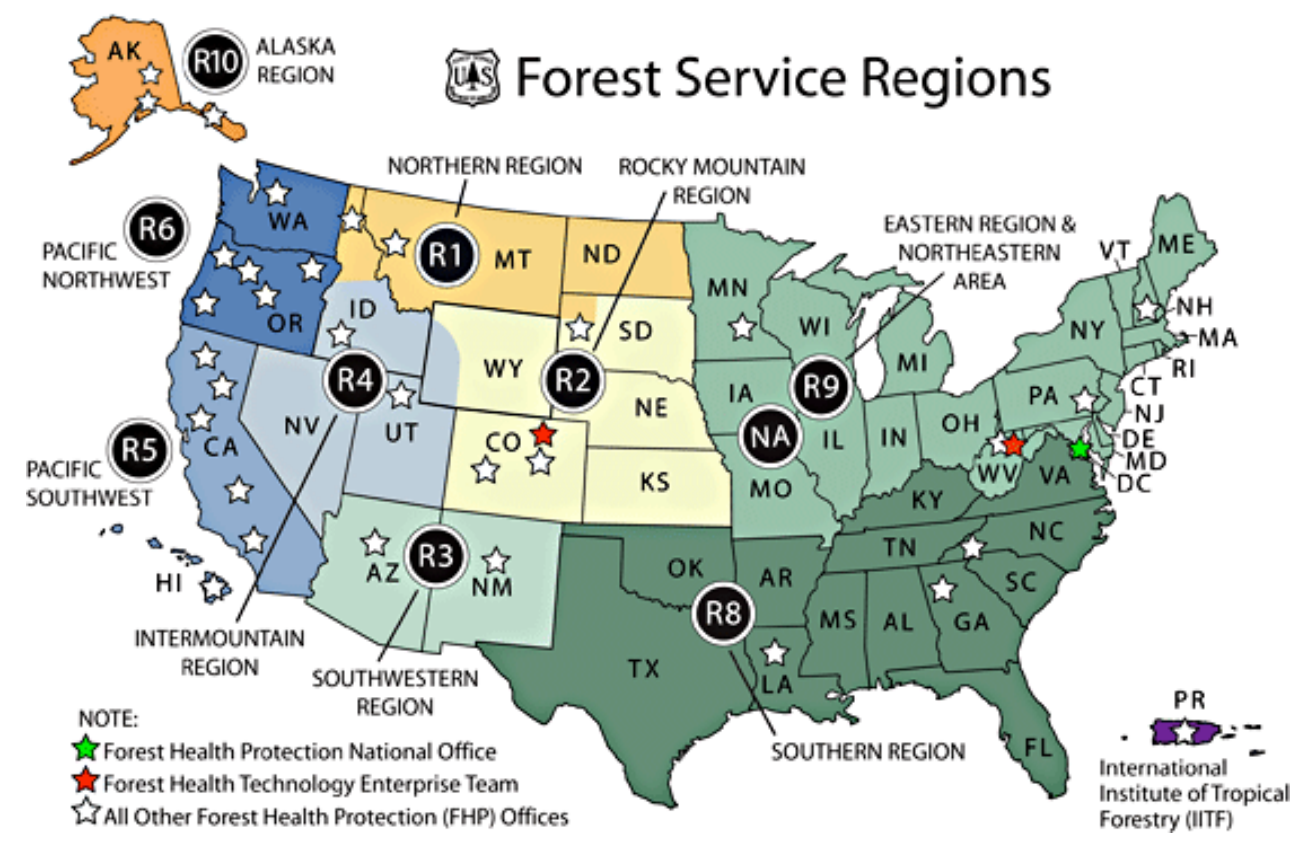

Figure 1: U.S. Forest Service Regions, http://www.fs.fed.us/foresthealth/regional_offices.shtml

The Forest Service in the Pacific Northwest

The Pacific Northwest (Region 6) includes seventeen national forests, a national scenic area, a national grassland, and two national volcanic monuments, all within the states of Oregon and Washington. It abuts the regional units that comprise much of the

25 "Reaves Appointed to Top Research Job at USDA Forest Service," October 1, 2010; USDA Forest Service Website, http://www.srs.fs.usda.gov/news/reaves job.html [accessed February 8, 2013]. Research stations include the Northern (PA), Pacific Northwest (WA, OR \& AK), Pacific Southwest, (CA $\&$ HI), Rocky Mountain (9 states), and Southern (NC) research stations, as well as the Forest Products Laboratory in Madison, Wisconsin, and the International Institute of Tropical Forestry in Puerto Rico. U.S. Forest Service, "Research Stations' Locations," http://www.fs.fed.us/research/locations/ [accessed September 14, 2013]. 
U.S. West: the Northern Region, R-1 (Northern Idaho, Montana, North Dakota, and a small portion of South Dakota); the Intermountain Region, R-4 (Idaho, Nevada, and Utah, and Western Wyoming); and the Pacific Southwest, R-5 (California and Hawaii). The West also includes the Rocky Mountain Region, R-2 (WY, CO, SD, NE and KS), and the Southwestern Region, R-3 (Arizona and New Mexico). The Southern Region (R8) embraces thirteen states and extends from Texas to Florida and north to Virginia, Kentucky, Arkansas, and Oklahoma. Region 8 also includes Puerto Rico, while the Northeastern Region extends along the Eastern seaboard from the District of Columbia to Maine. Alaska stands alone as Region 10. Each region has its own particular historical, social, and ecological context that contributes to entwined occupational and cultural diversification, with mobility between regions historically providing a means to advancement.

The Pacific Northwest is particularly interesting for many reasons. Thirty percent of Washington's and 53 percent of Oregon's land base is managed by one or another federal agency. The region has been among the largest and richest timber producers in the nation and its varied landscape and majestic mountains have drawn many a Forest Service employee to its environs. Management of the 24.7 million acres of diverse Forest Service lands in Region 6 is complex, and overseen by nearly four thousand employees. An 86-mile long national scenic area, with its own set of rules and regulations, stretches along the Columbia River. The Forest Service administers the scenic area in collaboration with states, tribes, and local communities. The 112,000-acre Crooked River National Grassland in Central Oregon comprises a different landscape, offering a variety of 
recreational opportunities, while the Newberry National and Mt. St. Helens volcanic monuments create additional research and educational opportunities. National forests mantle many of the hills and valleys of the fifty-seven mountains that rise above 8,000 feet in the region. The moist and humid crags of the Coast Range receive high rainfall and fog drip, resulting in forests of western hemlock and Sitka spruce. The variable Cascade Range runs north and south, wet on the west side and dry in the east, its northern portion influenced by glaciations and high level snowfall. Heavy logging impacted west slope vegetation zones of Douglas Fir and western hemlock in the twentieth century, while lack of fire has adversely affected east side forests. An uplifted plateau and complex vegetation patterns that include fir forests, pine, and western juniper, mark the Blue Mountains, an area reliant on fire regimes and subject to insect outbreaks. Each ecological zone, from the pine and fir forests to the dramatic basalt banks of the Columbia River Gorge to the high desert steppe that extends from the Cascades to the Rockies calls for different land management practices and has been variably affected by environmental conflict. ${ }^{26}$

Because of its productivity and because mobility, which provides agency leaders with experience in a variety of landscapes and bureaucratic levels, has historically and unquestionably been significant to Forest Service advancement, many who have high level positions in the agency had on-the-ground training in Region 6, including minorities and women. These same employees have also witnessed and participated in the shift from

\footnotetext{
26 "Pacific Northwest Region Almanac," pp. 1-2; http://www.fs.usda.gov/Internet/FSE_DOCUMENTS/stelprdb5378417.pdf [accessed February 27, 2013 ].
} 
growing trees to ecosystem management, which also changed agency operations and culture. In 1990, the U.S. Fish \& Wildlife Service (USFWS) listed the Northern Spotted Owl, whose habitat covered 57 million acres, as threatened. In 1991, Judge William Dwyer placed injunctions on federal timber sales and restricted logging on most national forests and some private timberland. Meanwhile, possible listings of other threatened and endangered species drew national attention to Northwest forests and impacted the entire agency. The injunctions highlighted the need for a conservation plan and led President William J. Clinton to hold a forest summit in Portland, Oregon in 1993, followed by development of the 1994 Northwest Forest Plan. ${ }^{27}$ This plan set aside habitat for owls, reduced timber harvests on public lands, significantly decreased agency funding, increased economic aid to timber workers and communities dependent on timber revenue, and resulted in massive "reductions in force" (RIF's) or "downsizing" in the region.

Between 1987 and 2010, the Region 6 workforce decreased by half, from nearly eight thousand to fewer than four thousand employees. ${ }^{28}$ Significantly, these job losses contributed more than thirty percent of African American and nearly forty percent of American Indian job losses in the agency nationwide during the same period. Although many employees may have transferred to different regions, the old adage "last hired, first fired" took its toll in the Forest Service in relation to both women and minorities, especially because agency retention occurred in relation to seniority.

\footnotetext{
27 “Ecosystem Management," United States Department of Justice website, http://www.justice.gov/enrd/4712.htm [accessed March 2, 2013].

University of Washington, Center for the Study of the Pacific Northwest, "Timeline," http://www.washington.edu/uwired/outreach/cspn/Website/Classroom\%20Materials/Curriculum\%20Packet s/Evergreen\%20State/Section\%20III.html [accessed February 9, 2013].
} 


\section{The Historic Forest Service Work Force}

Understanding the Forest Service workforce and culture in the latter twentieth century begins with Herbert Kaufman's 1960 study, The Forest Ranger, a public administration primer and the agency's seminal study. As Kaufman described the agency in 1960, foresters filled 90 percent of professional positions. Socialization practices privileged hiring from within; recruitment, selections and staffing with foresters; and maintaining regular lateral and diagonal transfers. Not only did foresters hold the primary occupational positions in nearly all areas, white men held all of the professional positions. This had been the case since the organization's inception. For most of agency history, a forestry degree provided entrée to line officer status and thus, decision-making authority. Although engineers entered USFS in large numbers in the 1950s to facilitate road building, it took until 1979 before the first non-forester became chief. In a 2013 interview, a long term female employee fondly recalled that chief, describing the agency tumult during an era of change:

I remember when it was a big shock when the Chief of the Forest Service was an engineer. What did he know about forestry? He was an engineer. He was our Max Peterson. I know it was a shock wave. That's the agency that is still in turmoil. We don't turn things over quickly. Our major resource takes two hundred years to mature, or more. ${ }^{29}$

This long term orientation to land management at least partially explains organizational resistance to modifications. This dissertation explores other formal and informal factors that shaped historical change in the late twentieth century.

29 Mindy Hackett interview by Donna Sinclair, Rosslyn, Virginia, February 1, 2013. 
Some women had always worked for the Forest Service, typically as clerical staff in district and regional offices. Others, Forest Service wives, often worked for free, filling in wherever and whenever needed as an unpaid labor force. A very few worked in professional positions. Eloise Gerry went to work for the Forest Service soon after the Forest Products Laboratory opened up in Madison, Wisconsin in 1910. Hired because of her specialized training for cutting wood specimens and preparing photomicrographs (microscopic photos), Gerry obtained a Ph.D. from the University of Wisconsin and worked for USFS for forty-five years. ${ }^{30}$ Hallie Daggett began work on the Siskiyou National Forest in 1913 as the first female fire lookout. Soon after, the labor shortages of World War I brought other women into the agency as guards and lookouts. Women continued to hold these positions intermittently as young men went off to World War II and Vietnam. An all woman fire crew even operated on California's Angeles National Forest as early as $1941 ;^{31}$ however, the agency did not employ women as foresters until the late 1950s and early 1960s, and then they were few, far between, and rarely fieldgoing. Not until 1979 would any woman — a landscape architect—enter a decision making line officer position, and there would be no female chief until the forester Abigail Kimbell took charge in 2007 for a two year period.

A few minority employees also worked for the agency early on, and at least one minority male became a line officer in 1900. The Hispanic ranger Jacinto Reyes had

\footnotetext{
30 Lisa W. McBeath, "Eloise Gerry, A Woman of Forest Science," Journal of Forest History (July 1978) in James G. Lewis, The Forest Service and the Greatest Good: A Centennial History (Durham, NC: Forest History Society, 2005): 172.

$31 \quad$ Hallie Daggett worked as a forest guard from 1913-1927; "women in fire 1941.pdf," FHS Collection F18.4, File, women.
} 
worked as a vaquero on his family's land in the San Fernando Valley and then served at the same ranger district for thirty-one years, not far from Ranger Don Cuddy, of Nez Perce and Walla Walla ancestry. ${ }^{32}$ Direct employment for African Americans in the Forest Service came much later. Meanwhile, the Forest Service partnered with the U.S. Army to utilize African American CCC workers in the 1930s. Like other CCC crews, young black men between the ages of eighteen and twenty-five fought fires, planted trees, built campgrounds and engaged in other conservation activities, but did so from segregated locales. During WWII the U.S. military employed the African American Triple Nickles, ${ }^{33}$ who surveyed the forests of the Pacific Northwest seeking Japanese balloon bombs and fighting fires.

With fewer than a dozen African Americans of more than forty thousand trained foresters over the century as the Forest Service began diversification efforts in the 1960s, the agency did not directly employ African Americans in professional positions until well into the civil rights era. Paul Logan worked as a forester in the Pacific Northwest beginning in the late 1940s, but passed as white to do so. At least two of the first professionally trained African American foresters, James P. Johnston and Charles H. Irby worked in the Pacific Northwest, but not before taking their skills overseas. Johnston became a forester in 1938 and obtained a master's of forestry from the University of Washington on the G.I. Bill in 1947. He worked primarily for private timber companies

32 “Jacinto Reyes, First Hispanic Employee in California, Region 5 (1990)." FHS Coll. 15.2, File, Regions - Region 5.

${ }_{33}$ During WWII, the $555^{\text {th }}$ Division (Triple Nickles), trained to become paratroopers in Europe. Instead, the military sent them to Oregon where they became the nation's first military smokejumpers and the second group of African Americans to work with the Forest Service. The organization's name is Triple Nickles, an alternative spelling of Nickel. 
in Oregon and Washington and also spent time as a forester in Haiti. Irby obtained a forestry degree in 1956 and went to work for the Bureau of Indian Affairs in White Swan, Washington before practicing forestry in both Africa and the Fiji Islands. He joined the Forest Service in 1971 after mandated diversification began, as a recreation planner on the Mt. Hood National Forest. Irby later became assistant director of area planning and development in the Washington Office. ${ }^{34}$ Until the late 1980s, the cadre of professional Forest Service employees remained primarily male, Caucasian, field-going foresters. It took the implementation of federal law combined with concerted agency and individual action before entwined diversification changed the occupational and social status of employees in any significant way.

\section{Diversifying the Federal Workforce}

\section{Legal Mandates and the Evolution of Workforce Diversity}

The idea of workforce diversity in the Forest Service connects intimately to the federal legislation and administrative directives that have gradually transitioned the U.S. government from attempting to end discrimination to seeking increased representation of women and minorities in the bureaucracy. Efforts to halt employment inequalities began with the 1940 Ramspect Act, which prohibited discrimination in hiring, promotion, transfer, salaries or other personnel action based on race. Franklin Delano Roosevelt's Executive Order (EO) 8802 followed, creating the Fair Employment Practices 
Commission (FEPC) in 1941, with a committee that called for non-discrimination but had no real teeth for enforcement. By the 1960s, it had become clear that non-discrimination policies alone would not include women and minorities in the workforce at anything other than the lower paying positions. A year after Congress enacted the 1964 Civil Rights Act, President Johnson signed EO 11246, calling for "affirmative action" in government contracts. This EO required all employers with more than fifty employees, public or private, and those who have government contracts of more than $\$ 50,000.00$ to file written affirmative action plans with the government, including hiring goals and timetables. Although specific processes and mandates have changed over time, a pattern of demographic tracking and goal setting by federal agencies began during this era.

In 1969, President Nixon called for recruitment in addition to non-discrimination. Through an EO drafted by the Civil Service Commission (CSC) the government required agencies to maintain affirmative action programs of equal employment opportunity. Two federal programs established by the executive branch to facilitate Equal Employment Opportunity (EEO) served this purpose early on, the 1967 Federal Women's Employment Program and the 1970 Hispanic Employment Program. Both required agency program activities for these underrepresented groups in federal employment. Yet, the government's affirmative employment program did not obtain a statutory basis until 1972 under Title VII to the Civil Rights Act, the Equal Employment Opportunity Act. Although Title VI had required service delivery by the federal government without discrimination - a key factor in representative bureaucracy goals - Title VII is most significant to achieving workforce representation in the U.S. Forest Service. It is Title VII 
that required agencies to maintain affirmative employment programs to ensure EEO enforcement. Title VII also extended the 1964 Civil Rights Act's anti-discrimination statute to state and local governments and prohibited reliance on "word of mouth" recruiting in a predominantly white workforce. ${ }^{35}$

Most importantly perhaps, the Equal Employment Opportunity Act provided authority to the judiciary to order monetary damages and injunctive relief for discriminatory action. This capability would haunt the Forest Service into the 1990s, as the agency responded to a lawsuit filed by Gene Bernardi, a GS-11 female sociologist at the Pacific Southwest Station in Region 5. Bernardi filed an EEO claim based on sexual discrimination regarding her position description in December 1972. In June, the lawsuit entered the California court system and by 1977, it became a class-action lawsuit that resulted in two consent decrees and forced the entire agency to rethink its hiring and promotion practices. $^{36}$

Meanwhile, Congress called for a federal workforce "reflective of the nation's diversity" through the 1978 Civil Service Act. Rather than simply ensuring nondiscrimination, this important piece of legislation sought full representation (demographic parity with the CLF) in the federal workforce. The act shifted responsibility for EEO to the Equal Employment Opportunity Commission (EEOC), rather than the Civil Service Commission. President Johnson had endorsed the idea of a

35 Dolan and Rosenbloom, 2003; Charles V. Dale, "Federal Affirmative Action Law," (CRS Report for Congress, September 13, 2005), http://fpc.state.gov/documents/organization/53577.pdf [accessed September 14, 2013].

$36 \quad$ Carla Fisher, "You're Not Getting Rid of Me: Cultivating Space for Women in the U.S. Forest Service, 1950-1990, Unpublished Dissertation, Purdue University (2010): 64. 
representative bureaucracy (1961), stressing affirmative recruitment and training efforts, and the Equal Employment Opportunity Act had created judicial accountability, but the Civil Service Act increased liability for noncompliance. More importantly, it included detailed instructions for determining minority and female underrepresentation and made the idea of representation concrete through numerical reporting. Perhaps most significantly, the act's "keystone" made achieving those goals part of evaluating the new Senior Executive Service (SES), whose members serve in key positions just below the top presidential appointees. The SES connects those officials (cabinet members, etc.) to the remainder of the federal workforce in more than seventy-five agencies. ${ }^{37}$

The same year, 1978, the Supreme Court upheld a minority set-aside at U.C. Davis Medical School in Regents of the University of California v. Bakke, a decision that set legislative standards for affirmative action and took other arms of the debate to the Supreme Court. Over the next decade, many public and private organizations created affirmative action plans, documented underrepresentation for women and minorities and attempted to increase their numbers in the workforce. These efforts slowed when the Reagan Administration issued regulations in 1987, permitting but no longer requiring, numerical goals. Since then, the legitimacy of achieving demographic representation has received mixed signals from the courts. In the City of Richmond v. J.A. Croson Co. (1989), the Supreme Court declared that all racial classifications demand the strictest scrutiny. This meant that race conscious affirmative action programs were only

37 Katherine. C. Naff, "To Look Like America," in Dolan and Rosenbloom, 36-37; "Senior Executive Service," Office of Personnel Management Website, http://www.opm.gov/policy-dataoversight/senior-executive-service/ [accessed February 16, 2013]. 
permissible when "narrowly tailored" to accomplish "a compelling state interest," rather than "remedial relief" for the disadvantaged. They also required strong evidence of past discrimination, which put the burden of proof on those bringing suit. Although in 1990 (Metro Broadcasting, Inc. v. FCC), the courts allowed programs to take race into account to further diversity, five years later in Adarand Constructors Inc. v. Pena the Supreme Court applied the standard of "strict scrutiny" to any race-conscious policies regardless of government level.

Meanwhile, several states began to chip away at affirmation action policy, with California and Washington leading in the 1990s by passing initiatives that banned "preferential treatment" and effectively outlawed affirmative action. At the constitutional level, the issue came to a head in Grutter v. Bollinger when the Supreme Court ruled in favor of considering race at the University of Michigan Law School and against it in undergraduate admissions. Michigan voters took matters into their own hands in 2006 and banned affirmative action through a statewide referendum that amended the constitution to forbid preferential treatment based on race, gender, ethnicity or national origin for public education, public employment, or public contracting purposes. Between 2008 and 2012 five more states passed proposals that essentially banned affirmative action in the public and private sector. The Supreme Court continues to hear cases related to reverse discrimination charges, with clear and overarching direction on affirmative action unlikely anytime soon. The bottom line, according to Charles V. Dale of the American Law Division for Congress is that "racial preferences in federal law or policy are a remedy of last resort, which must be adequately justified and narrowly drawn to 
pass constitutional muster." 38 The upshot for the Forest Service is that while representation is called for under Title VII and Civil Service Reform, other than mandated programs for women, Hispanics, and people with targeted disabilities, attaining that goal has been a matter of varying content and implementation of departmental policy. Its success has waxed and waned depending on leadership, commitment, and accountability at all levels. Diversification efforts demonstrate that who does what in the federal bureaucracy does, indeed, matter.

\section{Diversifying the USDA Forest Service Workforce}

For the USFS standing workforce of the late 1960s, the impact of equal employment opportunity efforts and Civil Service Reform would be dramatic. The most striking shifts occurred in fits and starts between the 1970s and the 1990s, both in terms of numbers and impact to agency culture. Under orders from the Department of Agriculture, leaders attempted to incorporate minorities into the agency, but achieved less success than with white women. By 1976, when the agency formulated its civil rights policy, minorities comprised fewer than eight percent of all employees, less than three percent at the professional level (see table below). Like women, many minorities were part of the new workforce responsible for an expanded scientific land management ethos but without the decision making authority accorded to forestry line staff. Four years later, in 1980, minority employment had increased slightly, both in terms of employment percentages and professional levels. Still, minority employment numbers lagged far

38 Dale, "Affirmative Action," 6. 
behind the goal of an 18 percent minority workforce by 1986, an objective based on CLF projections for the next decade. ${ }^{39}$ Agency leaders predicted difficulty for the first five years of diversification, followed by numerical escalation in keeping with hiring nontraditional employees.

The tables below show the initial progress for minorities and women over a four year period beginning in 1976 . Fewer than two percent of women and under three percent of minorities were professionals in 1976. Most were secretarial or employed in various aspects of administration, such as the Budget or Personnel departments, with some employed in Public Affairs. As agency leaders attempted to accommodate the law, occupational possibilities for women expanded, though not always with the blessing of the existing workforce. In fact, incorporating women and minorities into the workforce happened haltingly in a two steps forward, one step back approach that has lasted to the current day. Between 1976 and 1980 an initial large scale entry of women occurred, as the agency hired more than four thousand females. Nearly eight percent were professionals, often in one of the "ologists" categories. Their introduction placed the agency on its way to achieving parity for women with the civilian labor force at 33 percent by 1986 (see table, page 8).

Table 3: On Board Strength - from Civil Rights Update December 10, 1980

\begin{tabular}{|c|c|c|c|c|}
\hline Fiscal Year & \multicolumn{2}{|c|}{ Minorities } & \multicolumn{2}{c|}{ Women } \\
\hline & $\#$ & \% & 6167 & \% \\
\hline $\mathbf{1 9 7 6}$ & 2208 & 7.7 & 7013 & 23.6 \\
\hline $\mathbf{1 9 7 7}$ & 2448 & 8.2 & 8359 & 23.6 \\
\hline $\mathbf{1 9 7 8}$ & 2899 & 8.2 & 9424 & 27.6 \\
\hline $\mathbf{1 9 7 9}$ & 2831 & 8.3 & 10,540 & 28 \\
\hline
\end{tabular}

39 Civil Rights Update, Dec. 10, 1980, “misc. updates 1980-84.pdf” FHS Collection F5\&F5.2. 
Table 4: Professionals on Board - from Civil Rights Update December 10, 1980

\begin{tabular}{|c|c|c|c|c|}
\hline Fiscal Year & \multicolumn{2}{|c|}{ Minorities } & \multicolumn{2}{c|}{ Women } \\
\hline & $\#$ & \% & 137 & \% \\
\hline $\mathbf{1 9 7 6}$ & 218 & 2.7 & 282 & 3.7 \\
\hline $\mathbf{1 9 7 7}$ & 321 & 3.6 & 426 & 4.2 \\
\hline $\mathbf{1 9 7 8}$ & 350 & 3.4 & 562 & 5.2 \\
\hline $\mathbf{1 9 7 9}$ & 395 & 3.7 & 858 & 7.8 \\
\hline $\mathbf{1 9 8 0}$ & 532 & 4.7 & & \\
\hline
\end{tabular}

The Bernardi court case had facilitated incorporating women into the workforce and would continue to do so, as the entire agency responded to the 1979 consent decree in Region 5. The consent decree required the Forest Service to document underrepresentation of female employees in Region 5 and the Pacific Southwest Research Station over the next five years. It compelled the region to formulate a remedial affirmative action plan and also provided controls through independent consultants to remove bias from the formulation, implementation and enforcement of the plan. ${ }^{40}$ Despite these mandates, agency-wide between 1980 and 1984, several hundred women left the agency and in 1988, Judge Samuel Conti angrily sanctioned Secretary of Agriculture Richard Lyng for non-compliance. Conti ordered the Department to set aside \$1.5 million to upgrade the status of women in the Forest Service and to pay for a court appointed monitor. That year, another large scale hiring process brought more than two thousand additional women into the workforce, nearly doubling the numbers from a dozen years earlier. $^{41}$

40 Diane Winokur, U.S. Forest Service, FSM 8/81 R-5 SUPP 2 ,"History and Summary of Consent Decree." FHS Collection 18.4, File, Women in Natural Resources Conference - 1984, 140.

41 The 1976 female workforce was 6,167. In 1988, the agency employed 12,569 women. 
Meanwhile, the altered operations and changing culture of entwined diversification prompted white men to leave the agency in droves. Over five thousand men either retired or left between 1984 and $1995 .{ }^{42}$ The Forest Service would never be the same, but neither would its cultural demographics shift as dramatically as predicted in the years that followed. Despite employee fluctuations due to downsizing in the 1990s, when the workforce stabilized in 2011 at just over a hundred fewer employees than in 1995, it had added fifty three white men to the workforce. (see Table 5 below).

Table 5: Number of Employees, 1984-2011 ${ }^{43}$

\begin{tabular}{|c|c|c|c|c|}
\hline EEO Groups & 1984 & 1988 & 1995 & 2011 \\
\hline White Men (WM) & 21,075 & 18,852 & 15,878 & 15,931 \\
\hline White Women (WW) & 8,578 & 8,844 & 10,401 & 9,841 \\
\hline $\begin{array}{c}\text { African American Men } \\
\text { (AAM) }\end{array}$ & 561 & 574 & 657 & 636 \\
\hline $\begin{array}{c}\text { African American } \\
\text { Women (AAW) }\end{array}$ & 505 & 565 & 711 & 624 \\
\hline Hispanic Men (HM) & 967 & 942 & $\mathbf{1 , 0 3 9}$ & 1,474 \\
\hline Hispanic Women (HW) & 393 & 442 & 621 & 763 \\
\hline $\begin{array}{c}\text { Asian Pacific Islander } \\
\text { Men (APM) }\end{array}$ & 180 & 194 & 236 & 302 \\
\hline $\begin{array}{c}\text { Asian Pacific Islander } \\
\text { Women (APW) }\end{array}$ & 138 & 185 & 240 & 240 \\
\hline $\begin{array}{c}\text { American } \\
\text { Indian/Alaska Native } \\
\text { Men (AIM) }\end{array}$ & 613 & 713 & 861 & 678 \\
\hline $\begin{array}{c}\text { American } \\
\text { Indians/Alaska Native } \\
\text { Women (AIW) }\end{array}$ & 309 & 415 & 596 & 422 \\
\hline $\begin{array}{c}\text { Two or More Races } \\
\text { Men }\end{array}$ & -- & -- & -- & 107 \\
\hline $\begin{array}{c}\text { Two or More Races } \\
\text { Women }\end{array}$ & -- & -- & -- & 74 \\
\hline TOTAL & 34,129 & 31,726 & 31,240 & 31,117 \\
\hline
\end{tabular}

42 See Table 2: Civilian Labor Force (CLF) and Forest Service - Women and Minorities, 1976-2011, p. 11 . Chart compiled from Civil Rights Report and 2011 Diversity and Inclusion Report. 


\section{Cultural Transformation in the Civil Rights Era}

If one defines civil rights in terms of extending the benefits of citizenship through mandated integration and equal access to employment, then the "civil rights era" can be identified broadly from the 1954 Brown decision, forcing school desegregation, through a period of EEO legislation that includes the 1990 Americans with Disabilities Act, the 1991 Civil Rights Act, the 2009 Lilly Ledbetter Fair Pay Act, and even the 2011 repeal of Don't Ask-Don't Tell. That is the context in which the U.S. Forest Service's nearly allWhite, male organization has attempted to achieve parity with the civilian labor force. Fifty years after passage of the Civil Rights Act, the agency continued to make concerted efforts to diversify the workforce; however, many have been sadly disappointed by the agency's progress, or lack thereof, even as others note dramatic change during this era of entwined diversification. Still others claim the transition has destroyed the agency. ${ }^{44}$

The Forest Service workforce demography of the 1960s altered slowly, picking up speed by the early 1980s, as women, people of color and those with disabilities joined the agency. This movement toward social and ecological diversity shifted agency occupational and cultural demography. By the late 1970s, avenues to Forest Service employment for women and people of color included various youth and education programs like the Youth Conservation Corps and the Cooperative Education Program, among others highlighted through the biographies of agency employees. The Federal

$44 \quad$ Chart compiled from CR Report and 2011 Diversity and Inclusion Report. Christopher Burchfield, Tinderbox: How Politically Correct Ideology Destroyed the U.S. Forest Service, Stairway Press, 2013. Burchfield's thesis is that the agency substituted a race and gender hiring model for merit. Reviews of the book vary from full support for Burchfield's contention that the new demographics have destroyed agency culture and credibility to dismissal of the book based on lack of reliable sources. 
Women's Program (1967) and Hispanic Employment Program (1970) also provided a model for employee resource groups that developed within the agency by the mid-1990s. These "special emphasis" groups addressed cultural issues related to: African Americans, Hispanics, Asian Pacific Islanders, American Indians and Alaska Natives, people with disabilities, and gays and lesbians. The tangled context of entwined diversification-the intersection of ecological, occupational and social change - created agency chaos analogous to a wildfire ripping through a forest, the kind of blaze that leaves old growth singed but standing as it reshapes the land, its massive disturbance wreaking destruction while stimulating new growth. The flames of support for workforce diversity wavered weakly for a time then flared to a crescendo in the late 1980s. Sometimes rapidly, at times creeping slowly along the fringes, the fire of civil rights has continued to smolder into the Forest Service of the twenty-first century. Contemporary efforts to manageably rekindle attempts at parity seek to avoid the tensions and commotion of the past by carefully and steadfastly renewing partnerships for recruitment, regenerating retention efforts through a program of inclusion, and publicizing a policy of Cultural Transformation throughout the agency.

The impact of Cultural Transformation in the Forest Service remains to be seen, but as in the agency's first century it is historically contingent and based on both internal and external social and economic forces. By 2011, when the USDA released its Department-wide Diversity and Inclusion Plan, the Forest Service employed 31,117 people, a third of all Department employees. By far, the largest of the Department's seventeen agencies, the Forest Service is just under three times bigger than the next in 
line, the Natural Resources and Conservation Service (NRCS), formerly the Soil Conservation Service. ${ }^{45}$ Together, in 2011 the top six agencies in the Department employed 67,840 of the more than one hundred thousand employees of USDA or twothirds of the entire Department (see table below). Most striking is that the top two employers in the department, the Forest Service and NRCS both fell short of achieving parity in every minority group across the board. Nor did they achieve parity with the nation's 46\% female employment, and only Grain Inspectors and NRCS employed fewer women proportionally than the Forest Service. All other Department of Agriculture agencies employed more than $40 \%$ women. ${ }^{46}$

\section{Civilian Labor Force (CLF) comparisons in the Department of Agriculture vary} significantly by group and by agency. Departmentally, white men have fared best in the Forest Service and NRCS, constituting more than half of all employees for both agencies despite a 39 percent CLF. White women remain below CLF parity in all but four agencies, but approximate it in others, including the Forest Service. ${ }^{47}$ African Americans fare worst in the Forest Service than in any other agency. With the 2000 African American CLF at more than 10 percent, black men and women each composed only two percent of USFS employment in 2011, or four percent total. Only the Forest Service and

45 The Soil Conservation Service, begun in 1935 in response to the Dustbowl became the Natural Resources Conservation Service in 1994. The agency employed 11,283 people in 2011.

46 USDA Department of Agriculture, "Appendix E: FY 2011 Diversity Demographics by Agency," FY 2012-2015 Department-wide Diversity and Inclusion Plan" available at http://www.dm.usda.gov/employ/diversity/docs/DiversityandInclusionPlanFY11-15.pdf, 17. Grain Inspectors and NRCS employ $33.67 \%$ and $34.43 \%$ women respectively compared to $38.49 \%$ in the Forest Service and $46 \%$ CLF.

$47 \quad$ Half of the Department's agencies employed fewer than $30 \%$ white females and the Rural Business \& Cooperative Development Service and the Grain Inspectors respectively employed $10.29 \%$ and 10.07\%. The Rural Housing Service, Natural Agricultural Statistics Service, Food and Nutrition Service, and the Farm Service Agency exceed parity, with the Animal, Plant Health Inspection Service just below. 
NRCS are below parity departmentally for African American women. (see Table 6). Nor have Asian men or women achieved parity in the Department. Three of the seventeen Agriculture Department agencies employed less than one percent Asians, including the Farm Service Agency, NRCS and the Forest Service. ${ }^{48}$ Native Hawaiians and Pacific Islanders also face dismal employment prospects.

$48 \quad$ There were six agencies below parity for men and nine below parity for women. FS = Forest Service; NRCS = Natural Resource Conservation Service; FSIS = Food Safety \& Inspection Service; APHIS = Animal/Plant Health Inspection Service; RHS = Rural Housing Service; and FSA = Farm Service Agency. Those agencies below one percent Asian males included the Rural Housing Service (.69\%), the Farm Security Administration (.63\%), Natural Resources Conservation Service (.82\%) and the Forest Service $(.97 \%)$. The same agencies fell below one percent for Asian women with NRCS at the bottom $(.68 \%)$, the Forest Service next (.77\%), and FSA at .91\%. RHS had just over one percent Asian women $(1.07 \%)$. 


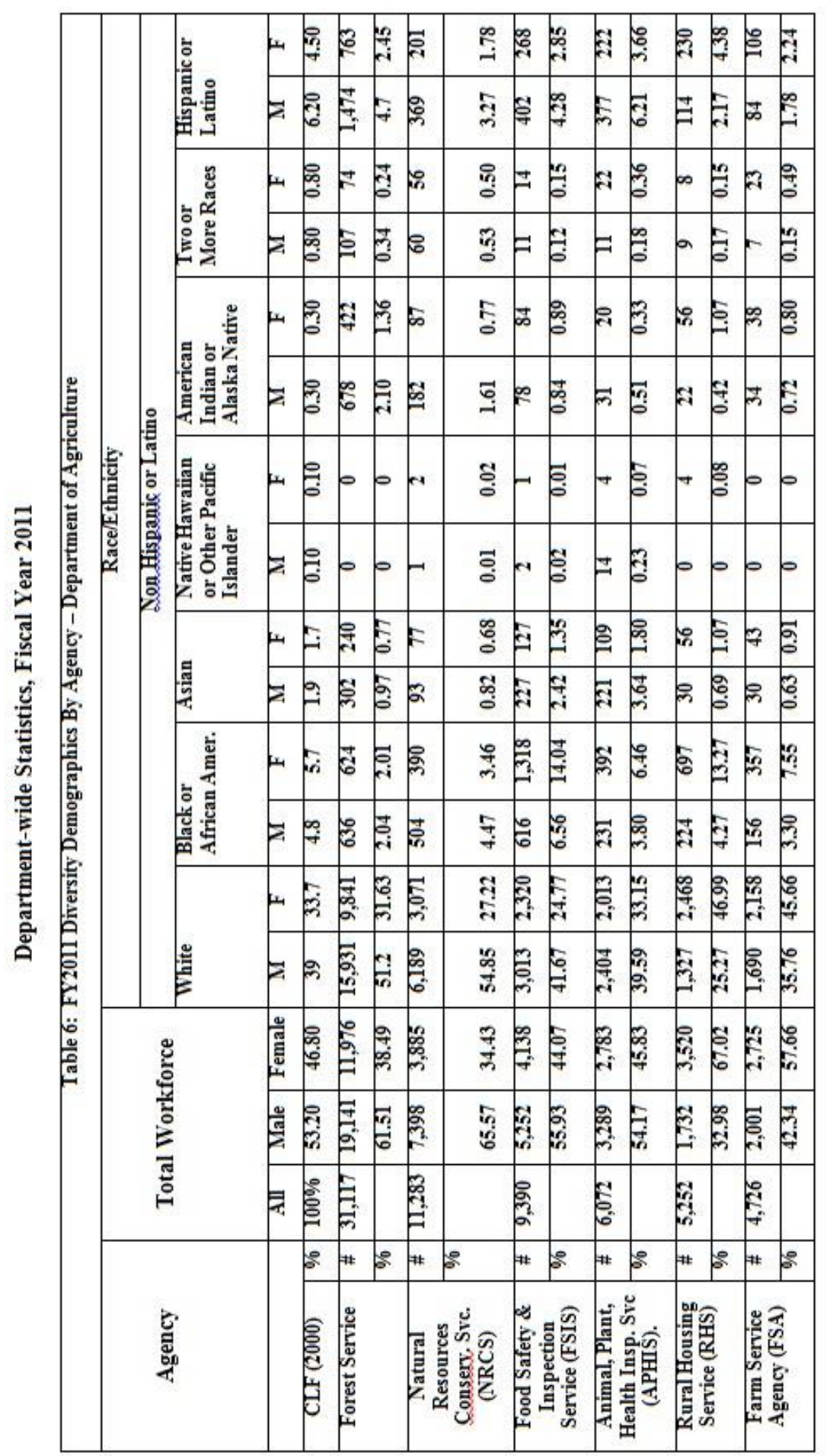


Only five agencies employed any Hawaiian/Pacific Islanders at all, with the Animal/Plant Health Services (APHIS) alone above CLF parity. ${ }^{49}$ APHIS is also the only agency in the Department to achieve parity with Hispanics, and then only with Hispanic men ${ }^{50}$ Again, the Forest Service fell short and none of the agencies achieved the less than one percent parity for those of mixed ancestry. ${ }^{51}$

These demographics raise the question of why the Department of Agriculture has had such a difficult time incorporating non-whites into its many agencies. The question is not whether diversification or representation is needed, but rather how a federal natural resource agency responded to legal mandates to diversify and achieve representation, and the role of individual actors in advancing the diversification agenda. Since the U.S. Forest Service is the largest agency in the Department and the worst in terms of employing African Americans in particular and people of color in general, it provides an ideal case study to examine workforce diversity, and to ask: Why has so little changed, despite ongoing efforts to diversify the workforce? How did the Forest Service make its initial demographic diversity gains between the 1960s and 1990s? What lessons can we learn from an historical understanding of these efforts? How do policy shifts impact workforce diversity efforts and what is the role of the individual actor in shaping policy outcomes related to increasing workforce diversity? Finally, how have social constructions of race and gender been used to maintain the entrenched power 
base? To answer these questions, this dissertation examines the legislative mandates that pushed the Forest Service to diversify in the 1960s and beyond, resulting agency policy shifts over time, how individual decision makers facilitate or hinder policy, and what historical data and qualitative interview analysis can reveal about the experience of workforce diversification for those deemed diversity employees.

Today's leaders recognize that the numbers tell a story of incremental yet minimal progress, and persistent barriers. Despite years of effort, not only has the Forest Service been unable to achieve its goals - atypical for the agency - in some cases it has gone backward. Some employees see the recent initiative, Cultural Transformation, as something the agency is "pushing a lot" and are surprised by lack of change. ${ }^{52}$ Others view the emphasis on diversity as unnecessary and disruptive and question the very notion that a policy of multiculturalism is a legitimate goal for governmental organizations. As a number of scholars have noted, many Caucasians think the U.S. has "arrived" at a level of integration that no longer requires special focus on diversity. Still others view causal discussions around lagging diversification as "race and gender baiting," taking offense at the very idea of unconscious bias and systemic racism.

In March 2012, Deputy Chief of Research and Development, Jim Reaves, sent an email to all agency staff. In it, he called Cultural Transformation the "key" to the agency's "future success," but noted some obstacles: "Folks don't really think about having a bias; it's unconscious. I have them, everybody has them. It's not something you

52 Informal conversation with Grey Towers employee, January 23, 2013; Author presentation at Washington Office - conversation with Cynthia Hale. 
do maliciously. In the workforce it drives your behavior. It plays roles in who we hire, how we treat people, how we do our work, who we associate with." Several responses to this email reveal attitudes toward Cultural Transformation. On a discussion board for Wildland Firefighters, one person referred to Reaves' statement as a "doozy" of a sentence, writing: "Translation - Did the Chief of the Forest Service just call me a bigot and sexist and it's ok because I didn't know I was one. Unconscious bias, really? WOW!"53 Another noted that agency leadership had stereotyped "us all as not open minded or not accepting of other cultures." Yet another interpreted Reaves' email as an assertion that agency employees are bigoted, racist and "disconnected from society, living in a log cabin reciting Jim Crow laws." ${ }^{, 54}$

On the flip side, there are those for whom the reignited emphasis on diversity provides hope for equality in the workplace - and elsewhere. A recent hire, Dr. Carlos Rodriguez-Franco is a scientist of Mexican origin, now a citizen of the United States, and a high level agency bureaucrat as Forest Management Science Director. His contagious enthusiasm for the program of Cultural Transformation in a 2013 interview, as he recounted positive efforts made by the agency, demonstrates leadership optimism. For Dr. Rodriguez-Franco, the Cultural Transformation initiative had not only revealed surprising attitudes regarding race and merit, its implementation also showed how open discussion can facilitate changes in attitudes. Other high-level leaders, too, exhibit passion for Cultural Transformation, pointing to increased numbers of diversity hires 
under the initiative as evidence of success, while acknowledging the long haul ahead. Still others remain disillusioned by earlier struggles, suspicious of what feels like a quieter version of historic agency action and remembering dramatic shifts made during the "Toward a Multicultural Organization" (TMO) era. ${ }^{55}$ For them, current efforts are positive but could be viewed as "Cultural Transformation Light."

\section{Women, Minorities, and the Pacific Northwest}

\section{Region 6 as a Proving Ground for Agency Employees}

The agency began hiring minorities and had developed a number of proactive relationships with minority community and educational organizations by the late 1960s. Initial efforts to diversify varied by region and continued to shift depending on funding, leadership, and individual commitment to diversity goals. The same year, 1979, that the agency appointed Wendy Milner Herrett as its first woman district ranger in Oregon, Charles "Chip" Cartwright became the first African American district ranger, in Washington State. Women in Region 6 also formed the Women in Forestry Network in 1979, an organization for professional women that held conferences and workshops, conducted training, and provided support and advice. The Network has since broadened into the organization Women in Natural Resources and now publishes an online journal. ${ }^{56}$ By 1990 , Hebert McLean reported that Region 6 "leads the pack nationally

\footnotetext{
55 Arthur Bryant interview by Donna Sinclair, January 29, 2013; John Kusano interview by Donna Sinclair, January 31, 2013.

56 Women in Natural Resource Website, http://www.webpages.uidaho.edu/winr/index.htm [accessed March 9, 2013].
} 
with 20 women district rangers in its 91 slots, or 27\%." According to McLean, many viewed the region as "the most progressive in terms of social/organizational change."57 The region's role in shaping the agency's civil rights validated that statement with some validity, but only so long as the green gold of big timber lasted.

While Region 6 may not always have been the most progressive unit in the nation, one thing is clear. Many of the agency's highest level women and people of color today have cycled through the region and their stories provide insight into fifty years of legislative, judicial, and internal agency change. They also reflect the layered connections between individuals, regions, and national operations of an organization in flux, one described by Herbert Kaufman in 1960 as homogenous and cohesive, in part because of its ability to generate agency identification through a willingness and capacity to conform. Homogeneity and heterogeneity are seemingly at odds; yet, the history of entwined diversification in the U.S. Forest Service, as told through the lens of Region 6 may illustrates how human ecosystems, as in the natural world, must adapt to complexity, albeit at varying levels of success.

Overlapping Connections - Entwined Systems and the Pacific Northwest

Close examination of the Forest Service as a microcosm of U.S. culture at large reveals multiple overlapping connections between human social systems and the natural world. Struggles for workforce diversity occurred in particular historical and geographic contexts, differing by region but always within the intersecting themes of entwined

57 Herbert McLean, “The Regendering of the Forest Service,” Forest World (Spring 1990): 27. 
diversification. As a center for environmental controversy, the Pacific Northwest diverges from other regions in relation to minorities' experiences before and after reaching the region, the incorporation of women into the workforce, and the wide range of public land ecosystems and communities. Because Region 6 includes the major timber states of Oregon and Washington, and because timber provided cash, from the 1970s through the 1990s the region served as a sort of proving ground for future leaders. This study highlights the experiences of women and minorities connected to the region, agency leaders at multiple levels, and those who worked in the civil rights arena, to examine workforce diversity historically through the lens of law, policy, and individual experience.

Documenting the history of workforce diversity in the U.S. Forest Service untangles layers of complexity in an ever more multifarious society. As Margaret Jacobs and others have noted, most western women's histories do not attempt to critically analyze whiteness, race, or class, leaving women of color on the sidelines of a triumphant narrative. The same is true of environmental and institutional histories. Jacobs suggests an alternative approach, one that incorporates the "other" as integral to understanding the policies and practices of a colonial western past. ${ }^{58}$

58 Margaret D. Jacobs, “Getting Out of a Rut: Decolonizing Western Women's History, Pacific Historical Review, 79, no. 4 (2010): 585-604. See also, Antonia Castenada, "Women of Color and the Rewriting of Western History: The Discourse, Politics, and Decolonization of History," Pacific Historical Review, 61, no. 4 (November 1992): 501-533; Susan Armitage and Elizabeth Jameson, Writing the Range: Race, Class, and Culture in the Women's West (Norman: University of Oklahoma Press, 1997); Albert Hurtado, Settler Women and Frontier Women: The Unsettling Past of Western Women's History, Frontiers: A Journal of Women's Studies, 22, no. 3 (2001): 1-5. 
With representative bureaucracy as a framework, and by making the "other" central rather than peripheral to the inquiry, this study demonstrates through agency change the entwinement of women and minorities with the national narrative and the natural world. It emphasizes interaction at all organizational levels and serves to identify the lessons USFS employees bring to and take from the region. Historical contingency related to entwined ecological and social diversification, illuminated through textual, oral, and quantitative data, enhances policy learning not only in the U.S. Forest Service but in all natural resource agencies. It also advances the national civil rights narrative by linking environmental history with a gendered American past tinted by Jim Crow, economic and cultural segregation, white privilege, and fights for religious, social, and sexual freedom. 


\section{Chapter 2: Theoretical and Historical Underpinnings of Workforce Diversity in the USDA Forest Service}

On May 9, 2007, the first female chief of the USDA Forest Service, Abigail

Kimbell spoke at an All Cultures Event held in North Carolina. In that speech she asked a pointed question: "Fifty years from now - under the clear assumption that there is still a Forest Service—what will the Forest Service look like in terms of its culture?" She noted that historically men staffed the agency, "men with rural backgrounds ... men who were predominately white" but, she said, "there is nothing intrinsically white or male or even rural about caring for the land." Kimbell noted that long term forest history is fraught with diversity in the human relationship with nature, yet the agency's employee composition remained primarily Caucasian and male.

By the time Kimbell spoke, agency leaders clearly recognized three significant and interwoven cultural issues that impacted the organization's workforce and increased the significance of a representative labor force. First, America had become overwhelmingly urban. By 2010 U.S. metropolitan areas hosted 81 percent of the nation's citizens. ${ }^{59}$ Second, by law, the organization must listen and pay attention to multiple public voices. Environmental mandates of the 1970s required public involvement in land management, so that rural and urban citizens gained a legally authorized say in natural resources decisions. Because of the need for healthy ecosystems locally and globally, Forest Service leadership began to acknowledge the interests of city dwellers in the use and management of national forests. Since then,

\footnotetext{
59 U.S. Department of Commerce, United States Census Bureau, "2010 Urban Area Census Facts," http://www.census.gov/geo/reference/ua/uafacts.html [accessed May 22, 2013].
} 
urban voices have become more prominent, including recreational forest users and those who support non-profit forest management partnerships with the Forest Service. ${ }^{60}$ Urbanites are not only interested in clean air and water, they also pay taxes that support national forest operations. In addition, Congress allocates the agency's financial resources from Washington, D.C.; thus, funding decisions originate in an urban context, made by people who live far from national forest lands. Third and tied to both of the above, by the time Kimbell spoke the nation's racial and ethnic population had become increasingly diverse. In 2013, demographers predicted that by 2050, people of color would compose more than 42 percent of the U.S. population. ${ }^{61}$ As Kimbell explained, the twenty-first century natural resource challenge is to remain relevant, an aim that requires the Forest Service workforce to reflect the diversity of the American population. $^{62}$

\section{Framing Workforce Diversity - the Literature}

There are several bodies of literature that frame the issue of workforce diversity in the USDA Forest Service. . The notion of representative bureaucracy provides a philosophical foundation for analysis, while organizational theory provides its

60 Organizations like the National Forest Foundation, Mazamas, and Friends groups, etc. often participate in land management activities and provide funding for work projects.

61 Jennifer M. Ortman and Christine E. Guarneri, "United States Population Projections: 2000 to 2050,” U.S. Department of Commerce, U.S. Census Bureau Website, http://www.census.gov/population/projections/files/analytical-document09.pdf [accessed May 22, 2013], 62

Abigail Kimbell Speech, "Sinking New Roots: How Is Forest Service Culture Changing?” USDA Forest Service Website, http://www.fs.fed.us/news/2007/speeches/05/roots.shtml [last modified May 16, 2007]. 
progressive era foundations, rooted in emergent organizational theories. Historical, demographic, and administrative analyses of the Forest Service and other federal agencies identify systemic organizational changes and highlight reports specific to women and minorities. The history of affirmative action and equal employment policies also influenced the legal landscape of workforce diversity in the agency and provides a foundation for incorporating critical race and gender theory, as appropriate.

Additionally, interpretive policy studies support my emphasis on qualitative biographical inquiry into the experiences of those Michael Lipsky has called "street level bureaucrats," the administrators whose discretionary decision-making affects policy implementation. ${ }^{63}$ These individual bureaucrats and the ways in which the structural forces of law, agency policy, place and community impact them, and subsequently alter the agency provide the focus for this study.

These bodies of scholarship and analysis, underscored by environmental history and interpretive orientation to policy studies, shape a multidisciplinary theoretical and academic context that contributes to eliciting meaning from the policy process In addition to increased understanding of how federal natural resource agencies initiate and reflect social change in the U.S., this study identifies multiple meanings associated with workforce diversity. It also provides an empirical foundation to compare administrative bodies that manage American lands and resources and are subject to the same external laws and policies. Works associated with women and people of color in natural

63 Michael Lipsky, Street Level Bureaucracy: Dilemmas of the Individual in public services, (New York: Russell Sage Foundation, 1980): xii. 
resources demonstrate the need for further empirical study. The review of literature that follows connects a theoretical foundation in organizational theory and representative bureaucracy with an approach to policy studies based on historical inquiry. This literature emphasizes the role of the individual in bureaucratic operations as a foundation for biographical interpretive methods of analysis and firmly links the fields of history and policy studies.

\section{Organizational Theory, Hierarchy, and the Individual Decision-Maker}

Organizations are distinct from other social collectives, in that they are selfconsciously constructed and managed as articulated and formalized tools for shaping the ordered world we would like to see. Efficiency efforts began in the eighteenth century when, in addition to the intellectual foundation for laissez faire capitalism, Adam Smith expressed the basic tenets and assumptions of classical organizational theory. Smith focused on division of labor and specialization, the "invisible hand" mechanisms that would provide the greatest rewards for marketplace competition. In 1856, Daniel McCallam followed to create a chart including organizational division of responsibilities, commensurate power, and a reporting system for managers. By the 1880s, theorists called for scientific study of organizations through observation, leading to Frederick Winslow Taylor's Principles of Scientific Management in 1911.

"Taylorism" identified methods and organizational arrangements to increase the efficiency and speed of machine-shop production. It offered the "one best way" idea as a foundational principle of scientific management. 
These organizational systems culminated in the efficiencies of progressive era conservation ${ }^{64}$ and clearly shaped Forest Service origins. In 1916, Henry Fayol published the first complete theory of management, identifying principles he viewed as universally applicable to all types of organizations (see Appendix A). The first Forest Service Chief, Gifford Pinchot, employed many of Fayol's principles in the agency's original organization. ${ }^{65}$ An iconic leader, Pinchot also espoused the motto that guided action and reinforced agency values and mission for nearly a hundred years, Jeremy Bentham and John Stuart Mill's principle of: "the greatest good for the greatest amount of people in the long run." In the late 1980s, this motto would shift to "Caring for the Land, Serving People." From its beginnings in 1905, the USFS sought to maintain a continuous supply of timber for the American people. An entrepreneurial agency rooted in public service, the Forest Service also tried to support itself through timber sales and so encouraged a combination of decentralization and highly regulated initiative.

Max Weber's work on bureaucracies best explains organizational development of the Forest Service. According to Weber, laws or regulations order bureaucracies, staffed by professionals appointed on the basis of merit and paid a salary for lifetime tenure. Weber defined bureaucracy as the "purest form or ideal type of rational-legal domination" through the following characteristics:

- 1) bureaucratic authority through fixed and official jurisdictional areas, generally ordered by rules, laws, or administrative regulations;

\footnotetext{
64 The argument for free markets usually rests on either the libertarian case that promotes allowing voluntary exchange without limiting individual liberty; or, the utilitarian argument that markets promote the general welfare.

Fayol, "Principles of Management," 59.
} 
- 2) a clear hierarchy of offices;

- 3) management based on written documents, with clearly specified functions;

- 4) officials appointed by a superior authority, not elected;

- 5) they are selected on the basis of professional qualifications (merit), ideally substantiated by a diploma and identified via examination;

- 6) they have a graded money salary and usually a pension. Officials are free to leave but may be terminated under certain circumstances;

- 7) the official's post is his (or her) major occupation, i.e., career;

- 8) there is a career structure, with promotion available either by merit or seniority;

- 9) the official may not appropriate the position nor associated resources;

- 10) the official is subject to unified control and disciplinary system. ${ }^{66}$

By 1959, when Samuel Hays wrote about conservation and what he called the "gospel of efficiency," the Forest Service epitomized the basic assumptions of scientific management and bureaucratic order:

- Organizations exist to accomplish production-related and economic goals; - There is one best way to organize for production, and that way can be found through systematic, scientific inquiry;

- Production is maximized through specialization and division of labor;

- People and organizations act in accordance with rational economic principles.

This final tenet, rational action in accordance with economic principles, also connected bureaucratic studies with advancing social science inquiry.

Emphasis on rational economic action would shape organizational studies throughout the twentieth century, even as theoretical understanding of organizations expanded. In 1926 Charles Merriam, who later worked with the policy theorist Harold Lasswell, pointed out, "that neither the facts and the technique of economics alone, nor of politics alone, or of history alone, are adequate to their analysis and interpretation. Social science and politics must come together to promote "intelligent understanding 
and control of human behavior." ${ }^{, 67}$ Efforts to understand human behavior in an organizational and policy context included the 1924-1932 Hawthorne studies, which provided evidence for a relationship between environment, motivation, and productivity by showing that workers increased production in response to positive changes in the work environment. Other reports, such as Mary Parker Follet's 1926 “'On the Giving of Orders" called for power with, as opposed to power over workers, adding a human dimension to management.

Efforts to integrate human and bureaucratic elements of organizations coincided with ongoing evaluation of just what constitutes "social science" and spilled into organizational theory. In the 1930 s, Robert K. Merton pointed out that the very act of predictive analysis introduces new factors and unanticipated consequences. Thus, social science can never be fully predictive. Meanwhile, Luther Gulick identified the functional elements of management with the mnemonic device POSDCORB (planning, organizing, staffing, directing, coordinating, reporting, and budgeting), all of which grounded the Forest Service. During the same era, Chester Barnard introduced the idea of cooperation within organizations, arguing for both incentives and persuasion to induce group efforts. Most classical organizational theorists (Weber, Towne, Fayol, Taylor, and Gulick) saw conflict between efficiency, equity, and the relational and autonomous aspects of organizational behavior. These classical theorists and "modern" structural and economic theorists privileged mechanistic, utilitarian structures based on specialization and the

67 Charles E. Merriam, "Progress in Political Research," The American Political Science Review, 20. (February 1926): 8, 12. 
division of labor as the ideal for organizational management. But in 1940, Robert Merton published, "Bureaucratic Structure and Personality" which identified inhibiting dysfunctions in Weber's "ideal-type" bureaucracy that prevented optimal efficiency and negatively affected people in the workforce. Abraham Maslow's identification of a hierarchy of needs in 1943 also shaped individualized understandings of human motivation, which ultimately worked into both organizational theory and policy studies.

Throughout the 1940s, neo-classical organizational theorists rejected the minimization of humanity in organizations. Their antipathy toward mechanistic, functional approaches that place humans in the realm of replaceable cogs, would set the stage for later organizational analysis through cultural theory (the symbolic frame), the human resources (or human-centered) approach, and the role of power and politics. The neo-classicists advocated for decision-making models to explain bureaucratic behavior, noting the significance of environment and organizational ethics and values within organizations. ${ }^{68}$ Herbert Simon and others at the Carnegie Institute of Technology saw decision-making at the heart of administration. Simon attacked the general principles of management as proposed by Fayol and Gulick as inconsistent and often inapplicable, and in 1947 urged the use of scientific method, i.e. logical positivism to answer policymaking questions. Harkening back to the basic principles of bureaucratic order, Simon developed the idea of bounded rationality, that individual actors "satisfice" because they do not have the intellectual capacity or information to maximize their decisions. They

68 The giants of the neo-classical school include James March, Philip Selznick, and Herbert Simon, three theorists who continued to make major contributions into the turn of the century. The neo-classicists of the Carnegie School include Simon, Cyert \& March, Barnard, Selznick, and Merton. 
act as rationally as possible within certain bounds or limits, including limited time, information, and limitations in human cognitive ability to recognize every feature and pattern of every problem. Simon also distinguished between programmed and unprogrammed decision-making and pioneered quantitative methods to improve organizational decision-making. In contrast, Philip Selznick asserted that organizations are made of individuals whose goals and aspirations may not coincide with the formal goals of the organization. Selznick developed the concept of cooptation, which described how companies subsume new elements into the policy-making process to prevent external threats to the organization or its mission. ${ }^{69}$

In 1960, Herbert Kaufman drew from the ideas of Luther Gulick and Herbert Simon to identify the Forest Service as the classic bureaucracy. It was homogeneous (nearly all white males), hierarchical, technically efficient, specialized, with a clear division of labor, and still committed to the conservation and use principles of its founder, Gifford Pinchot. Kaufman also identified the importance of discretionary and decentralized decision making by leaders, emphasized organizational problems and internal relationships, and confirmed functionality of the agency's matter-of-fact, utilitarian approach to managing public resources. He wondered why the "men" in the field followed orders, and attributed it to organizational culture:

The success of the Forest Service in welding the behavior of hundreds of geographically dispersed and relatively isolated Rangers into a unified organizational pattern apparently rests heavily on manipulation of the perceptions, thinking, and values of members of the Service. Were it not for 
these, it is doubtful the formal organizational controls on behavior would be nearly as effective as they are. ${ }^{70}$

Kaufman's study followed the Carnegie Group (Herbert Simon, Richard M. Cyert, James G. March, Chester Barnard, and Robert Merton.), who added the importance of values and interaction between individuals and organizations to ideas of satisficing and bounded rationality that shape predictable decision-making models through organizational structures that include standard operating procedures. ${ }^{71}$

As organizational theorists continued to propose mechanistic notions of change, in 1951 Harold Lasswell introduced the idea of the "policy orientation" to address social problems. My understanding and approach to policy studies draws heavily from Lasswell and later policy theorists, such as Frank Fischer, Paris \& Reynolds, and Deborah Stone, ${ }^{72}$ who support the use of qualitative methodologies. As Charles Lindblom presented incrementalism as a more complex way to understand organizational change, ${ }^{73}$ Lasswell critiqued mechanistic understandings of decisionmaking. "Running through much of the modern work that is being done on the decision process," Lasswell complained, "is the desire to abolish discretion on the part of the chooser and to substitute an automatic machine-like routine.” He took special exception

70 Herbert Kaufman. The Forest Ranger: A Study in Administrative Behavior (Baltimore: Johns Hopkins Press, 1960): xiii.

71 Ideas about satisficing, bounded rationality, and incentivizing come from the Carnegie Group: In 1958, James March with Simon presented the notion of bounded rationality in decision-making, describing how decision makers act as rationally as possible within certain bounds or limits, including time and, informational constraints, and limitations in human cognitive ability to recognize every feature and pattern of every problem.

$72 \quad$ Fischer, Frank, Evaluating Public Policy, (Chicago: Nelson-Hall, 1995); David C. Paris and James F. Reynolds, The Logic of Policy Inquiry (New York: Longman, Inc., 1983); Deborah Stone, Policy Paradox: The Art of Political Decision Making (New York: W.W. Norton \& Company, Inc., 2002). $73 \quad$ Charles Lindblom, "The science of 'muddling through," Public Administration Review, 19 (1959): 79-88. 
to the formalism of rational decision-making models guided by game theory, noting: "In effect the player becomes a computing machine operating with 'built-in' rules in order to maximize built-in preferences." ${ }^{74}$ Lasswell called for context in policy studies, and emphasized the significance of contingency and development - history - in clarifying a policy context.

Representative Bureaucracy: Theoretical and Historical Foundations of Workforce Diversity

When Herbert Kaufman identified the Forest Service as the classic bureaucracy in 1960 , the agency employed male career foresters in nearly every professional capacity and technocratic efficiency ruled activities. These demographics shifted dramatically within the next two decades, starting when President Kennedy's 1961 Committee on Equal Employment Opportunity endorsed a representative bureaucracy and stressed the importance of affirmative recruitment and training efforts. Further executive orders and legislation in the ensuing years embraced this pivotal idea, so that by 1978 under Civil Service Reform, the government called for a "competent and honest workforce reflective of the nation's diversity." 75 These and other legal mechanisms of the era led to racial and gender diversification efforts in the Forest Service. Before long, occupational diversity also increased the number of non-traditional employees, as the agency responded to environmental laws that escalated the need for scientific study, planning, and citizen

74 Douglas Torgerson, "Promoting the Policy Orientation: Lasswell in Context," in Frank Fischer, ed. Handbook of Public Policy Analysis: Theory, Politics, and Method (Boca Raton: Taylor \& Francis, 2007): 15-28.

75 Civil Service Reform Act of 1978, Section 3, PL 95-454 (S 2640), OCTOBER 13, 1978. 
involvement in decision-making. By the 1990s, not only had "ologists" joined the Forest Service, but the notion of representation had expanded to include people with disabilities and consideration of sexual orientation. None of these groups would have fit either the agency's 1960 self-perception or a social science understanding of Forest Service culture, but by the twenty first century, representation and inclusion had become significant to the agency's future.

The term "representative bureaucracy" stems from Donald Kingsley's 1944 study of the British Civil Service. Kingsley illuminated class differences in the British educational system when he found that children tended to remain in the class to which they were born. He also explored class representation in state administration, writing:

The democratic State cannot afford to exclude any considerable body of its citizens from full participation in its affairs. It requires at every point that superior insight and wisdom which is the peculiar product of the pooling of diverse streams of experience [emphasis added]. In this lies the strength of representative government. ... In a democracy competence alone is not enough. The public service must also be representative if the State is to liberate rather than enslave. ${ }^{76}$

Kingsley's language - “diverse streams of experience"-pre-dates contemporary rhetoric about workforce diversity in the federal government and connects biography to representation. Samuel Krislov furthered these ideas through a U.S. lens in the 1970s, stating:

How we solve the problem of Black participation in power and sharing of status and goods in American society will have a great effect on our self-image as well as on the image we project abroad. The American dream was built on several

76 Donald J. Kingsley, "Representative Bureaucracy," in Julie Dolan and David H. Rosenbloom, eds., Representative Bureaucracy: Classic Readings and Continuing Controversies (New York: M.E. Sharpe, 2003):): 13. 
major themes, but its dominant one was its ability to cope effectively with diversity in society. ${ }^{77}$

Krislov recognized that the ideal of equality in American society had not lived up to reality, and so proposed a representative bureaucracy as an avenue to a class free society. He saw inclusion as the "paradigm for future societies of promise and worth...," but also noted a problem with the idea. ${ }^{78}$ Weber would find representative bureaucracy an oxymoron, he wrote, "because bureaucracies handle matters and perform functions. They do not represent or mean or symbolize." However, Krislov understood the message inherent in Weber's original definition of bureaucracy as a system of rule, permanent, rational, and dehumanized, "a power instrument of the first order-for the one who controls the bureaucratic apparatus [emphasis added]. ${ }^{, 79}$ Krislov and others ${ }^{80}$ have since extended the notion that despite the rational-legal foundation of bureaucracy, individuals do matter. He followed Weber to point out that the person who writes the directive - "his or her style, values, concept of role - is as significant as who gets to be president, congressman, senator, member of parliament, or cabinet minister." ${ }^{\prime \prime}$

$77 \quad$ Krislov, Representative Bureaucracy, 18.

78 Ibid, 19. Krislov identifies this class free society as rooted in the "melting pot" of common American characteristics and lifestyle. The notion of a melting pot, popularized in 1907 by Israel Zangwill, leaves out issues of race and class that shape the characteristics of many Americans. Although Herbert Kallen suggested an alternative and more inclusive metaphor as early as 1915, the vision of a U.S. melting pot remains part of an American mythology.

79 Max Weber, "Bureaucracy," 1922, in From Max Weber: essays in sociology (New York: Oxford University Press, 1958): 9.

$80 \quad$ See for example, Frederick C. Mosher, Second Edition. Democracy and the Public Service (United States of America: Oxford University Press, 1968, 1982); Walter D. Broadnax, ed. Diversity and Affirmative Action in Public Service (Boulder, CO: Westview Press, 2000); Julie Dolan and David H. Rosenbloom, eds., Representative Bureaucracy: Classic Readings and Continuing Controversies (New York: M.E. Sharpe, 2003).

$81 \quad$ Krislov, Representative Bureaucracy, 7. 
Frederick Mosher enlarged the significance of administrative representation by explaining that individual bureaucrats are three steps removed from direct participatory democracy. First, the populace elects representatives. They, in turn, select and delegate power to appointees. For example, the president selects the Secretary of Agriculture for approval by the Senate. The Secretary, then, is two steps removed from the electorate. The third step occurs when personnel are neither elected nor politically appointive and removable, "but rather chosen in the bases of stated criteria..." Such personnel typically possess specialized knowledge and skills. They are technocratic experts, as in the USFS where a chief with lifetime tenure has been historically been promoted from within, rather than by political appointment. That pattern shifted in 1993 when President Clinton fired Chief F. Dale Robertson and replaced him with the wildlife biologist Jack Ward Thomas. Many felt the lines between political appointee and rank and file had blurred with Thomas's appointment, a sentiment upheld by selection of fisheries biologist Mike Dombeck as his successor. Dombeck, who had moved to the Bureau of Land Management (BLM) after twelve years in the Forest Service, returned as chief in a heavily criticized and uncharacteristic appointment from outside the agency in 1996. The forester Dale Bosworth replaced Dombeck in 2001, followed by foresters Abigail Kimbell in 2007 and Tom Tidwell in 2009. ${ }^{82}$ The fact of new appointments under each subsequent president has reinforced the notion of political appointments, although each chief has risen through the ranks.

82 Robertson was the first chief fired by a president since Gifford Pinchot, who had been fired by President Taft because of a disagreement over coal interests in Alaska in a controversy now known as the "Ballinger Affair." 
These shifts at the highest level of USFS leadership reflect political exigencies regarding natural resource use and management and mirror societal values, while raising questions about representation. Recent leadership changes include occupation and gender, but not race. As Mosher indicates, there are different types of representation. First, there is an active (or functional) representativeness wherein an individual or administrator presses for the interests of those they presume to represent. This is a potentially dangerous state, in that too much "active representation" constitutes a threat to democracy. Yet, a broadly representative public service should also provide limited satisfaction of government "by the people." According to Mosher, it is also possible to statistically measure the degree to which individuals collectively mirror society through passive (descriptive) representation. The values implicit in passive representation related to race and/or gender assume essentialist biological characteristics that scholars recognize as problematic; however, as affirmative action became law in the 1970s, representation by race and/or sex provided the key to inclusion. Legally protected diversity categories emerged based on contemporary understandings of race and gender and by the twenty-first century had expanded to include disability and more nuanced race identification. Additional definitions of diversity in terms of sexual orientation also developed internally. Alternative forms of diversity create a distinction between who has legal protection based on difference and who does not and raised questions about just what constitutes diversity. While the federal government sought parity with race, gender, and disability demographics in the civilian labor force, passive representation also reflected characteristics such as locality of origin (rural, urban, suburban), family 
occupation, education and family income, sex, race, religion, and so forth. For Mosher, passive representation and democratic decision-making are not automatic, although:

A broadly representative public service, especially at the level of leadership, suggests an open service to which most people have access, whatever their station in life, and in which there is equality of opportunity. These are values which Americans have honored - in speech if not always in deed ... The importance of passive representation sometimes resides less in the behaviors of public employees than in the fact that the incumbent employees are there at all. ${ }^{83}$

The fact that they are not there also reverberates significantly and highlights the complexity of the American Dream referenced by Krislov.

As historian Jim Cullen points out, equality of opportunity is how we typically square the difference between principle and reality - as a practical possibility, which equality of condition is not. ${ }^{84}$ Cullen's explication of the American Dream follows numerous critical legal and race theorists and historians, who have shown that in the U.S., systemic racism supported by law and prejudicial social mores impacts equality of condition and limits opportunity. My work shows that underrepresentation of people of color, especially African Americans, in the U.S. Forest Service more closely reflects the reality of American conditions than the ideal of equal opportunity. Diversification in USFS began in response to legal civil rights mandates but ultimately occurred within the context of emergent ideas about the intersection between race, law, and power identified by legal scholars like Derrick Bell, Patricia Williams, Kimberlé Williams Crenshaw,

$83 \quad$ Mosher, Democracy and Public Service, 21.

$84 \quad$ Jim Cullen, The American Dream: A Short History of an Idea (New York: Oxford University Press, 2003): 108. 
Mari Matsuda, Richard Delgado and Jean Stefancic. ${ }^{85}$ Bell's work is particularly important in that he was not only one of the main progenitors of critical legal and race theory, he also played a role in the USFS approach to diversification in the late 1980s and early 1990s, a story I tell in chapter eight.

\section{Empirical Studies of Representative Bureaucracy}

\section{Approaches to Representation}

Mosher's active and passive representation informs much of the analysis and theoretical development of representative bureaucracy. In terms of passive representation, empirical scholarship focuses on studies of the federal service and affirmative action. In 2000, Broadnax identified a number of factors that influenced the presence of women and minorities in the government workforce. They included equal employment legislation, affirmative action, recruitment, selection, promotion, pay,

85 Critical Race Theory (CRT) focuses on examining intersections of race, gender, law, and power. In the 1990s, legal scholars had begun to articulate connections between white supremacy and the law, issues that expanded to include a focus on gender and sexuality as well as more focused deconstruction of the law in relation to particular groups. See, Richard Delgado, Critical race theory an introduction, second edition (New York: New York University Press, 2012). Delgado, a professor at University of Alabama School of Law, often with his spouse Jean Stefancic has written prolifically about CRT, a movement and a scholarly approach that has bled into many other disciplines. Patricia Williams, a law professor at Columbia since 1991, writes about race, power, and sexuality for a public audience in a column titled "Diary of a Mad Law Professor" in The Nation. Kimberlé Williams Crenshaw specializes in race and gender law at UCLA and Columbia, and is the founding coordinator for Columbia's Critical Race Theory Workshop, which sparked intellectual exploration related to law, power, and society and facilitated expansion of critical legal studies to include other categories of oppression. Mari Matsuda also taught at UCLA and at Georgetown Law Center and later at University of Hawaii. Starting in the mid to late 1990s, she and others listed here began writing extensively about critical race theory, affirmative action, and effort to achieve racial emancipation and eliminate gendered subordination. Recent studies of whiteness, maleness and more nuanced categories of domination and subjugation have resulted from the work of the legal and literary critics of the late 1980s and early 1990s. 
retention policies, and political representation. Nina Ricucci also presents a concise summary of the efforts government organizations use to address workforce diversity challenges, concentrating on practices that promote passive representation and those that promote inclusion. Ricucci's work documents legal issues, demographics and diversity related programs and includes chapters on each of the primary diversity groups. She also identifies significant secondary diversity dimensions based on Marilyn Loden and Judy B. Rosener's 1990 Workforce America: work background; income; marital status; military experience; religion; geographic location; parental status and education. ${ }^{86}$ Additionally, Ricucci identifies important human resource issues, also significant to the Forest Service. These include family friendly benefits and policies, flexible work arrangements, and "cafeteria style" benefits to manage diversity.

In 2006, Chih-wei Hsieh and Elizabeth Winslow examined gender representation in the federal service. Based on demographic data from the 2000 Demographic Profile of the Federal Workforce, they discovered inequality between genders and racial groups, with gender inequality most prominent. They classified female representation as a matter of segmented equality, i.e., "when equality exists within a group or category but conditions between groups are not equal." ${ }^{87}$ Hispanics were underrepresented, while other groups (Whites, Blacks, Asians, Pacific Islanders, American Indians/Alaska Natives, and women) "range from nearly represented to overrepresented" in terms of

86 Norma Ricucci, Managing Diversity in Public Sector Workforces (Boulder: Westview Press, 2002): 28.

87 Chih-wei Hsieh and Elizabeth Winslow, "Gender Representation in the Federal Workforce: A Comparison Among Groups, “ Review of Public Personnel Administration, 26 (2006): 285. 
demographic parity with the general population. ${ }^{88}$ Hsieh and Winslow also showed that although underrepresented in higher-level positions, Black and American Indian/Alaska Native women held a higher proportion of all federal jobs than their male counterparts. Socioeconomic characteristics, educational attainment, and cultural role perceptions may also impact these differences. Like Ricucci, these authors concluded that educational reforms and flexible working arrangements to balance work and home create a positive emphasis on workforce diversity. ${ }^{89}$ A number of other studies have also identified passive-active connections. ${ }^{90}$

Regarding active representation, scholars have long argued that personal attitudes and values impact bureaucratic decision-making to some degree, but have minimized the salience of personal values to organizations. ${ }^{91}$ In one of the first empirical studies, Meier and Nigro concluded that organizational socialization provides a stronger force than sex or social origin, when men and women in the former supergrades responded almost identically regarding spending priorities. ${ }^{92}$ A number of studies in the 1980s and early 1990s also identified very little difference between male and female civil servants. Others showed women executives as more supportive of workplace

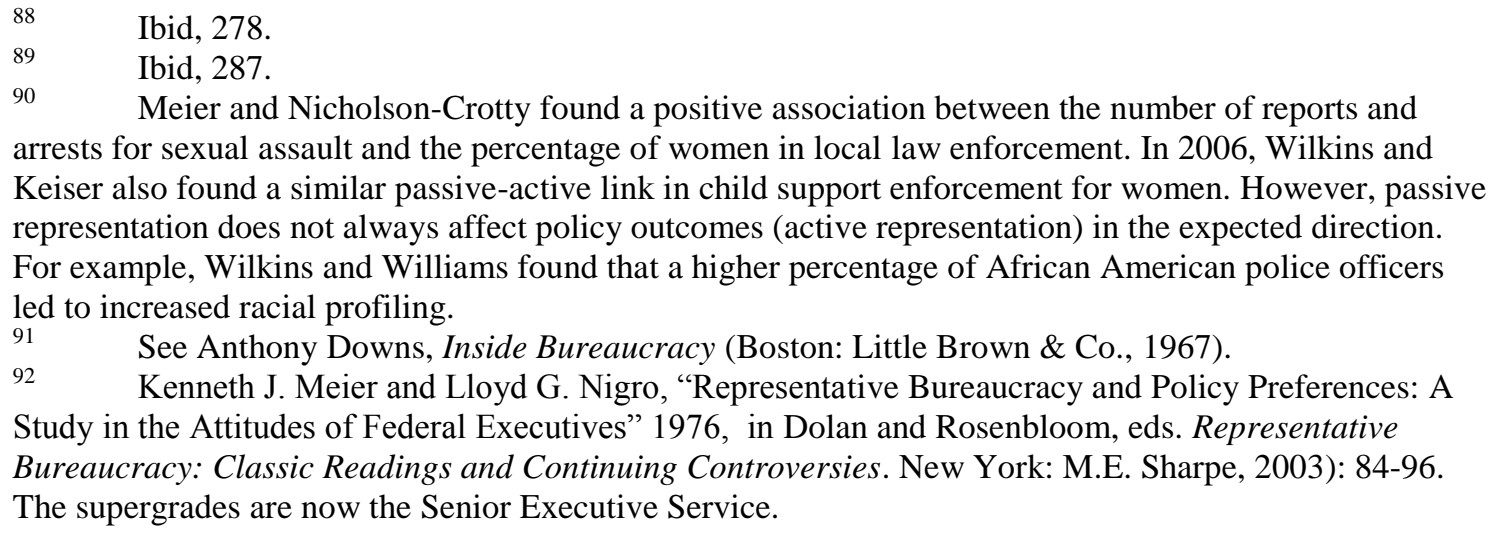
arrests for sexual assault and the percentage of women in local law enforcement. In 2006, Wilkins and Keiser also found a similar passive-active link in child support enforcement for women. However, passive representation does not always affect policy outcomes (active representation) in the expected direction. For example, Wilkins and Williams found that a higher percentage of African American police officers led to increased racial profiling.

$91 \quad$ See Anthony Downs, Inside Bureaucracy (Boston: Little Brown \& Co., 1967).

92 Kenneth J. Meier and Lloyd G. Nigro, "Representative Bureaucracy and Policy Preferences: A Study in the Attitudes of Federal Executives" 1976, in Dolan and Rosenbloom, eds. Representative Bureaucracy: Classic Readings and Continuing Controversies. New York: M.E. Sharpe, 2003): 84-96. The supergrades are now the Senior Executive Service. 
reforms in areas that disproportionately affect women, such as child care, affirmative action, pay equity, family leave, job sharing, and flexible work schedules. ${ }^{93}$ The changes in U.S. Forest Service operations regarding dual career families between the 1980 s and the end of the century support these contentions.

\section{Social Origins and the Civil Service - Passive and Active Representation}

A number of empirical studies have coalesced on a standard model for tracking the impact of social background on the performance of civil servants. The model links social origins, life experiences, attitudes, and decision-making, and focuses on contemporary concerns. These include "diversity and equal opportunity policy, democratic control of administration, administrative performance, and 'reinventing government," all of which influence workforce diversity in the U.S. Forest Service. ${ }^{94}$ Considerations include whether socialization into organizational norms hinders active representation or if social origin promotes it. ${ }^{95}$ These studies show variability regarding the impact of passive representation related to community of origin and gender. In some cases, black and Latino representation results in positive associations for those groups, in others organizational culture is stronger. Dolan identified women as closer in terms of decision-making and attitudes to men and women within their own departments than to

Dolan and Rosenbloom, 2003. Ibid, xi. Broadnax, 2000. 
other women. Her findings differ from research on women administrators, but are consistent with studies of women in legislative positions. ${ }^{96}$

Several studies related to racial representation in government have also yielded varying results. In the early 1990s, Hindera examined African American representation in regional offices of the Equal Employment Opportunity Commission (EEOC).

Through the percentage of total charges filed on behalf of African American employees or applicants, Hindera found that as the percentage of black investigators increased, so did the benefit to African Americans. ${ }^{97}$ Selden followed with a study of the Farmer's Home Administration, a USDA agency. She concluded that passive representation of African Americans, Hispanics, and Asians positively influenced loan allocations for those groups in the FHA rural housing loan program. These findings are particularly important because historically the agency employed few minorities, and has often implemented policies adverse to people of color. Selden also identified a "minority representative role" based on "attitudes, beliefs, and values "that led some public administrators to make decisions consistent with minority interests."98

A later survey conducted by Bradbury and Kellough confirmed that African American citizens and administrators are more likely to support governmental behaviors

96 Dolan, "Representative Bureaucracy in the Fed. Exec.," 357, 371.

97 John J. Hindera, "Representative Bureaucracy: Further Evidence of Active Representation in EEOC District Offices," Journal of Public Administration and Theory 3 (1993): 415-429; John J. Hindera, "Representative Bureaucracy: Imprimis Evidence of Active Representation in EEOC District Offices," Social Science Quarterly 74 (1993): 95-108.

$98 \quad$ Sally Coleman Selden, "Representative Bureaucracy: Examining the Linkage Between Passive and Active Representation in the Farmers Home Administration," American Review of Public Administration 27 (1997): 22-42; Sally Coleman Selden, Gene A. Brewer, and Jeffrey L. Brudney, "Reconciling Competing Values in Public Administration: Understanding the Administrative Role Concept," Administration and Society 31 (1999): 171-204. 
that specifically target the interests of the black community. It also found that white administrators sometimes serve as minority advocates, a role that many non-traditional Forest Service employees identify as critical to initial workforce diversity efforts. These results collectively confirm Rosenbloom and Feathersonehaugh's 1977 contention that "passive bureaucratic representation can serve as a prerequisite for greater active representation," 99 an important element in my study of the U.S. Forest Service. They also raise questions about the role of white allies and men in facilitating workforce diversity in the agency.

As Bailey points out, traditional theories linking active and passive representation are challenged by differing views of race, ethnicity, gender, and age, and the disappearance of "monolithic communities characterized by unique social and cultural experiences. .. . [making] it is difficult to say who should or could actively represent for whom." ${ }^{100}$ Most representative bureaucracy studies have examined attitudes, values, and questions of active versus passive representation through quantitative surveys measuring numerical outputs, such as under/over representation, legal suits, or percentages. However, the literature lacks the kind of qualitative empirical studies that trace how change occurs at the micro-level, the in between spaces that negate focusing only on either the significance of the individual decision-maker or the

99 Mark D. Bradbury and J. Edward Kellough, "Representative Bureaucracy: Exploring the Potential for Active Representation in Local Government," Journal of Public Administration Research and Theory, 18 (2007): 699, 712. For example, Asians tend to have a grade distribution similar to Whites and are generally highly educated. Hispanic men and Asian Pacific Islander husbands are more likely to be the primary earners, while black women are often the main breadwinners. 100 Bailey, "Representative Bureaucracy: Understanding its Past," 249. 
automaticity of the bureaucracy. More complex examinations of diversity are clearly in order.

My work examines the ways in which Kingsley's “diverse streams of experience" coalesce in a particular social and organizational structure. It contributes to a better understanding of representative bureaucracy through an investigative model that links social origins, life experiences, attitudes, and decision-making in an historical study of workforce diversity in a natural resource agency with a public service mission. This study shows the ways in which many of the processes affecting passive and active representation play out in the U.S. Forest Service and how they vary across the primary diversity categories (race, ethnicity, gender, physical ability, and sexual orientation), with special attention to issues of race. Dolan and Rosenbloom note that, with opportunity, civil servants tend to become active representatives. As I demonstrate, a tendency toward active representation occurs in the U.S. Forest Service, but is not always self-directed. In addition, the intensity of representation often shifts over the course of an individual's career, in keeping with position, levels of authority, and gender. I demonstrate that people of color in public service hold multiple representational roles internally and externally. How that representation manifests depends on occupation, place/region, workforce dynamics, and individual character. Close examination of the minority representative role in the Forest Service also reveals issues associated with family, the workplace, race, region, and culture in an America that remains systemically segregated. My research shows that the onus of 
accommodation to regional culture, racial separation and representation, and educating others about race is almost always on the employees themselves.

\section{Studying the USDA Forest Service}

\section{A Bureaucratic Superstar - Changing Values}

In 1985, Jeanne Clarke Nienaber and Daniel McCool identified the Forest Service as a "bureaucratic superstar" because of its internal stability and power to realign under exogenous shifts. Many of the factors that contributed to agency success in 1985 added to controversy around land management and occupational culture practices: its pro-development, multiple-use mission, utilitarian ideology, clear beginning and mission, recruitment from within, and external support. In 1991, Terence Tipple and Douglas Wellman identified a series of contextual changes that had altered the Forest Service, and implicitly, public administration as a whole, since the 1960s. Changes included opening a closed system through environmental and social legislation, and the need for representativeness and responsiveness through public involvement in lieu of efficiency and economy. These requirements have been particularly hard on the Forest Service, an agency birthed through technocracy and raised as a model of efficiency.

Greg Brown and Charles C. Harris also theorized that diversity in the USFS population would lead to agency shifts in value orientation. Through a mail-in survey of randomly selected staff and field level line officers, they found that employees of the early 1990s favored increased non-commodity forest uses and supported more 
environmental viewpoints than ten years earlier. ${ }^{101}$ However, Jennifer Thomas and Paul Mohai argued that the difference would not produce radical agency change, because despite greater numerical diversity, "the leadership ranks are still the domain of white male foresters." 102 In 1996 Sabatier, Loomis and McCarthy compared timber output levels with the attitudes identified by Brown and Harris, and concluded that the views of Forest Service officials did not affect timber outputs. Rather, differences came from Congressional mandates and budgetary administration, local constituency groups, court decisions, legal constraints, and the corpus of internal agency rules and procedures. Sabatier, et. al. argued that demographic changes had not changed agency outputs, because for the most part, non-foresters and women still did not staff decision-making line positions.

In 2007, Tomas Koontz examined state-federal differences in forestry related to legal constraints, citizen interaction, and forest administration, which he tied to differences in workforce diversity. According to Koontz, "societal demands, combined with new statutes, a diversifying workforce, and changes in citizen interaction eventually affected forest rangers' views about appropriate forest management." ${ }^{103}$ State administrators faced fewer legal constraints than federal administrators and had not engaged in the kind of aggressive affirmative action and equal employment opportunity

101 Greg Brown and Charles Harris, "The implications of workforce diversification in the U.S. Forest Service," Administration \& Society, 25 (1993): 85-113.

102 Jennifer C. Thomas and Paul Mohai, "Racial, Gender, and Professional Diversification in the Forest Service from 1983 to 1992," Policy Studies Journal 23, no. 2 (1995): 296.

103 Tomas M. Koontz, "Federal and State Public Forest Administration in the New Millenium: Revisiting Herbert Kaufman's The Forest Ranger." Public Administration Review (January/February 2007): 155 . 
programs operating at the federal level in the 1970s and 1980s. Thus, women and racial and ethnic minorities remained substantially underrepresented at the state level, with professional, gender, racial, and ethnic homogeneity reminiscent of the federal Forest Service more than 40 years earlier. In the late 1990s and early 2000s, state forest employees remained 95 percent male, 99 percent white, and 84 percent foresters. ${ }^{104}$ Because Forest Service employees came from different disciplinary backgrounds, Koontz linked legal changes to "greater workforce diversity, new ways of interacting with citizens, and more diverse (and less procommodity) views about appropriate forest management.",105

\section{Revisiting Herbert Kaufman's Forest Ranger}

Most qualitative empirical studies of non-traditional populations in the Forest Service, focus on white women, beginning with Elaine Pitt Enarson's 1984 book Woods Working Women: Sexual Integration in the U.S. Forest Service. Enarson examined sexual relations of production in integrated workspaces, what she called "an analysis of affirmative action in forestry." Between 1978 and 1979, she studied two national forests in Oregon, interviewing 50 women workers and 22 men associated through work or family life. Woods Working Women provided a feminist analysis of work and gender relations, sexuality, and sexual harassment. Enarson found that men in the Forest Service viewed women primarily as sex objects, which complicated work relationships;

$104 \quad$ Ibid, 159. Ibid, 160 . 
however, she accurately predicted the eventual, though conditional acceptance of women in the agency over time. Critics of Enarson's work claimed that the study lacked a broad social structural framework, concepts and systematic background data that would place her work into the sociological study of work, gender, or role transformation. It was neither generalizable to a larger population, due to selection bias, nor did it offer insights for professional women aiming to "move up the Forest Service management ladder." ${ }^{106}$ However, these critiques ignore the true value of Enarson's work - to provide the kind of experiential understanding of barriers faced by women in natural resource occupations at that time. As my work will show, a number of woods-working women in the 1970s later entered the professional sphere through formal upward mobility programs.

In their 1996 study of women line officers, Carroll, Freemuth and Alm provide the kind of generalizability called for by Enarson's critics. ${ }^{107}$ The authors surveyed the agency's 127 female unit leaders serving in line positions in 1992, i.e., those in decisionmaking roles at the forest or regional level, and had a 66 percent return rate. They compared the trajectories of female line officers with Kaufman's study of expected career paths in 1960 - “foresters" who had served on several different national foreststo determine whether women followed Kaufman's implied model for promotion. Carroll, et. al. examined the following characteristics: willingness to conform (waiving

\footnotetext{
106 Mary Lindenstein Walshock, Review of Woods-Working Women: Sexual Integration in the U.S. Forest Service by Elaine Pitt Enarson, Contemporary Sociology, 14, no. 3 (May 1985): 352-353. 107 Carroll, Franklin O.; Freemuth, John; Alm, Les, “Women Forest Rangers: Revising Kaufman's ‘The Forest Ranger,"” Journal of Forestry 94, no. 1 (January 1996): 38-41.
} 
personal preference regarding location and serving where most needed); technical competency (forestry or science degrees and field experience); self-selection (people who understood the difficulty of the work and knew promotion expectations); mentorship; promotion from within, i.e., "one had to be Forest Service to lead Forest Service; and the practice of "unhurried promotion" so that employees acculturate. ${ }^{108}$ The study indicated that while there had been demographic change, the core organizational culture had shifted very little. The most important precept, willingness to conform, remained robust. Forty percent of women had transferred five or more times and 75 percent at least three times. Line officer status still required higher education and almost 70 percent of the women had attended graduate school. The majority had master's degrees. Forestry, engineering and biology remained the three most significant disciplines in the agency, with all of the women classified under one of the scientific occupations before promotion to line officer; however, because Chief Thomas opened line jobs to all professional series in 1994 , the authors predicted this pattern could change. Mentorship, performance, length of service and loyalty remained important to advancement. Despite assertions that women were "fast-tracked," the numbers showed otherwise. $^{109}$ Just over 50 percent of line officers had 10 to 15 years experience with the agency, with nearly 40 percent at the $15-20$ year range. The authors attributed the strength and cohesion of organizational culture to the willingness to conform, but pointed out that reorientation efforts toward ecosystem management, combined with

Ibid, 38-40.

Ibid, 41. 
massive social and political change could shape the agency in ways Kaufman would have never imagined. The challenge for the future, wrote Carroll, et. al., lay in determining those "components of the traditional culture that should be preserved or enhanced and those components that should be changed." "110 The authors suggested "revisiting Kaufman every 25 years" to determine the agency's success in creating a diverse workforce, perhaps "one of the most important issues facing the Forest Service as it enters the second century."111 Yet, Carroll, et. al. do not provide the qualitative depth of Woods Working Women, nor do they focus on other non-traditional employee populations. This study provides a strong foundation for understanding workforce diversity in the U.S. Forest Service; however, it also demonstrates some of the problems associated with generalizability. While large samples may provide structural insight, specific regional context and individual experiences can add networked dimensions of understanding to workforce diversity. In addition to meaning making at the individual, district, and regional level in relationship to place, illuminating the tensions between individual human agency and top-down mandates may provide insight into critical decision points that could enhance workforce recruitment and retention. resource/environmental agencies," in American fish and wildly policy: The human dimension, ed. W. Mangun (Carbondale: Southern Illinois University Press, 1992): 235-236 in Carroll, et. al., "Revisiting Kaufman," 41.

111 Carroll, et al., "Revisiting Kaufman," 41.
} 
Forest Service History and non-traditional employees

Most Forest Service histories focus on changes in land use, environment, and environmental policy. Works by Paul Hirt, Char Miller, Harold Steen, and others focus on the ways in which the agency has managed the land, with social demography at the periphery. ${ }^{112}$ Consequently, Forest Service history has focused on land management decisions made in relation to the law, alongside timber, recreation, and research policies that inform individual decision-making, but not in the context of personal biases or social constructions of race and gender. Like most Forest Service historians, Harold Steen does not emphasize workforce diversity, but he does articulate two changes in operations so fundamental that he calls them "paradigm shifts." The first came from Congress, the second from the courts, and both created systemic changes that shaped contemporary Forest Service culture and operations. As Steen explains, Congress traditionally established mandates and left agencies to comply, but the National Forest Management Act (NFMA) of 1976 provided 15 pages of very specific direction for agency management. Such regulation contrasts with the single page 1960 Multiple Use Sustained Yield Act (MUSY). The NFMA and other prescriptive environmental laws,

112 Michael Frome, The Forest Service (New York: Praeger Publishers, Inc., 1971); Paul Hirt, A Conspiracy of Optimism: Management of the National Forests Since World War Two (Lincoln: University of Nebraska Press, 1994); Char Miller, Seeking the Greatest Good: The Conservation Legacy of Gifford Pinchot (Pittsburgh: University of Pennsylvania Press, 2013), Public Lands, Public Debates: a century of controversy (Corvallis: Oregon State University, 2012), and American Forests: Nature, Culture, and Politics (Lawrence: University of Kansas Press, 1997); Harold Steen, The U.S. Forest Service: A History, Centennial Edition (Durham, NC: Forest History Society, 2004); Samuel Hays, Wars in the Woods: The Rise of Ecological Forestry in America (Pittsburgh: University of Pennsylvania Press, 2007). Paul Hirt, Char Miller, and Harold Steen have taken an environmental history approach to agency history, while James G. Lewis presented a summary environmental and social history of the agency upon its one hundred year anniversary. Hirt grapples primarily with the agency's cultural hegemony of timber culture in $A$ Conspiracy of Optimism, while Miller's biography of Gifford Pinchot places the agency's first chief into the modern environmental movement. 
such as the 1970 National Environmental Policy Act (NEPA) led to "judicialized decision-making" about land management practices in lieu of the traditional technical decision-making authority of a forester with management responsibilities. ${ }^{113}$ These environmental management changes corresponded with mandates to create a representative labor force. I argue that workforce diversity is integral to the shifts cited by Steen, through an entwined diversification that climaxed in the 1990s, with ecological, social, and occupational shifts rooted in junctures between the human and natural worlds in a changing socio-historical context.

This entwined diversification expanded occupational and social diversity and increased operational complexity, even as Congress began an ongoing process of budget reduction. Although James Lewis's 2005 centennial history included more about women and minorities than any previous work, no one has focused closely on social diversity in the Forest Service. Lewis included one chapter discussing minorities, cultural biases, and general diversity issues, as well as an overview of the 1979 consent decree that increased female employment in the agency. He also showed the ironies of entwined diversification as he pointed out that workforce cuts under the 1985 Gramm-Rudman Act resulted in a 25 percent staff reduction nationally. Between 1980 and 1990, the Forest Service eliminated approximately five thousand positions, reductions concurrent with efforts to increase minority employment and comply with mandated hiring and promotion of women. Carla Fisher's 2010 dissertation followed to explore tensions around legal mandates to hire women from the 1950s to the 1990s. Fisher expanded

113 Steen, Forest Service, xi. 
understanding of the consent decree and its impact, showing that throughout the 1970s and ' 80 s women workers struggled to define legislation and equal opportunity "in ways that gave them access to a wider range of occupations." ${ }^{114}$ She also traced the relationship between changes in the agency and discussions around affirmative action in the 1990s. Consequently, her work provides a launch pad for deeper investigation into the formal and informal processes associated with workforce diversity.

\section{Assumptions, Methodologies, and Research Design}

Historical Institutionalism, Representative Bureaucracy, and Research Questions

No scholars have yet examined incorporation of minority populations into the Forest Service or how Kaufman's characteristics of agency success apply to people of color. Additionally, aside from Rung's (2002) look at the federal Civil Service and Selden's examination of the FHA, few representative bureaucracy studies are historical. My study of workforce diversity in USFS recognizes the importance of historical institutionalism and, as J. Edward Kellough puts it, that: "Relations among the three branches of government and the formal and informal rules and procedures governing their conduct ... have determined the shape of our responses to discrimination in fundamental ways." ${ }^{115}$ The historical institutional approach calls for examining the political, economic, and social aspects of change over time in relation to workforce diversity. The agency's institutional history reveals that diversity efforts have coincided

\footnotetext{
114 Fisher, "You're Not Getting Rid of Me," 4.

115 J. Edward Kellough, Understanding Affirmative Action: Politics, Discrimination, and the Search for Justice (Washington, D.C.: Georgetown University Press, 2006): 17-18.
} 
with large scale shifts in policy orientation, ongoing budget constraints, continued environmental lawsuits, and ever increasing anti-government sentiment. These shifts continue to place stress on an organization trying to define its role in an increasingly urban and diverse twenty-first century. What the institutional history does not reveal is the dialectical and entwined processes associated with diversification, its challenges, benefits, and meanings - to society, the agency, communities, and individuals. Nor does it explain why the agency has been unable to achieve parity with the civilian labor force, how people of color have attained leadership positions, relationships between passive and active representation, or the meanings of diversification to those identified as “diversity employees."

Given the importance of the representative bureaucracy idea, and given gaps in our knowledge about how that representation has been actualized in the largest agency in the Department of Agriculture, I have chosen to utilize Region 6 of the U.S. Forest Service as a lens through which to examine two primary questions: How has the USDA Forest Service incorporated non-traditional employees, especially minorities, into the agency? And, What roles do individual decision-makers play in facilitating or hindering that process? I will address these questions through a subset of queries organized around three intersecting historical areas: legislative mandates; agency policy; and individual experience. Research Questions focus on the following:

\section{Legislative Mandates}

- What external forces/legislative mandates have pushed the agency to bring women and people of color into the Forest Service? 
- What programs or policies are directly connected to legislated mandates and applicable to other federal agencies and/or the Department of Agriculture?

- How do these programs function structurally?

Agency Policy

- How has the Forest Service policy developed in response to legislated demographic changes?

- What internal structures have contributed to or detracted from achieving a representative workforce?

- How has the idea of workforce diversity developed and shifted over time as a primary policy goal and what is the role of individual leaders in that development?

- Which policies have been most effective in facilitating demographic representation in the Forest Service?

- What can close examination of place and region tell us about workforce diversity efforts?

\section{Diverse Streams: Individual Experience}

- How do individuals within the agency facilitate or hinder workforce diversity efforts?

- What can individual career paths and biography tell us about workforce diversity in the Forest Service?

- With Kaufman's model in mind, what can we learn about organizational culture and change over time through analysis of career paths and biography?

- What else can we learn through close examination of minority employee experiences?

- How do minority and non-minority employees engaged in equal employment, civil rights, and leadership positions view the long term development of workforce diversity?

- How do these individuals think the Forest Service can best meet its diversity goals?

- How do individuals compare Region 6 diversity efforts with other places around the nation?

- What lessons have individual minority employees or managers brought into and/or taken with them from Region 6 ? 
Representative Bureaucracy, Biographical Research, and Historical Methods

The representative bureaucracy literature upholds the notion that biographical research through in-depth interviews can contribute to a more complex understanding of the policy process. Mosher's extension of passive representation beyond classic race and sex categories, as well as Loden and Rosener's secondary diversity categories as articulated by Ricucci and Bailey also substantiate the use of interview methods. Dolan's emphasis on those in leadership positions and Selden's definition of minority representative roles upholds the need for studies of particular agencies. Like the FHA and other natural resource agencies, USFS had little to do with minorities prior to 1964 when Title VI of the Civil Rights Act required public notification and when Title VII mandated equal employment opportunity in 1972. Levels of representation have never achieved parity for women or minorities and are especially egregious in relation to African American populations; thus, understanding the historical context of workforce diversity — through contingency and development—should be valuable to the Forest Service and other federal agencies.

This study uses historical methods, records, and chronology to shape a narrative of change over time in the USDA Forest Service. I take a multi-disciplinary theoretical approach to examine the processes of entwined diversification in USFS in a manner useful to social scientists across disciplines. Just as the field of History bridges the Humanities and Social Sciences, this work is rooted in transitional spaces between historical sociology, cultural anthropology, environmental, institutional, and cultural history, interpretive policy analysis and evaluation, and critical race and gender studies. 
Quantitative and qualitative evidence from archives and government reports, oral testimony provided by participants in cultural and institutional change, and structural shifts associated with law and policy ground this history. While this study connects directly to questions of representative bureaucracy, my background and assumptions as an environmental historian and oral history practitioner also influence it.

\section{Environmental History and Narrative}

Environmental historians employ a variety of conceptual approaches, many of which combine elements of the material and ideal worlds. They use theoretical frameworks and methodologies rather than a single overarching method, incorporating ecological interpretations of history to help explain change. Donald Worster, Carolyn Merchant, Richard White, and William Cronon especially, examine interacting levels of ecology, production, and consciousness in human societies. As Merchant explains, ecology refers to the relationships between organisms and their surroundings, and includes social and cultural patterns. My taking an ecological stance to the history of workforce diversity in the Forest Service means that relationships ground the study not only in people's connections to nature, but also in their associations with one another in relation to nature. In this case, Region 6 serves as a unit of analysis to explore interactive processes at work in the agency. This holistic ecological approach allows me to address William Cronon's emphasis on "social environmental histories that take into 
account race, class, gender, and the modes by which societies reproduce themselves over time."116

For historians, time and narrative overlap; therefore, chronology organizes the inquiry that comprises the discipline of history and the story of workforce diversity in the Forest Service. I also rely on a narrativist approach to fold causality into stories of change over time, a relational methodology, nicely articulated by Cronon, who reminds us that what is important about nature is its meaning for human beings. "Because I care so much about nature and storytelling both," he writes, "I would urge upon environmental historians the task of telling not just stories about nature, but stories about stories about nature." ${ }^{117}$ This story of workforce diversity is exactly that, a narrative about permutations in nature through people, with the Forest Service as a microcosm of the human ecosystem that constitutes the Department of Agriculture. It is the job of those who make up that ecosystem to "Care for the land and serve the people," meaning the American public and its forests. Through their decision-making and actions, Forest Service employees inscribe stories of dialectical interaction between the human and natural worlds. They act as interlocutors in a system of laws and policies implemented differently in place, time, and through individuals who shape human and non-human ecological systems.

In recent years, environmental historians have begun to address the critical

\footnotetext{
116 Carolyn Merchant, "Essays" in Major Problems in American Environmental History, Lexington, MA, D.C. Heath \& Co., p. 2.

117 William Cronon, “A Place for Stories: Nature, History, and Narrative" Journal of American History 78, 4 (1992): 1347-1376.
} 
categories of race, ethnicity, and gender called for by this study of the Forest Service.

Scholars like William Cronon, Carolyn Merchant, Ted Steinberg Richard White, Mark

Fiege, Stephen Mosley, and Alan Taylor have noted that integrating the social

construction of race and ethnicity with developments in the natural world may provide

more nuanced understandings of human relations to the environment. Connecting social

and environmental history may also raise broader questions about power relations. ${ }^{118}$

Additionally, environmental history as a discipline has neglected gender, despite

challenges by leading scholars to move beyond environmental justice movements and

ecofeminism to include women in what have historically been "elite, male concerns,"

like forestry. Following Carolyn Merchant and Richard White, scholars like Nancy

Unger, Melissa Leach and Cathy Green, Vera Norwood, Linda Nash, Elizabeth Blum,

and Virginia Scharff have advocated for a twenty-first century environmental history

that explores the role of women, gender, and questions of sexuality. ${ }^{119}$

118 Carolyn Merchant, "Shades of Darkness: Race and Environmental History," Environmental History 8, no. 3 (July 2003): 380-394; Ted Steinberg, "Down to Earth: Nature, Agency, and Power in History," American Historical Review 107, no. 3 (June 2002): 798-820; Richard White, "Afterword Environmental History: Watching a Historical Field Mature," Pacific Historical Review 70, no. 1 (February 2001): 103; Mark Fiege, The Republic of Nature: An Environmental History of the United States (Seattle: University of Washington Press, 2012). See also, Mart Stewart, "Environmental History: Profile of a Developing Field," History Teacher 31, no. 3 (May 1998): 351-368; Mart Stewart, "Slavery and African American Environmentalism," in "To Love the Wind and the Rain": African Americans and Environmental History, eds, Dianne D. Glave and Mark Stoll (Pittsburgh: University of Pittsburgh Press, 2006); Stephen Mosley, "Common Ground: Integrating Social and Environmental History," Journal of Social History 39, no. 3 (Spring 2006): 915-933; Alan Taylor, "Unnatural Inequalities: Social and Environmental Histories," Environmental History, no. 4 (October 1996): 6-19.

119 Nancy Unger, "Women and Gender: Useful Categories of Analysis in Environmental History," in The Oxford Handbook of Environmental History, ed. Andrew C. Isenberg (Oxford University Press, 2014): 601. See also, Carolyn Merchant, "Gender and Environmental History," The Journal of American History 76 (1990): 1117-1121; Melissa Leach and Cathy Green, "Gender and Environmental History: From Representation of Women and Nature to Gender Analysis of Ecology and Politics," Environmental History 3 (1997): 343-370; Vera Norwood, "Disturbed Landscape/Disturbing Process: Environmental History for the Twenty-First Century," Pacific Historical Review (February 2001): 77-89; Linda Nash, 
As Connie Chiang points out, scholarship "needs to include, rather than ignore or ostracize, the people who use the lands and waters in question." ${ }^{\prime 20}$ I would add that it is just as important to include those who manage those resources. Mark Fiege clearly explains the significance of inclusion, "The color line ... was more than a legal abstraction; it was a material practice grounded in the social experience of landscape and its physical properties." ${ }^{\prime 21}$ The history of public forestry helps to illustrate how structural policies upheld the color line, the gender line, and social experiences related to the land. It also shows the processes that have unevenly reshaped those experiences. Although this study does not explicitly deconstruct whiteness as a category, as suggested by environmental historians and critical race theorists, it does demonstrate the historical advantages of whiteness and maleness in relation to nature. It also begins to expand understanding of a history that, until recently, has been the sole domain of white men.

\section{Project Origins - Voices from the Forest}

This project began with stories and narrative remains central in shaping it. From 2000 to 2003 I collaborated with USFS to teach a Portland State University capstone class that gathered oral histories from retirees who worked for the agency from the

"Furthering the Environmental Turn," Journal of American History 100 (June 2013): 131-135; Elizabeth Blum, Linking American Women's History and Environmental History: A Preliminary Historiography, http://www.h-net.org/ environ/historiography/uswomen.htm; Virginia Scharff, "Man and Nature! Sex Secrets of Environmental History," 31-48 and Vera Norwood, "Constructing Gender in Nature," 49-62, in John Herron and Andrew Kirk, eds., Human/Nature: Biology, Culture, and Environmental History (Albuquerque: University of New Mexico Press, 1999).

120 Connie Y. Chiang, "Race and Ethnicity in Environmental History," in The Oxford Handbook of Environmental History, ed. Andrew C. Isenberg (Oxford University Press, 2014): 574.

$121 \quad$ Fiege, in Chiang, "Race and Ethnicity," 590. 
1920s to the 1960s. Between 2004 and 2007, in partnership with the Region 6

Workforce Diversity Council, my students interviewed former and existing employees, primarily women and people of color who joined the agency between the late 1960s and the 1990s. The preliminary interviews conducted by students included six with forest supervisors, 11 with civil rights and special emphasis program managers, and several with minority employees involved with diversity issues in the agency. Although not created as such, these interviews constituted a pilot project that demonstrated the importance of biography to understanding place and policy. As I listened to student interviews, I felt as though I had landed on an alien, yet familiar planet. The white male employees of the early years worked as packers, built trails and ranger stations, acted as forest guards and fire lookouts, and strung some of the first telephone lines across national forests. They were former CCC boys, foresters, and engineers, who had lived on agency compounds and often identified the Forest Service as family. These men proudly embodied the pro-use, pro-development, timber-oriented esprit de corps of Kaufman's Forest Ranger.

The new generation of agency employees also worked in the woods, identified with a Forest Service family, and demonstrated intense loyalty; however, they complicated the notion of esprit de corps. They represented a wide variety of occupations, advocated for consensual, rather than hierarchical decision-making, and espoused an obligation to work with one another and for the public. They also voiced a commitment to demographic representation that included difference rather than the homogeneity of early years. Like an ecosystem, the work, experiences, and feelings of 
women and minorities regarding the agency reflected disturbance and regeneration, punctuated alterations and equilibrium, and patterns of complex and diverse succession. As I listened to the stories of this new Forest Service population, I wondered: how did the agency go from its well-known clarity of direction to such complexity?

\section{Complexity and Methodologies}

To answer that question, I began to investigate stories of agency change from the 1960s through the end of the century, to construct a history of workforce diversity. The words "story" and "history" come from the Latin and Greek historia, meaning learning or knowing by inquiry. By its very nature, history calls for inquiry into multiple remnants of the past, and integrating quantitative and qualitative data, i.e., mixed methods. It requires evidentiary interpretative transparency and draws from the methodologies and knowledge of outside disciplines. Historians shape this inquiry into systematic narratives of the past, to manifest accounts of empirical reality grounded in evidence and meaning, not to prove or disprove hypotheses.

My work draws from historians, ethnographers, and sociologists, past and present, and I examine workforce diversity through multiple strands of historical evidence. This inquiry includes archival documents and ephemera, government reports, census data, and documenting the memories, perceptions, and experiences of former and existing female and minority Forest Service employees. Rather than a survey to measure distinct variables, I follow the lead of Herbert Kaufman, who examined a single ranger district in each of five regions around the country. Kaufman recognized that an ideal 
study would include a district from each of the country's ten regions; however, he decided that a range of districts, from large to small would provide a "considerable spread of conditions under which administration of the national forests is conducted."122 Kaufman intuitively determined this span of administration would reveal common features and "major patterns of influence in the Forest Service." And, he wrote, "It is with these patterns that the study is concerned." 123

Like Kaufman, I do not have the resources to study every region in the nation. I also believe that individual units can elicit and mirror historical events and patterns at various levels; community, agency, region, and even the nation at large. Region 6 , Oregon and Washington, has historically hosted the largest workforce in the country and has been the site where many agency "firsts" began or gained experience. Such "firsts" are important because they open doors and provide role models for others, and they are minimally visible in agency histories. The literature justifies studying individuals in leadership positions, because of their potential decision-making influence.

Consequently, I examine the history of workforce diversity through the lens of Region 6, using historical data, as well as individual interviews with agency and regional leaders, Civil Rights staff, and select women and minority employees.

I decided to use an iterative dialectical model of law, agency policy, and individual experience to achieve my primary goal - connecting social structure with human agency through historical narrative. Social structure refers to the systems of

122 Kaufman, Forest Ranger, 17.

123 Ibid, 18. 
culture and institutions or frameworks that bound the choices made by individuals with the capacity to act independently, i.e. exert agency. Individual choice and action are rooted in a cultural framework explained by Clifford Geertz, who believed “...with Max Weber that man is an animal suspended in webs of significance he himself has spun." Like Geertz, "I take culture to be those webs, and the analysis of it" is "not an experimental science in search of law but an interpretive one in search of meaning. It is explication I am after, construing social expressions on their surface enigmatical."124 Interviews from the pilot project set personal experience into the context of activity and meaning in an open-ended format that allowed for individual expression. As Frederick Mosher recognized, we know “too little about the relationship between a man's background and pre-employment socialization on the one hand and his orientation and behavior in the office on the other." Biographical, open-ended interviewing allows these elements to unfold in a way that makes sense to the narrator, and so provides a foundation for analysis at various levels using qualitative social science methodologies. (see Figure 2 below) 
Figure 2: A Model of Interactional Methodologies

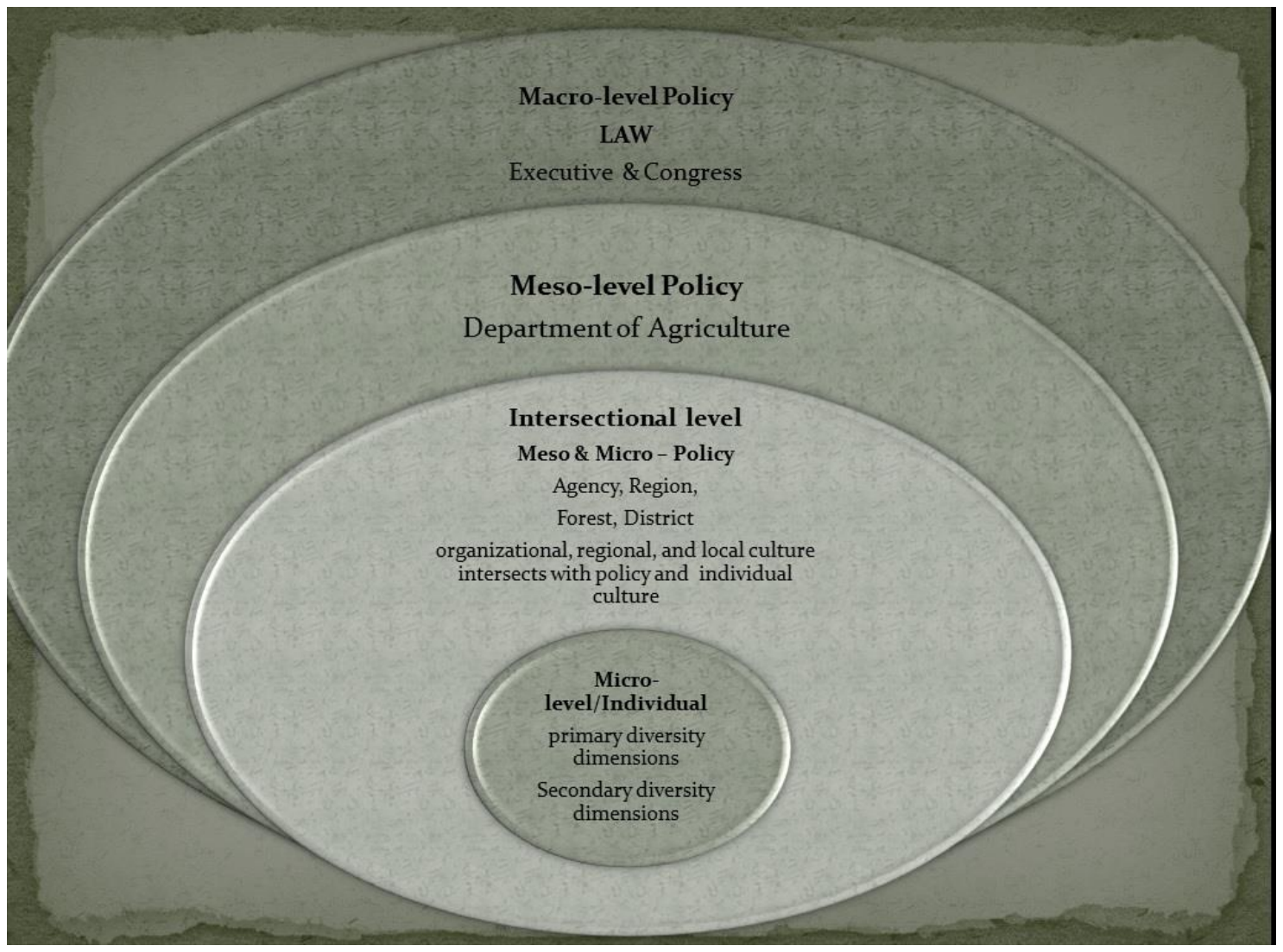

Using methodologies rather than a singular method allows me to pose questions about how people understand particular locales and the internal and external role of perceptions and attitudes in workforce diversity efforts. The stories of those who work for this public lands management agency are stories about nature, personal tales that demonstrate the call of forest and land. They become particularly important when interviewees recall the experiences that led them into the agency, whether youth programs, college recruitment, camping, hunting, or fishing, and whether they come from urban or rural environments. These stories also reveal attitudes and values, and provide a close look at how individual action and beliefs, combined with a strong 
measure of structural serendipity can increase diversity.

\section{The Research Process and Interview Methods}

After preliminary research, the bulk of archival data collection occurred in the archives of the Forest History Society (FHS) in Durham, North Carolina. In the fall of 2011, I scanned hundreds of documents related to workforce diversity in Region 6 and in the agency at large. The archives held documents related to national and regional policy, information about individuals and issues, and as suspected the materials reflected multiple entwinements between the Pacific Northwest and elsewhere. Most importantly, my visit to the FHS began a process of snowball sampling that expanded this history beyond a regional case study to one that does, indeed, investigate the experiences of individuals who have worked around the country. After a year of reviewing documents and thematic coding, using the software program Atlas Ti, I interviewed the first graduate of the Tuskegee Pre-Forestry Program, introduced to me by FHS executive director Steve Anderson. This interview set the foundation for my understanding of initial programmatic and non-programmatic efforts to diversify the Forest Service. It also led me to a host of other "first" African American employees, who because of equal employment policies in the late 1960s and early 1970s became "pioneers" of agency difference. It is with their stories, and those of their contemporaries, that the tale of entwined diversification in the U.S. Forest Service truly begins. Their connections to one another and to other minority firsts created trust relationships that allow me to flesh out this history of stasis and change. I subsequently interviewed 37 individuals, five who 
had participated in the pilot project, others including national and regional leaders, civil rights staff, and former agency employees.

The bulk of interviews occurred in person, but I also conducted three interviews via Skype and four by telephone. One narrator withdrew but did provide me with documentary information from the regional civil rights office. Appendix B, the Appendix of Interviews provides a comprehensive list of interviews with associated information, as well as the semi-structured interview instrument I developed for the project. I explored primary and secondary diversity dimensions and with some exceptions, narrators discussed individual and family background, significant historical events and social movements, outdoor youth activities, education, entry into the Forest Service, career path and influences, questions of mobility and agency culture (i.e., willingness to conform), and issues of representation appropriate to individual experience and/or position in the agency. Those who work in the civil rights arena of the agency or are in leadership positions bring "diverse streams of experience" into Region 6 and carry their Pacific Northwest experience elsewhere. Their interviews provided a link between social structure and human agency, from which patterns emerged.

As an oral historian, I follow the basic tenets of the Oral History Association, which include the importance of open-ended inquiry and preservation for the future. Thus, interviews ranged from 45 minutes to two and a half hours, with as much as five hours of audio for some narrators. I also adhere to qualitative research ethics that acknowledge the relational aspects of interviewing and call for collaborative coconstruction of narratives. I provided transcripts and excerpts for review to my narrators, 
negotiated inclusion of important information while respecting privacy, and in some cases used anonymous quotations to protect a narrator. I often tested emergent theoretical understandings of the project in subsequent interviews, with different narrators, through ongoing communication via email and telephone, and in writing. Finally, I continue to work with my narrators to determine the best location for long term preservation of their interviews, to make them accessible to other researchers and the U.S. Forest Service.

My approach to interview analysis incorporates lessons from historians and a broad subsection of qualitative analysts in the social sciences. I transcribed the interviews, listened to the audio against the transcript (auditing), and thematically and informationally "chunked" them for further analysis. Following Kathy Charmaz and Sharon Hesse Biber, I conducted line by line analysis on several interviews from each primary diversity category to identify general themes.I then used what Glaser and Strauss, following Herbert Blumer, ${ }^{125}$ call "sensitizing concepts" as I audited and reviewed the remaining interviews, including those conducted in the pilot project and by the Forest History Society. Unlike specific causal variables, sensitizing concepts emerge from the data through an inductive process. They alert the researcher to topics that, on the surface, may seem disconnected. ${ }^{126}$ Altogether, I reviewed more than seventy interviews, identifying specific historical information as well as latent and explicit

\footnotetext{
$125 \quad$ Herbert Blumer, "What is Wrong with Social Theory?" American Sociological Review, 19 (February, 1954): pp. 3-10.

126 Herbert Blumer, "Sociological Analysis and the 'Variable," American Sociological Review, 21, 6 (December 1956): 683-690.
} 
meanings. This approach to the history of workforce diversity provides the kind of close look at interactions between historical institutional macro-structures and individual agency that can result in policy learning. At the macro-level, it documents the implementation of major demographic shifts in this historically white and male organization. At the meso-level, it highlights workplace reforms that have facilitated workforce diversity, as well as changing ideas about diversity within and outside of the agency. At the micro-level, this study identifies factors that contributed to choosing, and sometimes leaving a Forest Service a career.

This study provides the kind of qualitative insight into representative bureaucracy that is missing from outcome based studies of passive and active representation. I recognize the importance of experimental methods and quantitative generalizations, but argue that understanding complex human action, especially in relation to social systems requires qualitative methods and analysis. In addition to the historians, anthropologists, and sociologists who developed, practiced, and theorized qualitative methods, I draw from numerous scholars who advocate naturalistic inquiry and interpretive policy analysis and evaluation. ${ }^{127}$ Finally, the work of critical race theorists who question notions of incremental change, critique the neutrality of constitutional law, and advocate telling stories and counterstories, also informs my

127 Interpretive Policy Analysis practitioners like Frank Fischer, David Paris and James Reynolds, Deborah Stone, Dvora Yanow, and Michael Quinn Patton among others, support interpretive approaches to policy analysis. Incorporating qualitative methods as explicated by Norman Denzin and Yvonna Lincoln, Valerie Yow, Catherine Kohler Reissman, Clanindin and Connelly (see bibliography) and other practitioners, can illuminate the values and attitudes of employees and community members that shape agency operations and policy outcomes at various levels. 
thinking. ${ }^{128}$ The significant thread through all of the analytical approaches is identifying meaning in story as a key to understanding the past and ourselves.

128 See Derrick Bell, And We Are Not Saved: The Elusive Quest for Racial Justice (New York: Basic Books, 1987); Richard Delgado, Critical race theory an introduction, second edition (New York: New York University Press, 2012); and Eduardo Bonilla-Silva, Racism Without Racists: Color-blind Racism and the Persistence of Racial Inequality in America (Rowman \& Littlefield, 2014). 


\section{Chapter 3: Workforce Diversification and the U.S. Forest Service, The Early Years}

The 1926 Cornell University yearbook includes a picture of Forestry Club

president Paul Howland Logan. "Slim" to his fellow students, Logan attended a

historically black college before transfer to Cornell where he obtained a five year

forestry degree and then joined the Forest Service. ${ }^{129}$ Logan would spend ten years as

chief lumberman of the Olympic National Forest in Washington State, participating in

cruising and mapping Washington forests, and then work for the Snoqualmie National

Forest before moving to Portland, Oregon. According to the 1940 census, the forester

Paul Howland Logan lived on Southwest $10^{\text {th }}$ Avenue, worked for the government, made $\$ 3,337.00$ in 1939 , was unmarried — and he was white. Sometime after 1920 and before

moving to the Northwest, this World War I veteran whose 1918 draft card identified him as "negro" officially changed both his birthplace and racial identity. ${ }^{130}$

Logan's story places the Forest Service squarely into the socio-historical context of race relations in the United States, and connects the agency with significant historical events past and present. It demonstrates specifically, and symbolizes metaphorically, limitations for African Americans in forestry, and the upward mobility associated with

129 Paul H. Logan - Rare and Manuscript Collections Images, Cornell University, http://insight.library.cornell.edu:8280/luna/servlet/detail/CORNELL 10 1 60170 111760:Paul-H-Logan [accessed June 22, 2013]. He attended Lincoln University. Although there are several Lincoln Universities in the U.S., I presume Logan attended the nearby Lincoln University in Pennsylvania that claims to have fostered interracial education from its inception, http://www.lincoln.edu/about.html [accessed June 22, 2013].

130 The 1900, 1910, and 1920 census all list Logan as mulatto and born in Tuskegee, Alabama. The 1930 and 1940 census, both taken in Washington State, identify him as white and born in New York. Although Cornell officially welcomed students of color from its inception in 1890, it is likely that Logan passed as white while at Cornell. The university was unaware of his race, although the school traces students of color. As university archivist Elaine Engst explained in an October 25, 2013 email to the author, no alumni folder is available, but Logan "seems to have been well-integrated into university life, serving as president of the Forestry Club and as the Business Manager of The Cornell Forester." 
maleness and light skin color. Born in Tuskegee, Macon Alabama in 1899, Paul Logan came from a racially mixed and educated family. His grandmother, Mariah "Cherokee Lilly" Hunt, a "free woman of color" lived in Georgia with her common law husband Captain Henry Alexander Hunt, a tanner and slaveholder who served in the Confederate Army. Together, they had eight children, including Logan's mother, Adella Hunt, a teacher at Tuskegee Institute who married fellow educator Warren Logan. Adella died in 1915, but Warren worked at Tuskegee until 1942 and taught bookkeeping, choral singing and band. He also served as treasurer, business manager, and sometimes acting principal in Booker T. Washington's absence. Before he entered forestry, Paul Logan who served in a segregated military and grew up at Tuskegee, worked there as an instructor of soldiers. ${ }^{131}$ Today, the Forest Service identifies Paul Howland Logan as its first African American forester.

When he joined the agency in the 1920s, Paul Logan faced limited choices. Aside from a small middle class of business owners, historically most African American men worked in manual labor or on railroads, while women drudged as domestics. Race shaped occupation tremendously, and in the segregated South where the "one-drop" rule applied, kinship determined race as much or more than skin color. Away from the South, light skinned African Americans might "pass" as Caucasian but often had to leave family and culture behind. Logan's mixed heritage and light skin provided an entrée into professional forestry, an avenue closed to most African Americans well into the twentieth century.

131 U.S., World War I Draft Registration Cards, 1917-1918 for Paul H Logan. 


\section{Unequal Opportunities in the Mid-twentieth Century}

For Southern Blacks, forestry connoted hard, dirty labor, with no association to upward mobility or possibility of authority. By 1910, African Americans constituted 25 percent of all forest industry employees. They typically worked as loggers, sweated in sawmills, or harvested and processed pine tar in the naval stores industry, a business that grew, as Josh McDaniel writes "primarily through the labor of former slaves and their descendants." In fact, after the Civil War, Blacks composed 80 percent of the southern turpentining workforce, toiling under severe conditions at lower wages than whites while living on turpentine plantations that perpetuated debt. Woods workers received minimal wages, lived in remote areas in poor housing, and relied on a harsh company store system for provisions. ${ }^{132}$ This peonage system, inadequate pay, and tough, grimy work placed lumbering alongside cotton picking, so that Blacks wanted out of the forests and into the professions. Many who later worked for the Forest Service recalled this outlook personally and communally. With few positive associations, it would take desegregation policies and a program of affirmative action to bring people of color-and women - into natural resource occupations in the latter third of the twentieth century.

As John D. Guthrie noted in a 1920 article in the Journal of Forestry, women served successfully as lookouts and guards during World War I. Because of woman suffrage, he determined, "an eventual certainty we may have some time not only female

\footnotetext{
132 James Lewis, "A Brief History of African Americans in Forestry," available at http://www.fs.fed.us/people/aasg/PDFs/African_Americans_and_forests_March21\%202006.pdf [accessed November 4, 2013]; Josh McDaniel, "Voices from the Turpentine Woods," Southern Quarterly (Fall 2008): 109-118, p. 109.
} 
forest guards but female forest rangers and even supervisors." ${ }^{\text {133 }}$ Throughout the century, the wives of forest rangers often labored alongside their spouses on agency compounds and in the field, typically as unpaid workers who provided a double bang for the government buck. A number of women obtained forestry degrees in the 1920s and 1930s, including Alice Craig, who graduated from University of California School of Forestry in 1928 and recalled "great resistance to her 'invasion' of a man's world.",134 Despite this informal and formal service, a 1950 employment bulletin explained that women were "not encouraged to apply" for field work or junior forester positions, even with forestry degrees. Rather, women were better suited to tend to agency business as part of clerical staff, with ample opportunity to work under male chief clerks as typists, auditors, stenographers, accountants, mail and file clerks, or property clerks, etc. Very clear agency policies ensured that opportunities for "women to advance beyond secretary [were] very limited." Although a few women worked as female botanists or statisticians, the agency declared, "The field work of the Forest Service is strictly a man's job because of the physical requirements, the arduous nature of the work, and the work environment."

Meanwhile, the federal policies that shaped admission into forestry for women and people of color from the 1930s through the early 1960s illustrate several significant issues. First, the experiences of women and minorities in relation to forestry demonstrate

\footnotetext{
133 John D. Guthrie, “Women as Forest Guards," Journal of Forestry 18 (February 1920): 151.

134 Excerpts from California Forester, 1979 and 1980 issues, in Women in Forestry, 5, no. 2 (Summer 1983): 2.

135 "A Job With the Forest Service: Information about Permanent and Temporary Jobs with the U.S. Forest Service," printed ca. 1950, File, "Women in FS - Employment Policies," Forest History Society, Collection F18.4.
} 
representative bureaucracy in action. Secondly, limited entry points to the Forest Service demonstrate the need for affirmative action and the role of government in effecting social change. Finally, with ongoing struggles to incorporate non-traditional employees into natural resource occupations, an historical perspective is critical to entwined diversification for federal agencies in the next century.

Separation and Equality, the Roots of Affirmative Action

The Fourteenth Amendment to the Constitution calls for equal protection under the law, but the Supreme Court has always interpreted equality through contemporary filters. In Plessy versus Ferguson (1896), the famous “separate but equal” case, Justice Henry Brown wrote, "If one race be inferior to the other socially, the Constitution of the United States cannot put them upon the same plane."136 Thus, the government upheld the constitutionality of separate but equal public facilities and refused to promote racial "co-mingling." However, for the dissenting Justice, John Marshall Harlan, the Constitution was "color blind, and neither knows nor tolerates classes among citizens." He admitted to social distinctions, but reminded the Court that with "respect to civil rights, all citizens are equal before the law." This dissent would provide a roadmap to legal, if not social equality in the half century to come.

136 Terry Anderson, The Pursuit of Fairness: A History of Affirmative Action (New York: Oxford University Press, 2004): 4. 
Following Plessy, "separate" became legal in much of the nation, with the “equal” part typically far behind. ${ }^{137}$ For example, Oregon's 1857 constitution excluded Blacks from the state altogether. The state also banned them from land grants, imposed special taxes, and prohibited interracial marriage among several groups, some laws not repealed until the 1950s. Although nearby Washington outlawed racial discrimination, segregation persisted in employment, housing, and other social areas. Many states enacted legislation on activities that ranged from who could vote to where people of color could live to the cost of car insurance, among other restrictions. Meanwhile, the 1882 Exclusion Act restricted Chinese entry to the U.S. for ten years, a law extended in 1892, made permanent in 1902, and not repealed until 1943. Early twentieth century immigration law incrementally excluded the poor, illiterate, physically and mentally disabled, and most of the world's people of color from the United States. By 1917, immigration restrictions tightened dramatically but exempted Mexicans, whose labor the nation needed. In 1924, the law banned ALL Asians from entering the U.S., including those from the Philippines, and excluded Asians from naturalization and citizenship, from owning land, and from marrying Caucasians. Many Western states, including Oregon and Washington had also passed alien land laws. Although the U.S. repealed Chinese exclusion during World War II, it took until the 1952 McCarren-Walter Act to remove any vestiges of the "aliens ineligible" clause for naturalization to U.S.

\footnotetext{
137 Anderson, Pursuit of Fairness, 2. Plessy v. Ferguson (No. 210), Harlan J. Dissenting Opinion, 163 U.S. 537, argued April 18, 1896, Decided May 18, 1896. Cornell University Law School, Legal Information Institute, http://www.law.cornell.edu/supct/html/historics/USSC_CR_0163_0537_ZD.html [accessed June 28, 2013].
} 
citizenship. Nor did large scale migration from outside Western Europe occur until after the 1965 immigration act repealed national origin quotas. ${ }^{138}$

In the interim, a series of incremental legal changes contributed to affirmative action policy. When Paul Howland Logan entered the Forest Service in 1928, the notion of equal employment opportunity remained distant. Over the next several years, an incipient "racial liberalism" began to develop as part of the emerging welfare state of the 1930s. Racial liberalism, as defined by Elizabeth Escobedo, emphasized "the redress of racial inequality through antidiscrimination litigation and legislation." It attempted "to discredit biological assumptions of racial hierarchy and sought an expanded role in improving the plight of racial minorities in America." ${ }^{139}$ In fact, some organizations, like the National Association for the Advancement of Colored People (NAACP) and the Urban League, pushed for racially liberal work policies in federal New Deal programs and the 1933 Unemployment Relief Act included an important and now familiar clause: "no discrimination shall be made on account of race, creed, or color."

Representative Bureaucracy, the New Deal, and Racial Liberalism

The actions of individuals in leadership positions during the New Deal reveal how representative bureaucracy may operate in the administrative branch of government. Illustrations of representative bureaucracy in action reinforce the

138 Takaki, 187; Jerry Garcia, "Japanese and Mexican Labor in the Pacific Northwest, 1900-1945," in Memory, Community and Activism: Mexican Migration and Labor in the Pacific Northwest, (Julian Samora Research Institute, 2005): 103-104; William G. Robbins and Katrine Barber, Nature's Northwest: The North Pacific Slope in the Twentieth Century (Tucson: University of Arizona Press, 2011). 139 Elizabeth Escobedo, From Coveralls to Zoot Suits: The Lives of Mexican American Women on the World War II Homefront (Chapel Hill: University of North Carolina Press, 2013): 6. 
importance of individual personalities and racial ethnic representation in the administrative arm of government. For example, Interior Secretary Harold Ickes, onetime president of the Chicago NAACP, desegregated facilities at the Interior Department and urged other department heads to do so. In 1933, Ickes appointed two aides on Negro affairs to his staff, one a black economist, Robert C. Weaver, the other a white liberal Georgian, Clark Foreman. He also prohibited discrimination in federal public works projects, and in 1934 Weaver and Foreman required contractors to hire a fixed percentage of black skilled workers in cities with an "appreciable Negro population." The quota clause of the Public Works Administration's housing division required skilled black workers to receive a portion of the payroll that corresponded with at least half their percentage in the civilian labor force. Robert Weaver noted that this system set a prima facie criterion to identify discrimination. "If the contractor does not live up to this requirement, it is accepted — until disproved — that he is discriminating against colored workers. Instead of Government's having to establish the existence of discrimination, it is the contractor's obligation to establish the absence of discrimination.",140

The World War II period incrementally reinforced the racial liberalism begun during the Great Depression, as a series of nondiscrimination acts and executive orders passed to bring women and people of color into the workforce and reinforce scientific administration notions of merit. The 1940 Ramspect Act prohibited discrimination based

140 Robert Weaver in Wolters, "New Deal and the Negro," 31. 
on race, creed, or color in federal employment. ${ }^{141}$ The same year, President Roosevelt's Executive Order 8587 amended the 1883 Civil Service Act to prohibit questions regarding religion or political affiliation on employment exams. Perhaps most importantly for people of color, EO 8587 abolished the Civil Service application photograph. ${ }^{142}$ Still, it took A. Philip Randolph threatening the president with a 100,000 protester march on Washington to add muscle to non-discrimination law. In 1941, Roosevelt issued Executive Order 8802 and created the President's Committee on Fair Employment Practices (FEPC). The FEPC forced the issue of employment equality regardless of race for those who received public monies in the civic and private sectors. By setting terms and conditions for federal contracts, regulating the Civil Service, and investigating complaints, the FEPC established critical enforcement tools for achieving equal employment objectives. ${ }^{143}$ And, as ideas about fair employment practices evolved, by 1945 more than twenty states passed laws that banned discrimination. ${ }^{144}$

When the war ended that year, the FEPC ceased operations; however, the federal focus on nondiscrimination and complaint investigation laid the foundation for later legislation. Subsequent laws would require affirmative steps to enhance employment conditions rather than simple inaction to avoid discrimination. Under EO 9980 in 1948, President Truman established another investigative body, the Fair Employment Board

141 Katherine C. Naff, Norma C. Ricucci, and Siegrun Fox Freyss, with the assistance of David H. Rosenbloom and Albert C. Hyde, Personnel Management in Government: Politics and Process, Seventh edition (Boca Raton, Florida: Taylor \& Francis Group, LLC, 2014): 326.

142 Kellough, Understanding Affirmative Action, 23; Margaret C. Rung, Servants of the State:

Managing Diversity and Democracy in the Federal Workforce, 1933-1953 (Athens \& London: University of Georgia Press, 2002).

$143 \quad$ Anderson, Pursuit of Fairness, 56; Kellough, Understanding Affirmative Action, 26.

$144 \quad$ Ibid, Kellough, 47. 
(FEB). Although it did not use the term affirmative action, the FEB sought to increase the minority presence in the federal workforce through proactive outreach to minority organizations and improved training for low level workers. The Truman administration also desegregated the U.S. military, an action that historian Terry H. Anderson equates with taxpayer ability to serve in agencies that were (and are) funded by all citizens; that is, representation.

Representation: Women, Minorities and Public Forestry, the Early Years

Administrative decisions made during the Great Depression at the executive, legislative and agency levels, exemplify internal workings of representative bureaucracy, as well as the disparate benefits the government provides to or withholds from certain groups. Women officially worked for the federal government for the first time between 1862 and 1868 when the Treasury Department hired a number of "lady clerks." It did not take long before legal inequalities arose that maintained the status and power of white males. By 1870, Congress passed a law that allowed department heads to determine pay rates for women clerks "at their discretion." Although the Civil Service Act of 1883 established the merit system, the discretionary salary policy meant that women typically received half the pay of men. The "lady clerks" made $\$ 600$ per year, while male clerks received between $\$ 1200$ and \$1800 annually. A 1923 "Classification Act" furthered the merit concept and introduced the notion of equal pay by determining 
salary on the basis of position duties and responsibilities; however, the 1870 law remained in effect and women continued to receive unequal pay in federal service. ${ }^{145}$ By 1933, the economy crashed, wages sank, and unemployment reached an unprecedented 25 percent, with 13 million people out of work. As David Kennedy points out, "if misery was widespread, its burdens were not uniformly distributed."146 Rural Americans, people of color, and immigrants experienced the highest job losses, while white men maintained priority in employment cutbacks. The Economic Recovery Act of 1933 slashed government programs, reduced federal workers' and veterans' salaries, and identified married female federal employees as "secondary" earners. If the government employed a husband and wife, the law called for firing one of them, and approximately 1,600 female government employees lost their jobs by $1937,{ }^{147}$ a ruling that carried into the state and private sphere. Not only did the federal government hack women's jobs first, many states passed laws to fire and ban married or pregnant women, regardless of family situation or need. Because the Attorney General ruled in 1934 that agencies could request men or women only for certain positions, men filled most professional and executive positions. They also held positions that required travel, were dangerous or challenging, called for public contact, and those that required working

145 Helene S. Markoff, "The Federal Women's Program” Public Administration Review, 32, no. 2 (Mar-Apr., 1972): 145.

$146 \quad$ David M. Kennedy, Freedom From Fear: The American People in Depression and War, 19291945 (New York: Oxford University Press, 1999): 164.

$147 \quad$ Susan Ware, "Women and the New Deal," The Great Depression and the New Deal: Minorities and Women During the Great Depression, Melvin Dubofsky and Stephen Burwood, eds. (New York: Garland Publishing, Inc.): 33-349, p. 338. 
outdoors. ${ }^{148}$ Consequently, New Deal programs prohibited women-the "weaker sex"from engaging in outdoor work, and because economic recovery programs emphasized conservation and construction projects, women experienced the worst aspects of the Depression. As Ellen Sullivan Woodward who headed the Women's Division of the Federal Emergency Relief Association noted, "It was harder to find 500,000 jobs for women than it was to find four million jobs for men."149

Unemployment also hit minorities first, hardest, and in higher proportions than Whites. For example, Chicago's African Americans constituted 16 percent of the unemployed, but only four percent of the population. When Pittsburgh's steel factories closed, the eight percent African American population accounted for 40 percent of the city's unemployed. ${ }^{150}$ Women of color fared worst of all, often earning half the wages of white women for the same work, even as all women earned less than men. ${ }^{151}$ Immigrants faced additional difficulties and some voluntarily returned to their countries of origin, while others left less willingly. ${ }^{152}$

The Civilian Conservation Corps, Minorities, and the She-She-She

While the nation's unemployment remedies included multiple public works programs, Emergency Conservation Work (ECW) and the CCC provided the strongest

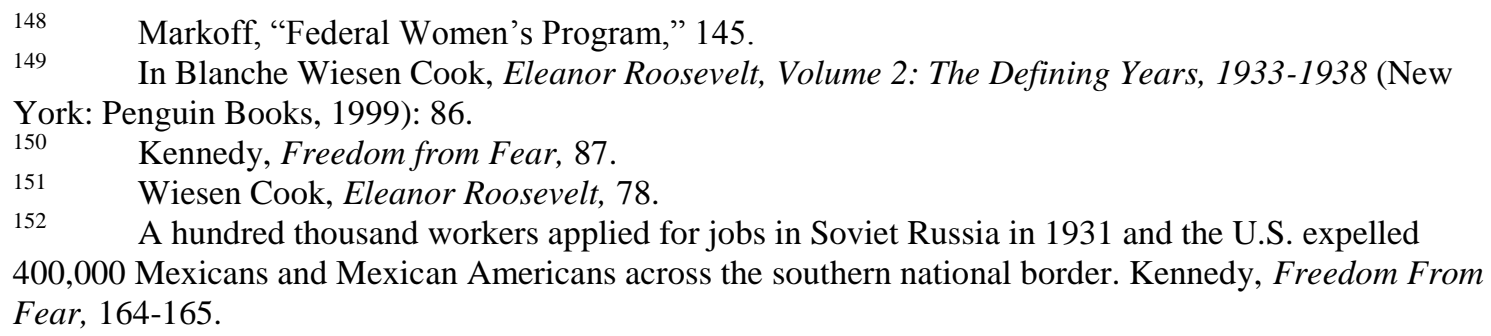


connection to forestry in the public sector. Examining these programs demonstrated the public impact of individual administrators in bureaucratic systems and the limitations placed on women and minorities in natural resources. The ECW, headed by the southern-born Robert Fechner, included the CCC organization of junior enrollees, war veterans and local experienced men in barracks camps as well as the American Indian Corps and camps in Hawaii, Puerto Rico, Alaska, and the Virgin Islands. Run by the Departments of War, Labor, Agriculture, and Interior, ECW also collaborated with the Veteran's Bureau and Department of Labor, both of which selected enrollees. Between 1933 and its demise in 1942, up to 3 million individuals worked under ECW in the nation's woods, grasslands, national, and state parks. Enrollees worked under supervision of a number of land management agencies, including the Soil Conservation Service and National Park Service but over the course of its life, the Forest Service administered nearly half the work projects of the CCC. This put approximately 1.5 million men in contact with the agency and introduced them to woods work, including about 100,000 African Americans. ${ }^{153}$

The CCC housed young men ages eighteen to twenty-five in two hundred-man camps operated by the U.S. Army. More than half of enrollees came from rural America, only 13 percent had high school diplomas, and 45 percent had never held jobs before. Consequently, the CCC helped families in need, benefited communities by purchasing goods and services in local economies, and provided skills that youth carried into the future. According to John Salmond, vocational training and guidance, work experience,

153 Steen, U.S. Forest Service, 215. 
education, and dental care "in the CCC brought corpsmen better health and a second chance... ${ }^{154}$ Perhaps most importantly in this hungry era, the CCC provided families with $\$ 25.00$ of an enrollee's $\$ 30.00$ monthly pay, housed them, and served the famished three hearty meals a day. As Henry Coe Lanpher pointed out in 1936, the "life-saving values inherent in adequate food, clothing, housing, and medical care" are evident in the disparity between death rates of CCC enrollees and "White enlisted men" of the same age: 2.87 versus 8.07 per thousand. ${ }^{155}$

Still, the CCC did not distribute its benefits equally to those most drastically impacted by the nation's economic downturn — women and people of color. Congress specified the basic requirements for enrollment: unemployment, citizenship, and no convictions for crime. Oscar DePriest, the only African American in Congress, also amended the organization's enabling act to bar discrimination based on race, color, and creed. ${ }^{156}$ The ECW director determined other policies. Enrollees must be unmarried males, from seventeen to twenty-eight years old, ${ }^{157}$ members of families on public relief, must have dependents by "blood or obligation," and could not be on probation or parole. These decision points demonstrate the administrative power to facilitate or limit access to public goods and services. ${ }^{158}$ Not only did the enabling legislation fail to bar sex

154 John A. Salmond, "The Civilian Conservation Corps and the Negro," The Journal of American History 52, No. 1 (June 1965): 75.

155 Henry Coe Lanpher, "The Civilian Conservation Corps: Some Aspects of Its Social Program for Unemployed Youth," Social Service Review 10, no. 4 (Dec. 1936): 625, 630-631.

$156 \quad$ Anderson, Pursuit of Fairness, 11-12; Weisen Cook notes that Oscar DePriest of Chicago, the only African American in Congress introduced the CCC amendment that read, "No discrimination shall be made on account of race, color or creed," but not sex, 88 .

157 Age limits varied during different periods in the life of the CCC.

158 Lanpher, "CCC Aspects," 627. 
discrimination, but despite suggestions by Eleanor Roosevelt and her group of likeminded women, the organization provided little relief or opportunity for women.

The first lady and her female associates envisioned a parallel corps for needy young women. The program would include outdoor recreation, education, and environmental and social work, but their efforts never fully materialized. Instead, from 1934 to 1937 the government funded a program mockingly known as "She-She-She." Unlike the CCC, the program performed minimal conservation work and did not train women for jobs. Camps varied by region, including one for sharecropper's daughters in Arkansas, a New Jersey camp for professional women, one in the Ozark Mountains, and a camp for Native women in North Dakota. Overall, the She-She-She helped up to 8,500 women; however, it never achieved the kind of broadly defined two year program of voluntary service and education sought by Mrs. Roosevelt. Some call the women's program a female $\mathrm{CCC}$, but it differed significantly. Rather than earning a dollar a day like the CCC "boys" for work performed during renewable six-month terms, the women's camps, ninety of them, provided fifty cents a week and permitted only a three month stay. They provided food, shelter, recreation, some education, and temporary solace for destitute women. But, with no basis in publicly valued work, or even family assistance, many viewed the "She-She-She" experience as a "camp vacation at the taxpayer's expense." 159

159 Jane Kahrmandis, "The She-She-She Camps of the Great Depression," History Magazine (March 2008): 13. 
Minorities also experienced the CCC differently than white males. Historians

have documented participation by Hispanics, Native Americans, and African Americans, but have almost completely ignored Asian Pacific American participation. ${ }^{160}$ Some, including Japanese, Chinese, and Filipinos in California joined the CCC, but unlike Native and African Americans they did not have separate programs. ${ }^{161}$ Nor, as Olen Cole, Jr. pointed out in 1999, did Hispanics constitute "special enrollees" or a single group in California. ${ }^{162}$ Maria Montoya did find some differences in New Mexico, where semi-integrated camps composed primarily of "Spanish-Americans" or "Hispanos" put enrollees into barracks separated by language and ethnicity. According to Montoya, despite "racist attitudes" in "the ranks of the New Deal's administrators," 163 the CCC

160 The Territory of Hawai'i, described by Director Fechner in 1938 as "cosmopolitan," differed from the mainland CCC. It included Japanese, Chinese, Filipinos, and Hawaiians, with men of twentythree different nationalities living and working together. Kathryn Ladoulis Urban and Stanley Solamillo note that the CCC began in Hawaii a full year after the program started on the mainland and that between 1934 and 1942, 7,195 young men served. "Civilian Conservation Corps In Hawai'i: Oral Histories of the Haleakalā Camp, Maui," prepared for Haleakala National Park, NPS Contract \#C8298090010, Honolulu, Hawai'i, Final Report July 20, 2011, National Park Service Website, http://www.nps.gov/hale/historyculture/upload/CCC-Oral-Histories-of-Haleakala-Camp.pdf [accessed September 19, 2013], pp. 14, 18, 47. Like Hawai'i, the territories of Puerto Rico and the Virgin Islands also drew from local populations, as did Alaska to some degree. Ronald Takaki, A Different Mirror: A History of Multicultural America (New York: Little, Brown, and Co., 1993, revised 2008): 180-188; Some Asian Americans participated in the Federal Arts Project, "Asian Americans and Citizenship," Claiming Citizenship Website, https://sites.google.com/site/claimingcitizenship/home/asian-americans, New Jersey Council for the Humanities, funded by National Endowment for the Humanities.

$161 \quad$ An image sent to me on September 20, 2013 by Jordan Wong of the Wing Luke Asian Museum in Seattle, Washington shows an integrated company in the CCC near San Francisco, where his deceased grandfather served. Inspection of the photo shows approximately ten or more people of color, including one who may be African American. It is likely that more than ten of the fifty-eight CCC men in the picture are Hispanic or Asian, as it is impossible to identify race and ethnicity accurately through images, especially black and white images from the 1930s.

$162 \quad$ Olen Cole, Jr. The African American Experience in the Civilian Conservation Corps (University Press of Florida, 1999): 17.

163 Maria Montoya, "The Roots of Economic and Ethnic Divisions in Northern New Mexico: The Case of the Civilian Conservation Corps, Western Historical Quarterly, 26, no. 1 (Spring 1995): 28. 
and other public works programs heavily impacted northern New Mexico, one of the poorest parts of the country. The organization put nearly $\$ 6$ million directly into enrollees' family coffers and added another $\$ 57$ million to the economy at large. For New Mexican Hispanos, the CCC provided limited education, an opportunity to improve spoken English, and job skills that made the CCC a turning point in the lives of many. ${ }^{164}$

The Indian CCC also provided job skills, limited educational opportunities, and some relief for individuals and communities during the Depression. With John Collier in charge of the Bureau of Indian Affairs (BIA), the government created the "Indian CCC" on two important factors: reservations needed conservation work and Natives would not welcome white enrollees to do it. Thus, the Indian CCC constituted a separate ECW program. The government allocated \$6 million for reservation work and Collier quickly established district offices on Native lands from Minnesota to Oklahoma, Arizona to Washington, and Montana to New Mexico. Work began in July of 1933 with tasks that included archaeological digs, reforestation, weed eradication, pest control, and construction of dams, reservoirs, and lookout towers, depending on the landscape. ${ }^{165}$ Three camp/work combinations reflected local needs and BIA supervisors' inclinations. American Indian enrollees included unmarried and married men over age eighteen. ${ }^{166}$ Most single males lived in boarding camps similar to those of the regular CCC, while others went to seasonal camps that moved from place to place. Married camps allowed

\footnotetext{
164 Montoya, "Economic and Ethnic Divisions," 26.

165 Donald L. Parman, "The Indians and the Civilian Conservation Corps," Pacific Historical Review, 40, No. 1 (Feb. 1971): 41-45.

166 Parman, "Indians and the CCC," 41-45.
} 
couples and their families to live near work sites and to receive a $\$ 12.00$ commutation allowance in addition to the usual $\$ 30.00$ monthly salary. Others yet lived in "home camps," and traveled daily to work sites. Thus, although conditions varied, the Indian CCC aimed to maintain and support family and culture, alongside reservation improvements. ${ }^{167}$

\section{Policy Implementation and Representation - African Americans in the CCC}

Policy development and implementation in the African American CCC illustrates the relationship between racial politics and the sometimes arbitrary dispensation of government benefits. It also reinforces the significance of representation and advocacy in equal employment opportunity. While the basic structure of the Indian CCC clearly differed, the black CCC appeared to mirror the mainstream organization. It employed young men, put them to work in the nation's woods and grasslands, and sent money home to their families. Black CCC enrollees lived in barracks, performed conservation work, ate well, and learned useful skills. Like other minorities, abject poverty and deplorable living conditions had worsened for African Americans during the Depression. In the North, as John Salmond notes, the old adage " "first fired, last hired' rang bitterly true," and in the South deprivation increased as White men took over traditionally "Negro jobs" like street cleaning and garbage collection. ${ }^{168}$ As government policies reduced crop production, many southern landowners also evicted African 
American tenant farmers. ${ }^{169}$ By 1933, black unemployment rates doubled the national average, and with more than two million on relief, as was true for all of Roosevelt's “Tree Troopers," the CCC helped African Americans. For the 200,000 Blacks who participated over its lifetime, the benefits of food, shelter, dental care, and education, alongside a sense of purpose and lifelong skills, were immeasurable.

African American participation in the CCC subverts notions that Blacks won't work in the woods, while illustrating the systemic origins of segregation in public forestry. Despite an emergent racial liberalism, Blacks faced continued limitations exacerbated by the white power structure during the Great Depression. Although Hispanics and Asians held semi-integrated status, CCC policies prevented nationwide integration by African Americans. Even as leadership at various levels struggled with contradictory values related to anti-discrimination, representation, and U.S. social systems, CCC administrators developed strict segregationist policies for the "Negro CCC."

Trouble began with the enrollment process in the South and quickly cemented national limitations. State administrators from Georgia and Mississippi to Florida and Arkansas to Alabama refused to select black enrollees altogether. Jessie Thomas of the Atlanta Urban League complained in May 1933 that no Negroes had been included in the first fifty men selected from the 60 percent African American Washington

\footnotetext{
169 From 1930 to 1940 , the number of black tenant farmers diminished by 192,000, yet a mere 3,400 African American farmers received resettlement loans. Raymond Wolters, "The New Deal and the Negro," The Great Depression and the New Deal: Women and Minorities During the Great Depression, Melvin Dubofsky and Stephen Burwood, eds. (New York: Garland Publishing, Inc.): 18, 20.
} 
County. ${ }^{170}$ Neither did nearby Clarke County, Georgia enroll any Blacks. Officials claimed that African Americans were already hard at work in the cotton fields and the economy needed their labor. Besides, as one bureaucrat explained, “'there are few negro families who need an income as great as \$25 a month in cash." ${ }^{\prime 171}$ When pressured for inclusion, Florida's relief director claimed lack of "merit" precluded African American selection. The Arkansas State director denied discrimination, reporting that, in fact, three Negroes had been selected. That number rose only when Department of Labor Selection Director Frank Persons threatened to completely withhold CCC funding from Arkansas, a tactic he also used in Alabama and Georgia. ${ }^{172}$ This "unusual exertion" to effect meager enrollments state by state, Salmond explains, "portended what was to follow as the CCC tried to place its African American enrollees in work camps throughout the country." ${ }^{, 173}$ Frank Persons' advocacy for equality also pitted him repeatedly against CCC Director Robert Fechner.

During the program's first year and a half, the CCC permitted some integration in the West and Northeast, especially in areas with low black populations. ${ }^{174}$ At times, it also placed black companies near white communities, where Blacks faced exclusion. In Belton, Montana, for example, merchants often posted "We cater to white trade only"

\footnotetext{
$170 \quad$ In Salmond, "CCC and the Negro," 77.

171 De la Perriere in Salmond, "CCC and the Negro," 78.

172 Olen, Cole, Jr., African American Experience, 14.

173 By June 12, enrollment reached the following by state: Georgia, 178; Alabama, 776; Mississippi, 46 or $1.7 \%$ of the total enrollment in a state more than 50 percent Black. South Carolina, also 50 percent Black, had the best record with African Americans comprising 36 percent of enrollees. Salmond, "CCC and the Negro," 79.

$174 \quad$ Salmond, "CCC and the Negro," 80.
} 
signs upon hearing about African American enrollees nearby. ${ }^{175}$ By the end of 1934 , organizational integration efforts ended and policies of "rigid segregation and confinement to the home state" alongside quotas became entrenched. ${ }^{176}$

As complaints about Negro camps poured into the national office, it became clear that many white communities wanted neither integrated camps nor segregated camps nearby. ${ }^{177}$ Stated reasons varied but were clearly rooted in fear of the unfamiliar and sexualized stereotypes about black men. Residents of numerous communities worried about changes to "social values" and predicted "drunkenness" and "social vices" in groups of single black men. In Contra Costa, California, where Paul Logan would later settle, ${ }^{178}$ inhabitants complained about intoxication amongst black CCC enrollees. Although never reported formally, neighbors described the camp as "a menace to the peace and quiet of the community." ${ }^{179}$ Washington D.C. residents feared an African American camp near a residential area where "women are left alone." In Thornhurst, Pennsylvania, citizens petitioned Fechner "righteously and vigorously" to prevent the Negro CCC from establishing a camp, and pointed to the "social danger of "isolating so great a number of unattached Negro males' in an area occupied 'permanently and exclusively by white people." These Pennsylvanians articulated the same phobias so skillfully documented by Ida B. Wells in Southern Horrors (1892), what historian Patricia Schecter identifies as "white supremacist sexual politics" in service of

175 Olen Cole, Jr., African American Experience, 4, 14, 16.

176 Salmond, "CCC and the Negro," 80.

177 Ibid, 79.

178 Paul Logan moved to Contra Costa County to work for the Forest Service sometime before 1950. 179 Salmond, "CCC and the Negro," 80. 
maintaining the economic and political order. ${ }^{180}$ Thornhurst residents wrote that they did not want to put black men in contact with the "“scores of boys and girls just attaining youth and early womanhood who should not be exposed to dangers that are possible, if not indeed, probable. $", 181$

Under community pressure to relocate camps on the one hand and demands by black organizations to increase enrollment on the other, in late 1934 Fechner ordered an investigation. The U.S. Army undertook the task and reported Northeast integration and strict Southern segregation. It also found many African Americans in companies outside of their home states, in direct opposition to policy. In response, Fechner ordered repatriation of all African Americans to their home states and ordered strict segregation in all corps areas. ${ }^{182}$ White camps must replace exiting CCC boys with white enrollees. The report showed that:

...local authorities were using a definite quota system [emphasis added] in the selection of Negro CCC enrollees. Negroes were chosen in most areas only as vacancies occurred in Negro camps. Furthermore this quota system had been established with the direct cognizance and encouragement of area and district military authorities. Several state selection agents reported to Persons that Army authorities had refused to accept colored selectees because they had 'no vacancies for colored men,' and actually had notified selection agents how many, if any, colored enrollees were required from each particular district. ${ }^{183}$

The army confirmed that Fechner's policies subverted both provisions of the CCC Act and repeated instructions by Frank Persons to accommodate "all colored eligibles," even

180 Patricia Schecter, “The Anti-Lynching Pamphlets of Ida B. Well, 1892-1920” Illinois During the Golden Age Website, Northern Illinois University, 2007, http://dig.lib.niu.edu/gildedage/idabwells/pamphlets.html [accessed September 20, 2013].

Salmond, "CCC and the Negro," 80.

182 Ibid, 83 .

183 Ibid. 
if it required camp reorganization. This was no voluntary segregation situation. Rather, CCC policy setting demonstrated the concrete impact of the very stereotypes that would vex future Forest Service employees.

Fechner's decisions resulted in further constrictions on CCC access for African Americans through the mid-1930s, as separate black/white camps became the CCC standard in 1935. Fechner's quota ruling of September 10, 1934 held, and when the organization expanded that year, the increase applied primarily to Caucasians. State directors could neither enroll African Americans without individual openings nor develop new camps. When Persons refused to implement segregationist quotas, Fechner went to President Roosevelt who called the issue "political dynamite," and quietly approved the policy, asking simply to keep his name out of it. Implementation of quotas to limit CCC participation by race proceeded.

That same year, the 1935 National Labor Relations Act prohibited employers from "unfair labor practices." The law called for employers to take "affirmative action," when needed, to place people at the level they would have been without discrimination. ${ }^{184}$ Still, like Southwestern Hispanics and reservation-based American Indians, black enrollees received limited educational and vocational opportunities. The Corps trained them for, and helped them find jobs as gardeners, poultry farmers, cooks, janitors, waiters, or chauffeurs, jobs appropriate to their contemporary racial station. It

\footnotetext{
184 Anderson, Pursuit of Fairness, 14-15; The 1939 Hatch Act made it unlawful to deprive someone of employment "on account of race, creed, [or] color" when such employment came from congressional allocations. President Roosevelt's 1940 Executive Order 8587 banned discrimination based on race, political, or religious affiliation. Congress also passed the Ramspect Act in 1940, prohibiting discrimination based on race, creed, or color.
} 
took until 1938 for African American supervisory personnel to replace Whites as leaders of black camps. Finally, in late 1941 as white youth obtained jobs in the booming war industries and the organization's enrollment dropped, the African American enrollment quota rose. But, entry into World War II prevented emergent prospects for woods work and by July 1942, the CCC organization ceased operations. ${ }^{185}$

\section{African Americans and Public Forestry in World War II, the Triple Nickles}

The Triple Nickles provide a reference point for black employees and affirmative links to natural resources that can dispel notions of Blacks as disconnected from forests. The CCC connects African Americans and forestry outside of logging and turpentining, a proud link to the past that expands the narrative of American history. The CCC did not bring African Americans into professional forestry, but did introduce approximately 200,000 young black men with the Forest Service and other government entities. Despite vocational pigeonholing, the organization introduced these youth to the idea of public service and a range of work skills, from fighting fires to building dams. Its organizational discipline also prepared enrollees for success in World War II and in their post-war lives. Yet even in wartime white officers led African American companies. Only two units differed, the Tuskegee Airmen and the $555^{\text {th }}$ Parachute Battalion, a less famous entity that supports an impressive African American Forest Service heritage.

185 Salmond, "CCC and the Negro," 87. 
The $555^{\text {th }}$, called the "Triple Nickles" because its original "colored test platoon" came from the Buffalo Division ( $92^{\text {nd }}$ Infantry), ${ }^{186}$ emerged at Fort Benning, Georgia in November $1943 .{ }^{187}$ At the time, most Blacks in the segregated army, college-educated or not, drove trucks, worked in mess halls or supply units, continued to ride in the back of the bus, and used "colored" toilets and drinking fountains. Although they also experienced discrimination, the Triple Nickles stood apart. They were trained alongside white soldiers, led by black officers, and they did so in the Pacific Northwest rather than overseas. When the Forest Service asked for help in defending the West Coast from incendiary devices in 1944 , the army responded by assigning the $555^{\text {th }}$ to the $9^{\text {th }}$ Service Command in Pendleton, Oregon. ${ }^{188}$ There, the Triple Nickles became firefighters in partnership with USFS, key members of the military's secret "Operation Fire-Fly." They pursued Japanese fire bombs, disarmed some, exploded others, and retrieved still more for intelligence purposes. The Triple Nickles also experienced the discrimination that accompanied being black in Pendleton, where only two bars and a Chinese restaurant would serve them, and at the same time spent the summer of 1945 fighting fire alongside Forest Service employees. ${ }^{189}$

\footnotetext{
186 The name is a play on the buffalo nickel, $555^{\text {th }}$, and the $92^{\text {nd }}$ as "buffalo soldiers" in the military.

187 The unit's symbol is three buffalo nickels joined in a triangle or pyramid with a black panther crouching on top of a white parachute. During the 1945 fire season, the Triple Nickles engaged in 36 fire calls and 1,200 individual jumps throughout Oregon, California, Washington, Idaho, Montana and Canada.

188 Tina Ray, “Fort Bragg's Airborne and Special Operations Museum's new exhibit tells the story of the 555 "h , www.army.mil, the Official Homepage of the U.S. Army, March 3, 2009, http://www.army.mil/article/17665/ [accessed October 6, 2013].

"Triple Nickles $-555^{\text {th }}$ Parachute Infantry Battalion" The Oregon Encyclopedia, http://www.oregonencyclopedia.org/entry/view/555th_parachute_infantry_triple_nickle_batallion/ [accessed July 10, 2013].
} 
The association of the Triple Nickles with the Forest Service links agency employees to the agency's past as a point of pride. The men of the $555^{\text {th }}$ became the nation's first military smokejumpers and followed the CCC as the second group of African Americans to work closely with the Forest Service. Because of their success, the original company grew to more than 400 paratroopers who would join the esteemed $82^{\text {nd }}$ Airborne Division, a full year before military desegregation. For contemporary Blacks in the Forest Service, the Triple Nickles provide a link to public forestry, and a heroic connection to national and organizational history. ${ }^{190}$ However, this reflective stance occurred later. By the 1950s, negative impressions of woods work flourished in black communities. The oppression of the southern turpentining industry combined with systemic limitations prevented African Americans from thinking of professional forestry as a career path or an avenue to upward mobility.

Negative associations with forestry and the persistent notion that urban Blacks are not interested in the outdoors have continued to curb recruitment efforts into the twenty-first century. In fact, some agency employees have challenged stereotypes about African Americans and nature through connections to the past. In 2000, Forest Service researcher Earl C. Leatherberry traced African American views of forests as both spiritual havens and sites of terror. He noted that forests historically provided both respite and escape, but became sites of danger in the Jim Crow era. Leatherberry claimed that "forests are embedded in the souls of black folks." In a 2013 interview,

190 The Triple Nickles transferred to the $3^{\text {rd }}$ Battalion, $505^{\text {th }}$ Parachute Regiment in 1947; Ray, "Fort Bragg's 555", "http://www.army.mil/article/17665/; Oregon Encyclopedia, “Triple Nickles." 
Deidra McGee, public affairs specialist, noted Leatherberry's work and clarified the importance of the Triple Nickles to both the Forest Service and black communities: "They were the first African American smokejumpers," she said, and are symbolic to African Americans in and out of the Forest Service. As McGee wrote in an October 2013 tribute to Lt. Colonel Roger Walden and Second Lt. Walter Morris, who the Forest Service honored on the national mall three years earlier, alongside First Sergeant Clarence Beavers:

Two of these valiant, pioneering men recently passed away or "took their last jump" as the Triple Nickles Association likes to say.... They will always be remembered for their bravery, sacrifice and groundbreaking achievements in wildland firefighting. We praise them for their courage and heroic service to the Nation with dignity, grace and valor. ${ }^{191}$

Drawing from the words of National Fire \& Aviation Director Tom Harbour, McGee wrote, "During a time of war and social prejudices, the commitment to serve their country through wildland firefighting was challenging and unique."192

Other Department of Agriculture agencies also interacted with African Americans. In 1946 Soil Conservation Service (SCS) director Hugh Hammond Bennett reported that more than fifty African American technicians worked for the agency in the South. By the 1950s, the Department of Agriculture began outreach to historically black colleges, seeking representative staff for those positions that put employees in direct

\footnotetext{
191 Deidra McGee, “Two African-American Smokejumpers take their last jumps,” USDA Blog, http://blogs.usda.gov/2013/10/24/first-african-american-smokejumpers-take-their-last-jumps/, October 24, 2013 [accessed November 19, 2013].

192 Ibid.
} 
contact with black farmers and communities. ${ }^{193}$ However, the need for representation seemed to differ when dealing with trees versus soil. In 1955, the U.S. Forest Service reported NO minorities employed. It would take EEO directives under the 1964 Civil Rights Act and a program of "affirmative action" to bring a significant number of Blacks into forestry in technical, administrative, and professional roles. Forty years after Paul Logan joined the Forest Service, the agency began to knowingly hire African Americans, and not until $1971 \mathrm{did}$ another professional forester come from Tuskegee.

\section{The Foundations of Affirmative Action}

\section{From Non-discrimination to Civil Rights}

Before addressing civil rights policy implementation in the USDA Forest Service, it is important to define and establish the legal and historical foundation of affirmative action, first by defining the term and then examining the policy processes leading to contemporary understanding of the concept. Scholars view affirmative action as an ambiguous distributive policy; that is, it "redistributes opportunity and valued resources," providing an "extra boost" to those who have experienced historical discrimination. It is a "loose term" that refers to a "variety of policy options, "variations that matter," writes J. Edward Kellough, "because different approaches to affirmative action have different implications for concepts such as non-discrimination and equal

193 Douglas Helms, "Eroding the Color Line: The Soil Conservation Service and the Civil Rights Act of 1964," Agricultural History, Vol. 65, No. 2 The 1890 Land-Grant Colleges: A Centennial View (Spring 1991): 39. 
opportunity." ${ }^{, 194}$ Affirmative action policy takes many forms, from efforts that emphasize recruitment and outreach to increase diversity, to career development or upward mobility programs in employment. Tracking representation of women and minorities are forms of affirmative action, as are numerical goals and considering factors such as sex and race in selection decisions. Programmatic affirmative action efforts change over time and differ by organization and private or public status. Affirmative action policy also fluctuates in relation to organizational autonomy and, as this story shows, affirmative action policy changes in relation to individual action and decisionmaking.

The idea of workforce diversity in the Forest Service emerged from the nation's growing understanding of inequality. Soon after the Supreme Court struck down "separate but equal" in Brown v. Board of Education (1954), backlash to desegregation ensued. Brown not only mandated an end to segregation in public education, it also highlighted the inherent inequality of all segregation. Subsequent events illustrated the power of law in officially supporting or halting separation by race, and set the stage for repealing Jim Crow policies. ${ }^{195}$

\footnotetext{
194 Deborah Stone, Policy Paradox: The Art of Political Decision-Making (New York: Norton, 2002): 46; Kellough, Understanding Affirmative Action, 23.

$195 \quad$ United States Commission on Civil Rights. "State of Civil Rights 1957-1983: The Final Report of the U.S. Commission on Civil Rights," November 1983, 20.
} 


\section{The Civil Rights Commission}

In 1957, Congress passed a Civil Rights Act that established a bipartisan commission to investigate complaints regarding civil rights deprivations and to collect information concerning equal protection under the Constitution. The commission hoped: "to prod the conscience of America" by monitoring, assessing, and reporting on federal enforcement of civil rights law to "guarantee equal rights..."196 The commission examined civil rights violations and emphasized the federal role in public life and employment. Although it could not enforce law, its findings and recommendations would reach Congress and the president. The commission's jurisdiction extended to include sex in 1972, added age and "handicap" in 1978, and organized citizen advisory committees by state the same year. These committees served as "the eyes and ears" of the commission, and in their first five years produced 350 reports on the status of women and minorities in the United States. In its 1983 "State of Civil Rights" report, the commission concluded that the U.S. needed stronger enforcement and additional legislation, "if, within our lifetime, this Nation is to provide equal justice for all.",197

The Civil Rights Commission documented barriers to minority access of public and private goods in multiple areas, including housing, education, voting, administration of justice - and employment. In 1961, it found African Americans disproportionately unemployed and concentrated in unskilled and semiskilled private and public employment. The commission noted that minority groups bore an "extra burden" from

196 Civil Rights Commission, "State of Civil Rights report," 3.

197 Ibid, 4. 
past and contemporary discriminatory practices regarding employment, training, and educational opportunities. They were especially vulnerable to cyclical and structural economic shifts, ${ }^{198}$ and black male and female unemployment rates nearly doubled that of Caucasians. Although not quite as high, Hispanic unemployment rates approximated those of Blacks rather than Whites. Migrant workers, "disproportionately black and Hispanic," also labored under "sometimes brutal employment conditions, earning pay at or below the poverty level." ${ }^{\prime 199}$ Commission reports, census data, and Bureau of Labor Statistics reports left no doubt that significant disparities existed between minority males, women of all races, and white men.

\section{Affirmative Steps - Legislating Equality}

Because of these social and economic inequalities, President Kennedy issued Executive Order 10925, and created the President's Committee on Equal Employment Opportunity in March 1961. The PCEEO heralded a shift in equal employment opportunity (EEO) from passive regulation into a proactive, change-making era that would last well into the 1980s. ${ }^{200}$ EO 10925 contained anti-discrimination language and, in the first specific use of term, obligated contractors, to: "take affirmative action to ensure that all applicants are employed, and that employees are treated during employment without regard to their race, creed, color, or national origins. Such action shall include but not be limited to" equality in promotion, pay, and training. The order

\footnotetext{
$198 \quad$ Ibid, 58.

Ibid, 59.

Kellough, Understanding Affirmative Action, 30.
} 
also directed the PCEEO to: "scrutinize and study employment practices of the Government of the United States, and to consider and recommend affirmative steps" [emphasis added] to achieve nondiscrimination in the executive departments and agencies. ${ }^{201}$ Steps included recruitment outreach and reevaluating qualification standards to ensure requirements related to job, rather than sex or race. The law mandated government contractors to file periodic compliance reports, provided punitive consequences for lack of fulfillment, ${ }^{202}$ emphasized good faith compliance efforts, and set similar expectations for federal agencies. For the first time, the government implemented a minority census. African American representation in the federal service rose to $13.1 \%$, almost exclusively in lower level positions. Forest Service leadership began to think about minority recruitment.

The PCEEO continued into the Johnson administration as the Civil Rights Act of 1964 shaped additional policy changes. Title VI of the law prohibited discrimination by any organization receiving federal funds, and Title VII directly prohibited discrimination by private employers of more than 15 persons, labor organizations, and employment agencies. Title VII also established the Equal Employment Opportunity Commission (EEOC) to supervise policy implementation, to receive and investigate complaints, and to recommend resolutions. ${ }^{203}$ The EEOC regulated private sector employment, but had no affirmative action program like the PCEEO. Because Southern Democrats pushed to

\footnotetext{
201 Ibid, 30-31; Anderson, Pursuit of Fairness, 60-61.

202 Punitive actions included contract termination, exclusion from future contracts, and Department of Justice prosecution.

203 Kellough, Understanding Affirmative Action, 31-32.
} 
cut agency EEOC budgets in equal measure to PCEEO funding, President Johnson issued another executive order. EO 11246, passed in September 1965, abolished the PCEEO and moved its federal contracting responsibilities into the Department of Labor, with oversight by the Civil Service Commission. However, it maintained the affirmative steps required by federal contractors and emphasized the same for federal departments and agencies. The Equal Pay Act (1963) had aimed to abolish wage disparities between men and women, but in October 1967, another executive order (11375) specifically banned employment discrimination against women by the federal government and its contractors. For the first time, the government began to collect and publish employment data on minorities and women. ${ }^{204}$

\section{Affirmative Action and Minority Goals}

By the 1960s, it had become clear that equality of opportunity simply could not exist under the disparate conditions between races in the United States. A hundred years after the end of the Civil War, the time had come to mandate, rather than plead for voluntary change. By 1967, the Office of Federal Contract Compliance (OFCC) required “manning tables" to identify minority employment goals in federal contracts. ${ }^{205}$ In 1969 , the OFCC identified minority goals as percentages to reflect the minority labor market. By May 1971 the CSC also established goals and timetables for minority employment in

\footnotetext{
204 Executive Order 11375 - Amending Executive Order No. 11246, Section 101, Relating to Equal Employment Opportunity, October 13, 1967, on "The American Presidency Project” at UC Santa Barbara Website, http://www.presidency.ucsb.edu/ws/?pid=60553 [accessed Feb. 2, 2014].

$205 \quad$ Kellough, Understanding Affirmative Action, 37-38.
} 
federal executive agencies, including the Department of Agriculture. These goals protected four minority groups: "Negro, Oriental, American Indian, and Spanish Surnamed Americans." ${ }^{206}$ As a federal executive agency, the Forest Service used these categories to track employment demographics.

Forest Service numbers from the 1960s show the agency employed very few people of color before the Civil Rights Act. They also show that although African Americans came first, other groups quickly outranked them, and that "Spanish Speaking" employees were distinct from Puerto Ricans or Mexicans.

Table 7: Forest Service Demographics June 30, 1962, 1963, and $1964^{207}$

\begin{tabular}{|c|c|c|c|c|c|c|c|c|c|c|c|c|c|}
\hline & \multicolumn{3}{|c|}{ Negro } & \multicolumn{2}{|c|}{$\begin{array}{c}\text { Spanish } \\
\text { Speaking }\end{array}$} & \multicolumn{2}{|c|}{$\begin{array}{c}\text { Spanish } \\
\text { Speaking } \\
\text { Puerto Rican }\end{array}$} & \multicolumn{2}{|c|}{$\begin{array}{c}\text { Spanish } \\
\text { Speaking } \\
\text { Mexican }\end{array}$} & \multicolumn{2}{|c|}{$\begin{array}{c}\text { American } \\
\text { Indian }\end{array}$} & \multicolumn{2}{|c|}{ Oriental } \\
\hline Year & 662 & 663 & 64 & 63 & 64 & $\begin{array}{l}63 \\
\end{array}$ & '64 & 63 & 64 & 63 & '64 & 663 & 64 \\
\hline Total & 124 & 142 & 139 & 428 & 284 & 16 & 16 & 287 & 232 & 188 & 118 & 82 & 70 \\
\hline $\begin{array}{c}\text { GS-1 } \\
-7\end{array}$ & 120 & 138 & 134 & 406 & 257 & 13 & 13 & 269 & 212 & 177 & 111 & 65 & 52 \\
\hline $\begin{array}{l}\text { GS-9 } \\
\text { or } \\
\text { more }\end{array}$ & 4 & 4 & 5 & 22 & 27 & 3 & 3 & 18 & 20 & 11 & 7 & 17 & 18 \\
\hline
\end{tabular}

Compiled from 1960s Forest Service Demographics, Collection 13.3, Forest History Society, Durham, NC

\section{Bringing Equal Opportunity to the U.S. Forest Service}

\section{Equal Employment Opportunity and USFS - the Civil Rights Act of 1964}

Desegregation and antidiscrimination law raise a very important question, one that all affirmative action scholars contend with, and that is: "Can government power be

\footnotetext{
206 Ibid, 43; Anderson, Pursuit of Fairness, 125.

207 The demographic chart says 119 for American Indians in 1964, but the numbers add up to 118 all other numbers prove the totals, so this must be a typo.
} 
used to change social relationships?" 208 A seemingly unrelated issue arises when environmental law enters the equation: how does environmental law change social relationships? Examining policy implementation in the U.S. Forest Service illuminates convergence through increased connections to the public between the social and the ecological. It allows microanalysis of the processes that effect social change as manifested in a particular time and organization, through legal mandates that pushed USFS to alter its workforce. Although the law applied to all agencies of the Department of Agriculture, a unique process of entwined diversification occurred in relation to the Forest Service goal of resource conservation within a well-established organizational culture. Civil rights and environmental legislation coincided when Congress passed the National Environmental Policy Act (NEPA) in 1969, nearly a decade after the 1960 Multiple Use Sustained Yield Act (MUSY) and on the heels of recent social mandates. By the end of the '70s, the clean air and water acts alongside RPA and NFMA further entangled agency diversification by bringing new types of employees to the Forest Service, including women, people of color and the "ologists" who changed occupational and social demography.

These shifts in law forced agency leaders to craft new entwined diversification policies. The first chiefs to work within this diversification context were Richard McArdle (1952-62) and Edward Cliff (1962-72). McArdle was a researcher and the first agency head to hold a Ph.D., while Cliff, who epitomized Kaufman's 1960 forest ranger typology, graduated in forestry from Utah State University in 1931. Edward Cliff began 
his career as an assistant ranger on the Wenatchee National Forest in Washington State and worked in wildlife management prior to stints as forest supervisor on the Siskiyou and Fremont National Forests. His career spanned the Great Depression, three wars, and massive civil rights and environmental shifts. It also extended through a period of massive road building and a seemingly endless rise in timber yields. This western forester followed a trajectory of mobility and managerial variety, the ideal route to agency leadership. He spent two years in Washington, D.C. near the end of World War II before becoming assistant regional forester for the Intermountain Region (R4). ${ }^{209} \mathrm{By}$ 1950, he became regional forester of the Rocky Mountain Region (R2) in Colorado and managed wide stretches of the West. ${ }^{210}$ In 1952, Cliff joined McArdle in the Washington Office as assistant chief.

As chief from 1962-72, Cliff witnessed nascent public interest in national forest management, increased demand for resources, from timber to recreation, and newly created wilderness areas in national forests. Each issue ultimately connected to workforce diversity. McArdle started hiring specialists for intensive natural resource management as social and ecological mandates poked through the crust of bureaucracy like newly entangled growth; however, Cliff took charge as the tendrils of bureaucracy gained mass. Cliff would be the leader to set a foundation for entwined diversification,

\footnotetext{
209 The region includes forests and grasslands in Utah, Idaho, Wyoming, and Nevada. USDA Forest Service, Intermountain Region Website, http://www.fs.usda.gov/r4 [accessed August 13, 2013 ].

$210 \quad$ Region 2 includes Colorado as well as most national forests in Wyoming and some in Kansas, Nebraska, and South Dakota. USDA Forest Service, Rocky Mountain Region Website, http://www.fs.usda.gov/r2/ [accessed August 13, 2013].
} 
engaging the Forest Service in a nationwide natural beauty campaign, rural areas development, the War on Poverty, and various other partnerships. ${ }^{211}$

Chief Cliff set agency policy but did so under the Department of Agriculture, the executive department most responsible for carrying out the law. Then and now, the Secretary of Agriculture establishes the policy agenda for multiple agencies.

Consequently, the 1964 Civil Rights Act impacted agencies in all executive departments, from Commerce and Defense to Interior and Agriculture. The law affected Agricultural Department organizations from the Farmers Home Administration to the Soil Conservation Service to the Forest Service. It also impacted natural resource agencies like the National Park Service and Bureau of Land Management, organizations that would sometimes compete for diverse employees. Although federal requirements under the Civil Rights Act solidified through later amendments, the initial legislation barred major discrimination in public access for racial, ethnic, national and religious minorities, and women. ${ }^{212}$

After passage, Secretary of Agriculture Orville Freeman met with state directors and top agency personnel to direct compliance with "the letter and the spirit of the Civil Rights Act." The Secretary called for immediate development of affirmative action programs for its implementation and investigation by agency of the act's impact. ${ }^{213}$ The law's Title VI prohibited discrimination by any organization receiving federal funds,

\footnotetext{
211 "Inventory of the Edward Parley Cliff Papers , 1931 - 1985," Forest History Society Website, http://www.foresthistory.org/ead/Cliff_Edward_Parley.html [accessed June 22, 2013].

212 Civil Rights Commission, Equal Opportunity in Farm Programs, viii.

213 Ibid.
} 
while Title VII mandated compliance for employers of 15 or more persons in the private - not the public - sector. ${ }^{214}$ For the first time, the law authorized a specific agency, the EEOC, to combat employment discrimination. ${ }^{215}$ It also sparked the seed of civil rights in USFS, eventually bringing women and people of color into public forestry in technical, administrative, and professional roles.

Initial implementation in the Department of Agriculture focused on Title VI. ${ }^{216}$ Title VII employment mandates did not apply fully to government agencies until amended to include local, state, and federal agencies in $1972 .{ }^{217}$ Meanwhile, unanticipated public connections to the 1964 Civil Rights Act emerged for the Forest Service. In addition to public notification regarding equal access to national forests, the agency had to determine how and to whom non-discrimination regulations applied, and then how to enforce the law in organizations rife with discriminatory segregation practices. Because of timber revenues, for example, Title VI impacted counties all over the nation. Non-compliant southern schools soon learned they could either halt segregation or lose forest revenues and commodities. Youth camps on public lands run by organizations like the Girl and Boy Scouts and Camp Fire Girls came under fire for

\footnotetext{
$214 \quad$ Kellough, Understanding Affirmative Action, 31-32.

215 Ibid.

216 Title VI affected communities that received forest revenue receipts, schools and youth groups that received food commodities through the Department or used public lands, and even homes for the elderly RG 16, Records of the Offices of the Secretary of Agriculture, General Correspondence, 19061976, boxes 4781-4783.

217 In 1972, the Equal Employment Opportunity Act amended Title VII to increase EEOC authority, make subject to the law employers of 15 rather than 25 employees, tighten sex discrimination regulations, and most importantly, subordinate educational organizations, local, state, and federal agencies to Title VII regulation. Employers could no longer impose mandatory leaves of absence on women or give them less favorable health insurance or disability benefits. "Milestones: 1972," Equal Employment Opportunity Website, http://www.eeoc.gov/eeoc/history/35th/milestones/1972.html [accessed November 14, 2013 ].
} 
segregation. The Department of Agriculture told cooperative extension services associated with public universities to change hiring and outreach practices. Even homes for the elderly risked losing government support. ${ }^{218}$

\section{Employment Outreach and Job Corps}

At the same time, the Forest Service intensified employment outreach to people of color for both temporary and permanent positions. It recruited from historically black colleges and universities, and minority organizations like the Urban League and NAACP. The agency developed urban programs like San Francisco's "Concentrated Employment Program" and recruited male and female youth from New York City. It also hired African American teachers for Job Corps, a 1960s War on Poverty program "intended to eliminate poverty" in partnership with private corporations and federal agencies, including USFS and NPS. The Job Corps partnership accomplished both conservation goals and diversified employment pools. Created under the 1964 Economic Opportunity Act and directed by Sergeant Shriver, Job Corps educated youth ages sixteen to twenty-four. It provided them with room and board in more than a hundred centers around the nation for up to two years, and helped them develop marketable skills.

Modeled after the CCC, Job Corps sought to "enable the hard-core poor to break out of the poverty cycle. ${ }^{, 219}$ Similarities between the CCC and Job Corps included the

218 RG 16, Records of the Offices of the Secretary of Agriculture, General Correspondence, 19061976, boxes 4781-4783. 
type of work performed and skill development at conservation centers, especially those run by natural resource organizations. As had been true of the CCC, the effects of poverty manifested visibly and invisibly in Job Corps enrollees. In 1967, the military rejected as many as 47 percent of those who served in Job Corps for physical (17\%) or educational (30\%) reasons. Eighty percent of enrollees had not been to a doctor or dentist in the previous ten years and enrollees averaged seven pounds underweight. Forty percent read below third grade level, with math skills only slightly higher. A majority of the youth came from substandard housing and "broken homes" with high unemployment rates and undereducated parents (less than eighth grade). Nearly 40 percent of enrollees' families were on relief.

Unlike the CCC, the program's major goal was to impart "those productive skills which are required in an urban society." The CCC incorporated fundamental learning, but its primary objective lay in conservation, with schooling "an afterthought" according to education scholar Franklin Parker. Job Corps made education a primary goal "from the beginning." ${ }^{220}$ Youth typically spent half their days in educational or vocational activities and the other half engaged in recreation and camp maintenance. By the end of nine months in Job Corps, the average enrollee could expect to raise two grade levels, gain ten pounds, and have teeth extracted and filled. Program completion meant the 
enrollee left with a 70 percent chance of getting a job, returning to school, or joining the military. For those who got jobs, earnings raised an average of fifty cents per hour. ${ }^{221}$ Multiple other distinctions existed between the CCC and Job Corps. With the movement for equality blooming, Job Corps incorporated poverty stricken youth of all races in integrated camps. It often hired African American teachers, who worked for the Forest Service, including Jetie Wilds who became the first Civil Rights Program Director for the agency, and others who had long term agency careers. Job Corps also included women, but only after Oregon Representative Edith Green pushed for their incorporation, pointing to the growing numbers of female headed households. As part of the House Committee on Education and Labor, Green secured agreement that women would constitute one-third of enrollees. Consequently, centers for men and for women opened within four months of each another. When Green complained that women constituted only ten percent of enrollees in the first year, Congress directed the Office of Economic Opportunity to incorporate more girls. By 1967, Job Corps operated 122 centers, nineteen of them for the 9,000 women in the program, the others for the 31,000 male enrollees. $^{222}$

Gender segregation also meant occupational segregation. Young men trained for higher paying jobs in the construction trades and learned skills like carpentry, masonry, plumbing, electrical wiring, blueprint reading, heavy equipment operation, surveying, mechanical drawing, metal fabrication, welding, and so forth. Despite the possibility of

\footnotetext{
221 Ibid, 365-366.

$222 \quad$ Jill Quadagno and Catherine Fobes, “The Welfare State and the Cultural Reproduction of Gender: Making Good Girls and Boys in the Job Corps," Social Problems, 42, 2 (May 1995): 175.
} 
young women becoming heads of households, the corps trained them for low paying clerical fields, health and medical services, assembly and beauty shop operations. Like the young men, Job Corps' female enrollees received remedial instruction in reading, writing, speaking and basic arithmetic. Women also learned about home and family life, nutrition and child care, ${ }^{223}$ with occupational segregation integral to "channeling women into low-paying jobs" and "training them to become family caregivers." As Jill Quadagno and Catherine Fobes point out, social programs often incorporated mechanisms that reproduced market inequalities through eligibility rules, a condition clearly visible in the CCC and in the Job Corps focus on male enrollees. Young men trained for jobs that would allow them to support families, while women's training maintained gendered divisions of labor in the household and marketplace. Like the CCC, Job Corps replicated gender inequities in the labor market and reinforced patriarchal family structures, pushing women to labor in private or gendered occupations rather than in the public primary wage earning sphere.

\section{Discussion: The Ironies of Opportunity}

This brief history of exclusion in public forestry from the 1920s to the 1960s demonstrates that the government shapes equal and unequal opportunity in the U.S. at every turn. From upholding segregation in Plessy v. Ferguson to passage of the 1964 Civil Rights Act, federal policy has molded social and occupational roles. Prior to 1964, as constitutional law, executive orders, and legislative acts espoused nondiscrimination

${ }^{223}$ Parker, "Salvaging School Failures," 366. 
with few mechanisms for enforcement, equality remained an ideal rather than a reality. The law, public policy, and the actions of those in power upheld white male dominance through most of the twentieth century, even within the emerging welfare state. In fact, according to political scientist Ira Katznelson the welfare state solidified "policy apartheid" through what Robert Lieberman called "discrimination by design."224 Such design is particularly evident in both the CCC and Job Corps.

Katznelson and others ${ }^{225}$ point out that New Deal relief efforts strategically upheld inequalities in two ways. First, occupational segregation created disparate benefits. Critical New Deal legislation like Social Security and unemployment deliberately excluded agricultural, clerical, and domestic laborers, occupations disproportionately staffed by women and people of color. Second, state administration of benefits enabled discriminatory practices. By allowing states to set their own fair wage standards, localities from California to Mississippi could maintain racially stratified economic disparities. In addition, the CCC used quotas to reinforce and maintain exclusion. As Katznelson explains, ““”Federal social welfare policy operated...not just as an instrument of racial discrimination but as a perverse formula for affirmative action, ${ }^{, 226}$ that is, affirmative action for White men.

Paul Logan's experience demonstrates the irony of affirmative action in practice, both through the limitations of race and the privileges associated with light skin.

\footnotetext{
224 Ira Katznelson, When Affirmative Action was White: An Untold History of Racial Inequality in Twentieth-America (New York: W.W. Norton \& Company, 2005): 43.

$225 \quad$ Wolters, "New Deal and the Negro," 14-61.

226 Katznelson, When Affirmative Action Was White, 51.
} 
Because he "passed" as white, Logan became a forest supervisor on the Olympic National Forest—long before the Forest Service knowingly hired Blacks. ${ }^{227}$ In 1940 , when more than half of all African Americans lived in rural areas, usually as tenant farmers or wage hands making less than \$200 per year, Logan earned over three thousand dollars. ${ }^{228}$ Whiteness allowed Logan to attain economic and social standing during the Great Depression, a time when poverty stricken women, people of color, and many rural Whites went hungry. As a government man and a forester, his job remained relatively secure.

New Deal policy decisions supported systemic inequalities and, as scapegoats for unemployment women and people of color remained at the bottom of the economic ladder. Although the Roosevelt Administration provided opportunities for several women at senior and midlevel positions, the government only minimally addressed the conditions of "ordinary" women. Females constituted only seven percent of Civilian Works Administration employees in 1933-34. By 1935, a number of women worked for the WPA; however, they earned the low pay associated with occupational pigeonholing in sewing rooms and canning, and contended with assumptions of men as primary breadwinners. ${ }^{229}$ Communities of color also accessed and benefited from government work programs to varying degrees. The National Youth Administration (NYA) and the CCC reflected what Raymond Wolters calls "the crucial influence, for good or ill, that 227 "Wilds of Olympic Forest Intrigue Visitors," Morning Oregonian, Wednesday, September 2, 1936 , p. 3.

228 Wolters, "New Deal and the Negro," 17.

229 At its peak, approximately 405,000 women were on the WPA, including those in the Federal Writer's and Art's projects. Several million women could not obtain work assistance of any kind. Ware, "Women and the New Deal," 341. 
officials in Washington could bring to bear on local authorities. ${ }^{, 230}$ NYA leadership under Aubrey Williams included advisor Mordecai Johnson, president of Howard University, and Mary McLeod Bethune, president of the National Council of Negro Women, as head of a Division of Negro Affairs. Consequently, contrasting examples of representative bureaucracy abound. For example, more African Americans worked at higher levels in the NYA than in any other New Deal Program, ${ }^{231}$ while the Tennessean CCC director mandated segregated camps nationwide and reinforced existing disparities. As demonstrated, organizational policies in the $\mathrm{CCC}$ shifted in relation to race, local control, and eligibility requirements that filtered out the poorest of the poor. In its first year, the army rejected nearly nine percent of potential CCC enrollees, often for physical reasons. Amadeo Quintana of New Mexico, for example could not meet the 125-pound weight requirement, and so ate three pounds of bananas and drank "plenty of water" before enrolling, "an effective and common strategy for those desperate to find work." ${ }^{232}$ Rejections in Chicago's Cook County during the second year of enrollment illustrates the extreme hardship faced by the ultra-poor. That year, the CCC rejected nearly 16 percent of potential enrollees because one in twenty men had "defective teeth." To join, a man had to "possess enough teeth and so placed as to enable him to properly masticate his food." ${ }^{, 233}$ If he could get in, the CCC enrollee gained access to the most important benefits of the organization, good food and dental care. If ineligible, he

\footnotetext{
230 Wolters, "New Deal and the Negro," 35.

Ibid, 36-37.

Montoya, "Economic and Ethnic Divisions," 23. Lanpher, "CCC Aspects," 628.
} 
and his family remained at the mercy of a systemically racist labor market and welfare assistance dependent on local practice.

Although the CCC could make possible a better future, skin color and ethnicity determined opportunity levels within the organization. Barely literate New Mexican Hispanos received very little education in CCC camps, while the Indian Education Program relied on the discretion of BIA agents. The African American CCC provided minimal educational opportunity and trained enrollees for menial jobs. Access to the benefits of the CCC for men of color took a backseat to white males, veteran and nonveteran. For example, the government limited local enrollment in New Mexico's Rio Arriba region at the same time as it imported white - but not African Americanenrollees from Oklahoma and Texas. The CCC experience topples notions that Blacks won't work in the woods, a still relevant stereotype because of ongoing underrepresentation of African Americans in USFS and attacks on affirmative action policies since the 1980s.

In 1967, John Salmond pointed out that Robert Fechner's exclusionary policies reflected "a strong section of prevailing white opinion." The organization's main purpose took precedence: "to reduce unemployment and accomplish useful conservation work, not to further the cause of American race relations. However desirable," he wrote, "the fullest employment of Negroes was only a matter of subsidiary concern.",234 Salmond, the first to address African American participation as "a blot on the record of the CCC," missed one of the most significant aspects of racial politics around the 
organization. The CCC and other public works programs of the New Deal actually did further race — and gender — relations, but did so by disproportionately distributing its manifold benefits to white men. Salmond and Wolters agree, however, that the systemic racism of the CCC and other New Deal programs constitute a missed opportunity to further equality in the United States.

Women and minorities moved further into private industry and the public sphere during World War II, through employment rooted in combined labor shortage and community pressures. President Roosevelt supported Fechner's segregation policies under the CCC, but when A. Philip Randolph threatened to march on the capitol with a hundred thousand African Americans he issued Executive Order 8802 and created the Fair Employment Practices Committee. By enforcing nondiscrimination, the law expanded inclusion in public employment for both men and women of color. However, public natural resource organizations remained almost completely segregated throughout the war, aside from two areas. First, as has been true during all major conflicts of the twentieth century, women served as forest guards and fire lookouts in World War II. Second, not only did the Triple Nickles spearhead military desegregation, they were also the first African American smokejumpers in the Forest service.

Alongside selective movement toward racial diversification, the federal government maintained gender stratification within the welfare state into the 1960s. Like previous work programs, Job Corps incorporated patriarchal economic control in its design, though less so than originally intended. While Eleanor Roosevelt advocated on behalf of women in the 1930s, with sparse results, Edith Green did so in the 1960s. Her 
advocacy brought women into Job Corps. Like Fechner's imposition of southern segregation mores on the entire nation and Person's advocacy for Blacks in the Department of Labor, Green's insistence that Job Corps include females demonstrates the significance of representation in the administrative sphere. Still, with African American men as the primary target group, fewer female than men's centers existed and they limited occupational options. For the most part, Job Corps training led these women to low paid service work, jobs more appropriate to supplemental than primary household support.

Whether the government should or should not use its power to deliberately change social and economic relations lies to some degree in viewing affirmative action as a redistributive policy. Distributive and redistributive policies are grounded in issues of equity, which involve basic fairness in society and thus in social relations. Basic opportunity, according to Gutmann and Thompson, means citizens will have access to basic goods and services to meet their needs. Fair opportunity is more ambiguous. "The principle holds that government should ensure that each citizen has a fair chance to secure opportunity goods such as advanced education and skilled employment."235 Although seemingly simple, Gutmann and Thompson explain how two additional principles impact interpretation of fair opportunity. First is the liberal principle that requires jobs go to those who are most qualified through a fair competition. According to this interpretation, fair opportunity is no different than the basic distribution of

235 Amy Gutmann and Dennis Thompson, Democracy and Disagreement (U.S.A.: Harvard College, 1996, 1997): 307. 
opportunity goods, such as education and income. However, in an egalitarian interpretation:

"fair opportunity permits or requires that some jobs go to those who are most disadvantaged, or at least to those who are relatively disadvantaged among those who are basically qualified. The failure of a society to distribute basic opportunity goods justly, according to the egalitarian interpretation, makes a difference in how skilled jobs should be distributed. When background conditions make it much harder for some people to compete for skilled jobs than others, then public policy should give an advantage to disadvantaged citizens in the competition. This amounts to a process of preferential hiring, which favors the basically qualified person of a relatively disadvantaged race or sex over a more qualified person of a relatively advantaged race or sex. $" 236$

The 1964 Civil Rights Act leaned toward redistribution by creating opportunities for the disadvantaged. Policy implementation would soon include efforts to mold qualified candidates from the disadvantaged through additional work programs and partnerships. The eventual intersection of environmental with social law in the 1970s would ultimately shape an entwined diversification in the U.S. Forest Service and other natural resource organizations. Meanwhile, notwithstanding initial diversification efforts, the permanent workforce remained homogeneously Caucasian and primarily male throughout the 1960s. Some deterrents faced by people of color, especially the urban poor, included what a 1967 EEO report identified as "a strong orientation of minority groups toward traditional occupations," likely related to common perceptions of forestry; however, attitudes were not the primary preventive culprit for the work hungry. Rather, money for necessary medical examinations, clothing, and food kitties often prevented the cash poor from taking agency jobs, as did transportation issues and family 
responsibilities. For Latinos and American Indians, according to the Forest Service, language barriers could present problems. And for poor women, child care needs and disruption of government assistance could prohibit short term employment. These issues identified in 1968 reveal systemic class inequities that continued to affect people of color disproportionately into the twenty-first century. ${ }^{237}$

237 "Quarterly Equal Employment Opportunity Report for the Forest Service for the period October - December 1967"; Memorandum to Carl B. Barnes, Director, Office of Personnel from O.M. Jackson, Director, Division of Personnel Management, re: reports, File No. 1380, February 9, 1968, 3. Forest History Society collection F13.2, File, "Personnel: Equal Employment Opportunity." 


\section{Chapter 4: An Agency in Flux: Muddling Through, 1968-1976}

The early '70s was, I guess, what you would call the beginning of the Affirmative Action generation. And you know, it was the best of times and the worst of times. The best of times in the sense that programs and organizations were committed to trying to change the way things had been, but the worst of times because there was a lot of resistance to that, and a lot of people who were used to the old ways. - Dr. Darrell Millner, January 14, 2014

At an early age, Nella Dickson of Smith County, Texas made choices that would lead her to the Pacific Northwest: "I made a decision...," she said in 2007. "I would not marry a rose grower and I was going to school to get me an education..." Neither would she become a maid, the job most available to African American women born in the 1930s. Instead, Dickson attended college, and when finances halted her pursuit of a nursing degree, she turned to the next best occupation for African Americans and for all women - she became a teacher. After obtaining a master's degree, Dickson taught for ten years in Texas, and then in 1968 de-segregation arrived at her public school. Just as the federal government began workforce diversification efforts, she lost her job:

...of course they couldn't place everybody, so. I was looking at the television one day and Job Corps was just opening up and they had two guys in military suits - at that time all Job Corps enrollees were primarily males; wore military attire. There was a telephone number, so I called. They sent me the application. I went home and told my momma and daddy I was going to sign up for the program...

Before long, Dickson joined the first wave of African American women to work for the

USDA Forest Service and headed West into an unfamiliar landscape:

In my hometown, all while I was growing up I think it snowed once, and it snowed twice when I was in Amarillo. We were driving up to Chehalis and all of these trees was covered with snow and, I mean, I didn't have my camera. 
Absolutely beautiful! ... It was just unbelievable, and absolutely amazing. You know, I would see some of this on television, but it was never the Pacific Northwest... And I just, [there was] something this pretty, and I didn't have the slightest idea that it was going on. ${ }^{238}$

Nella Dickson's depiction of her Northwest arrival focused on the splendor of the region's environment, but these memories include a familiar twist. She and her companions traveled by bus from Texas to Tacoma, Washington, a city with an African American population of only 6.8 percent in 1970, and where the singer Hazel Scott had been turned away from a hotel not long before. ${ }^{239}$ When the weather halted passage for the night, Dickson recalled as a simple matter of fact, “they didn't put us up in a hotel, either. We slept in the airport." After a brief stint teaching reading to youth in Chehalis, Nella transferred to the Timberlake Job Corps Center in Estacada, Oregon, one of four Job Corps Centers in Region 6. There, she met her husband, Ronald Dickson. The couple married on August 20, 1970 and although she loved Job Corps Nella left Timberlake because, she said, the Forest Service did not allow couples to work at the same site. For more than thirty years Nella Dickson worked in the Portland, Oregon Regional Office (RO), in both Human Resources and Civil Rights, while her husband remained seventy miles away at Timberlake Job Corps Center. ${ }^{240}$

\footnotetext{
238 Nella Dickson interview by Carly Inman, May 24, 2007. Portland, Oregon. Forest Service, Workforce Diversity Council Collection.

239 U.S. Civil Rights Commission, "School Desegregation in Tacoma, Washington" (May 1979): 3, http://www.law.umaryland.edu/marshall/usccr/documents/cr12t11.pdf [accessed March 21, 2014]; Isabel Washington was married to U.S. Representative from New York, Adam Clayton Powell, Jr. Quintard Taylor, "The Other Black Northwest," [NEED TO VERIFY if it was Washington or his second wife, Hazel Scott].

$240 \quad$ Nella Dickson interview by Carly Inman.
} 
Nella Dickson joined the Forest Service in a time of overlapping shifts in USFS and society, as the organization sought employees whom its leaders would not have considered only a decade earlier. These shifts occurred in keeping with changes in law and policy that mandated diversification by the Department of Agriculture and its many agencies. During the initial diversification process, the Forest Service began to stand out among Agriculture Department agencies, while the Pacific Northwest where Dickson remained, soon became a national model for civil rights in the Forest Service. In this chapter, I focus on the Pacific Northwest, including Oregon, Washington, and Idaho, as emblematic of entwined diversification in the U.S. Forest Service. Through close examination of policy implementation in the Northwest, I examine processes that impacted diversification of the workforce at large.

\section{Law, Policy, and Definitive Action}

Workforce Diversification by Law and by Policy

The mandate to create equal employment opportunity loomed large for Agriculture Department leadership in the 1960s and 1970s. On April 5, 1963 Secretary of Agriculture Orville Freeman appeared on the cover of Time magazine. The story within highlighted the Secretary's status as a World War II Marine, his terms as the governor of Minnesota, recreational activities with Robert McNamara, the Secretary of Defense, and much regarding the complex issues facing U.S. farmers. The article 
contained no mention of discrimination in the Department of Agriculture. ${ }^{241}$ That June, Assistant Secretary for Administration in the Department of Agriculture, Joseph M.

Robertson wrote to Freeman regarding the status of minorities. Robertson enclosed a copy of Martin Luther King, Jr's "Letter from a Birmingham Jail" and also urged the Secretary to prioritize increased diversity:

The inertia in this area is unbelievable until you see it at first hand. We continue to live in a pattern of culture that has been developed over the last century, and to get us out of this is going to take, in my opinion, direct involvement by the Secretary of Agriculture and by his agency heads and that this program must be given a different order of priority from sugar, or rural areas, or any other commodity. If not, we will make about the same rate of progress that we have made in the past two years. ${ }^{242}$

And maintaining the rate of progress of the previous two years would mean very little advancement. Creating change would require the Department and its agencies to prioritize workforce diversity, and to address discrimination in society at large.

In the 1960s and 1970s, minority men and women went to work for the Forest Service via the 1962 Manpower Development and Training Act. Additional hiring opportunities came from community based programs authorized under the Economic Opportunity Act of 1964, with Operation Mainstream, the Neighborhood Youth Corps (NYC), and the Work Incentive Program (WIN) geared toward disadvantaged populations. These Manpower programs brought men of color into forestry, technical

\footnotetext{
241 Pete Daniel, Dispossession: Discrimination Against African American Farmers in the Age of Civil Rights (U.S.A.: University of North Carolina Press, 2013): 3.

242 Joseph M. Robertson to Orville Freeman, June 6, 1963, Folder "Civil Rights," General Correspondence, Record Group 16, Records of the office of Secretary of Agriculture, National Archives and Records Administration, Washington, D.C. in Douglas Helms, "Eroding the Color Line: The Soil Conservation Service and the Civil Rights Act of 1964," Agricultural History, Vol. 65, No. 2. The 1890 Land-Grant Colleges: A Centennial View (Spring 1991): 47.
} 
programs, field work, and firefighting. The agency also hired increasing numbers of women for administrative positions, firefighting, and limited field work.

Although initial diversification efforts brought women and minorities primarily into low pay field and office positions, Job Corps brought educated African Americans like Nella Dickson into the agency. It also introduced urban and rural youth to woods work and provided an employee recruitment pool. In 1970, the agency reported that all Forest Service units engaged in one or more of the Manpower Training programs, with "Qualified Corpsmen from our Job Corps Civilian Conservation Centers...identified and encouraged to accept employment with the Forest Service." ${ }^{243}$ Community and educational organizations added other venues for recruitment. Some minority job candidates came from programs initiated with historically black colleges and universities (HBCUs), and others through contracting with minority owned businesses or direct employment of wage grade temporary and full-time employees. By 1970, the Youth Conservation Corps (YCC) introduced youth ages fifteen to nineteen, from all backgrounds, to the Forest Service. For a brief time during that decade the Young Adult Conservation Corps (YACC) also brought scores of young men and women, aged sixteen to twenty-three, to national forests. The Forest Service even engaged senior citizens in outreach efforts. (see table 8 below)

\footnotetext{
243 Memo to the Secretary of Agriculture, from Edward P. Cliff, Chief, re: Secretary's Memorandum No. 1662 - Civil Rights, December 24, 1970. Collection F5, File, Civil Rights Action Plans, Forest History Society (Durham, North Carolina). Hereafter FHS
} 
Table 8: Human Resource Programs, FY $1976^{244}$

\begin{tabular}{|c|c|c|c|}
\hline Program & Total Enrollees & Total Minority & Total Women \\
\hline Job Corps & 3,761 & $1,923(51 \%)$ & $114(3 \%)$ \\
\hline $\begin{array}{c}\text { Young Adult } \\
\text { Conservation Corps } \\
\text { (YACC) }\end{array}$ & 6,433 & $1,522(23.5 \%)$ & $2,551(39.7 \%)$ \\
\hline $\begin{array}{c}\text { Youth Conservation } \\
\text { Corps }\end{array}$ & 12,377 & $2,307(18.75 \%)$ & $5,955(48 \%)$ \\
\hline $\begin{array}{c}\text { Senior Community } \\
\text { Service Employment } \\
\text { (SCSE) }\end{array}$ & 3,095 & $640(21 \%)$ & $1,126(36 \%)$ \\
\hline
\end{tabular}

In the 1970s, the juncture of ecological, occupational, and social variation became enmeshed as the agency contended with multiple mandates for change in both land and people management. Even as the agency inaugurated an interdisciplinary approach to resource management, it also inched toward a national Civil Rights Program. In some regions, leadership made nominal efforts to bring minorities into the agency, while others took the charge seriously. For the most part, women remained a sideline until after the 1972 Equal Employment Opportunity Law added "sex" to Title VII of the Civil Rights Act; however, women gained employment traction in the decade that followed. Consequently, workforce diversification occurred in fits and starts that could depend as much on leadership and individual initiative as formalized policy.

Reporting, Training, and "Definitive Action"

In September 1969, on the heels of EO 11478, recently appointed Secretary of Agriculture Clifford Hardin issued Memorandum No. 1662, the USDA Policy on Civil

\footnotetext{
244 "Servicewide Assistance Programs for Women and/or Minorities (non-employment programs)" in Civil Rights Update, 1980-84. Collection F5, File, Civil Rights Updates, 1980-84, FHS.
} 
Rights. Memo 1662 directed that USDA "renew and strengthen our efforts to strengthen equal access" to Agriculture Department programs. This reinforcement should occur "without regard to race, color, or national origin," so that "all eligible people, particularly minorities and the underprivileged" could receive program benefits. Memo 1662 required Agriculture Department agencies to develop and implement a "comprehensive civil rights program to insure that the intent of the law and President Nixon's equal opportunity policy is effectively carried out in all programs and activities." ${ }^{245}$ This memorandum served as the policy foundation for all Agriculture Department agencies and provided guidance regarding civil rights for years to come. In response, Chief Edward Cliff issued his civil rights policy memo of April 7, 1970, to guide USFS Cliff affirmed the Secretary's directives to establish a civil rights program in keeping with Hardin's decree, "which," he wrote, "I support and adopt as Forest Service policy." Following Hardin, Cliff identified civil rights program implementation as a top priority: "To make the USDA-Forest Service policy a reality," he wrote, the Forest Service must "also encompass social goals and values such as the Civil Rights program." Chief Cliff ordered all deputy chiefs to provide systematic review and progress reports. He also directed that each region develop unit action plans comparable to the service-wide Civil Rights Action Plan, enclosed with the directive.

Memo 1662 outlined the USDA policy on civil rights, with equal employment opportunity as part of a broader agenda that included leadership training, program Rights Action Plans, FHS; Secretary's Memorandum No. 1662, "Supplement 2, USDA Policy on Civil Rights," August 9, 1971. Collection F5, File, Civil Rights: Update, FHS. 
evaluation, compliance with non-segregation laws and regulations, audits, and investigation regarding non-compliance. The Secretary's Memo also called for "realization of equal employment opportunity through a continuing affirmative program in each agency." 246 Although the memo commanded upper management to make their first reports by June 10 and complete civil rights training by the $30^{\text {th }}$, Chief Cliff waited six months to formalize the Secretary's policy. In the interim, the Forest Service developed a formal equal employment opportunity plan of action that it distributed with the April 7, 1970 policy directive. The preamble to the plan identified commitment with a capital $\mathrm{C}$ as its first priority. It read:

All Forest Service Management officials must be personally committed to carrying our [sic] forcefully the Equal Employment laws and policies of the United States Government. And, further, they must give personal and continuous direction to national and local programs designed to implement these laws and policies. This commitment can be satisfied in a large measure by:

1. Giving strong line direction to and requiring accountability from Regions, Stations, and Areas.

2. Obtaining complete understanding of all employees in each organizational unit.

3. Capitalizing upon both satisfactory and unsatisfactory experience.

4. Accomplishing program goals in accordance with the Federal Personnel Management System. ${ }^{247}$

The plan identified the chain of command responsible for reporting and evaluation of civil rights activities and created a feedback loop for recommending

\footnotetext{
246 Secretary's Memo 1662, September 23, 1969, “USDA Policy on Civil Rights,” 4.

247 Preamble to the Forest Service Action Plans for EEO, attachment with Secretary of Agriculture Memo 1669 from Edward P. Cliff, Chief, Memorandum to Regional Foresters, Directors, Area Directors, Deputy Chiefs, and Washington Office Division Directors, re: Policy and L/T Civil Rights Action Plans, April 7, 1970. Collection F5, File, Civil Rights Action Plans, FHS.
} 
program changes, adjustment or redirection by action item plan numbers in four major categories: I. Procurement Contracting; II. Recruitment and Retention; III. Training; and IV. Upward Mobility. The chief handed responsibility to the deputy chiefs for each major system, State \& Private Forestry, Research, National Forest System, and Administration. Moving up the line, these leaders would report to the Deputy Chief for Administration, who reported to the Chief, who reported to the Secretary of Agriculture, with each providing feedback to send down the line. Chief Cliff closed his April 7, 1970 policy memo by highlighting his personal commitment to civil rights:

I intend to do what is necessary at all levels for a complete satisfactory civil rights program service-wide, and I am directing that you do like-wise in your areas of responsibility. Civil Rights within the USDA and the Forest Service is continuous and requires the personal commitment and leadership of each of us. Every unit manager will be furnished copies of these action plans and be guided accordingly. I do not question your commitment to the goals of the program, but I do ask that you initiate affirmative action [emphasis added] to translate your commitments into even greater results. ${ }^{248}$

Despite this statement of commitment, with only two months to reply, the agency left little time for unit level response.

Still, most region and area directors did, indeed, submit reports by the first June 10 deadline; however, most reflected very little civil rights activity during the previous year. In fact, Deputy Chief Edward Schultz suspected that unit leaders did not see civil rights as their responsibility. Rather, they viewed the Chief's directions to ensure affirmative action "as a job for Personnel Management or Administrative Services," complaining that very few line officers gave the issue their "personal attention." The 248 Ibid. 
results did not impress Deputy Chief Shultz, who wrote that he would continue to

remind the field of the "need" for "definitive action." These criticisms remained internal.

The report submitted to Secretary Hardin on July 1, 1970 emphasized the

accomplishments of a few units and blamed lack of communication regarding the action plan for what appeared "to be somewhat low accomplishment levels.",249

Two regions stood out in terms of efforts aimed toward employment, Region 4

(the Intermountain West, including Idaho ${ }^{250}$ ) and Region 6 (Oregon and Washington).

Despite historically small minority populations. Northwest leadership jointly hired more than half of all minorities who worked for the Forest Service the previous year (July 1 December 10, 1970). [See Pacific Northwest States by Race, 1950-1990, Appendix C,

Table C.1.]

Together, Regions 4 and 6 accounted for 65 percent of the 342 minorities hired by the entire agency. Including the Washington Office, Research Stations, and State \& Private Forestry raised the total employment of minorities to 420, with still more than half hired in the Northwest. ${ }^{251}$ Region 4 also reported that it identified minorities for employment in outside regions, and that it promoted a "Chicano forest worker" from a

\footnotetext{
249 Secretary's Memo No. 1662, September 23, 1969.

250 The core of the Pacific Northwest region is typically identified as Oregon, Washington, and Idaho. Region 6 is composed of Oregon and Washington. Although most of Idaho is in Region 4, which also includes Nevada, Utah, and a small portion of Wyoming, northern Idaho is part of Region 1, which incorporates all of Montana and North Dakota, along with the Northwest portion of South Dakota. 251 "Summary of Minorities Hired from July 1 through December 10, 1970," in Memo to the Secretary of Agriculture, from Edward P. Cliff, Chief, re: Secretary’s Memorandum No. 1662 - Civil Rights, December 24, 1970. Collection F5, File, Civil Rights Action Plans. There were 150 minorities identified in Region 4 and 84 in Region 6 in 1970. Region 4 reported 139 minorities at the end of the previous reporting period (December 1969), 26 of them full-time, the remainder temporary. These numbers represented increases over previous years that would be inconsistent with including the Sho-Ban Firefighters in the count.
} 
Wage Grade (WG) 2 position to a WG-6 position as a Truck Driver. Other minority employees in R-4 included a "Negro" clerk-typist, a "mentally retarded youth" employed as a student aid, an "Oriental" engineer, and five minority employees in the Engineering Division - two Japanese, one Indian, one Chicano, and one Negro. ${ }^{252}$

\section{The Forest Service and American Indians}

Partnerships with the Bureau of Indian Affairs provided one avenue for connection between the Forest Service and Native populations. At locations near reservations, federal agencies like the Forest Service and National Park Service worked with the BIA to hire Native people for temporary summer employment. ${ }^{253}$ In some cases, the Forest Service provided technical assistance and set up industrial production plants (sawmills and chipping plants) using national forest timber on reservations. Direct permanent and temporary hires of Native employees, forestry curriculum development, and organizing Native fire crews also contributed to organizational diversification. ${ }^{254} \mathrm{By}$ the early 1970s, the Forest Service partnered with tribes around the country, with employment programs that provided Forest Service aid to American Indians and Alaskan Natives (identified as Eskimos) including allocations of more than $\$ 250,000.00$ in 1970. These funds covered administrative costs, not wages, supplies or materials, and funding.

\footnotetext{
252 Ibid, 5-6.

253 Mary Funk met her husband Charles Funk, of Chinook and Chehalis descent around 1957, as he worked for the Forest Service alongside other Native Americans near the Quinault Indian Reservation. Personal communication, June 20, 2014. Data by race for this period is unavailable.

254 “1971 \& 1972 Indian Information.” Collection F5, File, Civil Rights: Indian Opportunity. FHS.
} 
At the time, no programs existed "exclusively for Indians,",255 but national forests connected with tribes based on location. Some activity took place in the East. For example, the Allegheny National Forest advised Seneca Indians regarding economic, social, and land management activities; however, the highest levels of engagement occurred in the U.S. West. In New Mexico and Arizona, for example, the Forest Service maintained lists of Indian college students for employment, and Taos Indians received fire and land management training. In Albuquerque, a special NYC (National Youth Corps) trained Native people for possible full-time employment with the Forest Service. ${ }^{256}$ In California and the Dakotas, Native groups had numerous contracts with the agency for things like timber stand improvements, planting, janitorial services, brush cutting, and even fence building. ${ }^{257}$ On the Lassen National Forest, the agency assisted Indians with contracts for timber sales, timber and stand improvements, fire suppression, and reforestation. $^{258}$

Those Wonderful Sho-Bans

It takes strong, rugged, men to stand up to the 12-hour days of hard work while filling their lungs with searing smoke that causes painful hacking and coughing. - P.M. Obert ${ }^{259}$

255 Ibid. Memo to William A. Carlson, Director, Planning Evaluation and Programming Staff, from E.W. Schultz, Deputy Chief, re: "Forest Service Aid to Indians and Eskimos," January 13, 1971.

${ }^{256}$ Ibid. Memo to George H. Walter, from Robert M. Lake, re: "Training for Indian Youths,” March 31, 1972.

257 Memo to the Secretary of Agriculture, re: “1310 Planning,” Jan. 4, 1972. Collection F5, File, Civil Rights: Update. FHS.

$258 \quad$ Memo to Alfred Edwards from Robert M. Lake, re: "Forest Service Developments Affecting Indians," August 20, 1971. Collection F5, File, Civil Rights: Indian Opportunity. FHS.

${ }^{259}$ P.M. Obert, "Those Wonderful Sho-Bans," American Forests, Vol. 74, No. 3 (March 1968): 57. 
Early on, Region 4 moved to the fore in terms of BIA/USFS partnerships. The agency had worked with Native fire crews for several years prior to the first formal EEO reports, with the Sho-Ban Firefighters standing out as a partnership example. In 1962, an informal group of firefighters from the Fort Hall Indian Reservation in southeast Idaho partnered with USFS and the Bureau of Land Management (BLM) to professionalize firefighting on and off the reservation. Bob Tank, a BLM employee helped to develop the training program that led 138 members of the Shoshone Bannock Tribes - Sho-Bans - to become "smoke-chasers." 260 Their training included working with helicopters, practice in rapid loading and unloading, ferrying, "Helitank drops," rescue tactics and cargo hauling. They also practiced handling chainsaws and using heavy equipment. They learned about fire lines and back-fire, mop-up operations, using marine pumps, hoses and hand tools, and to administer first aid. By 1965, the Area Redevelopment Act provided funds through the Idaho State Department of Vocational Education for additional training, allowing ongoing participation to include an annual two-week refresher course.

The Sho-Ban Firefighter's main office stood on the reservation, run by Jimmy Dann who maintained constant contact with the Forest Service, the BLM, and the Weather Bureau. Despite some oversight, the men maintained independence from the agencies. They operated in 25-man crews and selected their own crew bosses and squad leaders. The group even sported their own insignia, worn on the left sleeve and the front of a white hard hat - a white buffalo skull on a blue background with red letters, SHO${ }^{260}$ Ibid, 56. 
BAN at the top and FIRE FIGHTERS below the skull. ${ }^{261}$ Firefighters ranged in age from 18 to 60 and were either enrolled or wedded to tribal members, and had to be in top physical condition. Most were married, had not completed high school, and lived on the reservation in "inadequate housing." They typically worked seasonally, often in potato cellars. $^{262}$

Firefighting provided an alternative for these men to earn a decent wage $(\$ 2.18 / \mathrm{hr}$ ), while remaining connected to the reservation. A man could make more money if fighting fires outside of Idaho in states with higher minimum wages. The year following organization, 1963, the Sho-Bans fought the 120,000 acre Crane Creek fire near Boise. They remained for a week before attacking a 56-mile fire line on the Grand Teton National Forest. When a massive fire swept through northern Idaho, Washington, Montana, and Canada, destroying 400,000 acres of timber in 1967, the Sho-Bans joined 15,000 other firefighters already in Idaho's panhandle and fought fire throughout the Northwest. The summer's activity earned them notoriety in the fire community and by the late 1960s, the Sho-Bans - the only organized crew of its kind in Idaho - had earned a reputation for efficiency, courage, and excellence in firefighting. Consequently, they “triggered a chain reaction" on reservations in Idaho, Oregon, and Washington. ${ }^{263}$ In January 1971, for example, the Forest Service worked with several Pacific Northwest

Ibid.

Ibid, 57.

Ibid, 38, 56. 
tribes to develop programs for reservation employment, to hire Native people directly, and to recruit enrollees for Job Corps. ${ }^{264}$

\section{Native Americans and Manpower Programs}

In addition to wage contracts, employment assistance, and reservation development, contact between USFS and Native peoples occurred primarily via Manpower and Youth Programs, and firefighting. (see table below) In fact, during the Wenatchee fire of 1970, more than six thousand American Indians participated in firefighting, some from the Southwest and 850 from Alaska. Three national forests in Montana that proposed Manpower Training Programs included those that served the Crow and Northern Cheyenne Reservation, the Blackfeet, and the Landless Indians of Central and Eastern Montana. The national forests aimed to provide training and job skills, tool use, farm and ranch skills, exposure to planning, organization, and logistics of work crews, "and the cultivation of work habits and attitudes."

Table 9: Forest Service programs that employed American Indians, $1970^{265}$

\begin{tabular}{|l|l|}
\hline \multicolumn{1}{|c|}{ Program } & Number of Employees \\
\hline Operation Mainstream & 70 \\
\hline Neighborhood Youth Corps (NYC) & 60 \\
\hline Work Incentive Program (WIN) & 1 \\
\hline Manpower Development and Training Act (MDTA) & 1 \\
\hline On the Job Training & 300 \\
\hline College Work-Study & 15 \\
\hline Permanent Forest Service Employees & $100+$ \\
\hline Seasonal for the past summer & $200+$ \\
\hline Organized Firefighting Crews - 60 crews & $1400+$ \\
\hline State Foresters use in excess of 2,000 Indians for firefighting & \\
\hline
\end{tabular}

264 Memo to H. Johnson, Division of Manpower and Use Conservation Programs, USDA, Washington, D.C. from, Jack Handy, USFS Portland, Oregon, re: "To Confirm Telephoned Information of 1-5-1971." Collection F5, File, Civil Rights: Indian Opportunity.

$265 \quad$ Memo from Schultz to Carlson, January 13, 1971. 
Job Corps provided the Forest Service another introduction to Native peoples, particularly in the West. A special center operated by the Tribal Council of the Salish Kootenai on the Flathead Indian Reservation enrolled only Indians. Regular conservation centers enrolled Native peoples just like anyone else, with participation varying by location. In 1970, Job Corps centers in South Dakota (Boxelder) and Montana (Trapper Creek), enrolled about six percent Native youth. At the Angell Center in Oregon, 4.4 percent of enrollees were American Indians and 23.7 percent Alaskan Natives, while national enrollment of Native peoples was only 1.6 percent. The Hobart Indian Camp on the Tahoe National Forest in California enrolled youth from the Stewart Indian School near Carson City, Nevada. The students earned \$1.68 per hour, with room and board furnished. The BIA employed a counselor and cooking staff for the camp and the Forest Service provided two foremen and a director, as well as half the time of another Forest Service employee, while both agencies made vehicles available. By 1972, the agency also piloted a Youth Conservation Program on the Tahoe National Forest.

\section{Diversification in the Pacific Northwest (Region 6)}

Region 6 activities also illustrate some of the ways the Forest Serve began the diversification process, with its efforts highlighted for U.S.D.A alongside Region 3 (the Southwest) and the Northeast Experiment Station, both of which had much higher regional minority populations. ${ }^{266}$ Although Region 6 ranked among the best in terms of 
employment, leadership took a lackadaisical approach to Title VI, the key to most EEO activities elsewhere. In 1969, Region 6 still had not conducted Title VI compliance reviews; however, it reported it would review and document all programs in the coming season. ${ }^{267}$ Nor had there been any EEO violations reported. Equal employment clauses had also been placed into all contracts, and in keeping with the Secretary's order to make "[s]pecial efforts" to "assure that job opportunities in the Department [were] made known to men and women of all races, religions, and ethnic backgrounds, ${ }^{, 268}$ EEO staff contacted small business minority groups. Field efforts to work with minorities included hiring a 10-man Chicano tree planting crew and a three-man Chicano thinning crew on the Rogue River National Forest, while the Winema National Forest had a thinning contract with an Indian woman.

\section{Recruiting Minorities in Region 6}

In addition to minority contracts, the agency sought to recruit and employ minorities directly. By 1970, Region 6 had developed a 16-point program to take advantage of the recruitment season and existing placement opportunities. The six Recruitment and Retention responsibilities highlighted by Acting Regional Forester Robert Torheim in the plan indicated strong commitment to diversity. First, the region decided to place "any professional minority in any discipline" represented in the workforce into a permanent position after a probation period. Management should

\footnotetext{
2671970 R-6 report, June 10, 1970. Collection F5, File, Civil Rights Action Plans, 7.

268 Clifford Hardin, Secretary of Agriculture, "Secretary’s Memorandum No. 1662, USDA Policy on Civil Rights,” September 23, 1969. Collection F5, File, Civil Rights Action Plans. FHS.
} 
review "GS-4 and below vacancies for restructuring or consideration for filling by qualified minorities.” The region would fill entrance level positions in the Regional Office (RO) with minorities and the plan focused on strategies for creating "developmental positions," with leadership to identify training stations to grow full- and part-time employees into permanent positions. The region would provide training for less qualified minorities from the worker trainee register and other recruitment sources. It also reassigned an employee with teaching experience to help others upgrade typing skills and gain clerical skills. By the time of the first report to the chief, this pilot training program had begun, with some trainees already at work. By July 1 under an expanded program, new trainees would be assigned to the training center for a 30-day evaluation and orientation. Those capable and interested would be placed in realistic work assignments and moved into regular positions with permanent full-time (PFT) status as vacancies occurred. Additionally, "plans would be made for their career development." ${ }^{269}$ Meanwhile, although the report does not indicate how it would address the issue, it also included "Allayment of concern for ceiling overages" due to minority hires.

Recruitment and relationship development with minority organizations stood at the center of workforce diversification efforts. Forest units recruited people of color for summer work and intensified efforts to identify jobs and coordinate minority recruitment between forests and other regions. Regional leaders also worked to build a multicultural seasonal workforce through outreach to the Northwest's indigenous population and 
Chicanos. They explored available Indian Manpower sources on Northwest reservations and nearby areas and activities, with Torheim reporting satisfactory working relationships with Indian groups. ${ }^{270}$ Similarly, regional leaders sought out MexicanAmerican manpower sources. Under guidance of EEO staff from the RO, the Siuslaw National Forest hosted representatives of the Willamette Valley Migrant League and the Chairman of the Governor's Advisory Committee on Chicano Affairs. Forest representatives attended this meeting bringing specific job offers to the table. They also discussed the possibility of Chicano crews bidding on contracts for thinning, brush disposal, trail maintenance, and so forth. By the time of the June 1970 report, the region had begun to coach minority contractors in how to bid and also sought funding sources for research on minority forest use.

\section{Recruitment Challenges in Region 6 - "Good Action!"}

Workforce development efforts included youth populations at both the high school and college levels. The region negotiated agreements with sixteen colleges and universities to participate in the off-campus Work-Study program and also hired numerous NYC, YCC, and WIN graduates, some of whom had been converted to permanent status. ${ }^{271}$ The agency also recruited students via the nation's HBCUs and assigned three minority employee recruiters to personnel offices of forests within or near urban areas. Regional EEO and recruitment staff developed relationships with Work

1970 R-6 Report, 5. Ibid, 6. 
Experience Coordinators at most Portland high schools, especially those with minority and disadvantaged students. Student activity centered at Jefferson High School in 1970, with a mini-course on federal government opportunities attended by selected students. The agency also placed a female African American counselor at the school to recruit for the Summer Aid Program and refer students to USFS for potential careers. Additionally, the Forest Service established a conservation course (mostly minority group students) at John Adams High School in Northeast Portland, the area of the city with the highest African American population. ${ }^{272}$ Graduation would lead to either full-time employment with the Forest Service or enrollment at either the community college Forestry Technician School or Oregon State School of Forestry. ${ }^{273}$

Despite this leadership commitment to diversification, dissonance between mandated policy and agency outcomes often occurred at multiple scales. At the regional level, the agency responded to criticism from the black community "that we and other Federal agencies were not reaching the hard-core blacks" by setting up a meeting through the Federal Personnel Council, the region's EEO staff, and representatives of black job placement and learning centers, federal employment offices, and referral organizations. The meeting clarified the limits of outreach. Agencies would not extend

\footnotetext{
272 The innovative John Adams High School was a new Portland school built in 1969 with a curriculum designed by four Harvard School of Education graduates. Located at NE $42^{\text {nd }}$ and Killingsworth. the school drew students from the Jefferson, Madison, and Grant High School areas. The school closed in 1981 and became a middle school for a short time. It was used by Gus Van Sant for his film Elephant and, due to mold problems, low enrollments, and poor construction, it was demolished in 2007. Carl Abbott, personal communication, June 13, 2014; Allen Dobbins, “Adams High School," The Oregon Encyclopedia, http://www.oregonencyclopedia.org/articles/adams_high_school/\#.U5tkYrElKzA [accessed June 13, 2014]

2731970 R-6 Report, 6.
} 
recruitment beyond formal initiatives like the Concentrated Employment Program (CEP) or other those organizations that provided initial screening "to reach the extreme hardcore and perform the needed rehabilitation services. ${ }^{274}$ Dissonance at the unit level included what Pete Daniel calls "passive nullification" of diversification efforts. As one retired female employee explained, Forest Service staff often resented requirements to hire minorities from outside the region, preferring to recruit and hire locals as they always had. At John Day, Oregon in the 1970s, for example, the district was supposed to hire Native students from an Indian school in Nebraska, but:

No one ever showed up. Ever. Every year for I don't know how many years; they were just a joke for us - we [were supposed to have] two employees. Now, one year the school called us and said they had started hitch-hiking. I said, [laughing] "You know how far it is from Nebraska to John Day, Oregon?" ... They never showed up. .... we always hired in their place because we knew we were always going to be short two Indian kids [laughing] from Nebraska. If they'd ever showed up we'd always have two too many people which we'd probably been all right with. But none of them ever showed up. And nobody ever cared. .... And the schools weren't even held accountable to make sure if they placed people that they actually and truly placed people. ${ }^{275}$

Still, when it came to "definitive action," Region 6 was ready and able to report on activities accomplished, planned and in progress (See Table below). In fact, a

2741970 R-6 Report, 3; It is not clear what the term "hard-core blacks" means in this context; however, in writing about Job Corps Franklin Parker (see p. 109) also used this term regarding those in poverty. The term itself refers to the most doctrinaire or extreme, uncompromising, etc., and clearly indicates problematic 1970s stereotypes about who is African American and/or poor. Most likely, the term refers to urban African Americans and like the notion that African Americans need "rehabilitation," it indicates dysfunction.

275 Jacque McConnell interview by Julie Watkins, May 7, 2005, John Day, Oregon. Workforce Diversity Council Collection. 
handwritten note on the margins of the report from Acting Regional Forester Robert

Torheim to Chief Cliff reads: "Good action!",276

Table 10: Definitive Action - R-6, June 10, 1970 Reporting period

\begin{tabular}{|c|c|c|c|c|}
\hline $\begin{array}{c}\text { Division/Department/ } \\
\text { Location }\end{array}$ & $\begin{array}{c}\text { Number } \\
\text { hired }\end{array}$ & $\begin{array}{c}\text { Racial/gender } \\
\text { designation }\end{array}$ & $\begin{array}{c}\text { Status } \\
\text { Occupation }\end{array}$ & Hire Date \\
\hline $\begin{array}{c}\text { Division of Engineering, } \\
\text { RO }\end{array}$ & 8 & "minority group",277 & unknown & June 1970 \\
\hline $\begin{array}{c}\text { Division of Fire Control, } \\
\text { RO }\end{array}$ & 2 & "minority group" & $\begin{array}{l}\text { GS-6 clerk } \\
\text { unknown }\end{array}$ & $\begin{array}{l}\text { Previous } 6 \\
\text { mos. }\end{array}$ \\
\hline $\begin{array}{l}\text { Division of Range } \\
\text { Management, RO }\end{array}$ & 2 & "minority group" & unknown & $\begin{array}{l}\text { Previous } 6 \\
\text { mos. }\end{array}$ \\
\hline $\begin{array}{c}\text { Division of Timber Mgt., } \\
\text { RO }\end{array}$ & 1 & "minority" & unknown & Hired \\
\hline $\begin{array}{c}\text { Division of Watershed, } \\
\text { RO }\end{array}$ & 1 & "minority" & Soil scientist & June 1970 \\
\hline $\begin{array}{c}\text { Division of Fire Control, } \\
\text { RO }\end{array}$ & 1 & "minority group" & Temp. for summer & Planned \\
\hline $\begin{array}{c}\text { Division of Timber Mgt. } \\
\text { RO }\end{array}$ & 1 & "minority" & unknown & June 15 \\
\hline Deschutes NF & 2 & "minority" & $\begin{array}{c}\text { Landscape architect } \\
\text { Civil engineer }\end{array}$ & Hired \\
\hline Deschutes NF & 4 & "Indians" & $\begin{array}{c}\text { Temp. positions } \\
\text { pending conversion to } \\
\text { PFT }\end{array}$ & Hired \\
\hline Deschutes NF & 1 & "minority" & $\begin{array}{l}\text { Job Corps grad. perm. } \\
\text { position }\end{array}$ & Hired \\
\hline Deschutes NF & At least 8 & "minority group" & Seasonal & Hired \\
\hline Gifford Pinchot NF & 10-plus & "minority group" & Summer employees & Hired \\
\hline Ochoco NF & 5 & "minority" & Unknown & $\begin{array}{l}\text { Recruited } \\
\text { since } 4 / 30\end{array}$ \\
\hline Olympic NF & 3 & "minority group" & Permanent & Hired \\
\hline Olympic NF & 9 & "minority group" & Temporary & Hired \\
\hline Rogue River NF & 1 & Indian & Unknown & Hired \\
\hline Rogue River NF & 2 & Chicanos & Unknown & Hired \\
\hline Siskiyou NF & 1 & "minority" & Permanent & Hired \\
\hline Siskiyou NF & 5 & "minority" & Seasonal & Hired \\
\hline RO and Umatilla NF & Crew & "all-girl survey crew" & Unknown & Recruited \\
\hline Winema NF & 2 & "minority group" & Unknown & Hired \\
\hline Winema NF & 7 & "minority group" & Seasonal & Hired \\
\hline
\end{tabular}

2761970 R-6 Report, 1.

277 I presume the "minority group" designation refers to African Americans, since both women and other ethnic groups are named by race/ethnicity. 
In keeping with this "Good Action," the Regional Office provided special new worker training and upward mobility opportunities for minority group employees. On the Gifford Pinchot National Forest, a minority personnel specialist received three formal training opportunities in the six months prior to June 10, 1970. And, while some regions did not report at all, Region 6 stated that its Division of Operations held a two-day Civil Rights training session for employees. ${ }^{278}$ Upward mobility reporting also included two women at the GS-7 and GS-9 levels on the Siskiyou National Forest, providing cash awards to female and minority employees, and recognizing employees for their civil rights efforts. EEO efforts brought a quality step pay increase to an Olympic National Forest personnel specialist and at the Glide Ranger District on the Umpqua National Forest, the woman who broke into the forestry technician series then received the first ever annual award to an "outstanding employee."279

\section{Civil Rights Development in USFS}

\section{Civil Rights Training}

By the first formal civil rights report in June 1970, all R-6 forest supervisors and division chiefs had completed at least a one-day Civil Rights training program, with plans underway to provide such training to all supervisory personnel in the following year. In response to Memo 1662, the agency had developed a civil rights training

$278 \quad 1970$ R-6 Report, 6.
$279 \quad$ Ibid. 
program that it distributed agency-wide, ${ }^{280}$ and by the time Chief Cliff reported to Secretary Hardin, nearly two thousand employees $(1,816)$ had attended a workshop. The Department of Personnel Management issued a "Guide to Conducting Civil Rights Training" that laid out the training package very clearly, with optional activities that could be tailored by region. Pre-reading materials for all participants included the Chief's April 7, 1970 policy memo, the Service-wide Civil Rights Action Plan, various staff position papers, and optional pre- and post-reading materials. Training sessions aimed to acquaint employees with national civil rights problems and to increase team members' knowledge about agency civil rights policy. Workshop sessions always included an overview of basic policies, an assessment of the local civil rights situation, a film with discussion, and attempts to relate position papers to the program and activities of the regional work team. Leaders could also expand training through optional activities, discussions, and films to examine attitudes, improve interracial communication, and develop plans to address civil rights issues. ${ }^{281}$ In the first optional activity, participants selected training objectives and jointly assessed the local civil rights situation with the team leader. Participants might also weigh in on which film to show and discuss during the training.

Optional activities and films provide some insight into social issues faced by the agency, as well as its EEO priorities. Training sessions could use the film Black Anger, a

\footnotetext{
280 E.W. Schultz, Deputy Chief to All Deputy Chiefs, "Civil Rights Training in EEO,” September 21, 1970. FHS Collection F5, File, Civil Rights: Indian Opportunity.

281 U.S. Forest Service, "Guide to Conducting Civil Rights Training," enclosure to Memorandum re: "Training in EEO" from Edward Schultz to Deputy Chiefs, September 21, 1970. Collection F5, File, Civil Rights Action Plans. FHS.
} 
30-minute recorded discussion by a group of articulate, candid, and often hostile black men and one Latino male. Black Anger introduced agency employees to minority male experiences in a world that "most white people" had never heard about. Two other films focused on African American workers and identity issues in white workplaces, while Reis Tijerina, introduced employees to the biography of Tijerina, a self-identified "Indio-Hispano" who sought to take back the national forests in the 1970s. ${ }^{282}$ All films included guided discussion modules to prompt personal and social exploration. Optional activities also provided opportunities to connect with local minority groups, either by bringing them in as speakers or incorporating them into civil rights planning and program development through the workshops. Team leaders determined how open the process would be, but the agency guide suggested opening the process internally and externally. ${ }^{283}$

Even before the agency developed a national civil rights program, Region 6 leadership tried to convey some understanding of minority experiences through civil rights trainings. In 1968, all regional supervisors received copies of the book The Negro Family "as required reading, a book intended to acquaint them with what society deemed the "Negro problem," 284 a sticky framing of the situation that reflects the

\footnotetext{
282 Reis Tijerina is" best known for founding the Alianza Federal de Mercedes. The group organized heirs seeking to regain Spanish and Mexican land grants protected under the Treaty of Guadalupe Hidalgo, an important component of the Chicano Movement." University of New Mexico, Rocky Mountain Online Archive, http://rmoa.unm.edu/docviewer.php?docId=nmu1mss654bc.xml [accessed June 24, 2014]; Interview with Reis Tijerina, by Ray Siqueiros and Rene Teyechea, http://www.youtube.com/watch?v=W5L77qrKsxg [accessed June 24, 2014].

"Guide to Conducting Civil Rights Training."

284 “1968 EEO progress report.” Collection F13.2, File - Personnel: Equal Employment Opportunity.
} FHS. 
agency's lack of familiarity with African American culture. Meanwhile, the film A Time for Burning provided a radical perspective on American history, presented in measured tones by the barber Ernie Chambers. ${ }^{285}$ In the film Chambers, who would become a Nebraska state senator in 1970, points to religious hypocrisy and colonial oppression to explain why solving interracial problems would require real, concerted action:

We've studied your history. You did not take over this country by singing 'We Shall Overcome.' You did not take over the world like you have it now by dealing fairly with a man and keeping your word. You're treaty breakers. You're liars, you're thieves. You rape entire continents of people...your religion is a farce and you demonstrate it everyday...As far as we're concerned, your Jesus is contaminated just like everything else you've tried to force on us is contaminated. I wish you would follow Jesus like we followed him. Cause if you did that, we'd be in charge tomorrow. ${ }^{286}$

Statements like the above likely shocked and perhaps repelled Caucasian Forest Service employees, making inclusion of this movie in regional training materials all the more reflective of regional commitment to diversification through an honest accounting of the past. Still, for Northwesterners, where the African American population had increased tenfold in Oregon and Washington between 1940 and 1970, and had quadrupled in Idaho [See Pacific Northwest States by Race, 1950-1990, Appendix C,

\footnotetext{
285 This 1966 documentary explores Black-White relations in Omaha, Nebraska as the Lutheran pastor, Reverend William Youngdahl attempts to connect his parishioners with African American Lutherans. In the movie, barber Ernie Chambers, who later became the longest serving senator in Nebraska history (1970-2005) explains why "Your Jesus is contaminated." The film, commissioned by the Lutheran Church, was nominated for Best Documentary Feature in the 1967 Academy Awards. New York Times "Movies - Trailers and Clips, A Time for Burning, 1966, http://www.nytimes.com/movies/movie/192244/A-Time-For-Burning/trailers [accessed June 29, 2015]; Paul Putz, "A Time for Burning in Religion, Race, and Civil Rights in Omaha," Religion in American History Website, October 20, 2013 Blog Post, http://usreligion.blogspot.com/2013/10/a-time-for-burningirreligion-race-and.html [accessed June 29, 2015].

$286 \quad$ Ibid, Ernie Chambers, A Time for Burning Trailer [accessed June 29, 2015].
} 
Table C.1), ${ }^{287}$ the learning curve regarding people of color remained steep. As the agency moved toward ecological and occupational diversification and the social milieu began to shift, a convergence of individual initiative, funding support, and civil rights commitment emerged in the Northwest. Despite its homogeneity, at least some, if not most regional leaders supported workforce diversification in the decades to come. This fact became clear in the following two decades as Region 6 transferred its diversification lessons to the national arena. Like most policy shifts, commitment to diversity occurred at multiple intersecting levels, starting with a directive from the Secretary of Agriculture to all agencies mandating each appoint a director of Civil Rights.

Jetie Wilds, Civil Rights and the U.S. Forest Service

Putting people productively to work and realizing their potential, benefit both the Nation and the individuals. "The Civil Rights Program, ca. 1981

Jetie Boston Wilds, the second of twelve children and an African American man, was born in the urban environment of Tampa, Florida before World War II. Wilds' parents worked in the service industry, his mother as a laundress for hotels and motels and his father in a grocery store. As a child, Jetie Wilds dreamed of becoming a professional ball player and when he went to Atlanta's Morehouse College and became a Mathematics major, he also lettered in baseball. But his time at the men's HBCU shifted Wild's outlook from sports to real life. When he arrived at Morehouse in 1957,

\footnotetext{
287 The African American population increased from 2,565 to 26,308 in Oregon, 7,424 to 71,308 in Washington, and 595 to 2,130 in Idaho during this period. Quintard Taylor, In Search of the Racial Frontier: African Americans in the American West, 1528-1990 (U.S.A.: Norton, 1999): 253, 279.
} 
Wilds signed up for a course from Martin Luther King, Jr. But, he recalled in 2013, he never sat in King's classroom: "he was always in the movement somewhere." Still, Wilds encountered the civil rights leader many times, and:

Once I heard him, I knew then that it would be just too selfish to just think in terms of baseball, when he was saying that we had a greater responsibility ... the professors were saying, 'you have a greater responsibility. The thing that I think Morehouse does for you, that goes beyond just the exposure, is that they actually make you think that you can do it. That not only do you have a responsibility to alter the world in terms of making it a better place, but it'll make you think that you can make it a better place, and that's a very positive thing.

Morehouse taught young African American men to be proud, said Wilds To excel. To see the world differently. Perhaps most importantly, the school taught him that he could be "more than a baseball player." With civil rights activity all around and classmates like Julian Bond, ${ }^{288}$ Wilds became "fired up" by the civil rights movement.

Jetie Wilds returned to Tampa in 1962 to teach junior high and high school Mathematics. But yearning to make a greater impact, he applied to Job Corps, the “domestic part of Peace Corps." And, "that's how I got into the Forest Service," he said. The organization first sent him to what he called "West-by-God Virginia," where the agency ran the Anthony Job Corps Center, an all-male conservation center. According to Wilds, most of Anthony's enrollees were Black, some from the city, others escaping reform school. Still more came from poverty-stricken rural Virginia and West Virginia. For Wilds, Job Corps fulfilled what he had "been trained mentally to do" at Morehouse

\footnotetext{
288 Horace Julian Bond, a lifelong civil rights activist, helped to found the Student Nonviolent Coordinating Committee and became the first president of the Southern Poverty Law Center. "Julian Bond Biography," Online Encyclopedia of World Biography, http://www.notablebiographies.com/Be-Br/BondJulian.html [accessed July 3, 2014].
} 
- effect change. He saw the organization's basic purpose as helping disadvantaged youth to "re-create" themselves through work and education, "in an environment away from the one that had been toxic," where they learned skills they could take into the workforce.

On his first day, Wilds bumped into the entrenched bureaucracy of the U.S. Forest Service, an agency bound by systemic institutional, racial, and cultural restrictions. This first clash occurred when he sought travel compensation for his journey from Florida to Neola, West Virginia. The administrator responsible for reimbursement refused payment because Wilds had used paved interstate roads, rather than traveling via the Rand McNally route used by agency employees. Wilds remembered thinking "this is a hard-nosed group," even as he understood "this is one person acting that way." In some respects, this incident reflected the cultural misinterpretation that beset the Forest Service in its relations with African Americans. Not only did the agency fail to instruct Wilds regarding travel requirements, neither did it occur to anyone that as a black man, Wilds would avoid taking back roads through the South. He insisted on receiving payment, and got it.

Wilds' experience in Neola also set the stage for the young activist's role in shaping a strong Civil Rights Program for the U.S. Forest Service. When he joined the agency as a GS-9, Wilds quickly noticed inequalities. While many Caucasian teachers were also GS-9, "some of the African Americans coming in as teachers from other places started out at 5." He began to ask questions. "So they asked me to do a report ... with regards to what was happening with African Americans, the instructor side, in that 
Job Corps center." This started Jetie Wilds on a journey that led him from Neola to the Northwest, and then to Washington, D.C. Three years later, the Anthony Center closed and in 1969 Jetie Wilds headed to Portland, Oregon. There, he took charge of developing an environmental education center from a recently closed Northwest Job Corps site that had previously served as CCC Camp Cispus. He recalled that his "responsibility was to transform that center into an environmental education center ..." to develop a program for sixth grade environmental education.

In Oregon, Wilds sought to focus his passion for social justice, which he described as "what I'm about and part of my narrative." At the time, the Forest Service was "caught up in the movement to change ... and make government more fair and more representative of the larger population." With his interest in occupational equity piqued at Anthony, Wilds examined the workforce composition almost upon arrival to Portland. He quickly determined that the Forest Service needed an "intervention" to increase diversity. So, after transferring the environmental education center from the Forest Service to the state on the first national Earth Day, April 22, 1970, Jetie Wilds moved into Personnel, home of the agency's Equal Employment Opportunity office. There he began to develop a course of action that would inform the agency's national civil rights program. 


\section{Civil Rights in the Pacific Northwest}

When Jetie Wilds moved to Personnel, he not only reported on employee

demographics, he also developed curriculum and sensitivity training that he recalls,

"really started moving things in a different way." The goal was:

...to train our people into understanding ... these new people, strange people, called African Americans, Hispanics, Indians, Asians, and then women, to let them know that the skills were there. All we had to do is provide opportunities for them. But you had to prepare these guys, white males, who were very honest and innocent in that belief system. ... I don't remember finding anybody who was just angry or evil. They just didn't believe in it, you know, that these people could do that job. And they believed very much in what it is that they were doing, that they were the only ones who could do it and they were the only ones trained to do it, and to a large extent when it came to the out of doors, and in the field, they were. But they weren't the only ones capable of being trained.

So then, I got selected to lead the training session. I selected people, put them through the kind of training I wanted, developed a curriculum that was going to move us in that direction, and the rest is history. And that history included training about four thousand people while I was in the Pacific Northwest...

"The Movement" shaped Wilds' training presentations, reflecting the tenor of the times

and of the place. Wilds tried to bring a broader social consciousness to Forest Service

employees, and consequently, a key part of civil rights education came through the

stories of individual minority group members:

... we had Indians who were concerned about the McQuinn Strip ${ }^{289}$ and how that land was being used and abused, and their burial grounds were being disturbed. ... We had the grape boycott coming out of California and lettuce and stuff in Oregon. So you had the Hispanics who were raising hell with the

289 The McQuinn Strip controversy concerned the boundaries of the Warm Springs Reservation in which the federal government wrongfully surveyed and allocated lands from the 1855 Treaty of Middle Oregon. After a century of protest, the government returned 61,360 acres of public lands from the Willamette and Mt. Hood National forests to the Warm Springs' possession. Joshua Binus, "Mcquinn Strip Land Dispute," Oregon History Project, http://www.ohs.org/education/oregonhistory/historical_records/dspDocument.cfm?doc_ID=D3DDB800FA5D-E80D-04D8EA27E48D8F6F [accessed June 24, 2014]. 
farmers. You had the Black Panther Party that was around the nation concerned about what was happening with African Americans. You had the women's movement starting. ... they were basically white women, meeting in kitchens, in living rooms, complaining about how they were being treated.

And so, my responsibility, as I saw it, was to meld, or put all of them together. So I got every leader in a particular area, from each of those groups, put them together, taught them the curriculum, pulled in white males from the area who already had empathy, and we put together a team.

For the Southern-born Wilds, Oregon seemed "more receptive" to inclusion than some other locales. But, like many other national forest regions, especially in the West, it was also more homogenous than places like West Virginia, Florida, or Washington, D.C. Consequently, the training program focused on helping employees to understand cultural difference and group values. For example, Wilds recalled telling trainees, "when one African American won, like Jesse Owens or Joe Lewis," that meant "we won," meaning all African Americans. When Bruce Jenner won in the Olympics, "as long as we were against other people in the world, it was U.S.A., U.S.A. But when [he] came back to the United States he was an individual" whose achievements became his own. African Americans, says Wilds, "had a sense of community, that one person did well, everybody had done well," especially in 1969 and 1970; a sense of group identity. According to Wilds:

We'd give the kind of examples that I'm talking about. We would have discussions around that, until people understood that people were having different experiences in our America, all right? ... We had real examples. And then they had what they called ... the American Indian Movement, they called it AIM. And AIM was doing what NAACP, what FEW [Federally Employed Women] does now but FEW had not been organized at that point. ...

Sensitivity trainings also included "converts," white male representatives "who were leaders, who then saw themselves as wanting to be part of bringing about change.... 
there wouldn't be any change, real change without those individuals.... the line

organization.” Equal employment opportunity would require buy-in from people willing

to craft a more inclusive future:

...we felt what we had to do was develop this curriculum to deal with our raw emotions of why it is that we behave in a certain way; because as far as being in the Pacific Northwest.

I'm not talking about other parts of the country. I'm saying where this started in the Pacific Northwest, what we'd find is that these are good loving people who mistreated other loving people out of habit, and out of how they was reared, and if we could somehow get them to think beyond that period, just maybe they would be willing to accept these individuals into the workforce, which was the end product of where we were trying to go."

As Wilds recalled:

...some of them decided that it made sense... and why weren't we fairer? By the definition of the whole society. I don't think that many people thought they were unfair. They thought that they were fair but we described what is fair, and fair meant that we should - from our perspective - that we should have a mix of individuals in a society such as ours. So, some of the white male line officers joined us also. So we had everybody interested in bringing about a different mix, participating.

Everybody included professors from Portland State University who could help

leadership understand the psychology of racism and sexism. Black Studies professor

Darrell Millner, for example, facilitated agency training for the Forest Service and other

federal organizations contending with diversification and training mandates from

leadership. As he explained:

...one of the things that happened in the period that you're interested in, the '70s and ' 80 s, there was a lot of pressure, a lot of expectation that those people would address these issues, look at these problems. And then there were mechanisms that were created to allow that to happen, mechanisms like "Black History Week" that became Black History Month, okay, and that's my connection to 
those kind of organizations. If they need to address these issues, and they have very few people within their organization who have any knowledge or background, or ability to do that, then they go externally to do it. So they invite people like me to come in during February and give a presentation on Oregon Black history, or Black cinema history, or something like that.

Outside trainers also educated agency workers in Portland and elsewhere. Millner recalled providing one-day civil rights training sessions in Eastern Oregon, Idaho, and across the Columbia River in Vancouver, Washington, noting that location did not determine whether he received a warm welcome or hostility. It was "not predictable, but both were possibilities.

Still, when asked if the Northwest was one of the regions that moved forward first in terms of workforce diversity, Wilds replied, "Oh yeah." He and his crew trained Forest Service employees from California and Alaska to Atlanta. But, there was pushback to diversification efforts and to trainings described by more than one person as "in your face" experiences. When someone complained to the Secretary of Agriculture about the nature of the workshops, they halted, but only for a short time. According to Wilds, individual participants and allies of the civil rights team wrote to the Secretary of Agriculture, ${ }^{291}$ claiming the sessions had changed their lives, and the program moved ahead. In fact, "the power structure in the Pacific Northwest turned the sessions back on. So we started back up, and we were more powerful than ever." Indeed, Wilds' efforts

\footnotetext{
${ }^{290}$ Darrell Millner, interview by Donna Sinclair, January 14, 2014, Portland, Oregon.

291 Based on the time period Jetie Wilds spent in the Northwest (until 1975), the Secretary referred to was most likely Earl L. Butz, Secretary from 1971 to 1976. Butz resigned in 1976 because of a racist comment, an "obscene characterization of black Americans" reported by the Christian Science Monitor, which according to Pete Daniel, "suggested a USDA culture that tolerated humor at the expense of minorities and that perpetuated stereotypes and undermined equal opportunity reforms." Daniel, Dispossession, 219, Loc 4003 Kindle Version.
} 
were so successful that in 1975 when the Secretary of Agriculture mandated all agencies establish formalized civil rights programs, the Forest Service tapped Jetie Wilds to develop the national Civil Rights Program for the Forest Service.

Shaping a National Civil Rights Program

The Civil Rights Program objective is to develop action plans ensuring that all persons, regardless of race, color, creed, sex, age, religion, handicap, or national origin be afforded equal opportunity to participate in any program activity administered by the Forest Service. "The Civil Rights Program," ca. 1981

On September 17, 1975 the Forest Service established the Washington Office Civil Rights Staff Unit by authorization of the Department of Agriculture. ${ }^{292}$ For the first time, the agency Civil Rights Program existed separately from Human Resources, a status that would fluctuate over the years. Previously there were:

...people who happened to be in Personnel, who dealt with what they called Equal Employment Opportunities, and they were supposed to make sure that anything that came through there was fair and all that. And that any recruiting materials represented all the people. But then they set up this Civil Rights organization that was similar to what we had in Portland. It was a model, the same thing that we had in the Pacific Northwest, that I had responsibility for ... so we just moved that to D.C., minus the training part. And so I became the first director of Civil Rights for the Forest Service, 1975.

Establishing the nationwide Civil Rights Program was "easier than one would think,"

said Wilds, "because the pressure was on the Forest Service. It was first on the Secretary of Agriculture." Jack Deinema, the agency's head of administration recruited Wilds for the job. At first, Wilds lacked what Herbert Kaufman called "willingness to conform."

\footnotetext{
292 “Authorities and Responsibilities, The Civil Rights Program,” ca. 1981. Collection F5, File, Civil
} Rights: Minorities. FHS. 
He refused the offer. But "then they explained it to me in a different way," recalled Wilds. "They said: 'if you don't come, the Forest Service will forget you and they might decide to send you someplace you have never been.' And so after it had been explained to me in that way," Wilds took the job. ${ }^{293}$ Consequently, in D.C., he had "full support" from the Chief of the Forest Service, John McGuire, a forester with economics training who moved up the "line" traditionally. Wilds characterized McGuire's response to the Agriculture Department in terms of his position: "a very powerful individual. ... the chief reported to the Secretary of Agriculture. And so, the chief wanted to look good, and they had told him what we had done in Region 6 . And we had demonstrated that throughout the Forest Service.”

With support from the chief, Wilds developed a stand-alone Civil Rights program, one that mandated accountability for diversification at multiple levels. The "Civil Rights Umbrella" created during this period included: equal access to services for the public and women and minority-owned businesses; shaping policies related to civil rights law; providing civil rights training; measuring civil rights impacts of major policies and actions taken by the Forest Service; dealing with Title VI federal financial assistance programs; monitoring and evaluation of all civil rights goals; and overseeing equal employment opportunity. The Civil Rights director coordinated agency activities involving assistance to American Indians and evaluated the agency's minority business

293 John "Jack" Deinema confirmed this account of events through an email exchange on April 8, 2015, writing, "I retired as Deputy Chief of Administration in 1979 and clearly remember the emphasis we placed on the Civil Rights program and the excellent work performed by Jetie Wilds. And the facts you presented are essentially correct as I recall them." 
assistance program. The program set standards and monitored agency adherence to procedures regarding discrimination complaints in programs, activities, and employment. Wilds' job included aligning agency policy and targets with Agriculture Department positions.

Civil Rights also coordinated and prepared the agency affirmative action plan. It established standards for statistical reporting and evaluation measures for minority participation, including employment. ${ }^{294}$ The main objectives of EEO were to 1) eliminate discrimination in the Forest Service; and 2) "promote an affirmative action program which will place women and minorities into positions and pay scales equal to what they can really do." ${ }^{295}$ Wilds recalls proposing a "budget model" to achieve targets representative of local populations, a model in which “.... a part of performance would be based on how many dollars they [leaders] expended for the cutting of the trees or the building of the roads, as well as who did the cutting of the trees and who did the building of the roads." For the first time, supervisors were required to have a "different mix of employees," a mix that included women and people of color. Performance evaluations would reflect the presence or absence of that blend, and accountability stemmed from consistent oversight and reporting. In addition to incorporating workforce diversity in performance evaluations, Wilds suggested that each region should have "somebody like myself," a civil rights director at each region and station. The chief accepted the idea

294 "The Civil Rights Program," 1. Ibid, 2. 
and with the addition of computers, interregional communication regarding civil rights became possible.

A nationwide civil rights group composed of women and people of color worked to develop strategies for outreach and for incorporating non-traditional employees into the agency. Mack Hogans, who worked for the agency in the Pacific Northwest from 19741979 recalled that Jetie Wilds was "charismatic, very effective," and "had a tough job." In fact, "in those days, he ...had to push pretty hard." One of the ways he did so was to create a nationwide advisory committee, described by Hogans as "a rainbow:"

...when I was there, the Forest Service had just created something called the Civil Rights Group. And they had Civil Rights leaders in the Washington office and all of the regional offices, and may have had a representative or two on all of the national forests, the actual forests. And there was a very, very concerted effort to diversify the Forest Service. And the focus was primarily on black people. And they had something called the Civil Rights Task Force ... and I was on it for a couple of years - it was comprised of African Americans who worked for the Forest Service, Hispanic Latinos, Native Americans, and women. And our job was to advise the chief on policies to address diversity within the Forest Service.

National and regional civil rights directors met at least annually, and sometimes twice a year, as did the Civil Rights Task Force, to help formulate policy and provide guidance to leadership on bringing women and people of color into the agency.

The high level of support for Civil Rights occurred, recalled Jetie Wilds, because the chiefs he worked with, John McGuire (1972-1979) and Max Peterson (1979-1987), both supported the Civil Rights Program. And as it evolved, according to a 1981 overview, the Forest Service began to change its approach to employee development. Whereas, prior to the 1970s, the clear progression to leadership occurred via forestry and 
subsequent line positions, the Civil Rights Program pushed the agency to consider developing employees to:

- Get the greatest use out of each person's ability and potential.

- Give each person pride and satisfaction in what they do.

- Set an example of complying with all laws, rules, and regulations.

- Show the Forest Service as a leader in equal opportunity. ${ }^{296}$

As the agency contended with changing and multiple publics, the civil rights team sought to convince leadership that promoting equal employment was "both good management and a sound social policy."

\section{Discussion: Muddling Through the Turbulent Times}

The initial social diversification of USFS could easily be described in terms of Charles Lindblom's muddling through, a time of visibly incremental change that started with the "semi-revolutionary" shifts occurring in the outside world. ${ }^{297}$ At the highest level, it took executive orders and Congressional action to force institutional desegregation around the nation. In the Department of Agriculture, agencies varied by mission, history, and cultural orientation, so that each had its own set of issues that affected workforce diversity. While the Secretary of Agriculture mandated nondiscrimination and equal employment opportunity across the board, each agency determined its own manifestation of those issues. In the U.S. Forest Service, the time lag from issuance of Memo 1662 in September 1969 to policy formalization through the

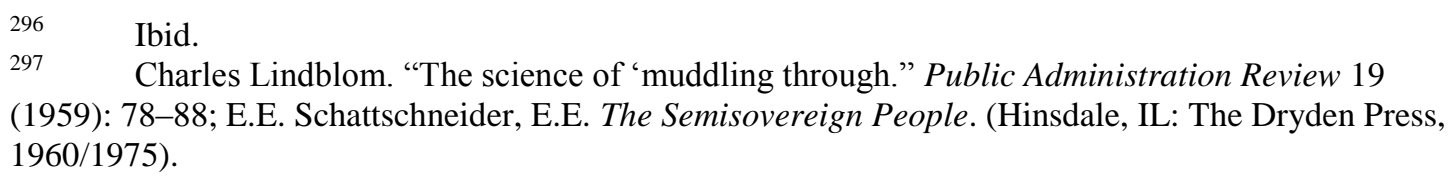


Chief's April 7, 1970 policy memo demonstrates that the agency sought to provide clear direction regarding EEO from the highest levels. It also shows the disconnection of agency leadership from the social issues of the time. Not only did top leadership receive minimal regional response by June 1970 when the initial reports were due, despite clear direction, some regional leaders brushed off responsibility for diversification. Deputy Chief Schultz charged supervisors with effecting change. They looked to Human Resource Departments. Sometimes very little occurred at all. It took until March 13, 1972 for the Forest Service to comprehensively screen and evaluate reports from each of the nine regions. The agency then sent three reports to the Secretary of Agriculture. There had been some improvement since the initial screening period, but many units still remained far from anything approximating diversification of the workforce.

Muddling through began with the agency struggle over how to cope with diversification mandates. These were resource managers, primarily foresters, men from the World War II and Cold War generation. Their training and orientation had been to "cut and run," to ensure the productivity of national forests, and to hire young men like themselves to ensure robust and continued timber yields. Even including a wider public by virtue of the 1960 Multiple Use Sustained Yield Act, and especially NEPA, strained the historic direction of agency leadership. Consequently, it often took a great deal of time to determine how to proceed, with action stemming from the top of the line in the interest of providing clear direction. For example, a supplement to Memo 1662, issued May 28, 1971, called for taking specific measures to assure all eligible individuals were informed of non-discrimination policy, and it called for agencies to prepare public 
notification plans. As in the past, the Forest Service first complied at the Washington Office (WO) and then sent the public notification plan to leadership around the nation. The WO requested that each region prepare "such a plan as meets situations unique to your individual location." The directive went out in October 1973, nearly a year and a half after mandated by the Secretary. ${ }^{298}$

The direction set by the Secretary of Agriculture in Memo 1662 focused primarily on public notification, with some emphasis on equal employment opportunity; however, neither Memo 1662, nor its Supplements included sex. Employment diversification focused on African American men, with Hispanic and Native American men also featured. Asian Americans were noted, but not specifically targeted. Neither did the Department or the agency prioritize female employment until 1972. Amidst efforts to increase public participation, agency systems to create employment equality developed slowly. Like so many changes in the 1970s, formal policies followed rather than led social shifts. Nella Dickson's experience illustrates this pattern. In 1970, dual career couples in the Forest Service were rare, but not unknown. Most likely, moving Nella Dickson from Timberlake to Portland had more to do with unformed agency policy, individual leadership, and funding cutbacks in Job Corps than existing rules. By 1980, the agency highlighted couples working together in its agency report and in the decade that followed, issues associated with dual career couples became key.

298 Washington Office Memo, Planning, re: Policy, Civil Rights/Public Notification Plan, October 26, 1973. Collection F5, File, Civil Rights: Update. FHS. 
This period of muddling through also provides a window into policy learning. From the late 1960s through the mid-1970s, the Forest Service discovered that diversification required flexibility, often connected to funding, alongside commitment and accountability. Perhaps most importantly, creating a diverse workforce would require cultural change for the Forest Service. Although the agency would not identify Cultural Transformation by name until the twenty-first century, the changes in organizational culture that led to the notion had emerged by the mid-1970s in conjunction with changing ecological and social values.

\section{Flexibility and Funding}

The flexibility required for diversification was visible in the non-traditional partnerships effected by the Forest Service with other agencies and social organizations. The ways in which Region 6 staff developed multiple relationships with schools and other organizations provide a case in point. Connections between the Forest Service and American Indians provide another. Because public land management agencies engaged in government to government relations with Native Americans, a much different association developed than with other groups. In some cases, tribes managed large tracts of land adjacent to national forests, which made partnerships beneficial for the agency and for tribes. As with the CCC, programs created for indigenous people often kept them in place, while partnerships could provide a market for national forest timber.

Overlapping funding streams facilitated relations between the Forest Service and tribes. The Sho-Ban Firefighters existed because of an intersection between windows of 
individual initiative and opportunity on the part of BLM, Forest Service, and BIA employees, and policy directives promoting diversification. Their employment drew from perceptions of Native peoples as well as geography. For example, writer Paul Obert viewed firefighting as a good option for the Sho-Bans, because they had "stamina, determination and ability to keep going where white crews have to be relieved." ${ }^{299}$ One man he interviewed did not want to leave the reservation for a lot of reasons: home, his people, and a preference for familiar culture and customs. Additionally, wrote Obert, "Fighting fires with a group of his own people seems to give him a sense of pride and belonging. ${ }^{, 300}$ Consequently, American Indians provided a low cost, intermittent labor force for the Forest Service that proved especially useful during firefighting season.

The notion of social engineering also peppered diversification efforts. Although the term "social engineering" has negative connotations because of its association with authoritarian governments, all nations shape society through laws and policies, rules and regulations, values and attitudes. The idea of engineering society stems from the belief that systematic study of culture can lead to better social structures. The collection of social and economic data by the Civil Rights Commission, alongside scientific understanding, helped to shape U.S. decision-making and policy in the latter third of the twentieth century. By 1964, Lyndon B. Johnson explicitly called for "the best thought and the broadest knowledge from all over the world to find" the answers to American problems of poverty, racism, and environmental degradation. When the administration

299 Oberg, "Those Sho-Bans," 57.

$300 \quad$ Ibid. 
declared "unconditional war on poverty" in America, Johnson called for support from all Americans to replace "despair with opportunity." 301 This war would be fought on the social front through education. As the president explained in his May 22, 1964 speech to the University of Michigan, the solutions to America's problems required the nation "to create new concepts of cooperation" and a "creative federalism, between the national Capital and the leaders of local communities." ${ }^{302}$ This creative federalism led to the Manpower and Youth Programs of the 1960s, alongside many other initiatives.

The Manpower and youth programs of this period stemmed from the same entwinement of environmental and social laws used by the Johnson Administration to move toward a Great Society. They also reflect the gratuitous notion that while the agency had much to offer minority populations, people of color had very little to give back. While programs directed toward people of color and youth offered education and opportunity, they also sought to shape "attitudes toward work," reflecting mainstream assumptions that minorities lacked work ethics. When reaching out to Native Americans, USFS stated that it would provide training and job skills, tool use, farm and ranch skills, exposure to planning, organization, and logistics of work crews, goals that replicated the historically assimilative objectives of the government. Adding "the cultivation of work habits and attitudes" to program aims also reflected the belief that Native youth had nothing to offer. Youth programs like the YCC and Job Corps also

301 President Lyndon B. Johnson's Annual Message to the Congress on the State of the Union, January 8, 1964, LBJ Presidential Library online, http://www.lbjlib.utexas.edu/johnson/archives.hom/speeches.hom/640108.asp [accessed July 3, 2014 ]. 302 President Lyndon B. Johnson's Remarks at the University of Michigan, May 22, 1964, LBJ Presidential Library online, http://www.lbjlib.utexas.edu/johnson/archives.hom/speeches.hom/640522.asp [accessed July 3, 2014]. 
focused on shaping work habits and attitudes specific to the Forest Service, while introducing minorities to forestry and environmental ethics. Both programs included education as key to their goals. The YCC's environmental education component proved critical to the bill's original passage and to its ongoing funding. For Job Corps, a basic education could make youth more employable overall and provide a route into the Forest Service, other natural resource agencies, or private corporations. With decreased funding under the Nixon Administration, Job Corps focused less on basic education and more on skill development, and teachers like Nella Dickson and Jetie Wilds moved into other Forest Service positions, often in the Human Resources or Civil Rights departments.

By 1980 , the agency allocated $\$ 155,209,000$ million to Human Resource programs, including the YCC, YACC, Job Corps, and Senior Community Services Employment programs. In each case, the agency identified a return that exceeded initial investments. Through a calculation of the value of the work accomplished, the number of persons served, and the person years accomplished, the agency determined that every dollar spent yielded $\$ 1.10$ for YACC, $\$ 1.20$ for the YCC, and $\$ 1.15$ for the SCSE. By that time, Job Corps post-program employment placement had increased to 93 percent. ${ }^{303}$

While funding facilitated flexibility, successful diversification often called for bending the rules at various levels. For example, the 1970 Hispanic Program removed testing requirements for Cooperative Education entry. Following Memo 1662, the 
Deputy Chief for Administration of USFS expedited the interview process. He gave permission to employ applicants at grade GS-5 and below without further interviews from divisions. He also granted authorization for personnel management to make job offers at the grade for which individuals qualified, rather than starting them at the lowest grades. This enabled the WO personnel officer to employ twenty-one minorities for WO divisions during the 1970 reporting period. ${ }^{304}$ At the regional level, one of the issues faced by the agency was "reaching qualified minorities" through standard Civil Service Commission registers. Consequently, the Portland RO noted a need for "high-level special attention" to the CSC system, and sought to exempt minorities from the National Summer Employment Exam requirement. ${ }^{305}$ All of this "definitive action" occurred as a consequence of direct mandates from the Secretary of Agriculture and the Forest Service Chief.

\section{Commitment \& Accountability}

As Darrell Millner stated, the 1960s and early 1970s were the best of times and the worst of times for multiracial opportunity and attempts to change racial conditions. As the best of times, the 1960s brought about new beginnings. It was a period of ecological and social shifts, an experimental phase in which civil rights law and funding supported policies of inclusivity aimed to create a Great Society. During this era, the

\footnotetext{
304 Memo from Edward Cliff to the Secretary of Agriculture, Through William M. Seabron, Assistant to the Secretary on Civil Rights, re: Memo 1662, December 24, 1970. Collection F5, File, Civil Rights Action Plans.

1970 R-6 Report, 3.
} 
Forest Service began to evolve from a homogeneous organization with negligible numbers of female and minority employees, to an organization that undertook various modes of diversification. Drawing heavily from broader public policy initiatives, the agency brought in educated African Americans like Nella Dickson and Jetie Wilds, hired increasing numbers of minority contractors, and partnered with minority organizations and educational institutions to increase diversity at the field level. For the first time, Forest Service leadership faced its own role in the white power structure, even as it perceived itself as different from other Department of Agriculture agencies. In fact, former chief John McGuire noted that unlike the Soil Conservation or Extension Services, public discrimination in the Forest Service "never got to be a big issue, perhaps because there weren't too many black forest landowners to begin with. ${ }^{306} \mathrm{By}$ the 1970s, Forest Service leadership seems to have taken the Department's workforce diversification charge seriously. The agency went beyond creating a Civil Rights Program in name only to ensuring accountability for diversity in performance reviews. This focus demonstrates agency recognition that the support of line leadership was critical to diversification.

It was also the worst of times, in that resistance to change and passive nullification could undermine social innovation. The decentralized nature of the Forest Service also made it possible for distant employees to ignore mandates. Despite leadership support of civil rights activities, discriminatory local practices continued and

\footnotetext{
306 John McGuire, interview by Harold K. Steen, September 1987, Falls Church, VA. Produced by the Forest History Society in co-operation with the United States Forest Service. Durham, North Carolina: Forest History Society, 1988, 2004.
} 
would only ease slowly and with time. In 1960, Herbert Kaufman had wondered why the "men" in the field followed orders, a seemingly simple, yet complex process that he examined closely. Kaufman concluded that organizational culture played a significant role in the "success of the Forest Service in wielding the behavior of hundreds of geographically dispersed and relatively isolated Rangers into a unified organizational pattern." Kaufman also noted that the unification of culture rested "heavily on manipulation of the perceptions, thinking, and values of members of the Service. Were it not for these, it is doubtful the formal organizational controls on behavior would be nearly as effective as they are," he wrote in $1960 .{ }^{307}$ When it came to diversification, Kaufman's assessment was right on target. On the one hand, line level commitment to increase diversity did, indeed, effect change. On the other, values and interactions between individuals and organizations determined outcomes in the agency. When leadership tried to alter homogeneous values, discretionary decision-making combined with passive nullification could counter social diversification.

\section{Cultural Transformation}

As the best of times and worst of times, the Forest Service experienced incipient cultural change during this period. For the first time, the notion of consensus emerged, a novel approach to working that disrupted established agency patterns. The 1969 National Environmental Policy Act called for public input regarding Environmental Impact Assessments and the agency consulted the public regarding a variety of issues.

$307 \quad$ Kaufman, xiii. 
Concurrently, civil rights training sessions incorporated consensus-based decisionmaking as part of the workshop process. The nationwide training guide also suggested that this might be a good time to include members of local minority groups in natural resource planning discussions. Team leaders were also prompted to consider whether or not the team should jointly decide priority areas. At the highest levels, the agency provided clear direction that flexibility and consensus belonged in decision-making. As an example of this fundamental shift in thinking, John Kusano recalled one of the first projects he managed:

I was doing the NEPA document on spraying herbicides on our little ranger district. So somebody from the public comes in and says, "Hey, I live in this little valley that's surrounded by national forest and I want to know where you guys are spraying, because ... I want to do something to protect my property when you guys spray."

So I said, "Okay. Let me go and check with my district ranger." I go into my district ranger and I say, you know, "This guy wants to know..."

He said, "You tell him it's none of his business. We spray whenever and wherever we want and we don't have to answer to you and we don't have to tell you." So I went and told him that... When you think of that now, that is like crazy. You would never do that. I mean nobody would ever think that the public doesn't even have the right to know what we're doing on the national forest.

For the generation of foresters typified by Kusano's district ranger, this period of change became the worst of times.

As the best of times, Forest Service leadership had high hopes for social diversification and the emergent Civil Rights Program began to solidify the agency's social direction. For the first time, the notion of representation in relation to the general population arose. As the description of the Civil Rights Program explained, "We want the number of them so placed to be based on the general population, not how many are 
in the Forest Service or in any local place. ${ }^{״ 308}$ The 1970s would provide a turning point through both the Equal Employment Opportunity Act of 1972 and Civil Service reform near the end of the decade. By then it had become clear that very concerted programmatic efforts were required not only to bring women and people of color into the federal government, and into the Forest Service, but perhaps most importantly, to keep them there. Retention would be the main difficulty for workforce diversification as the century waned. With the chiefs' backing and the actions of thousands of unnamed advocates for inclusion, the Forest Service established a thriving Civil Rights Program in the 1970s that set the stage for moving toward a multicultural organization in the decades that followed. In fact, in 1976 the agency set a ten-year goal for diversification. Minorities should progress from 7.7 percent of agency employees to 18 percent by 1986 , while female employment should increase from 21.6 percent to 33 percent during the same time period. ${ }^{309}$ These shifts would include major cultural impacts and modifications in resource management that connected ecological, occupational and social diversification, the subject of chapter five.

308 "The Civil Rights Program," 2.

309 Miscellaneous Updates 1980-84. Collection F5, File, Civil Rights Updates 1980-84. FHS. 


\section{Chapter 5: "Black Foresters Needed" - Professionalizing the Minority Workforce}

"The need for African-American, Hispanic, and Native American Indian professionals-women and men-in forest resources and related sciences remains a national priority to ensure a diverse work force and leadership in these areas that are so critical to our national economy and the quality of life of our citizens." - Dr. Bennie D. Mayberry, Tuskegee University, 1993

In the early days of the U.S. Forest Service, the "rough and ready ranger," a manly cousin to the typical cowboy, managed the landscape. He traveled by horseback, carried a gun, watched for fire, built the first ranger stations, and cleared the way for public forest access. This turn of the century ranger could have been part Native, like Nez Perce and Walla Walla descendant Joseph Don Cuddy, or Hispanic, like the fourth generation Californio, Jacinto Damien (J.D.). He would not have been African American, unless, like Paul Logan he passed for white. Reyes was not the only Hispanic ranger, ${ }^{310}$ but by mid-century, most ethnic diversity in leadership faded. The professionalized Forest Service required a forestry degree to enter line leadership, something held by very few people of color despite calls for a representational workforce. Recognizing the importance of leadership to workforce diversification, by 1968 the Forest Service sought to professionalize the minority workforce, starting with foresters through the Tuskegee Pre-Forestry Program and continuing with the "ologists" as access to education and occupational diversity expanded. By 1978, the agency employed 77 foresters and more than 700 forestry technicians of nearly 3,400 minorities

\footnotetext{
$310 \quad$ Joseph Rodriguez also served as district ranger in New Mexico Forest History Society, "Joseph A. Rodriguez,' http://www.foresthistory.org/ASPNET/People/Rodriguez/Rodriguez.aspx [accessed May $23,2014]$.
} 
in the workforce; however, "ologists" were not yet documented by race. [See "Most Populous Permanent Full-time Jobs, 1972-1979,” Appendix C, Table C.5]

\section{Inequalities of Opportunity}

By the 1970s, the legal demand for representation led thousands of minorities to employment in the Forest Service, though only a select group became professionals. Rudy Edwards, for example, became a temporary forest worker in 1964, a "first" for the Chickasawhay Ranger District in Mississippi. Less than a decade later, he joined USFS in a professional position. Edwards credits his grandfather and father, veterans of WWI and II as his inspiration. Military service, he said, provided the elder Edwards men with the sense that they belonged, as part of the U.S. citizenry. Next came a sense of place that rooted him in forested landscapes. Despite "the superintendence of the racism" of the segregated South, Edwards knew the nearby DeSoto National Forest as "federal land." He'd learned from his grandfather that “...it was just as much your right to go and participate in it as it was somebody else's." Having a forest in his backyard also fostered a love of nature: "I mean I could go to the creek and fish, and I could disappear into the

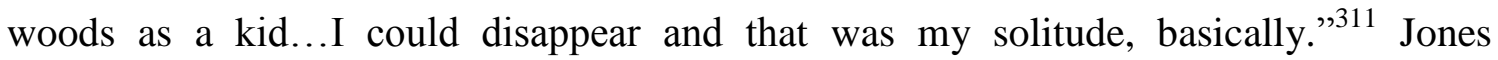
County, Mississippi also provided Edwards' father with a ten thousand dollar a year job in the Masonite Corporation, decent wages for any Southerner at the time. By moving into unprecedented supervisory positions and becoming a role model for leadership, Edwards' father also paved a path to the Forest Service for Rudy.

311 Rudy Edwards, interview by Cody Rubick, 10 May 2005. Region 6 Civil Rights Collection. 
When Rudy Edwards and his friend Bobby Johnson went looking for summer jobs in the summer of 1964, Edwards' understanding of citizenship rights intersected with his love for the DeSoto. The two Boy Scouts went to the local employment office and:

...the employment guy said, 'Well you know guys, you need to go down to the federal office, there, at the USDA; you know, President Johnson signed a new, not to discriminate law, and you should go down there and see what kind of jobs they have open that you could take.'”

The opportunity they found was employment as GS-1 and ' 2 forest workers. Edwards recalled:

So we go uptown and we go to the ranger's office up there in the federal building. Ralph Jacobson, Ranger Ralph Jacobson. So his assistant was sitting there. We come in. She's looking at us like, of course, you know, these two little colored boys. She wanted to know, What the heck do they want? Because normally we don't - those jobs are, preference jobs or "preferred jobs" are for White boys.

And so we said, "Well we're here to see about the jobs." And of course her jaw about drops, because she wants to know - she's thinking of two things. That the NAACP has sent these outside agitators in here to start something, or these are some crazy boys from Laurel [laughs] that don't know what they're getting into. 312

Still, the ranger took their applications and checked references. By the time they arrived home:

...the word was out that we were integrating the Forest Service in Laurel, and it wasn't the NAACP, but it was just two local guys. So, when we showed up again - my dad, he just said "That's what you want to do, that's how it happens, son. It's one of those things. You're just there," and so, "be careful." So the next day, we went back up.

$312 \quad$ Ibid. 
And the ranger said, "Well, I knew this day was coming, so I might as well do it with you guys... And he said, "So I'm going to do this. But, you know that a lot of people are going to be pissed off out there in those woods when you show up. Because these jobs have always been preferred for white kids." 313

This experience reinforced another lesson taught by his father. Rudy Edwards needed an education to move ahead. By 1975, master's degree in hand, Edwards would join the "ologists" as soil scientist for the Umpqua National Forest, one of a growing number of African American professionals in the Forest Service by that time.

This chapter documents some of the ways in which minority men, especially African Americans, became foresters and scientists in USFS, the federal programs that supported professionalizing the minority workforce, and the exigencies of advancement. A close look at the emergent minority professional workforce provides several lessons. First, many in the Forest Service have believed mainstream stereotypes about African Americans, including the notion that they dislike the outdoors; however, African Americans are not averse to the outdoors, only to backbreaking labor that barely provides subsistence, much less upward mobility. Second, economic and social challenges to bringing people of color into the Forest Service existed at multiple levels, from the individual to the institutional, the local community to the nation. Third, the stories presented here show that education, funding, and commitment to diversity were key to the entwinement of ecological, social, and occupational diversity in USDA Forest Service.

$313 \quad$ Ibid. 
Forestry Education and the Land Grant Institutions

Too many people, for too many years, argued that education and health and human welfare were not the Government's concern. And while they spoke, our schools fell behind, our sick people went unattended, and our poor fell deeper into despair. President Lyndon B. Johnson upon signing the Higher Education Act of 1965, November 8, 1965

Career foresters emerged alongside state land-grant institutions, the depletion of Midwestern forests, and the harvest of abundant Western timber resources. Land grant schools incorporated the idea, as Senator Justin Smith Morrill, progenitor of the Morrill Land Grant Act later said, that "a higher and broader education should be placed in every State," and made available for "not manual but intellectual instruction" to support the industrial classes in entering professional life. ${ }^{314}$ Under the 1862 act, each state received 30,000 acres to establish public universities for:

...the endowment, support, and maintenance of at least one college where the leading object shall be, without excluding other scientific and classical studies, and including military tactics, to teach such branches of learning as are related to agriculture and the mechanic arts, in such manner as the legislatures of the states may respectively prescribe, in order to promote the liberal and practical education of the industrial classes in the several pursuits and professions in life. ${ }^{315}$

Establishment of agricultural colleges across the nation in the nineteenth century supported western resettlement and upward mobility for white America. Although people of color typically provided the low-cost labor force to support natural resource extraction and agricultural production, most land grant colleges did not welcome African

\footnotetext{
314 Morrill speaking before the Vermont Legislature in 1888. Association of Public and Land-Grants Institutions, "The Land-Grant Tradition" (2012). http://www.aplu.org/document.doc?id=780, [accessed May 22, 2014], 4.

315 Association of Public and Land-Grants Institutions, "The Land-Grant Tradition" (2012). http://www.aplu.org/document.doc?id=780, [accessed May 22, 2014], 3.
} 
Americans. Rather, like American Indians sent en-masse to boarding schools in the decades to follow ${ }^{316}$ and Hispanic instruction left unconsidered altogether, black American education focused on vocational skills, the very type of "manual" instruction that the 1862 universities sought to surpass.

The land-grant schools developed in tandem with Yale Forestry School, established in 1900 and alma mater to the first two chiefs of the Forest Service, Gifford Pinchot (1898-1910) and Henry S. Graves (1910-1920), who brought European practices to the U.S. Yale set the standard for professional forestry, and as its first intellectual leader Graves thought "graduate education, as in law and medicine, would define the new profession." ${ }^{317}$ And he was right. Forestry schools created uniform practices grounded in bureaucratic efficiency from a regulatory standpoint and in terms of workforce practices. By 1906, Gifford Pinchot's Use Book regulated agency activities. Rangers kept daily diaries as they traversed tree-laden mountains and maintained regular communication up the line from the ranger station to the district to the forest supervisor's office. From there, the Regional Forester sustained connections to the Washington Office and back down the homogeneous line, effectively weeding out the possibility of women or people of color in Forest Service leadership. Forestry schools turned out professionals steeped in models of efficiency, productivity, and clear, direct regulations that set lasting organizational standards.

316 The Carlisle Indian School founded by Richard Henry Pratt in 1869 provided a model for Native boarding school education nationwide.

$317 \quad$ Yale School of Forestry and Environmental Studies - History, http://environment.yale.edu/about/history/ [accessed May 22, 2014]; by 1906, University of Michigan partnered with USFS on the Ann Arbor Experiment Station, and by 1914, University of CaliforniaBerkeley also started a forestry school. 


\section{African Americans and Professional Forestry}

Aside from Paul Logan, only one known professionally trained African American forester worked for the Forest Service by 1960. Carroll B. Williams, Jr. served in the Marine Corps, likely went to school on the G.I. Bill, and graduated from University of Michigan with a 1963 Ph.D. in Forestry. He specialized in Entomology and Statistics, and became a "Pioneering Scientist" at the Pacific Southwest Research Station at Berkeley in 1957. Williams, Jr.'s first detail took place at the Pacific Northwest Research and Experiment Station from 1958 to 1960 and he worked for the Forest Service until 1985. Two other African American foresters also had Pacific Northwest connections. James P. Johnston worked in private industry throughout his career but connected with other African American foresters through the Society of American Foresters. ${ }^{318}$ Charles Irby obtained a B.S. in Forestry from Utah State University in 1956 and worked for the Bureau of Indian Affairs in White Swan, Washington, but needed experience, more education, and an open door before joining the Forest Service. Irby obtained the education by returning to Utah State in 1961 for teaching certification and then spending three years in private industry in East Africa. He joined Peace Corps in 1968 and became deputy director in the Fiji Islands. Finally, in 1971, Irby became a recreation planner on the Mt. Hood National Forest in Oregon. Advancement required him to move first to Pennsylvania, then Washington, D.C. and finally to California where he became a deputy forest supervisor on the San Bernardino

318 Mayberry, Share the Vision, 179-180. 
National Forest in 1981. Eight years later he became a forest supervisor, one of the first high level African Americans in the agency. ${ }^{319}$

Meanwhile, Williams, Jr. had a distinguished career in which he worked at the Northeast Experiment Station, on National Science Foundation Advisory Panels, and even as a lecturer at Yale School of Forestry from 1969-1972. ${ }^{320}$ Yet, despite his many distinctions and forestry training, Williams, Jr. held a different kind of authority - as a project leader and scientist - than the classic district ranger. It would be the 1990s before a scientist became chief for the first, and as of 2014, only time. Although Williams, Jr. lectured at Yale, ${ }^{321}$ very few Blacks attended the foremost forestry school in the nation. Angela Kuhne, Assistant Dean in the School of Forestry and Environmental Studies (F\&ES) at Yale notes that the school kept no records on gender or race until 1980; however, photographs and surnames indicate some students of African, Asian, and Hispanic descent by 1960 . Even so, only a small proportion of minority students graduated in the last two decades of the twentieth century. Of the 1,531 graduates of Yale's F\&ES School between 1980 and 2000, 4.5 percent were students of color, and only thirteen (one percent) were African American. ${ }^{322}$

\footnotetext{
$319 \quad$ Ibid, 178-179.

$320 \quad$ Ibid, 177-178.

$321 \quad$ Yale's first African American student graduated in 1857. "Who Was the First African American Student at Yale?" Yale Magazine online (May/June 2014), available at https://www.yalealumnimagazine.com/articles/3876, [accessed July 28, 2014].

"Forestry \& Environmental Studies Degrees Awarded by Race and Gender," compiled by Yale University Archives and received via Angela Kuhne, Personal Communication by email, June 12, 2013. Records indicate 13 African American graduates, 22 Hispanic graduates, 26 Asian graduates, 7 graduates who claimed two or more races, and a single American Indian/Alaskan Native male graduate during the twenty year period, 1980-2000. Dr. Kuhne notes lack of reliability regarding use of photographs and surnames to document race/ethnicity, but post 1980 records indicate that very few students of color obtained degrees in Forestry and/or Environmental Studies at Yale.
} 
Had Williams, Irby, or Johnston been born later, perhaps one of them could have entered a Forest Service "line" position before the youthful Charles "Chip" Cartwright, who became the first black district ranger in the nation in 1979. But occupational and social limitations nullified that possibility. Born just after WWII, Chip Cartwright never planned to be a Forest Service pioneer. But a sense of adventure, love for the outdoors, and a congerie of ability, ambition, and serendipity led him to a significant place in agency history. As Cartwright explained in 2013, his journey began with "a strong connection to what grows on the land and how you get it to grow," a relationship he attributes to summers in the heavily forested Blue Ridge Mountains of Virginia. These annual visits to the Shenandoah Valley helped him relate "to what is wild, what is open, and have a connection to the land." His relationship to forests and mountains contrasted with childhood in the city of Petersburg, but fit the extended family's rural heritage perfectly. Cartwright's notions of possibility also stemmed from exposure to a wider world and romanticized views of forestry from television:

Something happened in the ' $50 \mathrm{~s}$. Remember there was a television program called Lassie? Okay, with Timmy Martin. Well, one vacation time, Timmy and family went to the Pacific Northwest. They got caught up in a major catastrophic fire. The family got separated. Lassie got injured and was saved by forest ranger Corey Stewart. I started watching that program... and the lifestyle that Corey Stewart had, that romantic lifestyle, that type of country, the big trees, the open sky, using all forms and means of transportation to get to do your job, reaching out and helping people, that type of thing appealed to me as a little kid.... Maybe it was round about eight years of age I began reading about national forests. I began reading fiction as well as true accounts of what it was like to be a forest ranger... And that kind of got me focused, so when it came time to graduate, my mom and dad wanted me to - I had good grades - they knew for sure I could be a doctor or a lawyer, you know. But I said, "Nope, I want to be a forest ranger."

And they said, "What?" You know, "What's a forest ranger?" 
So I described to them what a forest ranger was. My mom said, "Well, is there anybody like us there?" In other words, anybody who looks like you who does that. Well, I didn't know of anybody who did, but I chose to believe that there were people in the U.S. Forest Service who looked like me.

Cartwright would find that no one looked like him at Virginia Tech forestry school in 1967. Nor did he encounter many African Americans, women, or other minorities in the professional Forest Service workforce in the early 1970s. It would take focused efforts by the agency in partnership with educational institutions to increase the number of professional minorities in the Forest Service over the next twenty years.

Agricultural Education in White and Black - the HBCUs

"Cast down your bucket where you are." Cast it down among the eight millions of Negroes whose habits you know, whose fidelity and love you have tested in days when to have proved treacherous meant the ruin of your fireside. Cast down your bucket among these people who have without strikes and labor wars tilled your fields, cleared your forests, builded your railroads and cities, brought forth treasures from the bowels of the earth... - Booker T. Washington, Atlanta Compromise Speech, $1895^{323}$

When Congress passed the 1862 Morrill Land Grant Act, only four colleges existed specifically for African Americans. Because of these inequities, the Second Morrill Land Grant Act (1890) supplemented funding for post-secondary institutions that did not use race or color as an admissions criterion, and states that established separate land-grant colleges for Blacks. These institutions became known as the "1890 land-grants.” These institutions joined other Historically Black Colleges and Universities

\footnotetext{
323 Booker T. Washington, "Cast Down Your Bucket Where You Are": Booker T. Washington's Atlanta Compromise Speech," History Matters Website, http://historymatters.gmu.edu/d/88/ [accessed May 30, 2014].
} 
(HBCU's), those schools founded specifically for African Americans between 1866 and 1912 , in providing the kind of "intellectual instruction" accessed by Whites. While HBCU's often served as respite from a hostile society, then and now, all were specifically founded through "unique racial restrictions such as for 'people of color', for 'people of African descent', for the 'Negro or combinations thereof', which clearly indicated racial separation.” HBCU's provided remedial education for many who had never attended school at all and later served to bring to college level those students who suffered from the inadequate education provided by public schools following Plessy $v$. Ferguson (1896). ${ }^{324}$

Historically, HBCU's have trained the literate workforce that caters to the black population, including doctors, lawyers, teachers, and ministers, as well as providing industrial and mechanical training. Like the land grant schools, the 1890s focus on agricultural sciences, emphasizing sustainability and economics, conservation and environmental management, plant and social sciences or animal science and toxicology,

\footnotetext{
324 The four colleges included Paul Logan's alma mater, Lincoln University in Pennsylvania, as well as Cheyney State College in PA, DC Teachers College, Washington, D.C., and Wilberforce University, Ohio. Mayberry, 1993, 5; U.S. Department of Education Website, "Historically Black Colleges and Universities and Higher Education Desegregation” (March 1991), http://www2.ed.gov/about/offices/list/ocr/docs/hq9511.html [accessed May 28, 2014]; The 1890 schools included: Alabama A\&M University; Alcorn State University; Delaware State University; Florida A\&M University; Fort Valley State University; Kentucky State University; Langston University; Lincoln University; North Carolina A\&T State University; Prairie View A\&M University; South Carolina State University; Southern University System; Tennessee State University; Tuskegee Institute (now University); ${ }^{324}$ University of Arkansas Pine Bluff; University of Maryland Eastern Shore; University of the District of Columbia; ${ }^{324}$ University of the Virgin Islands; $*$ Virginia State University; West Virginia State University. Associated Public and Land-Grant Universities, "1890 Universities," available at http://www.aplu.org/page.aspx?pid=1074 [accessed May 19, 2014]; Mayberry, Share the Vision, 7.
} 
food and nutrition, among other majors. ${ }^{325}$ They also provide a variety of liberal arts and social science degrees. But, unless authorized as an 1862 land grant school, the 1890s do not receive federal funding for agricultural experiment stations. Instead, they receive special funding to finance agricultural research and extension. ${ }^{326}$ Still, the Department of Agriculture administers funding and oversight, and provides liaisons to each of the 1890 schools.

The HBCU's that have most closely connected to the Forest Service are Tuskegee Institute and Alabama A\&M (Agricultural and Mechanical). Alabama A\&M started under the 1862 land-grant act but did not receive land-grant funding until after 1890, nor did it have an accredited Forestry, Ecology and Wildlife Program until 2002. Like Alabama A\&M, Tuskegee Institute (founded in 1881) also provided industrial education. Tuskegee's notoriety came in part from the conflict between its first principal, Booker T. Washington and W.E.B. Dubois, head of the NAACP. Washington saw self-reliance through industrial education as the key to African American advancement. Consequently, students at Tuskegee engaged in work as well as classroom learning. This contrasted with Dubois' beliefs in the advancement of Blacks through intellectual elevation. Dubois also viewed Washington as a patsy for Whites because of Tuskegee's reliance on private funding by Alabama's elite. Later, even as HBCU's like Howard University stood at the center of the ongoing civil rights struggle, Tuskegee

\footnotetext{
325 Associated Public and Land-Grant Universities, "1890 Universities," available at http://www.aplu.org/page.aspx?pid=1074 [accessed May 19, 2014].

Via the 1887 Hatch Act and the 1914 Smith-Lever Act. The 1890s receive $15 \%$ of Hatch Act appropriations along with other program funds to support extension activities.
} 
strove to provide African Americans with practical skills to function in mainstream society. Still, as the first major educational institution to have an all-Black faculty, ${ }^{327}$ Tuskegee served as what Dr. Bennie D. Mayberry called a "gateway to emerging technological, scientific, and professional career opportunities.” By 1968, foresters would join the list of professionals trained at Tuskegee that included veterinarians and the Tuskegee Airmen. ${ }^{328}$

A well-known figure from Tuskegee, George Washington Carver was born a slave circa 1864, grew up in Missouri but moved to Kansas, where he graduated from high school. After attempting to homestead, Carver attended Iowa Agricultural College where he became the first African American to obtain an advanced degree in Agricultural Science. Next, Carver headed the Tuskegee Agricultural Department, where he launched an uplift campaign for black farmers. Although unable to achieve his antipoverty aims, Carver did push for "appropriate technology," undertaking research on numerous crops in an effort to move African Americans away from reliance on cotton. By the 1920s, Carver's work with peanuts brought national recognition to him, and to Tuskegee. ${ }^{329}$ This historic background, its location, multicultural mandates, and a

\footnotetext{
327 "Historically Black Colleges and Universities," Blackpast.org, http://www.blackpast.org/historically-black-colleges-and-universities [accessed May 26, 2014]; Alonzo Smith, "Howard University History," Blackpast.org, http://www.blackpast.org/aah/howard-university1867 [accessed May 26, 2014]; Alison Marie O’Connor, “Tuskegee University History,” http://www.blackpast.org/aah/tuskegee-university-1881 [accessed May 26, 2014]; Amy Jiwon Yoo, "Alabama A\&M University History," http://www.blackpast.org/aah/alabama-m-university-1875 [accessed May 26, 2014].

328 Mayberry, Share the Vision, 10.

329 Mark Hersey, “Carver, George Washington (1864? - 1943)," Blackpast.org,

http://www.blackpast.org/aah/carver-george-washington-1864-1943 [accessed May 26, 2014].
} 
convergence of leaders in the 1960s resulted in a partnership between Tuskegee and the

U.S. Forest Service that continues to this day.

\section{Seeking Equal Opportunity}

Developing the Tuskegee Pre-Forestry Program

\section{I know this from personal experience... a lot of the black folks in that region [South]...thought of forestry as logging. And that it was the worst profession that you could be in, and who would want to go into forestry? ...it's tough, it's nasty, it's ugly....it was like you were lowering your aspirations rather than raising them. ${ }^{330}$}

- Mack Hogans, 2012

In a serendipitous twist in $1968,{ }^{331}$ just forty years after the agency employed Paul Logan in Washington State, the Southern Forest Experiment Station worked out a cooperative agreement with Tuskegee Institute. With no more than five African Americans of 1,600 foresters trained in the U.S. by that time, Tuskegee and USFS partnered to bring Blacks into professional forestry through a program that connected with some of the earliest forestry schools in the nation. After two years of pre-forestry education, students would transfer from Tuskegee to a land grant forestry school before going to work for USFS or private industry. ${ }^{332}$ A combination of factors made the program possible, including laws, university partnerships, industry support, USDA Forest Service coordination, and especially funding. The Higher Education Act of 1965

\footnotetext{
330 Mack Hogans Interview by Donna Sinclair, October 18, 2012, Bellevue, Washington.

$331 \quad$ Executive Orders 10925, 10980, and 11246.

332 U.S. Department of Agriculture Forest Service, "Tuskegee Institute Trains Future Foresters,"
} Forest Research News for the MidSouth, Southern Experiment Station Newsletter (October 1970): 1-2. 
increased federal funding to universities by creating student scholarships, providing lowinterest loans to students, establishing a National Teachers' Corps, and extending needbased financial assistance to the general population for the first time in U.S. history. ${ }^{333}$ Title III of the act provided funding for "developed" universities to establish formal relationships with "developing" colleges and universities to exchange students between "sister" institutions. Seeking to foster education in various career fields in black colleges, Dr. K.S. Chahal, a Tuskegee faculty member of Asian Indian descent explored partnership possibilities by visiting Berkeley, Purdue, Michigan and other sites.

Funding, staffing, and recruitment for the Pre-forestry program overlapped. Dr. Chahal traveled to UC-Berkeley in 1966, to work out details regarding student transfer and curriculum for an agriculture/forestry partnership. Most importantly, UC-Berkeley committed to provide $\$ 15,000$ to fund two Tuskegee students for two years, seeking foresters to work in the Pacific Northwest. ${ }^{334}$ With Tuskegee and the University of Michigan designated "sister" institutions, early exchanges occurred in Education, Business and Social Work. ${ }^{335}$ Forestry came next. Keith Arnold, dean of the School of Natural Resources (1966 to 1968) at Michigan had worked for the Forest Service and helped develop the program. Michigan agreed to accept students, provide funding, staff natural resource courses at Tuskegee, and open its summer camp to pre-forestry

\footnotetext{
333 Since reauthorized with modifications multiple times.

$334 \quad$ Report from visit by Taylor and Fassnacht: "Dean Mayberry remarked that California's interest was in supplying foresters to the Northwest. He hoped, rather, the students would return to the South. He noted there were only three Negro members in the Society of American Foresters" (Drs. Taylor, of Forest Engineering Program at Auburn University and Fassnacht, assistant director of the Southern Forest Experiment Station, in Mayberry, Share the Vision, 17.

335 Mayberry, Share the Vision, 15; Brian Payne Interview by Donna Sinclair, January 28, 2013, Fairfax, Virginia.
} 
students. The only cost for Tuskegee would be travel and subsistence for eight faculty to spend two weeks each at Tuskegee, open courses to all students, and conduct lectures and seminars for faculty. Not only could Michigan faculty recruit Tuskegee students, as Dr. Mayberry wrote in 1993, the experience would acquaint professors with "the hard facts of higher education for African Americans." 336 Iowa State University, George Washington Carver's alma mater, would provide the third academic connection for the program. In the interests of recruitment and long-term investment, Weyerhaeuser also provided a grant for scholarships and recruitment. Private sector partners, including Crown Zellerbach, Georgia Craft, ITT Rayonier, Union Camp, Westvaco, International Paper, Lockhart Enterprises, and others provided summer employment for students. ${ }^{337}$

Program implementation required a broadly trained forester who could also serve as student advisor. ${ }^{338}$ The Forest Service met this need in 1967 through a Memorandum of Agreement to fund a professional forester onsite. The liaison would recruit students, teach courses, coordinate summer internships, and work in cooperative forestry, part of the State \& Private Forestry branch of the agency that provides assistance for community forestry. First and foremost in 1968, the liaison collaboratively coordinated the program's academic structure with Tuskegee faculty. This individual also cooperated with the U.S. Forest Service and the Union Camp Lumber Company to manage the school's five thousand forested acres. Pre-forestry program goals included making the forestland financially productive, introducing students to natural resource careers, 
increasing faculty, and eventually offering a Bachelor of Science in Forestry and Natural

Resource Management. Meanwhile, Tuskegee would provide basic preparatory coursework, bring remedial students up to speed, and provide a pipeline to existing forestry schools for African Americans. ${ }^{339}$

\section{Tuskegee Pre-forestry Program - the Early Years}

We were in a majority Black town [Tuskegee]. We lived in what we jokingly called the "white ghetto," because there was one end of town where there were some local white people who lived and there were some faculty members there, too. ... it was, it was weird. It was different to be a minority. ... we went to a movie on campus, in the gymnasium, and I remember we sat up in the balcony ... And we looked around and we thought wow! There's only three or four other white families here. ... And about two months later, we went up to Auburn University, ... I think at that point it was totally segregated, a state school ... we got there early, so we sat down in front of the auditorium ... And eventually I turned around to see how big the crowd was going to be ... And I looked around and ... I said, "My God, look at all of these white people." - Dr. Brian Payne, 2013

Alongside Dr. B.D. Mayberry and Tuskegee President L.H. Foster, Dr. Thomas Nelson, director of the Southern Forest Experiment Station in New Orleans was "instrumental in development" of the program. Nelson hired Brian Payne as the first

Forest Service liaison to Tuskegee. In 2013, Payne, a research scientist with a Ph.D. in Forest Economics and a third generation forester whose father ${ }^{340}$ and grandfather served in the agency's Pacific Northwest region recalled how he got the job:

“... one day in June of '68, I saw this job announcement on the board outside the coffee room [at the Pacific Northwest Experiment Station] and the announcement actually had been there for a while. But one day I stopped to read it and it advertised this position with the Forest Service, with the Southern

Ibid, 12.

Payne's father ultimately became an Associate Deputy Chief for the agency in Washington, D.C. 
Station, at Tuskegee, then Institute; now it's Tuskegee University, to help start a pre-forestry program..., 341

Payne immediately saw the job as an opportunity to effect social change. He recalled that his brother, a Yale graduate student had been run out of town, shot at, and "escaped with his life" while participating in mock elections in Mississippi. Yearning to contribute to the civil rights movement, Payne called his wife and asked, "How would you like to move to Tuskegee, Alabama?" She unequivocally said, "No.”:

I mean those were the days of Selma, Alabama, race riots, Bull Connor; you know, all of this stuff was in the news in the late ' 60 s. It was a dreadful place to be if you were at all interested in civil rights and so forth. But, then I brought home the job description that night and she read it and we got more interested in it, and decided, yeah, this might be the right thing after all. ... here was a job, in my profession, at a black university where maybe I could do some good, without getting shot at, and you know, use my training and so forth to do that. I also had realized through talking with folks at our church in Portland and other people at the office, that I did not know one single black person. And living in Portland, Portland was like many cities, kind of accidentally segregated, where there were Blacks in Portland but there were not many and they lived, typically, in a different district... So I didn't have any contact and that bothered me. ${ }^{342}$

Payne interviewed with Dr. Mayberry, who later became Tuskegee's Vice President for Development. Mayberry "really made it work," said Payne, who had five major goals for the two year job. First came recruitment and professional training of students. Second, liberal education, to introduce students to forestry and natural resources across the campus, and "spread the word," about resource conservation occupations. The third goal, research, helped to sustain support from the Tuskegee administration, when the State \& Private Forestry branch of the Forest Service helped to write a management plan

$341 \quad$ Payne Interview.

$342 \quad$ Ibid. 
for Tuskegee's forestlands. The plan worked for two reasons: 1) it met cooperative forestry research goals; and 2) when a Southern pine beetle infestation started killing trees, the Forest Service helped Tuskegee obtain a good price for the wood it owned. Payne's fifth goal extended work in progress, outreach from Tuskegee to other forestry schools and the profession to alert them about the importance of bringing minorities into forestry. ${ }^{343}$

By Fall 1970, eleven Tuskegee students majored in pre-forestry. Nearly forty students had been exposed to natural resource opportunities with two dozen having worked summer jobs on national forests. Others worked with Dr. Irene Nelson, an African American woman whose husband joined the staff at Tuskegee as part of the Forest Service research team studying the outdoor recreation "opportunities, needs, and benefits of low-income, rural, black people." 344

Why Become a Forester?

"I worked in the same laboratory as George Washington Carver worked in." Mack Hogans

343 Ibid; Mayberry, Share the Vision, 15-16, 18.

344 Brian R. Payne and Donald R. Theoe, "Black Foresters Needed: A Professional Concern," Journal of Forestry, Vol. 69, No. 5 (May 1971): 297-298. Portland, Oregon hosted a small African American population prior to World War II, with approximately two thousand Blacks in the city, about half in one neighborhood, the other scattered throughout the city. During World War II, the number of African Americans skyrocketed to over twenty thousand, increasing the population to more than eleven thousand after the war, many housed at Vanport, Oregon, a "temporary" public housing project that continued to provide homes to African Americans, veterans, and low-income people at war's end. Postwar Portland's segregated geographic distribution of African Americans increased significantly after the May 30, 1948 Vanport Flood wiped the city away and pushed Blacks into North Portland. See "Drawing the Color Line," Columbia Slough Community History, http://www.ccrh.org/comm/slough/afampdx1.php; Manly Maben, Vanport (Portland: Oregon Historical Society Press, 1987); Bosco-Milligan Foundation, Cornerstones of Community: Building of Portland's African American History, rev. ed. (Portland: BoscoMilligan Foundation, 1998). 
Why might a young African American man choose forestry in the 1960s over becoming a doctor, lawyer, or engineer? Why give up a prestigious career for a job that many viewed as "worse than farming"? ${ }^{345}$ In fact, few considered this path without concerted outreach and definitive opportunity. Unlike Chip Cartwright who dreamed of becoming a ranger, most African Americans fell into the profession through a conjunction of events, people, and interests. Mack Hogans and John Yancy, the first two Tuskegee Program graduates both came from rural Alabama communities, Hogans from Abbeville and Yancy from Auburn. Neither saw forestry as a career option before meeting Brian Payne. Although Hogans' family owned a 600 acre farm where as a youth he planted pine seedlings provided by the Soil Conservation Service (SCS), he does not attribute his forestry career to this experience. However, like Chip Cartwright and many others interviewed for this project, he does link his chosen profession with a relationship to the land: "I started going to the fields and doing work as early as I can remember," he recalled. As for Tuskegee, Hogans found inspiration there:

Tuskegee is not too far from where I grew up. And when I was in junior high school or high school, we took a tour up to Tuskegee. We went through the George Washington Carver Museum. And going through that museum, it was amazing to see the number of commercial items on display, that were essentially either created by George Washington Carver or he had created the foundation or the recipes or whatever; things like peanut butter, and so you're sitting there going, "Oh, a black man did this?" You know, so you felt like you were - and in those days the world was mostly black and white. And so you felt like, you know, this was kind of a source of pride, and boy, Tuskegee is really something incredible! That they produced all of this... and then the museum also talked about some of the firsts with African Americans and everything. So it was just, it was prideful to see all of that.

345 Mack Hogans Interview. 
Hogans entered Tuskegee as an Agronomy and Soil Science major, never thinking of forestry or USFS as a career option.

John Yancy came to the Forest Service through a different, though similar route. Yancy, whose father worked for USDA as a "jack of all trades...not high up on anyone's scale, ${ }^{, 346}$ recalled his youthful dreams: “I know I wanted to raise a family, I wanted to travel." Chuckling, he said, "I wanted to make ten thousand dollars a year. I wanted to be happy and those were my goals." When a high school vocational counselor suggested forestry as a possibility, he agreed to visit Tuskegee. There he met Bennie D. Mayberry:

And Dr. Mayberry, he was an icon. He just talked about forestry. I didn't really know what forestry was. I thought it was going to be cutting down trees and sitting up in a fire tower, and he started talking about it and he told me there was very few minorities in it, that there was a great need and that Tuskegee was on the cutting edge with putting minorities in fields and positions that, you know, minorities had [never] ventured off into and he thought I would be perfect to come to Tuskegee and be one of the first students in the program, and he just sold me right then and there on getting into forestry, getting into agriculture, and it was based on my father and his work with the Department. And he just loved what he was doing and it provided a stable income and that just kind of got me sold...

Hogans concurred, noting that Mayberry, Payne, and others made forestry sound interesting and filled with potential:

Dr. Mayberry had this idea that the Forest Service is out looking to diversify its ranks. ... professors from the University of Michigan ... they'd come in on a weekly basis, different folks. They would do Forest Management, Silviculture, Entomology, and they'd bring in some fisheries people. They'd bring in some wildlife people, and so you got this real exotic experience where you were

346 John Yancy Interview by Donna Sinclair, December 6, 2012, via Skype, Atlanta, Georgia and Washougal, Washington. 
dealing with people who were talking about things that really broadened my horizons about, not just forestry, but the world. ${ }^{347}$

According to Brian Payne, recruitment had been surprisingly easy. High school students were especially impressed by the $\$ 8,000$ /year starting salaries, a rate that easily counteracted pulpwood images of forestry held by many Southern African Americans. The YCC and Job Corps provided outreach opportunities, ${ }^{348}$ and once convinced of forestry as a viable option, the profession attracted students. "But," wrote Payne and Donald Theoe "personal contact and attention are required to aid the student in reaching this point." ${ }^{349}$ Payne invited Hogans and Yancy to his home and he accompanied them on campus visits, Yancy to Iowa State and Hogans to University of Michigan. At Michigan, Hogans remembered being treated "like a rock star," before reality hit:

I was escorted by people who took me around the campus. They would introduce me and I'm meeting everybody. I'd meet with the dean, I'd meet with the professors, and they'd take you out to this great, great restaurant and you know, just great food for a country boy who had never been anywhere before. And you know, cars to pick you up and take you places, and things like that. ... they introduced me to everybody, and I'd go to events and you know, they'd point me out and I'd stand up ... And so, when I went back, obviously they're not going to give that much time and attention to a single student. So it was like the reality was, okay, you're just a student, you know. You're not somebody special who is going to get special attention.

Still and perhaps most importantly, the University of Michigan paid to court Hogans and scholarships paid for his education. With Hogans and Yancy at the fore, more than 90 students graduated in the first 25 years of the Tuskegee Pre-Forestry Program. ${ }^{350}$ The

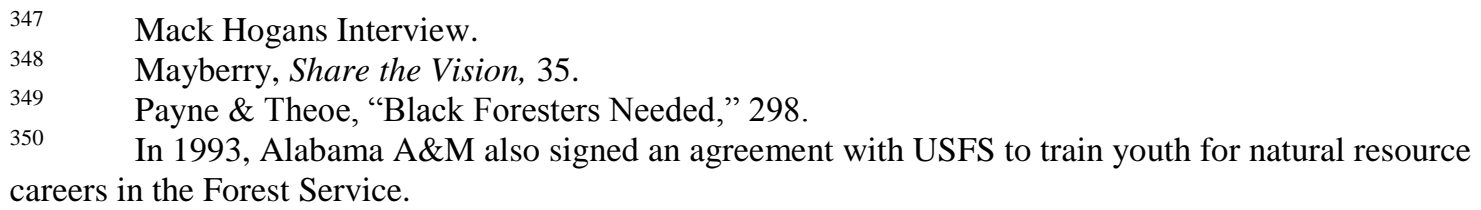


partnership later included a Job Corps center on the Tuskegee campus, the only one like it in the nation. ${ }^{351}$ Liaisons from USFS continued at Tuskegee. The white forester Larry Gadt followed Brian Payne, followed by three more white males in the position, but by 1979 an African American Tuskegee pre-forestry graduate, Ronald Smith served in the position as a Forest Service employee.

"Black Foresters Needed"

During that time, if we'd have gone to an 1890 institution and got what we call a forestry degree, it would not have been accredited by the SAF [Society of American Foresters] and people would not have given us the respect or the positions that title probably desired. By going to these 1862 universities, some of the better 1862 universities in the country, it gave the program...a little bit more credibility than if you had just gone to Tuskegee. - John Yancy, 2012

In May 1971 Brian Payne and Donald R. Theoe wrote a provocative article for the Journal of Forestry, "Black Foresters Needed: A Professional Concern." The two took the profession to task, noting geographic and occupational diversity, but with much in common; in fact, too much: "virtually all of us are white." So white that seeing an African American forester at an SAF conference or at work would be "exceptional." 352 Payne and Theoe presented a "problem situation: ${ }^{353}$

The underrepresentation of the Negro race in the forestry profession limits its ability to serve society. We need the best talent we can get in our profession, but we have been passing up an important source. Foresters are traditionally in the

\footnotetext{
351 Committee L. on Historically Black Colleges and Institutions. "Report, The Historically Black Colleges and Universities: A Future in the Balance," Acadame, Vol. 81, No. 1 (Jan.-Feb., 1995): 55.

352 Payne \& Theoe, 295.

$353 \quad$ Ibid, 296.
} 
forefront of concern for wise use of natural resources, but as a profession we have failed to tap some major human resources. ${ }^{354}$

The dearth of professional African American foresters highlights the realities of a Southern timber industry that employed scores of Blacks as laborers engaged in the dirty work of forestry, as loggers, pulpwood cutters, and on lookout towers. As one student told Payne and Theoe, "We've been trying to get out of the woods for so long, why should we want a job that's going to keep us there?"355 The foresters provided a twofold answer, one for students and the other for the profession. Students learned about the opportunities associated with professional forestry. To the profession, Payne and Theoe pointed to self-interest. Simply put, African American involvement in forestry was good business. A growing emphasis on urban forestry and engaging the inner-city public would bring foresters into contact with African Americans. But, they wrote, "As long as we remain a wholly white profession it will be difficult to convince these black Americans either of our sincerity or our ability to serve them." ${ }^{356}$

The next issue of the Journal of Forestry ${ }^{357}$ contained responses. Of six letters about the call for black foresters, three congratulated and supported the authors, three derided them. Bob Overstreet of Everett, Washington considered the article "well thought out and presented." 358 Lloyd Thorpe, of Seattle called it "long overdue," and applauded publishing a piece that let in a "tiny ray of light," one that should be viewed as a call to individual SAF members. To begin, wrote Thorpe, each SAF member and

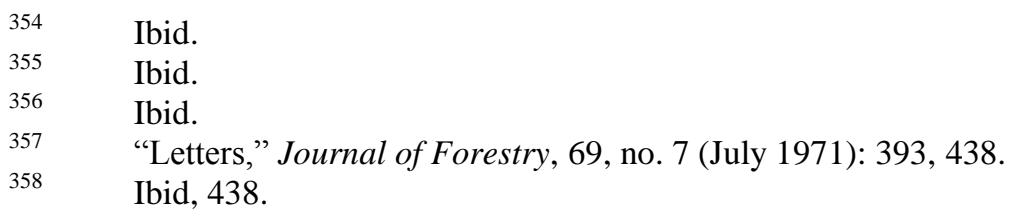


employee of a federal agency, industrial corporation, or in teaching should count the African Americans around him and ask: "Why this distressing disparity?"359 The most compelling letter came from a white forester, documenting the insidious ways that racism works through what one Forest Service employee calls "filtering mechanisms. ${ }^{, 360}$ Ronald M. Lanner of Logan, Utah commended Payne \& Theoe for "breaking the ice on an issue our profession has been studiously avoiding for many years," a failure he attributed to "the general lack of touch we foresters have with the realities of contemporary America." ${ }^{361}$ Lanner pointed out the relationship between forestry and other "economically depressed minority groups":

The Forest Service manages several national forests in Spanish-speaking areas of Colorado and New Mexico-yet those forests have almost no professionals with Spanish surnames. The Bureau of Indian Affairs manages millions of acres of reservation timber and is a large employer of foresters, but how many scholarships have they granted for young Indians to study forestry? And how many of the small number of trained black foresters have found gainful employment in the field of their choice? ${ }^{362}$

Lanner remembered in accepting a position circa 1958 with "a well-known federal forestry agency in California," he was told how glad his supervisor was to receive his application. Why? Because “another applicant, a black man with a master's degree and excellent qualifications" had applied. ${ }^{363}$ Lanner noted that Payne and Theoe listed several reasons for the paucity of black foresters, but left out one very important issue: "MONEY," which is what it takes to go to college. And, he wrote, "we are talking about

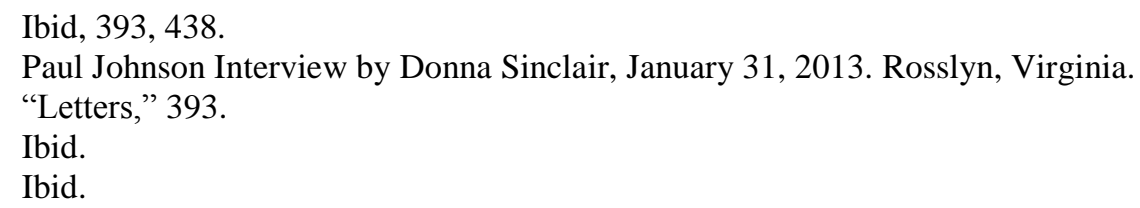


people who lack money. Find a source of scholarship money for black students interested in forestry, and you will see more black forestry students." 364

Disagreement came from the South and Midwest. Douglas Horan of Florida was "dismayed and surprised to see such valuable space used." Making a "play just for the sake of black foresters" was "a poor excuse for writing and printing such 'junk.' Why not," he asked "go the limit and say a percent of all ethnic groups should be included. ${ }^{365}$ Why worry about the eleven percent of people who are Negroes when not all whites can be foresters? He concluded: "Let's stick to the many forestry problems and leave the social problems alone. ${ }^{366}$ Mark V. Ryan of Ohio pointed to a glut in the market for foresters. He called the article "absurd" and the statement that Blacks don't go into forestry because they view doctors and lawyers as higher status "trite," since the same was true for Whites. With no sense of the occupational pigeonholing faced by disadvantaged groups, Ryan denied exclusivity, writing, "Let's face it, boys, heart surgeons we ain't!" ${ }^{367}$ Having been in the military and a civilian, he felt that, "avenues are available for advancement for anyone who is willing to pursue a given vocation." ${ }^{368}$ Blacks simply chose differently. The final letter provided the strongest critique as a Louisianan forester called the article "typical of the present-day, overapologetic attitude toward the so-called 'minority' race," which also wants to "punish the South" in keeping with contemporary mass media. Noting Payne and Theoe's reference to Anthony
Ibid.
Ibid, 438.
Ibid, 393.
Ibid.
Ibid. 
Downs' work on race and the Kerner Commission report of 1968, the forester wrote: "In short...I get more than a little sick of our contemporary pseudo-sociological bleedinghearts who have all the answers; it is only the questions that bother them." ${ }^{369}$

By the time the Louisianan wrote this polemic, the Forest Service had begun asking new questions and had some preliminary answers. In 1970, the agency worked with ten HBCU's to train African Americans in forestry and resource management and also provided three of USDA's liaisons. Forest Service units also contributed funding to black colleges, including $\$ 13,500$ to Paul Logan's alma mater, Lincoln University. Another $\$ 124,261$ went respectively to Howard University $(\$ 69,961)$ and Tuskegee $(\$ 54,300)$, with its "functional" pre-forestry program that "will offer an avenue of recruitment to meet Forest Service employment obligations and needs. ${ }^{370}$

\section{Finding Opportunity in the U.S. Forest Service}

The Tuskegee Graduates

During my junior year of college, one of 10 goals I established for myself was to secure the position of USDA Forest Service liaison officer to the Tuskegee University Forest Resources Program. In November of 1979, I achieved that goal... - Ronald Smith, USFS liaison to Tuskegee, 1979-1981

In a brief overview of his experience as liaison, the first African American liaison to Tuskegee, Ronald Smith noted a major barrier to attracting Blacks to forest

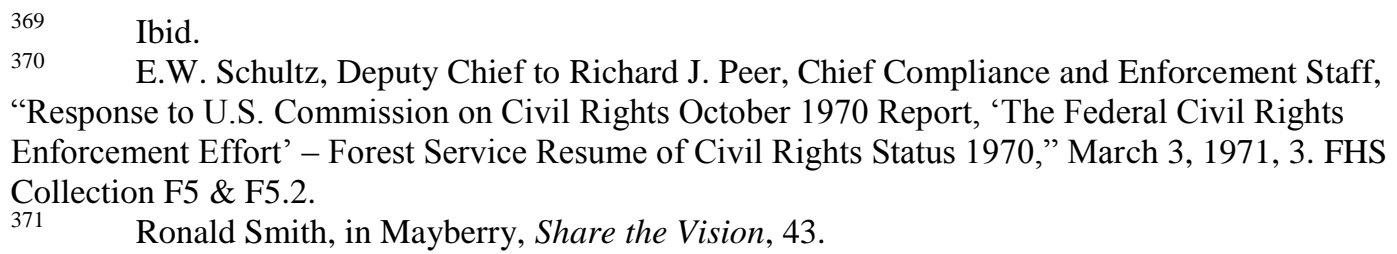


resource professions: lack of role models. The Tuskegee Program created those models and made them available and accessible to African Americans for the first time. ${ }^{372}$ Key examples included the first graduates, John Yancy and Mack Hogans, who both became distinguished members of SAF. Yancy moved up in the Forest Service, and worked concertedly to diversify the agency, while Hogans remained with USFS for only five years. The ambitious young man who said he would like to be chief in a 1979 Black History Month Newsletter, later recalled this comment as somewhat naïve for several reasons. First, Hogans worked in the Research arm of the Forest Service. Most chiefs came out of the National Forest Management system. But the second reason reveals most about the persistence of Forest Service culture. Advancement required conformity. When Hogans graduated, he turned down a job with the Forest Service, instead working in recreation and urban forestry in Detroit for several years:

And that pissed off a lot of people. They felt like they had invested a lot in me and they were trying to get the payoff for that program in Tuskegee and I was a symbol of that, a fairly visible symbol.... And then they eventually forgave me and gave me a job out here [in the Pacific Northwest].

After returning to the Forest Service, Hogans began school at the University of Washington, conducting research on race and recreation. The agency soon offered him another job, one that required transfer:

...they wanted me to go down to work at Clemson [University]. They wanted to keep moving me through chairs ... It would have been a promotion. I would have been what they call a project leader. That means you're in charge of a research unit.

372 Ibid, 45. 
And you know, and Clemson is not a big town, though. So I went down there and met with the dean and met with, you know, some of the Forest Service people down there and I told them, "No." And that pissed them off.

... I say pissed them off - what it did I think is that the Forest Service used to be very paternalistic. So if they tell you to go to Clemson, you go. You know, you got rewarded for obeying. And I wasn't, I wasn't drinking all of the KoolAid. So, I came back and then I told my bosses what I wanted to do and everything, and they kept saying, "Well, let's see now. You turned down this opportunity, you know, you turn down an opportunity, you might not get any." You know, very subtle. So, I decided that I would find a way to look at private industry. So I got through my master's. I was working on my doctorate and then I had a conversation with some people at Weyerhaeuser and months later they offered me a job...so I joined Weyerhaeuser and I left the Forest Service.

Neither did John Yancy work for the Forest Service immediately. After Tuskegee, he headed west to Berkeley, Brian Payne's alma mater. Often the "only minority" in his classes, this was a lonely time for Yancy, a period of culture shock and hard work. He remembered:

Berkeley just had a standard for academic excellence and you know, you just had to study and get into the groove, you just kind of forgot about making a lot of friends. I just tried my best to, you know; just do what I had to do. But most of the students would study in study groups, and I did not have a study group to study in, so did a lot of one on one to try to get by...

When his mother got cancer, Yancy enrolled at Iowa State University, a school that offered more funding, immediate employment, and was a little closer to home. Still the sole minority much of the time, Yancy took ownership of his future. He made friends. He joined study groups. He majored in forest management, the degree held by most foresters, despite encouragement to major in recreation. He also recalled these periods of isolation as preparing him for a predominately white world. "I just got used to the fact 
that if I was going to be in forestry I was going to have to deal with situations like that for the majority of my career. And so, it turned out to be true."

Yancy's first job with the Forest Service took him to Florida to work for the summer of 1971 on a reforestation crew. After graduation in 1972, he became the first professional African American on a South Carolina district, an experience he described as "unique because the Blacks in the fields thought that I was uppity, trying to be more than I should be. And the whites in the office had never had a Black in the office, so you know; they were trying to see if there was a way to get me out." Yancy found the environment unconducive to "learning and growing," and asked the region's personnel officer for a transfer. When faced with a ranger who said he could become a forester trainee, but predicted failure, Yancy left the Forest Service. He went to work for Union Camp, one of Tuskegee's private timber partners. Yancy became "the only Black of thirteen inventory foresters" and when his boss ranked him among the top three, he gained confidence and "busted" his "butt" to improve and maintain that status: "I wanted to go back to the Forest Service. I wanted to get a year, just get myself going and hear somebody tell me that I was doing good, okay? Union Camp did that." When he tried to return a year later, a personnel officer told him he'd have to go to Texas. Yancy said he would think about it and then:

I went home and went to visit the Tuskegee Ranger District. James Hunt, a white male was the district ranger, and I said, "You know, James," I said, I called him District Ranger Hunt, I said, "I used to work for the Forest Service and I really want to come back and I really want a job in Alabama but they tell me there's nothing here in Alabama."

He said, "Oh, did they tell you that?" He said, "Let me make a call." 
Yancy interviewed in Montgomery the next day and got a job "on the spot" as a GS-5/7 forester. At the end of two years, he qualified for promotion to GS-9.

Moving up the line took another relocation, this time to the ChattahoocheeOconee in Georgia. There, Yancy became the first African American forester on the district and the only one to work in the office. He recalled hearing he was hired to "upgrade" the district and disliked the associated feeling of tokenism, and when it came time for promotion his ranger told him, "You're not going to get it. You're going to stay at a GS-9."

Again, Yancy said, "Move me." This time he became a district TMA (timber management assistant). It took the support of more than one supervisor, but Yancy continued moving up the line. He became a district ranger on the London Ranger District in Kentucky in 1983, the second African American district ranger in the country, another "very unique experience." Yancy recalled arriving in Kentucky with his family:

...people would slow their vehicles down and kind of look. Because there was about maybe a hundred African Americans in the entire county and folks knew all of them. But I found out later that they was looking at me because they didn't like outsiders. They didn't like government officials and it didn't necessarily have to do with all about race.

To the present day, people of color who have joined the Forest Service have encountered a variety of responses in local communities. Their experiences demonstrate the historically contingent complexities of race in the United States, as well as an admixture of human behaviors - good and bad. As environmental and social mandates met in the mid-1970s, complications of race became further enmeshed in small towns across the 
country, even as the Forest Service sought a familiar leadership contingent: foresters. Meanwhile, occupational diversity required USFS to recruit soil scientists and other professional "ologists" in the 1970s, at the same time the agency hired female and minority employees on fire crews and in low level field and office positions.

\section{Entwined Diversification and Occupation - USFS in the 1970s}

"Our EEO progress significantly depends upon the ability to recruit and place minorities and women in management and line positions at mid-level grades and above rather than the lower graded support work. Therefore, it is particularly important that managers and supervisors carefully plan their staffing needs with affirmative action goals as an integral part of the process." - 1978 Workforce Data Book

The federal bureaucracy grew tremendously in the 1970s, and so did the Forest Service. After relatively uniform growth through the 1950s and early 1960s, employment leveled off until 1966 when Job Corps increased the number of employees hired. ${ }^{373}$ According to Ron Noland and Helen Weiler, reductions of permanent full-time staff in the next decade were also related to Job Corps. Still, from July 1958 to July 1980, the permanent full-time workforce remained stable at slightly over 20,000 employees. ${ }^{374}$ Reduced funding in the 1970 s led the agency to increase part-time and intermittent, mainly wage grade, hires, creating a workforce that fluctuated according to season and fire events. ${ }^{375}$ Between 1965 and 1974 the agency reduced its permanent

373 USDA Forest Service Personnel Staff, “1977 Personnel Report,” compiled by Ron Noland, Helen Weiler, Employment Group (Washington, D.S, 1977): 135.

$374 \quad$ PFT reached 21,497 in July 1980. Rob Rippey and Ted Marine, USDA Forest Service Personnel Management Staff. “1980 Work Force Planning Data Book” (Washington, D.C. 1980): i.

375 “1977 Personnel Report,” 135. 
workforce, nearly doubled its seasonal workforce, and added more than 2,000 temporary full-time employees, increasing the number of paid workers, or "career and career conditional" employees from 32,846 to 38,916 in 1974. [See "Forest Service Employment Statistics, 1965-1974" in Appendix C, Table C.2.]

An upward employment trend began in 1973 that reflected the growing diversity of professional occupations in the Forest Service, a workforce that changed in keeping with requirements of environmental laws that called for extensive and comprehensive long range planning. The planning process included agency activities, public land and resource management, research, and cooperative programs with State \& Private owners. ${ }^{376}$ It also included very deliberate "Manpower Planning" and documented statistics for the most "populous" professions. These included business management, technical, and professional resource occupations ${ }^{377}$ that reflected the shifting occupational demographics of the agency. [See "Most Populous Jobs, 1972-79," in Appendix C, Table C.5] Personnel staff also thought occupational data would help to: identify the real problems of the agency; support requests for new hires; prevent competition within the agency for business management professionals; and better plan

$376 \quad$ USDA Forest Service, Report of the Forest Service: Fiscal Year 1980 Highlights, 75 Years of Service. FS-364 (Washington, DC, 1980): 1.

377 Professional Resource occupations include: Range Conservation, Soil Science, Wildlife Biology, Landscape Architecture, Civil Engineering, Hydrology. Business Management Occupations include: Personnel Mgt., Computer Specialist, Administrative Officer, Management Analyst, Budget and Accounting, Accountant, Budget Administration, Public Information, Contract and Procurement. Technician Occupations include: Biological Tech., Range Tech., Forestry, Engineering, Construction Control, Surveying Technician, Electronics Technician, Physical Science Technician, Hydrologic Technician, Cartographic Tech. "FY 1980 Highlights," i. 
recruitment activities aimed at hiring minorities and women. ${ }^{378}$ The data compiled during this era show a rise in non-traditional occupations from 1967-1974. Further data reveal that the number of foresters decreased by seven percent between 1972 and 1979 . Meanwhile, the "ologists" and their technicians increased significantly, with the agency adding 39 percent more soil scientists (from 151 to 210), doubling the number of wildlife biologists (108 to 214), and increasing hydrologists by 29 percent, from 104 to 134. In 1979, for the first time the Forest Service hired geologists, 83 of them. The agency added 57 percent more forestry technicians and increased biological technicians by 23 percent, while the number of engineering and surveying technicians and construction inspectors decreased between 10 and 28 percent. Computer specialists increased by a whopping 130 percent, from 92 in 1972 to 212 in 1979 . As well as adding “ologists" and associated field workers, the agency altered several occupational categories to reflect both public mandates and the addition of women to the workforce, the subject of Chapter Six.

These shifts reflected how the entwined diversification of the latter twentieth century altered occupational categories in the Forest Service coincident with shifts in external social structures. Change included fluctuations in race and gender as well as occupation; however, it took time for occupational reconfiguration to reach the leadership level. Because of the overlapping nature of diversification, people of color and women often took center stage in that process.

378 USDA Forest Service Personnel Management Staff, “1974 Personnel Report,” prepared by Ron Noland, November 4, 1974. 
African Americans, Soil Science, and the USFS

I think the Soil Conservation Service kind of was the stepping stone where, they had this relationship with a lot of the 1890 schools in the South. That's where 1890 schools are, in the South, and they hired quite a bit to diversify their organization. So my first permanent assignment was in an arena where I was the pioneer, first African American. ... it was my role to say, "Hey, we're different. We can't be painted with the same brush stroke but whatever you give me, I'm going to do it to the best. - Paul Johnson, Minerals and Geology, 2013

Responsibility for diversification landed on all agencies in the Agriculture

Department, but the SCS got a slight headstart during the Great Depression by

recognizing benefits to soil health when black extension agents worked with black

farmers. Leon Blankenship, a WWII veteran hired by SCS in 1946, earned an

agricultural degree from Tuskegee and became the first professional African American

soil conservationist. By the 1950s, SCS employed forty Blacks, half of them

professionals for whom jobs were often harder, expectations higher, and resources fewer

than for Whites. While Whites typically dealt with farmers in a single district, black unit conservationists worked only with African American farmers, in multiple service areas, and usually when watershed or soil health required their participation; otherwise, services were hit and miss for the black public, with many unaware of SCS altogether. For example, Blankenship managed a segregated office in Louisiana with two technicians and a clerk to support a six-parish area, and also held night meetings to acquaint black farmers with SCS. ${ }^{379}$ When the organization desegregated in response to

379 Douglas Helms, "Eroding the Color Line: The Soil Conservation Service and the Civil Rights Act of 1964," Agricultural History, Vol. 65, No. 2. The 1890 Land-Grant Colleges: A Centennial View (Spring 1991): 42. 
the 1964 Civil Rights Act and the 1965 Civil Rights Commission agricultural report, ${ }^{380}$ Blankenship closed his office and moved to Ruston, Louisiana, where he continued working with Blacks. Although his white district supervisor recommended Blankenship succeed him, the veteran refused to move away from working primarily with African Americans until 1974. By then, the SCS stood at the head of the line in terms of HBCU partnerships and recruitment.

By that time, the U.S. Forest Service needed professionals other than foresters, a situation that facilitated professional minority recruitment. In fact, USFS sometimes recruited African American soil scientists right out from under the SCS. Paul Johnson, for example, obtained a soil science degree from Fort Valley College, [Georgia's] African American land grant college. He then worked summers for SCS through a partnership with University of Georgia, where he obtained a Master's in Agronomy. After college, Johnson worked full-time for SCS, but in the summer of 1973, he received a call from Chuck Dooley, the first USFS African American director of Personnel. Dooley offered Johnson a job in Texas, but at his existing grade. When he declined, Dooley asked where he might like to work. A month later, Johnson received an offer for "'promotion to a nine,' on the Bienville National Forest in Mississippi." Johnson recalled that Dooley “...started the conversation, 'I'm not going to take a no, it's a promotion and we want you to have it. We want you to take the job."' Johnson accepted and later learned that a classmate from Fort Valley recommended him. Felix Ponder: 
was working with the Forest Service. And it was during that window where the Forest Service, especially Region 8, was looking at bringing on more soil scientists. Blacks too, in that arena. They only had two or three [in Region 8 ] and all those was white and so they had this window of opportunity, where about eight or nine African Americans came through as soil scientists during that period.

Johnson recalled that Dooley had turned to Ponder because he "wanted high performing, focused African Americans that will continue this progress of diversification." Several other African American soil scientists followed Johnson and Ponder into the Forest Service, recruited by Dooley. ${ }^{381}$ At least two, Earl Ford and Arthur Bryant, worked for SCS in the Midwest, with Ford spending much of his career in the Pacific Northwest.

Earl Ford was born in Monroe, Louisiana in 1952. As one of 15 children, Ford grew up in an agricultural community, where his recollections of forest and farm tied into basic subsistence. Ford's family owned the land where they raised chickens and livestock and grew cotton, soybeans, and vegetables. Ford's father worked winters at the town lumber mill and his mother worked as a domestic servant, but the family spent summer and fall harvesting crops. As he explained in 2007:

When you live in the rural South, hunting and fishing is not a sport. It's survival. I've never heard of catch and release until I grew up and moved to the West. Because if you caught a fish it was for dinner. You didn't catch it to turn it loose or to see how big and pretty it was. I never understood - coming from a utilitarian culture, you catch what you need to eat and you hunt what you need to eat. We never went out and killed thirty rabbits. You needed one for dinner. So killing a deer to bring his head home ... I never grew up seeing antlers mounted on the wall. ${ }^{382}$

\footnotetext{
381 Earl Ford, Pilot Interview by Donna Sinclair November 2, 2007. Vancouver, Washington.

382 Earl Ford Interview by Patrick Kelly, April 30, 2007. Vancouver, Washington. Region 6 Civil Rights Collection.
} 
Ford's recollections paint a vivid image of the segregated South in a time and place where many Blacks were sharecroppers and parents taught their children what he called Southern "survival skills": Always address Whites formally as Mister or Missus, no matter how they refer to you. Never look a white woman in the eye. Don't buck the system.

Ford graduated in 1969 from a high school that had been desegregated that very year. He then attended Southern University, the HBCU his 4-H group visited, which had prompted him to question the future: "What did I want to do?" he asked. He considered poultry science, rejected Agricultural Economics, and then learned:

...they had this thing called Agronomy. That's what I want to do. I hadn't figured what it was yet, but Agronomy! And somebody told me it was plant and soil science. [To self] "So, yeah, I grew up on a farm, I could do that, I could do that. I could tell folks how to grow crops and stuff." ... I must have been fourteen or fifteen when I decided that that's what I wanted to do when I went to college. ${ }^{383}$

At Southern, Ford came into contact with the SCS, which had long been recruiting there.

He worked for the organization in 1971, his first job in McCook, Nebraska, where:

They had one black family in the county. And so that was my ... first introduction being immersed in a white community. It was like a cultural exchange experience. One day we were on the Mississippi River, boycotting Rhodesian chrome with the Southern Christian Leadership Conference and the students from Southern University, we were on one side of the river and the $\mathrm{Ku}$ Klux Klan was on the other side of the river and the Louisiana State Troopers were in the middle, trying to keep us from killing each other. So that was on the weekend, and the next Monday I was in McCook, Nebraska with 8,500 white people and me. ${ }^{384}$

Ibid.

Ibid. 
Despite, or perhaps because of the cultural dissonance associated with moving from the South to the Midwest, Ford found one of his first and perhaps most important mentors, the "life coach" who recommended that USFS might have more opportunity than SCS, since it employed fewer Blacks. Ford remembered this period fondly. There he was: "young, militant and black. And lo-and-behold, people were nice to me. People were nice to me." In McCook, he stayed for a few days with his boss, who introduced him around town - to the Rotary Club, the sheriff, the mayor, and at the local church. His picture went into the newspaper and residents welcomed him, from "hippies" to church "kids" to "cowboys." For the first time, he ate dinner with white people. He addressed them by their given names. And, he saw white families work their own property. His response?

I was always like, 'How can they manage all this land by themselves?' ... at home, Mr. Vernon, shit he got twelve black folks working on his farm.' Mr. Vernon - his khakis are always creased and his shirt is always starched. He's always standing on the turn-row pointing, telling folks what to do. He'd come out in the morning, he gone, you don't see him anymore. So that's the way they ran in the South. In Nebraska, these guys were working their own farm. So their jeans looked like mine. Their t-shirts were dirty and they got an old handkerchief in their back pocket that's dirty."

The experience broadened Ford's worldview. "So," he explained, "you got this lesson on how America worked and it didn't all work like the pictures that you had seen." Arthur Bryant, ${ }^{385}$ Ford's contemporary, also attended Southern University. His parents and eight siblings lived on a Louisiana farm that employed twenty to twenty-five African American families on site: “As soon as we were old enough,” recalled Bryant, 
"each of the siblings would have opportunity to work in the field on that farm, on that plantation." Later, he also did odd jobs on neighboring plantations. Like Ford, Bryant says the family “... was poor by most accounts but we were happy and well fed, and came from a strong family orientation, had a lot of love and support." Bryant's father remained a farmworker all his life, while his mother worked in domestic service and in the public schools. Bryant's brother, the first in the family to attend college, obtained a degree in Vocational Agriculture from Southern and went to work for the Farmer's Home Administration. Arthur followed his brother to Southern and graduated magna cum laude in 1975.

Following graduation, Bryant worked for the SCS in New England, North Dakota. He, too, remembers this as a time of personal and professional growth, a formative period he holds "quite dearly" because it prepared him for a career that often took him into overwhelmingly white environments. "I don't think I saw another African American for three months," he said. "I was the only one in that town and anywhere that I went in the surrounding areas." Bryant remembers learning a lot about himself, about tolerance, and about difference; that is, his difference. He found himself in a position "to help them [Whites in North Dakota] understand" his background and culture, an unexpected side duty for many people of color working in primarily white organizations and locales.

Bryant also recalled Felix Ponder, noting that he helped to connect the agency with "ologists" and science majors from the 1890 schools, "where there was a rich pool of folks like myself willing to step out and really looking for opportunities..." When the 
agency offered him a job, Bryant wondered: "What would a soil scientist do with the

Forest Service?" He realized the answer was:

quite simple...it takes soil to grow the trees. It takes soil to stabilize the environment around the natural resources and keep the sediment out of the streams, and being able to ... know ... where to build roads and recreation areas; everything was predicated on a strong soils information base. So it was quite clear then, where I would fit in. ${ }^{386}$

\section{An Alternative Path in the Era of the "Ologists"}

In this era of the "ologists," scientists of all varieties became important to the Forest Service. Jimmy Reaves, for example, became a biologist, a research scientists and self-described "farm boy" who spent much of his childhood on a South Carolina tobacco farm working alongside his sharecropping grandfather. Reaves graduated with a Biology degree from Voorhees College, an HBCU in Denmark, South Carolina then quickly pursued a graduate degree in forest pathology at Atlanta University. At the time, Reaves remembered, his "folks" in the community questioned why he would go to school "to work in the woods." As he explained in 2013 most people did not "understand the relationship and the expertise and the professionalism that you had in forestry. The only folks that we saw in forestry were pulpwood folks..." Going into forestry was "not favorable... you were pushed to be a doctor, lawyer, dentist. Not even so much as a businessman."

Like the soil scientists, Reaves joined the Forest Service because a recruiter asked if he would like some experience in forest research in a different part of the 
country. Just a year into his master's work, he knew it would slow him down but, there "were not a lot of jobs floating around" and Reaves found the opportunity too good to pass up.

Jimmy Reaves went to work in the silviculture lab in Bend, Oregon for the summer, where he encountered both a master's project and "a different culture, to say the least." The project stemmed from work in prescribed fire and ultimately led him to a Ph.D. ${ }^{387}$ After completing the master's, project leader Bob Martin helped Reaves to develop a prospectus, and signed him up as a Cooperative Education student which kept him working during the summers and allowed conversion to full-time employee status upon degree completion. As for Oregon's culture, Reaves became one of the few African American employees in the silviculture lab on the Deschutes National Forest in Bend, Oregon, an overwhelmingly white community:

...it was different. Coming from the attitudes in which I lived, I was always cautious, I was always very purposeful in everything that I did, especially when I got there. I didn't have a place to stay, because most folks who came there for the summer lived at Central Oregon Community College. But they were on the quarter system, so the apartments that the students rented would not be ready for another couple of weeks. And so, my project leader asked me to, to live with him, to actually live with a white family. That's unheard of in the South. [laughing slightly] Sooo, that was quite a different culture change for me..... You know, going to white churches. I had never been to a white church in the South. Even during funerals I had never been. And interacting with folks. And I got a different aspect of white folks.

Beyond exposure to white society, Reaves' experience in the Northwest broke down other stereotypes: "Meeting Native Americans from the old cowboy movies...

387 Jim Reaves Interview by Donna Sinclair, February 12, 2013. Rosslyn Virginia. Reaves worked on the Deschutes, Klamath, and Modoc national forests. Reave's master's project focused on studying the effect of ash leachates on the root disease fungus amaleria restoriae. 
demystified those myths, you know, that folks were folks." He also found that love of the land brought people together. Although the "thought processes" of Northwesterners differed from Southerners in relation to the environment, the "adventurous" approach to the land resonated with Reaves, who enjoyed recreational hiking.

Jimmy Reaves continued to spend summers in the Northwest. As a Co-op Ed. student in the last throes of a Ph.D., the agency hired him through a non-competitive appointment and moved him to Corvallis to work in a Pathology Unit at the Pacific Northwest Research Station. He recalls being one of two African Americans onsite and, carefully considering his words, said, "And so, there, it was, it was different, too. Yeah." Reaves and his wife disliked Corvallis so much they thought about leaving the Forest Service. When asked why, he also explained his motivation for staying:

Well, when I went there, to be truthful, I was hired as a GS-9 and most Ph.D.'s were hired as GS-11's.... I saw some disparity in treatment, not being as inclusive, the unit was not as inclusive as I saw when other folks came in. Scrutinized even more, mistakes. Discouraged in some ways. ... But then, and that's the beauty of sticking to it, because then I met folks. I met a person at Oregon State who was a world renowned pathologist, Dr. Lou Roth. He kind of took me under his wing. He was retired and he was still doing research and collecting data. He took me out in the field and ... it was a turning point of him encouraging me. A couple more people, a guy named Don Goheen ... in State \& Private. They were surveying for disease. And they really encouraged me, you know, there were some issues ... that they needed to be worked on from a science point of view. And I went out with them a couple times and got a better understanding of ecosystems and things like that. And so, after that, you know, I said, "Well, I'm gonna stick it out."

Reaves explained that the challenges extended beyond laboratories in which a supervisor had different expectations for white and black employees. Discussions about diversification centered on African Americans, but with little understanding of black 
culture by discussants. He found himself in the position of countering stereotypes of

Black Americans inside the agency and out, especially those connected to environmental perceptions:

You know, that [African Americans] didn't want to work in forestry, wanted to work for industry, that industry paid more, so we would want to go work for them and not the Forest Service. Completely disregarding the fact that conservation of the [environment], the conservation ethic was not a gene that only white folks had. You know, and if you think back in the history of black folks, you know, we came from that; you know, working on farms and working in the woods and in the forest, and utilizing the forest for ecosystem services, non-timber products, healing and those kinds of things. So it was not like it was that foreign.

Like the others, Reaves recalled the need to establish credibility with colleagues and with the public, "getting people to work with you, getting people to be [pause] honest, getting people to understand that you are there as a government employee and that you are there to spend the taxpayer's dollars wisely." Jimmy Reaves remained in the Northwest until around 1990, before moving into a position as liaison at Alabama A\&M, where he would later help facilitate accreditation.

\section{The price of advancement}

Each of the men highlighted here became examples for those who followed, facing challenges on multiple fronts regardless of location or occupation. Chip Cartwright stepped along a more typical path to leadership than those who rose through the ranks of science. The first African American to become a line officer - a natural resource decision-maker - Cartwright became a role model and path breaker, a traditional agency leader in an occupation held by few African Americans. Becoming a 
line officer took determination, political savvy, acquisition of expertise, and conformity, although sometimes advancement called for bucking the system. For example, John Yancy went directly to a trusted Alabama ranger when personnel thwarted him. He also understood the importance of mobility to moving ahead. Additionally, those African Americans who entered the Forest Service in the 1970s created informal networks that later became formalized. Meanwhile, most support occurred through personal contact. For example, Chip Cartwight identified Wendy Milner Herrett, also appointed the first female district ranger in 1979, as his key supporter. The two had not met in person, but discussed their experiences as "first" line officers by phone on a regular basis. In turn, John Yancy called Cartwright to strategize about advancement. The soil scientists knew and encouraged one another, as did the few African American scientists in the agency. These men also understood the need for white allies and mentors, noting that without them, promotion could be easily stifled.

The pace of advancement took more or less time depending on circumstance, and these men soon became aware of the costs as they moved into white communities and became cultural instructors. While young white Forest Service employees also experienced isolation, for African Americans placed in the midst of homogenous educational venues and communities, the difficulties associated with loneliness and difference multiplied. As Chip Cartwright explained, echoing the narratives of many others:

I prayed a lot! [laughs] You know, but I also developed relationships with people who did not want me to fail. I learned to look and see others who appeared to be handling this, you know, and to find out from them what were they doing? You 
know, to learn not to be sucked into the game of letting my anger control my actions, of learning how to keep my mouth shut at certain times. And when I did talk, make sure it came from a place that was influencing, that I was forceful, that I came with a surety, that I know who I am and I'm not going to let you suck me into being somebody who I was not. It took me a while to get there. It took me a while to get there.

Cartwright relied on his faith and family to survive the early years. Still, his professional success echoes that of Paul Logan and others in many ways. The price, he said, was "stepping outside of the black community. Stepping outside of a nurturing environment all the time, into one in which that nurturing might be there. Most likely it would not be. ${ }^{388}$ Cartwright often found support and obstacles in the same places - from professors, supervisors, co-workers, and community members. Internally, Cartwright worked to become part of Forest Service culture by modeling District Ranger Lynn Andrews on Washington's Colville National Forest:

it was there I met District Ranger Lynn Andrews, a white man. Lynn became one of my mentors. We never used those words, but he became one of my mentors. And it was he I wanted to be... So I learned a lot by watching Lynn. He put me in situations in which I would have to exercise control and expertise. He was always there to bail me out if he needed to. He let me make some mistakes, and it was because of him that when I went to the Okanogan National Forest after about three years, on the Okanogan Ranger District, my first time as a district ranger...I could not fail because I had learned from one of the best.

Thus, he focused on moving up the line, first as a district ranger on the Okanogan National Forest, followed by a stint on the Gifford Pinchot before gaining experience as a legislative affairs officer in Ogden, Utah, a position that included a lot of Public Affairs work and details in the Washington, D.C. office. Next came a job as forest

388 Charles "Chip" Cartwright Interview by Donna Sinclair, May 1, 2013. Skype, Texas and Washougal, Washington. 
supervisor of the Jefferson National Forest in 1988, making Cartwright the first African American forest supervisor in the country. In 1994 Cartwright became regional forester of the Southwest, R-3, where he remained until retirement in 1997. Cartwright's approach echoes that of many others. He worked to establish expertise immediately, so that his constituency would look past the color of his skin, deciding to effect change by mastering as he put it "the resource side of the house." In the early years, he stayed away from agency-wide diversification efforts, but felt that his very presence put a different face on public forestry. When he spoke to people, he said, they not only saw the uniform, they saw his skin color. That was his "multicultural outreach."

\section{Discussion: Expanding Diversification}

I've always known the Forest Service. I've always known the U.S. Department, Agricultural Extension Service. Racism or no racism, I mean we had it in my home. We had people $I$ know in my community that were black extension specialists. - Rudy Edwards, 2004

Defined occupations via scientific management combined with preventing access to education whitewashed forestry in the twentieth century, a trend visible through unequal access to agricultural colleges, forestry schools, and public work through much of the twentieth century. Job disparity shaped African American attitudes toward forestry, not lack of interest. Men like Carroll Williams, Jr., Charles Irby, and James Johnston obtained professional forestry degrees in the West and Midwest, education unavailable in the segregated South and limited in the East, and then practiced occupations restricted by race, place and organization. Not until the 1970s did entwined 
diversification bring minority foresters, scientists, and other land managers into the Forest Service. In the wake of the national civil rights movement, the most robust professional diversification efforts by the Forest Service focused on black men, starting with the Tuskegee Pre-Forestry Program. The agency used existing structures to shape the era of the ologists and Tuskegee provided a workable model that showed what the government can do by combining funding, flexibility, and commitment to diversity. A blend of partnerships, alongside non-traditional outreach resulted in training black foresters for both private industry and USFS.

The Tuskegee Program met and exceeded its original goal of introducing African American youth to natural resources opportunities. Now the Tuskegee Forest and Natural Resources Program, the school offers a variety of natural resource degrees, including four options for a bachelor's degree in Environmental Science, Natural Resource Management, Plant and Soil Sciences, or Forest Resources. The latter option allows students to pursue advanced degrees in forestry, fisheries, natural resources, and wildlife ecology by completing three years at Tuskegee and from one to three years at a partner university. Students earn a B.S. from Tuskegee and may obtain an M.S. from one of six schools: University of Florida; Oregon State; Mississippi State; Auburn; North Carolina State; and Duke University. ${ }^{389}$

The positive and negative responses to Payne and Theoe's 1971 "Black Foresters Needed" article also illustrates the challenges faced by people of color in the Forest

\footnotetext{
389 John Schelhas, Water Hill, Janet Haslerig, and Deidre Smith. "Sharing the Vision, Part 2: The Tuskegee Forestry and Natural Resource Program in the $21^{\text {st }}$ Century." Alabama Consortium on Forestry Education and Research, 2013. DRAFT, 37.
} 
Service. The forester who suggested leaving social problems alone ${ }^{390}$ did not recognize or care about inequalities of condition that required legal interventions to approximate equal opportunity. As the white forester, Ronald Lanner clearly explained, even the most qualified of black applicants could be passed over, filtered out, application nullified for no reason other than race. ${ }^{391}$ Lanner also pointed to the importance of funding for workforce diversification, as did Brian Payne, who recalled sometimes loaning money to students to access summer jobs. Payne's wife Almuth also worked with the Washington, D.C. Forestry Wives Club to create an essay competition. Mack Hogans won the first hundred dollar prize. In 1972, Weyerhaeuser provided a five year, $\$ 250,000$ grant to the Tuskegee Program for scholarships, a professorship, equipment, and a visiting lecturer program. This financial aid increased the number of program participants significantly. When the grant ended in 1977, the university formed a Forestry Resources Council to replace the funding, but to little avail. However USDA Forest Service has maintained its commitment since 1968, providing 19 Forest Service liaisons between then and 2009, each with a budget for travel, recruitment, student training and program development. Since its inception the agency has provided student scholarships and summer employment opportunities. In 1978, USFS employed 87 Tuskegee students. ${ }^{392}$

\footnotetext{
390 "Letters," 393.

Ibid. Schelhas, et. al., Tuskegee Part 2, 99-100.
} 


\section{Extending Opportunity - Beyond African Americans}

Not all employees who worked for the Forest Service in the 1970s were African American. In fact, in 1970 President Richard Nixon announced a Sixteen Point Program to assist Spanish speaking American citizens, including Puerto Ricans, Cuban Americans and other Latinos, in joining federal service. ${ }^{393}$ The plan called for a full-time coordinator in the CSC to dispense advice and ensure EEO compliance, intensive recruitment of Spanish speakers in major cities and the Southwest, educational outreach and summer employment for high school students, specialized recruitment teams for colleges with large Hispanic enrollments, and increased drafting for the Co-op Ed Program. Significantly, the plan allowed Hispanic applicants to bypass written testing. It also recommended making special efforts to inform Spanish-surnamed veterans of noncompetitive appointments, called for more training opportunities, and for EEO reporting to help identify problems specific to the Spanish-speaking population. In 1978, the Carter Administration continued efforts to increase Hispanic employment through reporting and analysis of issues related to Hispanics in a report titled Carter Administration and Hispanics Report: A Partnership to Progress. ${ }^{394}$

\footnotetext{
393 In 1978, this authority shifted to the Office of Personnel Management (OPM) under Civil Service reform.

394 In addition to town hall meetings held in seven states, the District of Columbia, and Puerto Rico to address Hispanic concerns, President Carter released a report that analyzed employment, among other pertinent issues. Armando Rodriguez, "OPM Sponsorship of the National Council of Hispanic Employment Program Managers, White Paper,” National Council of Hispanic Employment Program Managers Document Repository, http://nationalcouncilhepm.net/index.asp?page=resources\&content=Repository [accessed February 2, 2014]. President Carter also appointed 186 Hispanics in high-ranking positions; however, Armando Rodriguez who became chair of the National Council of Hispanic Employment Managers in 2010 has described ongoing attempts to increase Latino employment in the government as "marginally successful,"
} 
Prior to Civil Service Reform, like Native Americans most Hispanic employees likely worked on fire or as laborers, while the agency employed very few people of Asian descent. For the first time, in 1978 the agency began reporting workforce data on age, occupation, and the status of women and minorities. Personnel officials tried to address a need for information to shape decision-making regarding grade levels and occupation for recruitment, career counseling, and potential restructuring of positions for competition by minorities and women. By then, the agency employed 3,398 people of color, the bulk African American (38\%), Spanish American (38\%) and American Indian (18\%). Only twenty-four Asian employees worked for USFS. The agency provided a breakdown by race and gender [See Career and Career Conditional Minorities by Region and Race/Ethnicity, 1978 \& 1979, Appendix C, Tables C.10 and C.11], but did not present complete occupational data by minority status. It reported on professional employment categories (range conservation, forestry, soil science, wildlife biology, landscape Architecture, civil engineering, and hydrology) but not by race. However, the agency documented minority employment in forestry and civil engineering and associated technicians, computer specialists, administrative and personnel officers, occupations that employed 31 percent of all minorities in 1978 and more than 50 percent

despite legislation. ${ }^{394}$ His assessment is valid, as evidenced by a less than three percent employment increase from 1972 to 2012 when Hispanics constituted only 5.8 percent of federal executive branch employment. ${ }^{394}$ Hispanic employment in the executive branch of the federal government stood at $5.8 \%$ in 2012, 3.3\% male, and 2.5\% female, Office of Personnel Management Website, "Executive Branch Employment by Gender and Race/National Origin, 2001-2012," http://www.opm.gov/policy-dataoversight/data-analysis-documentation/federal-employment-reports/reports-publications/executivebranch-employment-by-gender-and-racenational-origin/ [accessed February 4, 2012]. 
in 1979. By 1978, the agency employed 77 minority foresters and 40 in civil engineering, both occupations that could lead to line positions. Within the following year, the number of minority foresters had nearly doubled to 140 or five percent of all minority employees, despite an overall reduction in force of 4,800. Another 34 percent worked as forestry technicians and 16 percent in Personnel. The number of Asian employees also increased to more than 200 during that year, even as the number of minority employees decreased significantly to 2,733. [See Civilian Labor Force (CLF) and Forest Service - Women and Minorities, 1978-2005, Appendix C, Table C.5] Many of these minorities came into the program through youth programs in the early to mid-1970s. Robert Alvarado for example, one of eleven children from a California farmworker family of the San Joaquin Valley, learned about the Forest Service through the YCC. At age fifteen Alvarado spent a YCC summer on the Sierra National Forest. He then joined the Co-op Ed program, went to college, and became a wildlife biologist. Others came in through Fire, and advanced in the agency through education and expanding opportunities. Dale Hom of Seattle held his first job with the Forest Service as a firefighter working under the Student Temporary Employment Program, STEP, and then moved into the realm of Recreation. He worked on outdoor campground management before taking a job as a YACC crew leader and then directing a residential program. Hom later became forest supervisor on the Olympic National Forest. Fire also brought both Kevin Chung, a Californian of Chinese and Hispanic ancestry, and Bill Otani of Hawaiian Japanese heritage to the Forest Service. Chung later worked as an Equal Employment Opportunity specialist, Otani as a wildlife 
biologist and Asian Community liaison. Others, like John Kusano, of Japanese ancestry, and the Hispanic Mike Hernandez, entered the agency through traditional forestry paths. As the agency diversified, Kusano entered the realm of Human Resources at the national level. Hernandez became a district ranger on the Mt. Hood National Forest.

A close look at regional variation shows that in 1978 the bulk of African Americans worked in the South (398 of 1259 total), the Washington Office (178), and "other" research stations and areas (290). Regions 5 and 6 also employed more than a hundred African Americans each, 146 and 113 respectively. Along with more than 500 Spanish Americans in Region 3, R-2, R-5 and R-6 also employed the bulk of Hispanics [See "Minorities by Region and Race, 1978” \& “...1979,” in Appendix C, Tables C.10 and C.11]. Most striking is that Region 6 employed 15 minority foresters, the highest number in the nation and one that more than doubled the following year to 39, despite reductions in force. The race of minority foresters is not clear, but based on regional variation and the overall proportion of minorities, R-6 foresters were likely African American and Hispanic. A close second, Region 3 employed 14 minority foresters and 270 minority forestry technicians, likely Spanish American. Like R-3, Regions 5, and 6 also employed the highest number of minority forestry technicians in 1978 and 1979, and also employed more than half of all the agency's American Indians. With Regions 5 and 6 consistently the largest employers in the agency - more than half of all employees - it not surprising that a majority of minority foresters would work in the Northwest and California. Nor is it surprising that the South and the Washington Office employed the most African Americans or that the Southwest (R-3) employed significant numbers of 
Spanish Americans (554), or that the spike in Asian hires occurred in California and the Northwest, given the demographics of those regions. It is surprising that the Northeast employed so few minority foresters (4) and Alaska (R-10) so few Native Alaskans at all. These regional differences varied slightly in the years to come, but by the end of the 1970s diversification emphases shifted to issues of gender and professional advancement. The number of government employees grew steadily in the 1970s until Civil Service Reform in 1978. Ongoing reductions in the permanent USFS workforce thereafter, from more than 38,000 permanent staff to just over 31,000 in 2011 have presented added challenges to diversification.

Stereotypes, Stories, and Diversified Conformity

The stories here demonstrate that despite perceptions of the industry as dirty, backbreaking, and low paid labor, African Americans could find a home in professional forestry. When people understood the potential in natural resource careers and were provided educational opportunities and funding, Forest Service employment became attractive. This appeal would be borne out by the many African Americans who advanced in the agency in the 1980s and 1990s, as well as those graduating with forestry and natural resource degrees today. Young people considering forestry careers faced layers of internal and external challenges in the Forest Service. First, agency culture generally did not support occupational diversity as a path to leadership. Mack Hogans, for example, envisioned an alternative career path to the top at a time when the agency did not support occupational difference and non-conformity meant a sure end to one's 
career. Men like John Yancy and Chip Cartwright established expertise both within and outside USFS and conformed with agency mission and culture in order to advance. For those unwilling to transfer, careers progressed slowly, an issue that heightened as more women entered the workforce, and one that still plagues those seeking advancement. Paradoxically, the need to understand regional differentiation contributes to mobility requirements for promotion, while homogeneity is at the root of agency efficiency and bureaucratic operations. Indeed, esprit de corps stems from shared values at multiple levels, most especially in terms of commitment to the agency and its conservation mission. However, willingness to conform goes deeper than mobility. It is the invisible conformities in white culture that often present the greatest difficulties for minorities, presenting the need for a sort of diversified conformity; that is, accommodation by diverse employees to agency, male, and white culture. As noted earlier, Chip Cartwright recognized the need to model Ranger Lynn Andrews - to become Forest Service. He also determined that gaining acceptance from the public would occur by establishing expertise, as part of Forest Service. Becoming Forest Service also meant integrating into white communities, as did Cartwright and many others through activities like church participation and providing natural resource education to school children. 


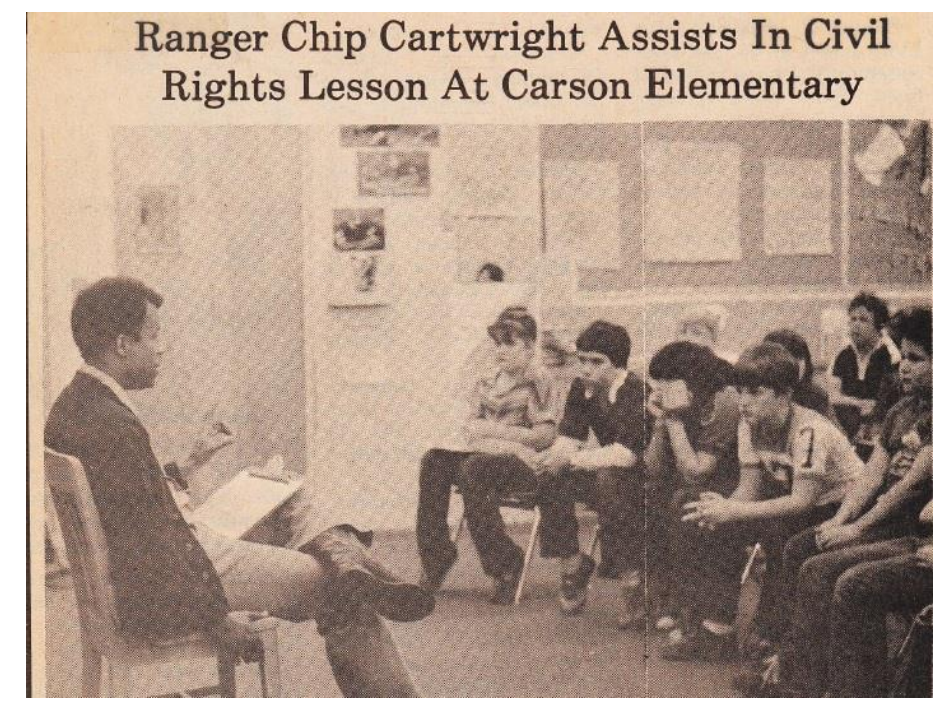

Figure 3: Chip Cartwright at Carson Elementary. Image from Skamania County Pioneer

By the 1970s, it became clear that forestry could provide a desirable career path for African Americans and other minorities. The men highlighted here described strong relationships to the land, in ways that belie the notion that Blacks and forestry are incompatible. They also belie stereotypes about Hispanic and Asian abilities and interests. Nor are Native Americans and rural folk the only groups interested in outdoor work. As Sidney Clark, an African American from East L.A., who joined USFS in 1979 said:

...Region 6 is Oregon and Washington. Okay? And then you've got Region 5 right next door, which is California. Don't tell me that there isn't people of color, African Americans, who don't want to work for the Forest Service. Because it is.

Because [discrimination], it's at every level. It's at every level. It's at this level, mid-management level, and just seasonal workers and technicians. And the professional ranks as a forester. It's at every damn level, because it's a cultural, systemic thing that goes way back in how they view, especially African Americans in forestry with the stereotype: [mocking] "Well, they don't want to work in the woods. They good for all in the city. Trees at night? Shit, they afraid of bears." It's so dumb. Think about where we come from. From the woods, with bears and lizards and alligators and everything else from the Southern and 
Midwestern states! Who happened to migrate west, looking for better opportunity!

Clark and others identify cultural misunderstanding at the center of attitudes about diversification, in USFS and associated communities. For example, while in college, Clark got invited to a "kegger" where someone described his clothes as "bitchin." He remembered: "So I grab the guy by his collar. I said, "Man, don't you be calling me the b-word!" ..."Where I come from, them's fighting words!"

And so my friend went, "No, no, no, no!" he said, "That's a compliment!"

I said, "What?" [incredulous]

He said, "That's a compliment!"

I said, "Bitchin' is a compliment?" [disbelieving]

He says, "Yeah! That just white slang!" [laughs]

Clark told this story as an illustration of cultural difference between African Americans and Caucasians, and to demonstrate that there is indeed, "white culture."

Dr. Jimmy Reaves also experienced a white culture unaware of itself. He recalled liking Bend better than Corvallis because:

People were real. ... you run into some folks who could be narrow minded. But most, I'd say ninety five percent of the time, folks were, I'd say honest. If they didn't know something - you have to realize, some folks had never seen an African American in person. So you get some questions. You'd just look at them and say, you know, "Why are you asking me that?" But it was all in earnest, and I learned to deal with that.

Like Reaves, each of the men highlighted here learned about white culture, even as they taught others about themselves. These men were among the first professionals in a group of African Americans and other minorities who joined USFS in the 1970s, men who 
came into the agency through forestry, natural and social sciences, and Job Corps. Increasing numbers of women and ethnic minorities resulted in overlapping strands of diversification that transformed the public face and internal voice of the agency. Yet, as their experiences demonstrate, entrenched bureaucratic culture remained in place. Yancy's choices - to major in forest management, to gain expertise outside the agency, to make use of informal networks - coalesced so that by 1983 he followed Chip Cartwright as the second African American district ranger in the nation. Hogans, on the other hand, left the agency in the interests of greater advancement. Although highlighted as part of the Research arm of the agency during Black History Month in 1979, Hogans rightly noted lesser potential for advancement as a social scientist focused on recreation than if he were in the National Forest System. He also realized that his desire to remain in the Northwest would quash a rise up the line. Not so at Weyerhaeuser. In 2003, Hogans retired as a company vice-president.

Occupational and social diversification eventually shifted the constraints of advancement in the Forest Service slightly, but only as more women, people of color, "ologists" and planners joined the agency. Arthur Bryant followed Cartwright and Yancy in the 1980s as the third African American district ranger and the first soil scientist to achieve that position. At the time of his interview, Bryant headed Homeland Security for the Forest Service as a member of the Senior Executive Service. Jimmy Reaves, also in the SES, became Deputy Chief of Research and Development for the agency in 2011, supervising thousands of employees in one of the world's largest sustainability research organizations. 
The 1971 debates in the Journal of Forestry are very telling in terms of diversification priorities. All parties assumed forestry as a male domain and African Americans as the target minority group. These perceptions changed in the 1980s as the agency incorporated more women in the workforce and minority populations continued to shift, trends that intersected with occupational diversification and cultural encounters in the years to come. In the decade after 1976, minority employment increased only half as much as it had in the first decade of diversification, reaching twelve percent, while the proportion of women rose from 22 to 31.5 percent by 1986 and 40 percent by 1992 . The ways in which women sought to attain decision-making power as their numbers increased is the subject of the next chapter. 


\section{Chapter 6: Re-gendering the Forest Service - Paving the Way in Region 6}

During the last two or three years, it seems, there has been a proliferation of women being assigned to firefighter and other fire suppression jobs. At first, I am convinced, this was done here and there by some of our fire folks who thought it was "cute," others may have thought it was "smart" or the "in" thing to do. Still others, perhaps, though that they were "striking a blow" for equality. Now, I'm afraid, its gaining momentum through pressures generated in the area of equal employment opportunity and in the spectre of the so-called Equal Rights Amendment. I submit, however, that firefighters and fire control are neither acceptable or appropriate activities in which to push such social programs for women, anymore than the belief that front line combat should include women. Carl Hickerson, Director, Fire Management, Pacific Northwest Region, National Fire Chiefs Workshop, Charleston, South Carolina, 1974

On December 10, 1974, Carl Hickerson addressed a meeting of national fire chiefs in South Carolina. Hickerson's speech, "Should Firefighters Wear Petticoats???" was so egregiously offensive that a copy remains among the few civil rights documents preserved by the Forest Service Portland, Oregon Regional Civil Rights Office. The speech's title is but a precursor to Hickerson's contention regarding a "progressive erosion" in the agency's fire suppression operations, a "debilitating malignancy" leading to poor performance and reliance on quantity over quality. Firefighters already had it easy compared to the old days. They received per diem, overtime, hazard, and even Sunday, night, and standby pay for time that an earlier generation would have donated. A fire chief should not have to worry about special services for females or adhere to changing management styles. Permissive working conditions led to problems, especially when "participatory management" entered the conversation. Fire as foe demanded confrontation and command, a "hard-nosed" fire boss willing to make tough decisions 
and a staff - of men - eager to follow. For only men had the strength, stamina, proportion of muscle and fat to body weight, "emotional stability under stress" and "logical" decision-making capacity under physical duress to safely fight fires. In fact, unlike minority males who had "long been a cornerstone" of fire services, the presence of female firefighters could result in trapping, burning, or even fatally injuring firefighters. Hickerson told his audience, "I am as certain of this as I am of sunrise." 395 The "radical FEW [Federally Employed Women] and their gullible and ignorant followers" waged an already failing fight, proposed the Northwest fire chief. Women were certainly "more than equal to men," especially in "their God-given ability to bear children and "natural' responsibility to raise them," a "heavy burden" men could share only partially. Any woman who could function efficiently in fire clearly had more male than female in her. Even congressional law supported Hickerson, he claimed, providing early retirement for law enforcement officers and firefighters, to employ "relatively young and vigorous men," to perform at peak efficiency under duress and to accelerate the retirement of older men. It seemed "inconceivable," he stated, "that [in] the Forest Service, you and I would promote or even tolerate the assignment of women in our jobs." Hickerson feared the "Radical Lib Movement" would invade every profession, storm every "craft and skill," and ultimately destroy American family life. The Forest Service, he suggested, should follow "steadfast" organizations like the military and the

395 Carl Hickerson, "Speech: Should Firefighters wear Petticoats??" (1974): 6. Region 6 Civil Rights Collection. 
Alaska Pipeline Project which maintained "No Women Allowed" policies. ${ }^{396}$ Indeed, the Forest Service must discriminate:

against anyone because of poor or unacceptable performance; because of physical or mental inability to fully and safely perform; because of substandard productivity; or because of inappropriate or illegal conduct. I believe too, we must discriminate against disruptive or diversionary influence; against more costly special accommodations or facilities; against double standards and special treatment for some and not all. ${ }^{397}$

At home in Region 6, a male supporter of civil rights told Mary Albertson, the newly appointed Federal Women's Program Manager (FWPM) in the region and the first FWPM in the nation, about this sexist speech given to a national, male-only audience. Albertson immediately requested a copy. It took three months but, she explained in a 2007 interview, the "deputy regional forester finally gave it to me with instructions that I was not to make copies; I was not to give it to anyone." She then faced a dilemma. A colleague told her, “Mary, if you were doing your job as Federal Women's Program manager, you would leak that speech out to the National Organization of Women." But her supervisor, Jetie Wilds, warned otherwise, telling her she would lose the organization's trust and it would ruin her career. Most importantly, she would "do in any possibility" to positively impact the agency. Wilds advised her to gain "respect and credibility and trust and then go about making these changes from the inside..."

Albertson chose not to expose Hickerson to the media:

But that was such a key lesson for me to learn. I could have destroyed everything that I have done in the Forest Service -- and I think I've contributed significantly

Ibid, 4-7.

Ibid, 7. 
-- and along with it my career, had I followed somebody's advice who was not thinking of the organization or myself. ${ }^{398}$

Instead, Albertson reported Hickerson to the Department of Agriculture and tucked the speech away. When a new Civil Rights director took over in 2010, the speech remained in a single box of materials culled from two cabinets full of documents in the Region 6 civil rights office. ${ }^{399}$

In this chapter, I examine the re-gendering of the Forest Service workforce in the Pacific Northwest of the 1970s, with special emphasis on organizational efforts to advance the status of women in natural resources. This chapter also explores the barriers faced by women seeking to enter non-traditional occupations in an era of shifting gender roles. It describes how a small group of women in the agency's most populous employment region drew from existing structures, tested policies and created new programs to effect change. Consequently, the Northwest's female Forest Service workforce strengthened the status of women agency-wide and in natural resources everywhere.

\section{Women's Work in the U.S. Forest Service}

\section{Miss Forest Service}

The first women to work for the Forest Service called their bosses "Mister," took dictation, answered the phones, organized parties, and did whatever their jobs required,

\footnotetext{
398 Mary Albertson Interview by Nick Deshais, May 9, 2007. Region 6 Civil Rights Collection. $399 \quad$ Materials saved by Sherry Wagner, Region 6 Civil Rights Director, 2010-2013. Region 6 Civil Rights Collection.
} 
from ordering flowers to organizing field trips for other employees. These were "The Clerics" and they comprised the bulk of female Forest Service employees well into the late twentieth century. Whether among the elite "W.O. [Washington Office] Clerical Staff," receptionist, transcriber, clerk-typist, or mail clerk on a district, these women occupied the lowest paid positions in the agency, usually topping out at GS-5 - entry level for male foresters. A comparison of recruitment brochures from the 1950s through the 1970s demonstrates the shifting occupational status of, and expectations for women in the Forest Service. In the 1950s, the agency told women not to bother applying, except to the secretarial pool. By the 1960s, the agency sought female employees, but as the image below suggests, they served in support roles, wearing high heels, dresses, and girdles, not outdoor garb. 


The Forest Service enjoys many
benefits made possible by a
distinctive group of ladies known as
the Clerical Staff. Some of their
better known projects are the
"Family" meetings and the "Show-
Me" trips that are presented for the
pleasure and career enrichment of
all W.O. employees.

With the implementation of civil rights legislation, recruitment brochures included the statement that "all qualified applicants receive consideration for appointment without regard to sex, race, religion, color, national origin, politics, or any other non-merit factor.” A 1967 agency brochure also noted that women could work in "nearly every occupation open to men in the Forest Service." But, four of the five images in the brochure portrayed this stated reality: "The majority of Forest Service 
positions open to women are support staff jobs..." ${ }^{, 401}$ Women could work in natural resources, but with limitations.

That the agency focused on hiring females for "women's work" is evident in the differences between two other employment brochures produced in 1969. A "Tell it to a Woman” Forest Service brochure suggested that each office create a women's activity program aimed to educate female members of the public. The brochure noted that Jane Q. Public "is an important person," because she "controls the Nation's vote," handles its money, and influences its men and young people. Moreover, she seeks worthwhile projects - and what could be more important than conservation? In fact, why not hire a female specialist to handle contacts with women, educate the public through films, speakers, literature and advice, organize program activities, talk with or join women's groups and “provide access to women's organizations for you and your staff”? A Department of Labor leaflet, on other hand, predicted that women would soon become that natural resource staff as more females obtained "the specialized education needed" for such careers. ${ }^{402}$ Professions with "special appeal to women" included: fishery specialist, forester, park naturalist, range conservationist, recreation resource specialist, soil conservationist, soil scientist, and wildlife specialist. The brochure also suggested other professions that could lead to natural resource careers, such as architect, biologist,

401 "Women in the Forest Service" recruitment brochure. U.S. Department of Agriculture Forest Service, June 1967. Revised October 1967. FHS Collection F18.4, File, "Women in the Forest Service Publications."

402 "Leaflet 50," U.S. Department of Labor Wage and Labor Administration Standards, Women's Bureau, January 1969. FHS collection F18.4, File, "Women in the Forest Service - Career Development." 
botanist, chemist, economist, engineer, geologist, landscape architect, lawyer, personnel officer, public information officer, writer and editor.

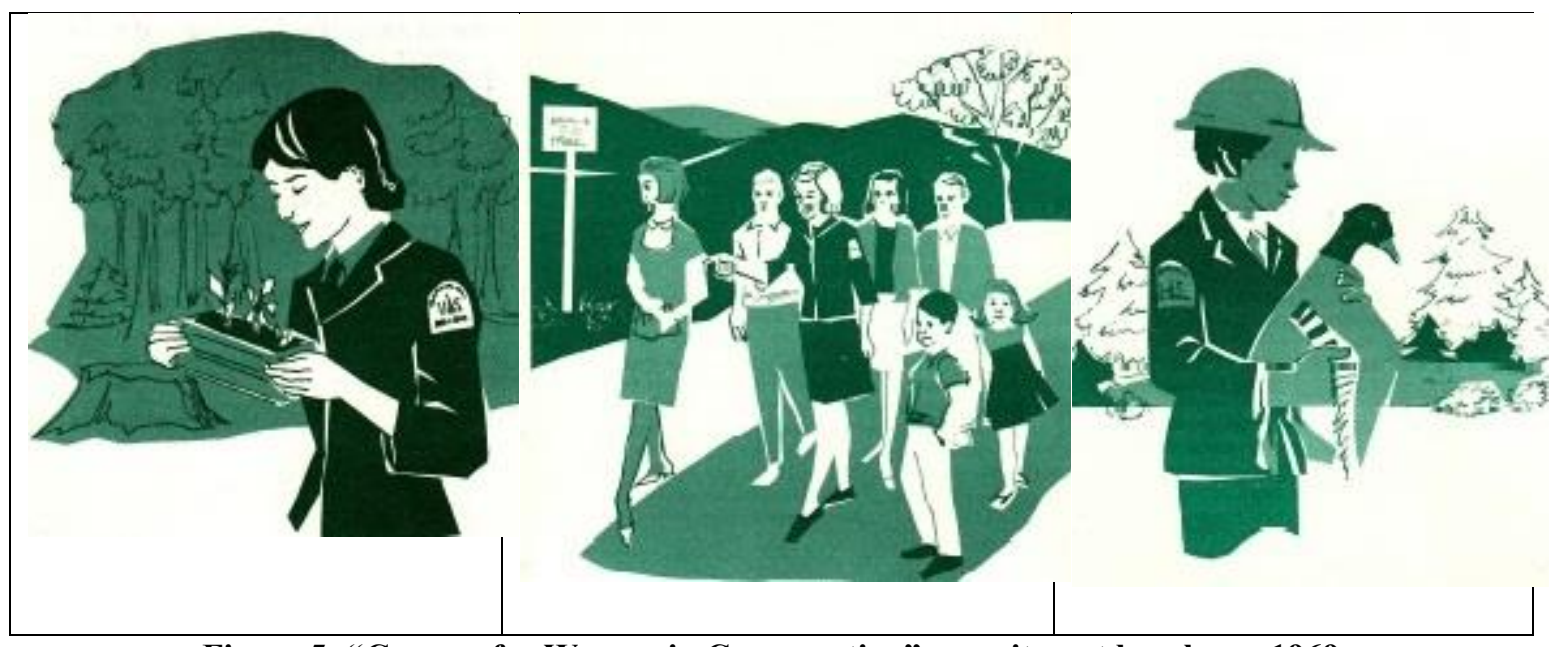

Figure 5: "Careers for Women in Conservation" recruitment brochure, 1969

This brochure (see above) sought to modernize the professional female figure through images of women with short hair and blocky ranger jackets. It even included a professional black woman in a hard hat. Still, the women shown full figure are wearing skirts and leading a group of school children on a nature walk.

The story of Erma Kirk, featured in a 1971 USDA Newsletter, reinforced notions of femininity and what constituted women's work in USFS. The "FS Girl" and staffer in the D.C. office International Forestry Division is pictured (below) snuggling up to Smokey the Bear, with a brief article discussing her USO activities as chair of the planning committee for the organization's Junior Conference in Boston. 


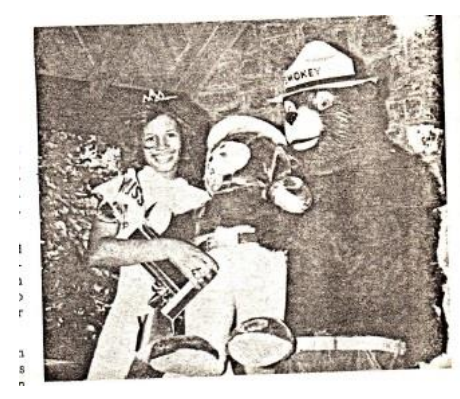

Figure 6: Erma Kirk, Miss Forest Service

The article noted that Kirk joined the Forest Service in 1968, but rather than comment on her abilities, it declares: "Erma is as pretty as she is gracious. The volunteer hostess recently charmed FS judges to win the title of Miss Forest Service 1971 and congratulations from Smokey Bear." 403

\section{Recruiting Women for USFS}

The following year, the agency's own visual imagery for recruitment began to reflect a rapidly changing reality. "Are you a woman looking for a career in conservation of our natural resources?" asked a 1972 USFS recruitment brochure. "CONSIDER THE FOREST SERVICE!" it exclaimed, highlighting a tall woman in a pants suit and long hair standing confidently on the inside cover (Figure 7 below).

403 "FS Girl Helps USO," “USDA Faces the Women's Issue," USDA Employee Newsletter, 30 , no. 19 (September 22, 1971): 4. FHS collection F18.4, File: Women-Women in Agriculture/Conservation." 

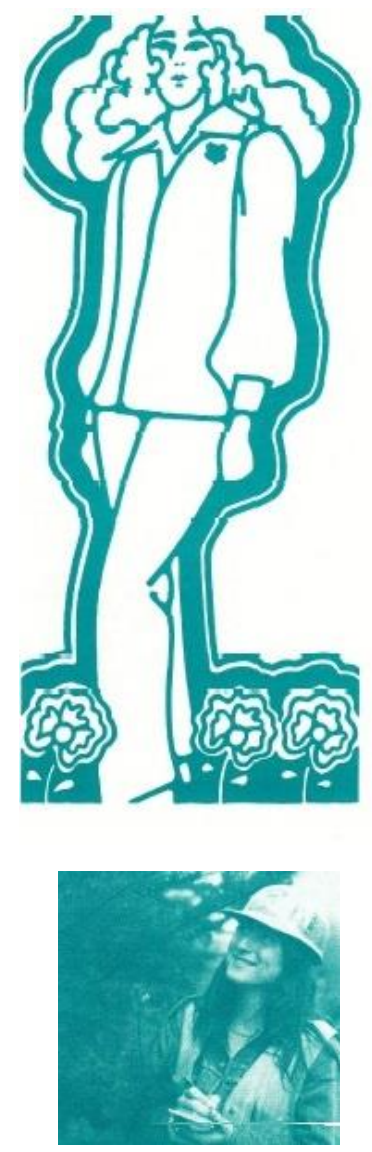

Barbara Fennessey

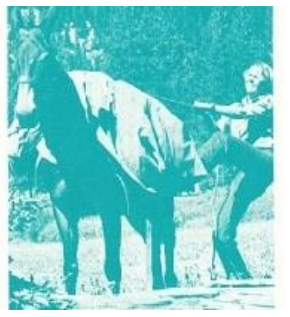

Cindy McReynolds

Figure 7: 1972 Recruitment Images
The next pages document the history and work of the Forest Service, with an image of the youthful, dark-haired Barbara Fennessey wearing a hard hat and standing next to a Douglas Fir. Like most women attracted to forestry before the 1970 s, Fennessey planned to enter forestry research, but summer employment with the Forest Service led her to "timber management because she likes to work in the field." Fennessey graduated from Washington State University, and then became a professional forester on the Siuslaw National Forest. ${ }^{404}$ Another Northwester, Cindy McReynolds of Reed College in Portland is identified as the first female packer hired by the Forest Service. (left) The brochure depicts still other women at drafting tables, in chemistry laboratories and engaged in public educational activities. Two other images, those that include African American women, indicate potential for clerical work and in Business Administration. 
The brochure ends with a section on the path to and benefits of a Forest Service career. The Civil Service provided the first step on the path. Executive agencies filled permanent positions via a list of "eligibles," established by competitive examination, arranged by score, and provided by the Civil Service Commission (CSC). Any number of agencies might contact an individual to offer a good government job. Benefits included tangible outcomes like sick and annual leave, low-cost health and life insurance, a good retirement plan, job security and regular salary increases based on performance and longevity. In addition, by the early 1970s, the Forest Service offered training opportunities so that employees could "develop their talents to the maximum extent," with "equal consideration for promotion and placement." In fact, many women had begun their careers "as clerk-typists or secretaries and through Agency training or self-development have progressed to more responsible, specialized positions."

In most ways, the advancement promises of the "Women in the Forest Service" brochure portended an era to come rather than reality, for occupational inequalities persisted well into the twentieth century. In 1966, fewer than four percent of all women then employed by the agency ranked above GS-7 and only fourteen women worked in the professional series, most in the research branch of the agency. ${ }^{406}$ Getting women to work for the Forest Service proved less difficult than placing them into positions that

\footnotetext{
405 Ibid, 11.

406 Clare Hendee, Deputy Chief, Memorandum to Regional Foresters, Directors, and Area Directors, re: Internal Audit (Audit of Civil Rights Activities), March 9, 1967, with attachment - "Audit Report, Audit of Civil Rights Activities in the Forest Service, U.S. Department of Agriculture, Washington, D.C., July 1, 1964 to June 30, 1966. FHS Collection F5, File, "Civil Rights-Reporting/Manual Changes."
} 
provided lucrative pay, much less any degree of power. From 1968 to 1970, women filled a fourth of the full-time general schedule positions in the Department, primarily in clerical and office occupations at GS-5 or below. ${ }^{407}$ The number of women at grades GS-7 and above had increased slightly, but the disparity between average grade levels of men and women in 1970 is telling: 5.2 versus $9.11 .^{408}$ It would take a series of increasingly stringent mandates aimed at increasing the presence and status of women to effect a significant degree of change.

Female Foresters: The Early Years

"Some of the women trained in forestry have married foresters. The forester's wife could at times be more helpful if she had a knowledge of forestry. However, the profession of forestry is not recommended for women: it is a man's work. ${ }^{409}$ - E.C. Demmon, "Opportunities in a Forestry Career," 1967

"It was generally felt that a girl could not possibly work in the woods," said Margaret Stoughton, a 1930 forestry graduate from Iowa ${ }^{410}$ Like other women who entered the profession prior to the 1970s, Stoughton's professor encouraged her to take courses in statistical analysis so that she could work in Research. Her statistical preparation and high scores on the Civil Service Exam resulted in an offer from the Forest Service: "for work which will be practically confined to the office and will consist of computation of data obtained from field studies by other members of the staff

\footnotetext{
407 FHS Collection F18.4, File, “USDA Women's Issue Newsletter, 1971.” 69.2 percent of women in the Department worked in general clerical and office occupations in 1971.

$408 \quad$ Ibid.

409 Cynthia Miner, “Opened Doors: Women Foresters and the U.S. Forest Service," Forest Service Bulletin, 6, no. 3, (1984): 4-5. FHS collection F18.4, File, "Women in the FS-General Articles."

410 "Ms. You've Come a Long Way," in Southwestern Region Administrative Bulletin (May 1979): 1. FHS collection F18.4, File, "Women in the FS Biographical Info."
} 
and perhaps... in laboratory work.' The salary was $\$ 2,000.00$ a year." When she told her professor, he said, "Don't waste time writing! Wire your acceptance!" Stoughton then became the first woman hired as a junior forester in the USDA Forest Service. ${ }^{411}$ She also joined the Society of American Foresters in 1931, but left in 1937 to marry the forester, Charles Abell. When later asked to provide advice to women, Stoughton Abell encouraged them to pursue forestry, pointing out that increased public interest called for an informed public. She also suggested special training in "an area that interests you, like planting, public relations, etc.” As she had witnessed and experienced, women trained in forestry could make a mark in the Forest Service, if not always in the woods.

A small number of women followed Depression-era female forestry graduates like Stoughton into the Forest Service, women like Joanne McElfresh, Geraldine Larson, and Anne Heisler, among others. McElfresh graduated from the University of Montana School of Forestry in 1956, and joined the agency to work as a timber management and plans inventory specialist. Possibly the second woman to qualify as a forester by the Civil Service Commission, McElfresh spent nearly thirty years working for the agency. ${ }^{412}$ Larson, who joined the Forest Service in 1967 would break barriers in the 1980s. Anne Heisler, the first female junior forester on the Mt. Hood National Forest in Oregon, attended Washington State College during the same period as Larson. In 2005, she described the atmosphere at forestry school. Women could not wear jeans on

\footnotetext{
411 At the Appalachian Forest Experiment Station in Asheville, North Carolina.

412 FHS Collection F18.4, File, "Women in the FS-News Items." In a 1976, USDA Newsletter, McElfresh is identified as "the first woman classified by the Civil Service Commission as, and hired by the Forest Service as, a professional forester." It is possible that others qualified between 1930 and 1957. "Person to Person: Joanne McElfresh," USDA Newsletter, 35, no. 4 (February 18, 1976).
} 
campus, except on Saturday until noon. They wore heels and gloves into town. They had curfews; "That's just how it was then."

This was 1959 and women didn't do a lot of things ... While they were in high school if someone talked to you about a career it was, women could be teachers or they could be nurses. But mostly they could get married and stay home and raise children. So women working in a field like forestry, engineering or any related field didn't happen."

But Heisler had a different plan. As a Girl Scout, she spent summers working at camp and had backpacked in the Olympic Mountains. Heisler knew she wanted to major in forestry. She simply thought she "would like it. That's why most people go into what they end up doing," she said. Heisler, who worked as a forest lookout on the Rogue River National Forest during the summer of 1962, obtained a traditional forestry education:

In the sixties it was a very interesting time because things were changing rapidly in forestry. After World War Two there was a big push to get a lot of timber cut for housing for the returning G.I.'s. So there was a big housing push and that was the focus of forestry while I was going to forestry school. ... this was preNational Environmental Policy Act. That didn't happen until 1969. Way before Earth Day and the environmental movement, so it was pretty much what a lot of people refer to as "dirt forestry." Kind of get out the cut kind of stuff, so I learned a lot about measurement, cruising, log scaling, developing nursery plans and management plans for tracts of timber. That's what we were learning in forest management.

Despite having a degree in forestry management in 1963, finding a job was hard. Anne received three offers before graduation, but each time: "they came back and said, 'Well something has happened, we're not going to have that job.' The joke was that I had been fired from three jobs before I'd been hired. And most of the guys who had worked there 
during the summer time ended up getting those jobs." Instead of a field position, the regional Forest Service recruiter:

...came out to the college campus and he pretty much sat there with his fingers tented in front of him going, "Hmm," at me. And finally he said after these jobs fell through, he suggested that I apply for a clerk typist position, which irritated me to no end. So I went back to working with the Girl Scouts that summer in Hood Canal in Washington State.

At summer's end, Heisler again contacted the Forest Service. She wrote letters to the places she wanted to work. "And the Mount Hood Forest was the only one that wrote back.” Deputy Forest Supervisor Dick Worthington, later regional forester, hired her. Although "not a forward thinking person," in many respects, Heisler's letter "intrigued" him. He put her to work as a junior forester on the Columbia Gorge District, where she spent the next year and a half in the field before promoting up into an Information and Education (now Public Affairs) position. There, she put her Girl Scout outdoor school training into action and spearheaded curriculum development for a residential outdoor school program that started in 1964.

\section{Re-gendering the Forest Service by Law and Policy}

It is the policy of the Government of the United States to provide equal opportunity in Federal employment for all qualified persons, to prohibit discrimination in employment because of race, color, religion, sex or national origin, [emphasis added] and to promote the full realization of equal employment opportunity through a positive, continuing program in each executive department and agency. The policy of equal opportunity applies to every aspect of Federal employment policy and practice. ${ }^{413}$ - EO 11375, 1967

$413 \quad$ Executive Order 11375. 


\section{Gender Disparities and Affirmative Action}

It took the force of law to bring large numbers of women into the U.S. Forest Service. In the 1950s and early 1960s, the disadvantages faced by women originated in a process that allowed agencies to request "men only" or "women only" applicants from the CSC, thus maintaining economically gendered hierarchies. In fact, a 1960 study showed that agencies specified male applicants for only a third of all jobs, but 94 percent of agencies requested men for GS-13 to GS-15 policy positions. When President Kennedy appointed Eleanor Roosevelt to head the first Commission on the Status of Women, these disparities surfaced publicly. At the Commission's request, the CSC demanded substantiation for sex specification, which halted or hindered the practice of recruiting by sex in most agencies starting in $1962 .{ }^{414}$ With the Equal Pay Act in place by 1963, women's economic and social advancement inched forward.

Externally imposed gender diversification in the federal government stood still until Lyndon B. Johnson signed a new executive order in 1967. Although EO 11246 had banned discrimination in federal employment and contracting, unlike the Civil Rights Act, it did not include sex. EO 11375 rectified that omission. It called for "affirmative action," created the Federal Women's Program (FWP), and put the CSC in charge of hearing sex-based discrimination complaints. These included issues of promotion or demotion, transfer, recruitment, and advertising, layoff or termination, and rates of pay as well as training and sex segregation by occupation. The CSC outlined general agency

\footnotetext{
414 Andrea Warner, "In the Beginning, there was the Forest Service's Federal Women's Program," Women in Natural Resources 15, no. 1 (September 1993): 10.
} 
obligations and delegated responsibility for developing, administering, and evaluating overall effectiveness of EEO programs, including the FWP. ${ }^{415}$ The Federal Women's Program, which spanned the entire federal government, sought to increase "the employment and advancement of women in every facet and level of the federal government..." Indeed, the Nixon Administration charged the FWP with developing an overall affirmative program of equal opportunity in 1969, as part of yet another executive order, EO $11478 .{ }^{416}$ Still, in 1970 most women in federal service remained in low-paid, pink collar jobs, with over half at GS-6 or below, demonstrating a clear need for the FWP. ${ }^{417}$

The plight of women's status in government came to President Richard Nixon's attention early in his administration, as journalist Vera Glaser queried him about the dearth of women in his cabinet, only three of two hundred high-level appointments. Nixon, a long-term proponent of the equal rights amendment, responded that he had not been aware of the situation and noted, "I shall see that we correct that imbalance very promptly." Shortly thereafter, a newly created Presidential Task Force on Women's Rights and Responsibilities identified the inequitable status of women in government and the administration set out to improve the standing of women in federal service. ${ }^{418}$

415 Markoff, “Federal Women's Program," 145.

416 "Executive Order 11478-Equal Opportunity in the Federal Government," National Archives Website, Federal Register," http://www.archives.gov/federal-register/codification/executiveorder/11478.html [accessed November 5, 2014]; Markoff, "Federal Women's Program, 144. $417 \quad$ Ibid, 146.

418 The Nixon Presidential Library and Museum hosts an exhibit, with an online component, titled “A Few Good Women: Advancing the Cause of Women in Government, 1969-1973." The exhibit highlights the origins of the Nixon Administration's commitment to the advancement of women in government. Interview clips from 2007 include Frederic V. Malek, White House personnel chief from 
On April 21, 1971, the president sent a memo to federal leaders pointing out that "THE NATION'S MANY highly qualified women represent an important reservoir of ability and talent that we must draw on to a greater degree... . We must now clearly demonstrate our recognition of the equality of women by making greater use of their skills in high level positions." The memo directed departments and agencies to develop and implement action plans to attract more qualified women to top positions (GS-16 and up to presidential appointees) by the end of the calendar year; to put plans into action for increasing the number of women in mid-level positions (GS-13-15), career and appointive; to place women on advisory boards and committees with vacancies; and to designate an overall coordinator for the project. The same June memo called for administrators to fill 25 percent of USDA advisory board vacancies with women. At the agency level, it called for a systematic plan to locate highly qualified women and to seek placement opportunities for more important positions. The goal? To have two additional women in GS-16 or above positions by the end of the calendar year and 50 additional women in grades 13 to 15 . Despite these mandates, Secretary of Agriculture Hardin appointed a man to coordinate the efforts. ${ }^{419}$

In response, the FWP set out to move women into technical and professional positions throughout the federal government. It sought to eliminate dead-end jobs, created "bridging" programs between clerical and professional occupations, and

1970 to 1973. Barbara Hackman Franklin, White House staff assistant, 1971 to 1973, and Bobbie Kilberg, White House fellow from 1969 to 1970. An overview of the incident with Vera Glaser and interview clips are available at http://www.nixonlibrary.gov/themuseum/exhibits/2012/specialexhibits_AFGW.php [accessed June 23, 2015].

419 E. Fritz Behrens, Executive Assistant to the Secretary and Department liaison to the White House and Congress. 
emphasized training opportunities to increase the status of the more than half million female government employees. FWP managers reached out to women's colleges and universities, community and educational organizations, and began to address issues faced by women in the workplace, such as childcare and the need for flexibility. And although it noted that most women worked by necessity, the FWP also proposed that women had the "right to choose what to do with their lives." For those who believed married women should not work outside the home, suggested Helene Markoff:

...it is imperative they not apply their personal beliefs to 51 per cent [sic] of the population. Such an extension of personal beliefs turns that belief into prejudice. It is prejudice when you judge all women by some women. It is unjust to those who seek employment and advancement; it is contrary to public policy; and it is illegal. $^{420}$

In fact by 1972, with passage of the Equal Employment Opportunity Act, Title VII of the Civil Rights Act applied to federal employees for the first time. The law expanded oversight in the private sector to organizations with 15 rather than 25 employees and tightened sex discrimination regulations by giving the Equal Employment Opportunity Commission authority to sue in federal court. ${ }^{421}$ In 1978 , the Pregnancy Discrimination Act further amended Title VII, making it illegal to discriminate against a woman due to pregnancy, childbirth, or medical conditions related to pregnancy. Employers could no longer impose mandatory leaves of absence on women or give them less favorable health insurance or disability benefits because of pregnancy. The same legislation

\footnotetext{
$420 \quad$ Markoff, "Federal Women's Program," 145.

$421 \quad$ "Brief Summary of the Legal Mandate for Equal Employment Opportunity and Affirmative Action Regarding Employment Discrimination," no date, 1. FHS Collection F18.4, File, "Women in Natural Resources Conference (1985).”
} 
outlawed employer retaliation against individuals who file discrimination complaints or join class action suits. ${ }^{422}$

By the end of the decade, the legal shift caused by the 1972 law rippled throughout the Forest Service via a lawsuit that impacted USFS policy nationwide, especially in the timbered West. On June 29 1972, Gene Bernardi, a sociologist in Region 5 filed suit in federal court under Title VII, asserting that she had been passed up for promotion because of her sex. Further, because Bernardi alleged that the Forest Service commonly discriminated by sex, she brought a class action suit that applied to all women employed in Region 5 as of November 2, 1972. The case did not go to trial, but after a long period of discovery both parties agreed to a "consent decree" in 1979. It took until 1981 for the court to issue the decree that required the Forest Service to start documenting female underrepresentation in Region 5 and the Pacific Southwest Research Station. Among other actions, the court also ordered the region to formulate and enact an affirmative action plan to remedy that underrepresentation. Most importantly, the court ordered the agency to increase female employment so that the sexual composition of the permanent workforce equaled that of the civilian workforce by job series and grade level within five years. Although not applicable beyond Region 5, the consent decree impacted the entire agency. Tentacles of the decree filtered quickly and deeply into California's

\footnotetext{
$422 \quad$ "Milestones: 1972," Equal Employment Opportunity Website, http://www.eeoc.gov/eeoc/history/35th/milestones/1972.html [accessed November 14, 2013]; USDA Forest Service, WO/Civil Rights Staff, "Reference Guide: Key EEO and Civil Rights Laws, Statutes, and Regulations," (April 2010): 3-4.
} 
northern neighbor, Region 6, where Northwest leadership and female employees sought to increase the number and status of women before so mandated.

From Desk to Field

You leave this organization with a splendid record not only of long and faithful service, but also of pioneer work in forestry education. It is doubtful if anyone did more than you in the early days to interest women in the Nation's forest problems. You were the first member of the Forest Service to specialize in the preparation of material for teachers. - Chief Ferdinand A. Silcox, parting message to Daisy Priscilla Edgerton upon retirement, $1938^{423}$

From the beginning, women helped to shape Forest Service culture and land management practices, typically working as clerics and in agency administration. ${ }^{424}$ Some worked directly in Research, ${ }^{425}$ but most women with forestry training applied scientific knowledge to public education. Frances Flick, for example, worked in the USDA Library, where she helped many a man conduct forestry research. ${ }^{426}$ Edith Mosher joined the Forestry Division in 1902. By 1909, she published two books on fire studies, followed in 1910 by the agency's first public educational materials for students. The publication, "Forest Study in the Primary Grades" established environmental

423 USDA Forest Service, “Mrs. Edgerton Retires," Service Bulletin, Washington, D.C., 22, no. 26 (December 26, 1938). FHS Collection F18.4.

${ }_{424}$ For example, Edna Crocker worked for the Bureau of Forestry in the late 1880s and remained with the agency until 1944, secretary to such luminaries as Henry Graves and Gifford Pinchot. Bertha Adams began as a stenographer for the General Land Office in 1890 and retired from the Forest Service 39 years later. When presidents created forest reserves, Adams typed the proclamations, helping to shape how the national forests operated.

425 The pioneering scientist Dr. Eloise Gerry spent 44 years at the Forest Service Products Laboratory in Madison, Wisconsin, retiring in $1955 .{ }^{425}$ C.E. Randall, "Women in Forestry" typescript (August 29, 1956). FHS Collection F18.4, File: Women in the FS-Biographical Info.

$426 \quad$ C.E. Randall, 1956, FHS Collection F18.4. 
education in the Forest Service. ${ }^{427}$ Daisy Priscilla Edgerton produced a "best seller" bulletin for the public in 1930. Twenty thousand copies of "The Forest, a Handbook for Teachers" and "Famous Trees" lasted only a few months and included research that made Edgerton "an authority in this field." Over the decades women of varying backgrounds and skillsets worked in I\&E (later Public Affairs), taking dictation, compiling public materials, transcribing and even writing speeches for line leaders.

Whereas the agency devised training programs to hire professional men of color, in the early 1970s, white women began to join the agency as "field-going females." Many worked in temporary jobs, some in positions occupied intermittently by women since the early years, at firewatch, at nurseries and on clean-up brush crews. Such positions suited women, the agency, and their families well, claimed USDA Some women, like Hallie Daggett and Molly Ingoldsby had permanent field positions as lookouts in the early years, but most worked seasonally, if at all. Mid-century wartime had provided the bulk of seasonal woods work for women. For example, an all-female fire crew formed on the Angeles National Forest in 1941. The same group of women attended guard school the following year. ${ }^{428}$ Another group of women fought fire on the Deschutes National Forest in $1945,{ }^{429}$ and still others worked in the woods during the 1940s. As Pauline McGinty, who became a forestry technician 1967, said:

427 Unknown, "Edith R. Mosher: Founder of Environmental Education in the Forest Service.” File: Women in the FS-Biographical Info. FHS Collection F18.4.

428 "Edward A. Grant, Retiree, to Miss Bonnie Kreitler, Editor, USDA Information, re: 1971 USDA Newsletter," 30 September 1971.

$429 \quad$ Image from Rachel Kline, Historian, Forest Service Heritage Stewardship Group, received September 10, 2014. 
I could remember World War II- the men were gone and women did all of the jobs in the woods. They drove the logging trucks...they did a lot of scaling, a lot of timber jobs in the woods. But when I came along in the late ' 60 s and they'd see me, the men loggers, out driving by in their pickup, it would bring traffic to a halt if they saw me out there in work boots and jeans. It was just - they couldn't believe it and yet their mothers had worked in the woods and their older sisters. So, that was always kind of interesting to me that people forget that women have always been in jobs like that. When they needed to they stepped up and did it without even thinking about it. ${ }^{430}$

By the 1970s, women did more than step up. They began to slowly infiltrate previously all-male occupations. Like American Indians and Hispanics, at first fieldgoing women often worked in segregated crews. In 1971, the Lolo National Forest in Montana announced the "first" all-female fire-fighting crew, a group of 20 Montana and Idaho "co-eds" who trained on a practice fire that summer. "They're official now," announced the "Women's Issue" of a USDA newsletter in which the Department used language reflective of women's assumed juvenile status, "The Lolo had "an all-girl mistletoe crew," while for two years a female brush crew had been planting trees, burning slash, and collecting pines for the tree nursery on the neighboring Coeur d'Alene National Forest in Idaho. On the Tahoe National Forest, an "all-girl fire dispatching team" operated, while the Superior National Forest hired the first "two-girl wilderness patrol" in the agency. The Mt. Hood National Forest in Oregon, employed an "all-girl engineering surveying crew" On the nearby Siuslaw, Barbara Fennessey did "regular field chores - thinning with chain saw, slash burning, stream surveys, plantations examinations," work she had performed on the Wallowa-Whitman National 
Forest the year before, along with firefighting on other national forests. ${ }^{431}$ USDA quickly identified women as dependable workers for intermittent field work. They served the agency well: “the Forest Service needed employees who didn't mind staying 'on call' to work when needed or being laid off when weather changed." According to USDA, "The local ladies found this arrangement very satisfactory." 432

While some women appreciated on call or intermittent jobs, others needed fulltime work, whether to supplement family income or as sole providers. McGinty, for example, married right out of high school in 1954, but returned to her hometown in Glide, Oregon in 1961, divorced and with three small children in tow:

I was living with my parents in the house I grew up in and the job opportunities were very slim. I had to take a typing test, there was a civil service test that you had to take. I had to take it about three times [laughs] before I passed it. I really was not a typist. I did really well on everything but the typing. So, anyway, I went down and I got the job. ... the men in the office decided that they wanted someone that would be there - especially for anything that had to do with the timber part of the Forest Service ... they made the job busy enough so that I was working pretty much full time. GS-2, typing.

A conjunction of economic need, interest, and timing led McGinty to become the first woman in the region to work as a forestry field technician in 1967 . The need was economic. Within a few months of starting her job as a clerk-typist, McGinty told the ranger that she wanted to move up to a GS-3 position. She had to make more than 75 cents per hour. Her interest came from a childhood spent in the woods or on the river, and a desire to do more than type, something the "timber beasts" encouraged. They

\footnotetext{
431 "Women's Lib in the FS," Information Digest, Washington Office with $3^{\text {rd }}$ and $4^{\text {th }}$ Quarter Alumni Notes (1972): 12-13. FHS Collection F18.4, File, "Women in the FS-News Items."

4321971 USDA Women's Issue Newsletter.
} 
taught her to draw sale area maps and when the men were out of the office, she scaled

timber and measured cordwood. "In those days," said McGinty:

...women were not allowed to wear anything but dresses. If we had come to work in pants we'd have been sent home. So, I would go out with the scale sheets and I learned enough, they taught me enough to recognize some of the bigger defects in logs... they'd do the measuring - they usually knew what the size of those logs were-and they would point out any defect and I would be able to recognize some of the defects.

Occasionally, women from the office helped to burn slash and McGinty "just loved it."

But, when she asked to go to fire school, "What a laugh that admission drew!"433 The

Forest Service hosted an annual fire school to train all employees:

So I asked them if I could go to fire school. "Yeah, sure you can go as a second cook. But there's really no need for you to go because, you know, women don't fight fires."

So I went as a second cook and every break I got I had my nose poked in one of the classrooms learning how to do things. It was thirteen years before I was finally allowed to go to fire school. And I learned a lot then. I learned a lot that I hadn't picked up over the years. ${ }^{434}$

McGinty's timing peppered with assertiveness, led her to move through various field positions and retire at a GS-11 level: "I always worked outside my job description every chance I got because it opened up opportunities," she said. "And I firmly believe that's how I got as high as I was on a high school diploma.”

Women Foresters and the Timber Beasts: "Rangerettes" and "Nature Fakers"

When women foresters started appearing, they were to be treated like any other what they called "junior foresters." They were to be working in every area on the district and also go to every training session that came up. There were a lot

433 Pauline McGinty, "Recollections," (1992). FHS Collection F18.4.

$434 \quad$ McGinty by Blaha, 2005. 
of in-house trainings for different departments and they were to get to go to all of it. But some were given that right and some were being told, "You're just here for a short time anyway, don't plan on sticking around. - Pauline McGinty, 2005

By the early 1970s, the Forest Service employed a handful of female foresters in various locales. ${ }^{435}$ Meanwhile, more women entered the woods as forestry technicians and aides. The number of women foresters reported for the mid-1970s varies by source, but as late as 1976, women staffed 84 percent of all clerical jobs in the agency and 15 percent of administrative and technical jobs. ${ }^{436}$ A 1976 New York Times article that featured women rangers concluded that women fared better in the National Park Service (NPS) than the USDA Forest Service. NPS hired proportionally more women rangers than the Forest Service; however, all government agencies bore the brunt of competing with veterans. ${ }^{437}$ Although it is not clear who the Times classified as "ranger," professional disparities are clear. Women in both agencies contended with "male chauvinists" who referred to them as "rangerettes" and "nature fakers," attitudes that could make woods work both difficult and lonely. ${ }^{438}$

Cynthia Miner provides insight into why female foresters may have chosen nonfield professions or moved from the outdoors into the office. Miner, who worked with

\footnotetext{
435 A 1972 Region 3 newsletter notes that Rebecca Cooper worked as a forester and "There are four others working for the U.S. Department of Agriculture throughout the country. "R-3 Has Woman Forester," Southwestern Region Administrative Bulletin (September 1972). FHS Collection F18.4. $436 \quad J a m e s$ G. Lewis, Forest Service centennial history, 175. The numbers vary according to source, but according to Cynthia Miner, of 4,785 professional foresters, only 15 were women in 1976. By 1984 there were 501 female foresters out of 5,751 foresters in the agency.

$437 \quad$ Fourteen women and forty-one men. Note that there is a distinct difference in a seasonal NPS ranger versus a Forest Service "ranger."

4381976 - Notes sent to Stan Johnson, miscellaneous doc from NY Times, March 15, 1976, "Women Park Rangers Peril: Male Chauvinists Lurk Everywhere.” FHS Collection F18.4.
} 
the Forest Service on Washington State's Colville National Forest as a student forestry aide in 1975, later recalled an experience when, at the end of a satisfying day of marking trees the crew stopped: "five of the six men pulled out round tins of snuff, took their chews and began talking to one another about the upcoming deer hunting season." Miner, who knew very little of rifles and deer "felt apart from the huddle of men" and stared at the tracks they'd made, "one set--mine--much smaller than the others." At the time, she wrote, her co-workers and supervisors were "all men. No professional women worked as foresters on the district." Miner returned to school, then worked two summers, with the promise of permanent employment through the Cooperative Education Program. "As are most foresters, I was trained by men," she wrote, many of whom accepted her "with apprehension. A few sexually harassed me. Hostility existed, as it does today [1984], from men who felt women have unfair career advantages over them because of affirmative action." 439

Women often heard, "the only reason you got the job was because you're a woman." ${ }^{440}$ In fact, a 1977 study done by the American Forestry Association found that only 57 percent of forestry graduates found jobs. Those with advanced degrees and work experience were most competitive. A woman with outstanding records, summer job experience and in "good physical condition" had "the advantage over her male classmates," unless that classmate was a vet. "But almost everyone agrees that this advantage will eventually disappear as more women enter the profession," reported

439 Miner, "Opened Doors," 4.

440 Ibid. 
American Forests. ${ }^{441}$ A less accomplished female forestry graduate had a disadvantage. While field work could make the difference in finding a job, it also presented problems like finding housing for women. According to Linda Karns, "living at remote logging camps in government barracks is 'an exercise in tolerance and understanding' for everyone. A shortage of bunk space usually means the woman will have to sleep in a storage room or on a living room couch." 442 Consequently, many districts hired female foresters reluctantly.

In the 1970 s, women began to work as "data analysts in forest survey and hydrology, road and bridge technicians and designers, laboratory researchers on forest insects and disease, conservation education specialists, and many more specialists."443 Activities of the "ologists" varied. For example, Jessie Gonzales monitored the habitat needs of eagles, ospreys spotted owls, and bats on the Umpqua National Forest. Heather Caldwell on the Wenatchee National Forest also monitored owls, but as an "owl-caller" made nocturnal visits to the forest to identify owl habitat for timber harvest planning purposes. In nearby Idaho, Jenny Carson climbed towering Ponderosa Pines to place old sticks on snags to give ospreys a head start on nest building in the spring. Meanwhile, at the Mt. St. Helens National Volcanic Monument, Rhonda Beckman kept close tabs on water quality and rehabilitation in her position as a hydrologic technician. ${ }^{444}$ Despite

\footnotetext{
441 Richard Pardo, "Can a Woman be a Forester?” American Forests (September 1978): 23.

442 Ibid, 24.

$443 \quad$ Miscellaneous document, FHS Collection F18.4.

444 USFS, "Women in Non-Traditional Forest Service Roles," Ideas (April 1985): 2. File:

Women in the FS-News Items, Coll. F18.4, FHS.
} 
doing important natural resource work, however, the female "ologists" remained outside the main sphere of decision-making - that of the agency's foresters.

By 1978, women entered forestry school as "readily as men and in the short term, their employment prospects seemed better than their male classmates." ${ }^{445}$ But, claimed American Forests, no true equality existed. A woman faced "degrees of curiosity, prejudice, resistance, and skepticism from the public and her male coworkers." ${ }^{446}$ Even supporters held stereotypes, like women "do possess some special skills that men lack," such as organizational ability and a detail orientation. These attitudes led even trained female foresters into administrative positions and desk jobs. ${ }^{447}$ The article also points out that yes, a woman has to be in good physical condition to be a forester - but so does a man. Still, the combination of affirmative action mandates and increasing numbers of women at forestry schools made the late 1970s and early 1980s a potentially promising time for intrepid female forestry pioneers.

\section{The Federal Women's Program in Region 6}

Unsung Heroes - the FWPM's

It needs to be remembered that every Forest had a collateral duties FWPM (Federal Women's Program Manager) and these women (and a few other women on every Forest/most Districts) were the backbone of the FWP. They were the unsung heroes of the program - who dealt with the innuendoes, the sexist language, the sexist posters, the sometimes improper conduct of some employees towards women; the overlooking of women for special assignments; managers' exclusion of women in meetings, task forces; the local recruitment that often focused on male

\footnotetext{
$445 \quad$ Pardo, 22.

446 Ibid.

447 Ibid, 24.
} 
buddies; they provided support for newly hired women in natural resource positions; and many, many other actions/efforts. Without these women, the Region could not have progressed as it did - Mary Albertson, $2015^{448}$

Although EO 11375 initiated the Federal Women's Program in 1967, it took Nixon's 1971 mandate to increase the status of women, followed by the 1972 Equal Employment Opportunity Act to push the Forest Service into building up the agency's Federal Women's Program (FWP). Mary Albertson, an immigrant from the Azores Islands with a Bachelor of Social Sciences and a secondary teaching credential, joined the agency as a clerk on Oregon's Willamette National Forest in 1972. A year later, she moved to the Portland Regional Office as a civil rights specialist under Jetie Wilds and became the first permanent full-time FWPM in the agency. ${ }^{449}$ Albertson recalled learning that she got the job because of her response to a question asked of all the candidates:

"If managers just don't want to do the job, how are you going to convince them that they should hire women?"

And I responded, I said, "Well, it's the law! And they work for the federal agency." Something like that. "All managers have to abide by the law because they're federal employees."

They said that was different from everyone else who said, "Well, I'll tell them this and that, and I'll try to convince them."

And I just said, "Well, it's the law." So they said that's why I got hired.

Albertson started her job in November and the following month, December 1973, attended a women's seminar in Portland. There, she encountered nearly 200 women from the region, ideal timing for her new position, because she "got a lot of feedback

\footnotetext{
448 Email from Mary Albertson to Donna Sinclair, January 11, 2015.

449 Mary Albertson, "Progress of Women in the Forest Service," Women in Natural Resources, 15,
} no. 4 (September 1993: 5; Mary Albertson, Interview by author, 10 November 2014, Portland, Oregon. 
about everything." She then "wrote a letter to the regional forester talking about all the problems that the women saw."

First, suggested Albertson, each national forest should host a collateral duty FWPM. Program activities and the amount of work time allotted for FWP activities varied, from five percent on most districts to 15 or 20 percent in a supervisor's office. The impact and presence of the FWP also varied widely. As Elaine Enarson and others point out, the program became a "vehicle for defining and communicating problems" women faced, for facilitating data collection, and a way to focus management on women's issues. It also brought women together. In the early stages of FWP implementation, awareness sessions equipped women with "tools to succeed," like knowledge of upward mobility resources. Later, the program emphasized goal setting and accountability processes to ensure the integration of women into all levels and occupations in the organization. ${ }^{450}$ Perhaps most importantly, the FWP provided a means for women to support one another. They published a monthly newsletter, held regular meetings, and hosted career-planning sessions and lunch-time talks to help women plan for the future. ${ }^{451}$

As Enarson noted in 1978, the program took shape based on "the personalities of those actively involved and by the local problems and management." ${ }^{, 452}$ Albertson recalled a threefold focus in the beginning: dispelling myths about women, empowering

\footnotetext{
$450 \quad$ Albertson, "Progress," 4.

$451 \quad$ Elaine Pitt Enarson, Woods Working Women: Sexual Integration in the U.S. Forest Service (Tuscaloosa, AL: University of Alabama Press, 1984): 130-131.

452 Ibid, 15.
} 
them to advance, and providing concrete advancement opportunities. The FWP printed information about working women, and tried to get people "used to them" via the FWP and regional newsletters. They incorporated women's issues into sensitivity trainings hosted by the Civil Rights Department. They encouraged "women, to get them to the point where they felt comfortable reaching out, where they felt comfortable saying, 'I'm not going to make coffee' and those things." FWP managers wanted women "to understand that they are capable of doing things, and to seek out the opportunities." And they emphasized organizational understanding. Women typically thought, "Oh if I just work hard, people will know this and promote me. Well, that's not how the real world works," said Albertson.

On a practical level, an FWP manager might find housing for women arriving on the district, lobby for work gloves in women's sizes, or set up a series of speakers or meetings. Pauline McGinty volunteered as one of the early collateral duty FWPM's and epitomized many women in the region during that period, the "unsung heroes" 453 of the FWP. In the early days, McGinty worked as a resource clerk, "which meant that I did all the timber parts, but I did that at the same time as I was a receptionist." She plotted timber sales from inside the office but really wanted "to be out there, you know, cruising the timber like they were and dragging a chain through the woods with a compass," work that required becoming a technician or forestry aid. When the opportunity arose, McGinty took the Civil Service exam to qualify as a forestry technician. She learned

453 Email from Mary Albertson to Donna Sinclair, January 11, 2015. 
quickly that advancement required her to ask for what she wanted, something women often found difficult. "That's one of the things—-when I got into the Federal Women's Program that I'd counsel women on is about tooting their own horn, letting people know what their capabilities were and showing them," she said.

Education and dialogue for staff, forest supervisors, district rangers and women grounded FWP activities. Women needed to know their rights under the law and those in power had to understand mandated obligations to create a discrimination-free workplace. To that end, McGinty recalled efforts to hold annual general meetings; however, staff found them hard to schedule. When planning a large conference, McGinty's supervisor told her, "Well you're going to have to have two days because only half the women can go at a time because someone has to answer the telephones and do the typing." The next year, a new forest supervisor said, "No, you're going to have it in one day. All the women can go. The men can either wait with their typing or type it themselves and I want them signed up for the switchboard to get training." This was a "real eye-opener for the men," claimed McGinty. They learned to do "women's work" and began to recognize the stereotyping of certain positions. McGinty learned too:

I had it in my head that all women should get to work in the woods and that was my thrust, get all the women out in the woods. Well, that was kind of silly and finally one of the women that worked in contracting said, "Pauline, I don't want to work in the woods, but I do want some career potential or career opportunities that I'm not getting now because the men are." And that was a wake-up call for me and I kind of put my focus in other areas. But that was the main thing women wanted, to be listened to, to be treated like equals and to have job opportunities that weren't open to them. 
McGinty also recalled FWP discussions about topics beyond legality. "The biggest thing that would irritate women," she said, "was-if two women were standing and talking the men assumed they were gossiping...They would walk by, two women talking, usually about business and say, 'Get back to work and quit gossiping.' That would infuriate women... So that's one of things we talked about."

Although the FWP stimulated discussion and helped to dispel stereotypes, some viewed it as irrelevant and others shied away from the program's "feminist reputation attached to activists. ${ }^{454}$ Some resented it outright, concerned that women were taking men's jobs. At the same time, women fought for consideration in jobs directed to "menonly," despite the law:

And it didn't take anything away from the men. Even though they felt that they were losing jobs to the women and minorities they were not. They were still in the majority.... At first, women were put into positions to meet quotas. There were quotas-although we said there weren't, there were. There were records kept about how many women, how many minorities and at what grade levels. That was one of my main jobs was statistics on where women were and what their grade level was and how many we'd hired and how many had lost their jobs or had quit for whatever reasons.

McGinty saw her role as encouraging FWP activity at the district level to facilitate problem solving, despite antipathy from men:

...we'd try to talk to them about it [FWP] and why it was needed and knowledge was a pretty powerful thing ... It seemed like especially the younger men were receptive. They understood the need and it didn't bother them so much. The older men, it was so different, it was just so different. Women were doing jobs like they were doing. Women were entering ... the field and they hadn't ... had to deal with it before. I mean, going to the bathroom — one of my coworkers came to me during a fire and he said, "Pauline, what do I do when I'm on night 
duty and I'm walking a fire line and I have to go to the bathroom, and I don't know where the women are?"

I said, "You turn your back to whoever or whatever you think might be there, because they're not going to stand and stare at you. They're not going to shriek and say 'Oh no!' They're just going to go on and do their work. Don't worry about it. It's no big deal to the women."

What to do about going to the bathroom with women in the woods is a topic that most people_-men and women — remember today with wry laughter. "They didn't know what to do with us," said McGinty. "I used to carry a big red bandana in my hip pocket and when I was out in the woods if my bandana was hanging on a bush, they went the other direction. It was easy like that."

\section{Changing Roles of Men and Women}

I have worked all my life with men, and I have discovered that some of them are very smart, some of them are very stupid, and most of them are mediocre hacks. Women fall in to the same categories. We will have equality when a female schlemiel moves ahead as fast as a male schlemiel. That's equality. - Dr. Estelle Ramey, USDA Vol. 34, No. 13, 612s17s

In 1976, Mary Albertson spearheaded a series of workshops in Region 6 known as "Changing Roles of Men \& Women." ${ }^{455}$ While not the most significant of civil rights efforts, these workshops illustrated issues that plagued the agency at large. Although initially planned as a "Men's Seminar," Albertson decided to change the focus "to women and men - to speak about human liberation instead of men's and women's...

Consequently, the seminar addresses the benefits, of role re-evaluation to both men and

${ }^{455}$ Edith "Edie" Seashore, whose work with the National Training Lab focused on cultural change in organizations also brought Changing Roles workshops to Region 5 sometime in the 1970s, although the timing is unclear. Mary Albertson not only recalled developing this series of workshops in the Pacific Northwest, she also had documentation of the letter she sent throughout the region to implement the workshops in 1976. 
women." In June, Albertson sent guidelines to each of the forests "as a means of examining attitudes about roles," something she felt would "assist the Region towards reaching the objectives of the Federal Women's Program." ${ }^{456}$ The guidelines included justification for the seminar: "Men are not going to give up their special benefits of the present system unless they see other benefits that would accrue them as a result of women being thought of as equal." Albertson made the point that the women's movement was, in fact, positive for men as well as women, not a conspiracy. The workshop would encourage men and women to dispel stereotypes, not just those about the weakness of women, but expectations about male competition, success, and control. One activity asked participants to rank value statements, demonstrating that people make them all the time. Then, the facilitator should discuss some of the many value judgments people make on a daily basis, inverting common attitudes by ranking statements like: "Men's place is at home." "Men are more ambitious than women." "Men are not emotional." "Child-rearing is a woman's job," and so on.

Although Albertson would later say that trying to alter attitudes was not the right approach to achieving equality, some individuals had positive recollections of the "Changing Roles" workshops. For example, Linda Goodman, an employment specialist and FWPM on the Willamette National Forest at the time, recalled this as a period of budding conflict, with:

...women stepping out of the roles that they'd had for so long and men being uncomfortable. We were seeing an up-rise in sexual harassment and decided that

456 Mary Albertson, Memo to Forest Federal Women's Program Coordinators, "Seminar: Changing Roles of Men and Women," June 10, 1976. Albertson's personal documents. 
we needed to put on more training. I put on some sexual harassment training, but Changing Roles for Men and Women was a regionally sponsored course that I helped facilitate.

Goodman recalled hosting a three-day interactive workshop to raise awareness and

alleviate fears in a safe environment, speed up learning about difference and help men to become comfortable with women in the workplace. To achieve these goals, participants gathered into small groups of men and women to:

... kind of drill down a little bit down into what their issues might be. And how men could feel confident and comfortable going out into the field all day, alone with a woman, and not be afraid that either their wives would be concerned or that they would be concerned that they might be charged with a sexual harassment complaint down the road. So how do you work together and avoid those kinds of conflicts? Again, it's so common place now that it seems kind of silly."

Range Conservationist Linda Cartwright described the late 1970s as a "turning point" in the agency's efforts to transition the male-dominated agency to a more diversified organization. Trainings focused on race and gender played a role in those efforts, and could be mandatory:

Like anything else I'm sure it had a lot of suspicion on the part of the old guard. But at the same time I think we were really trying to turn the corner as an agency and actually give people some tools to do that. And that was kind of the beginning of pushing the change and supporting it with some training and along the way the whole social environment is demanding that we do that very thing at a much quicker pace." 457

Unlike other approaches to women's issues, men also participated in these workshops, and male supporters stood out, some volunteering to mentor individual women, others

457 Linda Cartwright, Interview by Jon Knowlson, 12 May 2007, Hood River, Oregon. Region 6 Civil Rights Collection. 
mentoring entire staff. One of Linda Goodman's male supervisors brought speakers in from all over the country and also taught women to facilitate various workshops aimed at career advancement. She recalls one of her early supervisors who talked:

... about his experience of going from being a very dictatorial kind of leader to finding a way to have the sensitive side come out. Because that's the other part of Changing Roles for Men and Women. Men get to let their sensitive side come more and before it was, "Nope! We get the job done, go home." And it was great to be able to see men let that sensitive side out as well.

The workshops also reflected entwinement in the occupational, social, and environmental shifts of the 1960s and 1970s. In part, diversity training like "Changing Roles" initiated discussion regarding what Herbert Kaufman called "willingness to conform" and extended beyond mobility as a criterion for advancement to asking: did women have to act like men; that is, become authoritative and commanding, to "succeed in the Forest Service?" Recalled Goodman, some said, “No, we don't have to.” Others said yes, "In order to be successful," women must adopt a hierarchical Forest Service approach, also identified as male. "But," she said, "many of us have proven that to be not so true. We can be ourselves and be successful." Diversity training flipped the authoritarian approach to management that typified the Forest Service upside down, reflecting the movement toward participatory management so reviled by Fire Chief Carl Hickerson. "Changing Roles" in particular, while not the only type of diversity training, reflected shifts in organizational culture, from whether women had to behave in certain ways to achieve agency success, to how men and women ought to manage not only the land and its residents, but also those who worked in public service. 
The Changing Roles workshops demonstrate how policy learning moved from place to place within the agency, as the workshops dispersed via individuals committed to effecting change. In 1979, Susan Odell moved to Region 5, one of the first two female district rangers in the country. Odell, like Goodman had become involved in facilitating "Human Rights" and "Changing Roles" workshops in the Pacific Northwest. As Mariposa District Ranger on the Sierra National Forest, Odell brought "Career Counseling" seminars, "Human Rights" and "Changing Roles" with her to California, something she proudly noted in her resume. ${ }^{458}$ She also recalled that the workshops came from Edie Seashore, the organizational development guru, formerly of American University. ${ }^{459}$

The 1990 Changing Roles workshop in Washington, D.C. , hosted by the Computer Science and Technology, Forest Inventory, Economics, and Recreation Staff at Harper's Ferry, West Virginia demonstrates the coalescence of entwined diversification. Supervisors were to hand pick very specific participants for the 50person workshop intended to break down stereotypes. By then, the workshop's goals formally extended beyond gendered interactions to include issues associated with occupation and leadership. The primary goal was to shape a better understanding and acceptance of how roles had changed by "having attendees confront their own attitudes (rather than confront each other) and openly discuss the issues," from identifying coping

458 Susan Odell Resume. FHS collection F18.4, File, "Women in Natural Resources Conference $(1985) . "$

459 "Edith Seashore," School of Public Affairs, American University Website, http://www.american.edu/spa/faculty/eseashore.cfm [accessed June 6, 2015]. It is not clear where the Changing Roles workshops originated. Although likely that the idea came from Edith Seashore, Mary Albertson developed Changing Roles in R-6 in 1976, as one of several types of workshops. 
mechanisms to discussing gendered expectations. ${ }^{460}$ As a harbinger of the twenty-first century, the workshop also sought to eliminate barriers stemming from unconscious attitudes. The biggest indicator of entwined diversification came from the criterion for choosing participants. They must be 50 percent female and male and must represent all occupational categories and grades, from line and staff, supervisory and non-supervisory roles. $^{461}$

\section{Sexual Harassment}

The incidence rate of sexual harassment in the Federal workforce is widespread--42\% of all female employees and $15 \%$ of all male employees reported being sexually harassed. - Sexual Harassment in the Federal Workplace: Is it a Problem? Merit Systems Protection Board, March 1981

The FWP provided an avenue for developing solutions to everyday problems, and although it held no authority to sanction, it raised awareness regarding difficult issues, like occupational inequities and sexual harassment. The FWP allowed women to speak to one another. They found out what was happening in the districts. They borrowed ideas. They shared stories. They strategized. "There was one case," said McGinty:

... that had a high recreation use and the guy that was in charge of all of the summer workers was making sex a requirement for whether women got hired back. When I found out about that - this was after I was in the Federal Women's Program - I found out about it and ... I couldn't get the women to talk about it for a long time. And finally I got one that would talk as long as I never told

460 Clyde A. Shumway, Director of Computer Sciences and Telecommunications, Memo to WO Staff Directors and WO Detached Units, re: Changing Roles for Women/Men Workshop (September 21, 1990): 1. FHS Collection F13.2, File, Changing Roles Workshops.

461 Ibid. 
anybody or gave anybody her name. Well, I went screaming into Personnel just ranting and raving and the personnel officer said, "Oh, it's okay, Pauline, we know about it and we've already taken steps."

They transferred him to another area. They just transferred him out. There was not punishment, there was nothing done. But he was off of our forest so we didn't have to worry about it anymore. And that's how things were taken care of then.

This story is one of many. As Elaine Enarson notes in Woods Working Women, sexual harassment in the Forest Service of the 1970s increased as the numbers of female employees rose. In one 1977 FWP survey, nearly half of one hundred female respondents on a southern Oregon forest had experienced some level of sexual harassment at work. Of the 44 who responded affirmatively, over half identified harassment as verbal (65\%), with 31 percent claiming both verbal and physical sexual harassment. Another four percent reported sexual harassment as physical only. Of these respondents, about half were clerical, and a third seasonal workers. ${ }^{462}$

Reflecting the tenor of the times, many people interviewed for this project recall sexual innuendo, obscenity, coarse jokes, "cheesecake slides" in the middle of professional presentations, and nude calendars as common in the male dominated workplace of the 1970s. More than one woman discussed the "Christmas Kisser," a staff officer who used the holiday season as license to visit ranger districts and kiss women wetly on the lips, whether they liked it or not. Enarson also reported incidents that paint an even grimmer picture of the atmosphere. In one case, a woman's supervisor pulled her onto his lap with a telephone cord and kissed her, a seemingly common "type" of 
occurrence. ${ }^{463}$ More unique cases include, among others: a woman sent into the woods with a purported rapist. She made sure she never turned her back to him; a crew boss who threw a woman onto the ground and repeatedly kicked her for physically repelling his advances - in front of the crew; and the story of a young woman on her first job with two male co-workers. She found herself backed up against a pickup door as one of the men openly masturbated while walking toward her, until the second man stopped him. The woman told her parents who went to the district ranger. "She quit her job and her co-worker was 'talked to; about his 'problem,'” wrote Enarson. ${ }^{464}$ This was the tone of the 1970s, the context in which a small number of Forest Service women joined together to effect change.

The Women's Forestry Network

With a few exceptions, it seemed that deans didn't want to do what the civil rights acts told them they had to begin doing: give their growing female student populations, along with their male students, some experience with female intellectual authority. "There aren't any qualified women out there," the deans and forest supervisors would shout in unison. Our flyers, however, gave women a

\footnotetext{
$463 \quad$ Ibid, 112.

$464 \quad$ Ibid, 113; FHS collection 18.4, The Equal Employment Opportunity Commission defined sexual harassment in 1980 as: unwelcome sexual advances, requests for sexual favors, and other verbal of physical conduct of a sexual nature," especially when related to employment conditions or decisions, "interfering or creating an intimidating, hostile, or offensive working environment." The Office of Personnel Management defined sexual harassment in 1981 as: "deliberate or repeated unsolicited verbal comments, gestures or physical contact of a sexual nature which are un welcome." Office of Merit Systems Review and Studies, "Sexual Harassment in the Workplace: Is it a Problem? A Report of the U.S. Merit Systems Review Board” (March 1981): 42.

http://www.mspb.gov/netsearch/viewdocs.aspx?docnumber=240744\&version=241014\&application=ACR OBAT [accessed March 29, 2013]. Although the FWP highlighted sexual harassment in the workplace, not until Meritor v. Vinson in 1986, did the law did not hold employers accountable, prompting organizations to begin crafting sexual harassment policies. Lin Grensing, "Sexual Harassment: New Solutions for an Old Problem."
} 
chance to see where the jobs were, to apply for them, and to demonstrate that indeed, qualified women were "out there." - Lei Lane Burrus-Bammel, ca. 1990"465

In 1979 Andrea Warner, Civil Rights Specialist at the Pacific Northwest Forest and Range Experiment Station, met Linda Donoghue, with whom she and Albertson launched an organization to promote the advancement of women. Warner had begun working for the Forest Service on California's Six Rivers National Forest in 1969 as a resource clerk, before moving first to the Pacific Northwest and then to Alaska as an EEO and Staffing Specialist. Donoghue worked at the North Central Experiment Station in Lansing, Michigan, where her Ph.D. research focused on organizational barriers to women professionals in the Forest Service. Concerned that emphasizing new hires of women and minorities could overshadow issues faced by existing women in the agency, Donoghue and Warner decided to "get all the Region 6 women foresters together for a meeting." ${ }^{466}$ Warner then contacted Mary Albertson, with whom she had worked on civil rights trainings and women's issues, hoping that Albertson could make the meeting official -- and she did.

Through the Federal Executive Board, Mary Albertson knew Dr. Alice Armstrong of Portland State University. She and Armstrong, whose research focused on social and psychological barriers that limit women's potential for leadership, had collaborated, putting on female empowerment, "political savvy" workshops around the region. According to Albertson, Dr. Armstrong proposed a professional women's

465 Dixie L. Ehrenreich, "Documenting Progress: The Women in Natural Resources Journal, Journal of Forestry, Vol. 94, No. 11 (November 1996): 12.

$466 \quad$ Warner, "In the Beginning," 8. 
conference in Portland, the first ever in the Pacific Northwest. Albertson sat on the planning committee. Although not originally connected to the Forest Service, when Warner and Donoghue suggested bringing Forest Service women together under the auspices of the conference, Albertson viewed it as a great opportunity. ${ }^{467}$ She obtained approval to bring Forest Service women to Portland for a meeting in conjunction with the PNW conference co-sponsored by Alice Armstrong's Institute for Professional and Managerial Women and Portland State University, October 4-7, 1979. Thirty-eight professional, clerical and field level women in the Forest Service met for a day and a half to focus on breaking into non-traditional occupations in the Forest Service. They arrived from around the Northwest, Eugene, Portland, Vancouver, and elsewhere, while Linda Donoghue flew in from Michigan. ${ }^{468}$

Linda's meeting objectives included defining and identifying barriers faced by women in professional positions, proposing solutions, and recommending formal and informal outlets for the information. As Warner later recalled, "Talking about the barriers was easy, coming up with solutions that could be implemented and would make a difference wasn't." ${ }^{469}$ Workshop attendees included fifteen foresters from various areas: classic forestry; silviculture; salvage; presale; reforestation; logging systems; and recreation; as well as a number of aides, technicians, and miscellaneous occupational categories. Louise Parker, a GS-13 Public Information Officer and Mary Albertson, Civil Rights, at GS-12 ranked the highest. One systems logging forester and two

\footnotetext{
$467 \quad$ Mary Albertson interview by Donna Sinclair, November 10, 2014.

468 Warner, "In the Beginning," 8.

$469 \quad$ Ibid, 9.
} 
researchers ranked at GS-11, Linda Donoghue among them. Five female GS-9's of eleven in the agency attended, half of them foresters, as did nine women at GS-7, including a hydrologist and civil rights specialist Andrea Warner. Eleven GS-5's and seven GS-4's were present, several of them forester trainees, and one a student. A single GS-3 forestry technician joined them. Of this group, about half had worked in the Forest Service for a year or less, another half from five to ten years, and four had been employed with USFS for eleven or more years. ${ }^{470}$ Together, the group determined the major need for Forest Service women - uniting forces.

This realization led them to create Women in Forestry, a "communication and support network," a "movement" and a "vision" at one and the same time. Mary Albertson produced the first "Women in Forestry" Newsletter in December 1979. Linda Donoghue produced the next seven issues, two in 1980, four in 1981, and one in 1982, all of which contained contributions by members regarding human and natural resources, training and development opportunities, book reviews, job opportunities, and more. Some forest supervisors wanted the newsletter officially sanctioned and distributed to the entire region. But, women in the Forestry Network worried that an agency seal of approval could challenge freedom of speech through stringent Forest Service guidelines and "probable censorship ... We didn't want anyone controlling our newsletter but us!" remembered Warner. ${ }^{471}$ Consequently, the Network kept the 
organization outside the formal mantle of the Forest Service and charged a $\$ 10.00$ subscription rate per year ${ }^{472}$

By 1982, more than one hundred people subscribed to the newsletter. That summer, after nine publications handled by Donoghue and Albertson, and on the heels of a conference at University of Idaho called "Women in Natural Resources: An International Perspective," the Women in Forestry Newsletter ended. ${ }^{473}$ Molly Stock, a professor of Forestry Resources, and research scientist Dixie Ehrenreich took on publication, and turned the newsletter into a full-fledged journal. In the first issue of the "new" Women in Forestry, Stock and Ehrenreich noted the original goals and concepts for the journal would remain the same, with one addition, the inclusion of cultural resource management because "most archaeologists on the nation's forests, in the parks and waterways, are women.” Their goals echoed those of Donoghue, Albertson, and Warner: to create a journal "for, by, and about professional women," and a new goal, to expand it from forestry to natural resources. ${ }^{474}$

By 1985, the network included women and men from a variety of natural resource organizations, federal, state, private, and even international, and the journal's name changed to Women in Natural Resources. When Molly Stock left, Lei Lane Burrus-Bammel stepped in from the West Virginia Forestry Department to help Dixie continue the effort. Since then, women from various natural resource organizations have

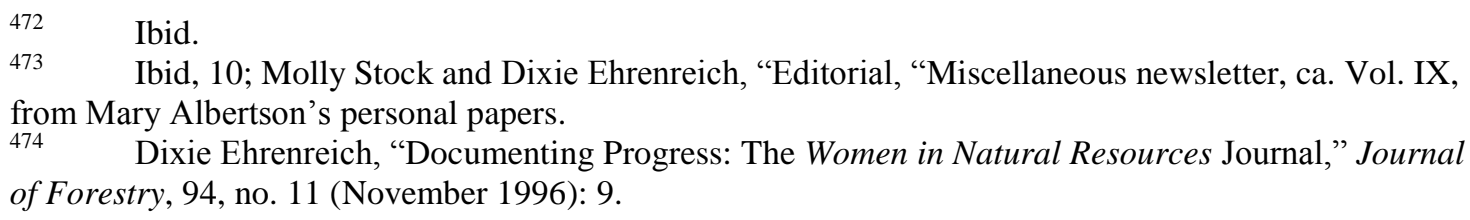


joined the Women in Natural Resources network, conducting interviews, providing book reviews, advertising natural resource jobs and offering advice for women in nontraditional fields. ${ }^{475}$

\section{Discussion: Expanding Representation in Region 6}

I ask that you work aggressively and creatively, to provide maximum employment opportunities for women in the Federal career service. This means developing, within merit principles, innovative programs to recruit and hire qualified women and to be sure they have the opportunity for satisfying career development. - President Jimmy Carter, Memorandum for Heads of Departments and Agencies, November 17, $1977^{476}$

When forestry professionals like Anne Heisler joined the Forest Service in the 1960s, they encountered limited options. Although Heisler started out in the field, advancement in the 1960s essentially required her to move into an Administrative position, where she put her forestry training to use as an educator, as had many of the women who came before her. In the decades that followed, Heisler participated in some of the most significant land management issues of late twentieth century Pacific Northwest forestry, from how to operate under the aegis of spotted owl timber reductions to creation of the 1986 Columbia River Gorge National Scenic Area Act. Unlike most women at the time, Heisler's appointment as junior forester brought her

\footnotetext{
$475 \quad$ Odell, 1; “The View from Women in Natural Resources: Life Experiences and Gender Equity Fill the Pages," Women in Natural Resources, 24, no. 3 (2003-2004), available at http://www.webpages.uidaho.edu/winr/winrgroup.htm [accessed November 11, 2014].

${ }^{476}$ The American Presidency Project Website, University of California Santa Barbara, Federal Employment of Women Memorandum for Heads of Departments and Agencies, November 17, 1977, http://www.presidency.ucsb.edu/ws/?pid=6941 [accessed May 4, 2015].
} 
into the agency as a professional, whose pay scale began where most women's careers stopped. Today, most internships or student jobs are GS-3 or GS-4 on the pay scale, the rank held by most permanent full-time female Forest Service employees in the 1960s through the early 1970s.

In 1977, President Jimmy Carter reaffirmed Executive Order 11375, calling for affirmation and evaluation of federal EEO efforts. The president noted a need for "Special efforts" to eliminate sex discrimination from laws and policies and sent the memorandum to Secretary of Agriculture Bob Bergland, who forwarded it to Chief John McGuire as a directive for action: "I expect to see significant improvements made in your department or agency as a result of your personal initiatives, and I hope you will be especially sensitive to the concerns of older women and women from minority groups," wrote the president. ${ }^{477}$ The memo calling for aggressive recruitment, hiring, and advancement of women preceded broader Civil Service Reform legislation in 1978, which functioned as part of the President's Reorganization Project and mandated increases in the numbers of women in the mid- and senior levels of federal organizations.

Civil Service Reform, 1978

Civil Service Reform attempted to address federal employment as whole, rather than piecemeal, with special emphasis on data collection, systematizing process, and

477 Bob Bergland, Secretary of Agriculture, Reaffirmation of President Jimmy Carter's EO 11375, November 17, 1977, to Heads of Departments and Agencies. FHS collection F18.4, File, "Women in the Forest Service-Publications." 
enforcing EEO requirements. President Carter issued two Reorganization Plans followed by the congressional legislation, the Civil Service Reform Act of 1978 (PL 95454), which he said "adds the muscle to the structure" of improving the federal personnel system. Goals included putting merit principles into statute, defining prohibited personnel practices, and establishing clear processes related to hiring, rewarding, and disciplining employees, while safeguarding employees against political intrusion. ${ }^{478}$

The Civil Service Reform Act abolished the Civil Service Commission and distributed its functions primarily among three agencies: the newly established Office of Personnel Management (OPM); the Merit Systems Protection Board; and the EEOC to systematize equal employment opportunity government-wide. Merit based hiring free from "prohibited personnel practices" would shape this workforce "reflective of the nation's diversity," the statement Mary Albertson found most significant, "and I used it often!" she said. ${ }^{479}$ The law also established a new EEO recruitment program for federal service and created leadership accountability by including affirmative action goal achievement in evaluations for a new Senior Executive Service (SES). Additionally, state and local governments had to collect and report data on female and minority employment, to establish affirmative action programs. Most importantly, Civil Service Reform provided the EEOC with authority to act legally against government units

478 Jimmy Carter. "Civil Service Reform Act of 1978 Statement on Signing S. 2640 Into Law." October 13, 1978. The American Presidency Project, http://www.presidency.ucsb.edu/ws/?pid=29975 [accessed November 20, 2014].

479 PL 95-454 (S 2640), OCTOBER 13, 1978, An Act to reform the civil service laws, original text, Equal Employment Opportunity Website, http://www.eeoc.gov/eeoc/history/35th/thelaw/civil_service_reform-1978.html [accessed September 26, 2013]. 
charged with discrimination. As J. Edward Kellough confirms, "By the mid-1970s, goals and timetables and the preferences they imply were firmly established as part of the affirmative action process.

Civil Service Reform brought some uniformity in the GS scale, with most entrylevel positions at GS-5 to GS-7, mid-level positions at GS-8 to GS-12, and top level supervisory positions at GS-13 to GS-15. At each rank, the possibility exists for ten step pay increases. District rangers, staff officers, and research station project leaders typically work at the GS-11 or GS-12 professional level. Forest supervisors are found at the GS-13 or GS-14 level, depending on the size and activity of the forest. Civil Service Reform removed the GS-16 and GS-17 levels, except in research, so that top level supervisors, regional foresters, deputy chiefs, or area administrators must enter the competitive Senior Executive Service to advance. Between 1976 and 1992, women in the Forest Service increased from 22 percent of all employees to a high of 40 percent. More importantly, by 1992 the average grade of women increased from below GS-5 to GS-7.4, an indication of growing numbers of female professionals in the agency. ${ }^{481}$

Upward Mobility - Law, Policy, and Representation

It took the multiple legal mandates of the 1960s and 1970s to increase both the number of women in the Forest Service and to raise their status. The 1972 Equal Employment Opportunity Act provided a critical link between the Civil Rights Act and

480 Kellough, Understanding Affirmative Action, 45.
481 1992-1993 Workforce Data Book, 1. 
federal female employment. By subjecting the government to Title VII, agencies had to exceed half-hearted efforts to employ women and begin concerted recruitment and hiring activities. For the first time, they really had to take affirmative action related to women. The Federal Women's Program played a major role in shaping success related to that action. The FWP meant female representation in government via the law. The organization employed women like Mary Albertson to assess and increase the status of women, even as they acted as advocates and promoters. The FWP created a formal structure for organizing social change at multiple levels, including formally and informally addressing sexual harassment in the workplace.

Status improvement for women during this period occurred due to a mix of factors, part law and policy, part women's initiative. The formal women's networks and institutional support that developed from the FWP, alongside informal connections, made the women of Region 6 leaders in advancing women's status in the Forest Service and in natural resources nationwide. As the largest timber producing region in the nation, Region 6 not only employed more men and women than anywhere else in the Forest Service, it was rich. From 1960 to 1989, the Pacific Northwest harvested between 3.5 and 5 billion board feet every year but three, the highest in the nation. ${ }^{482}$ Consequently, the region's resources supported development of major training sessions and a forward thinking Civil Rights Program. While affirmative efforts initially focused primarily on people of color, on the heels of the 1978 consent decree in California,

482 Gerald Williams, Foreword by Mike Dombeck, The U.S. Forest Service in the Pacific Northwest: A History (Corvallis: Oregon State University Press, 2009): 372. 
women's advancement moved to the top of an agenda informed by massive internal and external social change. With license to battle sexism granted by law and the freedom to access historically male, well-paid jobs for the first time, women operated within a sanctioned structure of equality for the first time. While those involved in the USFS Civil Rights arena focused on all underrepresented groups, the proportion of white women in the agency surpassed gains made by minorities. Mary Albertson attributed this trend to increased educational opportunities, the sheer numbers of non-minority females already in the workforce, and formal upward mobility programs, topics addressed in chapter seven. These women, in turn, transmitted messages about selfsufficiency and advocacy, while identifying examples of "success" all around them.

Women and Bears

Despite formal support and like African Americans, women continued to face entrenched, essentialist attitudes about their relationship to nature. One example of advocacy stands out as both a reflection of the persistence of gendered notions of reality and the empowerment provided by the FWP. In 1981, Andrea Warner and Linda Donoghue joined forces to address the idea that women should not go into the woods during menses. Their concern stemmed from a "Safety Tip" in the June 1979 edition of the Forest Service Health and Safety Codebook, stating that "Women should avoid traveling into grizzly country during their menstrual period." When Warner called the Washington Office to identify the source of information, she found that it stemmed from a joint National Park Service/Forest Service public brochure titled “Grizzly, Grizzly, 
Grizzly." Further research revealed that an implicit connection between women, bears, and menses had emerged in 1967, when two women were mauled to death in Glacier National Park; however, additional research by NPS and others did not support the theory. ${ }^{483}$ Instead, Warner and Donoghue found that multiple odors attract bears. Two factors made human susceptible to attack: a dirty camp and coming upon a bear while hiking. In fact, they reported, "Men, as well as women, have been involved in these encounters: yet, there is no attempt to restrict men from grizzly country," such as restricting men with open wounds from woods work.

Warner and Donoghue reported the lack of evidence to Forest Service administrators, voicing concern that supervisors might limit the activities of field-going women employees or institute discriminatory policies. Instead, they suggested, the agency should emphasize safety for all, not restrictions for a single group, as had already occurred when:

1) A supervisor asked management to prepare a written policy on what to do about field-going women when they are in their menstrual cycle.

2) Women employees had been asked to tell supervisors when they were menstruating.

3) A woman employee had been told by her supervisor that she could not go into the woods with him for up to five days before starting her period, but that she could go alone.

Warner and Donoghue recommended removing statements regarding women and bears from all handbooks and public materials. Instead, they proposed the agencies identify non-odorous disposal methods for tampons, pads, and other garbage. Their

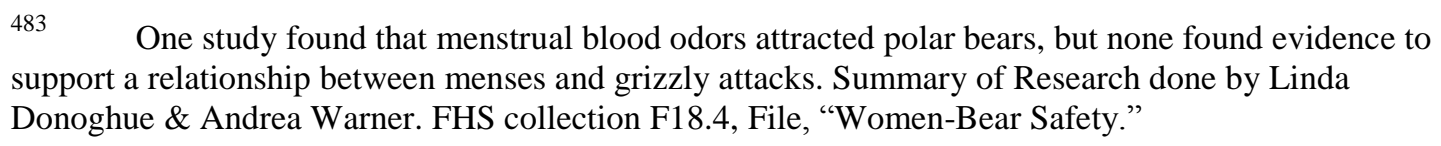


recommendations rested on the view that safety concerns regarding menstruation must be 1) couched in concrete data; and 2) included with other safety suggestions like refraining from the use of perfumes or deodorants in the woods, practicing personal cleanliness, keeping sleeping bags and personal gear odor free, and not sleeping in the same clothing used when cooking - safety recommendations for women and men. ${ }^{484}$

In 1991, the Journal of Wildlife Management published a study conducted by Forest Service employees from the North Central Experiment Station. The employees tested the attractiveness of menstrual odors to male and female black bears of all ages under various conditions in northeastern Minnesota, and concluded the bears were not attracted to menstrual odors presented through garbage or via menstruating women. ${ }^{485}$ The same year, as the agency rewrote the Health and Safety Codebook, Andrea Warner sent the chief a memo regarding women and bears. Warner noted that neither NPS investigation nor recent research supported restrictive statements in government brochures that dealt with hiking in bear country: "We believe this statement to be unfounded and inappropriate and it should be excluded from the Handbook," she wrote. "Forest Service employees continually perform a number of hazardous jobs," protested Warner, "but emphasis is placed on doing them safely rather than restricting them," especially in relation to gender. After some time passed, Warner sent a copy of this 1991

484 Ibid, 3; Memorandum to Chief, "Forest Service Health and Safety Code Handbook," Robert W. Williams for Michael A. Barton, Regional Forester, Alaska Region, May 20, 1991. FHS collection F18.4, File, "Women-Bear Safety."

$485 \quad$ Lynn L. Rogers, Gregory A. Wilker, and Sally Scott, "Reactions of Black Bears to Human Menstrual Odors” Journal of Wildlife Management, 55, no 4 (1991): 632-63. Available at http://www.bearstudy.org/website/images/stories/Publications/Reactions_of_Black_Bears_to_Human_Me nstrual_Odors.pdf [accessed November 13, 2014]. 
memo to the agency's historian Terry West, including her original research findings. In the note to West, she wrote: "This issue has a little different bent to it than most dealing with women in the Forest Service - but nonetheless may be worth keeping. The Handbook is still not rewritten. I have a whole folder of research I've done on this that I'm keeping."

In 2012, the National Park Service at Yellowstone Park released a report noting that "black bears and grizzly bears are not attracted to the odors of menstruation." Various media outlets picked up the story, including Mother Jones and Huff Post Green. In fact, the Huffington Post article "Do Women on Their Periods Attract Bears? New Study Busts Myth,” from August 14, 2012 pointed out that such persistent myths reinforce the notion that women are not suited for survival in masculine domains. The idea that woods work is not for women held less power in 2012 than in 1981; yet, every time a new study demonstrates that menstruation is not connected to violent bear attacks, it's new news to many, including government employees. As Huff Post points out, “... it would appear that the real bias toward women has come from our culture and the National Park Service [and Forest Service], not from the bears."

It took determination for women like Andrea Warner, and others, to continue pushing against a culture so permeated by sexism. Formalized programs rooted in law, like the FWP, and informal organizations like the Women in Forestry Network provided avenues for resistance and proactive change. Key individuals, "who had credibility with

\footnotetext{
486 Stephanie Pappas, "Bears Not Attracted to Menstruating Women," Livescience - online newsletter website (August 25, 2012). Available at http://www.livescience.com/22688-myth-bears-attackmenstruating-women.html [accessed November 12, 2014].
} 
their peers," in management at the forest and regional level, also acted as "pro-active articulate proponents" for diversifying the workforce. The Civil Rights Department offered awareness and sensitivity trainings around the region, while other workshops dealt with concrete issues like resume writing, dressing for success, and "political savvy." These workshops complemented programs like "Changing Roles of Men and Women" and "Human Rights" trainings that transmitted ideas about equality nationwide. ${ }^{487}$ By 1985, the Society of American Foresters even partnered with "Women in Natural Resources" for a major symposium in Dallas, Texas, indicating at least some changes in attitude. But, to really effect change, women needed to move into positions of power, as directors and line officers. Only then might their presence engender cultural shifts, even as their numbers grew. 


\section{Chapter 7: "Go West Young Woman" - Upward Mobility and the Pacific}

\section{Northwest}

\section{As we go marching, marching, Unnumbered women dead Go calling through our signing Their ancient cry for bread No art and love and beauty Their trudging spirits knew Yes, it is bread we fight for But we fight for roses too.}

- "Bread for all, and Roses, too - a slogan of women in the West," James Oppenheim, The American Magazine, $1911^{488}$

When Gloria Brown went to work for the Forest Service in 1974, NO women or African Americans held the decision-making authority of line officer (district ranger, forest supervisor, regional forester, or agency chief.) At first, she worked in the transcription pool of the Washington, D.C. office, a position she found "interesting but just a job.” She explained, “you weren't a maid, you weren't cleaning houses and you weren't cleaning hotel rooms, so it was a white collar job... an important job.” As her three children grew, Brown worked during the day and studied journalism at night. Then, in 1981 a drunk driver hit and killed her husband, leaving Gloria a single parent at age thirty, emotionally wrought and struggling to support her family on a GS-6 salary. Soon, she lost her house. Rootless, the family moved from place to place in Maryland, neighborhoods she described as less than "nice" or "safe." Gloria worried about money,

488 The poem "Bread and Roses" inspired by a political slogan from a speech given by Rose Schneiderman, "The worker must have bread but she must have roses too" was cited by Linda Donoghue for Women in Natural Resources, 1992. The slogan appeals to the need for fair wages and dignified working conditions. 
single parenting, and the children's future. She could no longer afford the kids' Catholic School. She began to question her status in the Forest Service and later recalled telling co-workers, "I want to work my way up into this agency. I want to be a person who's looked at as someone who makes decisions about what we do in Forest Service."

Gloria Brown began to strategize. She finished her degree. She asked questions. And she heard from her white male mentors that to advance, she would need to leave D.C. To that end, she transferred from Information \& Education (I\&E) to a lower level secretarial position in the Resources Planning Department (RPA), where she had seen people rotate through on "details" before promoting out. There she gained exposure to the agency's resource issues and environmental conflicts. She also worked for supervisors who helped her to advance. When a Public Affairs position opened up in Missoula, Montana in 1985, Gloria applied and got the job. "It was all about the money in those days," she said, "to feed those kids." ${ }^{489}$ And when racism infiltrated the children's lives in Missoula, her W.O. contacts helped her move to the Portland, Oregon Regional Office in 1987, where she found agency support and an African American community. Gloria Brown soon figured out how to become a decision-maker, by identifying the Willamette National Forest as the place for advancement. The forest supervisor for the region's major timber producer, Mike Kerrick, supported a forward thinking management team and had sent several female "firsts" out into the wider world of the Forest Service. When a job in Public Affairs opened up, a position that put her on the Forest Leadership Team, Gloria applied and then made a deal with Supervisor

489 Personal Communication by author with Gloria Brown, October 2014. 
Kerrick. She would ensure publication of the forest plan underway for the previous ten years and would forego any leave or training time. In return she asked that Kerrick agree to send her to Oregon State University for special certification in Forestry. The day before he retired, Kerrick signed the paperwork and Gloria returned to school.

Gloria Brown's experience is atypical in that she moved from the Washington Office into the field, rather than the reverse, what she calls a Forest Service "breech birth." It is typical in that she, like most women in the early 1970s, started her career in the clerical pool. It is unusual in that Gloria was an urban black woman with little outdoor experience; yet, her story is familiar in that she supported a family as a single parent. She needed the economic security that would come with advancement. Moving West provided the opportunity. But Gloria Brown is remarkable. In 1999, when she took over the Siuslaw National Forest, she became the first female African American forest supervisor in the nation, the first black woman in charge of an entire national forest. A complex set of conditions set the stage for Gloria's advancement, including the precedent of other female "firsts" in the Northwest and its national forests. She, in turn, became a role model for African American women. As the largest timber producing region in the nation, in 1990 Region 6 supported 7,560 permanent employees and up to two thousand temporary employees. ${ }^{490}$ By then, the region had become a training and proving ground and a destination for women line leaders.

In 1990, Herbert McLean noted that the Pacific Northwest "leads the pack" in regendering the U.S. Forest Service. With a third of the agency's sixty female district

490 Williams, USFS in the Pacific Northwest, 303. 
rangers in the region and still others moving into professional positions via the clerical pool or as direct hires, McLean provided sound advice for advancement: "Go West young woman."491 There, a new generation of employees included women from a wide variety of occupations filled with opportunity, even as gendered barriers led them to vigorously challenge the status quo. By the late 1980s many of these women wanted to move beyond fire line and brush removal, transcription and filing, mail delivery and reception into careers that would provide the dignity, economic security, and power that comes with authority. Like Gloria Brown, they wanted full participation in Forest Service decision-making. As the saying goes, these women fought for bread - and they fought for roses, too.

In this chapter, I examine some of the ways in which women in the Pacific Northwest advanced in the Forest Service of the 1970s through 1990s. Many of these women were "firsts" to enter high level positions. As Nella Dickson pointed out in 2007, "firsts" are important "because once the door is open, it's hard to shut it again, and the more who come through, the easier it is for those who follow." Their experiences also demonstrate the importance of formal programmatic efforts to enhance status, while also revealing the significance of individual initiative and informal support networks. Stories of upward mobility in Region 6 and associated western locales illustrate both standard and unconventional avenues to leadership for women. The individual stories that follow also demonstrate the importance of youth and natural resource education and internal and external upward mobility programs. They depict ways in which entwined

491 Herbert E. McLean, "Regendering," 27. 
ecological, occupational, and social diversification shaped a new group of decisionmakers that included former clerks and secretaries, biologists, foresters, and women of color. By highlighting career paths, and formal and informal barriers, I argue that what has been traditionally deemed "women's work" in the Forest Service provided valuable preparation for leadership in the era of entwined diversification.

\section{Upward Mobility in Region 6}

"The deal was wonderful."

If you were interested in the agricultural life, then you married a farmer... you were trained to be a helpmate. You didn't do it on your own. - Mindy Hackett

Female advancement in the U.S. Forest Service did not occur by chance. As discussed in previous chapters, youth work programs like Job Corps and YCC introduced non-traditional employees into the agency; however, as this chapter will show, providing professional employment took initiatives like the Cooperative Education (Co-op Ed) and upward mobility programs that provided opportunity for promising recruits and education for existing employees, especially women. When the Forest Service created its Civil Rights Program in 1976, the agency used the brand new Co-op Ed program as a primary recruitment tool. Co-op Ed students worked from two to six months a year while in college and "converted" to permanent employment upon graduation. ${ }^{492}$ During the program's first year (1976), the agency hired fewer than a hundred students. By 1981, more than a thousand Co-op students worked with USFS, 
making it one of the agency's "most effective programs from an affirmative action recruitment standpoint." However, by 1982 budget cuts and hiring ceilings reduced the number of participants to 790 and prevented conversion for many students. Meanwhile, the proportion of female Co-op Ed students increased from 50 percent to 62 percent, while minorities remained near 30 to 32 percent. The program has continued to function with various levels of funding and under different names into the twenty-first century. ${ }^{493}$

In addition to the planned professionals who came into the Forest Service via Co-op Ed or as external hires, a select number of women participated in upward mobility programs within the Forest Service. These women moved between occupational categories, and took advantage of government programs that helped them become professionals able to join in the decision-making processes necessitated by the era of the ologists. Some moved into staff positions or research, while others eventually entered the line. Some of the stories to come illustrate this path to professionalization, while others emphasize natural resource training and its manifestations in the Forest Service of the latter twentieth century.

Mindy Hackett's experience stands out for taking her from a small Oregon farming town and a life of domesticity to the urban environment of Washington, D.C. as a planning professional. It also exemplifies challenges and barriers to advancement in the work world of the 1970s Forest Service, and the opportunity provided by formal

\footnotetext{
493 USDA Forest Service, Human Resources and Personnel Management, "1982 Personnel Report”; Office of Personnel Management Website, http://www.opm.gov/policy-data-oversight/hiringauthorities/students-recent-graduates/ [accessed April 11, 2015].The Co-op Ed program became known as SCEP (Student Career Experience Program) in the late 1990s and is now called Pathways.
} 
upward mobility programs. Hackett came of age in a time and place that carried clear gendered expectations and limitations. "Where I grew up," in rural Oregon of the 1950s she explained, “women, in my particular social caste...didn't work outside the home. If they did, there was failure..." As a girl, Hackett joined 4-H, but not "boys only" organizations like the forestry club or FFA (Future Farmers of America). Like others whose economic exigencies made them push for more, Hackett took a circuitous path to a profession. She spent a short time in the Air Force, ${ }^{494}$ and then, she said, “...of course, I got married, because that's what you do. And then I started a family, because that's what you do." With three children to support, Hackett worked summers for the Forest Service and went to Oregon State University on the G.I. Bill, with the idea that she would study Agriculture and Forestry followed by a graduate degree in extension work:

And I hit bureaucracy. "You're a freshman. You can't possibly know what you want to do. You're a girl. Well, you could do recreation, but there's no place in the field for women. If you want to do research, that would be fine, but you're a freshman, you can't know what you want to do.

Dissuaded from professional forestry, Hackett enrolled in tech school at Umpqua Community College in Roseburg, Oregon. There, she obtained a two-year degree in forest technology, "just at the time when the Forest Service was downsizing and releasing their techs and hiring foresters in those field going positions." When her husband got a job in Portland, Hackett went to work full-time for the Forest Service, in Finance. That "was in 1979 and I've worked for the Forest Service ever since," she said;

494 "Highlights in the History of Military Women, Timeline,"

http://www.womensmemorial.org/Education/timeline.html [accessed June 29, 2015]. Based on her start date with the Forest Service, Mindy Hackett was likely in the WAF, rather than USAF. Her service would have been just before or during the transition from the Women in the Air Force program, created under President Truman in 1948, to full incorporation of women into the U.S. Air Force in 1976. 
however, like many others, Hackett spent nearly a decade in clerical and administrative roles before advancing.

According to Mary Albertson, who transferred to Personnel in 1982, the Region 6 "formal upward mobility program" moved "a lot of women from clerical, technical jobs." The emphasis on women's advancement gained force during what Albertson described as "the fat years, you know, before 1990, we had over eight thousand permanent employees before downsizing, and we had a lot of money. I mean timber was king. We had lots of money coming in from there." ${ }^{495}$ The program allowed women to compete for funds for two years of schooling by creating a plan to qualify for one of the professional series positions. "And the deal was wonderful," recalled Hackett, noting there were a number of single mothers on staff: "We will pay your books and your tuition, and you will get paid your full time salary, whatever job you're at, but you only need to be at your desk twenty hours a week." The rest of the work week could be devoted to school.

Hackett, who majored in Geography, recalled being asked to "Blue-sky brainstorm" her future in the agency:

... here was my dream in 1982. I'm going to retire as the director of Planning in Portland, Oregon, for the Forest Service. Now that was just way beyond - I mean I actually got feedback from people who looked at my application that that was just, that was just silly; that was just way beyond any possibility that I would ever have, to do that. 
But along the way Mindy Hackett fell in love with Economics, too. She graduated from Portland State University as a double major in 1986, qualifying her for a GS-5

professional series position. But, when she decided to seek "on-the-job training and asked the Timber director about next steps: "He leaned back in his chair and he looked at me and he said, 'I don't get it. You have a husband. You have a job. Now go and do it.' [That was] 1986." Despite funding her education, the agency "had no plans to use that investment in any way, shape, or form.” Hackett realized advancement would require mobility when a male colleague told her:

Mindy, you are going to have to leave Region 6. Anybody who knows you, knows you as a clerk-typist, and they simply are not going to be able to see your application objectively. You have got to leave the region." Which, I had never anticipated doing. [5 second pause, laughs wryly] And it was painful. It was awful. We had a family. We had a house. We had a life.

Two years later, Hackett's marriage dissolved and she obtained her first professional position, on the Siskiyou National Forest. "I was hired as a geographer," in 1988 she explained, "but it was the economic background, in addition, that helped." The four year period that followed marks what Hackett considers her true beginning with the Forest Service:

And I've moved forward. I would have to say that I've done extremely well. I believe. I mean, I have to stop and kind of look at my life from that twenty nine year old GS-3 clerk-typist and realize that I've succeeded beyond my dreams, actually.

I am a GS-14 planning specialist. Which just, it still kind of makes my jaw drop. .... In the Washington Office. And I am working in Planning, after spending, in California, ten and a half years kind of doing a variety of things, and we're beginning to implement a new planning rule and I'm ... [at the] table for that thought, that focus, that discussion. So yeah, I've done exceedingly well. And, as far as I can tell, and from my perspective, I've done it without a mentor. 
Leaders of the Pack

I had never heard of forestry. Ecology was not yet a widely known concept, yet in the early 50s I was able to attend a field course in natural environments of the Puget Sound area. Traveling through the Northwest, I saw examples of both good and bad land and resource management, and I became fascinated by the Forest Service's role in conservation. ${ }^{496}$ - Geraldine Larson

Line officers are the leaders in the Forest Service. They manage the agency at its various levels, while natural resource and administrative officers serve as counterpart to the line, informing decision-makers and supervising staff as professional directors. In 1976, women held only one percent of all professional positions in the agency, eleven percent of all administrative or technical positions, and NO line positions. Only four percent of all women in the agency ranked at GS-11 or above. Nor did any women hold positions as Regional or Washington Office Directors or Station Directors. Two years later, the proportion of women professionals remained low but some had begun moving into positions of authority. For example, research entomologist Jackie Robertson became the agency's first female project leader in 1978, at the Pacific Southwest Research Station. ${ }^{497}$ Geraldine Larson became deputy forest supervisor the same year, and in 1979 Wendy Milner Herrett who started her career in Region 6, became a district ranger. By 1983, a Civil Rights Update noted eight women line officers, less than one percent of agency leaders; however, the number and status of women in leadership positions continued to rise throughout the decade.

\footnotetext{
496 Daina Dravnieks, "The Surprising Career of Geraldine 'Geri' Larson: The first and highest ranking line officer in the Forest Service." Women in Forestry (Summer 1985): 14.

$497 \quad$ "Women's History Month - Forest Service Scientist Shows Grace and Compassion While Working Her Way to the Top," USDA Blog, http://blogs.usda.gov/2013/03/08/women\%E2\%80\%99shistory-month-forest-service-scientist-shows-grace-and-compassion-while-working-her-way-to-the-top/ [accessed November 15, 2014].
} 
Table 11: Women in the Forest Service Workforce, 1976 and 1992

\begin{tabular}{|c|c|c|}
\hline Women in Forest Service Workforce ${ }^{498}$ & 1976 & 1992 \\
\hline Women as percent of total permanent workforce & $19 \%$ & $40 \%$ \\
\hline Women as percent of professional positions & $01 \%$ & $26 \%$ \\
\hline Women as percent of Adm/Tech positions & $11 \%$ & $41 \%$ \\
\hline Percent of total women GS-11 and above & $04 \%$ & $24 \%$ \\
\hline \multicolumn{3}{|l|}{ Number of } \\
\hline Women in Senior Executive Service (SES) & & 4 (out of 57 ) \\
\hline Women District Rangers & & 100 (out of 617 ) \\
\hline Women Regional \& Washington Office Directors & & 12 \\
\hline Women Forest Supervisors & & 10 (out of 122) \\
\hline Women Deputy Forest Supervisors & & 11 \\
\hline Women Deputy Regional Foresters & & 3 \\
\hline Women Station Directors & & 1 (out of 9$)$ \\
\hline Women Regional Foresters & & 1 (out of 9$)$ \\
\hline
\end{tabular}

Note: The SES did not begin until 1978 under Civil Service Reform.

The agency's gendered hierarchy revealed major economic disparities for women, and some advantages to working in the Pacific Northwest and California. In 1978, women averaged GS-5.91 service wide. Women in Region 6 surpassed all other regions at GS-6.17 for NFS (National Forest Systems) and GS-6.58 at the PNW Research Station. ${ }^{499}$ Men averaged 9.88 service-wide and 9.82 in Region 6. Albeit with some fluctuation, R-6 remained among the top two regions in terms of women's advancement to the end of the century. As late as 1989, most women in the agency averaged GS-6.6, with men still nearly three points higher. By then, most women came closer to the R-6 average at 6.42, while the PNW and PSW Research Stations remained

\footnotetext{
498 Mary Albertson, "Progress of Women in the Forest Service," Women in Natural Resources, 15 , no. 4 (September 1993: 5.

499 USDA Forest Service, Human Resources and Personnel Management, "1980 Workforce

Planning Data Book," 19. In 1980, women's status decreased slightly in R-6, to a GS-6 average, with R-5 at 6.10; however,
} 
highest, at GS-7.28 and -7.75 respectively. ${ }^{500}$ By 1992, the proportion of women in professional, administrative, technical, and leadership positions in the agency had increased dramatically. [see table 11 above]

These increases occurred most successfully in Region 6 for several reasons. First, compared to the rest of the country R-6 had money and jobs, even in the midst of cutbacks in the 1980s. Second, the Region 6 Civil Rights and Personnel Departments took diversification mandates seriously. People like Jetie Wilds and Mary Albertson integrated workforce goals by making supervisors as accountable for diversifying staff as cutting trees. Although civil rights staff instituted similar accountability measures in Region 3 (the Southwest), by no means was this approach universal across the agency. ${ }^{501}$ Third, if not finally, select leaders in the region saw diversification as opportunity, rather than burden. From regional foresters to forest supervisors, high-level leaders in the West provided opportunities for female advancement that proved most successful in terms of women entering "the line."

\section{Entering the Line}

Paths to Leadership

Once you prove you can do the work, the difference between male and female foresters disappears. Abigail Kimbell, presale forester in Kodiak, Alaska, 1978, Forest Service Chief, 2007-2009 ${ }^{502}$

\footnotetext{
$500 \quad$ Ibid. Men averaged 9.46 in 1989; Tom Martin and Mary Lynch, Personnel and Civil Rights Staff, Washington Office, "Workforce Data Book, 1988-1989," 26.

$501 \quad$ Personal Communication with Eleanor Towns, telephone call with author, January 14, 2015.

502 Abigail Kimbell in Richard Pardo, American Forests (September 1978): 22.
} 
By 1990, McLean's advice to "Go West young woman" reflected the reality of upward mobility for women in the Forest Service. The three-fold jump in the number of women line officers in the previous five years occurred mainly in the West. Not only did Region 6 "lead the pack" with its twenty female district rangers of sixty in the nation, adding California's eleven female district rangers meant that over half of the agency's female rangers worked in the two westernmost regions. ${ }^{503}$ While R-5 struggled to meet consent decree mandates, several women who became top leaders in the U.S. Forest Service either began training on the ground in the Northwest or cycled through.

The first female line officer, Geraldine Larson of New York City, worked as a secretary and raised a family before joining USFS. Her story shows the opportunities that arose with the entwinement of ecological, occupational and social diversification. Larson's introduction to national forests and parks occurred on an automobile trip from East to West. "Up until that time," she said:

I had never heard of forestry. Ecology was not yet a widely known concept, yet in the early 50s I was able to attend a field course in natural environments of the Puget Sound area. Traveling through the Northwest, I saw examples of both good and bad land and resource management, and I became fascinated by the Forest Service's role in conservation. ${ }^{504}$

Typically, Larson's professors suggested she go into teaching or research, areas "...considered easier for women to get into than the field jobs the men were vying for." Larson, who graduated at the top of her 1962 University of California-Berkeley forestry class, obtained a master's in Botany in 1965 and began working for the agency in 1967

503 McLean, "Regendering," 27; Region 8 (the South) employed a lonely two female rangers of 104 in the nation.

504 Dravnieks, “Geri Larson,” 14. 
as a Region 5 Public Information officer. In 1972, she became the region's first environmental coordinator and in 1985, the agency's first female forest supervisor. Despite being her first “field job," Larson's supervisor position on the Tahoe National Forest made her the highest ranking woman in the agency.

Although not a forester, Wendy Milner Herrett moved "through the chairs" as Forest Service employees say. Her career, which began and ended in Oregon, exemplified the era of entwined diversification through a non-traditional path to advancement and overlapping differences through gender and occupation. Born in Cheyenne, Wyoming and raised in Denver, Colorado, Wendy Milner loved the Western landscape and fortuitously ended up in the Northwest. A few months after graduation from University of Oregon, the Portland, Oregon Regional Office of USFS hired her, and in June 1971 she went to work on the Mt. Hood National Forest. There, Wendy encountered as many as seven other professional female staff, including Anne Heisler, who dealt with "all kinds of guff because she went in as a district type forestry person." She "had to put up with a pink hard hat and all of those things" said Herrett, who felt that landscape architecture eased her entry to a professional position: "there weren't as many of us and we weren't directly competing with the men for certain types of jobs." Landscape architects heralded a new and contested era but as she explained, ideas about gender roles shaped opportunities for both men and women:

I think women had an easier time as landscape architects than some men did because it was considered almost, you're dealing with aesthetics, that's kind of effeminate. Some of the men landscape architects, I think, had to overcome some of that attitude, where women, you know, obviously you're dealing with aesthetics. It's OK; it's a woman's thing! But dealing in the overall land 
management, they weren't used to having them [landscape architects] in the meetings and the training sessions, giving them training and asking questions on land management or offering opinions. ${ }^{505}$

In 1974, Wendy Milner became the first forest landscape architect for the Routt National Forest in Region 2 (Rocky Mountain Region). There, Regional Forester Craig Rupp approached her with the idea of becoming a district ranger, soon launching her into the type of mobility the agency required for advancement. Two years later she moved to the Black Hills National Forest as a resource assistant, and gained experience in budget management, supervising staff, and dealing with the public. Five years later, Wendy Milner became district ranger on the Blanco Ranger District, White River National Forest, Colorado (R-2). There she married Tom Herrett, a seasonal employee who soon joined the U.S. Geological Survey and also became a federal employee. In 1983, she headed east to advance her career through a Loeb fellowship at the Graduate School of Design, Harvard University and also attended public policy classes at the Kennedy School of Government. After a semester at Harvard, she took a position as forester on the legislative affairs staff in the Washington, D.C. office. There, she worked on legislation related to the Columbia River Gorge National Scenic Area Act, and other wilderness bills, gaining the W.O. (Washington Office) experience that helped her advance. She returned West in 1986 as deputy forest supervisor of the Mt. Hood National Forest. There, she entered the realm of the spotted owl and the marbled murrelet, two birds whose endangerment reduced timber harvests and budgets, and

505 Wendy Milner Herrett, Interview by Jacqueline Reiner, Salem, Oregon, June 13-15, 2000. FHS Oral History Collection, Durham, North Carolina, 2001. 
slashed staff throughout the decade. From 1990 to 1992, Herrett ran the Siuslaw National Forest as forest supervisor. She then became director of Recreation in the Northwest, one of a limited number of female directors in the agency and the only woman on an all-male management team. ${ }^{506}$

Susan Odell, the agency's second female district ranger, made her way to the West and in the Forest Service also through an alternative path. Odell, an Oregonian until age thirteen, obtained a Bachelor's in Forest and Wildlife Management from Virginia Tech in 1973, with special emphasis on "environmental conservation." After three years as an environmental educator on the Mount Rogers National Recreation Area in Virginia, she moved to Oregon as a forester in presale and sale administration on the Malheur National Forest. There, she and a colleague, Brenda Woodard became the first female chair and vice-chair of an SAF (Society of American Foresters) chapter in Oregon. After two and a half years, Odell transferred to the Ochoco National Forest in Prineville, Oregon, where she worked in the Planning Department as a writer-editor for two years, spending one as the forest's public administration officer. While on the Ochoco, Odell participated in creating the Women in Forestry newsletter/journal, in part because she and other emergent professional women hoped to figure out together how to balance career and family. Odell, who married her college sweetheart, described their relationship as "non-traditional" and her husband as a "trailing spouse," who followed her career rather than the reciprocal. She had always assumed she would either work part-time or leave the workforce to raise children, but times were changing. As her

506 Ibid, "Biographical Summary." 
career progressed, she and others began to ask, "Was the Forest Service going to be an entity that could handle professional employees having children and still trying to have a career?" ${ }^{507}$ Without role models in natural resource arenas, "let alone the Forest Service specifically," female professionals had no idea how to manage career and family. In turn, the Forest Service had to determine how to handle issues associated with women in leadership positions and in the field. Susan Odell unexpectedly moved to the forefront of these issues by entering the line in 1980 as the second female district ranger in the nation, the first with a forestry degree.

She also became one of the first women to advance in the wake of the 1978 Region 5 consent decree. While she recognized that the agency "fast-tracked" her to district ranger on the Mariposa Ranger District, Sierra National Forest, she attributed her rapid rise to an education reflective of organizational needs in the era of the ologists. In fact, Odell had no plan to enter the line until others suggested it: "I was on the Ochoco and was on the forest planning team, and we were wrapping up the unit plans, and they were going to go to a different structure. There were a couple of people that were encouraging me to consider to apply to be the new planning team leader." Instead, she sought supervisory experience on a district and applied for staff positions. She recalled "pretty much looking at lateraling from that SO [Supervisor's Office] job on the

507 Miner, "Opened Doors," 4; Background Information for Susan Odell, Resume, FHS Collection F18.4. 
Ochoco." ${ }^{508}$ And this is where she ran into what some call the sticky floor, the repeated rejections that meant she would not advance.

One day, though, three different people told her about a ranger job on a GS-11 district. "There aren't many of those left. You ought to go look at it," said a colleague. At first, she laughed. When the second person approached her, she looked at the position description and thought, "Well, GS-11 ranger, yup. I've heard there aren't that many of those left. But it's still a real ranger job. It's still a real district. ${ }^{, 509}$ However, she did not mention the position to her husband until the forest supervisor suggested she apply:

At the time, I think it was something like twelve or thirteen evaluation criteria in addition to the SF-171.... I had my portable typewriter at home, and I'd be working on some of these evaluation criteria, and I'd go, Oh, I can't do this. And I'd walk away from it and go have a cup of coffee or something, and then I'd think, Well, no, I promised myself I'd sit down and try to see if I could respond to each of these criteria and what I would think at the end. And so by the end of the weekend, I said, Well, if I get offered the job, I have to have faith that any forest supervisor cares more about the district and the responsibilities than they do about anything that was cooking at the time [sic; that is cooking now] about hiring more women or whatever, that the forest supervisor is going to have to think I really can do the job. And I'm going to have to trust the system from that standpoint.", 510

By the time she finished writing the application, Odell believed she could do the job.

She began to see her diversity of experience as a benefit to the agency, to say: "Wow!

This is different than somebody who's only done timber work the whole time." Lack of a "traditional, straight timber forester path" and the "environmental conservation" option provided her with the "all the core courses for forestry." She had also taken electives

\footnotetext{
$508 \quad$ United States Department of Agriculture, Region 5 Oral History Project. Susan Odell Interview by Aaron Shapiro, May 8, 2007, Washington Office, http://digitalassets.lib.berkeley.edu/roho/ucb/text/odell_susan.pdf [accessed January 21, 2015]. $509 \quad$ Ibid, 63.

$510 \quad$ Ibid, 64.
} 
like Economics, Urban and Community Planning, Air Pollution, and even a course on Mining, Man, and the Environment, "really a different way of, ... putting forestry into perspective, from my standpoint in terms of: What else do you need to know if you're going to be a forester for the future?" ${ }^{511}$ Reflecting on the process, she realized her strengths lay in being "a natural resource and people specialist.... an integrator." ${ }^{\text {512 }}$ That is what qualified her to become a district ranger.

Odell spent nearly four years on the Mariposa Ranger District, where she carried her training and experience from Region 6 into the Pacific Southwest Region by facilitating workshops. She then moved to the Big Bear District in the mountains east of San Bernardino, where she became the first female line officer to have a baby. ${ }^{513}$ When Odell returned to work she faced a new challenge: how to lead while raising children. The federal government only slowly began to recognize that working parents needed support, so that availability of childcare and flexibility for parenting varied widely. Odell recalled that she and some others "started pioneering the idea of bringing child care into the planning of critical training sessions," making it possible for professional women and single parents, male and female to participate in important activities. ${ }^{514}$

\section{Structural and Informal Barriers to Line Positions}

I would like to share with you some thoughts and opinions on why I think women in line management are a valuable asset to the Forest Service. First of all, the roles of line officers in the Forest Service are changing. The days of the Ranger

Ibid, 20.

Ibid, 66.

Ibid, 92 .

Ibid, 93-94. 
being the technical expert in Silviculture, Range, Fire, and Recreation are over. More and more, Rangers are being required to be people and program managers. We set District objectives, resolve programmatic conflicts, deal with performance, career counseling and listen to and work with our public. Because of the change in roles, there is a new emphasis on people management skills such as listening, conflict resolution, negotiation, public speaking, and counseling. Through socialization, women have developed many of these skills and come to the workplace ready to complement the skills of their male peers. - Mary Jane Moore, Region 4 Line Officers Meeting, Boise, Idaho, $1986^{515}$

In 1986, Mary Jane Moore, a district ranger on the Sitgreaves-Apache National Forest spoke at a Region 4 line officer's meeting about how the agency could "do better" regarding women. By better, said Moore, she meant "more numbers and more successes," for women in line. Moore's speech reflected the changing operational context in the era of entwined diversification. Working with the public had become increasingly important and while many people believed that women inherently possessed "people management skills," Moore pointed out that women had been socialized in ways that could now benefit the agency. Moore had "often puzzled over the problem of increasing the number of professional women in the Forest Service." Having "looked at numerous "certs"" with women rarely on the list, Moore identified a "pipeline problem." Just about the time the number of women in natural resource education programs had begun to increase, the Forest Service reduced its hiring at professional trainee levels. Consequently, even as more women obtained natural resource degrees, employment opportunities decreased.

\footnotetext{
515 Mary Jane Moore, “Women Rangers - How Can the Forest Service Do Better?” speech by Mary Jane Moore, Lakeside District Ranger, Apache-Sitgreaves National Forest, Stamped March 31, 1986 Personnel Mgt., FHS Collection 18.4.
} 
Some men perceived opening the line to women, "as a threat to their opportunities for career advancement," said Moore; however, competition also came from expanding occupational opportunities. The only way to minimize the threat would be to "continually emphasize the organization's expectation of excellence and leadership in line management." Nor should natural resource background be the "primary determinant" for the kind of district a person should manage. "I think that today a person's skill in program and budget management and execution and their people management skills may be more indicative of potential success on any district than their technical knowledge in a resource field. ${ }^{, 516}$ Although, "this question of resource experience is a very key one," she said, it limited opportunities for women as rangers.

Mentoring also played a key role in adding women professionals to the agency. By 1986, hiring limits meant that future ranger candidates already worked for the Forest Service. They simply awaited identification, training, and positions. What is mentoring? asked Moore. ${ }^{517}$ It had existed "for years" as part of an "informal system of career advancement," she said. "I know that I have had at least three" mentors who "... were extremely helpful to me in my career development, in that they provided emotional support, alternatives for career paths, exposure and more importantly some degree of advocacy." Sometimes, they even provided "a much needed kick in the hind end when I needed to get going or when I had started to slide." Leadership had a responsibility to identify those with potential, and "deliberately set about mentoring, nurturing, and

$516 \quad$ Ibid, 2.

$517 \quad$ Ibid, 3. 
sponsoring these people. They need us and our organization needs them," she advised. 518

Next asked Moore: How do we increase the number of "successes" for women leaders? Her answer lay in expanding conceptions of potential based on skills needed for the job, rather than natural resource background, a reflection of entwined ecological and occupational diversification. Her own achievements stemmed from "skills in public involvement, developed over 12 years in land management planning." As a ranger, "daily interaction with a large and diverse number of interests" meant developing conflict management skills and improving the Forest Service image in the community. Location, too, could make a difference. For example, Northern New Mexico was not "ready for a woman line officer" in 1986, said Moore. ${ }^{519}$

Barriers to the line also connected directly to formal issues associated with entwined diversification. Until the late twentieth century, the typical path to agency leadership included moving from woods worker to mid-level forester to administrator. The professional forester would train in the woods, learning to mark timber, build trails, maintain campgrounds, and engage in sundry maintenance activities before ascending the line. This young male forestry graduate might become a district ranger in ten to fifteen years, with forest supervisor a distant but potential goal. A select few would become program directors with even fewer rising to regional forester. By the late 1980s, women began this trek, moving from woods workers to mid-forestry positions,

$518 \quad$ Ibid.

Ibid, 4. 
preparing management plans, administering timber sales, and working with planning teams that included co-workers in biology, recreation, hydrology, soil science, archaeology, geology, and more. ${ }^{520}$ Individuals might advance to relatively high GS levels in Administration or as Natural Resource Staff, but the primary agency decisionmakers in USFS - line leaders-required classification as GS-460 foresters.

Consequently, even as the number of women increased in USFS, their work in typically female occupations like Information and Education/Public Affairs, and Recreation kept most of them out of decision-making positions well into the 1990s.

\section{Moving Up the Line}

High Level Line Leaders - The Women's Trail Through Region 6

And, anyway so we had a meeting in Portland. The forest supervisors sent all their Federal Women's Program Mangers in, all their part-time people. I remember... that we were sitting in a circle and talking about: where do we want to go in twenty years? So we had all these goals ... we wanted to have a woman regional forester in twenty years. ... and then we had ... the greensheet, which was our Region 6 [newsletter]. And it was published in this, and I remember going down the hall and some men laughing at us: "Oh yeah! A woman regional forester!" And they laughed.

And one of the people in the room, who was part of this setting goals... was Linda Goodman. She was a GS-3 clerk at that time. No one would ever have imagined that from a GS-3 clerk, personnel clerk, she would have gone on to become the regional forester, but she was the first woman regional forester [in the region]. It was past the twenty year time frame. - Mary Albertson, 2014

In the era of entwined diversification, only a few women advanced via traditional occupational pathways like forestry, Abigail Kimbell among them. As a child, the

$520 \quad$ Miner, "Opened Doors," 4. 
Boston-born Kimbell spent summers in the White Mountains of New Hampshire and loved the outdoors. The Forestry Program at University of Vermont, where she was one of only three women in the program led to her first summer job for the Forest Servicein Region 6. Kimbell "absolutely loved it," in part because stories of Oregon had called to her since childhood: "With the wild animals it was incredible. The huckleberries were great, the mushrooms... it was my first time in the arid west..." After graduation in 1974, Kimbell went to work as a temp on the Umatilla National Forest. So, when the Bureau of Land Management (BLM) called her for a permanent job, she jumped at the chance, not knowing she would be the first female forester at the BLM office in Medford, with "no female engineers" and only one female forestry technician. Then, said Kimbell: "I had this wild hair I had to get to Alaska. And the BLM didn't hire foresters in Alaska... but the Forest Service did," so Kimbell became a presale forester in Kodiak, Alaska. When an undesirable transfer appeared imminent, she applied for an advanced technical training program at Oregon State University instead, completing a master's in Forestry and Forest Engineering in $1982 .^{521}$

With experience under her belt and an advanced degree, Kimbell should have been a shoe-in for any job. But hiring women in non-traditional positions could be difficult. Linda Goodman recalled:

$521 \quad$ Abigail Kimbell Interview by James Lewis, April 17, 2012, draft, Forest History Society Oral History Collection; “Abigail Kimbell: $16^{\text {th }}$ Chief of the Forest Service, 2007-2009," U.S. Forest Service History on FHS Website, http://www.foresthistory.org/ASPNET/People/Kimbell/Kimbell.aspx [accessed November 24, 2014]; “OSU Forestry Alum Chosen as New Forest Service Chief,” Oregon State University College of Forestry Website, http://www.cof.orst.edu/cof/news/forestservicechief.php [accessed December 5, 2014]. 
...talking to a district ranger. He was six-foot-ten and I was wanting to hire a woman... she went to school at Oregon State. It was a year-long program and when she finished she needed to find a job. And as a special emphasis program manager I got her name. So I went over and interviewed her and talked with her and knew we needed to hire her. I knew we needed to bring her on board. She was already a federal employee so it was just a matter of us on the Willamette agreeing. And I remember talking to this six-foot-ten guy and I ended up standing on a chair so that he and I could be eye to eye and I said, "All I'm asking is that you interview her. If you don't want to hire her, you don't have to but I'm asking you to interview her." And he agreed to interview her and he ended up hiring her. And she's been successful in every job she's ever been in. We really liked her. ${ }^{522}$

The woman was Abigail Kimbell, who moved through the ranks as district planner, then district ranger in Kettle Falls, Washington from 1985 to 1988, then in La Grande, Oregon until 1991. From there, she returned to Alaska as a forest supervisor on the Tongass National Forest, where she stayed until taking over Wyoming's Bighorn National Forest in 1997. Between 1999 and 2002, Kimbell headed up two more national forests and national grasslands, before landing in Washington, D.C. as the Associate Deputy Chief for National Forest Systems. In 2003, Kimbell became a regional forester in Montana, following in the footsteps of Elizabeth Estill and Eleanor Towns, the only two female regional foresters prior to $2000{ }^{523}$ Linda Goodman had been third, appointed regional forester of the Pacific Northwest earlier in 2003. Little had Goodman or the looming district ranger known in the 1980s that they were hiring the agency's first female chief. Nor did Goodman know she would both lead and follow Kimbell as a

\footnotetext{
522 Linda Goodman, Interview by author, May 10, 2005, Portland, Oregon. Region 6 Civil Rights Collection.

523 Both were appointed in 1998, Elizabeth Estill in Region 1, and Eleanor Towns replacing Chip Cartwright in Region 3, the Southwest.
} 
"first" in the agency, especially because she did not have a forestry background, the main criterion for the line.

Goodman, who grew up in Washington State, came to the Forest Service when her husband became a teacher in Quinault, Washington. "And in Quinault you could do about three things": work at the school, become a logger, or "you could work for the Forest Service." She chose the latter: "I started as a receptionist - typist at the Forest Service over thirty years ago now, in September of '74," she recalled in a 2005 interview. ${ }^{524}$ Ultimately, Goodman found that she liked supervising people, loved the agency's esprit de corps, and quickly learned about natural resources. On the Willamette National Forest, she moved into "an employee development position," which increased opportunity. She remembered: "I had a really good supervisor who was a great mentor [Fred Schultz] who asked me if I had thought about going back to school. So that's how I ended up going back to school and getting my degree" in Management. Several moves later, Goodman became a personnel officer and then an administrative officer. Other mentors followed, people who told Goodman, "You ought to try this. You know, 'why don't you go do this?"”

Tom Thompson, who retired as Deputy Chief of National Forest Systems and would mentor many diverse candidates, proposed her first line officer experience. "Why don't we have you go try a detail as a district ranger?" he told her. "And I went out to the Oregon Dunes, the National Recreation Area, outside of Reedsport, and was acting

\footnotetext{
524 Linda Goodman, Interview by Andrew Kroger, May 3, 2005, Portland, Oregon, Region 6 Civil Rights Collection.
} 
ranger for four months. I absolutely loved it." Without "that taste of managing the land," Goodman may not have become a regional forester, she said. Her journey also included a stint as "acting deputy forest supervisor" on the Siuslaw National Forest, a "really long term assignment without actually having the job, ${ }^{, 525}$ and an opportunity to earn the forestry credits needed to qualify as a GS-460 Forester under the Office of Personnel Management, the same certification obtained by Gloria Brown. ${ }^{526}$ Goodman converted "to a forester right about the time the Forest Service looked at how hard it was for diverse people, from diverse backgrounds, whether they be engineers, or biologists, how hard it was for them to qualify to become rangers." ${ }^{.527}$ In 1995, Goodman became director of the agency's eighteen Job Corps Centers, headquartered in Denver, Colorado. She returned to Portland four years later as deputy regional forester for Region 6. From October 2001 to June 2002, she got her "W.O. experience" as acting chief of staff for the Forest Service, a position created to mentor those with potential into high level positions. ${ }^{528}$ When Goodman went West again in 2003, she did so as regional forester for the Pacific Northwest, where she remained until her 2008 retirement.

\section{The Associate Chiefs}

The relationships amongst women leaders demonstrate how female representation in leadership often begets the presence of other women along the way.

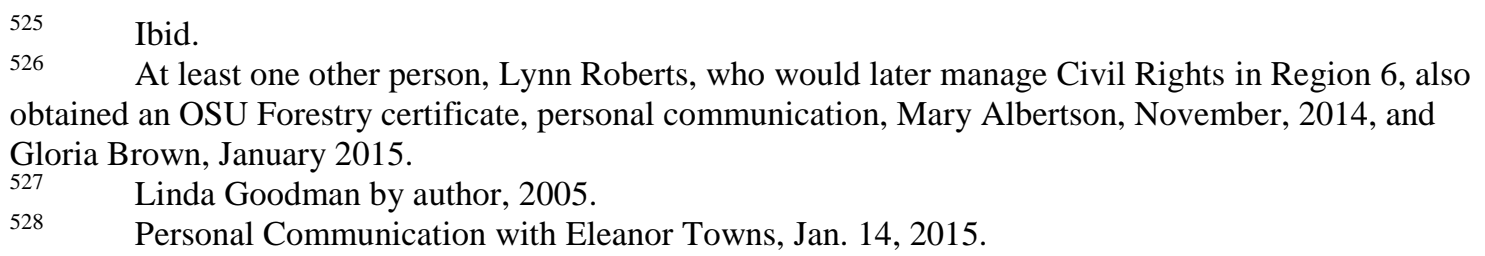


Like most women at high levels in USFS, Sally Collins - a mentor to Linda Goodman and others - took an alternative route to the top. Collins earned a B.S. in Recreation from the University of Colorado and headed straight to graduate school for a Master's in Public Administration at University of Wyoming, emphasizing Planning and Natural Resource Management. Despite summer work with the Forest Service, the avid backpacker decided the BLM would provide a better fit. Collins became a wilderness specialist in Colorado and then a NEPA coordinator in the same office, followed by a stint as the state's mineral leasing specialist for BLM. But, when her husband got accepted into Oregon State University's Oceanography Program, Collins joined the Forest Service. For three and a half years, she worked as a half-time planner on the Siuslaw National Forest and did mineral leasing work in the Portland regional office. She then became a staff officer on the Deschutes National Forest in eastern Oregon, in Lands and Minerals, before becoming deputy forest supervisor on the Deschutes in 1993 and forest supervisor in 1996. During her last year on the Deschutes, Collins entered the Senior Executive Development Program. When she left for Washington, it was as Associate Deputy Chief, a position she held for fourteen months before she became Associate Chief from 2000 until 2008, the highest ranking officer in the agency after the chief. $^{529}$

\footnotetext{
529 Sally Collins went on to work as head of the Department of Agriculture's federal Office of Ecosystem Services and Management. Keith Chu, "Sally Collins eager to explore 'big ideas' for region," Bend Bulletin, February 22, 2010, http://www.bendbulletin.com/news/1418360-153/sally-collins-eager-toexplore-big-ideas-for [accessed January 14, 2015].
} 
The next female Associate Chief for the Forest Service, the forester Mary

Wagner joined the agency via the YACC (Young Adult Conservation Corps), a short-

lived cousin to the YCC for young adults ages $16-23 .{ }^{530}$ Wagner found her first mentors

through the YACC position she held in the headquarters office of the San Bernardino

National Forest:

I met the forest botanist and the forest range conservationist and the fire management officer and the forest wildlife biologist. And those four individuals sort of took me under wing as a little enrollee, and I got to go out on a national forest and do all of the really cool work that people would imagine a forest ranger got to do, and that was it. I wanted to work for the Forest Service after that. 531

After community college, Wagner headed to Humboldt State University for a degree in

Forest Management and remained in touch with the San Bernardino folks as a Co-op Ed

student. Although USFS had offered her a forester trainee position, budget cutbacks

forced the agency to withdraw the permanent job offer by her 1981 graduation, so, she

said, "I can understand why this isn't going to happen but do you have anything?

Anything at all?" So, the agency sent her to fire school on the Salmon River outside of

Warren, Idaho. There, she learned to run a chainsaw, how to drive a fire engine, and how

to put fires out, "and it was just a really great time," Wagner recalled fondly in 2013. All

\footnotetext{
$530 \quad$ Code of Federal Regulations, PART 32 - GRANTS TO STATES FOR ESTABLISHING YOUNG ADULT CONSERVATION CORPS (YACC) PROGRAM [ 43 CFR 32 ], http://cfr.regstoday.com/43cfr32.aspx [accessed January 21, 2015]; the YACC started late in the 1970s and provided adults with year-round conservation-related employment and education opportunities. YACC had an annual appropriation of \$260 million, employed about 25,000 individuals, and operated at state and federal levels. Funding ended for the YACC as a result of the 1980 federal elections, "but the program would provide a working model that many future state and local conservation corps would utilize." U.S. Department of Interior $21^{\text {st }}$ Century Conservation Service Corps Advisory Committee, "History of the Service and Conservation Corps Movement," http://www.doi.gov/21csc/history/upload/21CSCBackground.pdf [accessed January 21, 2015]: 2. Mary Wagner Interview by Donna Sinclair, February 13, 2013, Rosslyn, Virginia.
} 
of this occurred under a supervisor named Bob Schneider, who cared little for "what you could not do." Rather, "What he could train you to do was the issue. So he invested in us, because there were men who didn't know how to operate chainsaws as well. So all of us learned how to do that together." Wagner got lucky: "Bob Schneider was that supervisor who left that indelible impression that it was quite possible for everybody to succeed here, no matter what you knew."

In 1983, Mary Wagner became a permanent employee on the "classic old style" Fairfield Ranger District, Sawtooth National Forest. Being a female forester in Idaho in the 1980s could challenge the boldest of young women. As Claire Lavendel, also sent to Idaho in the 1980s, explained, she had been told to wear a dress on her first day as a forester. She refused. Wagner's difficulty came from knowing she competed directly for a job with a young man who had worked at the district as a temp for several years:

...I wasn't really in tune with that dynamic until it was sort of after....Because it was all so fresh and so new and shoot, I thought I had died and gone to heaven. Fairfield, Idaho, a town of four hundred people and I'm thinking I've died and gone to heaven because the Forest Service wanted me and I got a job.

When she moved to the Forest Supervisor's office (S.O.) in Twin Falls, she began to notice the changing workforce. As Wagner explained, the regional forester's team decided to diversify by bringing non-traditional candidates into leadership positions, starting at the GS-9 and GS-11 levels and adding deputy district rangers into the mix. "I ended up in one of those positions," she said:

...so when I got a GS-11 Resource Assistant position or TMA position, part of that was an invitation...to actually be in a developmental role on the Forest Leadership Team. So, I got to see what district rangers did and what staff officers 
did and what a forest supervisor did, before I had an inkling that that was even anything I was interested in.

Wagner went to Twin Falls in 1987 as a GS-9. By 1989, she became a district ranger on the Vernal Ranger District in Northeastern Utah. ${ }^{532}$ She then spent the next twenty years in key leadership positions, gaining experience throughout the West as a district ranger in Carson, Nevada, then on the Humboldt-Toiyabe National Forest where she worked as deputy supervisor before becoming a forest supervisor in Utah. Along the way, Wagner obtained a master's degree in Public Administration and then went to the W.O. as the agency's first Director of Wilderness and Wild and Scenic Rivers and Assistant Director for Recreation, Heritage, and Wilderness Resources. In August 2008, Abigail Kimbell appointed Wagner as Regional Forester for the Pacific Northwest, a replacement for Linda Goodman. In 2011, Mary Wagner followed Sally Collins to the position of Associate Chief.

Entwined Diversification, the Line, and Women of Color

When I went back to Montana, again the Forest Service was still in this mode of supporting people of color, women, to be successful in mainstream and in leadership roles in the Forest Service. And the timing was great for me. The region I was in put on a number of assistant or deputy district ranger jobs that they wanted to use to be able to recruit a good pool of women and minorities to get into leadership roles. And they're all competitive and one of those jobs came up in a town that was just literally a half hour from where I was working and maybe twenty minutes from where I lived. - Leslie Weldon, 2005

When Mary Wagner left for Washington, D.C. in 2011, Deputy Regional Forester Elizabeth Agpaoa replaced her as acting regional forester in Portland before 532 Ibid. 
transferring to the Southern Region. Agpaoa, the daughter of a Filipino father and a Chinese mother, was in the vanguard of a new contingent of leaders who entered the agency in the late 1970s and early 1980s. Her path to regional forester illustrated entwined diversification in action via shifting ecological ethics. Agpaoa, who graduated from Humboldt State University, learned about the Forest Service at a job fair via a Pacific Northwest recruiter, just as she settled on Biology as a major. The recruiter sent her application to the Willamette National Forest and Human Resources brought her on as a Co-op Ed intern. From 1979 to 1981, Agpaoa spent summers as a "Wildlife Co-op" on the Oakridge Ranger District, where she implemented projects created under legislation that allowed the agency to leverage dollars from timber sales to use for wildlife habitat. "So," she said, "my first job on the forest was to come up with different projects for wildlife, to tap these funds... and then ... create the projects, and then at some level implement the projects."

Agpaoa soon became a district biologist on the Blue River Ranger District on McKenzie Bridge. As she recalled:

... when I first came in I was the only woman professional biologist, but by the time I was five years in, there were a number. Of course, we all knew who we were, so that kind of tells you how few we were. [amused] But there were a number of biologists, both men and women, at that time. ... it was the big boom day of the Willamette. So, because of their budget and their workload, they were able to hire a huge amount of new employees who were these employees ... of interdisciplinary skills, gender diverse, and ethnic diverse. ... So, you know, probably within five years in the early ' 80 s, it just really started booming from where I sat on the Willamette. ${ }^{533}$

533 Elizabeth Agpaoa, Telephone Interview by Donna Sinclair, January 20, 2014. 
Part of the boom had to do with RPA (Resources Protection Act) and NFMA, both of which called for professional forest plans but most growth came from massive timber sales. The Willamette cut as much as 900 million board feet per year in those days, ${ }^{534}$ which meant it had money for everything from Co-op Ed employment to civil rights training, to the leadership training that Agpaoa described as primarily "for the public, and for the different meetings that we were having with people of different interests." Training included conflict resolution, collaboration, and "just how to communicate difficult ideas. How to be in a room with people that disagreed with you," something agency employees encountered more and more as the organization became ensnared in conflicts between big timber and environmentalists.

Agpaoa spent nearly twelve years working in the field, first as a district biologist on the first round of forest plans, then as a planning biologist. From there, she went to the regional office in Portland and became a NEPA (National Environmental Policy Act) specialist. In 1991, Ms. Agpaoa became district ranger on the Galice Ranger District, Siskiyou National Forest in Oregon, her home until 1998. When she arrived, she found five other rangers, all women, but she became the first Asian woman ranger for the Siskiyou National Forest, likely the first in the agency. She described the job as:

... a special thing. My first time I supervised or was responsible for ... fifty people ... those first fifty, there's just something special about your relationship with them, and the kinship, and the fact that the district is where the rubber meets the road...

\footnotetext{
$534 \quad$ Lawrence and Mary Rakestraw, USDA Forest Service Pacific Northwest Region, "Appendix Willamette National Forest Commercial Timber Sales, 1909-1989," History of the Willamette National Forest (1991). http://www.foresthistory.org/ASPNET/Publications/region/6/willamette/app-7.htm [accessed April 11, 2015].
} 
everything that happens on the land happens at a ranger district.... It was a great time."

It was also a time of severe cutbacks: "We went through several cycles of reduction because our timber sale volume dropped hugely. We were the first forest in the region to really have to take that big drop." By the mid-1990s, "we started reducing really big." By the time Agpaoa left the Galice in 1997 to work as a Planning Director and Information Officer, her staff had been cut from 50 to 25 . But, her communications training on the Willamette had prepared her well. Liz Agpaoa continued to move up the line, first as forest supervisor on the Cibola National Forest in Northern New Mexico, then in Washington, D.C. as Chief of Staff for Dale Robertson:

And the Chief of Staff was a call from the Associate Chief, [Sally Collins] asking me if I was going to put in for this job. And actually, she called in April, and she said, "Isn't Sam graduating from high school?" [laughs] I said, "Yeah, he is." She goes, "Well, what do you think about putting in for this job?"

Agpaoa told Collins, a former Northwest colleague, that she did not want to go to D.C., her children were in high school. But:

...you want to help your leaders. That's sort of the Forest Service thing. If leadership needs help; you want to help them. For Sally to call and tell you, "You've got to put in for this job; would you consider putting in for this job?" I said, "Yes. I'll put in for it." So I was lucky enough to get it.

The position took Agpaoa from "balance in the Southwest to political firestorm... It was a huge challenge. I tell people it's lightning in a bottle, that's how it was." She not only learned to understand power but sometimes "saw power not used well" in the Washington Office. Still, the position provided a ticket up the ranks. Agpaoa recalled 
asking Robertson if he would support her advancement. He did, and sent her to the Northwest as deputy regional forester under Linda Goodman. When Goodman retired in 2008, Agpaoa became "acting" regional forester until Mary Wagner arrived. "[T]he next logical step was a regional forester," said Agpaoa. "Because there's only nine of them in the whole Forest Service," the question to Chief Abigail Kimbell was: "Do you think I'm ready for it? Would you consider me for it? And the answer was, 'Yes, we would."' Kimbell sent Agpaoa to Atlanta, the first woman regional forester for the South:

So the last three jobs have been sort of compulsive, and not assumed, because they are just so few and far between at this point. Thirty thousand employees, and there's only nine of these. It's not assumed, and you can't assume them, because I think it has to be a conversation. ${ }^{535}$

Yet another female regional forester entered this conversation via the Pacific Northwest, Leslie Weldon, a fisheries biologist and African American woman.

Born to a military family in Pullman, Washington, Weldon spent her youth in suburban Oxon Hill, Maryland but became familiar with forests on the Blue Ridge Parkway of Virginia through the YCC. She started her college career in the forestry program at Virginia Tech but soon turned to Biology. When Chip Cartwright visited his alma mater with another recruiter to bring minority students into the Forest Service, they encountered Weldon, who loved the idea of working in the Northwest during the summer. In 1981 Leslie Weldon became a Co-op Ed employee "way out West" in Washington State, and entered the pipeline that would make her a Forest Service star. During her first two years, Weldon monitored seedlings, fought forest fires, and hooted 
for owls on the Mt. Baker-Snoqualmie and Umpqua National Forests. Then, degree in hand, she became a full-time employee in Washington State in 1983, then a staff biologist for the Northern Region in Missoula, Montana from 1987 to 1991. Next, she decided to:

go and explore what it would be like to be in line, to be in a district ranger job and I didn't want to just immediately apply for ranger jobs. I was a GS-12 and ranger jobs were GS-12 at that time in many places. I could have just straight out competed but I had been off the ranger district for so long. I wanted to be prepared for what I would be taking on and I have a deep commitment to myself that any position that I go into, I can fully do. You know, and rely on my experience, that would show that I am competent for a job. Because there is enough stigma that came already for me getting into positions that, "Oh, she got selected because she's an African American woman." And while in cases I was helping the agency meet their goals, I wasn't ever and I never will take a job that I'm not fully prepared to get into. So, what I chose to do was compete as a twelve and I competed for a GS-11 job, so it was a voluntary downgrade ... 536

Knowing the hurdles she faced as an African American woman whose performance would be closely judged by all, Weldon chose a status downgrade in order to ascend. In 1992, she moved into the line as district ranger on the Stevensville Ranger District, Bitterroot National Forest. There, she gained experience with the public and sought to "implement collaborative, ecosystem-based management of forestlands." 537 Another opportunity arose in 1996, one that provided an alternative type of W.O. experience. Weldon became Forest Service Liaison to the U.S. Army Environmental Center in Maryland, where her work continued to reflect an agency shift in thinking, as the notion of managing ecosystems expanded USFS horizons. As liaison, Weldon

\footnotetext{
536 Leslie Weldon Interview by Tania McDonnell, May 11, 2005, Bend, Oregon. Region 6 Civil Rights Collection.

537 Leslie Weldon, Deputy Chief, USDA Forest Service, Biographical Sketch, March 16, 2012. Personal communication with author, February 2013.
} 
pioneered an interagency partnership for technical assistance in natural and cultural resource management on army bases and other military installations. She then moved even further into the realm of decision-making as Executive Policy Assistant to Chief Mike Dombeck in 1998. When Sally Collins went to Washington, D.C. as Associate Chief two years later, Weldon replaced her as forest supervisor on the Deschutes National Forest. While in Oregon in 2005, she explained her motivation to enter the line: I have other African American women who came before me, and Gloria [Brown] is one of them you know. I'm on Gloria's shoulders. She was the very first [female] African American forest supervisor in the Forest Service and that was only six years ago [1999], which is just amazing, who came and opened it up so that I [say], "Okay, I can do that too.",538

Despite pressure to advance, Weldon remained in Oregon for seven years. She waited until her twin sons graduated from high school in 2007 before returning to D.C. in charge of External Affairs in the Office of the Chief, a position that provided another major rung on the ladder of achievement. Before returning West two years later as the Northern Region Forester, Weldon directed the agency's Legislative Affairs, Office of Communications, Media, and National Partnership Office. Leslie Weldon became the fifth female regional forester from the Pacific Northwest, of seven women to have ever held the position. Two years later, in 2011 she became deputy chief of National Forest Systems, blazing yet another trail as the first woman and the first African American to serve in this position as lead executive for policy, oversight and direction for natural resource programs in the entire agency.

538 Leslie Weldon Interview by Tania McDonnell, 2005. 
Becoming One of Nine - "Go West Young Woman"

As we increase the number of women in management, I think the message for all employees is that we are seeking excellence in our line officers. The skills are changing and competition for a limited number of positions will increase. Traditional career paths may also change as personal as well as professional goals influence selections. From our pool of potential candidates, both men and women, we are seeking the best regardless of gender. As we continue moving rapidly in this direction, the message of excellence should not only help in increasing our numbers but also increasing our successes. - Mary Jane Moore, $1986^{539}$

In 1976, Debra Stewart studied the career paths of women in federal employment.

Despite affirmative action, women still had not made it to the top. But, she proposed, the government could address the issue by creating alternative paths or "multiple career routes" for women executives. Stewart suggested policies that would support flexible work schedules and institutionalizing permanent, part-time promotion tracks for women while de-emphasizing "freedom of movement" as a criterion for advancement. She also proposed job sharing options for couples, which would benefit men as well. Career counseling, advertising and legitimizing alternatives could facilitate the advancement of women, as would support for comprehensive, quality child care. Basically, Stewart asked the government to view employees as "whole people." Otherwise, women especially, would not succeed. ${ }^{540}$

Still, when Mary Jane Moore spoke in Idaho, a host of ongoing systemic barriers to women in executive leadership remained. A handwritten list of names from 1984 showed just over a dozen women at the GS-14 level and above, an improvement over earlier years but a far cry from anything approximating bureaucratic representation.

$539 \quad$ Moore, "Women Rangers," 5.

540 Debra Stewart 1991, 297 in Carroll, et. al., "Revisiting Kaufman,” 39. 
They included a female research station director, a deputy forest supervisor (Geraldine Larson), and several women in charge of administrative programs like Personnel. ${ }^{541}$ These women, at the vanguard of female leadership, came from a variety of backgrounds, very few with traditional forestry training. Although Geraldine Larson had a forestry degree she also had a master's, not a necessary step for most forest supervisors. Nor had Larson risen through the ranks. Instead, she advanced via a traditional female position in Public Information, a non-traditional job as environmental coordinator, and appointment as deputy forest supervisor without first acting as district ranger. Not surprisingly, Larson's appointment as the agency's first female line officer had occurred on the heels of the 1978 consent decree.

It took another push in Region 5 before the agency really promoted women to higher level leadership positions. In 1988, Judge Samuel Conti ruled the Department of Agriculture in contempt of the initial consent decree and ordered the Forest Service to carry out the ruling over the next three years. That year, Beverly Holmes, a Cherokee woman from Tulsa, Oklahoma moved to Region 5 as Special Assistant to the Chief on Consent Decree issues. Another judge repeated the decision in 1991, the year Holmes became a deputy regional forester in R-5. The number of professional women in the Forest Service jumped to 26 percent the following year, with four women, Holmes included, in the SES. ${ }^{542}$ Beverly Holmes, who joined the Forest Service in 1974 after

\footnotetext{
541 R1 - Barbara Holder; R5 - Geri Larsen, Jane Westenberger, and Gwen Hoover; R-9 - Kathleen Wolfe, Beverly Holmes (INT), Susan Kossoth (SE), Barbara Weber (NC), Anne Fege (NE); WO - Mary Davis (INS), Jo Wentzel (PM), Christine Pytel (AM), Barbara Passuth.

$542 \quad$ See Table 2, p. 11.
} 
seven years with the Bureau of Indian Affairs, was not the only executive female recruited into the Forest Service from another agency.

The first two female regional foresters - also in the West - provide a case in point. Like Holmes, neither advanced via the traditional line officer pathway. Elizabeth Estill, an ecologist and a member of the SES joined the Forest Service in 1988 after fourteen years with the Tennessee Valley Authority. Ten years later, she became the first woman regional forester, managing the Rocky Mountain Region. ${ }^{543}$ Eleanor Towns, also appointed in 1998, came to her position as regional forester through a less likely route. An African American woman from Illinois, Towns had worked with Job Corps as a residential adviser, then in a YMCA program called "Better Jobs for Women.” In 1972, a time she described as "new for minorities [and women] within the government to be working at that GS-11, 12 level," she joined the BLM in Denver, dealing with Title VI of the Civil Rights Act in the Office of Contract Compliance and helped the BLM to write affirmative action plans. ${ }^{544}$ By then, she had a bachelor's in teaching and a master's in counseling and guidance. ${ }^{545}$ When she transferred to the Forest Service in 1978 as regional civil rights director for the Rocky Mountain Region, Towns recalled experiencing for the first time "this whole on the ground, I am the line officer. I am the little sovereign out there in the field" mentality. Meanwhile, she obtained a juris

543 Margaret Rossiter, Women Scientists in America: Forging a New World Since 1972 (Baltimore, MD: Johns Hopkins University Press, 2012): 164.

$544 \quad$ Eleanor Towns, Interview by James Lewis, June 2, 2010, Westminster, Colorado. Forest History Society Oral History Collection, draft.

$545 \quad$ Eleanor Towns obtained her bachelor's degree in 1961 from the University of Illinois and her Master of Arts in counseling and guidance in 1968. She would obtain a juris doctorate in 1982 from the University of Denver. [Eleanor Towns, personal communication with author, January 14, 2015]. 
doctorate from University of Denver's College of Law in 1982, fulfilling a lifelong dream. Towns worked her way up but not through the usual "chairs" as district ranger and forest supervisor. Rather, before she replaced Chip Cartwright as regional forester in the Southwest (R-3), she strategically sought out a position as Director of Lands, Soils, Water, and Minerals for the Rocky Mountain Region, headquartered in Denver, Colorado. She later got her W.O. experience as Director of Lands for the entire agency ${ }^{546}$ Like many women, Towns went West to advance, but unlike most men she entered the line via Civil Rights and two advanced degrees, rather than forestry.

It would be another five years before women reached the position of regional forester via the line - Linda Goodman and Abigail Kimbell in 2003. It took another five to six years before Mary Wagner, Elizabeth Agpaoa, and Leslie Weldon followed - all five from Region 6. As Eleanor Towns explained in a 2010 interview:

There was a time when you absolutely had to have spent some time in Alaska. Okay, Gail had that. I can remember when she was I think a rec person on the Chugach. There was a time when ... you had to have come through the Pacific Northwest. That was the timber powerhouse. And when the Hatfield money dried up and when the spotted owl thing and whatnot, that shifted to the Northern Region.

Towns' statement is borne out by the following list of all female regional foresters to date.

546 USDA Forest Service Website, "Regional Foresters: Eleanor S. Towns,” Region 3 - History and Culture, http://www.fs.usda.gov/detail/r3/learning/history-culture/?cid=stelprdb5199223 [accessed January 3, 2015]. 
Table 12: Female Regional Foresters, USFS, by date of appointment, 1998-2013

\begin{tabular}{|c|c|c|c|c|c|c|c|c|}
\hline & R-1 & R-2 & R-3 & R-4 & R-6 & R-8 & R-9 & R-10 \\
\hline 1998 & & $\begin{array}{l}\text { Elizabeth } \\
\text { Estill }\end{array}$ & $\begin{array}{l}\text { Eleanor } \\
\text { Towns }\end{array}$ & & & & & \\
\hline 2003 & $\begin{array}{l}\text { Abigail } \\
\text { Kimbell }\end{array}$ & & & & $\begin{array}{l}\text { Linda } \\
\text { Goodman }\end{array}$ & & & \\
\hline 2008 & & & & & $\begin{array}{l}\text { Mary } \\
\text { Wagner }\end{array}$ & $\begin{array}{l}\text { Elizabeth } \\
\text { Agpaoa }\end{array}$ & & \\
\hline 2009 & $\begin{array}{l}\text { Leslie } \\
\text { Weldon }\end{array}$ & & & & & & & \\
\hline 2010 & & & & & & & & $\begin{array}{l}\text { Beth } \\
\text { Pendleton }\end{array}$ \\
\hline 2012 & $\begin{array}{l}\text { Faye } \\
\text { Krueger } \\
\end{array}$ & & & & & & & \\
\hline 2013 & & & & $\begin{array}{l}\text { Nora } \\
\text { Rasure }\end{array}$ & & & $\begin{array}{l}\text { Kathleen } \\
\text { Atkinson }\end{array}$ & \\
\hline
\end{tabular}

The table above provides a visual representation of the relationship between the Pacific Northwest and advancement to the Northern Region (R-1) and elsewhere. In 2010, Beth Pendleton joined this charter group as regional forester in Alaska, where she had gained much of her experience. In 2012 Faye Krueger replaced Leslie Weldon in Region 1, the only region to have had three female regional foresters. Kreuger also obtained her experience in the West, from Montana to Idaho to Alaska before serving as deputy regional forester in the Southwest and associate deputy chief for National Forest Systems. In 2013, regions 4 and 9 got their first female regional foresters. While Nora Rasure (R-4) gained most of her training in the West and Southwest, Kathleen Atkinson spent much of her time in the South, gaining some western experience in Wyoming and South Dakota. Ironically, by the time of Rasure's and Atkinson's appointment (2013), only Region 5 - home of the consent decree - had not had a woman regional forester. 


\section{Discussion: Revisiting Herbert Kaufman}

You Have to "be" Forest Service to Lead Forest Service

\section{I hope that women are going in the directions that they really choose now, that they can set goals without feeling like they are pioneers. - Susan Odell, $1984^{547}$}

The 1980s became a change point for the Forest Service, a time when the shifting values of the outside world infiltrated the agency like never before. Bringing women and "ologists" into the Forest Service and ensuring their advancement called for changes in standard paths to leadership, reshaping agency operations and culture. When she first started with the Forest Service in 1973, Susan Odell thought the agency would never accept women in line positions. Only eleven years later she reported, "I am proof that they have been. Women have to be verbal about what they want. It's a challenge to walk a line between informing people of what you want and demanding it." ${ }^{548}$ The women who rose to top levels of service incorporated this lesson into their development. They learned to strategize, to verbalize, to assert, and when to remain silent. As Ellie Towns said, everything she did positioned her to become regional forester, from moving to Lands and Minerals at the regional level to taking a job in Washington, D.C., despite a desire to remain in the West.

By 1992, 40 percent of the Forest Service's 32,000 employees nationwide were women, including ten of the 122 national forest supervisors and 100 of the 617 district rangers. That year, Carroll, et. al. conducted a survey of 127 female line officers, defined

547 Miner, “Opened Doors," 5.

548 Ibid, 4-5. 
as decision-makers in any of the three branches of the Forest Service: National Forest System (chief, associate chief, deputy chiefs, regional foresters, forest supervisors, district rangers); Research (station directors, assistant directors, project leaders); and state and private forestry (deputy chief). ${ }^{549}$ Harkening back to Herbert Kaufman's 1960 assessment of the agency, Carroll et. al. compared values needed for advancement in 1960 versus 1992. In Kaufman's time, promotion to the line was predictable based on: willingness to conform (including waiving personal preferences as to locations, i.e., serving where needed); “technical competency," i.e., forestry or related science degrees were prerequisite, especially degrees in forest science, range science, and engineering; self-selection, i.e. by the time young people entered forestry, they knew what they were getting into regarding hard work, etc.; being mentored toward promotion by senior, more powerful sponsors; and finally, promotion from within. As Kaufman, followed by Carroll, et. al. put it, "one had to be Forest Service to lead Forest Service."550 These were the qualities that gave the Forest Service the "superstar" status asserted by Nienaber and McCool in $1985 .^{551}$

Most (82\%) of those surveyed by Carroll, et. al. also felt that having a mentor had been important to their own advancement. Eighty-five percent of respondents had male and 34 percent had female mentors. In fact, the women highlighted here demonstrate the importance of mentorship. Mindy Hackett did not feel as though she had a mentor, but neither did her significant advancement lead to the line. For her, the formal upward 
mobility program made the biggest difference in professionalization. Those women who entered the line did have mentors, with the same names often cropping up. For example, Craig Rupp who suggested Wendy Herrett enter the line, also asked Eleanor Towns how she would like to advance. Towns had completed her law degree and made a conscious choice to move into Lands and Realty. Tom Thompson is another mentor whose seniority allowed him to make a difference once he identified a promising candidate for the pipeline. In fact, Thompson convinced Abigail Kimbell to leave Colorado for Washington, D.C. in 2001, just as he became deputy chief for NFS. He was also among the first she told about becoming chief. ${ }^{552}$ Once they obtained positions of power, women like Elizabeth Estill, Sally Collins, and many others also facilitated the advancement of other women.

In addition to the role of mentors, Carroll, et. al. had asked whether the agency still followed Kaufman's implied model for promotion. ${ }^{553}$ According to Debra Stewart's analysis, an alternative career path could mean that an employee: "might not have to move nearly as often, possess one of a narrow set of scientific or engineering degrees, require traditional mentors, or even come from within the Forest Service itself." ${ }^{, 54}$ They concluded that Stewart's advancement scenario had not yet occurred at full-scale. Women continued to transfer for promotion, with 43 percent of those in line having transferred five or more times. Nearly 75 percent of the women polled had transferred at least three times. Certainly, the women highlighted here support that contention,

\footnotetext{
$552 \quad$ Abigail Kimbell by James Lewis.

$553 \quad$ Carroll, et. al., 38.

554 Stewart in Carroll, et. al., "Revisiting Kaufman," 39.
} 
confirming the significance of mobility even fifty years after Kaufman (2010). The study findings clearly illustrated that promotion still came from within. "Simply put," they wrote, "one must still be Forest Service to lead Forest Service." 555 To some degree, however, incorporating women into the workforce weakened this notion. Before the agency advanced women internally, several of the early highest ranking females came from outside the agency, their presence also reflective of the entwinement of social and ecological diversity: the ecologist Elizabeth Estill, from the Tennessee Valley Authority; the civil rights director and later regional forester, Eleanor Towns from the Bureau of Land Management, and Beverly Holmes from the Bureau of Indian Affairs, whose work focused on the consent decree and environmental coordination. Perhaps, it could be said that one had to become Forest Service or even leave Forest Service to lead Forest Service. Not only did several of the women highlighted here work for the BLM, Gloria Brown left USFS to obtain experience as a line officer. After she completed school and did a stint as acting district ranger on the Rigdon Ranger District on the Willamette National Forest, the agency offered Brown a temporary one year ranger position. She turned it down, reasoning that a year provided enough time to mess up, but not enough to fix mistakes. Instead, she went to Baker City, Oregon as area manager for the BLM in 1994, a position comparable to district ranger. In January 1997 she returned east to head up the BLM Minerals and Leasing Adjudication Office, and to be closer to her family. But, after years in the West, Gloria disliked the harried environment of Washington, D.C. She came back to the mountains of the Pacific Northwest in October 1997 as 
manager of the Mt. St. Helens National Monument. And Mt. St. Helens was such a

dream job," said Gloria Brown:

because as you know it had erupted in 1980 and this was 1997, and so ... while I was there we actually had the twentieth anniversary for Mt. St. Helens. But it was like working in a laboratory, because you had this natural environment that was recovering from the explosion. So you got to work with scientists and you got to work in environmental education, and you got to see this landscape where you go into certain areas and it had been devastated and you could see the devastation still. And you'd go into another area and you could see all this rebirth, how it was healing itself. It was just amazing. 556

From there, she became forest supervisor on the Siuslaw in 1999, placing her at the fore of the very small group of African American higher level female line leaders. Shortly after Brown went to the Siuslaw, Leslie Weldon took Sally Collins' position on the Deschutes. A very few African American women had been district rangers in the South, but these women were first in the West. ${ }^{557}$

\section{Occupational Diversification and Diversified Conformity}

Until nearly the end of the century, only men - foresters and engineers - led the Forest Service at its highest levels. The major distinctions that arose regarding promotion from Kaufman's time to the twenty-first century had to do with issues of

\footnotetext{
556 Gloria Brown, Interview by Janice Waldron, May 24, 2004, Portland, Oregon. Region 6 Civil Rights Collection.

557 Clara Johnson became forest supervisor on the Chattahoochee-Oconee National Forest in Region 8 not long after Gloria Brown was appointed. According to Cynthia Hale's source from the Tuskegee Ranger District, Denise Cook was the first female African American district ranger - at the Tuskegee. Melody Mobley also worked in the Pacific Northwest during her early training and then rose to become one of the highest ranking African American women in the agency in the early 1990s. Mobley ultimately filed a discrimination suit against the Forest Service and left the agency. Arthur Bryant Interview by Donna Sinclair, January 29, 2013, Rosslyn, Virginia; Steven Anderson Files - Society of American Foresters - Diversity, Forest History Society, Durham, North Carolina.
} 
technical competency and willingness to conform. Mary Jane Moore had addressed one of the main inhibitors to women in line in the 1980s: rigid expectations about resource experience limited their potential as rangers. ${ }^{558}$ One might need to $b e$ Forest Service to lead Forest Service, but must one be a forester or engineer? Moore thought not: ${ }^{559}$ "excellent technical skills does not always mean excellent leadership skills," she said. ${ }^{560}$ In fact, women in line could provide new perspectives: "I truly believe in the ecological concept that diversity is healthy, whether for a forest or an organization. Diversity in line will better enable us to understand and meet the needs of our employees as well as strengthen our ability to achieve our long term mission," she had claimed. Moore was right about imminent occupational diversification. By 1993, women filled more than 14 percent of line positions, moving "through the chairs" as district rangers to reach higher levels ${ }^{561}$ and in 1994, twenty-three women headed up national forests. That year, Chief Jack Ward Thomas, the first and only wildlife biologist to lead the entire agency, made an important announcement for those "ologists" and others aspiring to advance. Line officers could:

now be chosen from a broad range of professional series (the FS title assigned according to one's background). Line officers will now be classified as 340-Series program managers, and line jobs will be open to any professional series. Public administrators and archaeologists will compete directly with foresters and engineers for line jobs. ${ }^{562}$

\footnotetext{
$558 \quad$ Moore, "Women Rangers," 2.

559 Ibid.

$560 \quad$ Ibid, 3

561 Carroll, et. al., "Revisiting Kaufman,” 39.

562 Ibid, 41 .
} 
This policy both reflected and anticipated a sea change in the Forest Service, a diversified conformity that meant the agency employed entirely new groups of people socially and occupationally, while advancement required continued adaptation to the agency's cultural norms. Whereas social diversification brought women and people of color into the agency, ecological diversification meant changes in land management that required professional diversity. The push toward "ecosystem management" would soon require even more diversity. Still, despite the possibility of non-foresters becoming managers, diversified conformity stemmed from the fact that forestry remained the gold standard for advancement and esprit de corps relied on homogeneity of thought. To the end of the century, and likely beyond, employment as a forester or engineer has remained among the best criterion for advancement, with biology close behind.

The trajectory of female regional foresters demonstrates that diversified conformity prevailed in agency leadership, despite expanding notions about who qualifies at the highest levels. Among the first group of female regional foresters, Estill had a natural resource background from the inception, while Eleanor Towns had a master's and obtained both a law degree and W.O. Public Lands experience; however, these two "firsts" were exceptions. Only significant advanced education could compensate for lack of a forestry degree. The newest female regional foresters for example, Atkinson, Kreuger, and Rasure, all trained as foresters, while Beth Pendleton has both a Biology and Journalism master's. The only other female RF's with Biology degrees are Weldon and Agpaoa, also the only two women of color. All of these women joined ranks as regional foresters in what could be called the third round of female 
appointment in 2008 and 2009. In the late 1980s and early 1990s, both Linda Goodman and Gloria Brown had to obtain forestry certification in order to promote into the line. While Goodman recalled the schooling as beneficial, Brown found it relatively useless in her primary duty as a line leader: managing people.

As demonstrated in Chapter Six, historically, women in the Forest Service engaged in environmental education and outreach programs, doing work as a matter of daily operations that became increasingly important in planning and public outreach. The kind of "women's work" entailed in Public Affairs prepared Brown, Odell, and many of those highlighted here for leadership. As the agency engaged in more complex planning processes, these women often typed Environmental Impact Assessments and other planning documents, facilitated community meetings, explained complex scientific issues to the public and absorbed significant resource and agency knowledge in the process. Additionally, as anticipated by those in Civil Rights, the Cooperative Education Program provided a pipeline into the agency. Washington Office experience in departments like RPA provided yet another means of agency acculturation. Cycling people through Washington Office positions like legislative affairs and the newly created Chief of Staff, what Eleanor Towns called a sort of "shadow" governance, provided another. ${ }^{563}$

In turn, as women penetrated the agency at ever higher levels, cultural issues from outside the Forest Service seeped in. Agency newsletters began to address issues faced by working mothers, such as pregnancy in the field, childcare, and the need for flexible 
work schedules. As spouses took turns relocating in the interest of one another's careers, dual career families required elasticity. Families might have to live separately, and professionals may need to fend off advancement pressures in the interest of providing stability for children. Requiring mobility as a key to leadership demonstrates the ongoing need for conformity in the agency. Those who will not move simply do not advance. The fact that all of the high level female leaders highlighted here had to "get their W.O. experience" in order to advance demonstrates conformity, but sometimes with a twist. Sally Collins, Leslie Weldon, and Elizabeth Agpaoa all provide a case in point for the way that diversified conformity operates. Weldon followed Collins to the Deschutes, staying for six years, while Collins had remained for thirteen, time enough for her daughter to go from Kindergarten to high school graduation. ${ }^{564}$ Liz Agpaoa, too, remained in the Northwest for her children's sake. While mobility remains the gold standard for promotion, as Collins pointed out there are some benefits to remaining in place. Collins went to work on the Deschutes in 1987 as a staff officer and then:

... was Deputy Forest Supervisor for three years, and Forest Supervisor for seven. That's enough time to really give a person a sense of what works, and what doesn't work, in a leadership position on a single unit. While there is value in moving around, there is also value in seeing continuity, and having to live with your mistakes - you have to admit them, and move on. So, staying on the Deschutes really worked for me, both personally and professionally. That was the longest I'd lived in one place in my whole life! It's not a plan that will work for everyone, and it's not possible for everyone, but I am grateful that it worked for me.

564 Sally Collins, Associate Chief of the FS, Interview by Daina Dravnieks, Women in Natural Resources, 23, 3, 2002. http://www.webpages.uidaho.edu/winr/Collins.htm [accessed November 2, 2014]. 
None of these high level female leaders were thrust into their positions without more than adequate training and considerable time in service. The combination of mobility and stability provided a wealth of beneficial experience for leadership. In fact, one of the most significant findings made by Carroll, et. al, concerned time in service before entering the line. In 1992, fewer than five percent of female line officers had advanced in five to ten years, although the "story" has been that women and minorities were fasttracked in the 1980s. Not so. Women had to serve as long in previous jobs as Kaufman indicated before promotion to management. More than 86 percent of female respondents in 1992 had ten to twenty years of experience before entering the line. So, wrote Carroll, et. al., "it appears that unhurried promotion is still the norm-years spent in each grade fell well within Kaufman's 1960 expectations.",565

Table 13: Time in Grade before entering the line. Kaufman, 1957, in Carroll, et. al., $1996^{566}$

\begin{tabular}{|l|l|l|}
\hline Grade & Time to Achieve & Average Age \\
\hline GS-9 Forester & 8 years & 41 years old \\
\hline GS-11 & 15 years & 44 years old \\
\hline GS-12 & 22 years & 48 years old \\
\hline GS-13 & 23 years & 50 years old \\
\hline
\end{tabular}

Table 14: Number of years spent by women line officers in federal service, $1992^{567}$

\begin{tabular}{|l|l|}
\hline Years & Percent \\
\hline $5-10$ & 4.8 \\
\hline $10-15$ & 50.6 \\
\hline $15-20$ & 36.1 \\
\hline $20-25$ & 6.0 \\
\hline $25-30$ & 2.4 \\
\hline
\end{tabular}

Certainly, the agency appointed Wendy Herrett and Susan Odell as district rangers relatively quickly. Although Herrett had nine years in the Forest Service, Odell had only

565 Carroll, et. al., "Revisiting Kaufman," 40.

566 Ibid, 40. These statistics are not presented in table form in the article.

567 Ibid. 
six. Although atypical, more than one man also advanced at that pace. That the agency promoted both women to the line on the heels of the 1978 consent decree, and moved them into Region 5, gave rise to general assertions that women advanced without requisite experience. In fact, as indicated above, rapid advancement was the exception, not the rule, and had as much to do with shifts in land management and occupation as gender.

As Susan Odell explained, her qualification for line reflected the need for a new kind of ranger, one as versed in ecosystems as timber. Gender may have played a role in the choices made to advance these women, but occupational diversification held sway. In fact, when it came to discrimination, Liz Agpaoa recalled that in this era of entwined diversification, in her experience ethnicity played the lesser role all around. "I didn't have just ethnic and occupation," she said while laughing:

I had all three. You know, interesting enough, ethnic was not as pronounced, even though I was often in these remote settings. In the beginning, because there was such headway to be made in trying to have a different professional perspective at that time, when we were doing all these heavy-duty, project timber sales, that probably was my day-to-day challenge, was how to integrate the idea of resources with biology. That was probably the greatest day-to-day challenge. ... Gender probably was next, because of the work in the field.... But I have to say that the Willamette, because of it number and size, and probably location to I-5 and Eugene, I didn't really see the challenges of ethnic diversity.

That is not to say that racial issues did not arise for women and men of color. While occupational difference and gender often created barriers both to advancement and internal and external relations, race provided distinctive challenges with which the agency, the public, and individuals had to grapple. The structural and informal efforts 
made by the Forest Service and its employees to move the agency toward a multicultural organization, racially and culturally, are the subject of the next chapter. 
Chapter 8: Moving Toward a Multicultural Organization, 1986-1993

In May 1985, Dick Flannelly, John Karwolski, Cathy Burger, and I met in Milwaukee to discuss Chief Max Peterson's initiative on the Forest Service's Heritage, Values, and Traditions. The Chief wanted to set up a history seminar for Forest Service staff. Dick ... knew that my doctorate is in American History so he included me on the project as a consultant. There was a great deal of discussion at the meeting regarding the different values of new people coming to work at the agency, from a woman and minorities standpoint and also the expansion from the forester discipline as line officers to the "ologists" who were then being hired. I remember Dick wondering aloud, "What is it that ties us all together? We have NFS, Research, and State and Private [Forestry] in addition to all of this new, younger generation." No one said anything at first and then I said, "It seems to me that no matter what your education and background is, people who work for the Forest Service care for land and they serve people. - Dr. Patricia Woods, letter to Lou Romero, December 11, 2009 ${ }^{568}$

In early 1985, the U.S. Forest Service held its first ever agency-wide forest supervisors conference. Known as "Snowbird," this conference addressed agency leaders' concerns connected to advancement, people and politics, balancing resource programs, and Forest Service image, communications, and workforce morale. Those present also chose a motto for the November 13-15 conference: "Caring for the Land and Serving People.” Lou Romero, the agency's only Internal Facilitator and Change Consultant, recalled a positive reception to the slogan. When Robert Tippeconnic, of Comanche descent and supervisor of the Coronado National Forest "passionately" referred "to the conference theme as being the most clear and compelling statement of the Forest Service mission he had ever seen or heard expressed," ${ }^{569}$ others nodded in agreement. Tippeconnic, who would become the agency’s Tribal Government Program

568 Lou Romero, "Caring for the Land and Serving People," The Origins of the U.S. Forest Service Motto." Forest History Today (Fall 2012): 38.

$569 \quad$ Ibid, 36. 
Manager for State and Private Forestry, ${ }^{570}$ was not the only one who appreciated the motto. That month's WO "Friday Newsletter" cited Chief Max Peterson saying that "Caring for the Land and Serving People" meant the agency no longer supported the idea that "We have always done it that way." Said Peterson, "Either We Change or We're On The Path to Becoming Dinosaurs." Peterson's comments about change reflected a new vision for the Forest Service, concretized in an October 1986 "Caring for the Land and Serving People" pamphlet, and carried forward by F. Dale Robertson, who became chief in 1987. By 1993, the motto had become an iconic refrain for the Forest Service mission, reflecting awareness of the association between humans and the environment. ${ }^{571}$ Solidifying connections between land and people occurred in overlapping stages from the late 1980s through the early 1990s, first under Max Peterson, then through Chief Robertson and Associate Chief George Leonard. Both the "New Perspectives/Ecosystem Management" approach to resources and the peopleoriented "Toward a Multicultural Organization" effort, TMO as employees called it, drew from holistic ideals about the value of diversity. Viewed together, these two initiatives solidify the role of entwined diversification in shaping a multicultural organization.

By 1991, the strands of entwined diversification - social, ecological, and occupational - solidified in the TMO report, called the "blue book" by employees. The

$570 \quad$ USDA Forest Service, Toward a Multicultural Organization: Report of the USDA Forest Service Task Force on Work Force Diversity (March 1991): vi (hereafter, TMO Report); Memorandum to F. Dale Robertson, Chief, from Jetie Wilds, Jose Cruz, Corey Wong, Robert Tippeconnic, re: Cultural Diversity on National and Regional Group Assignments, July 26, 1993. FHS Collection F13.3, File, "Work Force Diversity - General."

571 Romero, 36-37. 
blue book extended the work of the agency's Service-wide Civil Rights Committee (SCRC) and reflected an unprecedented leadership commitment to workforce diversity. In a report titled Equal Opportunity is for Everyone, Robertson, the southern-born forester and public administrator, who led the agency until the end of 1993 pointed out two important facts. First, people talked a lot about "workforce diversity," but the term "means different things to different people." Second, he pointed to the "can-do" culture of the agency: "We have always had challenges;" he wrote, "however, none have been insurmountable. Work force diversity is no different.."572 Chief Robertson may have been overly optimistic about both workforce diversity and resource management, but the preceding thirty years had, indeed, bequeathed important lessons. Overlapping strands of diversification since 1960 meant the agency had expanded its definitions of multiple use, had diversified occupationally to meet increased regulation, and had incorporated people into the workforce whose presence would have shocked Herbert Kaufman's forest ranger. As the direction of the agency in the late 1980s showed, diversification required increasing and differential levels of flexibility. To create a truly diverse workforce would require bending agency structures as never before.

\section{A Workforce Reflective of the Nation's Diversity}

\section{A More Modern Organization}

Maybe we haven't done as well with the civil rights issues but, you know, we've done a cultural change in our approach to resource management and we did

572 USDA Forest Service, Personnel and Civil Rights, Equal Opportunity is for Everyone: 1988 Civil Rights Report (1989): iii. 
it, I think, fairly quickly. I don't know what sociologists would say in terms of how quickly organizations like this adapt but, Forest Service today is very different than the Forest Service that I joined back thirty years ago. It's just, almost completely different, it's just almost staggering how our mindset, how the agency's approach to resource management has so fundamentally changed. - John Kusano, 2013

In this chapter, I examine how the Forest Service attempted to create a "workforce reflective of the nation's diversity," the charge of the 1978 Civil Service Reform Act. In the ten years following that mandate, the idea of representation became increasingly important, yet still distant. Between 1976 and 1986, the proportion of women in the Forest Service grew from 22 to 31.5 , then by 1992 to 40 percent of agency employees. Minority employment grew from eight to 12 percent in 1986 and then to 15 percent in 1992, reaching 16 percent in 1996. [See Civilian Labor Force (CLF) and Forest Service - Women and Minorities, 1978-2005, Appendix C, Table C.5]

As late twentieth century leaders strategized to meet social mandates, many employees felt threatened by the idea of USFS "parity" with the civilian labor force. Others scoffed at the notion that the agency moved too quickly. Jose Salinas, Jr., a soil scientist turned district ranger in the Pacific Northwest, declared in 1988: "In the light of the composition of our nation's workforce ${ }^{573}$ and the fact that the Civil Rights Act has

\footnotetext{
573 The minority CLF in 1980 was $13 \%$. Mitra Toossi, "A Century of Change: the U.S. labor force, 1950-2050,” Bureau of Labor Statistics Website, http://www.bls.gov/opub/mlr/2002/05/art2full.pdf [accessed March 18, 2015].
} 
been with us for 25 years, the progress in the last 10 years is not exactly 'rushing into parity.','574

By the late 1980s, the Forest Service sought to move beyond monocultural land management practices and find social heterogeneity at the same time, even as criticism of the very notion of multiculturalism erupted. During the tenure of Chief Robertson, 1987-1993, two major workforce diversity initiatives, "Workforce 1995" and "TMO," yielded substantial progress for one but minimal outcomes for the other. Meanwhile, policy efforts like "New Forestry," "New Perspectives," and "Ecosystem Management" pursued ecologically based approaches to caring for the land, expanding practices that extended occupational diversity by further incorporating non-traditional employees. This wide-ranging approach to land management encapsulated by the motto, "Caring for the land and Serving People" reflected what Elizabeth Estill called "the gospel of integrated resource management, that people management is part of the job, and education and information is really essential to people management." ${ }^{, 575}$ Successful on multiple levels, the USFS “TMO” era created diversification strategies worthy of emulation by other government agencies, a model to which the Forest Service could recommit in the twenty-first century. From 1986 to 1992 , the agency not only numerically ${ }^{576}$ increased workforce diversity, but for the first time the Forest Service also identified social

\footnotetext{
$574 \quad$ Jose Salinas, "Parity 1995" (speech at Strength Through Diversity Conference, Welches, Oregon, November 3, 1988); 1988 Equal Opportunity Report, 28; The Forest Service workforce increased from 22 to 31 percent female between 1978 and 1988 and eight to 12 percent minority in the same time period. ${ }^{575}$ Elizabeth Estill interview by Daina Dravnieks, Women in Natural Resources, 13, No. 2 (December 1993): 28.

576 From 1982 to 1990 , the agency increased its minority labor force from 10.5 percent to 15 percent, with women's numbers increasing a full ten percent during this period. Most of the increase occurred from 1986 to 1990 in response to the Work Force 1995 initiative.
} 
diversification as a strength, rather than a command, an idea that had also emerged in popular culture. As a New York Times editor pointed out on February 16, 1990, American educators had begun to recognize "that one of our strengths as a nation is our extraordinary diversity., ${ }^{577}$ Under Robertson's leadership, the agency grasped onto this idea as a way to advance workforce diversification. Despite initial progress, the agency struggled with reduced budgets and staffing so that by 1993 diversity gains stagnated.

In the narrative that follows, I examine the efforts to broaden workforce representation that heralded the TMO era. I examine key formalized diversification efforts in the agency under Chief Dale Robertson and address less formal diversification practices, while highlighting the role of service-wide and regional civil rights activities. I argue that social diversification occurred simultaneously with changes in agency stewardship of the land, cementing intersections of entwined social, occupational, and ecological diversification. The number of non-traditional employees grew by 30 percent from 1986 to 1990, with a higher ratio of professional women in non-traditional occupations than men. This entwined diversification via social and occupational representation by women and minorities resulted in formalized external partnerships, a proliferation of internal programs to increase diversity, and a shift in agency values to accommodate, if not prioritize non-commodity forest uses. Consequently, I highlight formation of the African American Strategy Group and other special emphasis groups that made the Forest Service a trendsetter in the Department of Agriculture, while

\footnotetext{
577 “Understanding America's Diversity," The New York Times, February 16, 1990, Section A, Column 1, Editorial Desk.
} 
contributing to conflict within and outside of the agency. The meeting point of social and ecological diversity strands is most acute in the early 1990s through incorporation of non-traditional employees, ecosystem management policies, and the economic consequences of lagging timber production in Northwest forests. These intersections suggest that if social diversification were as integral to the agency mission as ecological diversification, creating a representative workforce just might be possible.

Equal Opportunity is for Everyone

In 1987, minorities and women represent 12 percent and 31 percent, respectively, of our work force of almost 31,000 . There has also been a noticeable upward movement of minorities and women into line positions. We now have minorities and women in the Senior Executive Service/ Candidate Development Program, directing staffs at the Regional and Washington Office levels, and as Assistant Directors of Research Stations. - Workforce 1995 Brochure

When Dale Robertson took charge of the USDA Forest Service, he walked into a civil rights melee at the Departmental level. In the face of allegations of discrimination in 1986, Secretary of Agriculture Richard Lyng had issued a civil rights policy calling for commitment and accountability to equal opportunity and civil rights. As the new Secretary, Lyng wanted people to know his "fundamental views." Discrimination must be eradicated: "We must be so completely dedicated to an anti-discrimination policy that when the slightest hint of discrimination shows up it is quickly spotted and eliminated as a glaring inconsistency." Lyng would "not tolerate discrimination in any form" and called for training supervisory staff so that "equality of opportunity and respect for civil 
rights" would become "integral" to decision-making. Civil rights must be "clearly reflected in the performance decisions you make" about management staff in the Department. Lyng directed agency leaders to "immediately assess the resources, technical skills, qualifications, and performance of the civil rights staff" and "mandate that their counsel be accepted and acted upon." Agency directors must provide periodic assessments, the first due within 60 days of the June 12, 1986 message. "Here is a word of caution:" wrote Lyng:

Do not take this matter lightly. I expect you to assume personal responsibility and accountability for complying with the recommendations and assessment; and, I expect you to correct any program or management practice that results in inequitable treatment. Failure to do this will be viewed as a grievous weakness in management which, in my view, no other accomplishments can offset. ${ }^{578}$

Almost immediately, Max Peterson sent a letter to leadership endorsing Lyng's statement. F. Dale Robertson became chief six months later.

Having worked alongside Max Peterson as Associate Chief, Robertson understood the situation and immediately launched a major civil rights initiative to reaffirm and extend Forest Service civil rights policy. The notion of representation also fit snugly into the recently coined agency mission of "Caring for the Land and Serving People" and Robertson challenged agency leadership to achieve "a workforce that better reflects the nation's diversity" by the mid-1990s, a "workforce representative of the

\footnotetext{
578 Richard E. Lyng, Secretary of Agriculture, "Commitment and Accountability for Equal Opportunity and Civil Rights," June 12, 1986, reprinted in USDA, "Framework for Change" Workforce Diversity and Delivery of Programs" Brochure, October 1990, FHS Collection F18.4, File, "Women in the Forest Service - Publications."
} 
civilian workforce at all levels." 579 "Workforce 1995" reflected a vision and set goals for workforce diversification, extending the agency's civil rights agenda further than ever before. The initiative emphasized recruitment, retention, upward movement, organizational culture, and public awareness, determined in part through a series of committees, reports, and strategic plans to move the organization toward a multicultural organization in the century to come. The ensuing Equal Opportunity is for Everyone report urged all regions, areas, and research stations to figure out how to remove barriers in the workforce and to develop specific action plans. In keeping with Reagan Administration regulations that permitted but no longer required "quotas," the national Personnel and Civil Rights Department noted: "Numerical goals are still appropriate," when employment data shows "evidence of manifest imbalance or a conspicuous absence of women and minorities in the various occupational categories... ${ }^{580}$

The nationwide employment data did, indeed, show both imbalance and absence of female and minority employees. Numbers for both had increased slightly in 1987, but still lagged compared to civilian labor force (CLF) data, with women a full ten percentage points behind. ${ }^{581}$ (See table below) Still, the agency had progressed since the 1970s. At 13 percent of the overall workforce, minority employment came within five percentage points of the 1980 CLF. Occupational categories revealed disparities. In administrative positions and traditionally female clerical work, women and minorities

\footnotetext{
$579 \quad$ USDA Forest Service Personnel and Civil Rights, brochure, "Workforce 1995 - Strength through Diversity," FHS collection 13.3, File, "Personnel - Strength Through Diversity."

$580 \quad 1988$ Equal Opportunity Report, 1.

581 Ibid, "Exhibit A - Summary Analysis Work Force," 102.
} 
exceeded the CLF, while nearly comparable in technical categories. Predictably, the most egregious and economically significant differences existed in the professional and “Others" categories. Although professionals made up a third of the agency's total workforce, female and minority Forest Service professionals lagged far behind the CLF in that important category. Meanwhile, those in the "Others" CLF for women and were two and a half times more prevalent in the Forest Service than outside for minorities. $^{583}$

Table 15: Distribution of EEO Groups and Comparison by PATCO (Professional, Administrative, Technical, Clerical, and Other, i.e., wage grade) ${ }^{584}$

\begin{tabular}{|l|c|c|}
\hline & CLF Percentage & $\begin{array}{c}1988 \text { Forest Service } \\
\text { Percentage }\end{array}$ \\
\hline Total Females & 42.4 & 32.9 \\
\hline Total Minorities & 18.4 & 13.0 \\
\hline Professional & & 15.0 \\
\hline Total Females & 32.0 & 7.0 \\
\hline Total Minorities & 12.5 & 52.8 \\
\hline Administrative & & 14.2 \\
\hline Total Females & 32.0 & \\
\hline Total Minorities & 12.9 & 52.8 \\
\hline Technical & & 14.2 \\
\hline Total Females & 47.0 & \\
\hline Total Minorities & 17.7 & 93.8 \\
\hline Clerical & & 19.4 \\
\hline Total Females & 72.8 & 56.3 \\
\hline Total Minorities & 20.9 & 41.6 \\
\hline Others & & \\
\hline Total Females & 10.0 & \\
\hline Total Minorities & 17.0 & \\
\hline
\end{tabular}

Men and women of color also remained the most severely underrepresented by racial group and specific profession, ${ }^{585}$ despite upward mobility and professionalization 
efforts. Black men topped the list of underrepresented groups at nine of thirteen

professions. Asian males did somewhat better as foresters, fishery biologists, civil engineers, and biological technicians, while Hispanic men lacked representation as soil scientists. Native men lagged only as fishery biologists and range technicians, while Native women were underrepresented in every category but range conservationist, civil engineer, administrative and contracting officers, and forestry technicians. Black women fared worst of all. Save entomologists - of which there are very few in the agency black women consistently topped the underrepresentation list. ${ }^{586}$ Asian females were a close second, underrepresented in all professions but entomologist and civil engineer, while only administrative and contracting jobs reflected the CLF for Hispanic women. Worse yet, a look at voluntary and involuntary separations shows overrepresentation of women and minorities who voluntarily left the agency in 1987, especially in the lower GS levels (1-8) and in administrative, clerical, and technical occupations. Professional occupations differed in that of eleven voluntary separations in 1988, nine were white women, one an Asian male, and one a white man, while at the GS 9-12 professional range, fewer women and minorities voluntarily left the agency. ${ }^{587}$

civilian labor force is used as a standard to determine under-representation. While the term is defined, the percentage of difference required to constitute under-representation is not identified by EEOC. It appears that any disparity between the CLF and agency workforce appears to constitute under- or overrepresentation. Equal Employment Opportunity Commission Website, http://www.eeoc.gov/index.cfm; "Equal Employment Opportunity Program Terminology,” National Archives Website, http://www.archives.gov/eeo/terminology.html [accessed March 31, 2015].

586 Hispanic women, Asian men and women, and American Indian females comprised the list of ${ }_{587}$ underrepresented groups for entomologists.

$587 \quad 1988$ Equal Opportunity Report, 110. 
Of the full-time, permanent professionals who separated involuntarily, only two at the GS 5-8 level were let go at all, one black and one Hispanic male. At the GS 9-12 level, eight involuntary separations included one Hispanic and seven white males. In the Administrative category, the two GS 5-8 involuntary separations were a white female and a black male, while the three GS 9-12's were female, two white and one Asian. At the lower levels, women and minorities comprised approximately half of all involuntary separations in technical fields. In the clerical category, $A L L$ of the 19 involuntary separations were women and minorities, 11 of them white women. Few women or people of color at the GS/GM 13-15 level were separated in any category, no surprise since very few women or people of color worked at that level. ${ }^{58}$

Other status factors included competitive and noncompetitive promotions, and quality step increases, which raised pay. Women and minorities did well when competing for promotion in the professional arena, exceeding their proportions in the 770 competitive promotions in the agency under Workforce $1995 .^{589} \mathrm{In}$ fact, women and minorities in "significant" line officer positions increased dramatically in the late 1980s. At the district ranger level, the agency added 34 minority and 74 female line officers between 1986 and 1990. The number of others in significant positions also rose. (See Table below)

$588 \quad$ Ibid, 112.

589 White females received 26 percent of competitive promotions and minorities 10 percent. 
Table 16: Changes in the number of Minority and Women Line Officers, 1986-1990 ${ }^{590}$

\begin{tabular}{|c|c|c|c|c|c|c|c|c|}
\hline Position & \multicolumn{4}{|c|}{ Minority Line Officers } & \multicolumn{5}{c|}{ Women Line Officers } \\
\hline & $\mathbf{1 9 8 6}$ & $\mathbf{1 9 8 7}$ & $\mathbf{1 9 8 8}$ & $\mathbf{1 9 9 0}$ & $\mathbf{1 9 8 6}$ & $\mathbf{1 9 8 7}$ & $\mathbf{1 9 8 8}$ & $\mathbf{1 9 9 0}$ \\
\hline Forest Supervisors & & 5 & 6 & 5 & 1 & 1 & 3 & 3 \\
\hline Deputy Forest Supervisors & & 2 & 3 & 5 & 2 & 2 & 7 & 8 \\
\hline Assistant Research Dir. & & 3 & 3 & 1 & 0 & 2 & 3 & 1 \\
\hline District Rangers & & 25 & 28 & $\mathbf{4 1}$ & $\mathbf{1 3}$ & 33 & 53 & $\mathbf{8 7}$ \\
\hline
\end{tabular}

Outside the professions, women and people of color did not fare well. In Administration, minorities were promoted proportionately, but not women. Women constituted half of all administrators, but received only a third of more than a thousand promotions in that category. Even in the clerical field, women were not promoted in proportion to their numbers in the agency. ${ }^{591}$ And despite detailed numerical reporting in every other area, all the equal opportunity report contains about noncompetitive promotions is: "Data reflects a manifest imbalance for minorities in all categories." Both women and minorities received disparate numbers of quality step increases, minorities three percent fewer than their representation in the agency, women three percent more. The Personnel and Civil Rights Department concluded: the data clearly

$590 \quad$ Table compiled from 1988 Equal Opportunity Report, 134 and, Public Timber Council of the National Forest Products Association, "The Forest Service: An Agency in Transition, An Analysis of Changes in Personnel and Changing Employee Attitudes," (ca. 1990): 16. FHS Collection F13.2, File, "Personnel - Forest Service in Transition."

$591 \quad$ Ibid, Agency in Transition, 114. Although 94 percent of those in the clerical field were women, they got 74 percent of the competitive promotions, while minority promotions remained proportionate at 22 percent.

Ibid, 113. 
showed "that affirmative action recruitment and hiring efforts need to be continued, with the goal of having a diversified work force at all levels and in all categories. ${ }^{, 593}$

The Forest Service, Service-wide Civil Rights Committee (SCRC)

I chaired that committee, and back then anybody who chaired that committee, they were sort of seen as up and coming and it normally propelled them into something afterwards. But it sort of fitted where I was, as far as my philosophy and my, really the enthusiasm that $I$ had for really trying to assist the agency in civil rights matters... It was a very important time, in that you had the opportunity to come back after each one of those service-wide meetings and address the National Leadership Council as far as what deliberations were made and what you normally came with was two or three key recommendations to the National Leadership Team, and that person got to come back and be on the agenda, and really get some visibility. - Arthur Bryant, 2013

Because the data so often revealed imbalance, the agency had created a Servicewide Civil Rights Committee in 1978. Formed on the heels of Civil Service Reform, SCRC served an important role in reviewing and developing Forest Service civil rights policies and direction to address staff conflicts. Established to advise the chief, twice yearly the SCRC drew together representatives approved by the chief from each region and research station, with a WO representative and a bargaining unit representative. The committee reviewed proposed and existing policies and procedures and responded to emerging civil rights issues, made recommendations to line managers to correct or modify barriers, and monitored implementation of approved recommendations. The SCRC served as a conduit between line and staff, "a channel of communication for all employees," and so could consult with individuals and groups regarding any subject.

$593 \quad$ Ibid, 114. 
Representatives elicited data and proposed issues from their work unit's Civil Rights Action Committee (CRAC)/Civil Rights Action Group (CRAG), Human Resources staff, leadership, and others and sent them to the chair for committee consideration. In Region 6, the CRAG met four times per year.

SCRC had a clear reporting format. Identify the issue. Describe the situation. Present options for resolution. Make recommendations in writing to the chief. His formal reply would determine further action. ${ }^{594}$ In 1988, the SCRC identified six critical issues: to bring targeting and accountability in line with Work Force 1995 concepts of diversity; mobility barriers; civil rights of women and minorities not consistently upheld during fire emergencies; severe underrepresentation of minorities in the workforce; age discrimination; youth lack knowledge about Forest Service programs, benefits, and employment opportunities. ${ }^{595}$ Attitudes mattered when it came to geographic mobility. While employees obtained very real experience through multiple geographic assignments, non-mobile employees were "sometimes perceived as not being loyal to the agency," a factor that could impact opportunities for advancement. Nor did women and minorities always get "the same consideration" as that extended to "some employees," meaning white males. In fact, managers often lacked sensitivity regarding mobility impacts, financial, psychological, or cultural, that could affect women and 
minorities disproportionately. Mobility policies must be aligned with "modern-day needs."

Attitudes also mattered in fire events. The 1987 fire season illustrated typical harassment toward women and Native Americans. For example, individuals in both groups had received assignments below their qualification levels and been denied career development opportunities. Racial slurs and sexual comments were commonplace. Even security and law enforcement personnel harassed Native firefighters. Those who tried to stand up for women or Indians paid for it: "Retribution felt by some white males for supporting civil rights," reported the SCRC. Rest and relaxation policies were also applied inconsistently, "(racially biased)" on the one hand, with women sometimes receiving preferential treatment on the other. The SCRC explained that emergencies often caused "unusual or abnormal behavior that should not be condoned." Because no one felt that civil rights issues should supersede safety on a fire, the agency had never explicitly determined what constituted "acceptable" behavior during these emergencies. To achieve clarity, the chief requested further review of Fire and Aviation Management in the Pacific Southwest and Northwest, and a nationwide action plan. He added a lawenforcement specialist to each regional fire team. They, along with security personnel were to attend Region 5's civil rights and EEO training courses to ensure team adherence to the law. Fire policies, too, needed modernization." ${ }^{, 597}$

$596 \quad$ Ibid, 139-140. Ibid. 
Some issues could be addressed more easily than others. For example, by definition, striving to achieve parity would improve diversity, allowing targets to shift in keeping with Workforce 1995 goals; however, defining commonly agreed upon meanings of diversity would be more difficult. Similarly, attitudes translated into hiring barriers, like the perception that qualified minorities, men and women, did not exist. Specific outreach to minority women remained minimal, and those already employed encountered few mentors or developmental opportunities. And, when minority females applied for jobs, selection rates lagged behind nonminority women. "While we do not want to hamper the ongoing efforts to promote nonminority women," concluded the SCRC, "we feel an added effort needs to be placed on minorities with an emphasis on minority women."

The SCRC suggested that the WO P\&CR (Washington Office Personnel \& Civil Rights) Recruitment Branch review recommendations to increase representation made by the Region 6 Minority Employment Workshop, strategies from the P\&CR in Denver, and those developed for an Employment Officers Conference in Albuquerque. P\&CR should identify specific actions with the highest payoff for recruiting minorities. In keeping with the Workforce 1995 plan, the agency also planned to sponsor a national minority conference, using an upcoming Region 6 minority conference as a "prototype." The chief approved this recommendation. He suggested looking to the 1987 Intermountain Region conference as well and limited the conference to USFS employees, identifying it as an opportunity to develop internal networking systems and 
mechanisms for employee retention. Age discrimination and minority youth outreach should be addressed at the conference, as would partnerships, long-range planning, and increased outreach, all of which Chief Robertson saw as "essential" to diversifying the workforce. ${ }^{599}$

\section{Entwined Diversification and the Pacific Northwest}

Strength Through Diversity - Region 6

You folks in Region 6 and the Pacific Northwest Station are leading the civil rights effort in the Forest Service. This conference is a prime example of that leadership. Everyone in the Forest Service will be looking at your example-and hopefully, will be emulating your efforts here this week. - Jerry Sesco, Deputy Chief for Research, November 3, 1988

The 1988 "Strength Through Cultural Diversity Conference" in the small unincorporated town of Welches, Oregon really kicked off the multicultural organization, "TMO" period for the U.S. Forest Service. The agency-only get together hosted by the PNW Research Station drew employees from all over the country to the little town at the foot of Mt. Hood. The success of a large women's forum held just a few years earlier ${ }^{600}$ had spurred the R-6 Minority Work Group to recommend this conference to the regional forester. For four days, ${ }^{601}$ attendees discussed, explored, shared, and learned from local and national experts and one another. General plenary sessions set the conference tone through cultural presentations and talks by renowned diversity speakers and high level agency leaders. Participants also attended specific

\footnotetext{
$599 \quad$ Ibid.

600 Likely the Women in Natural Resources Conference in Dallas, Texas, 1985.

$601 \quad$ Monday October 31 to Thursday November 3, 1988.
} 
panels, presentations, and workshops in keeping with the primary objective of the conference - to serve as "a forum for ethnic employees to discuss and explore the development of networks and strategies" for developing their talents and skills, to identify advancement opportunities, and to discuss the benefits provided to the agency by a diverse ethnic workforce. ${ }^{602}$ Although the conference emphasized minority employee participation, it also aimed to educate the entire workforce about issues like recruitment and retention of minorities, backlash, agency commitment to affirmative action, cultural awareness, and minorities in Fire.

The conference started with an overview of sessions by Rudy Edwards, followed by remarks from regional forester Jim Torrence. Along with others who have been highlighted here, Elizabeth Agpaoa participated in the first panel, "Strength Through Cultural Diversity" She later described the conference as "phenomenal," with "something for everyone," with a "palpable" energy that came from "seeing the potential of women and employees of color and background in that one space for a week." Afternoon panels included Jetie B. Wilds, Mary Jo Lavin, Mary Albertson, and Darrell Millner, among others, and explored topics related to upward mobility, cross cultural relations, dealing with racism, and agency commitment to diversity goals. Each event and speaker reflected the emergent idea that diversity ought to be a source of strength. The Warm Springs Indian dancers performed that evening after a talk by keynote speaker, Thomas Shortbull, a North Dakota State Senator and Oglala Lakota tribal 
member. Within just a few years, Shortbull became president of Oglala Lakota College, one of the original tribal colleges to establish the American Indian Higher Education Consortium (AIHEC), an important recruitment partner to USFS ${ }^{603}$

Jerry Sesco, National Deputy Chief for Research joined the conference on Wednesday. Having spent the previous day in a W.O. retreat focused on civil rights, affirmative action, and Work Force 1995 he carried a message as Chief Robertson's representative: "Tell them that the leadership of the Forest Service is committed to having a diversified workforce by 1995 . Tell them I'll be eligible to retire in 1995-and when I retire-I want to leave the Forest Service having met this goal. Tell them I need their help and support." ${ }^{604}$ Likely, one of the first things Sesco heard that morning was a general session focused on minorities in the Pacific Northwest, followed by a rousing "Parity 1995" speech from Jose Salinas, Jr., who addressed roadblocks to parity and the perceived barriers that obstructed diversity, deconstructing the most common assertions. The availability argument was an "over-used cliché," a myth from an earlier era that ignored agency partnerships with entities like Haskell Indian Junior College, he said. That some were not "ready to accept" people of color applied to just a small segment of forest users. So, too bad. As for lack of minority interest, yes, some minorities wanted to live near urban areas but so did some Whites. Regarding quotas, reminded Salinas, everyone qualified on a "cert" can do the job, and no one really knows who is "best

603 Shortbull became president of the college in 1995. The AIHEC started in in 1973. "Statement of Thomas Shortbull, American Indian Higher Education Consortium, June 18, 2014," http://www.aihec.org/what-we-do/docs/FY15/SCIAhearing_Shortbull6-18-2014.pdf [accessed March 18, $2015]$.

604 Jerry Sesco speech, "Setting the Pace," November 3, 1988, Welches, Oregon. 
qualified." The idea that diversification decreased quality of work simply did not match the performance of women and minorities already in the agency. Besides, the directive to achieve parity came "from the very top of the organization."

The "first one there" - Civil Rights and Region 6

The frequent complaint that 'we can't find qualified blacks' may be proof that the affirmative-action policy is serving its real, though unacknowledged, goal: excluding all but a token number of minorities from opportunities that previously were available only to whites. - Dr. Derrick Bell, And We Are Not Saved, $1987^{605}$

With the idea of "a diverse workforce by 1995 " firmly in place, other sessions in Welches focused on understanding, implementing, and reshaping diversification policies. From career paths to barriers and biases, panels presented statistics, examined selection processes, and focused on how to increase representation. Career development, networking, competition, and mentoring also entered the picture. Reflecting an emergent openness in process and decision-making, workshops and working groups met to discuss issues for later presentation to the regional forester, the station director, and at "Home." A forum for informal, open discussion with the Station director addressed career issues for minorities in Research. As expected, Region 6 also presented "aggressive recruitment strategies to reach parity by 1995": the Co-op Ed Program; understanding recruitment and hiring regulations; ongoing evaluations of minority status at all levels, with projections and follow up at the district and regional levels. A panel on retention addressed perhaps the most significant issues for minorities - promotional opportunities, 
the personal price of moving ahead, mobility and leaving one's cultural community, and the need for flexibility. Did the Forest Service have a responsibility to help new employees adjust? If so, how and to what degree $?^{606}$

With cultural presentations throughout the week, including the North Portland Jefferson High School Acting Ensemble, a Hispanic comedienne, a Filipino Stick Dance troop, regional Native drumming and singing, and West Indian presenters, the cap to the conference came from the keynote speaker on Wednesday night. Later known as the godfather of critical race theory, Derrick Bell was no pretender when it came to affirmative action. Nor would he have promoted anything but a rapid push toward full representation. This one-time NAACP lawyer had been a civil rights activist since the early 1960s and became the first African American Harvard law professor. He also served as dean of the University of Oregon Law School from 1980 to 1985, the first black dean of any non-HBCU law school in the nation, no doubt providing the connections that brought him to Welches in $1988 .{ }^{607}$ By then, Bell had become disillusioned with civil rights progress. Although his speech from that fall day is unavailable, dozens of publications before and after, alongside his talk title, "The Trouble with Affirmative Action" provide insight into the likely nature of Bell's message; that the appearance of racial progress meant affirmative action benefited Whites as much or more than Blacks. That racial advancement would occur at a slow

\footnotetext{
606 "Program Summaries for Specific Sessions," Strength Through Cultural Diversity program, 1988. Region 6 Civil Rights Collection; Mary Albertson, Interview by author, 10 November 2014, Portland, Oregon.

607 Mary Albertson has no recollection of who asked Derrick Bell to speak or what he said.
} 
and steady pace was "more reassuring than accurate," he wrote. Incremental approaches to racial justice were downright "wrong." Whites would only accept racial justice when it helped them achieve other goals, like meeting affirmative action requirements. ${ }^{608}$

Still, affirmative action was a necessary evil and Bell supported litigation as an avenue toward equality, although even favorable rulings would ultimately disappoint. Three personal examples demonstrated the paradox that came with affirmative action. Although hired fresh out of law school by the Department of Justice, Bell left in 1959 when told for the third time to halt his association with the NAACP. When the University of Oregon Law School refused to hire an Asian American woman in 1985, he quit as a matter of principle, and returned to Harvard the following year (after a stint at Stanford). Finally, not long before speaking to Forest Service employees about the trouble with affirmative action, and soon after publishing And We Are Not Saved: the Elusive Quest for Racial Justice ${ }^{609}$ Professor Bell staged a five-day sit-in at his Harvard

608 New York Times, January 11, 1962; June 12, 1964. The year he joined the University of Oregon Law School Bell published a seminal work, Brown v. Board of Education and the Interest Convergence Dilemma. The dilemma was that white Americans would only support racial justice to their own benefit. In fact, according to Bell, people of color may have been better served through court-ordered equivalency in education than by the 1954 desegregation decision in Brown. While Brown ruled segregation unconstitutional, Brown II, in 1955 stemmed from deliberations about how quickly to desegregate schools. The NAACP called for desegregation "forthwith," meaning rapidly; however, Justice Frankfurter inserted the phrase "with all deliberate speed" to initiate a gradual process of desegregation. Bell argued that the decision in Brown stemmed more from concerns about America's worldwide anti-Communism role and perceptions of the U.S. as racist than a desire for genuine equality and progress for African Americans. Gradualism provided the usual answer to racial problems. Born in 1930 in Pittsburgh, with a law degree obtained via the G.I. Bill from the University of Pittsburgh School of Law Bell had not only witnessed the slow progress around civil rights, he had experienced the ugly realities of racism firsthand. He had also consistently protested inequality and injustice throughout his life, from going to jail for standing his ground regarding equality in public accommodations in a Jackson, Mississippi train station waiting room to serving as lawyer to Cleveland Donald, Jr., the third African American student to enroll at the University of Mississippi.

$609 \quad$ In 1987, Bell published And We Are Not Saved: The Elusive Quest for Racial Justice exploring the disappointments of the civil rights movement. 
office. This time, he drew national attention by protesting the school's refusal to hire an African American woman in a tenure track position. By then, he had determined that organizations often imposed a "stopping point" in hiring blacks and other minorities, regardless of qualifications. A little representation went a long way in the white world. ${ }^{610}$ The presence of this renowned critical legal theorist reflected a real commitment to social diversification in the Forest Service-at least on the part of organizers.

The conference adjourned on Thursday with several sessions that looked to the future, drawing primarily from the 1987 Hudson Institute report, "Workforce 2000." This report, produced for the Department of Labor and followed by a similar document for the Civil Service Commission predicted that the U.S. would experience labor shortages and at the same time face dramatic demographic shifts. The Workforce 2000 session, presented by the Department of Agriculture, presented data and trends expected for the next generation, followed by a half hour overview of the Department's perspective on workforce diversity. Baby boomers would slide into retirement and the number of female, minority, and immigrant workers would increase considerably. Hudson predicted native-born white males would comprise only 15 percent of the net entrants into the workforce, with women at two-thirds of new entries. Low skill jobs would disappear, as high skill occupations proliferated. These reports tremendously

610 Bell, And We are Not Saved, 153; "Biography of Professor Derrick Bell,” Derrick Bell, Official Site, http://professorderrickbell.com/about/ [accessed February 15, 2015]. 
influenced the direction of personnel policymaking government-wide. It was time to take action. $^{611}$

The conference ended with a "Setting the Pace" speech by Jerry Sesco, who posed strategies for the next century. Managers should be rewarded for becoming "passionate advocates" for diversification. USFS must continue to sponsor events and conferences like this and the agency needed women, minorities, and the differently abled in policy level positions. Efforts to define and clarify the concept of workforce diversity and its benefits should also continue. Finally, said Sesco, the conference had provided a "dynamic" forum for "planning your assault" to reach the Workforce 1995 finish line. "It wouldn’t surprise me if you (R-6 and PNW) were the first one there."

A "Hammer" in the Courts - the Northern Spotted Owl

“the Forest Service will never be the same again.” - Chief F. Dale Robertson, 1990

Since [NFMA] was passed the Forest Service has gone from 284 to 688 wildlife biologists, 75 to 236 fisheries biologists, 47 to 206 archaeologists, 7 to 84 ecologists. The new disciplines attract enthusiasts from across the United States, many of them more liberal, worldly, and wildlife oriented than their predecessors...They bring new perspectives and it shows up on the ground. - William Dietrich, The Final Forest, 1992

Meanwhile, the most significant piece of Salinas's speech reflected the emergent idea that rather than a drawback, cultural diversity could benefit the Forest Service. Some saw ecological diversity as similarly beneficial, but to the land, not the agency;

611 U.S. Office of Personnel Management report, "Revisiting Civil Service 2000: New Policy Direction Needed" (September 1993); Kristi Cameron, Joan Jorgenson, and Charles Kawecki, "Civil Service 2000 Revisited: Old Assumptions New Facts and Forecasts," Public Personnel Management 22, 4 (Winter 1993): 669.

$612 \quad$ Sesco speech. 
however, the two clearly overlapped. The laws that mandated long range planning and public involvement for multiple use included the 1976 NFMA, which required preserving and enhancing "the diversity of plant and animal communities... so that it is at least as great as that which would be expected in a natural forest." ${ }^{, 613}$ Within a decade after NFMA, interdisciplinary teams had shifted from relying solely on foresters "to benefiting from the strength of many resource perspectives." Although some employees rejected the team approach, others felt incorporating the "ologists" had improved resource management. "Likewise," claimed diversity proponents, “decisionmaking and policy setting will be strengthened by integrating the diversity of views in a multicultural organization in these processes." ${ }^{614}$

These ecological and social strands of diversity converged as never before by the late 1980s. "We are no longer a homogeneous society," noted Salinas. Employees interfaced with an increasingly diverse public, while women and minorities brought "a whole new set of ideas, concepts" and "approaches to doing business. It is both socially and economically unsound not to recognize or not to draw from the fast-growing labor pool of women and minorities." Ecological and social diversification could make the Forest Service relevant and provide a competitive edge in drawing the best of the best into the workforce. Rather than viewing it as a "chore or mere duty imposed by Chief Dale Robertson," the agency ought to view diversification as "an opportunity to tap a

613 Gerald Williams, The USDA Forest Service: The First Century, 1905-2005, Centennial Commemorative Edition, PS-650, revised April 2005.

$614 \quad$ TMO Report, 4. 
long-neglected pool of talent, creativity, and energy.” As Salinas articulated, following Robertson and others:

We are a "Can Do" outfit and are known for our willingness to accept new challenges. When it comes to meeting targets, we do not accept anything less than 100 percent from employees. Why should Chief Dale Robertson accept less from us than Parity 1995. We excel in caring about the land. Should we not do the same in the area of human rights? ${ }^{615}$

But, did the Forest Service really excel in caring for the land? By the time of the Welches conference, trouble with the Northern spotted owl indicated otherwise. In the early 1970s, Oregon State University student Eric Forsman had discovered and verified the primary habitat of this little known bird - old growth forests of the Pacific Northwest. Spotted owls live in tree snags, survive for up to 15 years, and often return to the same nest sites - in virgin old growth timber.

From giants that are hundreds of years old to youthful conifers sprouting from the detritus of nurse logs, the ancient forest hosts multiple biotic systems, varieties of foliage, multiple canopy layers, and species galore. These conifer forests release more oxygen and filter more carbon dioxide from the air than any other plant life on the planet. Multifaceted and intricate at even the microbial level, the character of old growth differs widely depending on epoch, geography, and disturbance history. There is no single definition of old growth so far as age and size are concerned, but one factor remains consistent: the ancient forest is composed of a complex ecosystem that includes live and dead trees and plants, littered forest floors, and rich habitat for more than 
mammals and birds. Bugs, slugs, mosses, and lichens also live on the ground, in rotting wood and within and on the surface of these humongous trees; in the very forests undergoing massive harvests by mid-century.

The public visibility of immense clearcuts during the 1970s increasingly clashed with environmentalism and started a "conservation saga" with decades-long reverberation. In 1975, the State of Oregon listed the spotted owl as threatened but, although the U.S. Fish \& Wildlife Service (FWS) recognized threats to the owl in 1981, it determined the bird did not warrant listing under the Endangered Species Act (ESA). Cutting continued. ${ }^{616}$ In 1983, the Forest Service named the owl an "indicator species" for the health of old growth ecosystems. The next year, the State of Oregon called for special management action for protection of 375 owl pairs. In 1985, scientists designated by the Audubon Society called for immediate management intervention. By 1987, FWS again considered the bird's status for endangered species listing, but to no avail. On appeal, the federal district court determined "arbitrary and capricious" action by FWS when it did not list the owl as endangered or threatened. FWS began a third review. Meanwhile, the Forest Service created a special management plan in 1988, but noted the owl had a "poor" chance of long-term success. Not surprisingly, people resisted the plan on two fronts. Environmental groups claimed it did not adhere to the law. Big timber claimed economic hardship. In the interim, Washington and Oregon states both listed the

\footnotetext{
616 James G. Lewis, Forest Service centennial history, 203-204; 216; Barry R. Noon and Kevin S. McKelvey, "Management of the Spotted Owl: A Case History in Conservation Biology," Annual Review of Ecological Systems, 27 (1996): 135-136. The region harvested 5.7 billion board feet in 1973 and 4.7 bbf in 1974. Gerald Williams, "Appendix E: Timber Harvest Cut and Sold" in The U.S. Forest Service in the Pacific Northwest (Corvallis: Oregon State University Press, 2009): 372.
} 
spotted owl as threatened and endangered, placing pressure on the federal Fish and Wildlife Service to do the same. ${ }^{617}$

The real pressure, though, was on the forest ecosystem itself. Northwest national forests harvested under a billion board feet annually from their inception in 1905 until 1944. By the 1950s, a housing boom, industrial forestry, road building, and increased silvicultural efficiencies multiplied the assault on ancient Northwest forests. The region's harvest reached two billion board feet in 1951, four billion in 1960, and five billion in 1965 as the public demanded lumber for housing, overseas exports increased, and the Forest Service entered its heyday of productivity. The highest cuts ever occurred in 1973 and 1987 at 5.8 and 5.5 billion board feet respectively. Nationwide, the agency harvested close to 14 billion board feet in 1987 , the highest ever in its history. The Northwest, one of nine national regions, produced 35 percent of the total. ${ }^{618}$

Even as social diversification got underway, environmentalists figured out that endangerment of the fluffy fowl could potentially stop what biologist Jerry Franklin called "dirty clearcuts," the piles of wide open, log strewn, newly barren spaces that eliminated wildlife habitat. Traditional forestry would "no longer fly in the federal government," recalled Dale Robertson a decade later. As the public saw it, clearcutting "looked like abuse of the land. But the real driver was the Endangered Species Act." The northern spotted owl became an environmental "hammer" in the courts. ${ }^{619}$ Its

\footnotetext{
$617 \quad$ Noon and McKelvey, 136; Lewis, Forest Service centennial history, 217.

618 Williams, “Appendix E,” 371-372; Lewis, Ibid, 202.

619 F. Dale Robertson Interview by Harold K. Steen, August 12-14, 1999, Sedona, Arizona, Forest History Society Oral History Collection, 2.
} 
preservation signaled the end for colossal timber harvests and sales. Throughout the mid-to-late 1980s, environmentalists repeatedly brought national attention to the fate of old growth forests in the courts, through the media and via civil disobedience. Routine decisions began to go in front of a judge and case law built up against the agency. "Forestry as the Forest Service had been practicing it under multiple use forestry, as being taught in forestry schools, wasn't meeting the test. We were slowly grinding to a halt..." Forestry "hit the wall," ${ }^{620}$ recalled the chief. That wall included drawing public attention to clearcutting through a cross country tour of an old growth tree, and daring measures by protesters who sat in front of logging trucks or pounded metal spikes into trees to halt timber harvests.

Congress got involved in 1990, by placing a rider on the 1990 Interior Appropriations Bill that specified additional protection for the northern spotted owl and exempted federal agencies (USFS and BLM) from legal appeals. As part of the rider, Section 318 established an Interagency Scientific Committee (ISC) to develop a longterm conservation strategy for the northern spotted owl on public lands. Led by wildlife biologist Jack Ward Thomas, the committee recommended creating a network of habitat conservation areas (HCA's) by designating approximately 2.4 million hectares (close to six million acres) of federal land, in addition to existing wilderness areas and national parks throughout the range of the northern spotted owl. Eric Forsman and four other researchers joined Thomas, who also led previous ecosystem research teams in

${ }^{620}$ Robertson interview by Steen, FHS; Harold K. Steen, "Traditional Forestry Hits the Wall: Excerpt of Interview with F. Dale Robertson (August 12-14, 1999). Forest History Today (Spring 2000): $2-3$. 
developing guidelines to manage wildlife and timber. The team presented the ISC report to agency heads for the USFS, BLM, NPS, and FWS in April and on June 26, 1990, the U.S. Fish and Wildlife Service listed the northern spotted owl as a threatened species. ${ }^{621}$ Harvest levels dropped to 3.8 billion board feet that year, heralding reductions that would take the cut below a billion board feet by $1995,{ }^{622}$ the same year the agency aimed to achieve demographic representation of the workforce.

New Forestry, New Perspectives and the Advent of Ecosystem Management

We are going through an agency identity crisis. We are changing from an agency characterized by certain traits to something that is not yet clearly defined. We are very def[i]nitely in a transition process. And as often happens in times of transition, chaos increases in the interim. - Jerry Mason, Community Relations, reporting on Chief Robertson's comments at the 1991 RF\&D meeting, Bend, Oregon ${ }^{623}$

In response to increasing tensions around clearcuts, the spotted owl, and the role of big timber in managing national forests, several new forest management initiatives arose in the late 1980s. First "New Forestry," then "New Perspectives" emerged, morphing into a more lasting focus on "Ecosystem Management" as the primary approach to resource management in the 1990s. The policy of ecosystem management developed out of conflict over how to foster biodiversity while meeting public demands for multiple use, maintaining relationships with the timber industry, and managing national forests and grasslands nationwide, especially in the Pacific Northwest. In the

$621 \quad$ Lewis, Forest Service centennial history, 217; "Northern Spotted Owl," Arcata Fish and Wildlife Service Office Website, http://www.fws.gov/arcata/es/birds/NSO/ns_owl.html [accessed March 22, 2015]. 622 Noon and McKelvey, "Management of the Spotted Owl,"136; Williams, “Appendix E,” 372.

623 "Three Perspectives From Emerald City," Comments by Jerry Mason at Region Six Community Relations Conference, Bend, Oregon, January 29, 1991. FHS Collection F15.2, File, "Region 6 - (Pacific Northwest) Miscellaneous (1962, 1985, 1991, 1993)." 
wake of the environmental movement, the public had become increasingly concerned about the aesthetics and environmental impacts of industrial timber production. NFMA and the entry of the ologists into the Forest Service revamped how many agency employees viewed resource management by the 1980s, effectively halting traditional forestry. ${ }^{624}$

In 1988, a group of Forest Service employees created an in-house employee agency, the Association of Forest Service Employees for Environmental Ethics (AFSEEE), led by Jeff Debonis. In early 1989, Debonis composed a "blistering attack" on agency practices, excoriating the agency's land management practices in a letter to Chief Robertson. He then reprinted the letter in AFSEEE's first publication, Inner Voice, and sent the newsletter to every Forest Service employee and ranger district across the country. The headline asked:

Are you afraid to speak out for what you know is ecologically right? Do you feel isolated and alone because of your resource ethics? Do you think the Forest Service needs to become a more ecologically sensitive organization? Would you like to help promote this kind of change within the agency? ${ }^{625}$

At the time, Debonis worked on the Willamette National Forest, the Northwest's largest timber producer, so littered with clearcuts that "From the air," wrote William Dietrich, "its polka-dot pattern of clearcuts made the forest look like a target used for machine gun practice." ${ }^{626}$ A self-described "timber beast" turned tree hugger, ${ }^{627}$ Debonis saw big

\footnotetext{
$624 \quad$ Steen, "Traditional Forestry," 2-3.

625 In William Dietrich, The Final Forest: the Battle for the Last Great Trees of the Pacific

Northwest (New York: Penguin Books, 1992): 165.

626 Ibid, 164-165.

627 Ibid, 161.
} 
timber and the Forest Service as allies, and knew the agency viewed environmentalists as a threat. He also knew that in the 1970s, agency scientists had warned that spotted owls were in trouble. "We ignored them," he said. "We've been totally neglecting our job.”

Debonis had a point. The agency's timber program received 35 percent of all funding, with non-commodity uses like recreation, fish and wildlife, soil and water each getting only two to three percent of the budget. ${ }^{628}$ Region 6 forests produced a major share of the timber sold annually from the entire National Forest System and also hosted a large proportion of the nation's recreational use. In 1990, the region employed more than thirteen thousand people, 7,560 of them on a permanent basis and over a thousand classified as foresters. Based on an internal survey of employees, ${ }^{629}$ more than half (52\%) felt that the agency should reduce timber harvests, emphasize recreation and wildlife research, and focus on ecosystem management. In fact, at the 1989 national forest supervisor's meeting in Tucson, Arizona, "Sunbird," 630 the chief received a memo from 123 forest supervisors complaining about "unrealistically high" allowable timber quantities." It would be nearly impossible to make the cut, even with full funding. Despite supporting timber production as one of many multiple uses, agency leaders also wanted better ecological management, rather than "the 'short-term political expediency' of timber production." 631

\footnotetext{
628 Lewis, Forest Service centennial history, 204.

629 Results of the James Kennedy and Thomas Quigley Forest Service Values Study presented at the Sunbird conference, November 13-16, 1989, Tucson, Arizona. Agency in Transition, 8.

$630 \quad$ Ibid, 2, 32.

631 In Lewis, Forest Service centennial history, 204.
} 
By the late 1980s, as Chief Robertson dealt with criticism from both AFSEEE and his own leadership, he and his management staff turned toward the ideas of Jerry Franklin, an ecologist who did ecosystem research for the Forest Service as early as the 1960s. Franklin advocated an alternative approach to forestry, something akin to Aldo Leopold's "biotic" view of the land, with a bent on "reservation" of forest debris. ${ }^{632}$ Trained in forestry, but enraptured by ecology, early on Franklin recognized "the important role that trees continue to play in forest ecosystems after they are dead." ${ }^{633}$ This "Father of New Forestry" learned that lesson at the H.J. Andrews Experimental Forest in the Central Oregon Cascade Range, where ecosystem research had been underway since the 1940s. ${ }^{634}$ There, the Andrews Ecosystem Research Group identified the importance of organic debris, large and small in preventing erosion and providing habitat. ${ }^{635}$ When Mt. St. Helens erupted on May 18, 1980, covering more than two hundred thousand acres with ash, pumice, and scorched trees lying side by side like toothpicks, the disaster set the stage for even more understanding of ecosystems. "Even though we knew better," said Jerry Franklin:

we were still thinking in terms of disturbances as destroying things, as laying waste, as eliminating everything from a place, and it doesn't. And so out of that came the epiphany of the biological legacy [that both dead and green trees are

632 William Allen, “New Forestry’ Is Kinder, Gentler Way Of Logging,” St. Louis Post-Dispatch, Tuesday, May 12, 1992.

633 "Forest Frontiers: Jerry F. Franklin," American Forests (Fall 2012), 140 Years of Protecting American Forests Website, http://www.americanforests.org/magazine/article/forest-frontiers-jerry-ffranklin/ [accessed March 23, 2015].

634 Ibid.

635 Lewis, Forest Service centennial history, 208-209. By the 1960s, the agency also conducted ecological studies at the Hubbard Brook Experimental Forest in New Hampshire, research that showed links between the "small ecosystem with the larger biochemical cycles of the earth," demonstrating that forest practices could impact water supplies and quality not just at the small watershed level, but even further away. 
needed to sustain ecosystems]. And of course out of that came the notion...that you could harvest timber in ways that would be closer to emulating natural processes. ${ }^{636}$

With Mt. St. Helens as a giant petri dish, scientists watched a diverse ecosystem emerge much faster than they had ever imagined. Researchers began looking at forests on a broad landscape scale and the agency experimented with leaving "biological legacy" trees, an approach that Robertson promoted under Franklin's "New Forestry" designation. Chief Robertson and Associate Chief Leonard started several "pilot" tests in the late 1980s, combining differently-aged trees with "downed trees, brush and standing dead trees," to provide nutrients and wildlife habitat. ${ }^{637}$ For the first time timber management focused on the forest not just the trees, an emphasis that put the Northern spotted owl at the center of debate.

When Chief Robertson reported to Congress about how he would handle timber harvest levels and endangered species, he explained that he would take "a bigger, broader, new perspective of the forest," rebranding New Forestry as "New Perspectives" and "pitch[ing] it as an alternative to timber-dominated multiple-use management. Overnight, what had been a pilot program became the management approach for the National Forest System." ${ }^{638}$ Not for the first time, Robertson took flak from all around. Employees came down on all sides, for and against but nearly all were surprised by the announcement of a major resource management initiative at a congressional hearing.

\footnotetext{
636 Jerry Franklin interview in Lewis, Forest Service centennial history, 211.

637 Even before it was named, this approach was being used on the Shawnee National Forest in Illinois and on the Mark Twain in the Missouri Ozarks, where the agency followed private landowner Leo Drey in practicing uneven-aged management. Lewis, Forest Service centennial history, 212-213. 638 Ibid, 214.
} 
The public had no idea what he was talking about. Environmentalists saw New Perspectives as a public relations scam, since clearcutting continued, while industry leaders feared reduced harvests. Agency researchers and leaders understood the owl's incipient decline, but under pressure from various "publics" and Congress, how could they stop the bird's demise?

The timber machine had been started. Turning it off had to happen at a higher level. Robertson realized clearcutting had to go early in his administration, but felt he had to identify the alternatives first. The chief may know what he wants to do from a major policy standpoint, but you have to:

work the process in Washington to get support from the political establishment, both Congress and your political bosses. You can't just decide someday to announce the end of clearcutting. You've got to have the president with you and certain members of Congress, the secretary of agriculture and a lot of other people. So just because I had concluded that we had to get away from clearcutting as a standard practice, it was a long ways to go before you could get an official position on that. ${ }^{639}$

When Al Gore led an environmental cohort to the Earth Summit in Rio de Janeiro in June 1992 and publicly criticized the Forest Service, Robertson saw his opportunity. With some political machination, via former Secretary of Agriculture Clayton Yeutter and EPA Administrator Bill Reilly, the chief suggested an alternative to total preservation in national forests - Ecosystem Management; an approach that would maintain and strengthen entire ecosystems. President Bush made the announcement at the Earth Summit, and a policy was born. ${ }^{640}$

\footnotetext{
$639 \quad$ Robertson by Steen, 85.

640 Ibid; Lewis, Forest Service centennial history, 214-215.
} 


\section{National Diversity Efforts}

All Together Now Conference

The collage of the participants was impressive. The Chief was there; so were cooperative students... There were technicians; there were Forest Supervisors. Color was everywhere - black, white, yellow, red and brown. Women and men of all sizes and shapes. The physically disabled were there. A soft southern drawl of a woman from Alabama contrasted sharply with the accent of the person from the Lake States. The dress code was great - there wasn't any. - Michael T. Rains, State $\&$ Private Forestry, Northeastern Area ${ }^{641}$

Meanwhile, the USFS national diversity conference took place in Atlanta, Georgia at the end of 1990 (November 28-29). In an Email to his division, Michael T. Rains of State \& Private Forestry in the Northeastern Area described the conference as a "three-dimensional experience." The chief, who remained the entire time, started the event with a ribbon cutting ceremony and a speech focused on the most "pressing goals" of the agency: to achieve workforce diversity by 1995; to become outstanding in managing workforce diversity; and to change and reshape agency culture. The conference heralded an era in which people would work together to create a "peopleoriented" organization "internally and externally." Rains viewed the conference as consciousness altering: "It's now Tuesday morning, about 8:00 a.m.," he wrote, "and I am sitting in the Grand Ballroom. ... The lights go out and a slide tape program begins. No words, just music and pictures. That's not right! It wasn't JUST music and pictures. The show was comprised of a haunting melody and a 'painting of the agency.' It was magnificent and concluded with a resonating script of "ALL TOGETHER NOW." The

${ }^{641} \quad$ Michael Rains, "All Together Now Diary," FHS Collection F13.3 (1990), File, "Personnel: Work
Force Diversity - "All Together Now" Conference." 
"Signers" for the deaf added to Rains' excitement. "Their hands would move so fast" that they translated "feeling and passion," not just words. The visage of a "grand opportunity to 'see and hear' a story about people and a future Forest Service" would always stay with him. ${ }^{642}$

In many ways this conference echoed the "Strength Through Diversity" conference in Welches. Attendees learned about "cultural bias" as a phenomenon and the "vitality" of "varying cultures" in the work environment. They heard about minority experiences - from the people who had them. Byron Kunisawa, born in an internment camp in Topaz, Utah talked about his life and explained the difference between affirmative action (focuses on "equity") and workforce diversity (focuses on "utilization and potential") as he saw it. Beverly Holmes spoke about women's progress and gave a "formula for the agency's future: "Commitment + Hardwork + Courage + Imagination + Responsibility $=$ Success in Workforce Diversity.” A Hispanic woman, Patricia Barela Rivera suggested "pulling yourself up and making things happen," and Evelyne Villiness, a polio survivor, educated the audience about issues faced by the "physically challenged." "Realize our strengths and put us to work," she concluded. Additional sessions focused on minority retention, mobility, backlash, and myth busting."

Although similar to Welches, the All-Together Now conference seems to have underscored agency-wide organizational and management issues, especially those

\footnotetext{
642 Ibid.

643 Memorandum from Thelma Strong, Planning Co-Manager to National Diversity Conference Participants, re: National Diversity Conference, "Concurrent Sessions," September 21, 1990. FHS Collection 13.3, File, Personnel: Workforce Diversity, “All Together Now Conference.”
} 
associated with incorporating women into the workforce. Sessions included truth versus myth about the Consent Decree, a workshop on gendered body language and power that ran twice in one day, and increasing personal effectiveness. Panels examined partnerships, the needs of an expanded public, and the recruitment challenge of demographic trends. Whereas Welches provided cultural presentations and forums for discussion with leadership, Atlanta's diversity workshops addressed career issues through videotaped programs. Entry level employees could discuss issues associated with difference and learn about cross cultural communication. Supervisors and upper management could explore managing a diverse workforce and how outside organizations were changing to "maximize their diverse human resources" through the film, "Profiles in Change." This session combined the usual topics, recruitment, training, and mentoring, with newer ideas like team building, accommodating difference, communicating, rewarding, and holding managers accountable.

Finally, Leslie Weldon conducted the closing ceremony and "what an impressive person," wrote Rains. While in D.C., Weldon had earlier become "involved with some efforts in the Forest Service to start growing diversity and success for Blacks" and other ethnic groups. "So," she remembered, "that was a really important time" as Forest Service leadership started to focus on "what it meant to be a multicultural organization." When Weldon and her husband returned West where he could go to school, she was "really happy" to continue working with the national conference. ${ }^{644} \mathrm{Jim}$ Reaves

644 Leslie Weldon Interview by Tania McDonnell, May 11, 2005, Deschutes National Forest, Oregon. Region 6 Civil Rights Collection. 
(Director of Research, 2011-) also recalled meeting Weldon (Deputy Chief, NFS, 2011-)

at this "uplifting" time, noting that those minorities and women in executive or

management positions in the early twenty-first century came into the agency "during

that period," a time Mary Wagner (Associate Chief, 2011-) called "formative,"

personally and for the agency. Wrote Chief Robertson when he released conference

proceedings to regional foresters and station directors: "The conference marked the

beginning of a major change throughout the organization which will continue as we

move ahead with the implementation of the report of the task force on work force

diversity, "Toward a Multicultural Organization.,"645

\section{Toward a Multicultural Organization}

In a culturally diverse work force, employees of differing race, color, age, sex, national origin, religion, marital status, and people with disabilities contribute effectively at all levels of the organization. Employees are given every opportunity to develop, advance, and contribute to the organization's mission. The organization understands, embraces, and effectively uses the diverse values, beliefs, and behavior of its employees. - Definition of Work Force Diversity, Toward a Multicultural Organization: Report of the USDA Forest Service Task Force on Work Force Diversity, March 1991

Among those in Atlanta, Lamar Beasley stands out for introducing the initial results of the "National Workforce Diversity Task Force," resulting in the report, Toward a Multicultural Organization in March 1991. After approval by Chief and Staff every district in the nation received this guide to multiculturalism. Beasley, a white

\footnotetext{
645 Jim Reaves Interview by author, Rosslyn, Virginia, February 1, 2013; Mary Wagner interview by author, Rosslyn, Virginia, February 13, 2013; Memorandum from F. Dale Robertson to Regional Foresters, Station Directors, Area Director, and WO Staff Directors, re: "Multicultural OrganizationProceedings of the 1990 National Diversity Conference," October 11, 1991, FHS Collection F13.3, File, "Personnel: Work Force Diversity - "All Together Now" Conference."
} 
Southerner from a poor rural North Carolina background had gone to school on the Korean G.I. Bill to become a forester. Within four years of joining the Forest Service in 1962, he became a district ranger and soon thereafter directed a Job Corps Center in West Virginia, where he knew Jetie B. Wilds. Beasley's meteoric rise in the agency included a commitment to diversity issues, formed as Job Corps director. As forest supervisor on the Kisatchie National Forest, Beasley hired Arthur Bryant and then followed Bryant's career, a quiet mentor from afar. ${ }^{646}$ In 1975 , Beasley moved to Washington, D.C. where he became the W.O. Environmental Coordinator. Two years later he directed RPA, the Resources Protection Act Department Gloria Brown joined in order to advance. Among other high level positions between 1980 and 1991, Beasley acted as Deputy Chief of Programs \& Legislation, NFS, and director of the Southern Forest Experiment Station before moving into his final pre-retirement job, Deputy Chief of Administration for the entire agency. Beasley retired in $1994 .{ }^{647}$

When asked in a 2013 telephone interview why Dale Robertson chose him to direct the national task force, Beasley's self-effacing humble style tinged with southern charm provided at least part of the answer. Hesitatingly, he responded:

If I tried to answer that it'd sound boastful. If I tried to answer it with what I think was the reason he asked me it would sound boastful. I don't like that. But, we had been very successful on the units where I'd worked, heading up deputy areas and what have you. I'd been able to, working with the staff, have clarity in our goals, and have structure in how we were going to work to reach those goals. ${ }^{648}$

\footnotetext{
646 Arthur Bryant Interview by Donna Sinclair, Rosslyn, Virginia, January 19, 2013.

$647 \quad$ Lamar Beasley resume. Sent to author by Mr. Beasley.

648 Lamar Beasley, Telephone Interview, April 15, 2013.
} 
Dale Robertson commissioned the task force - likely at the 1989 "Sunbird" meeting $^{649}$ - to help the agency reach its Workforce 1995 demographic parity goals, a policy USDA adopted in $1993 .{ }^{650}$ Beasley did not choose the more than 30 staff on the team, who included high level and entry level employees, people of all races and ethnicities, men and women. Yet, "it was a wonderful mix. It was a mix in everywhere you looked," he said. The committee drew from the work of the SCRC ${ }^{651}$ to consider all matters pertaining to workforce diversity. Defining workforce diversity in operational terms became a primary goal, along with establishing specific strategies to achieve "Workforce 1995" goals.

\section{Dr. James Crowfoot, dean of the School of Natural Resources, University of}

Michigan, played a key role in creating the framework on diversity outlined in the "Blue Book." ${ }^{652}$ Crowfoot drew from work by Bailey W. Jackson and Evangelina Holvino,

649 Anonymous notes reported on Robertson's May 15, 1991 presentation to the W.O. about the TMO report. The note says that the TMO task force formed at Sunbird, the second meeting of forest supervisors, with one thing on the agenda - workforce diversity. It is not clear when that second meeting happened, but since the TMO taskforce worked over an 18 month period in 1989-1990 and Tucson is the location for the 1989 meeting, this is likely the conference known as Sunbird. FHS Collection F13.3, File, "Personnel: Work Force Diversity - General."

$650 \quad$ Message Scan from Gordon Meyer to for Terry L. West, re: "Forwarded: Civil Rights Staff News Update - OP Document," July 26, 1993. "News from the Department," July 1993, U.S.D.A notes that Secretary Espy sent a March 31, 1993 letter to Congressman George Brown that said USDA would establish "a Department objective to achieve parity with the CLF for minority employment." FHS Collection, F13.2. "File, Civil Rights: Forest Service Civil Rights Program."

$651 \quad$ According to Arthur Bryant.

652 James E. Crowfoot notes that the framework for diversity and multiculturalism in work organizations is based on the following: Chesler, Mark A. and James E. Crowfoot, Racism in Higher Education I: An Organizational Analysis. Program on Conflict Management Alternatives Working Paper \#21. Ann Arbor: University of Michigan, Center for Research on Social Organization, 1989, pp. 1-63, and Chesler, Mark A. and James E. Crowfoot, "Racism on Campus" in Ethics and Higher Education, William W. May, Ed. New York: MacMillan, 1990, pp. 195-230. “Appendix: Multicultural Organization: What is Needed in the USDA Forest Service?” (January 1991) in TMO Report, fn, p. 30. 
who presented a democratizing vision of multicultural organizations in language that incorporated the notion of representative bureaucracy. A multicultural organization:

- Reflects the contributions and interests of diverse cultural and social groups in its mission, operations, and product or service;

- Acts on a commitment to the eradication of social oppression in all forms within the organization. It is also sensitive to the possible violation of the interests of all cultural and social groups whether or not they are represented in the organization;

- Is one where the members of diverse cultural and social groups are full participants at all levels of the organization, especially in those organizations;

- Follows through on its broader external social responsibilities including its support of efforts to eliminate all forms of social oppression. This also involves the support of efforts to expand the multicultural ideology. ${ }^{653}$

In short, the task force product, Report of the USDA Forest Service on Work

Force Diversity, proposed reshaping agency consciousness, a process that some might say had already begun. The task force identified its work as the culmination of initiatives beginning with the 1976 civil rights policy that established numerical targets and continuing with the 1987 extension of diversity goals and vision via Work Force 1995. According to TMO supporters, the report was an "ingenious" culmination of "minimovements" and events meant to provide a "roadmap" for diversification to agency leaders, a time of "value orientation" that made "perfect sense." ${ }^{\text {"654 }}$ Said Arthur Bryant, TMO was the "pinnacle" of diversification and Lamar Beasley was its patriarch. "It wouldn't have come about had he not been the person at the helm at that point." ${ }^{\prime 655}$

653 Bailey W. Jackson and Evangelina Holvino, "Multicultural Organization Development," Program on Conflict Management Alternatives, Working Paper \#11. Ann Arbor: University of Michigan, Center for Research on Social Organization, 1988, 6-7, in Crowfoot Appendix, 30.

${ }_{654} \quad$ Arthur Bryant interview; Elizabeth Agpaoa Telephone Interview, Mary 29, 2013; Lamar Beasley interview; Mary Wagner interview.

$655 \quad$ Arthur Bryant interview. 
Changing Paradigms: What is a Multicultural Organization?

If you are the U.S. Forest Service and we all are here on this planet due in part to having this agency who's entrusted to steward these resources for current and future generations. Then we, literally, are connected to all people. I mean the natural system and the human system are inextricably connected... it was a moment that a lot of people sort of reference back to as a really, like the formal departure point for a journey that we knew was going to be long lasting. - Mary Wagner, Associate Chief, 2013

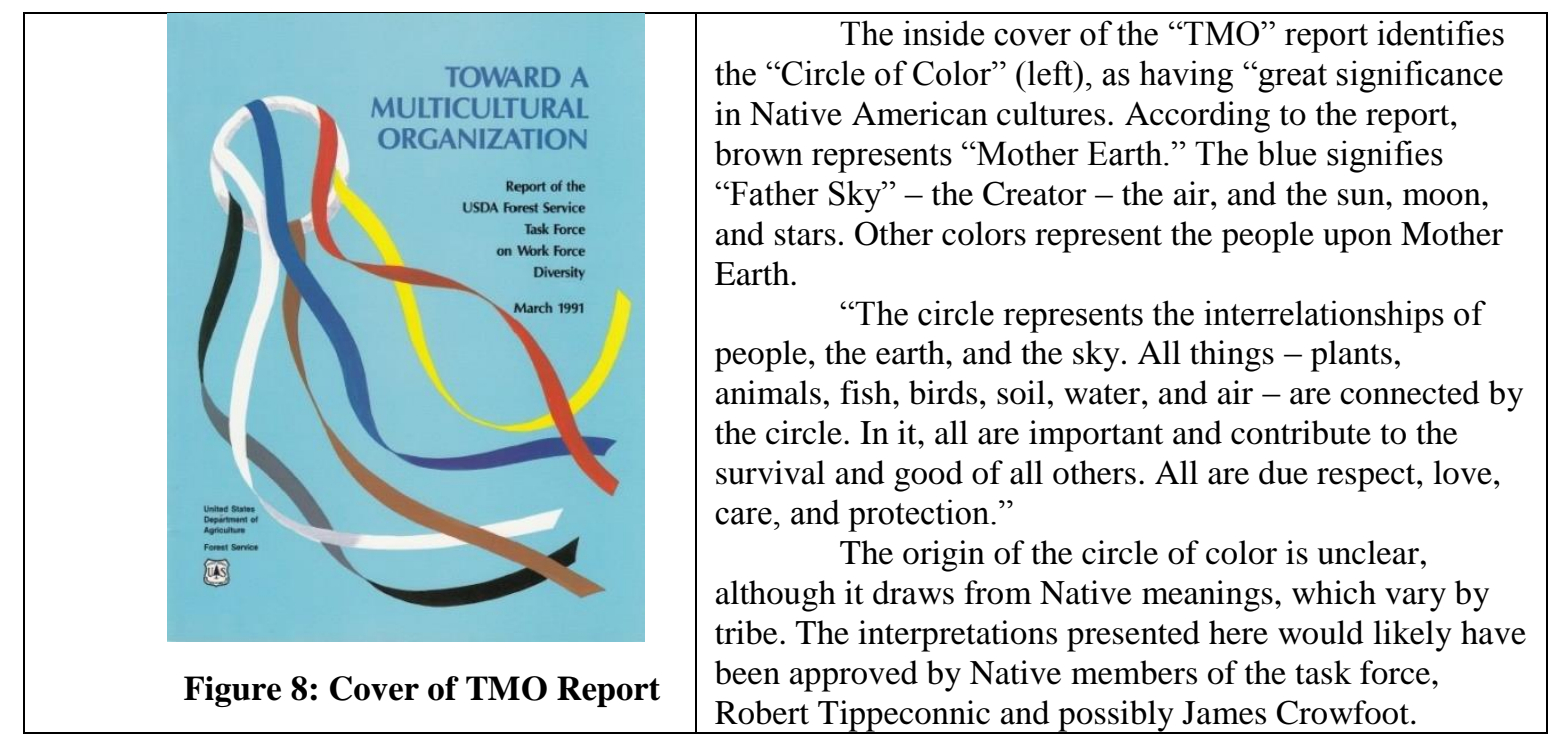

The report's cover reflected two decades of ecological, social, and occupational entwinement leading to the main diversification strategy: converting the agency into a "multicultural organization," which Beasley noted would require "a behavioral change" that "leadership can't dodge..." In fact, the task force viewed this change as a "social imperative." Reinforcing the "interrelationships" signified in the image above, diverse Forest Service employees would "work in a caring and nurturing environment in which leadership, power, and influence are shared. ${ }^{.656}$ Strategies to achieve a multicultural 
organization promoted participatory, "multicultural management" to draw from "the diverse backgrounds and abilities of employees" to make the agency competitive in the labor market. This meant replacing traditional "quasi-military" approaches with shared decision-making. Rather than personal and group discipline, the "primary adhesive" that "binds Forest Service employees together" should be "mutual respect, common purpose, and love for each other. An organization with those ties," stated the report, "will be an employer of choice. $" 657$

Anticipating resistance between the idealistic goals of the report and the reality of an agency beset by personal and organizational biases and history, the task force recommended systematically identifying and addressing the needs of all employees using a marketing approach. In fact, TMO and New Perspectives both called "for greater flexibility and more sensitivity to land management." These interwoven strands of diversification echoed in the report's final strategy statement: "We note that similar changes are being recommended to increase creativity and improve quality in the workplace. We also see a relationship to the New Perspectives philosophy, which must embrace new values and attitudes to succeed." 658 Consequently, the task force recommended a paradigm shift. The Forest Service must "carefully and honestly" define the relationship between workforce diversity and its mission; that is, determining if and

Ibid, 4. Ibid, iii. 
how workforce diversity is essential to "caring for the land and serving people." 659 They proposed this aspirational statement:

The Forest Service is multicultural and diverse. Employees work in a caring and nurturing environment in which leadership, power, and influence are shared. All employees are respected, appreciated, and accepted for their contributions and perspectives. As a result, Forest Service efforts and services are highly innovative, effective, and satisfying. ${ }^{660}$

The task force had no doubt about the importance of workforce diversity in carrying out the mission. The trick, they felt, would be to convince everyone else of its centrality. Change could occur through power sharing, modifying organizational structures, and addressing value laden cultural issues that impacted work; such as, use of time, expressing emotion and/or conflict resolution, recognizing achievement, what constitutes appropriate dress and/or humor/behavior, acceptable problem-solving styles, balancing tasks and processes, and even the types of celebrations, rituals, or holidays appropriate to the work place. ${ }^{661}$ Funding would be an issue, but the need was urgent. Employment of white males was on the decline. The agency's public image needed to change. Last but not least, an aging workforce verged on retirement. The Forest Service must become a multicultural employer of choice: "And do it now!" 662

The task force set eleven goals, described each situation, and proposed tactics to achieve change (See Appendix D, TMO Goals and Strategies). At a very basic level, these goals and strategies boiled down to commitment and accountability by leadership,

$\begin{array}{ll}659 & \text { Ibid, } 5 . \\ 660 & \text { Ibid, } 3 . \\ 661 & \text { Ibid, 6. } \\ 662 & \text { Ibid, 7. }\end{array}$


recruiting and retaining diverse employees, improving work environments, valuing and ensuring acceptance for all employees in the agency and in communities, improving work/family relations, and providing recognition of diversification efforts at all levels. Although hopeful goals like "ensuring acceptance for all" and "power sharing" did not reflect the reality of everyday life, Chief Robertson publicly supported this TMO path to diversification. Having set a new direction for the agency, Lamar Beasley reported that being task force chair was "one of his greatest experiences."663

\section{Introducing Multicultural Change}

Implementing TMO

There are points in the Task Force report that I believe in and identify with. The task force did a good job in describing a vision. The report was discussed with C\&S [Chief and Staff] and RF\&Ds [Regional Foresters and Districts], and top management has endorsed the idea and concepts in this report. - Chief F. Dale Robertson, May 15, 1991

Not only did the chief respond positively to the TMO presentation and vision, he so fully supported implementation that he quickly had a resolution drawn up to indicate leadership backing. The resolution noted that formal presentation in February identified four overall strategies and eleven specific goals for achieving a multicultural workforce. It reaffirmed concerns about achieving workforce diversity and recognized "the value of a caring environment" for employees. Finally, it "resolved" that Chief, Staff, and the management team "strongly" endorsed and supported "the principles outlined" in the 
TMO report. Most importantly, Chief and Staff committed "to taking a leadership role in accomplishing the goals of the report."

The Chief then held an "Introduction to Multicultural Change" meeting at the W.O. (May 15, 1991), to reinforce his commitment to organizational change. Earlier generations "did their best, based on how they understood the world and what they thought was good and right," he said. But, "[w]e have to change with the times. The work force is changing, society is changing and the Forest Service needs to change with it...It is inevitable...” The Forest Service knew how to recruit but failed at retention. "To be an Employer of Choice," and keep up with the competition meant "managing diversity. We have to have a caring and nurturing environment, look beyond the numbers for what it is that we want to be - what we stand for." The significance of TMO lay in "basic ideas, concepts and strategies... and whether they capture the essence of what we, the Forest Service, as an organization want to stand for and what we want to be in 1995 and 2000 and beyond..." Becoming a multicultural organization meant "significant" broad based "cultural change," conditions faced by all organizations in light of shifting demographics. "We have a choice," said Chief Robertson, "we can plan for the change or be dragged along." There had been a time when foresters and engineers could not accept one another's views. "But we're now interdisciplinary and better for it." Being interdisciplinary meant changes in resource management, and in work relationships.

\footnotetext{
664 Memo from Chief Dale Robertson to Regional Foresters, Station Directors, Area Directors, and WO Staff, re: Multicultural Organization, March 7, 1991. FHS Collection F13.3, File, "Toward a Multicultural Organization."
} 
For the first time in history, a Forest Service Chief espoused egalitarianism in the agency: "I want us to have an open organization where people can express their views freely, and we value all perspectives and values. ${ }^{, 665}$ Robertson also expanded his staff to include five "multicultural members for Chief and Staff," stating that he wanted to bring a greater diversity of viewpoints to deliberations and capitalize on diversity already present in the agency. These individuals - Karen Liu, Glen Contreras, Robert Lewis, Gary Elsner, and Christine Pytel - would serve for a year at the GS14/15 levels as full members of Chief and Staff, not simply group representatives. Robertson urged high level leadership to also seek diverse perspectives. In fact, he declared: "I cannot overemphasize the special responsibility, and my expectations of Line Officers" in implementing TMO. Management staff must do their utmost to achieve a multicultural organization., ${ }^{, 666}$ If this meant checking off diversity boxes, then so be it.

The chief's mandates launched implementation, but it took until February 1992 for the agency to distribute the TMO plan service-wide. Introducing the "bold concept" of TMO involved one-day employee workshops at headquarters round the nation. Each region then held meetings to develop implementation plans, with efforts varying from distributing the booklet to each unit to creating complex plans. The National Implementation Plan for TMO grouped the original eleven goals into six "National Focus Areas," to link them with strategies from the report for "logical and relevant

\footnotetext{
665 Memo from Chief F. Dale Robertson to WO Employees, re: "An Introduction to Multicultural Change," July 26, 1991. FHS collection F13.3, File, "Toward a Multicultural Organization."

666 Memo from Chief F. Dale Robertson to Regional Forester, Station Directors, Area Directors, and WO Staff, re: "Multicultural Perspectives," July 26, 1991. Ibid.
} 
implementation." Areas included: Training and Development; Work Environment; Outreach and Recruitment; Work and Family; Standards for Accountability; and Recognition. Response varied. Some regions created marketing tools and/or training materials to reinforce TMO ideas. Others placed critical Civil Rights performance elements into evaluations, while some focused mainly on partnerships or family/work policies. ${ }^{667}$

The TMO era had really begun with Agriculture Secretary Lyng's 1986 civil rights mandate to increase diversification activities in the Department, by then known for its poor civil rights record. In response, the Forest Service became a leader, by launching diversification initiatives that set a departmental standard and through leadership involvement. F. Dale Robertson did more than direct staff to diversify. He personally attended a USDA conference with 1890 land grant institutions in April of 1988 and then chaired the working group that suggested a joint U.S.D.A/1890 taskforce. The group proposed placing a USDA office on each 1890 campus, each with at least one Departmental representative to facilitate communication and recruitment - in the spirit of the Tuskegee program begun by the Forest Service in 1968. The working group also recommended a more hands-on approach by USDA for student financial assistance.

Robertson left the 1988 conference as the first chairperson of the USDA 1890 Joint Task Force and one of five agency heads working alongside five presidents of HBCU's. This group carried the conference's seventeen recommendations to the Secretary of 
Agriculture, all focused on strengthening ties with 1890 land grant colleges and Tuskegee University.

\section{Special Emphasis Programs}

\section{Dale Robertson was "willing to step out and take some of those really hard} stances at that time." - Arthur Bryant.

In 1990, the Office of Advocacy and Enterprise sent a letter to Civil Rights

directors in the D.C. area, along with a calendar of "special emphasis events." The bulk of programs, trainings, and conferences focused on African Americans, Hispanics, and women, with the National Congress of American Indian meeting scheduled for November. For the most part, only broad-based organizations like the NAACP, the National Organization for Women (NOW), Blacks in Government (BIG) and the U.S. Hispanic Chamber of Conference hosted programs. The Department of Agriculture sponsored a regional training conference for women. At the time, some "special emphasis" programs existed at the agency level, but unlike the Federal Women's Program (FWP) and the Hispanic Employment Program (HEP), none were mandated by law.

Among the many impacts of Civil Service Reform, the charge to alleviate underrepresentation of minorities and women in government service stands out alongside achieving a workforce "reflective of the nation's diversity." How to do so presented a persistent challenge that required the participation of employees in outreach to their own communities. The National Organization for Blacks in Government (BIG) 
formed in 1975 and incorporated as a non-profit the following year, ${ }^{668}$ later including state and municipal employees; however, Chief Robertson supported creation of one of the first un-mandated "employee resource groups" in the Department of Agriculture, the USFS African American Strategy Group (AASG), a grassroots effort based on specific agency issues. The precursor to the AASG, the Washington Office Network started in the late 1980s with just a handful of Forest Service employees, said Leslie Weldon: "We would get together for lunch and kind of have a networking meeting and get together for other small discussions and then that eventually turned into one of nationwide strategy, [the] African American Strategy Team or Strategy Group.” Arthur Bryant also recalled the group's inception, a meeting “on the weekend at somebody's house." Bryant said he had the "raw idea" for the group, but Jetie Wilds provided the "brainpower" behind it:

All I knew is that I wanted to pull together, at that time ... what I considered, six or seven of the better minds of folks here in headquarters, that could come together and talk about, what is it that we can do to help the agency to help us? To help the agency to see where it may not, necessarily, be fair and equitable in terms of who's getting opportunities and how do we share that in a nonthreatening, very helpful way.

AASG became a tool for empowerment, in part because Wilds had the ear of the chief, who agreed to an AASG representative in every region and research station. "And then," said Wilds, "you had to have a way of dealing with them, and [I] convinced the chief again that we needed an annual meeting to bring these people together to do planning, and I called it the African American Strategy Group.” From its inception AASG sought to bring African American perspectives to the Forest Service. The "whole

668 National Organization of Blacks in Government, BIG, http://bignet.org/index.php/aboutus/philosophy-a-history [accessed March 18, 2015]. 
objective of that group," said Bryant, "was to assist the agency in identifying areas of concern to the African American community in particular. And then recommending how the agency could be responsive to those concerns and needs," by doing thing like keeping a list of African Americans prepared for the line: "when somebody was ready on that list that we thought was worthy of our support... we would either go sit down and have an audience with the chief or we'd write a letter to the chief."

Activities varied, but in addition to acting as watchdog for equity, the AASG received a $\$ 25,000$ per year allocation. The funding supported public programming, meetings, outreach communications, and attendance at conferences like the BIG national training conference held in Seattle in June 1993, where the Reverend Jesse Jackson, Jr. spoke. The conference, attended by approximately 120 agency employees, provided "one of the most educational training experiences" and "most cost effective" in Jetie Wilds' career. "Less than three hundred dollars for nine 2-hour seminars is a bargain indeed," he reported. ${ }^{669}$ It soon became traditional for the chief to attend a BIG preconference meeting with USFS employees, coordinated by the AASG.

AASG also provided a model for other "employee resource groups" in the Forest Service and in the Department. Although AASG already functioned, in 1992 the Code of Federal Regulations authorized agencies to designate EEO directors, EEO officers, and “such Special Emphasis Program Managers" [SEPM's] as necessary to carry out the functions of EEO programs in all organizational units of the agency and at all agency

669 Jetie Wilds, "Blacks in Government (BIG) Conference report," August 30, 1993. FHS Collection F13.2, File, "Personnel - African Americans in Agriculture." 
installations. ${ }^{670}$ The new regulation combined with TMO prompted other agency special emphasis programs to form. In January 1993, Chief Robertson signed the charter and bylaws for a Hispanic SEP, to coordinate Hispanic Heritage Month programs and diversity training that year. In May, the agency officially recognized a Service-wide Association of Asian/Pacific Islander employees by signing a partnership proclamation in a ceremony during the regional forester and station director's meeting. Interim committee chair, Corey Wong signed, while John Kusano, program manager for the Asian and American Indian special emphasis programs worked on a directory of Asian American employees. Meanwhile, an "eager group of Forest Service employees” created an association for people with disabilities, Pathfinders." Its long-range plans included establishing an intergovernmental coalition of federal, state, and local government employees. As had APA, Pathfinders developed a framework to achieve their primary goal: to "act as ally and partner with management in promoting equality, dignity, and independence for people with disabilities.” Larry Payne, a deputy regional forester, and Lamar Beasley co-sponsored the group. Patricia Jackman, Civil Rights staff, served as contact. Jackman would later help to form the agency's special emphasis program for gay, lesbian, bisexual and transgendered employees in 2009. By then, the Department of Agriculture formally recognized seven special emphasis programs: African Americans; American Indian/Alaska Natives; Asian American/Pacific Islanders; Persons with Disabilities; Gay, Lesbian, Bisexual, and Transgendered; Hispanics; and Women. The 
Department also observed heritage months for each of these groups, including GLBT Pride Month in June. ${ }^{671}$

\section{A Watershed for Entwined Diversification}

Achieving a multicultural organization is very similar to implementing a new perspectives approach to natural resources. A new or different organization entity should be formed to help the Agency approach human issues with a more wholistic [sic] approach that values people as a resource, their uniqueness, and their interconnectedness." - TMO Report, 1991

Nineteen ninety-three was a seminal year in the U.S. Forest Service. As the agency adopted Ecosystem Management, the idea of social diversification had also expanded. Chief Robertson, recipient of several conservation awards, then won "Best Manager in USDA for Workforce Diversity" in 1992 and the SES award for "Outstanding Career Executive Leadership and for Success in Meeting the Challenge of Change" in $1993 .{ }^{672}$ As a TMO evaluation team later reported, “excitement was building.” Expectations soared. ${ }^{673}$ In July, the W.O. Civil Rights staff issued a newsletter service-wide so the workforce could "fully participate" in shaping a multicultural organization.

"Incidentally," they stated, "in support of this growth, The Forest Service has requested that our name be changed to the 'Multicultural Organization Staff,", which never occurred. Still, the Civil Rights staff reorganized to incorporate full-time special

671 USDA Office of the Secretary, DR 4230-002, re: "Special Emphasis,” June 4, 2009; Patricia Jackman Interview by author, Rosslyn, Virginia, February 13, 2013.

Senator Mark O. Hatfield, Floor Statement, Appointment of the New Forest Service Chief, November 3, 1993, FHS Collection F13.3; F. Dale Robertson Resume, in Robertson Interview by Steen, 133-134.

673 TMO Revisited, 8. 
emphasis program managers under African American educator, Luther Burse, who reported directly to the chief.

Meanwhile, the language of TMO became an entrée into expanding employee rights for those without federal legal status. ${ }^{674}$ When Region 5 produced a report documenting the discrimination and fear faced by gay and lesbian employees in California and the Northwest, the SCRC called for policy creation. Noting that sexual orientation was "conspicuously absent" in civil rights publications, including the TMO report, SCRC pointed out that the agency "may actually be sending a nonverbal message that these individuals are not considered a valued part of our workforce.” Then, citing ongoing complaints by gay and lesbian employees, they pointed to the TMO vision statement: “"All employees are respected, appreciated, and accepted for their contributions and perspectives.' Given this vision," they wrote, "it is imperative that we make every effort to include our entire workforce, including gay, lesbian, and bisexual employees."675 The chief, in turn, accepted eight out of the nine SCRC recommendations. He immediately asked Personnel Management to prepare a "no harassment" policy statement that expanded the definition of diversity by including sexual orientation, marital status, veteran's status, and political affiliation alongside those categories covered by law. As the Federal Times reported, the sexual orientation report suggested the Forest Service

6741993 Civil Rights Updates; "People: Luther Burse,” Jet (January 25, 1993): 20.

675 SCRC Issue\#94-FTC-02-92. Meg Walker, Federal Times staff writer, "Forest Service Bans Discrimination Against Gay..." no date—-stapled to Memo from F. Dale Robertson, Chief, to Joe Mitchell, Chairperson, SCRC (Service-wide Civil Rights Committee), re: Response to the Service-wide Civil Rights Committee's (SCRC) July 1992 Meeting Recommendation, December 29, 1992. Includes an enclosure with Robertson's response to the committee's recommendations. FHS Collection F13.3, File, "Personnel - Sexual Orientation." 
"take the lead in protecting the rights of gay, lesbian, and bisexual employees," and it did. At Chief Robertson's behest, the agency’s Personnel Manager agreed to send a letter to the Department "requesting that training in this area be included for EEO counselors. I'm hopeful that the Department will agree," wrote the chief, "however, if they do not agree, the Forest Service will continue moving forward" by incorporating sexual orientation into training and everyday diversity issues. By April 1993, the Department issued a no harassment policy that also included sexual orientation. Meanwhile, Chief Robertson agreed to the use of electronic networks for gay and lesbian employees to associate. He rejected a single issue: creating a brochure specific to sexual orientation, instead ordering the R-5 publication, "Sexual Orientation: An Issue of Workforce Diversity" sent to every employee and included with all employee orientation materials.

In the interim, the agency also developed a service-wide recruitment coordination board and deepened partnerships with historically black colleges and institutions. The USFS and Tuskegee University celebrated 25 years of partnership in 1993. John Yancy, by then a forest supervisor in Alabama through Dale Robertson's support, coordinated the event for the agency. Some of the program's earliest graduates attended, Mack Hogans among them, as did the original liaison, Brian Payne, with Dr. Bennie D. Mayberry and Chief Robertson also present. In 1993, the agency also partnered with Alabama A\&M and worked with the university to develop the Center for Excellence in Forestry. Within the next five years, more than eighty Alabama students per summer worked for the Forest Service. Jimmy Reaves, who became the USDA liaison to 
Alabama when he left Corvallis in 1990, and then worked in the Forest Service research unit on the Alabama campus, played a "major role" in SAF accreditation in 2002. The university became the only HBCU/1890 institution to offer an M.S./Ph.D. program in plant and soil science and the only one with a four-year professional forestry degree. ${ }^{676}$

On the Work/Family Life front, the agency implemented a CIP (Continuously Improving Our Work Environment Program) survey related to the task force and later adopted by the Department for use in "sensing" employee satisfaction. A Balancing Career and Personal Needs report identified pleas for telecommuting, daycare, personal leave, and more flexibility related to family when it came to travel options. Some improvements occurred because of presidential orders, such as the 1993 Family and Medical Leave Act and encouragement for federal agencies to use "flexiplace" as a cost efficient, family-friendly option. ${ }^{677}$ Others came out of policy decisions at the local level. Some units allowed children in the office, others helped parents to identify childcare solutions. The agency also officially changed its mobility policy. Employees no longer had to "automatically transfer to be promoted"; that is, unless they were in line or key staff positions. ${ }^{678}$

\footnotetext{
676 John Yancy Skype Interview, December 6, 2012; Memo from F. Dale Robertson to Regional Foresters, etc., re: "USDA Initiative with 1890 Institutions," December 15, 1988; USDA Soil Conservation Service, "Building Partnerships Through Dialogue," Symposium Proceedings, Nashville, Tennessee, April 24-16, 1988. FHS Collection 13.2, File, "Personnel - 1890s Task Force"; the USDA Center of Excellence in Forestry Website noted in 2015 that 60 percent of the agency's foresters graduated from Alabama A\&M, http://www.aamu.edu/academics/alns/bes/fewp/pages/coe.aspx [accessed March 29, $2015]$.

In 1997, the federal average for "flexiplace" work was 4.8\%. The Forest Service averaged 1.5\%, TMO Revisited, 23-25.

678 USDA Forest Service, "Mobility," Intermountain Reporter, Ogden, Utah: Intermountain Region (February 1991): 3. FHS Collection F13.3, File, "Personnel - Mobility."
} 
As for Training and Development, education for a multicultural workforce lagged, while supervisory and technical training improved, but only on a case by case basis. Still, the Training and Development implementation team identified eight multicultural organization strategies, including an agency-wide multicultural resource center and arming employees with the knowledge and skills for success in a multicultural organization. The team also suggested replacing all references to Forest Service family with Forest Service Community. They also called for accountability standards for multicultural training, delegating the design and implementation of local training programs to multicultural teams, developing guidelines for future multicultural teams, and clarifying the role and contribution of employee resource groups in a multicultural organization. Still, the idea of "multicultural skill" as a necessity did not resonate with most employees, or their supervisors. Multicultural training took a back burner to other types of skill development. Soon, the movement toward a multicultural organization would also move to the edge of agency focus and in the age of the Internet, in-person diversity training all but halted. ${ }^{679}$

\section{Discussion: Turning Points}

Our pilot test philosophy and efforts like it should become our normal way of doing business. We really need to tap into the strength of our people or else we're not going to make it in these turbulent times. We've got to have a charged up and turned on group of talented people. And we have to provide them the options, flexibility and freedom to make things work successfully and get the job done - particularly with less resources since we'll never have all the money we need to get the job done. We need to move quickly in 
spreading the Pilot Test philosophy so that it becomes the norm in the

Forest Service. - F. Dale Robertson, 1989

The "Same Bottom Line"

Tension and change shadowed F. Dale Robertson's tenure as leader of the Forest Service. From the second consent decree ruling to the spotted owl decision, this chief contended with internal and external conflict, all the while pushing the agency to broaden its mission to include land and people. The agency had been headed in the direction of ecological and social diversification since the late 1960s via ecosystem research, interdisciplinary land management processes, and programs and policies mandated by law that altered the workforce occupationally and demographically. As he headed to a "Reforming the Forest Service" meeting in Seattle in the spring of 1989 Chief Robertson recalled feeling "low now because things seemed so difficult." But, he decided to find the silver lining and arrived "full of confidence and ready to take on the world." The conference itself included a lot of talk about foresters managing old growth ecosystems, about biodiversity and mosaic management, about complexity, and concern over fragmentation. It pointed to NFMA as a foundation for diversity, and alerted management that current timber practices led to "managing out of biodiversity." One attendee noted that the "participants were almost all white," about a third female, with only one woman on a panel. They "probably represented where the power and expertise for environmental concerns are centered today," wrote the participant.

Likely, Chief Robertson also noticed homogeneity amidst discussions of diversity. Upon return, he sketched out a six-point working agenda, underscored by 
philosophical goals: "our mission is 'Caring for the Land and serving people;"' he reminded; "Gifford Pinchot called for the 'greatest good for the greatest number over the long run;' wise use; basic land stewardship; multiple use-sustained yield; and Forest Service values." Always, wrote the chief "...the same bottom line, perhaps with different words!" ${ }^{680}$ He then outlined a "Chief's 6-point Working Agenda," to guide the agency forward. The six points provided goals "specific enough to measure progress...general enough that there are lots of options, flexibility, running room, and freedom for people to fill in details in their own way." The list provides insight into Robertson's priorities. Numbers two through six identified: partnerships; building strong grass-roots community support systems; customer satisfaction; rounding out Forest Service programs in a multiple use framework - "the basis of our work"; innovative/creative people-oriented Forest Service culture - the "pilot-test philosophy." Workforce Diversity topped the list, with Luther Burse, formerly president of Fort Valley State College, as staff assistant to help the agency meet its Workforce 1995 goals. ${ }^{681}$ Burse brought an "outside perspective" to help the agency "see some things that we're blind to." Robertson and Burse planned to meet with new forest supervisors, regional staff and assistant station directors: "I don't want the message diluted and want everyone to know personally how important this issue is."

$680 \quad$ "Incentives for Better Forest Management, Reforming the Forest Service," penciled on side, Jeff Blackwell (likely the author), Planning, Region 6, Spring 1989. FHS Collection 15.2, File, "Region 6 Miscellaneous."

$681 \quad$ Burse remained with the Forest Service until 1998 when he returned to the field of Education, "Luther Burse," Notable Kentucky African Americans Database, http://nkaa.uky.edu/subject.php?sub_id=136 [accessed March 28, 2015]. 
Workforce 1995 and TMO never did achieve CLF representation, but they came close. As the SCRC demonstrated in 1986, women and minorities faced demonstrable underrepresentation in nearly all areas, not just numerically but also occupationally. Chief Robertson launched his workforce initiative in 1987. By 1992, the female workforce nearly achieved parity at 40 percent. Minorities also increased faster than ever before. In 1976, minorities constituted eight percent of the USFS. workforce. It took ten years to add four percent to the minority workforce. By 1991, the Forest Service increased minority employment another three percent. Twenty years later, that number had inched upward only slightly, even as the minority CLF nearly doubled to 33 percent. Meanwhile, during the TMO era, both minority and female leadership positions increased dramatically, by six times on both counts (see Table 16, p. 317). ${ }^{682}$

Chief F. Dale Robertson appears to have honestly prioritized workforce diversity, as evidenced by numerical progress in the TMO era. The Department of Agriculture adopted parity as policy in 1993. The Forest Service had done it six years earlier-in 1987. Commitment to diversity also manifested in other ways. For example, when the chief introduced TMO at the Washington Office in May 1991, one attendee asked what support, if any, the new Secretary of Agriculture (Edward Madigan) would provide "for the creative move (multiculturalism)?" The chief responded: “I don't expect any change. We (the Forest Service) should not sit back and wait for a pronouncement from the secretary." Why? Chief Robertson reiterated, "because this is the right thing to 
do.” The Forest Service had established its first Tribal Government Program Manager in the Washington Office in 1988, because of the legal obligations of working with tribes but also to facilitate partnerships. The Washington Office Network that morphed into the African American Strategy Group also formed around that time. Movement toward parity, development of multicultural teams, and other diversity initiatives occurred for several reasons in the Forest Service TMO era. Yes, the Department of Agriculture mandated agency diversification efforts, but the TMO era solidified programs and policies that would be followed departmentally and by other agencies. Forest Service leadership set goals, identified the "can-do" managers to achieve them, promoted women and minorities to leadership positions, and ensured that advancement in the age of entwined diversification meant supporting ecological and social diversity.

Most importantly, leadership recognized the need for flexibility. For Robertson, the "pilot test" philosophy cited at the beginning of this discussion applied to both natural and human resources. When Jeff DeBonis created AFSEEE and agency leaders protested timber policies, Robertson and Leonard paid attention. When the R-6 minority workgroup organized the Welches conference in 1988, they invited keynote speakers like the godfather of critical race theory, Derrick Bell, and Indian education advocate Thomas Shortbull. The elasticity of human ecosystems is evident in these orators whose presence reflected a racial progressivism unmatched in the agency at the national level, regardless of intention. Although national organizers looked to Welches as a model, the Atlanta conference more clearly reflected the host of institutional problems associated with ecological diversification. It also suggested expanding definitions of diversity, 
more focused on gender and power, disability, and management issues in the coming century than racial progress. Still, the diversity conferences, small and large, that took place in the TMO period demonstrate the pilot test philosophy in action, as does the pliability of the TMO process. As Lamar Beasley pointed out, TMO took a lot of time and money to develop. There is no better indicator of commitment than funding upward of thirty employees at various levels and from around the nation in meeting face to face over a period of eighteen months. But what happened to TMO?

\section{The Northwest Forest Plan}

In many ways, the social diversity efforts of the TMO era were overshadowed by struggles over ecological diversification. In April 1993, newly elected president Bill Clinton called a forest summit in Portland, Oregon. By then, the owl and the marbled murrelet had been listed as threatened, some species of Pacific salmon were threatened and endangered, and more than a hundred and sixty Northwest species had been identified for possible listing. The forest meeting brought together the president, Vice President Al Gore, cabinet members, environmentalists, logging and lumbering representatives, and community members, but neither the head of the BLM or the Forest Service were asked to speak. Its outcome, the Northwest Forest Plan drafted by the Forest Ecosystem Management Team (FEMAT) under Jack Ward Thomas, relied on government-wide partnerships amongst natural resource agencies. ${ }^{683}$ Although

683 Forest Service, BLM, National Marine Fisheries Service, Environmental Protection Agency, and FWS. 
contested, when the courts approved the plan in December 1994, environmental gridlock ended at last. $^{684}$

Timber harvests had begun to decrease by 1990, but the effects of ecosystem management would be years, perhaps decades in the making. Workforce reductions, too, began in 1990, first with a voluntary employment freeze followed by mandated reductions that cut the Region 6 workforce in half by the end of the decade. By then Chief Robertson and Associate Chief Leonard were long gone. Having dealt with some of the most contentious issues ever in an agency beset by controversy from its inception, Robertson "was ousted" at the end of 1993. First, under pressure from Congress for not cutting enough and then from environmentalists for cutting too much, Robertson's handling of the spotted owl debate prompted the Bush White House to direct Secretary of Agriculture Edward Madigan to fire him in 1993, but he “declined," wrote Harold Steen. Robertson's “implementation of the Thomas report, named for Jack Ward Thomas... was seen as too restrictive to commodity users.” But under the Clinton Administration, the new Secretary of Agriculture, Mike Espy - the first and only African American Secretary well into the twenty-first century - announced Robertson's removal, "because he represented Republican priorities," determined Steen. ${ }^{685}$ Dale Robertson left behind an agency that had made significant strides, but whose attention was increasingly consumed by endangered species and economic impact concerns that would set its agenda in the coming years. 


\section{Chapter 9: Strength Through Diversity}

Will the agency be successful in creating a diverse workforce? "This is, perhaps one of the most important issues facing the Forest Service as it enters its second century. The question is whether the agency can find strength from the many, achieve diversity in an increasingly diverse world, and discover ways to continue to lead natural resource management in our complex democracy. Put another way, perhaps the challenge facing the Forest Service today is one of taking what worked for it in the past - what gave it one of the strongest organizational cultures in government - and learning how best to adapt that for the challenges ahead. This may be as daunting a challenge as the move to ecosystem management" (Carroll, et. al., 41).

This final chapter briefly reviews the fate of USDA Forest Service diversity efforts in the 1990s and then draws larger conclusions about workforce diversification in the late twentieth century. It addresses the role of law and policy in shaping equality of opportunity and the civil rights relationship between USDA and its many agencies. It reviews the evolution of entwined diversification in the 1970s and 1980s and identifies areas in which the Forest Service set the pace for civil rights progress. It also pinpoints leadership shifts that swayed the trajectory of inclusion. Finally, it identifies the role of biography in narrative policy analysis and addresses the many lessons of representative bureaucracy identified through this study.

The story of Sidney Clark illustrates the continued challenges in changing agency culture. On April 28, 1997, Sidney Clark walked into his office at the Forest Service Regional Office in Portland, Oregon to find two sheets of paper lying face down on his chair. A year earlier, Clark had represented another African American employee at a special Department of Agriculture civil rights session and had experienced veiled repercussions ever since. But, there were no hidden meanings that Monday morning. 
The first piece of paper, a typewritten mock application to live in Etna, California looked like an official Forest Service document, but upon closer inspection made clear that the type of person who ought to be working for the agency was not an urban black man. Rather, the application called for "personal information" like "Neck Shade," light, medium, or dark red, and asked "Are you married" to your sister, cousin, or son. A line for CB Handle and "Pa's Name (if known)" and "Ma's Name" rounded out the personal section. Under Interests and Qualifications, the theme of backwoods redneck living as the qualification for life in Etna continued, through queries about bumper stickers ("As a Matter of Fact The Road Does Belong To Me"), singers (country), recreation (T'backy spittin'), truck equipped with (gun rack, fuzz buster) and weapons owned (varmit rifle), hat emblem (Skoal, for one), and memberships held by the applicant: VFW, KKK, NRA, PLT, Elks, Moose, or American Legion. If the intention still remained cloudy, the second piece of paper - a handwritten scrawled note - did not. The note read:

\section{"YOU TROUBLE MAKIN' NIGGER GET THE FUCK OUT OF OUR COUNTY!",686}

Four days later, regional forester Robert Williams issued a letter to All R-6 employees seeking information about this "mean, threatening and vicious" material. By May $5^{\text {th }}$ the story hit the local newspaper, the Columbian, where Clark said that officials had yet to take action to find the perpetrator. Clark requested that the FBI get involved, since the incident constituted a hate crime. Earl Ford, then an ecosystem manager on the Gifford

\footnotetext{
686 Message scan for Jerry Williams, from Susan Johnson, re: Forwarded: Hate Mail, May 2, 1997, previously from Earl Ford to Susan Johnson. FHS Collection F5, File, "Civil Rights - African Americans."
} 
Pinchot National Forest and editor of the newsletter for the Pacific Northwest Chapter Coalition of Minority Employees, sent out a copy of the hate mail, along with a letter noting that the incident had been reported to the Secretary of Agriculture and the FBI. "For all those that consider this a foolish prank," he wrote, we don't think there is any humor in hate crimes, and we are morally outraged by this latest act." 687

In fact, the same mock application had been left on the desk of the employee represented by Clark at a special Department of Agriculture session in Sacramento the year before. The forum had been initiated when Lawrence Lucas, president of the Minority Employee Coalition, an organization formed in 1994 sent an open letter to the Secretary. Lucas wrote:

I ask you do to the unusual - seek to hear the pain and suffering that people on your staff refuse to hear. Have a civil rights forum not for your Assistant Secretaries, Administrators, managers, not for your civil rights directors who walk a fine line between management and employee, but for the People, for the suffering. Give yourself a chance to know the truth, hear the other side... ${ }^{68}$

Secretary Glickman responded by setting a forum date for May 14, 1996. The Coalition, which formed in 1994 and now had 600 members and eight chapters nationwide, announced that it would call a press conference on May $13^{\text {th }}$ to draw attention to the "human and public cost of widespread discrimination at USDA." The coalition reported it had been unsuccessful in working with the Secretary and his administration to eliminate barriers in program service delivery and employment. The

687 Ibid; Loretta Callahan, "Forest Service Investigating Hate Mail Incident at Regional Office," The Columbian, May 5, 1997, B-3.

688 Letter from Lawrence Lucas, President, Coalition of Minority Employees to Dan Glickman, Secretary of Agriculture, re: “Open Letter to Dan Glickman,” February 16, 1996. FHS Collection F5, File, "Civil Rights - Participation in Forest Service Programs by Ethnic Minorities." 
issues they planned to address included: discrimination, reprisals against employees, and hostile work environments, mismanagement in program delivery, lack of accountability, and glass ceilings for people of color, women, and those with disabilities. ${ }^{689}$ Prior to the forum, a group of approximately forty anonymous employees sent another letter to Secretary Glickman, noting that over "the last three years" USDA had paid "very little attention" to problems in the "former" Office of Civil Rights Enforcement, which had been divided between Civil Rights, Operations, and Management Services. The letter included nineteen allegations related to the EEO complaint process and sought investigation by an unattached qualified investigator and appointment of qualified senior managers to head the program complaints and civil rights departments. ${ }^{690}$

A plethora of EEO complaints faced the agency, evidence that the system did not work well. The department itself recognized that lack of accountability and unclear performance guidelines in relation to civil rights resulted in a "widespread belief among many employees ... that managers of the Department are not being held accountable for their performance in civil rights." In fact, ever since the department had pushed for increases in minority and female employment and agencies like the Forest Service stepped up in ways that provided measurable results, the number of EEO complaints had risen consistently. New formal complaints had averaged fifty-five per month since 1993. By 1996, several hundred complaints had been filed with the Department. ${ }^{691}$

\footnotetext{
689 News Release, April 25, 1996, Collection F5, “Civil Rights - Minority Participation.”

690 Letter from "Concerned Employees" to Dan Glickman, Secretary of Agriculture, "Office of Civil Rights Enforcement," May 1, 1996, Collection F5, "Civil Rights - Minority Participation.”

691 TMO Revisited, 9.
} 
One of those complaints came from Earl Ford, who filed a racial discrimination suit against his supervisors at the Gifford Pinchot National Forest in December 1996. Ford also initiated a class-action suit against the Forest Service on behalf of minorities, women, the disabled and others in Region 6. When Sidney Clark, then-president of the Northwest chapter of the Coalition of Minority Employees received hate mail, Ford also went to bat for him in his capacity as newsletter editor for the organization. He quickly alerted others and spoke publicly about discrimination faced by minority USFS employees. Ford was not alone in protesting conditions in the Forest Service. Class action suits had been filed, separately, on behalf of white males and Hispanics in Region 5 and African Americans in Region 8. Nothing formal seems to have come of the Region 6 class action suit, but with a new Forest Service chief in place in 1997, the agency looked back to the TMO era and recommitted itself to workforce diversity.

\section{The Aftermath of TMO}

Orientation, Preference, and Policy

Although some employees appreciated the USFS emphasis on diversity in the late twentieth century, many resisted formally and informally. For example, when Michael Rains reported on the national diversity conference by Email, a handwritten note at the top of the printed testimony reflected the internal tension and external criticisms of multiculturalism. It read: “Classic document -- ass kissing!” A woman filed a suit against the Forest Service for sexual harassment by a lesbian in Region 6 in 1993 
and when the complainant quit and received unemployment, the agency challenged it. ${ }^{692}$ In response to TMO, the European American special emphasis group formed, as did a Christian group. All demanded access to the DG (data general) email system, calling for the "special rights" of minority groups. And, as the number of EEO complaints increased significantly, years often passed before people received even a response.

A letter to Chief Robertson from Lee Bowers of Oregon's Silver Lake District on June 18, 1993 illustrates a semi-typical response to the changing agency culture. Written in response to the R-5 sexual orientation report and subsequent debates, the letter writer requested that if the chief were to meet with those who wrote the sexual orientation report, his group should also attend to clarify their "reaction" to sexual orientation as a matter of workforce diversity. From Bowers' perspective, the chief had done more than call for a harassment-free workplace. Rather, he clearly supported a "lifestyle" based on sexual "preference," not orientation. The group felt that including sexual "preference" as a category for "a non-hostile and harassment-free work environment for all employees" meant they had been told to "accept the homosexual lifestyle and become an advocate of it." He explained:

We in R6 have put a considerable effort into defining what is acceptable to Christians and what is not. We do not advocate harassment, but we do request that you not attempt to stifle our input or us as a group. Christians have been the backbone of this Nation and will continue to be so. ${ }^{693}$

\footnotetext{
692 "Harassment claim involves lesbian," Oregonian, October 24, 1993, B6.

693 Letter from Lee G. Bowers to F. Dale Robertson, Chief, June 18, 1993. FHS collection F13.3,
} File, Personnel - Sexual Orientation. 
Bowers "demanded" further discussion if the tenets of departmental and agency policy "are the driving force and basis" for the sexual orientation report. Furthermore, the "racist and sexist" TMO document which the chief had signed "inferred that white males were not contributing to diversity," that they were "the cause of all the problems of this nation.” In keeping with the larger social backlash to diversity, Bowers and his cohort questioned whether multiculturalism, which had been "bandied about" as a solution to social ills and a goal for the agency was really "all it's made out to be?"694

\section{Reverse Discrimination}

Arguments about the place of workforce diversity in the agency, interpretations of the law as colorblind and what it means to be part of a protected class occurred electronically and via snail mail throughout the 1990s. When a group of men in Region 5 filed suit against the agency in 1992, charging reverse discrimination, the drama heightened. Melody Mobley, one of the first female African American foresters in the agency (who worked in Washington State in the 1970s) responded to the white male allegations with a letter to Secretary Edward Madigan, and a firestorm of backlash ensued. As the top ranking African American female in the agency, Mobley observed that she was "an outstanding example of the potential of many minorities and women" who had benefited from enforcement of Equal Employment Opportunity laws. She also reminded the Secretary that USDA stood near the bottom in the federal government for employing women, minorities, and people with disabilities; especially African

$694 \quad$ Ibid. 
Americans, male and female. "As you well know," she wrote, "the remedy for underrepresentation in the work force is deliberate action, not just good inten[t]ions. ... The desirability of work force diversity is not a subject for debate within the agency." Diversification was a matter of law. ${ }^{695}$

Some Forest Service employees thought the agency had gone beyond the law. Ralph Johnson, “a working, field forester” followed Mobley's letter to the Secretary with one of his own. Johnson argued that equal employment law excluded non-merit factors such as race and gender and that the Civil Service Reform Act (PL 95-454) did "NOT" call for recruitment of women and minorities only. Johnson cited the law itself, which directed recruitment from "qualified individuals from appropriate sources in an endeavor to achieve a work force from all segments of society," with selection and advancement based on "relative knowledge, and skills, after fair and open competition which assures all receive equal opportunity." ${ }^{696}$ All employees should "receive fair and equitable treatment in all aspects of personnel management," noted Johnson; therefore, recruiting only the best and brightest of women and minorities was exclusionary. Marsha McHenry, “a working, African-American female” replied, copying Mobley and suggesting that Johnson share her letter with others on the male class-action list. McHenry told Mr. Johnson to "keep in mind the reasons that those laws had to be enacted in the first place. It certainly was not because we had been receiving fair and equitable treatment all along." It doesn't "feel so good," she wrote to Johnson, not to 
receive the "elite treatment and/or unlimited employment opportunities" to which white males were accustomed. Take a look around "YOU," she suggested. "What does the minority population look like? What did it look like 10, 15 years ago? Interesting, huh?"

And so it continued. Each side presented its own logic, evidence, and interpretations of past and recent trends. Johnson pointed to the average time in service and average grade for minorities and females in recent years. McHenry observed that white males seemed to have suddenly noticed EEO laws, despite their existence for years. Thomas Locker of Truckee, California admonished that not everyone who "qualifies" on a certificate is "equally qualified. The old Civil Service test scores" used to rank employment candidates, so that only those in the high 90s on a hundred-point scale would be selected. "Many within the Forest Service," wrote Locker, "feel that "to eradicate discrimination' white males with 'scores' in the high 90s are now being passed over in order to select women or minorities with 'scores' in the low 70s." Locker countered Mobley's contention of USDA's employment record by pointing to recent Region 5 statistics regarding new hires of women (58\%) and their promotions (50\%). If white males were 45 percent of the CLF, wrote Locker, they should have been hired in the same proportions. Even if underrepresentation did exist, "its cause is not malicious or deliberate." And if it were deliberate, those punished had not committed the crimes. Where Mobley called for deliberate action, Locker asked: what do you "call it when affirmative action requires that a less qualified person gets a job you hoped for?"697

697 Letter from Thomas Locker, Fire Engine Captain, Truckee, California to Secretary Edward Madigan, December 14, 1992. FHS Collection F5, File, "Civil Rights: Male Class Action Lawsuit." 
Land Over People

Over the past 35 years, Congress has done an excellent job of layering numerous contradictory forest and resource management laws on top of one another, all the while expecting immediate and clear results from the Forest Service. In fact, over half of the laws affecting forest management in the United States today have been passed since 1964. - Senator Mark Hatfield, November 4, 1993, on the floor of the Senate concerning F. Dale Robertson

In November 1993, Senator Mark Hatfield berated the Senate for its treatment of Forest Service Chief F. Dale Robertson. Congress caused the problems in the Northwest woods, not Robertson. Whether wittingly referring to the Civil Rights Act or not in the statement above, Senator Hatfield's chronology accurately identified 1964 as a key year for change, the beginning of an end. The environmental laws of the 1970s had clearly reshaped Forest Service operations through incorporation of the "ologists" and more interface with the public; however, the laws that guided workforce change also shook up the internal stability of the organization. Where unity had been strength, diversity appeared divisive, evidencing a primary critique of multicultural policy. Diversified conformity provided a tenuous and unpredictable medium that, like tampering with natural ecosystems, could produce unforeseen results. The Forest Service was, indeed, in an environmental - and social - quagmire that would continue well into the twenty-first century. With Bill Clinton in place, Jack Ward Thomas had become not just the first wildlife biologist to lead the agency but also the first political appointee in the position. Thomas took the job, expecting an appointment to the Senior Executive Service that never happened, while inheriting a policy he had played a major role in shaping. Environmentalists rested easier with a wildlife biologist leading the agency but people in 
logging communities cringed. Most agency employees resented the politics that put Thomas in place and many disliked the policies associated with his presence, while others preferred them. And Thomas got credit from the public for ecosystem management, the policy put in place by Robertson, who pointed out that clearcutting should have slowed under NFMA but political demands had prevented it. Rather, said Robertson, the agency found the exception that allowed for clearcutting and "burn and cut" became the standard.

Still, having facilitated protection of the spotted owl, Thomas found himself well-positioned for environmental leadership. Workforce diversification was another story. When he became chief, Thomas recalled hearing that the agency's "primary mission was civil rights and meeting the Secretary of Agriculture's objectives in that arena." He disagreed. "I did the best I could to carry out the civil rights agenda," he later said, "but I thought it was going too far to make that our most important task." Thomas supported workforce diversity, but to a limited extent. He was a big game biologist, not a public administrator. With diminishing funding alongside expanding concepts of land management, it quickly became clear to employees of color that Thomas emphasized land over people.

By 1994, the Department of Agriculture had earned the moniker "the last plantation" because of discrimination toward black farmers and employees. ${ }^{698}$ As the backlash to TMO heightened, the African American press turned its attention to the Forest Service. In fact, the agency's director of civil rights, William Atkinson, sent a 
letter to the Assistant Secretary of Agriculture in June 1994 to note "refusal of top Forest Service management" to ensure minority representation at Forest Service leadership gatherings, reasoning "that 'this is not going to be a civil rights meeting." So long as "the White male dominates" high level positions, said Kent Schneider, the agency's cultural heritage program manager, there would be little change or advancement for women and minorities. "My women and minority colleagues are stuck in place," he said. "They are marginalized, powerless to do anything about it except leave. Many have." A month later, the $A F R O$ newspaper in Washington, D.C. reported that African American professionals in the Forest Service felt "the current Chief, Jack Ward Thomas 'makes it very clear to us that people issues are not a priority." ${ }^{\prime 699}$

\section{TMO Revisited on the Last Plantation}

I think once we got to those numbers, we just thought, okay, it's going to take care of itself. And it doesn't take care of itself. People retire. ... I came in with this cohort of women and minorities, big cohort. Because we were 40,000 employees then... we came in with this big push and big budget to create. We had a lot of leeway and choice to make the new hires. - Elizabeth Agpaoa, 2014

In 1994, Secretary of Agriculture Mike Espy created a "Blue Ribbon Task Force on Equal Opportunity and Diversity" to emphasize civil rights for the entire department, not just civil rights staff; however, soon after forming the team Espy left under a shadow, having been accused of improperly accepting gifts. Although ultimately exonerated, by 
then Dan Glickman had replaced him. ${ }^{700}$ In May 1996, as the Agriculture Department held hearings at the behest of Lawrence Lucas, the task force submitted its report. It identified four key issues: accountability; underrepresentation/underutilization; complaints management; organizational structure and resources; and recommended civil rights education and training in diversity management. Like the Forest Service five years earlier, the task force called for establishing and communicating new values and a new vision. ${ }^{701}$ Meanwhile, the Department of Agriculture came under fire again as black farmers protested in front of the White House.

In response, Secretary Glickman chartered another team. The USDA "Civil Rights Action Team" (CRAT) held eleven listening sessions nationwide, and surveyed the department's thirty-two agencies to identify a host of common issues: sexual harassment, favoritism, hostile work environment, and lack of protection from reprisal. The resulting 1997 report, Civil Rights at the United States Department of Agriculture made ninety-two recommendations and appointed thirty-three implementation teams. The team quickly established policies against reprisal, while calling for immediate adjustment upon report of hostile and volatile workplace conditions. It assigned EEO complaints to special teams for resolution through mediation, arbitration, or similar alternative dispute resolution practices for employees who filed before January 1, 1997.

700 Ann Devroy and Susan Schmidt, “Agriculture Secretary Espy Resigns," Washington Post, October 4, 1994, A01, http://www.washingtonpost.com/wpsrv/politics/special/counsels/stories/espy100494.htm [accessed April 15, 2015];Bunthay Cheam, "Espy, Mike" BlackPast.org, Remembered and Reclaimed Website, http://www.blackpast.org/?q=aah/espy-mike1953 [accessed June 29, 2015]. Ann Veneman, in turn, replaced Glickman, the first and only woman to run the Department of Agriculture. Subsequent Secretaries under the Obama Administration have been white males.

701 TMO Revisited, 10. 
CRAT echoed the earlier taskforce regarding organizational structure. Before 1994, most agencies had their own civil rights offices whose directors reported to each agency head; however, sometimes civil rights offices reported to program managers in the field, not an agency's civil rights office at all. This was certainly the case for the Forest Service at various times. Nor did all agencies have civil rights programs. CRAT determined each should have a civil rights director, someone in the career SES who would report to the agency head who, in turn, would report to the assistant Secretary for Administration. Rather than operating on an ad-hoc agency basis, the Office of Civil Rights would monitor and oversee regulations to ensure agencies operated effective programs that were "proactive and adequately staffed and funded." The reorganization sounded promising. Civil rights programs should set measurable goals and timetables to address employment issues. It also returned EEO counselor positions from the Department of Agriculture to agencies, including USFS. ${ }^{702}$ Basically, CRAT called for more accountability by USDA for agency activities, better civil rights training for all, and dedicated staff with a more significant role for special emphasis program managers that included utilizing the Forest Service CIP (Continuous Improvement Process) worklife surveys to facilitate retention. ${ }^{703}$ USDA also directed all agencies to report on their

702 Civil Rights Action Team, Civil Rights at the United States Department of Agriculture: A Report by the Civil Rights Action Team (Washington, D.C., February 1997): 38, 51, 52, 54. According to CRAT, USDA received about two hundred discrimination complaints per year, with an average of nine per month resolved. This resulted in an ever increasing backlog of complaints at the Departmental level, CRAT Report, 25.

703 In 1982, the department had employed sixty-three special emphasis program managers. Ten years later, that number had decreased to twenty. The 1994 reorganization had proposed fifty-six full-time equivalent SEPM's, but in 1997 "staff dedicated to program delivery [was] well below the proposed increase." ${ }^{703}$ CRAT recommended a more significant role for the SEPM's, who did little more than 
civil rights resources, right down to the field unit. For the Forest Service, the directive meant reassessing TMO.

In July 1997 newly appointed Forest Service Chief Mike Dombeck traveled around the country to talk with employees about the importance of civil rights and "charged" them "to reconnect with the ideas from the Toward a Multicultural Organization (TMO) report." Dombeck's “New Directions, New Opportunities" message emphasized commitment to civil rights and increased the priority of fixing diversification problems. Once again, USFS shifted into civil rights gear, with diversity supporters identifying the CRAT report as opportunity: "Implementation of TMO and CRAT could give us the desired Agency workforce composition and performance," reported a Forest Service "TMO Revisited" taskforce. This new group noted that the lead responsibility for implementation had gone to the W.O. and most recorded progress had to do with actions planned, not executed. Some TMO recommendations had been finalized, some were ongoing, and some had simply not been addressed at all. ${ }^{704}$

The TMO Revisited group produced a report in 1998 that outlined the strengths and weaknesses of the earlier initiative. On a positive note, TMO support from leadership had provided "excellent ideas and intentions" to take the Forest Service into the twentyfirst century. The focus on training, equity, participatory management, and cultural change included all employees through programs like flextime, flexiplace, childcare centers, and parenting rooms. The CIP had been one of the best outcomes. It provided 
regular feedback to the agency that made it possible to choose strategies for improvement, from the unit level to the W.O. Another positive and lasting outcome came from establishing special emphasis groups with charters, budgets, and work programs to assist the agency in areas like outreach, recruitment, and mentoring. TMO programs also included developing community support for new employees and drawing community members into joint visions for the future.

Unfortunately, TMO's external and internal problems far surpassed positive outcomes. Budgetary fluctuations and downsizing left little to no funding for implementation of TMO, and had produced "confusion and demoralization which sapped energy and diverted attention away from efforts at creating diversity." ${ }^{705}$ By 1992, the agency had stopped hiring permanent employees from outside, although blanket exceptions existed for people with disabilities, Co-op Ed students, and Presidential Management interns. Rather than reassign, promote or fill positions from elsewhere, the agency also maintained surplus lists to rehire those affected by downsizing which made additional diversification difficult. It took until February 1995 for the hiring freeze, voluntarily imposed by the agency in 1990, to be lifted. By then, the minority pipeline had slowed to a trickle. At the same time, attacks on affirmative action in the Supreme Court and at the state level ${ }^{706}$ created internal unrest for the Forest

\footnotetext{
705 Ibid, 13.

706 Proposition 209 in California, 1996, and Initiative 200 in Washington State, 1998 were first in a series of state initiative to pass colorblind non-discrimination laws that effectively repealed affirmative action in state government.
} 
Service. Still, the agency maintained surplus lists into 1997, when the CRAT report resulted in a departmental directive to halt the practice. ${ }^{707}$

Revisiting TMO also resulted in a better understanding of the demographic shifts near the end of the century. Within five years of the 1987 Hudson Institute and Office of Personnel Management (OPM) reports that had sparked TMO, questions arose regarding their validity. Predictions about demographic shifts in the civilian and federal labor forces had not accounted for an increasingly global economy or the end of the Cold War. Nor did they foresee downsizing in executive agencies like the Forest Service that had been affected by loss of timber revenues due to environmental constraints. ${ }^{708}$ Hudson had correctly observed a shift away from blue collar occupations and increasing need for college trained and technically skilled employees; however, government downsizing overall increased the professional and administrative labor pool in the 1990s, a situation certainly true of the Forest Service. Higher labor force participation rates and immigration also countered earlier concerns about a smaller, more diverse, and less educated labor pool. Not only had Hudson overstated growth in racial diversity, but expanded educational access had resulted in a larger pool of college or technically

707 TMO Revisited, 51, 52. Memorandum from F. Dale Robertson, Chief, to Regional Foresters, Station Directors, Area Director, and WO Staff, re: "Freeze on Outside Employment," November 9, 1992. FHS Collection F13.2, File, "Personnel - Employment Freeze.” Using its own LE\&I (Law Enforcement and Investigation) employees to investigate agency employees also stopped as a result of the CRAT report.

$708 \quad$ U.S. Office of Personnel Management report, "Revisiting Civil Service 2000: New Policy Direction Needed," published in September 1993. Kristi Cameron, et al., "Civil Service 2000 - Old Assumptions," 669. 
trained minorities and women than expected by century's end. ${ }^{709}$ OPM determined: “The fundamental issue confronting the federal government as it enters the 21 st century is reengineering the management systems to best utilize the workforce." 710

Alongside losing its status as self-sustaining through timber income, these external and internal issues had prevented TMO from creating a USFS workforce reflective of the nation's diversity. For one thing, shortly after launching TMO people had to start "getting by" with fewer employees and as much or more work. At the same time, budget reductions and downsizing led to early retirements and thinned the ranks of TMO supporters. Mobility, too, worked against TMO. Because locals often constituted the long-term field workforce, while leaders moved from place to place, resisters could easily outlast diversification proponents who transferred in and out at the district level. The "atmosphere of backlash" often created "defiance" for those "feeling overloaded, out of control and confused by so many changes." ${ }^{\text {711 }}$ Without systems to support cultural change, employees felt unsettled. Nor had the agency anticipated the number of EEO complaints that would stem from the push to increase diversity. The "can-do" attitude had worked for a short time, but with cultural consequences. That historically authoritative leaders would operate collaboratively in teams did not go over very well with a lot of employees. The reward system also contradicted collective directives, because although the agency emphasized team efforts, it provided awards to individuals.

709 According to Cameron, Jorgenson, and Kawecki, African Americans entering the workforce are projected to increase from 10.7 percent in 1990 to 11.6 percent in 2005. The Hispanic population entering the workforce is predicted to increase from 7.7 percent in 1990 to 11.1 percent in 2005. Asians entering the workforce are predicted to increase from 3.1 percent in 1990 to 4.3 percent in 2005 .

$710 \quad$ Cameron, Ibid.

711 TMO Revisited, 22. 
The TMO taskforce had called for major cognitive shifts, but still operated under existing systems. USFS Handbooks and Manuals (FSH-FSM) did not reflect multicultural policies and authorities.

The mechanistic approach to organizational management collided with the 1990s symbolic framing that called for more than satisficing, bounded rationality, and incentives to induce cooperation. Rather than settling for adequate results, the TMO group wanted to create optimal outcomes through a human-centered organization grounded in nurturing, caring for, and supporting people. "In a sense," wrote the task force of the late 1990s, "some diversified workforce strategies fall outside the scope of civil rights responsibilities. Enforcement and accountability, therefore, lack conventional processes needed to implement the broad range of organizational and behavioral changes which TMO envisioned." In short, TMO had been too idealistic. ${ }^{712}$ The taskforce suggested a number of practical strategies to counter idealism, while supporting diversification. They came down to systematic evaluation of outcomes and benchmarks, drawing from existing structures like the SCRC; accountability at all levels; determining measurable expectations and defining consequences for not achieving goals; analyzing cost-benefit of strategies; and developing measurable outcomes. They also suggested a number of benefits of diversity, including: making the most of social change; increasing rapport with the public to help secure support; making better use of candidate pools, demographic trends, and labor shortfalls; and consequently, enhancing the agency's

712 Ibid, 12. 
survivability. ${ }^{713}$ The taskforce also identified other problems with existing

diversification strategies or lack thereof. Women and minority workers had been brought in without training plans leading to promotion, a key element for human resource managers in creating a multicultural workforce. Successful affirmative action efforts required strategic employee development, determined by matching people to the right jobs, evaluating selection processes, and creating individual development plans for all employees. As Linda Human noted in 1996, many organizations paid lip-service to the need for affirmative action and managing diversity but few incorporate those kinds of objectives "into either their strategic planning process or reward system.",714

Those currently in the leadership ranks arrived primarily through informal mentoring and showcase experiences, paths to leadership that could be easily disrupted by politically motivated appointments. There had been three chiefs between 1987 and 1997 , and high turnover in other areas. The original TMO report had reinforced the concept of accountability for workforce diversity, the national task force reiterated its importance, and it had even been included as one of many performance elements. But, without coordinated efforts to track accomplishments or hold field units responsible through monitoring, TMO had been doomed. No consequence or penalties for non-compliance or non-support had ever been identified or invoked. In fact, as a later assessment stated, accountability had "hardly been considered in the status of TMO." The internal backlash to TMO, external critiques of affirmative action and multicultural policy, subsequent

\footnotetext{
713 TMO Revisited, 14-16.

714 Linda Human, "Managing workforce diversity: a critique and example from South Africa," International Journal of Manpower, 17,4-5 (April-May 1996): 46.
} 
government mandates, and the tremendous impact of downsizing on the agency at large meant that individual commitment without accountability could only take the agency so far.

One of the most significant strategies in TMO Revisited had to do with connecting GPRA, the Government Performance and Results Act, with natural resource management; that is, the TMO Revisited team recognized the need to link "land management work and new planning frameworks." The 1993 GPRA mandated that agencies would develop five-year strategic plans based on mission and major functions, along with measurable performance goals and targets. ${ }^{715}$ This mandate prompted the taskforce to state that TMO must be associated with other efforts and priorities to remain at the forefront, "rather than being perceived as a nice extra or a dead balloon." Still, while the agency's annual reports included GPRA alongside environmental laws as the key legislation guiding operations, they still do not include the significant laws that guide workforce diversity: 1964 Civil Rights Act; 1972 Equal Employment Opportunity Act; 1978 Civil Service Reform Act; 1990 Americans with Disabilities Act; 1991 Civil Rights Act, and a host of Executive Orders well into the twenty-first century. Nor do the reports include related legislation that connected the agency to youth programs and recruitment, included as part of stated program delivery, especially programs like Job Corps. Incorporating TMO into the heart of operations by including the TMO process in the manual and handbook directions, as well as recognizing the role of social legislation

715 Office of Management and Budget, "Government Performance and Results Act of 1993," https://www.whitehouse.gov/omb/mgmt-gpra/gplaw2m\#h2 [accessed April 28, 2015]. 
in agency activities could facilitate workforce diversification. As the TMO Revisited team wrote, "Most FS employees do things 'by the book.' if we want cultural and organizational 'rules' and norms to change, we need to change what the book says."

\section{Caring for the Land, Serving People under Entwined Diversification: An Overview}

\section{Shaping Unequal and Equal Opportunity}

A major focus of this dissertation has been to document and assess how USDA Forest Service incorporated non-traditional employees, especially minorities, into the agency from the 1960s through the 1990s. A secondary focus has been to examine the role of individual decision-makers in facilitating or hindering that process. In 1964, the U.S. Forest Service entered its most economically productive years via a homogeneous, white, male forester workforce. By the 1990s, a conjunction of legislative "events" coalesced to shift agency culture and dynamics away from intensive timber management and toward ecosystem management. These alterations transpired in the context of what I have called "entwined diversification," the overlapping connections between social, ecological, and occupational diversification in the Forest Service. While others have documented the impact to the agency caused by the environmental movement, most scholarship only briefly alludes to links between ecological and social diversification.

\footnotetext{
716 TMO Revisited, 14. For example, at the front of the agency's 1997 annual report, the following laws are listed: MUSY, 1960; Wilderness Act, 1964; Forest and Rangeland Renewable Resources Planning Act (RPA) of 1974, as amended; NFMA, 1976; Forest and Rangeland Renewable Resources Research Act of 1978, as amended; Cooperative Forestry Assistance Act of 1978; Chief Financial Officer's Act of 1990; Food, Agriculture, Conservation and Trade Act of 1990 (Farm Bill); International Forestry Cooperation Act of 1990; Government Performance and Results Act of 1993 (USDA Forest Service, Report of the Forest Service, Fiscal Year 1997, Washington, D.C., May 1998).
} 
As historian Connie Y. Chiang has pointed out, “...race and ethnicity are constructions; scholars of environmental history have added that nature has played a formative role in shaping those constructions." ${ }^{, 717}$ In fact, the entwinement of environmental and social legislation created strands of change in USFS that expanded occupational categories, and by virtue of social mandates, also broadened agency demography.

Until the 1970s, most federal natural resource organizations remained almost exclusively white and male, making such entities ideal for analyzing "whiteness" and the "flow of power between and within racial and ethnic groups," as suggested by environmental historians. ${ }^{718}$ Agencies maintained occupational monopolies via educational and social systems that facilitated advancement for some and obstructed others. Chapter three demonstrates how the government shaped unequal opportunity for women and people of color in the public arena in the 1930s by using quotas to limit rather than expand equal opportunity. The systematic efforts to prevent African Americans from accessing the benefits of the New Deal also reveal a chronological extension of what Mark Fiege has identified as the "King Cotton" life cycle of the slave. Fiege identifies competition between the basic needs of African Americans and the cotton harvest prior to the Civil War. The early years of public forestry confirm Fiege's contention that nature helps to shape power relations, ${ }^{719}$ as visible in the conflict between Robert Fechner and Frank Persons. Alongside the inequities of segregated

\footnotetext{
$717 \quad$ Chiang, "Race and Ethnicity," 574.

$718 \quad$ Chiang, "Race and Ethnicity," 574.

719 Mark Fiege, The Republic of Nature: An Environmental History of the United States (Seattle: University of Washington Press, 2012).
} 
CCC units, She-She-She camps existed as a shaky shadow of the tree troopers. In keeping with Frederick Mosher's contention, the CCC example also illustrates that a quota system can either enhance or restrict diversity. ${ }^{720}$ Restrictions associated with the CCC demonstrate, as Margaret C. Rung observed in Servants of the State, that because government sets social policy, its representatives may also choose to either legitimate racism and sexism or set a different standard. ${ }^{721}$ To that end, executive orders, legislation, and the courts have impacted both the concept and the empirical manifestation of creating a representative bureaucracy in the United States, as have gendered constructions in the human relationship to nature.

Chapter four puts racial liberalism into play by showing how concerted government action began to formally document and address social inequity and expand equality of opportunity. Only policies of affirmative action could meet inequality head on. Consistent with Charles Lindblom's observation that incremental change begins with "semi-revolutionary" shifts in the outside world, ${ }^{722}$ the Forest Service "muddled" through policy decisions to increase workforce diversity between 1968 and 1976. Social diversification occurred at first only through low wage, typically seasonal technical positions. Minorities worked on fire or tree trimming crews, lookout towers, and in brush disposal or trail maintenance. The agency recruited some women for these positions, although most permanent female employees worked in the mail room, as resource clerks, receptionists, or sometimes in Administration and/or environmental

\footnotetext{
$720 \quad$ Mosher, 2003, 27.

721 Rung, Servants of the State, 2002.

722 Lindblom. "Muddling Through," 78-88.
} 
education. Formal Upward Mobility Programs like Job Corps, the Concentrated Employment, Neighborhood Youth Corps, or Work Incentive Program introduced youth to the Forest Service and familiarized Forest Service employees with them. As Lamar Beasley recalled, when he first went to Job Corps, he "saw these young men, sixteen to twenty-one years of age, who were smart as they could be, but never had an opportunity, not an opportunity at all and what Job Corps provided for them was an opportunity... to see those young men...develop and what they became was rewarding." ${ }^{, 723}$ In line with Jim Cullen's statement that equality of opportunity cannot exist without equality of conditions, Beasley witnessed the difference in circumstances between the middle class, young people of color, and poor rural whites. He also saw that Job Corps elevated conditions through education and training that could at least begin to equalize the playing field. Convinced by this experience that "many people just need a chance, just need a chance," Beasley used his position in the agency to provide advancement opportunities for women and people of color.

Job Corps also brought diverse professionals into the Forest Service, people like Nella Dickson and Jetie Wilds, whose presence influenced the agency approach to civil rights issues. Chapter four also demonstrates the development of civil rights training, recruitment efforts and partnership, and touches on some of the paradoxes associated with diversification. Civil rights training immediately required an atypical openness, as exemplified by participant choice in workshop exercises. Ironically, flexibility and consensus stood at the center of diversification directives, while accountability existed

723 Lamar Beasley Interview. 
only minimally. Although the Secretary of Agriculture established civil rights policy and mandated reporting, some regions virtually ignored the orders while others padded reports to create the appearance of activity. This is when Region 6 began to shine, in part because of Northwest timber wealth, but also due to leadership commitment that allowed a progressive civil rights program to develop under the auspices of Jetie Wilds. Inception of the USDA Forest Service Civil Rights Program under Wilds stemmed from a social context deeply connected to "The Movement" for African American equality and set the tone for agency diversification for years to come. The first step, documenting demography and status began in Human Resources. Next came training. As directed nationally, civil rights workshops focused on education. By then, television had introduced individuals like Martin Luther King, Jr. and Malcolm X to the public at large and illustrated civil rights injustices; however, the intensity of the times penetrated agency workshops and sometime pushed people to confront personal biases in ways that many found uncomfortable. In Region 6, nature continued to influence social relations as well-funded civil rights workshops also introduced employees to issues at home: battles over land by the Warm Springs Indians; the social safety net provided by the Black Panthers; and manifestations of the Farmworkers Movement in the Willamette Valley. 


\section{Entwined Diversification and Expanding Opportunity}

Meanwhile, several pieces of environmental legislation ${ }^{724}$ fused to initiate entirely new occupations and ways of managing the land. USFS employees began to work in teams that included range conservationists, archaeologists, and hydrologists in addition to the soil scientists and other "ologists," whose presence sometimes created as much tension as did other kinds of difference. This era of the "ologists" sparked the employment of professional women and minorities, including African Americans, Latinos, Asian Americans, and American Indians. As illustrated in chapter five, the connection between USFS and Tuskegee Institute launched in 1968 provided a model for later partnerships with historically black colleges and universities (HBCUs), tribal colleges, and the Hispanic Association of Colleges and Universities. This chapter also demonstrates the importance of HBCUs and the opening of natural resource professions to African Americans following a century of exclusion in the post-Civil War United States. Additionally, chapter five reveals both minority relationships to the land and lack of exposure between races. Here, I demonstrate the institutional processes by which USFS enlarged its relationships to communities of color, as well as the initial emphasis on employing African American men as the key to diversification. These efforts show that there was little validity to the common assumption that people of color lacked the desires and abilities to participate in forestry. They also confirm that assertive outreach yielded positive results in the early 1970s.

724 National Environmental Policy Act, Resources Protection Act, and National Forest Management Act. 
Women entered the picture more formally when Congress passed the 1972 Equal Employment Opportunity Act. As chapter six demonstrates, early female forestry graduates typically resigned themselves to working in research, public information and/or education. After 1972, as women graduated from forestry schools they held the expectation that federal jobs must be as available to them as to men. This chapter illustrates the tenor of the times, barriers faced by women and actions taken by the federal government to mandate inclusion. Measures included formation of the Federal Women's Program, which provided an important way for women to share their experiences, network, and to advocate for one another. In addition to highlighting the role of the FWP, this chapter illustrates emergent diversification through trainings that first contended only with gender to workshops that also addressed how occupational shifts impacted agency relations. Furthermore, civil rights trainings of the 1970s show that there is nothing new about the idea of unconscious bias. Just as men resisted changing attitudes toward women, in the twenty-first century white men and women often become reactive to the idea that unconscious racial attitudes impact workforce relations or interactions with the public.

\section{Entwined Diversification in a Multicultural Organization}

These initial diversification efforts set the stage for the three final chapters, one focused on female upward mobility, the next on creating a multicultural organization, and finally a summation that illustrates shifts in the idea of multiculturalism and the reality of its lived experience. Chapter seven illustrates entwined diversification through 
the relationship between big timber, shifting environmental ethics, and advancement for women in the West. Here, tales of upward mobility demonstrate that, as William Cronon suggested, narratives of people are also "stories about stories about nature." Such narratives also call attention to how the construction of social categories like gender occur in tandem with changes in the natural world. ${ }^{725}$ These overlapping accounts demonstrate connections between law, funding, ecological and occupational diversification, and individual commitment to women's advancement by specific leaders, male and female. They also exhibit representative bureaucracy in action through intersections among high level female leaders and junctions between individual action and structural support via internal upward mobility programs. The entwinement of ecological and social diversification created entirely new trajectories to leadership through revamped relationships to nature. Jobs like public affairs specialist, often held by women, became more significant to community outreach and consequently, to advancement for women. Path breaking women provided models for those who came behind them, whether by identifying alternative trails to the line, breaking barriers as leaders, or successfully navigating racialized and gendered expectations. This chapter demonstrates that the sheer numerical presence of white women, and their connections to mainstream society, eventually brought general acceptance of their presence for most, if not all. Once women went beyond the tipping point, the agency followed.

725 Chiang, "Race and Ethnicity," 573. 
By the time the agency formally established the Civil Rights Program in 1976, it set a goal to move from eight to eighteen percent minorities and from twenty-two to thirty-three percent females in the following ten years. But, as chapter eight demonstrates, minority employment slowed by the mid-1980s due to changing affirmative action guidelines. Minority employees increased by only four percent from 1976 to 1986 , while the agency nearly achieved its goals for women. As this chapter reveals, disparities in status came from difficult to overcome occupational restrictions related to ideas about land management; however, the 1986 mandate by Secretary Lyng to increase the numbers and status of women and minorities sparked new action in USFS. Chief Robertson reaffirmed the agency's civil rights policy and set a new direction through "Work Force 1995." In that initiative, the agency explicitly and publicly sought to create a workforce reflective of the nation's diversity as a matter of policy_six years earlier than the Department of Agriculture. Between 1987 and 1990, the agency promoted dozens of women and people of color into line positions and intensified outreach activities. In addition to following recommendations made by the Service-wide Civil Rights Committee, Chief Robertson also put Lamar Beasley in charge of what became the TMO taskforce. Under his hands-off approach, this large group of diverse employees nationwide set a direction for taking USFS into the twentyfirst century as a multicultural organization. This interest in diversity, initially a response to law and policy from above, strengthened during the TMO era due to the commitment of internal decision-makers and the activism of employees. By the mid-1980s, minority and female workers had learned to advocate for their own needs. The mandated FWP 
provided a vehicle for women's networking and a way to address advancement barriers, while the Women in Forestry Network provided a model for employee organization. The Forest Service established the first tribal government program manager in the Washington Office in 1988, primarily for policy issues related to sovereignty and land. The Office of Tribal Relations (est. 2004) later added education to its activities. ${ }^{726}$ By the late 1980s, African American "ologists" and foresters organized black employees in the Washington Office Network and then morphed into the African American Strategy Group, which provided another model for employee resource groups at both the agency and departmental levels. The federally organized Hispanic Employment Program did not provide much cultural support, but several additional groups formed in 1993, including the Forest Service Hispanic Employees Association, Asian Pacific Islanders, Gays and Lesbians, and People with Disabilities. The 1973 Rehabilitation Act had prohibited discrimination against people with disabilities by any organization receiving federal funding, but the federal government did not document their presence in the workforce until passage of the 1990 Americans with Disabilities Act, which prohibited discrimination in employment, public services, public accommodations, and telecommunications. 


\section{Reflections and Conclusions: Representation and Narrative}

Representation in Action

Under Civil Service Reform in 1978, the government directed creation of a "competent, honest, and productive Federal work force reflective of the Nation's diversity," and improvement of public service quality by shifting from the Civil Service Commission to the Office of Personnel Management. Federal employment would be governed by "merit system principles and free from prohibited personnel practices."727 Reflecting the nation's diversity means representation, a concept that has guided this inquiry and which illustrates that who directs policy shapes workforce diversification at every level. Since the agency's inception, in keeping with Henry Fayol's principles of management, a clear line of authority (scalar chain) has directed activities, from executive orders and congressional law mandating equal opportunity to policy directives from the Secretary of Agriculture to the chief of the Forest Service, and down the line. Yet, as Max Weber proposed, the bureaucracy is "a power instrument of the first order-for the one who controls the bureaucratic apparatus [emphasis added].",728 Policy implementation in USFS demonstrates that racialized and gendered policy constructs begin at the policy formation stage, as evidenced through the CCC and Job Corps. Oscar DePriest, an African American man made sure to include African Americans in the former, and Oregon's Edith Green ensured female participation in the latter. Here, representation at the policy formation stage expanded opportunity.

727 Equal Employment Opportunity Commission Website, "EEOC $35^{\text {th }}$ Anniversary," PL 95-545 (S 2640), October 13, 1978, http://www.eeoc.gov/eeoc/history/35th/thelaw/civil_service_reform-1978.html [accessed April 1, 2015].

$728 \quad$ Weber, 1922, in Gerth \& Mills, 1958, 9. 
The individuals who implement policy directives, too, have tremendous power to shape the democracy at every decision point. For example, clear representational issues arose through the exclusionary policies put in place by CCC director Robert Fechner and the sanctions threatened in response by Labor Department selection director Frank Persons. Every numerical step forward in terms of Forest Service diversity started with a directive from the Secretary of Agriculture. How quickly and how completely the Forest Service moved ahead depended on who was in charge. This lesson was as true for natural resource management as social diversification. For example, Dale Robertson pointed out that NFMA should have prohibited cut and run practices in 1976, but clearcuts prevailed because of combined public demand and congressional mandates. Yet, the ecological turn raises questions of occupational representation. Had an ecologist like Elizabeth Estill been in charge of the Forest Service in 1976, might the agency have made cut and burn the exception rather than the rule? No one knows, but it is clear that who is in charge makes a difference - when it comes to environmental and social management practices.

As Samuel Krislov pointed out, a representative arm of government is likely to bring multiple perspectives into decision-making processes. Creating diversity in government occurs through recruitment, which can expand or limit representation at will, depending on a regime's goals. When Clayton Yeutter became Secretary of Agriculture in 1990, he reaffirmed Secretary Lyng's civil rights policy and issued his own "Framework for Change" to diversify the workforce within ten years. Yeutter, a good friend of Dale Robertson's, called for leadership by example, excoriated complacence, and charged 
agencies with overcoming under-representation in entry, middle, senior, and SES levels, providing advancement in the workplace, and achieving equity in program delivery. Most importantly, Yeutter mandated that agencies include a critical element of Equal Employment Opportunity/Civil Rights in performance reviews. With the warning that 80 percent of the incoming workforce would be women, minorities and immigrants in the next decade, Yeutter admonished, "Backsliding cannot and will not be tolerated.",729 With Yeutter in office for two years, starting in February 1989, Robertson implemented Workforce 1995 and the Forest Service made significant numerical and social gains by promoting women and people of color. Commitment levels varied during this period, but individuals at every level participated in shaping a program that did, indeed, increase diversity. For example, during the TMO era the Forest Service ranked third in USDA for Hispanic employment. Only the Office of Advocacy and Enterprise and APHIS (Animal and Plant Health Inspection) employed higher percentages. ${ }^{730}$ National educational initiatives also expanded and the status of women and people of color increased significantly.

The Forest Service made a surprising number of demographic advances, both before and during the TMO era. Leadership from the late 1960s to the early 1980s under chiefs Cliff, McGuire, and Peterson spearheaded civil rights initiatives that bore fruit in the TMO era. The Tuskegee Pre-Forestry Program, for example, set a model for those who

\footnotetext{
$729 \quad$ Framework for Change brochure.

730 OAE had only 53 employees, five of them Hispanic. APHIS employed nearly five thousand, with $417(8.4 \%)$ Hispanic. Latino employees constituted 5.5\% of all federal employees and 5.6\% of Forest Service - nearly two thousand. "Management Seminar Newsletter," FHS Collection F5, File, "Civil Rights: Forest Service Civil Rights Program."
} 
followed, while the Women in Forestry Network developed through individual initiative. The level of success for new programs and policies to facilitate social diversification varied, depending on the values and attitudes of those in charge. A convergence of supportive leadership, funding, and initiative in the 1970s and 1980s made Region 6 a site of innovation for the agency at large. This position emerged from a combination of high staffing levels and funding. Innovation also occurred through the commitment of multiple individuals under the auspices of regional foresters whose resources allowed flexibility and whose directives mandated diversification. As in ecology, the openness of the system increased both complexity and diversity. When timber funding lessened, so did program elasticity, often making diversification a lower-level priority. Ironically, as the agency further incorporated ecological diversification into its generalized policies, the human ecosystem also reconfigured. Occupational and social diversification converged in the late 1980s and early 1990s, only to de-entwine as diminishing timber resources and increasing ecological obligations created a financial drain. Decreased funding often led special emphasis programs to function in name only, even as technological advancements removed face to face diversity workshops and employees began rote computer training.

\section{Representation and Diversification}

This inquiry began by examining how the Forest Service made its initial demographic diversity gains between the 1960s and 1990s and what has happened since. The goal has been to identify how policy shifts impact workforce diversity efforts and to 
examine the role of the individual actor in shaping policy outcomes. Two other primary questions have guided this inquiry. First, why has so little changed, despite ongoing efforts to diversify the workforce? The answer lay in response to the second question: what lessons can we learn from an historical understanding of diversification efforts? The historical narrative arc of Forest Service diversification provides some insight into the issues associated with creating a workforce reflective of American society. The story goes something like this... The Forest Service, an agency created during the Progressive era with organizational behavior defined by Gifford Pinchot's Use Book, became a bureaucratic superstar in the twentieth century. Its expertise lay in efficiently harvesting trees and protecting them and the populace from fire through a workforce of white male foresters highly committed to the enterprise and the organization.

Then, a period of entwined diversification incorporated entirely new categories of occupations in the Forest Service, even as diversification efforts also connected to traditional forestry jobs. Women and people of color who would have been excluded from the agency altogether not so many years before joined USFS. Each region responded differently to the incorporation of non-traditional employees, in part due to nationwide cultural differences, but especially in relation to funding streams for program development, training, outreach, and recruitment. Because of its size and access to funding, Region 6 became a site of innovation for diversification and a proving ground for non-traditional employees. These non-traditional employees joined the newly trained foresters in stimulating a cognitive shift in USFS that culminated in the "New Forestry" and "Ecosystem Management" initiatives. This ecological turn emerged from the 
embattled landscape of the Pacific Northwest and joined a concurrent strand of social diversification in efforts to move the agency "Toward a Multicultural Organization." This period led the agency to consider humans as part of a broader ecosystem in which diversity constituted strength and humans formed part of the biotic system. With the mantra of strength through diversity, the agency increased the numbers of diverse employees and their status. It also added people with disabilities and varied sexual orientation to the category of "diversity employees," those identified initially only in terms of legal racial categories. At nearly the same time, unfortunately, the bottom dropped on the agency's funding stream. Ecological diversification slowed timber revenues, and practically halted social diversification.

At the 1988 Strength Through Diversity Conference, Jerry Sesco had predicted that Region 6 would be most likely to achieve parity first in the agency. The significant increases from 1987 to 1990 placed the region clearly on that path, as minority employment increased by 45 and female employment by 40 percent during that three year period; however, loss of funding and downsizing deflated those gains. Region 6 staffing levels dropped further than anywhere else in the agency. From 1990 to 1996 in R-6, pre- and post-downsizing, the agency lost approximately 29 percent each of minority and non-minority employees, 27 percent of its female employees, and 30 percent of its male employees. As minority and female employment increased slightly overall from 1987 to 1996, male employment dropped nearly 16 percent. Meanwhile, the grade levels of women, minorities, and white men came closer together than ever before. With the average agency GS level at 8.8, men ranked 9.3, women 8.0, non- 
minorities 8.8, and minorities 8.2. [See Region Six employment, Appendix C, Table C.13] In light of significant job loss, the semi-stasis in numbers and increase in status appear remarkable. By no means had the region achieved equality, but that it maintained proportionate minority gains in the midst of eliminating more than two thousand job partially explains increased tensions throughout the 1990s.

It was in the context of these pressures that the agency continued diversification efforts, primarily focused on youth and most often (though not always) through the efforts of "diversity employees." In the midst of downsizing, the agency made programmatic exceptions to bring in students of color via Co-op Ed. In R-6, employees developed a host of educational programs to introduce young people to national forests and increase diversity. Examples included the ongoing urban youth programs begun by Earl Ford in 1991 on the Gifford Pinchot National Forest, among others. Ford, who became president of the Vancouver NAACP, collaborated with the NAACP, the Coalition of Minority Employees, and Vancouver Parks and Recreation to form Rites of Passage, a four-week award-winning ${ }^{731}$ summer program. Rites of Passage introduced students to natural resource work, while using African American history to also address academic, cultural, career, and social needs of underrepresented high school and middle school students in Clark County, Washington. The Inner City Youth Institute, begun in 1995 out of Oregon State University provided another avenue to introduce minority

731 Rites of Passage focused on building positive self-image as learning about the environment. Among other awards, the program won a "Caring for the Land and Serving People Award" from the Region 6 Regional Leadership Team in 2007 and a Pacific Coast Trails Association (PCTA) partnership award in 2010. 
urban youth to natural resource work. A residential YCC program on the Mt. Hood National Forest also started in the late 1990s under David Gross, who recruited underrepresented youth from North Portland. Dale Hom, who spearheaded community education about Chinese miners out of the Olympic National Forest, also partnered with the Tacoma Urban League for outdoor youth education, and worked to create an Engineering Center of Excellence Program to develop diverse entry-level engineering staff. Rudy Edwards' work as Puget Sound liaison also contributed to creating a more diverse employment pool, while many others interviewed for this project focused on outreach and recruitment to communities of color by introducing youth to outdoor education and employment possibilities.

While leadership fulfilled mandates to diversify, and a number of white allies facilitated outreach and recruitment, as in Selden's FHA findings, nearly all of the minority employees included in this study took on minority representative roles, sometimes making decisions consistent with minority interests, but often moving into diversity support roles. For example, minority foresters, biologists and teachers became Human Resource, EEO, and Civil Rights Specialists. They engaged in outreach to students of color around the region, typically in addition to their regular duties. Despite natural resource expertise, they became special emphasis program managers and recruiters, and facilitated partnerships with other organizations in order to maintain or increase diversity. In nearly every case, whether formally or not, minority employees talked about engagement with communities of color, and the general public, at some level of representation. 
Representation, Narrative, and Policy Analysis

The value of narrative in public policy analysis is that stories illuminate the underside of reality, the intangibles that implicitly shape outcomes. Biographical narratives provide meanings behind the documents and the numbers. For example, narratives can illustrate the very real impact of government programs through education and youth programming. Robert Alvarado's story of throwing away one letter for another in order to enter the YCC illustrates a decision point that changed his life, and ultimately that of his family. For Alvarado, the YCC and educational opportunities meant moving away from a life of picking cotton and living in a cramped house with eleven siblings. It also meant leaving family and community, and reflects a theme of isolation present in many narratives provided by people of color. Parting from one's community sometimes meant exclusion by family and friends. Women of color, especially, faced challenges on all sides as they not only left communities but had to reject cultural and familial gendered limits to do so. For example, one Latina woman who joined the Forest Service spent years alienated from a family that disapproved of her choice to attend college.

Biographical narratives can also dispel stereotypes, as when Daryl Hodges, an African American fish biologist from Philadelphia recalled the first time he saw Mt. Hood:

And the sun was coming up, and it was like, it was a reddish glare of the sun, and it was above the clouds and just, the colors, the hues that are red, got orange and got a lot of yellow and the wind was blowing and the dog was running around, and I was like, "Wow, this is like a once in a lifetime event." 
Regardless of focus, biographical interviews often raise outwardly disconnected topics. For example, in nearly every interview I or my students conducted with African American Forest Service employees, religion came up, prompting the question: "What's church got to do with this?” Through line by line analysis, some patterns emerged. Nella Dickson mentioned church revivals immediately. When asked about civil rights, Gloria Brown remembered witnessing events on television. She then recalled her church's involvement with the 1963 March on Washington. Later, she said that her mother regularly sent tapes of sermons and familiar gospel music to her from home. When asked about her parent's approach to civil rights, Leslie Weldon said: “They talked in terms of what we could do to ensure that we would be successful....to be our own person and be independent in the future. And, what our religious ... values taught us as far as always loving, you know, loving the other person.,"732

Stories of faith added unexpected depth to intersections between region and race and can even uncover problems associated with agency diversification. Nella Dickson's narrative most clearly unlocks the social dimension of this relationship. As she said in 2007: "I am never going to be in a [majority] situation when I think in terms of government, business and social community. ... When I go to church on Sunday, it'll be a majority. But other than that, I'm never going to be a majority. No matter what the situation is." For Nella, church provided a "homeplace," in which she was among the majority. Because she worked in Civil Rights, she also did Forest Service outreach to Portland's black community through church. When recruitment resulted in no jobs for

732 Leslie Weldon Interview by Tania McDonnell. 
those she encouraged to apply, Nella felt personally responsible. This negatively impacted her perception of agency efforts to diversify and she finally stopped recruiting. $^{733}$

Shandra Terry, a public affairs officer in the regional office recalled her first immersion in white culture at age eleven when she moved into the mostly white suburbs near Pine Bluff, Arkansas. The second time happened when she went to Medford, Oregon in 1990. Her experience demonstrates connections between the social and spiritual dimensions of religion and the Forest Service. When asked about interracial relations in Pine Bluff, Shandra described Sundays as "the most segregated day of the week....Whites didn't go to church with Blacks and Blacks didn't go to church with Whites." But Shandra's mother took the family to revivals and prayer meetings at a White Pentecostal Church. She remembered feeling happy that "we can all celebrate the same God." ${ }^{, 734}$ Familiarity with white culture through church, school, and through the arts at home unexpectedly prepared Shandra for the primarily white Pacific Northwest, giving her "the exposure" and the "tools" to make friends across cultures and races. Her faith also equipped her to deal with difference and helped her "adapt" to her work environment. Shandra attended a White Pentecostal Church in Medford, Oregon for several years before moving to Portland.

The role of church in these narratives overlaps with a significant "plus" factor for Forest Service employees of color. In the rural Pacific Northwest, the location of most

\footnotetext{
733 Nella Dickson Interview by Carly Inman.

734 Shandra Terry Interview by John Helzer; Shandra Terry Interview by Donna Sinclair, April 16, 2013.
} 
ranger districts, white people are unlikely to have experienced much face-to-face crossrace exposure. Even in the region's largest cities, where Caucasians may interact with people of color, they rarely experience what it is like to be the minority. However, African Americans in the Forest Service must often act as race representatives, whether they want to or not. Two further examples demonstrate the impact of a regionally segregated society. Both display how the burden of accommodation to separation, and education about race falls on the minority representative's shoulders. In the first, Leslie Weldon attended a university extension meeting in Madras, Oregon, where a farmer asked her:

"What are you doing here?"

"I said, Well, I was invited"; you know, "I work with this person and I work with that person." ...

He said, "Well, what exactly is your position?"

I said, "Well, I'm the forest supervisor of the Deschutes National Forest." "Oohhhhh." [surprise from him] So he goes and makes a drink and he comes back

and he goes, "Must be really something for a gal like you to be working in forestry out here."

"Well," I said, "Well actually, yeah it is quite rare." I said, "There's three African

American, maybe four African American women who are forest supervisors in the Forest Service right now so it is pretty unique." 735

The next example is a manifestation of regional and rural/urban segregation. When asked if she ran into problems in Medford, Oregon, Shandra Terry explained that many rural Oregonians "were not educated on who people of color were."

“... a couple of times I was in a grocery store, little kids would come up to me and think I was made of chocolate. No joke. They would think I was actually made of

735 Leslie Weldon Interview by Tania McDonnell, 2005. 
milk chocolate. And, as you look at my skin, you know, to a little child I could be a little chocolate woman, you know what I'm saying?... so the little kid was [laughing] standing in line and ... he came over and just looked up at me like the Statue of Liberty. He just had his mouth wide open and I was like, "Hi."

And he was like, "Are you made of chocolate?" vanilla?"

And I said "No, I'm not. But, I have a question for you. Are you made of

And he said, "I don't think so."

And I was like, "See look at my hand." And he put his against mine. I said, "I have dark skin and you have light skin." I was like, you know, "Hey, it's all the same, but mine's just a little darker than yours." ... "we have the same skin. Touch my skin." And so we had a little lesson right there in the grocery store line.

And the little boy was like, "Oh, so you're not made of chocolate."

I was like, "No, but I wish I were because I love chocolate. I would be invisible because I would eat myself all up," you know?

So he said, "Oh, okay."

So he was about five or six. There was no harm done there. And so, I looked at his mom. His mom was like, "I am so sorry. Oh, I am so embarrassed."

I was like, "Well, you know what, here is how you can redeem yourself. Promise me right now that you will educate your child on people of color, that people are still people although they may not be the same color as he is."

These and other stories show that whites' lack of exposure to people of color can magnify the multiple representational roles carried by employees of color. They also demonstrate the role of biography in understanding individual ability to advance or to stay in the agency. Family background, social structure, and individual considerations can influence agency experience, and impact retention. Paying attention to stories of faith in these narratives unravels the significance of exposure across racial boundaries, as well as helping to identify coping mechanisms when racism appeared. Shandra could 
cope because she had learned, as she put it, to "bloom where you're planted." She believes that most people are good and want you to thrive. ${ }^{737}$

From an individual standpoint, faith may provide the means to sustain difficulties in the workplace. For example, when Gloria Brown had trouble, she talked to God, her parents or her husband. "And," she said, "I listen... and I think it's a real key to my success." She confirmed: "from a standpoint of uplifting you, praying that your circumstances would be better, that you'd be safe, the church meant all of that to us as African Americans..." From an organizational angle, recognizing and compensating for lack of cultural institutions like church or ethnic marketplaces in communities where whites have multiple social outlets may facilitate retention in the Forest Service. Even in locales with some cultural venues available, minority representatives can facilitate comfort levels for new employees, and thus retention. For example, although not in Civil Rights but living in a relatively white suburban area, Earl Ford sought to create closer regional connections for young people of color and also engaged them organizationally. As Daryl Hodges recalled:

With me working with the African American Strategy Team as a chairperson, I automatically became part of the Workforce Diversity Council, because every member of the Workforce Diversity Council at the regional level was a chairperson of some group. Now, as it's related to Vancouver, [Washington] that was Earl Ford; you know, that was a way of Earl, I mean Earl was a staff officer, you know, Earl was a mentor, Earl, you know, brought us into the program. We spent a lot of time ... at Earl's house in the summertime; you know, he would invite students over from Oregon and Washington and Region 6, just so we could just come together and see each other, and see that we're not out here by ourselves.

737 Gloria Brown Interview by Donna Sinclair, 2013; Leslie Weldon Interview by Tania McDonnell, 2005. 
Other lessons about community support come from narratives of life in the Forest Service. Among the most important is that passive and active representation can make a difference in social diversification at a very practical level. Hodges recalled as many as nine African Americans on the Gifford Pinchot in the 1990s, "And that's a lot for one forest," especially in the Pacific Northwest. Ford and others mentioned by Hodges mentored him through school, pushing him to achieve when he had a rough semester in his studies of fish biology. For Hodges, mentorship was key, but being mentored by other African American men made all the difference concerning retention.

As demonstrated throughout this dissertation, it is clear that representation impacts policy at the macro-level. At the micro-level, stories like the following told by Gloria Brown are also telling about the significance of representation in leadership. While forest supervisor on the Siuslaw National Forest, when she learned that two young African American men had to walk along the road to work in Tillamook, Oregon, she directed the local ranger to give them a government vehicle to drive. She also gave them her phone number - not something a forest supervisor typically does. When asked why, she explained that they walked:

...half a mile. For a young person it's a piece of cake. But, it didn't look like a half a mile where they went to school. The walk didn't. And people weren't staring at them. ... It was uncomfortable for them. And so, so that was the way we figured out we'd get those kids a car. "Make sure they have a driver's license. Get them a Forest Service car. I'll take responsibility." 
Closely tracing the process of social diversification shows that, far from operating on pure bureaucratic efficiency, who works for the Forest Service matters. A workforce reflective of the nation's diversity can increase interracial exposure within and outside of the agency, while also providing ethnic representation and identification for the public at large. The long-term impacts of such representation are less than tangible but clearly exist.

Physical manifestations of representation are more palpable. For example, Kathy Armstrong, a wildlife biologist diagnosed with multiple sclerosis, became a crew member on a barrier-free recreation project in the 1990s. She recalled taking her wheelchair out on an unimproved trail at Takhlakh Lake in the Gifford Pinchot National Forest for a foot by foot site evaluation to determine how much land needed to be cut or filled to create a level trail. "I had some fun times out on the grounds that now are essentially barrier-free. There are a lot of places we can go out on the forest now even in the region to enjoy that kind of activity, of going out on the trail and camping," she recalled. ${ }^{738}$ As this and so many others stories demonstrate, representation matters not just in what the agency does but in how and who does it.

Narrative adds complexity to policy analysis. When asked about the hate mail situation he faced in 1997, Sidney Clark declared the situation had been settled at the highest levels of the Department of Agriculture, and that was it. What he did want to talk about was growing up in Los Angeles, developing a love for the land through the Order of the Arrow, going to forestry school, conflict on a fire crew, and interpersonal

738 Kathy Armstrong Interview by Jeff Becker, May 13, 2005, Vancouver, Washington. 
relations that facilitated acceptance - on all sides. In short, Sidney Clark preferred to remember his long-term career with an agency he loved, not because he shied away from discussing racial conflict but because those memories were painful, and the precursor to the hate mail showed both the inaccuracy of stereotypes and the possibilities of working for USDA Forest Service. Those are the narratives that mattered most to him, the triumphant stories that illustrate possibility to future generations of African Americans in the Forest Service.

\section{Interpretive Theoretical Contributions}

By employing a narrative historical approach to the largest agency in the Department of Agriculture, the U.S. Forest Service, this dissertation adds to the theoretical literature on representative bureaucracy and the challenges of implementing the concept. It firmly links the fields of history and policy studies by empirically demonstrating the overlapping connections between law, agency policy, and individual action. This dissertation also elucidates the human complexities of bureaucracy. It shows that far from operating automatically, individuals effect change at multiple bureaucratic policy levels. This study also identifies a host of meanings associated with workforce diversity by means of an empirical environmental history approach to social reproduction, as proposed by Carolyn Merchant. Consequently, this study exhibits interconnections of environmental and social law through permutations in nature via people, and vice versa. Ecological and social diversification in USFS changed agency demography and how diverse employees worked together, while land management 
mandates increased connections to the public during the era of the ologists; thus, entwined diversification reveals how the law can, indeed, change social relationships. This analysis also demonstrates how social organization shapes the differing experiences with nature of women and people of color. It identifies the flow of power between and within racial and ethnic groups, and pays attention to whiteness as a distinct racial identity. ${ }^{739}$

At its most basic level, the intertwining of ecological and social diversity shaped a complexity of operations intended to make the Forest Service relevant - an "employer of choice" - in the twenty-first century. As the Region 6 example shows, the disentwining of diversification factors through changes in land management, reduction in force, impingements to affirmative action, and consolidation of functions rehomogenized the workforce, especially in terms of Black and White. By 2006, African Americans in the Region 6 Forest Service and the BLM joined forces to recruit African American employees. By then, the combined African American workforce for the two agencies had dropped from sixty-eight to thirty-seven employees, a reduction of nearly fifty percent. In the early 1990s, the Forest Service alone employed over a hundred African Americans in the region. As administrative functions, including Human Resources and Information Technology for USFS consolidated in Albuquerque, New Mexico in the early twenty-first century, the R-6 African American Strategy Team predicted further declines in the black workforce.

739 Chiang, "Race and Ethnicity," 574. 
Viewing the Forest Service historically as part of a larger ecosystem in the Department of Agriculture offers another theoretical contribution to organizational and policy studies. As an ecosystem, USFS workforce diversity connects urban and rural, social and natural worlds. It suggests the analytical framework of entwined diversification in a natural resource agency that allows examination of various strands that influence change. The ecological metaphor is particularly appropriate to the Forest Service, an organization composed of natural resource professionals. Michael Moore, assistant state forester for the Michigan Department of Natural Resources, has identified the forestry profession in terms of ecological succession; that is, replacing one community with another, creating a "more vibrant, far-ranging, and more representative community. ${ }^{, 740}$ By viewing the social systems of the Forest Service as similar to a natural ecosystem, we see that the human biosphere, too, regenerates through disturbance, often in different, sometimes stronger form. Although in the late twentieth century, white males constituted the old growth of the Forest Service, a more complex biotic system has developed, with diversity not always visible. As Elizabeth Agpaoa explained, the strength of diversity is not just about gender and color, but rather "diversity of thinking and problem solving." The entwinement of ecological and social diversification played out both tangibly and intangibly in the Forest Service. For example, entwined diversification occurred in part, from advancment via Recreation, a

\footnotetext{
740 In Dalej Blahna and Susan Yonts-Shepard, "Public involvement in resource planning: Toward bridging the gap between policy and implementation," Society and Natural Resources, 2, no. 1 (1989): 222.
} 
new career path. Mary Wagner, for example, was the first director of Wilderness and Wild and Scenic Rivers and later became associate chief.

From the standpoint of organizational theory underscored by the idea of representative bureaucracy, this study indicates that hierarchical mandates, individual initiative, and representation each play a significant role in agency operations, and that the Forest Service no longer functions in keeping with Frederick Winslow Taylor's orderly and efficient systematic processes. As Dale Robertson very clearly stated, by the early 1990s the time had ended for doing things in "one best way." In fact, ecosystem management and multiculturalism, both of which required open systems, emerged nearly in tandem, and in keeping with directives by the Department of Agriculture. In April 1993, Secretary Espy, the first and only African American to head the department, issued an EEO and Civil Rights policy statement in which he noted that "Diversity is a source of strength for USDA as we tap the talents, creativity, and energy of all Americans who desire to serve, or who have an interest" in the department's programs. Dale Robertson's adoption of "multicultural values" to guide agency operations drew from the notion of diversity as strength, an idea espoused in the Forest Service by at least 1988 in the Welches, Oregon "Strength Through Diversity" conference.

The foundation for the idea of strength through diversity as an organizational policy drew from emergent ideas of multiculturalism, not just in the workforce but in society at large. Although not explicitly, multiculturalism derived from Herbert Kallen's "Democracy versus the Melting Pot," the 1915 study of American nationality. Kallen suggested that the common life of the American nation came from its political tradition, 
and that rather than identify the U.S. as a "melting pot," "each nationality" ought to express "its emotional and voluntary life in its own language." For Kallen, “American civilization" could mean eliminating the squalor of the European past for:

a multiplicity in a unity, an orchestration of mankind. As in an orchestra, every type of instrument has its specific timbre and tonality, founded in its substance and form; as every type has its appropriate theme and melody in the whole symphony, so in society each ethnic group is the natural instrument, its spirit and culture are its theme and melody, and the harmony and dissonances and discords of them all make the symphony of civilization, with this difference: a musical symphony is written before it is played; in the symphony of civilization the playing is the writing, so that there is nothing so fixed and inevitable about its progressions as in music, so that within the limits set by nature they may vary at will, and the range and variety of the harmonies may become wider and richer and more beautiful. ${ }^{741}$

The idea and development of the word "multicultural" in the 1990s stemmed from the same impulse described by Kallen, to orchestrate a society based on the idea that those with different backgrounds could come together without losing individual identity. Rather than ignoring difference, or pushing women, minorities, or the differently abled to adapt as quickly as possible through a "sink or swim" approach, James Crowfoot followed Kallen in the TMO report with a definition of multiculturalism that suggested variation could produce a powerfully motivated workforce. Strength through diversity meant that newcomers brought "valuable skills and different perspectives, knowledge, and commitments that require[d] the organization to change its values and practices in order to recognize, accept, and utilize the full human resources of the organization." 
This approach to organizational management required "adjustments by all individuals and groups in the organization...the different subcultures of its members" would be "recognized and accepted." Together they would pursue the agency's mission, "while not allowing a 'melting pot' dynamic to eliminate their differences."

From the perspective of its proponents, multicultural values meant creating a workforce not just "sensitive to cultural differences," but rather one in which managers viewed difference as an asset, failure as a learning experience, "creativity, innovation, and entrepreneurship" as "critical" to success. In this desirable work environment, line officers would facilitate, rather than direct a workforce composed of a "true mix of gender, ethnicity, and background." No one would be "surprised" or "threatened" by difference and supervisors would be as adept in managing people as the environment. The agency would eschew dogmatic approaches to recruitment, promotion, mobility, and other work/life issues, while employees would feel free to register problems, secure in the knowledge of forthcoming internal support and solutions. The physical workspace, too, would be "spacious, esthetically pleasing, free of barriers, and accessible to all people." In addition to the generative creativity for managing the land, the benefits of this multicultural workforce would include "outstanding service to a user public with a variety of outlooks, values, and needs." ${ }^{, 742}$

The agency's adoption of a multicultural organization ignored strong social critiques of multiculturalism as official government policy. By neglecting the reality of power relations while proposing shared authority in the Forest Service, multiculturalism

$742 \quad$ TMO Report, 12. 
often denied the ambiguity of community for social actors, as well as the lived experience of the individual. ${ }^{743}$ The idea assumes there are uniform "multicultural values" and that multicultural policy can provide the solution to social ills. Stereotypes abounded on all sides, with whites often taking for granted the "naturalness" of ethnic groups and multiculturalists perceiving whites only in terms of Anglo-Saxon Protestants. One camp argued that a person's culture tended to determine behavior in relation to others in the workforce. Another noted that ideal-type understanding of groups ignored the complexity of other social variables, such as level of modernization, social class, level of education, language group, family status, regional and political differences, and the uniqueness of individuals, i.e., secondary diversity characteristics.

Ironically, or perhaps appropriately from a representational stance, a woman, Mary Follett Parker proposed the notion of power with as opposed to power over workers. In fact, the TMO taskforce attributed the idea of power sharing to contemporary analyses of "female culture," without knowing that in 1926 Follett had recommended the same approach as the Blue Book in 1991: adding a human dimension to management practices. Organizational and policy theorists like Harold Lasswell and Herbert Kaufman had also recognized the import of qualitative methods for understanding organizational behavior. Scholars like Donald Kingsley, Frederick Mosher, and Samuel Krislov took the human dimension of organizations further by relating models of representation to democracy, while later scholars focused on primary

743 Cynthia Levine-Rasky, "Discontinuities of Multiculturalism," Canadian Ethnic Studies, 38, no. 3 (2006): 87-104. 
and secondary dimensions of diversity and practices that promote active versus passive representation. This dissertation adds to those studies that have identified standard models for tracking social background. Considerations have included whether socialization into organizational norms hinders active representation or if social origin promotes it. As this study demonstrates, active representation often depends on who is in charge. Support from the top determines the level to which employees conform to existing value systems grounded in occupational homogeneity. As the workforce diversified socially and occupationally, tensions arose between conforming to a macho, forestry-oriented agency culture and ethnic, gendered, and racial tensions. Those who did not conform to mainstream agency values needed high level leadership support to stand outside of heteronormative, mainstream, Christian, white culture.

In 1993 Brown and Harris theorized that population diversity in USFS would lead to agency shifts in value orientation, while Thomas and Mohai proposed that value orientation would change slowly, so long as the leadership ranks remained the domain of white male foresters. A primary contribution of this study is demonstrating that occupational diversification brought USFS to a tipping point that impacted agency functions through ecosystem management. It makes clear that the overlap between ecological, social, and occupational diversity altered natural resource management, shifts more related to changing scientific understanding than any other factor. This study also demonstrates the significant connection between occupational diversification and recruitment, retention, and partnerships, while illustrating the need for flexibility in social diversification strategies. In many ways, the Forest Service has achieved that 
flexibility through what Nina Ricucci called "cafeteria style" benefits to manage diversity. Unfortunately, although changes in family friendly benefits and policies have enhanced the workplace for men and women, cultural change has focused disproportionately on women, rather than people of color.

Creating a workforce reflective of the nation's diversity would recognize the need for a bounded flexibility, something beyond Phillip Selznick's cooptation of new elements into the policy making process. Rather, much like ecosystem management, social diversification requires experimentation within boundaries, reshaping organizational culture to incorporate alternative, non-traditional employee values. As the TMO group identified, New Perspectives called for "greater flexibility and more sensitivity in land management." They sought the same for "people management" and recommended changes in organizational structure. The major structural change occurred in 1994 when occupational avenues to the line expanded; however, values and attitudes presented the biggest obstacles to shaping a multicultural organization. Issues included: time use; how to express emotions and feelings in the workplace; expression and resolution of conflict; recognizing achievement; appropriate dress and humor; desirable celebrations, rituals, and holidays; acceptable problem-solving styles; and balancing tasks and processes. ${ }^{744}$ Each of these issues produced some form of backlash, and raised new questions about organizational culture. While special emphasis programs had been created, in part to answer those questions, they could only go so far without high level

$744 \quad$ TMO Report, 4, 6. 
leadership support and funding. These programs that once received $\$ 25,000$ annually for flexible programmatic efforts soon had to request funding from Civil Rights on a case by case basis. A bounded flexibility approach would have focused on refining boundaries rather than removing flexibility, which is what occurred via the funding cuts. The Rites of Passage Program on the Gifford Pinchot National Forest provides an example of how a policy of bounded flexibility works. Natural resource education provided the boundaries for the program, but beyond caring for the land, this program addressed the very real cultural issues of students of color - people - by including African American history as part of the experience. As Linda Human notes, multiculturalism is also about remembering. She quotes Cecil Foster to say:

"Multiculturalism is about living and about the aspirations of the living...But multiculturalism is also about memory ... This is a memory of hatred and terror and dehumanization for those on the outside. It is also the story of privilege for the few on the inside ..." Some would rather forget, but writes Foster, "By not retelling the entire story, we run the risk of forgetting that multiculturalism was a difficult decision and that not everyone chose this path. (2005, ix-xi)." ${ }^{745}$

Within the bounds of outdoor education, young people learned that national forests belonged to them historically and today. The Rites of Passage Program is also a manifestation of active representation. Through the efforts of Earl Ford and many others associated with the program, students identified with minority staff as role models, and sometimes joined the agency themselves. 
This analysis of workforce diversity demonstrates the importance of the individual decision-maker and calls for further study at the micro and meso levels to identify how bureaucracies actually function. As is true with ecological diversification, automaticity may be more likely to hinder than to facilitate policy implementation related to social diversification. Like a natural ecosystem, diversified conformity may produce unforeseen results. When diversified conformity is partnered with bounded flexibility, however, change can happen "on the ground." The trick at the agency level is to figure out how much flexibility is too much, and how much actually enhances operations. The other trick is to educate the workforce to reduce backlash. As Jetie Wilds pointed out, most of the people he worked with were decent human beings. They simply did not understand the level of systemic segregation, disenfranchisement, and inequality of both conditions and opportunities that exists for people of color, women, those with disabilities, and those with less visible differences in gender or sexual orientation. This study begins to fill that gap. It also calls for further study of individual groups. American Indians, people with disabilities, and veterans have special status in the eyes of the government, while the situation for other minority groups varies by region. Each deserves more space to explore the processes that facilitate or hinder their incorporation into the U.S. Forest Service and other natural resource agencies.

To Samuel Krislov's point about settling the question of black participation in power and sharing of status in society, diversification efforts in the U.S. Forest Service provide several insights. First, Krislov's contentions about social participation can and should be extrapolated to other demographic groups whose experience demonstrates 
inequalities of both condition and opportunity. Although this dissertation varies in depth regarding the experiences of people other than African Americans and women, the universal lesson is that agency diversification is worthwhile, socially and organizationally. Incorporating non-traditional employees into professional positions in USFS provided upward mobility for individual employees, with positive consequences for future generations. The difference between the middle class lifestyle provided by government employment and sharecropping in the South, urban decay in the North, or agricultural farm work in California and the Southwest cannot be understated. Without further study, it is impossible to know all of the social benefits that came with upward mobility through the government bureaucracy, but based on disparities in mortality between middle class whites and people of color, the impacts are likely dramatic. At a minimum, life as part of the Forest Service "family" provided more choice for employees and their children. In several cases, these children went on to work in professional government positions, while several obtained advanced education to the doctoral level.

Organizationally, it is clear that over time, diversification changes the culture of a bureaucracy, which also has intergenerational implications. Those exposed to occupational and social difference in the workplace have no choice but to face their own discomfort, whether about race, gender, sexual orientation or disability. On the one hand, diversification draws together assorted groups who would not otherwise know one another. Even within the confines of a standardized language and culture, the sharing of personal space and reflecting upon origins facilitates intergroup relations. More than one 
person in this study noted that at the individual level, barriers began to break down when people got to know one another. Thus, face-to-face interactions are key to successfully achieving diversification goals and drawing upon the potential that can come from diversity. So, too, is leadership support. Although diversification is not completely outside the control of individual agencies, regions, or districts, support must exist at the highest levels and at every point along the line for significant change to occur. Leadership matters in yielding the kinds of results sought through initiatives like Workforce 1995 and the more recent Cultural Transformation. Additionally, the ability to diversify a workforce requires uniformly bounded flexibility, but with wide margins. Issues of recruitment and retention vary by region and cultural groups, eventually playing into agency culture shifts and the way in which the Forest Service cares for the land - and the people.

This study demonstrates that those boundaries may be too restrictive to provide the malleability needed to retain a representative employee pool. It also shows that, like caring for the land under ecosystem management, diverse seeds must be scattered throughout the agency, in every occupation and at every level. These kernels of diversification must germinate to sprout, sometimes through slow damp growth, at others through rapid flaming fire.

Workforce Diversity at Century's End: Nature and Storytelling

Achieving a multicultural organization is very similar to implementing a new perspectives approach to natural resources. A new or different organization entity should be formed to help the Agency approach human 


\section{issues with a more wholistic [sic] approach that values people as a resource, their uniqueness, and their interconnectedness." - TMO Report, 1991}

Picture an uprooted conifer amidst a dark, damp, green Northwest forest. Its

massive trunk crushes smaller trees around it. Large roots spread in diameter nearly fifty feet wide, a core so strong that only the powerful forces of nature - wind, ice, water, and time - can move them. Hard packed dirt clumps close to the base with smaller vine-like roots wound tightly together, often snarled around the branch-like stems. Time alone breaks down the massive tree, as worms, beetles, and other creatures soften it from the inside out and new life takes root in the decomposed matter beneath the bark. This overturned tree, with its exposed root system and crumbling innards provides a metaphor for entwined diversification in the U.S. Forest Service. By expanding the model of entwinement to include overlapping, often interactional entanglements at various levels - macro - meso - micro - the conifer root system allows a detangling of intersecting and often knotted strands. It permits movement from the solid, nearly unbreakable root foundation to microfilaments that reveal intersections of place (nation, region, state, locale), policy (departmental, agency, regional, local), and hierarchies of people at interacting levels. Untangling the snarled strands associated with diversification suggests analysis that, like Barbara Pamphilon's zoom lens metaphor: acknowledges that the levels are not discrete entities or binary opposites, for example, as with an individual or society, but are in fact in a relationship, intricately and intrinsically linked. Furthermore, when faced with contradictory data or concerns of validity of accounts, the researcher is reminded to zoom 
out/in to other complementary levels in order to interrogate the data. Thus, the zoom metaphor invites a dynamic and relational notion of data. ${ }^{746}$

Disentangling the fibers of diversity began with intersections of the major root system the federal government, policy, and individuals caught at particular junctures in time and place, uncovered through historical investigation. Through the metaphor of the old growth Northwest conifer, overturned and entwined, the processes that impacted diversification of the workforce at large are revealed. Departmental and agency policies connected those engaged in creating guidelines, those who carried them out, and the very real people who experienced and shaped resulting outcomes.

As William Cronon advises, what is important about nature is its meaning for human beings. Stories of diversification in the USDA Forest Service are tales about human relationships sparked by connections to the land. Carolyn Merchant and others would add that associations developed in the Forest Service between employees, and between the agency and the public, also occur in relation to nature. Caring for the land lays the foundation for those bonds, and as special emphasis program managers wrote to Dale Robertson in July 1993, “The evolution of ecosystem management and multicultural perspectives are two notable areas where cultural diversity can make significant contributions." ${ }^{, 747}$ When it comes to changing social and environmental relationships, some things must be mandated. Perhaps if the rollbacks on affirmative

\footnotetext{
746 Barbara Pamphilon, "The Zoom Model: A Dynamic Framework for the Analysis of Life Histories," Qualitative Inquiry 5, no. 3 (1999): 393.

$747 \quad$ Jetie Wilds, Jose Cruz, Corey Wong, and Robert Tippeconic to F. Dale Robertson, Chief, "Cultural Diversity on National and Regional Group Assignments," July 26, 1993. FHS Collection F13.3, File, Personnel: Work Force Diversity - General.
} 
action had not happened in the 1980s, followed by downsizing in the 1990s, the Forest Service would have achieved parity. But history is not about what could have happened. It is about what did happen and the ways in which the past can help to shape the future. The TMO task force did define workforce diversity in their primary recommendation to move beyond incorporating cultural difference, avoiding discrimination, or adding multicultural perspectives to becoming a multicultural organization.

Diversity and inclusion has becoming increasingly important. The business case, according to agency leaders, is that USFS should represent those they serve. As a public agency that "holds in trust the nation's forest and grasslands, and delivers programs to care for private landowners - how do you explain the absence of people like them within your organization?" asks Mary Wagner. As an agency entrusted with resources held in common, it is important for the public to feel a sense of ownership. On a very practical level, several narrators pointed out that simple exposure to national forests and the work the agency does is more likely to create public support for an agency that has often been criticized. Representative populations provide a stronger interface with communities of color. For example, what kinds of camping experiences work best for Hispanic families? What do Asian communities seek? Are African Americans aware of national forests as part of their public domain? These and other issues may be best answered by members of particular communities.

Elizabeth Agpaoa noted that part of the issue with social diversification is simply "staying in the intention of it." Once the agency came close to its goals, "we just thought, okay, it's going to take care of itself," she said. Now the agency recognizes that 
diversification does not regenerate automatically. In fact, as Agpaoa pointed out, she came into USFS with a large cohort of people, when it had the budget and flexibility to hire all kinds of people. In the early twenty-first century, many of those people have retired. New priorities in natural resources also impacted TMO implementation and turned attention away from multicultural goals. Many Forest Service employees paid attention to the "Caring for the Land" part of the agency's mission, but as rising tensions over natural resources and changing demographics took precedence, many became less enthusiastic about, or simply had less time for "Serving People.,"748

One of the biggest problems the Forest Service has is figuring out how social diversification fits into the mission. During the TMO era, regional foresters and station directors focused on developing the Mission, Vision, and Guiding Principles related to "Caring for the Land, Serving People." Finalized documents that borrowed from TMO and the 1993 Government Performance Results Act were released in early 1993, under the guiding principle that a multicultural organization is "essential to our success." A policy group also monitored implementation to assure congruence between the agency Mission, Vision, Guiding Principles, and overall objectives of TMO. ${ }^{749}$ As top leadership changed, priorities shifted, with each chief setting his or her own agenda; however, the phrase "Caring for the Land and Serving People" remained at the forefront of communications, the main story that the Forest Service tells about itself.

TMO Revisited, 13.

TMO Revisited, 8. 
Although identified as the "mission" at times in the early 1990s, the phrase has continued to serve as the agency's motto, a way to capture the goal of sustaining "the health, diversity, and productivity of the Nation's forests and grasslands for future generations." Traces of the TMO era remain in some of the stated elements of the mission. Multiple use management concepts include: Listening to people and responding to their diverse needs in making decisions and providing work, training, and education to the unemployed, underemployed, elderly, youth, and disadvantaged in pursuit of our mission. ${ }^{750}$ The agency's stated vision further reflects TMO, incorporating language from the Blue Book: "We are a multicultural and diverse organization; Employees are respected, accepted, and appreciated for their unique and important [added since TMO] contribution to the mission; and Employees work in a caring and nurturing environment where leadership is shared." The latter statement replicates that of the TMO report, but leaves out the words "power and influence"; that is, leadership is shared, but not power. The vision includes interesting, challenging work that is recognized internationally "as a leader in caring for the land and serving people."

\footnotetext{
$750 \quad$ USDA Forest Service Website, "What We Believe," http://www.fs.fed.us/about-agency/whatwe-believe [accessed March 18, 2015]. Other elements of the mission are: Advocating a conservation ethic in promoting the health, productivity, diversity, and beauty of forests and associated lands; Protecting and managing the National Forests and Grasslands so they best demonstrate the sustainable multiple-use management concept; Providing technical and financial assistance to State and private forest landowners, encouraging them to practice good stewardship and quality land management in meeting their specific objectives; Providing technical and financial assistance to cities and communities to improve their natural environment by planting trees and caring for their forests; providing international technical assistance and scientific exchanges to sustain and enhance global resources and to encourage quality land management; helping States and communities to wisely use the forests to promote rural economic development and a quality rural environment; developing and providing scientific and technical knowledge aimed at improving our capability to protect, manage, and use forests and rangelands.
} 
According to the agency's vision, the "American people can count on the Forest Service to perform." A host of guiding principles include an ecological approach to multiple-use management, using scientific knowledge in decision-making, meeting customer needs, forming partnerships, and supporting grassroots participation in making decisions. Shared leadership and valuing a multicultural organization remain "essential" to agency success. ${ }^{751}$ As Samuel Krislov pointedly noted, "The American dream was built on several major themes, but its dominant one was its ability to cope effectively with diversity in society."752 Social engineering through bureaucratic representation provides one means for coping with a diverse society, as the example of the U.S. Forest Service demonstrates. "But," as Herbert Kallen asked in 1915, "the question is, do the dominant classes in America want such a society?" The answer remains elusive.

\footnotetext{
$751 \quad$ Ibid.

752 Krislov, Representative Bureaucracy, 18.
} 


\section{Bibliography}

$\underline{\text { Books }}$

Anderson, Terry. The Pursuit of Fairness: A History of Affirmative Action. New York: Oxford University Press, 2004.

Armitage, Susan and Elizabeth Jameson. Writing the Range: Race, Class, and Culture in the Women's West. Norman: University of Oklahoma Press, 1997.

Bell, Derrick Bell. And We Are Not Saved: The Elusive Quest for Racial Justice. New York: Basic Books, 1987.

Bonilla-Silva, Eduardo. Racism Without Racists: Color-blind Racism and the Persistence of Racial Inequality in America. Rowman \& Littlefield, 2014. Broadnax, Walter D., ed. Diversity and Affirmative Action in Public Service. Boulder, CO: Westview Press, 2000.

Burchfield, Christopher. Tinderbox: How Politically Correct Ideology Destroyed the U.S. Forest Service, Stairway Press, 2013.

Clanindin, D. Jean and Connelly, Michael F. Narrative Inquiry: Experience and Story in Qualitative Research. San Francisco: Jossey-Bass Publishers, 2000.

Cole, Jr., Olen. The African American Experience in the Civilian Conservation Corps. University Press of Florida, 1999.

Cullen, Jim. The American Dream: A Short History of an Idea. New York: Oxford University Press, 2003.

Pete Daniel, Dispossession: Discrimination Against African American Farmers in the Age of Civil Rights. U.S.A.: University of North Carolina Press.

Delgado, Richard. Critical race theory an introduction, second edition. New York: New York University Press, 2012.

Denzin, Norman. Interpretive Biography. Qualitative Research Methods Series, Volume 17. Newbury Park, CA: Sage Publications, 1989. and Yvonna Lincoln. The Sage Handbook of Qualitative Research. Thousand Oaks, CA: Sage Publications, 2005.

Dietrich, William. The Final Forest: the Battle for the Last Great Trees of the Pacific Northwest. New York: Penguin Books.

Dolan, Julie and David H. Rosenbloom, eds. Representative Bureaucracy: Classic Readings and Continuing Controversies. New York: M.E. Sharpe, 2003.

Downs, Anthony. Inside Bureaucracy. Boston: Little Brown \& Co., 1967. Enarson, Elaine Pitt. Woods Working Women: Sexual Integration in the U.S. Forest Service. Tuscaloosa, AL: University of Alabama Press, 1984.

Escobedo, Elizabeth. From Coveralls to Zoot Suits: The Lives of Mexican American Women on the World War II Homefront. Chapel Hill: University of North Carolina Press, 2013.

Fiege, Mark. The Republic of Nature: An Environmental History of the United States. Seattle: University of Washington Press, 2012.

Frank Fischer, ed. Handbook of Public Policy Analysis: Theory, Politics, and Method. Boca Raton: Taylor \& Francis, 2007. 
Evaluating Public Policy. Chicago: Nelson-Hall, 1995.

Michael Frome. The Forest Service. New York: Praeger Publishers, Inc., 1971.

Geertz, Clifford. The Interpretation of Cultures. New York: Basic Books, 1973.

Glave, Dianne. Rooted in the Earth: Reclaiming the African American Environmental Heritage. Chicago: Lawrence Hill Books, 2010.

Gutmann, Amy and Dennis Thompson, Democracy and Disagreement. U.S.A.: Harvard College, 1996, 1997.

Hays, Samuel. Wars in the Woods: The Rise of Ecological Forestry in America. Pittsburgh: University of Pennsylvania Press, 2007.

Hays, Samuel P. Conservation and the Gospel of Efficiency: the progressive conservation movement,1890-1920. Cambridge: Harvard University Press, 1959.

Hirt, Paul. A Conspiracy of Optimism: Management of the National Forests Since World War II. United States: University of Nebraska Press, 1994.

Katznelson, Ira. When Affirmative Action was White: An Untold History of Racial Inequality in Twentieth-America. New York: W.W. Norton \& Company, 2005.

Kaufman, Herbert. The Forest Ranger: A Study in Administrative Behavior. Baltimore: Johns Hopkins Press, 1960.

Kellough, Edward J. Understanding Affirmative Action: Politics, Discrimination, and the Search for Justice. Washington, D.C.: Georgetown University Press, 2006.

Kennedy, David M. Freedom From Fear: The American People in Depression and War, 1929-1945. New York: Oxford University Press, 1999.

Krislov, Samuel and David H. Rosenbloom. 1981. Representative Bureaucracy and the American Political System. New York: Praeger Publishers, 1981. . Representative Bureaucracy. Englewood Cliffs, NJ: Prentice-Hall, Inc., 1974.

Lipsky, Michael. Street Level Bureaucracy: Dilemmas of the Individual in public services. New York: Russell Sage Foundation, 1980.

Miller. Char. Seeking the Greatest Good: The Conservation Legacy of Gifford Pinchot. Pittsburgh: University of Pennsylvania Press, 2013. Public Lands, Public Debates: a century of controversy. Corvallis: Oregon State University, 2012. American Forests: Nature, Culture, and Politics. Lawrence: University of Kansas Press, 1997.

Lewis, James G. The Forest Service and the Greatest Good: A Centennial History. Durham, NC: Forest History Society, 2005.

Mayberry, Bennie D. Share the Vision: The History of the Tuskegee University Forest Resources Program, 1968-1992, published by Tuskegee University and the U.S.D.A. Forest Service, 1993.

Merchant, Carolyn. "Essays" in Major Problems in American Environmental History. (Lexington, MA, D.C. Heath \& Co.): 2-31.

Mosher, Frederick C. Democracy and the Public Service. Second Edition. United States of America: Oxford University Press, 1968, 1982.

Naff, Katherine C., Norma C. Ricucci, and Siegrun Fox Freyss, with the assistance of 
David H. Rosenbloom and Albert C. Hyde, Personnel Management in

Government: Politics and Process, Seventh edition. Boca Raton, Florida: Taylor \& Francis Group, LLC, 2014.

Nienaber, Jeannie and Daniel C. McCool, Staking Out the Terrain: Power and

Performance Among Natural Resource Agencies. Albany: State University of

New York, 1995.

Paris, David C. and James F. Reynolds, The Logic of Policy Inquiry. New York:

Longman, Inc., 1983.

Patton, Michael Quinn. How to Use Qualitative Methods in Evaluation. Newbury Park: Sage Publications, 1987.

Reissman, Catherine Kohler. Narrative Analysis. Qualitative Research Methods Series, Volume 30. Newbury Park, CA: Sage Publications, 1993.

Ricucci, Norma. Managing Diversity in Public Sector Workforces. Boulder, Colorado: Westview Press, 2002.

Robbins, William G. and Katrine Barber, Nature's Northwest: The North Pacific Slope in the Twentieth Century. Tucson: University of Arizona Press, 2011.

Rossiter, Margaret. Women Scientists in America: Forging a New World Since 1972 Baltimore, MD: Johns Hopkins University Press, 2012.

Rung, Margaret C. Servants of the State: Managing Diversity and Democracy in the 4 Federal Workforce, 1933-1953. Athens \& London: University of Georgia Press, 2002.

Selden, Sally Coleman. The Promise of Representative Bureaucracy: Diversity and Responsiveness in a Government Agency. New York: M.E. Sharpe, 1997.

Schattschneider, E.E. The Semisovereign People. Hinsdale, IL: The Dryden Press, 1960/1975.

Shafritz, Jay M., Steven Ott, and Yong Suk Jang, Classics of Organization Theory, Sixth Edition. Belmont, CA: Wadsworth, Cengage Learning, 2005.

Steen, Harold. The U.S. Forest Service: a history. Durham, North Carolina: Forest History Society, in association with the University of Washington Press, 2005. Centennial Edition. Originally published in Seattle, WA: University of Washington Press, 1976.

Stone, Deborah. Policy Paradox: The Art of Political Decision Making. New York: W.W. Norton \& Company, Inc., 2002.

Takaki, Ronald. A Different Mirror: A History of Multicultural America. New York: Little, Brown, and Co., 1993, revised 2008.

Taylor, Quintard. In Search of the Racial Frontier: African Americans in the American West, 1528-1990. U.S.A.: Norton, 1999.

Weber, Max. From Max Weber: essays in sociology. New York: Oxford University Press, 1958.

Wiesen Cook, Blanche. Eleanor Roosevelt, Volume 2: The Defining Years, 1933-1938. New York: Penguin Books, 1999.

Williams, Gerald. Foreword by Mike Dombeck, The U.S. Forest Service in the Pacific Northwest: A History. Corvallis: Oregon State University Press, 2009. 
The U.S.D.A. Forest Service: The First Century, 1905-2005, Centennial

Commemorative Edition, PS-650, revised April 2005.

Yanow, Dvora. Conducting Interpretive Policy Analysis. Qualitative Research Methods

Series, Volume 47. Newbury Park, CA: Sage Publications, 2000.

Yow, Valerie. Recording Oral History: A Guide for the Humanities and Social Sciences.

Second Edition. Lanham, MD: Altamira Press, 2005.

Articles and Book Chapters

Albertson, Mary. "Progress of Women in the Forest Service." Women in Natural

Resources 15, no. 4 (September 1993): 5.

American Forests, "Forest Frontiers: Jerry F. Franklin," American Forests (Fall 2012), 140 Years of Protecting American Forests Website, http://www.americanforests.org/magazine/article/forest-frontiers-jerry-f-franklin/ [last accessed July 21, 2015].

Bailey, Margo. "Representative Bureaucracy: Understanding its past to Address its Future." Public Administration Review 64, no. 2 (March/April, 2004): 246-249.

Blahna, Dalej and Susan Yonts-Shepard. "Public involvement in resource planning: Toward bridging the gap between policy and implementation." Society and Natural Resources 2, no. 1 (1989): 209-227.

Blum, Elizabeth. Linking American Women's History and Environmental History: A

Preliminary Historiography, http://www.hnet.org/ environ/historiography/uswomen.htm

Blumer, Herbert. "Sociological Analysis and the "Variable." American Sociological Review 21, no. 6 (December 1956): 683-690.

"What is Wrong with Social Theory?" American Sociological Review 19 (February, 1954): 3-10.

Bradbury, Mark D. and J. Edward Kellough. "Representative Bureaucracy: Exploring the Potential for Active Representation in Local Government. Journal of Public Administration Research and Theory 18 (2007): 697-714.

Brown, Greg and Charles Harris. "The implications of workforce diversification in the U.S. Forest Service.” Administration \& Society 25 (1993): 85-113.

Cameron, Kristi, Joan Jorgenson, and Charles Kawecki. "Civil Service 2000 Revisited: Old Assumptions New Facts and Forecasts." Public Personnel Management 22, 4 (Winter 1993): 669.

Carroll, Franklin O., John Freemuth, and Les Alm. "Women forest rangers: revisiting Kaufman's 'The Forest Ranger.'” Journal of Forestry 94, no. 1 (1996): 38-41

Castenada, Antonia. "Women of Color and the Rewriting of Western History: The Discourse, Politics, and Decolonization of History." Pacific Historical Review 61, no. 4 (November 1992): 501-533

Chiang, Connie Y. "Race and Ethnicity in Environmental History." In The Oxford Handbook of Environmental History, ed. Andrew C. Isenberg (Oxford University Press, 2014): 573-599.

Committee L. on Historically Black Colleges and Institutions. "Report, The Historically 
Black Colleges and Universities: A Future in the Balance." Acadame 81, no. 1 (Jan.-Feb., 1995): 49-57.

Cronon, William. "A Place for Stories: Nature, History, and Narrative." Journal of American History 78, no. 4 (1992): 1347-1376.

Dolan, Julie. "Representative Bureaucracy in the Federal Executive: Gender and Spending Priorities. Journal of Public Administration Research and Theory 12, no. (2007): 353-375.

Dravnieks, Daina. "The Surprising Career of Geraldine 'Geri' Larson: The first and highest ranking line officer in the Forest Service." Women in Forestry (Summer 1985): 12-16.

Ehrenreich, Dixie L. "Documenting Progress: The Women in Natural Resources Journal, Journal of Forestry 94, no. 11 (November 1996): 8-13.

Fayol, Henri. General and Industrial Management, trans. Constance Storrs (London: Pittman, 1949): 19-42; original work published in 1916. In Jay M. Shafritz, J. Steven Ott, and Yong Suk Jang, Classics of Organization Theory, Sixth Edition (Belmont, CA: Wadsworth, Cengage Learning, 2005): 48-60.

Garcia, Jerry and Gilberto Garcia. Memory, Community and Activism: Mexican Migration and Labor in the Pacific Northwest. Julian Samora Research Institute, 2005.

Guthrie, John D. "Women as Forest Guards.” Journal of Forestry 18 (February 1920): 151.

Helms, Douglas. "Eroding the Color Line: The Soil Conservation Service and the Civil Rights Act of 1964." Agricultural History, Vol. 65, No. 2 The 1890 Land-Grant Colleges: A Centennial View (Spring 1991): 35-53.

Hindera, John J. "Representative Bureaucracy: Further Evidence of Active Representation in EEOC District Offices.” Journal of Public Administration and Theory 3 (1993): 415-429.

"Representative Bureaucracy: Imprimis Evidence of Active Representation in EEOC District Offices.” Social Science Quarterly 74 (1993): 95-108.

Hsieh, Chih-wei and Elizabeth Winslow. "Gender Representation in the Federal Workforce: A Comparison Among Groups. Review of Public Personnel Administration 26 (2006): 276-291.

Human, Linda. "Managing workforce diversity: a critique and example from South Africa." International Journal of Manpower, 17, no. 4-5 (April-May 1996): 46.

Hurtado, Albert. "Settler Women and Frontier Women: The Unsettling Past of Western Women's History." Frontiers: A Journal of Women's Studies 22, no. 3 (2001): 15 .

Jacobs, Margaret D. “Getting Out of a Rut: Decolonizing Western Women's History, Pacific Historical Review 79, no. 4 (2010): 585-604.

Kahrmandis, Jane. "The She-She-She Camps of the Great Depression," History Magazine (March 2008): 13-16.

Kallen, Horace M. "Democracy versus the Melting-Pot: A Study of American Nationality." The Nation, February 25, 1915. 
Kellough, Edward J. "Affirmative Action in Government Employment." Annals of the American Academy of Political and Social Science 523 (September 1992): 117130.

Kingsley, Donald J. "Representative Bureaucracy." In Julie Dolan and David H.

Rosenbloom, eds., Representative Bureaucracy: Classic Readings and Continuing Controversies (New York: M.E. Sharpe, 2003): 12-18.

Koontz, Tomas M. "Federal and State Public Forest Administration in the New Millenium: Revisiting Herbert Kaufman's The Forest Ranger." Public Administration Review (January/February 2007): 152-164.

Lanpher, Henry Coe. "The Civilian Conservation Corps: Some Aspects of Its Social Program for Unemployed Youth." Social Service Review 10, no. 4 (December 1936): 623-636.

Leach, Melissa and Cathy Green. "Gender and Environmental History: From Representation of Women and Nature to Gender Analysis of Ecology and Politics." Environmental History 3 (1997): 343-370;

"Letters." Journal of Forestry 69, no. 7 (July 1971): 393, 438.

Levine-Rasky, Cynthia. "Discontinuities of Multiculturalism." Canadian Ethnic Studies 38, no. 3 (2006): 87-104.

Lewis, James G. "A Brief History of African Americans in Forestry," available at http://www.fs.fed.us/people/aasg/PDFs/African_Americans_and_forests_March2 1\%202006.pdf [last accessed July 21, 2015].

Lindblom, Charles. "The science of 'muddling through." Public Administration Review 19, (1959): 79-88.

Markoff, Helene S. “The Federal Women's Program” Public Administration Review 32, no. 2 (Mar-Apr., 1972): 144-151.

McDaniel, Josh."Voices from the Turpentine Woods." Southern Quarterly (Fall 2008): 109-118.

McKenna, Francis R. "The Myth of Multiculturalism and the Reality of the American Indian in Contemporary America." Journal of American Indian Education 21, no 1 (October 1981).

McLean, Herbert. "The Regendering of the Forest Service." Forest World (Spring 1990): 22-27.

Meier, Kenneth J. and Lloyd G. Nigro, "Representative Bureaucracy and Policy Preferences: A Study in the Attitudes of Federal Executives." (1976) In Dolan and Rosenbloom, eds. Representative Bureaucracy: Classic Readings and Continuing Controversies (New York: M.E. Sharpe, 2003): 84-96.

Merchant, Carolyn. "Shades of Darkness: Race and Environmental History." Environmental History 8, no. 3 (July 2003): 380-394. "Gender and Environmental History." The Journal of American History 76 (1990): 1117-1121

Merriam, Charles E."Progress in Political Research." The American Political Science Review 20 (February 1926): 1-13.

Montoya, Maria. "The Roots of Economic and Ethnic Divisions in Northern New 
Mexico: The Case of the Civilian Conservation Corps. Western Historical Quarterly 26, no. 1 (Spring 1995): 15-34.

Mosley, Stephen. "Common Ground: Integrating Social and Environmental History." Journal of Social History, 39, no. 3 (Spring 2006): 915-933

Nash, Linda. "Furthering the Environmental Turn." Journal of American History 100 (June 2013): 131-135;

Noon, Barry R. and Kevin S. McKelvey. "Management of the Spotted Owl: A Case History in Conservation Biology." Annual Review of Ecological Systems, 27 (1996): 135-162.

Norwood, Vera. "Disturbed Landscape/Disturbing Process: Environmental History for the Twenty-First Century." Pacific Historical Review (February 2001): 77-89. . "Constructing Gender in Nature." In John Herron and Andrew Kirk, eds., Human/Nature: Biology, Culture, and Environmental History (Albuquerque: University of New Mexico Press, 1999): 49-62.

Obert, P.M. "Those Wonderful Sho-Bans.” American Forests 74, no. 3 (March 1968): 28-30, 56-57.

Pamphilon, Barbara. "The Zoom Model: A Dynamic Framework for the Analysis of Life Histories." Qualitative Inquiry 5, no. 3 (1999): 393-410.

Pappas, Stephanie. "Bears Not Attracted to Menstruating Women," Livescience (August 25, 2012).

Pardo, Richard. “Can a Woman be a Forester?” American Forests (September 1978): 22-25.

Parker, Franklin. "Salvaging School Failures: The Job Corps Acts." The Phi Delta Kappan 49, no. 7 (March 1968): 362-369/

Parman, Donald L. "The Indians and the Civilian Conservation Corps." Pacific Historical Review 40, no. 1 (Feb. 1971): 41-45.

Payne, Brian R. and Donald R. Theoe. "Black Foresters Needed: A Professional Concern.” Journal of Forestry 69, no. 5 (May 1971): 297-298.

"People: Luther Burse." Jet (January 25, 1993): 20.

Quadagno, Jill and Catherine Fobes. "The Welfare State and the Cultural Reproduction of Gender: Making Good Girls and Boys in the Job Corps." Social Problems 42, no. 2 (May 1995): 171-190.

Ricucci, Norma M. "Moving Away From a Strict Scrutiny Standard for Affirmative Action: Implications for Public Management." The American Review of Public Administration 37 (2007): 123-141.

Rogers, Lynn L., Gregory A. Wilker, and Sally Scott. "Reactions of Black Bears to Human Menstrual Odors." Journal of Wildlife Management 55, no 4 (1991): 632-63.

Romero, Lou. "'Caring for the Land and Serving People.' The Origins of the U.S. Forest Service Motto.” Forest History Today (Fall 2012): 35-39.

Sabatier, Paul, J. Loomis, and C. McCarthy. "Policy attitudes and decisions within the Forest Service." Journal of Forestry 94, no. 1 (1996): 42-46.

Salmond, John A. "The Civilian Conservation Corps and the Negro." The Journal of 
American History 52, no. 1 (June 1965): 75-88.

Scharff, Virginia. "Man and Nature! Sex Secrets of Environmental History." In John Herron and Andrew Kirk, eds., Human/Nature: Biology, Culture, and Environmental History (Albuquerque: University of New Mexico Press, 1999): 31-48.

Selden, Sally Coleman "Representative Bureaucracy: Examining the Linkage Between Passive and Active Representation in the Farmers Home Administration." American Review of Public Administration 27 (1997): 22-42 , Gene A. Brewer, and Jeffrey L. Brudney. "Reconciling Competing Values in Public Administration: Understanding the Administrative Role Concept." Administration and Society 31 (1999): 171-204.

Selznick, Phillip. "Foundations of the Theory of Organization" (1948). In Shafritz, Jay M., Steven Ott, and Yong Suk Jang, Classics of Organization Theory, Sixth Edition. (Belmont, CA: Wadsworth, Cengage Learning, 2005): 125-134.

Steen, Harold K. "Traditional Forestry Hits the Wall: Excerpt of Interview with F. Dale Robertson (August 12-14, 1999)." Forest History Today (Spring 2000): 2-8. Steinberg, Ted. "Down to Earth: Nature, Agency, and Power in History." American Historical Review, 107, no. 3 (June 2002): 798-820

Stewart, Mart. "Slavery and African American Environmentalism." In "To Love the Wind and the Rain": African Americans and Environmental History, eds, Dianne

D. Glave and Mark Stoll. Pittsburgh: University of Pittsburgh Press, 2006. . "Environmental History: Profile of a Developing Field." History Teacher, 31, no. 3 (May 1998): 351-368.

Taylor, Alan. "Unnatural Inequalities: Social and Environmental Histories." Environmental History, no. 4 (October 1996): 6-19.

Thomas, Jennifer C. and Paul Mohai. "Racial, Gender, and Professional Diversification in the Forest Service from 1983 to 1992." Policy Studies Journal 23, no. 2 (1995): 296-309.

Tipple, Terrence J. and J. Douglas Wellman. "Herbert Kaufman's Forest Ranger Thirty Years Later: From Simplicity and Homogeneity to Complexity and Diversity." Public Administration Review 51, no. 5 (September/October 1991): 421-428.

Torgerson, Douglas. "Promoting the Policy Orientation: Lasswell in Context." In Frank Fischer, ed. Handbook of Public Policy Analysis: Theory, Politics, and Method (Boca Raton: Taylor \& Francis, 2007): 15-28.

Toossi, Mitra. "A Century of Change: the U.S. labor force, 1950-2050." Available at Bureau of Labor Statistics Website, http://www.bls.gov/opub/mlr/2002/05/art2full.pdf [last accessed July 21, 2015]. Unger, Nancy. "Women and Gender: Useful Categories of Analysis in Environmental History." In The Oxford Handbook of Environmental History, ed. Andrew C. Isenberg (Oxford University Press, 2014): 601-643.

United States Department of Education Office of Civil Rights. "Historically 
Black Colleges and Universities and Higher Education Desegregation.” March 1991, available at http://www2.ed.gov/about/offices/list/ocr/docs/hq9511.html [last accessed July 21, 2015].

United STates Department of Interior $21^{\text {st }}$ Century Conservation Service Corps Advisory Committee. "History of the Service and Conservation Corps Movement." http://www.doi.gov/21csc/history/upload/21CSCBackground.pdf [last accessed July 21, 2015].

Walshock, Mary Lindenstein. "Review of Woods-Working Women: Sexual Integration in the U.S. Forest Service by Elaine Pitt Enarson." Contemporary Sociology 14, no. 3 (May 1985): 352-353.

Ware, Susan. "Women and the New Deal." In The Great Depression and the New Deal: Minorities and Women During the Great Depression, Melvin Dubofsky and Stephen Burwood, eds. (New York: Garland Publishing, Inc.): 333-349.

Warner, Andrea. "In the Beginning, there was the Forest Service's Federal Women's Program." Women in Natural Resources 15, no. 1 (September 1993): 10.

Weber, Max. "Bureaucracy," In Shafritz, Jay M., Steven Ott, and Yong Suk Jang, Classics of Organization Theory, Sixth Edition. (Belmont, CA: Wadsworth, Cengage Learning, 2005): 73-78.

White, Richard. "Afterword Environmental History: Watching a Historical Field Mature." Pacific Historical Review, 70, no. 1 (February 2001): 103;

Wolters, Raymond. "The New Deal and the Negro." In The Great Depression and the New Deal: Women and Minorities During the Great Depression, Melvin Dubofsky and Stephen Burwood, eds. (New York: Garland Publishing, Inc.).

Women in Natural Resources. "The View from Women in Natural Resources: Life Experiences and Gender Equity Fill the Pages." Women in Natural Resources, 24 , no. 3 (2003-2004), available at http://www.webpages.uidaho.edu/winr/winrgroup.htm [last accessed July 21, 2015].

Yale Magazine, ed. "Who Was the First African American Student at Yale?" Yale Magazine online (May/June 2014), available at https://www.yalealumnimagazine.com/articles/3876, [last accessed July 21, 2015].

Government Reports

Adams, Darius, Richard Haynes, and Adam Daigneault. "Estimated Timber Harvest by Region and Ownership, 1950-2002.” U.S.D.A. Forest Service, Pacific Northwest Research Station, General Technical Report, PNW-GTR-659. January 2006.

Dale, Charles V. "Federal Affirmative Action Law." CRS Report for Congress, September 13, 2005. http://fpc.state.gov/documents/organization/53577.pdf [last accessed July 21, 2015].

Office of Merit Systems Review and Studies. "Sexual Harassment in the Workplace: Is it a Problem? A Report of the U.S. Merit Systems Review Board.” March 1981. Available at 
http://www.mspb.gov/netsearch/viewdocs.aspx?docnumber=240744\&version=2 41014\&application=ACROBAT [last accessed July 21, 2015].

Rakestraw Lawrence and Mary. "USDA Forest Service Pacific Northwest Region, Appendix - Willamette National Forest Commercial Timber Sales, 1909-1989." History of the Willamette National Forest (1991). Electronic edition courtesy of the Forest History Society. Available at http://www.foresthistory.org/ASPNET/Publications/region/6/willamette/app7.htm [last accessed July 21, 2015].

United States Commission on Civil Rights. "State of Civil Rights 1957-1983: The Final Report of the U.S. Commission on Civil Rights." November 1983. "School Desegregation in Tacoma, Washington." May 1979. Available at http://www.law.umaryland.edu/marshall/usccr/documents/cr12t11.pdf [last accessed July 21, 2015]. . Equal Opportunity in Farm Programs: An Appraisal of Services Rendered by Agencies of the United States Department of Agriculture. Washington, D.C.: Government Printing Office, 1965.

United States Department of Agriculture. FY 2012-2015 Department-wide Diversity and Inclusion Plan" available at http://www.dm.usda.gov/employ/diversity/docs/DiversityandInclusionPlanFY11 -15.pdf [last accessed July 21, 2015].

. Civil Rights Action Team. Civil Rights at the United States Department of Agriculture: A Report by the Civil Rights Action Team. Washington, D.C., February 1997.

United States Department of Agriculture Forest Service. Pacific Northwest Region Almanac, Portland, Oregon, ca. 2009. Available at http://www.fs.usda.gov/Internet/FSE_DOCUMENTS/stelprdb5378417.pdf [last accessed July 20, 2015].

. Report of the Forest Service, Fiscal Year 1997. Washington, D.C., May 1998. . Toward a Multicultural Organization: Report of the USDA Forest Service Task Force on Work Force Diversity. March 1991.

Report of the Forest Service: Fiscal Year 1980 Highlights, 75 Years of Service. FS-364. Washington, D.C., 1980.

. Employment Group. “1977 Personnel Report.” Compiled by Ron Noland, Helen Weiler, Washington, D.C, 1977.

. Human Resources and Personnel Management. "1982 Personnel Report."

. Personnel and Civil Rights Staff. Equal Opportunity is for Everyone: 1988 Civil Rights Report, produced 1989.

. Personnel and Civil Rights Staff. "Workforce Data Book, 1988-1989." Prepared by Tom Martin and Mary Lynch, Washington Office.

. Personnel Management Staff. "1980 Work Force Planning Data Book." Compiled by Rob Rippey and Ted Marine. Washington, D.C., 1980. . “1974 Personnel Report.” Prepared by Ron Noland. November 4, 1974 . TMO Revisited Team. "TMO Revisited: An Evaluation Report \& Building 
Blocks to Meet $21^{\text {st }}$ Century Challenges." October 1, 1998. Available at http://www.fs.fed.us/cr/correspondence/final_tmo_report.html [last accessed July 20, 2015].

United States Office of Personnel Management. "Revisiting Civil Service 2000: New Policy Direction Needed." September 1993.

Urban, Kathryn Ladoulis and Stanley Solamillo. "Civilian Conservation Corps In Hawai'i: Oral Histories of the Haleakalā Camp, Maui.” Prepared for Haleakala National Park, NPS Contract \#C8298090010, Honolulu, Hawai'i, Final Report July 20, 2011, National Park Service Website, http://www.nps.gov/hale/historyculture/upload/CCC-Oral-Histories-ofHaleakala-Camp.pdf [accessed September 19, 2013]

\section{$\underline{\text { Collections }}$}

Mary Albertson's personal documents

Forest History Society, Durham, North Carolina:

Collection F4.5

Collection F5

Collection F5.2

Collection F6.3

Collection F13.2

Collection F13.3

Collection F15.2

Collection F15.4

Collection F18.4

Steve Anderson Society of American Foresters Collection

National Archives Record Group 16, Records of the Offices of the Secretary of Agriculture, General Correspondence, 1906-1976, boxes 4781-4783.

Region 6 Civil Rights Collection. Regional Civil Rights Department, Portland, Oregon.

University of Maryland Francis King Carey School of Law, Thurgood Marshall Law Library. Historical Publications of the United States Commission on Civil Rights Online. Available at http://www.law.umaryland.edu/marshall/usccr/ [last accessed July 21, 2015].

\section{$\underline{\text { Newspapers }}$}

The AFRO

Bend Bulletin

The Columbian

Federal Times

Morning Oregonian 
New York Times

The Oregonian

San Francisco Chronicle

St. Louis Post-Dispatch

Washington Post

Interviews

See Appendix B: List of Interviews

Speeches

Hatfield, Mark O. "Floor Statement: Appointment of the New Forest Service Chief." United States Senate. November 3, 1993.

Hickerson, Carl. "Should Firefighters wear Petticoats??" National Fire Chiefs Workshop, Charleston, South Carolina, 1974.

Kimbell, Abigail. "Kids in the Woods: Making the Connection," Recreation Exchange, Washington D.C. August 27, 2007.

" "Transformation Through Diversity." USDA Forest Service Forum, African

American Strategy Group, Nashville, Tennessee, August 14, 2007. . "Sinking New Roots: How is Forest Service Culture Changing?" All Cultures Event, North Carolina, May 9, 2007.

Mason, Jerry. "Three Perspectives From Emerald City." Region Six Community Relations Conference, Bend, Oregon, January 29, 1991.

Moore, Mary Jane. "Women Rangers - How Can the Forest Service Do Better?" Lakeside District Ranger, Apache-Sitgreaves National Forest, Stamped March 31, 1986.

Salinas, Jr., Jose. "Parity 1995." Strength Through Diversity Conference, Welches, Oregon, November 3, 1988.

Sesco, Jerry. "Setting the Pace." Strength Through Diversity Conference, Welches, Oregon, November 3, 1988.

Shortbull, Thomas. "Statement of Thomas Shortbull." American Indian Higher Education Consortium, June 18, 2014.

\section{Personal Communication}

Personal Communication by email, Mary Albertson, November, 2014, January 11, 2015. Personal Communication by email, Lamar Beasley, April 2013.

Personal Communication, Gloria Brown, October 2014, January 2015.

Personal Communication by email, John “Jack” Deinema, April 8, 2015.

Personal Communication by email and telephone, Rachel Kline, Historian, Forest

Service Heritage Stewardship Group, September 10, 2014.

Personal Communication by email, Angela Kuhne, Yale University, June 12, 2013.

Personal Communication by email and by telephone, Eleanor Towns, January 14, 2015. 
Personal Communication by email, with Jordan Wong, Wing Luke Museum, September 202013.

Unpublished Materials

Fisher, Carla. "You're Not Getting Rid of Me: Cultivating Space for Women in the U.S. Forest Service, 1950-1990.” Unpublished Dissertation, Purdue University, 2010.

Armando Rodriguez. "OPM Sponsorship of the National Council of Hispanic

Employment Program Managers, White Paper.” National Council of Hispanic

Employment Program Managers Document Repository, http://nationalcouncilhepm.net/index.asp?page=resources\&content=Repository [accessed February 2, 2014].

Schelhas, John, Walter Hill, Janet Haslerig, and Deidre Smith. "Sharing the Vision, Part 2: The Tuskegee Forestry and Natural Resource Program in the $21^{\text {st }}$ Century." Alabama Consortium on Forestry Education and Research, 2013. DRAFT.

U.S. Department of Agriculture Forest Service. "Tuskegee Institute Trains Future Foresters." Forest Research News for the MidSouth, Southern Experiment Station Newsletter (October 1970).

$\underline{\text { Websites }}$

American Social History Project/Center for Media and Learning (Graduate Center CUNY) and the Roy Rosenzweig Center for History and New Media, George Mason University. "History Matters: The U.S. Survey Course on the Web." http://historymatters.gmu.edu/ [last accessed July 21, 2015].

American University Website, School of Public Affairs, http://www.american.edu/spa/faculty/eseashore.cfm [last accessed July 21, 2015].

Arcata Fish and Wildlife Service Office Website. "Northern Spotted Owl." http://www.fws.gov/arcata/es/birds/NSO/ns_owl.html [last accessed July 21, 2015].

Association of Public and Land-Grants Institutions, http://www.aplu.org/ [last accessed July 21, 2015].

BlackPast, Reclaimed and Remembered. www.blackpast.org [last accessed July 21, 2015]. Operated by Dr. Quintard Taylor, University of Washington.

Cornell University Law School, Legal Information Institute, http://www.law.cornell.edu/supct/html/historics/USSC_CR_0163 0537_ZD.htm 1 [last accessed July 21, 2015].

Cornell University Library Special Collections. "Paul Logan." http://insight.library.cornell.edu:8280/luna/servlet/detail/CORNELL 10 1 6017 0 111760:Paul-H--Logan [last accessed July 21, 2015].

Department of History, George Washington University. "The Eleanor Roosevelt Papers Project." http://www.gwu.edu/ erpapers/ [last accessed July 21, 2015].

Derrick Bell, Official Site, http://professorderrickbell.com/about/ [last accessed July 21, 2015]. 
Encyclopedia of World Biography. http://www.notablebiographies.com/ [last accessed July 21, 2015].

Equal Employment Opportunity Commission Website. "EEOC $35^{\text {th }}$ Anniversary." http://www.eeoc.gov/eeoc/history/35th/history/index.html [last accessed July 21, 2015].

Forest History Society Website, http://www.foresthistory.org/ [last accessed July 21, 2015].

LBJ Presidential Library Online. http://www.lbjlibrary.org/ [last accessed July 21, 2015].

Lincoln University Website, Pennsylvania. http://www.lincoln.edu/about.html [last accessed July 21, 2015].

"Livescience." Science Newsletter, http://www.livescience.com/ [last accessed July 20, 2015]

National Archives Website. Federal Register. http://www.archives.gov/federal-register/ [last accessed July 21, 2015].

National Organization of Blacks in Government, BIG Website. http://bignet.org/index.php/about-us/philosophy-a-history [last accessed July 21, 2015].

New Jersey Council for the Humanities. Claiming Citizenship Website. "Claiming Citizenship: Asian Americans and the New Deal." funded by National Endowment for the Humanities, https://sites.google.com/site/claimingcitizenship/home/asian-americans [last accessed July 21, 2015].

Nixon Presidential Library and Museum, online, http://www.nixonlibrary.gov/index.php [last accessed July 20, 2105].

Northern Illinois University, University Libraries. "Illinois During the Golden Age Website." (2007) http://dig.lib.niu.edu/gildedage/idabwells/pamphlets.html [last accessed July 21, 2015].

Office of Management and Budget Website. https://www.whitehouse.gov/omb [last accessed July 21, 2015].

Office of Personnel Management Website, https://www.opm.gov/ [last accessed July 21, 2015].

Oregon State University College of Forestry Website. http://www.forestry.oregonstate.edu/ [last accessed July 21, 2015].

Portland State University and the Oregon Historical Society. Oregon Encyclopedia. http://www.oregonencyclopedia.org/ [last accessed July 21, 2015].

Triple Nickle Website. www.triplenickle.com.htm [last accessed July 21, 2015].

United States Army. The Official Homepage of the United States Army. http://www.army.mil/ [last accessed July 21, 2015].

United States Department of Agriculture Center of Excellence in Forestry Website. http://www.aamu.edu/academics/alns/bes/fewp/pages/coe.aspx [last accessed July 21, 2015].

United States Department of Agriculture Forest Service Website. http://www.fs.fed.us/ 
[last accessed July 21, 2015].

United States Department of Agriculture. USDA Blogs. http://blogs.usda.gov/ [last accessed July 21, 2015].

United States Department of Commerce, United States Census Bureau, http://www.census.gov/main/www/cen2000.html [last accessed July 20, 2015]. United States Department of Education Website. http://www.ed.gov/ [last accessed July 21, 2015].

United States Department of Justice Website. "Ecosystem Mgmt., The Northwest Forest Plan, And Old-Growth Dependent Species." http://www.justice.gov/enrd/4712.htm [last accessed July 21, 2015].

United States Department of Labor, Bureau of Labor Statistics, http://www.bls.gov/ [last accessed July 20, 2015]. United States Government Publishing Office. Electronic Code of Federal Regulations, http://www.ecfr.gov/cgi-bin/ECFR?page=browse [last accessed July 21,2015$]$.

University of California Berkeley Regional Oral History Office. United States Forest Service Region 5 Oral History Project, http://bancroft.berkeley.edu/ROHO/projects/usfs/ [last accessed July 21, 2015].

University of California Santa Barbara. The American Presidency Project. http://www.presidency.ucsb.edu/index.php [last accessed July 21, 2015].

University of Kentucky Libraries, Notable Kentucky African Americans Database, http://nkaa.uky.edu/subject.php?sub_id=136 [last accessed July 21, 2015].

University of New Mexico. Rocky Mountain Online Archive. http://rmoa.unm.edu/ [last accessed July 21, 2015].

University of Washington, Center for the Study of the Pacific Northwest. http://www.washington.edu/uwired/outreach/cspn/Website/index.html [last accessed July 21, 2015

Wildland Firefighters Website, http://www.wildlandfire.com/ [last accessed July 20, 2015]

Women in Military Service for America Website, http://www.womensmemorial.org/index.html [last accessed July 21, 2015].

Women in Natural Resource Website, http://www.webpages.uidaho.edu/winr/index.htm [last accessed July 20, 2015].

Yale School of Forestry and Environmental Studies - History, http://environment.yale.edu/about/history/ [last accessed July 21, 2015]. 


\section{Appendix A: Summary of Henry Fayol's General Principles of Management ${ }^{753}$}

\begin{tabular}{|c|c|}
\hline General Principles & Summary of Characteristics \\
\hline Division of work & $\begin{array}{l}\text { Specialization reduces the number of tasks per employee and allows for } \\
\text { production of "more and better work with the same effort." }\end{array}$ \\
\hline $\begin{array}{l}\text { Authority and } \\
\text { responsibility }\end{array}$ & $\begin{array}{l}\text { The right to give orders and the power to exact obedience, best made up of } \\
\text { both official and personal authority stemming from integrity and high moral } \\
\text { character. }\end{array}$ \\
\hline Discipline & $\begin{array}{l}\text { "is in essence obedience, application, energy, behavior, and outward marks } \\
\text { of respect" in accordance with organizational agreements with employees. It } \\
\text { is best established and maintained through good superiors at all levels, clear } \\
\text { and fair agreements, and judicious sanctions when necessary. }\end{array}$ \\
\hline Unity of command & $\begin{array}{l}\text { An employee should receive orders from only one superior. Dual command } \\
\text { "wreaks havoc" and is a "perpetual source of conflicts." }\end{array}$ \\
\hline Unity of direction & $\begin{array}{l}\text { Having "one head and one plan" for activities that have the same objective. } \\
\text { Exists through sound organization of the corporate body. }\end{array}$ \\
\hline $\begin{array}{l}\text { Subordination of individual } \\
\text { interest to the general } \\
\text { interest }\end{array}$ & $\begin{array}{l}\text { The interests of a single employee must not prevail over the concerns of the } \\
\text { entire group. }\end{array}$ \\
\hline Remuneration of personnel & $\begin{array}{l}\text { Must be fair and afford satisfaction to personnel and organization, so far as } \\
\text { possible. There are many options for remuneration, but profit-sharing does } \\
\text { not work in civil service. }\end{array}$ \\
\hline Centralization & $\begin{array}{l}\text { Levels of initiative and centralization vary. All that reduces the importance } \\
\text { of the subordinate is centralization. Expansion and initiative in the } \\
\text { subordinate is centralization. }\end{array}$ \\
\hline $\begin{array}{l}\text { Scalar chain (line of } \\
\text { authority) }\end{array}$ & $\begin{array}{l}\text { The chain of superiors from the ultimate authority to the lowest rank. The } \\
\text { "line of authority," links in the chain, is followed by all communications that } \\
\text { start from or go to the ultimate authority. }\end{array}$ \\
\hline Order & $\begin{array}{l}\text { "A place for everyone and everyone in his place." Social order requires each } \\
\text { employee to have an appointed place and that the organization has precise } \\
\text { knowledge and balance between human requirements and organizational } \\
\text { resources. }\end{array}$ \\
\hline Equity & $\begin{array}{l}\text { Desire for equity and equality of treatment are aspirations. The leader should } \\
\text { strive to instill equity throughout all organizational levels of the scalar chain. }\end{array}$ \\
\hline $\begin{array}{l}\text { Stability of tenure of } \\
\text { personnel }\end{array}$ & $\begin{array}{l}\text { Experience takes time. Stability of tenure and personnel is a matter of } \\
\text { proportion, but "a mediocre manager who stays is preferable to outstanding } \\
\text { managers" who come and go. }\end{array}$ \\
\hline Initiative & $\begin{array}{l}\text { The ability to "think out and execute" a plan is called initiative, and can be a } \\
\text { source of strength to an organization. A manager who encourages individual } \\
\text { initiative without personal vanity is best. }\end{array}$ \\
\hline Esprit de corps & $\begin{array}{l}\text { "Union is strength," a proverb fulfilled through unity of command. Two } \\
\text { primary principles maintain esprit de corps: personnel must be coordinated } \\
\text { without division; use verbal communication to avoid the potential for } \\
\text { misunderstanding that can arise through written communications. }\end{array}$ \\
\hline
\end{tabular}

753 Henri Fayol, "General Principles of Management," in Jay M. Shafritz, J. Steven Ott, and Yong Suk Jang, Classics of Organization Theory, Sixth Edition (Wadsworth, 2005): 48-60. Reprinted from Henri Fayol, General and Industrial Management, trans. Constance Storrs (London: Pitman, 1949): 19-42, original work published in 1916. 


\section{Appendix B: List of Interviews}

\section{Interviews by Author}

The following interviews were conducted between 2011 and 2014. Although not all narrators are cited in the body of the dissertation, together their recorded stories and informal conversations played a significant role in my understanding of civil rights and workforce diversity in USFS. I am grateful to each and every person listed here for taking the time to talk with me and for the open discussions about sometimes difficult and even painful issues. I have included brief demographic information about each person, as well as job titles at the time of the interview. Interviews conducted in Virginia in 2013 occurred through assistance from the Grey Towers Scholar in Residence Program. The Catherine Prelinger Award from the Coordinating Council for Women in History funded a second trip to the Washington Office and helped to pay for significant portions of interview transcription.

Elizabeth Agpaoa, May 29, 2013, Telephone Interview. Asian American (Filipino and Chinese descent). Started with USFS as a biologist in 1979. Worked in Region 6. Regional Forester for Region 8 (the South).

Mary Albertson, November 10, 2014, Lake Oswego, Oregon. Female immigrant from the Azores Islands. Started with USFS in early 1970s, became first Federal Woman's Program Manager in the county. Later directed Civil Rights in Region 6. Retired.

Lamar Beasley, April 15, 2013, Telephone Interview. Caucasian man. Joined USFS in 1962. Advanced to serve in three Deputy Chief positions and director of the Southern Research Center. Director of Toward a Multicultural Organization task force while serving as Director of Administration. Retired.

Shirley Bridges and Cynthia Hale, February 1, 2013, Rosslyn, Virginia. African American women. Bridges joined USFS in 1970s in California. African American Strategy Group liaison, Washington Office.

Cynthia Hale, executive assistant to Leslie Weldon and AASG representative in Washington Office.

John Butruille by Donna Sinclair and Gloria Brown, September 23, 2014, Leavenworth, Washington. Caucasian man. Forester and former Regional Forester, R-6. Retired.

Sidney Clark, April 23, 2013, Washougal, Washington. African American man. Joined USFS in 1970s through fire and then law enforcement in Region 6. President, USDA Coalition of Minority Employees, PNW. Retired.

Kent Connaughton, May 7, 2013, Portland, Oregon. Caucasian man. Joined USFS in early 1960s as a Forester. Region 6 Regional Forester.

Gloria Brown, April 24, 2013, Lake Oswego, Oregon. African American woman. Began in typing pool of USFS in 1974. Became first female African American Forest Supervisor in 1999. Retired.

Arthur Bryant, January 29, 2013 \& February 19, 2013, Rosslyn, Virginia. African American man. Joined USFS in the 1970 s as a soil scientist. Head of Homeland Security.

Charles "Chip" Cartwright, May 1 and May 8, 2013, Skype Interviews. African American man. First African American district ranger in the nation, 1979 - Washington State. Became first African American regional Forester. Retired.

Earl Ford, November 2, 2007, Vancouver, Washington. African American man. Soil scientist. Natural Resource Officer. Rites of Passage Youth Program. Pilot Interview.

David Gross, December 12, 2011, September 30, 2011 \& January 6, 2012, Vancouver, Washington. Caucasian man. Joined USFS in 1966 as a Forester on the Mt. Hood National Forest. Ran Camp Cody Residential YCC program and later non-residential YCC program. Senior Youth and Volunteer Programs Coordinator.

Mindy Hackett by Donna Sinclair, February 1, 2013, Rosslyn, Virginia. Caucasian Woman. Grew up in Oregon and joined USFS as a temp in the 1970s. GS-14 Planning Specialist in the Washington Office.

Daryl Hodges, December 20, 2012, Skype Interview. African American man. Fisheries Biologist who worked on the Gifford Pinchot National Forest in Washington State. Hodges served as a representative of the African American Strategy Group and liaison to youth programs. District Biologist, Region 8 (the South).

Mack Hogans, October 18, 2012, Bellevue, Washington. African American man. One of the two first graduates of the Tuskegee Pre-forestry Program. Left USFS to work for Weyerhaeuser. Retired from Weyerhaeuser as senior vice president of corporate affairs. 
Dale Hom, March 14, 2013, Olympia, Washington. Asian American man (Chinese descent). Joined USFS, first through fire and then as a crew leader for Young Adult Conservation Corps. Retired Forest Supervisor, Olympic National Forest.

Patricia Jackman, February 13, 2013, Rosslyn, Virginia. Caucasian woman. Joined USFS in 1990s. Special Emphasis Program Manager for People with Disabilities, Native Americans, and Lesbian, Gay, Bisexual and Transgender liaison. Co-founder of Pathfinders, the special emphasis group for people with disabilities. Civil Rights, Washington Office.

Paul Johnson, January 31, 2013 \& February 13, 2013, Rosslyn, Virginia. African American man. Joined USFS in 1970s as soil scientist. Assistant Director for Minerals and Geology.

Mike Kerrick by Donna Sinclair and Gloria Brown, October 28, 2014, Springfield, Oregon. Caucasian man. Forester. Former Forest Supervisor for the Willamette National Forest.

John Kusano, January 31, 2013, Rosslyn, Virginia, January 6, 2014, Washington D.C. Asian American man (Japanese descent). Forester who moved into Human Resources via Civil Rights. Involved in forming Asian Pacific American Association. Senior Staff Assistant in the Office of the Deputy Chief for Business Operations. Retired.

Deidra McGee, January 20, 2013, Rosslyn, Virginia. African American woman who joined the Forest Service in the early 1990s. Public Affairs Specialist, Washington Office.

Darrell Millner, January 14, 2014, Portland, Oregon. African American man. PSU Professor. Provided civil rights training to USFS and other agencies in the 1970s and 1980s.

Pedro Nieto, February 19, 2013, Rosslyn, Virginia. Hispanic man and veteran. National Hispanic Employment Manager. Civil Rights, Washington Office.

Brian Payne, January 28, 2013, Fairfax, Virginia. Caucasian man. Third generation Forest Service family from the Pacific Northwest. Forest Economist. Served as liaison to the Tuskegee Pre-Forestry Program, 1968-1970; also worked in International Relations for USFS. Retired.

Ruth Piotrowski, March 6 \& 8, 2013, Telephone Interview. Caucasian woman. Joined USFS in clerical position via Bureau of Land Management in the 1970s. National Federal Women's Program Manager. Civil Rights, Washington Office.

Robert Ragos, January 31, 2013, Rosslyn, Virginia. Hispanic man. Date of entry to USFS unknown. National Diversity and Outreach Branch Chief. Civil Rights, Washington Office.

Jim Reaves, February 1, 2013, Rosslyn, Virginia. African American man. Biologist who joined USFS in the early 1970s and worked in Oregon. Deputy Chief of Research and Development for USFS.

Carlos Rodriguez-Franco, January 30, 2013, Rosslyn, Virginia. Mexican immigrant. Joined USFS in 2007. Worked on Cultural Transformation initiative. Forest Management Science Director.

Robbi Crishon Skinner, January 6, 2014, Washington, D.C. African American woman. Administration. Retired.

Elaine St. Martin, April 1, 2014, Portland, Oregon. American Indian woman (Seneca and Tuscarora descent). Clerical staff. Retired.

Andy Stahl by Donna Sinclair and Gloria Brown, October 29, 2014, Eugene, Oregon. Caucasian man. Former USFS employee. Executive director, Forest Service Employees for Environmental Ethics.

Shandra Terry, April 16, 2013, Portland, Oregon. African American woman. Joined USFS in 1990 in Oregon. Legislative and Public Affairs Specialist, Region 6.

Mary Wagner, February 13, 2013, Rosslyn, Virginia, April 13, 2013, Telephone Interview. Caucasian woman. Joined USFS as a Forester in early 1980s. Former Region 6 Regional Forester. Associate Chief, U.S. Forest Service.

Leslie Weldon, February 13, 2013, Rosslyn, Virginia, May 13, 2013, Telephone Interview. African American woman. Fisheries biologist who joined USFS in the 1980s. Worked in Region 6 through much of her career. Deputy Chief for National Forest System.

Jetie Wilds, April 4, 2013, Telephone Interview. African American man. Joined USFS in late 1960s as a Job Corps teacher. Worked in the Pacific Northwest in Human Resources. Became the first civil rights director for USFS. Retired (Deceased September 2014).

Craig Willis, February 1, 2013, Rosslyn, Virginia. African American man. Joined USFS in 1998 as an EEO specialist after working for Department of Defense. National Black Employment Manager. Civil Rights, Washington Office.

John Yancy, December 6, 2012, Skype Interview. African American man. One of the two first graduates of the Tuskegee Pre-forestry Program. Became a Forest Supervisor in Region 8. Retired. 


\section{USFS Region 6 Civil Rights Collection}

Interviews conducted through Voices from the Forest Capstone course at Portland State

University, in partnership with USFS, 2004-2007, and held by USFS. Only selected interviews have been used in this dissertation, but the stories here led me to this study of civil rights in USFS and each participant contributed to my understanding of workforce diversity.

Mary Albertson by Nick Deshais, Portland, Oregon, May 9, 2007. Federal Women's Program/Civil Rights/Human Resources. Retired.

Robert Alvarado by Josh Hennigh, Portland, Oregon, April 30 \& May 15, 2004. Hispanic man. Wildlife biologist.

Kathy Armstrong by Jeff Becker, Vancouver, Washington, May 13, 2005. Caucasian woman with disability.

Kathy Bowman by Paul Hasty, Telephone Interview, May 9, 2005. Caucasian woman with disability. Writer.

Gloria Brown by Janice Waldron, Portland, Oregon, May 24, 2004. African American woman. Forest Supervisor. Retired.

Linda Cartwright by Jon Knowlson. Hispanic woman, range conservationist. Hood River, Oregon, May 12, 2007.

Kevin Chung by Joel Hixon. Asian and Mexican American man. (Chinese and Hispanic descent), Forester/Civil Rights. Portland, Oregon, May 4, 2004. Retired.

Nancy Coyote by Angelia Hall-Johnson, May 10, 2007, Portland, Oregon. Caucasian woman, temp worker on brush disposal, became disabled and entered Civil Rights and the Senior Youth Volunteer Program. Recruiter.

Susan Cox by Gina Conedera, May 8, 2007, Cascade Locks, Oregon. Caucasian woman. Range conservationist.

Nella Dickson by Carly Inman, June 12, 2007, Portland, Oregon. African American woman. Job Corps teacher, Human Resources. Retired (Deceased December 12, 2013).

Theresa Durazo by Nick Knight, Vancouver, Washington, May 1, 2007. Hispanic woman. Clerical staff, then Civil Rights Director, Gifford Pinchot National Forest.

Pferron Doss by Miriam Hough, May 9, 2005, Portland, Oregon. African American man. Hotshot smokejumper and Human Resources. Retired.

Rudy Edwards by Cody Rubick. African American man. Soil Scientist/Civil Rights. Vancouver, Washington, May 10, 2005.

Earl Ford by Patrick Kelly, April 30, 2007, Vancouver, Washington. African American man. African American Strategy Group and youth programs. Natural Resource Officer.

Cascade Anderson Geller by Kim Wagner, May 20, 2004, Portland, Oregon. Caucasian woman. Temporary worker. Firefighting and brush crew in the 1970s.

Linda Goodman by Andrew Kroger, May 3, and Donna Sinclair, May 10, 2005, Portland, Oregon. Caucasian woman. Cleric and Forestry. Became R-6 regional Forester.

Anne Heisler by Rob Loos, May 7, 2004, Gresham, Oregon. Caucasian woman. Forester. Retired.

Mike Hernandez by Tareq Al Jamal, May 13, 2005, Dufur, Oregon. Hispanic man. Forester. District ranger, Mt. Hood National Forest.

Claire Lavendel by Blai Vang, May 5, 2005, Vancouver, Washington. Caucasian woman. Forester. Forest Supervisor, Gifford Pinchot National Forest.

Christina Lilienthal by Chris Shockey, May 7, 2004, Roseburg, Oregon. Caucasian woman. Landscape architect.

Jose Linares by Steve Brian, April 28, 2005, Corvallis, Oregon. Hispanic male immigrant from Cuba. Civil Engineer. Forest Supervisor, Siuslaw National Forest.

Jacque McConnell, May 7, 2005, John Day, Oregon. Caucasian woman. Fire and Fuels. Retired.

Pauline McGinty by Joel Blaha, May 7, 2005, Philomath, Oregon. Caucasian woman. Lands/Federal Women's Program. Retired.

Roy Roosevelt by Richard A. Bunch, III, May 31, 2004, Portland, Oregon. African American man. Human 
Resources, Portland Regional Office.

Deselyn Sanders by Thao Tran, May 5, 2005, Vancouver, Washington. African American woman. Human Resources.

Robin Udey by Jeremy Thorburn, April 28, 2004, Portland, Oregon. Caucasian woman. Timber Sales and Civil Rights.

Leslie Weldon by Tania McDonnell, May 11, 2005, Bend, Oregon. African American woman. Biologist. Deschutes National Forest Supervisor. Later Deputy Chief of National Forest Systems.

\section{Archival, Published, and Online Interviews}

Sally Collins by Daina Dravnieks. Caucasian woman. Recreation. Became Associate Chief of USFS. Women in Natural Resources, Vol. 23, No. 3 (2002). Available at http://www.webpages.uidaho.edu/winr/Collins.htm

Elizabeth Estill interview by Daina Dravnieks. Ecologist. One of two first female regional foresters. Women in Natural Resources, Vol. 13, No. 2 (December 1993).

Beverly Holmes by Daina Dravnieks Apple. Cherokee woman. Special assistant to the deputy chief for administration to end the consent decree in California. Became deputy chief for administration in Region 5. Women in Natural Resources, Vol. 15, No. 1 (ca. 1993): 24-30.

Abigail Kimbell by James Lewis, April 17-19, 2012. Caucasian woman. Forester and first female chief of USFS. Retired. Draft transcript. Forest History Society, Durham, North Carolina.

George Leonard by Harold Steen, March 8-10, 1999. Caucasian man. Forester. Associate Chief. Retired. Forest History Society, Durham, North Carolina, 2000.

John McGuire, interview by Harold K. Steen, September 1987. Caucasian man. Forester. Chief of the Forest Service, 1972-1979. Forest History Society in co-operation with the United States Forest Service. Durham, North Carolina: Forest History Society, 1988, 2004.

Wendy Milner Herrett by Jacqueline S. Reiner, June 13-15, 2000, Salem, Oregon. Caucasian woman. Landscape architect and the agency's first female district ranger. Retired. Forest History Society, Durham, North Carolina, 2001.

Susan Odell by Aaron Shapiro, May 8, 2007. Caucasian woman. Recreation. Second female district ranger in nation. USDAFS Region Five Oral History Project, Bancroft Library Regional Oral History Office, available at http://digitalassets.lib.berkeley.edu/roho/ucb/text/odell_susan.pdf

F. Dale Robertson by Harold Steen, August 12-14, 1999, Sedona, Arizona. White male. Forester. Chief of USFS. Retired. Forest History Society, Durham, North Carolina, 1999.

Interview with Reis Tijerina, by Ray Siqueiros and Rene Teyechea, http://www.youtube.com/watch?v=W5L77qrKsxg [accessed June 24, 2014].

Eleanor Towns by James Lewis, June 2, 2010, Westminster, Colorado. African American woman. Civil rights director, Rocky Mountain Region and Regional Forester, R-3. Retired. Draft transcript. Forest History Society, Durham, North Carolina. 


\section{General Interview Questions}

1. Full name, date of birth and place of birth.

2. Background: Where are you from originally? What kind of work did your family do?

3. Ethnic heritage: What is your family's ethnic heritage?

4. Early education: What is your educational background? What were your career aspirations when you were younger?

5. Outdoors: What was your relationship with the outdoors like? What kinds of outdoor activities were you involved in?

6. What do you recall about national forests as a youth?

7. Were you involved in any outdoor youth programs? If so, describe. How did you get involved? How did it impact you?

8. Education: What made you decide to become a ___ ? Tell me about your college/vocational education. How did you choose your school? Your major? What were your interests? Did you have any connection to the Forest Service while going to school? (Student Career Employment Program, Student Temporary Employment Program, summer work, etc.)

9. Career Path: How did you come to work for the Forest Service? First job? When, where, how, why, who worked with.

10. Describe your career path: explore experiences related to workforce diversity in different locales. What have those transitions been like for you?

11. How does someone advance in the agency?

12. Mentors: Have you had one? Who? What role has your mentor played in your career? If you haven't had one, how has that impacted you?

13. What role do you think mentorship plays in career advancement?

14. Your heritage: how has your gender, ethnicity, race impacted you in your work? In the agency?

15. Has your work impacted relations with your community of origin? If so, how?

16. How does employment with the Forest Service impact your life outside of work?

17. Have you participated in any diversity training? If so, what type? Discuss.

18. How did you become - civil right manager, special emphasis program manager, forest supervisor?

19. What legislative mandates have impacted you/your program the most?

20. Tell me about your program: What was your program like when you first started in the position? How has that changed? What policies have you implemented? What is most challenging about the position? Most gratifying? What are your WFD goals? What are your biggest accomplishments? Biggest disappointments?

21. How is workforce diversity officially defined? How do you define it?

22. How do you represent (or not) your community of origin?

23. Forest Supervisor: how do you approach workforce diversity on your forest? What role does it play? Significance? What policies have you implemented? What are your WFD goals? How do you plan to achieve them? Most gratifying? What are your biggest accomplishments? Biggest disappointments?

24. What diversity-related programs or policies do you see as most successful? Most unnecessary?

25. The agency has been unable to achieve parity for minorities. Why do you think that is the case? What are the biggest hindrances? What do you think would help?

26. Workforce Diversity: How has the idea of workforce diversity changed since you started working for the Forest Service? How has workforce diversification impacted you? What are the main challenges to diversifying the workforce? The main benefits?

27. How does Region 6 compare to other regions in terms of workforce diversity efforts?

28. How important do you think it is (or not) for a workforce to be representative of the population? Why?

29. Does representation make any difference in terms of policy? In what ways?

30. There are several diversity programs to identify best practices for achieving WFD. What do you see as best practices to increase diversity?

31. Is there anything you would like to add? 


\section{Appendix C: Appendix of Tables}

\section{List of Tables in Appendix C}

Table C. 1: Pacific Northwest States by Race, 1950-1990 …............................................516

Table C.2: Forest Service Employment Statistics, 1965-1974 …...................................... 517

Table C.3: Civilian Labor Force (CLF) and Forest Service - \% Women and Minorities,

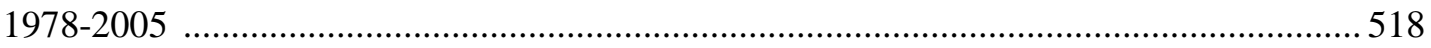

Table C.4: Minorities and Women: On Board Strength, 1976-1980 .................................518

Table C.5: Most Populous Permanent Full-time Jobs, 1972-1979 ....................................519

Table C.6: Full-time Comparison Analysis, June 30, 1962, June 30, 1963, and April 30,

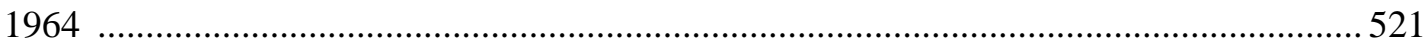

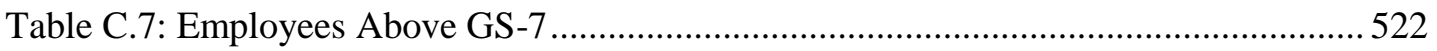

Table C.8: 1984-2011 Women Employees by Race and \% of Workforce ..........................522

Table C.9: Women in the Labor Force - Federal Employment, Civilian Employment and

Forest Service - by Race ….................................................................................. 523

Table C.10: Career and Career Conditional - Minorities by Region and Race/Ethnicity as of

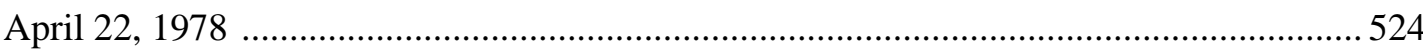

Table C.11: Career and Career Conditional - Minorities by Region and Race/Ethnicity as of

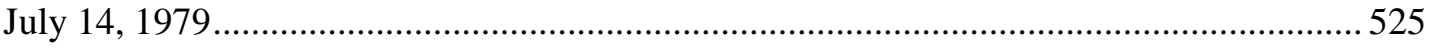

Table C.12: Professionals on Board - from Civil Rights Update December 10, 1980 .......526

Table C.13: Region 6 Employment (Permanent and Term) and Average grade by Sex and

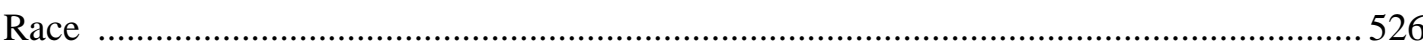

Table C.14: Society of American Foresters Accredited Programs in Professional Forestry

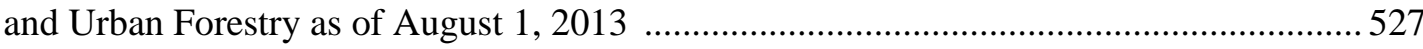


Table C.1: Pacific Northwest States by Race, 1950-1990 ${ }^{754}$

\begin{tabular}{|l|l|l|l|l|l|l|l|l|}
\hline $\begin{array}{l}\text { Pacific } \\
\text { Northwest } \\
\text { states }\end{array}$ & $\begin{array}{l}\text { Total } \\
\text { pop. }\end{array}$ & White & Black & $\begin{array}{l}\text { American } \\
\text { Indian, } \\
\text { Eskimo, } \\
\text { and Aleut }\end{array}$ & $\begin{array}{l}\text { Asian } \\
\text { and } \\
\text { Pacific } \\
\text { Isles }\end{array}$ & $\begin{array}{l}\text { Other } \\
\text { Race }\end{array}$ & $\begin{array}{l}\text { Hispan. } \\
\text { Origin } \\
\text { (of any } \\
\text { race) }\end{array}$ & $\begin{array}{l}\text { White, } \\
\text { not of } \\
\text { Hispanic } \\
\text { origin }\end{array}$ \\
\hline Idaho & & & & & & & & \\
\hline $\mathbf{1 9 5 0}$ & 588,637 & 581,395 & 1,050 & 3,800 & 2,304 & 88 & N/A & N/A \\
\hline $\mathbf{1 9 6 0}$ & 667,191 & 657,383 & 1,502 & 5,231 & 2,758 & 317 & N/A & N/A \\
\hline $\mathbf{1 9 7 0}$ & 712,567 & 698,802 & 2,130 & 6,687 & 3,212 & 1,736 & N/A ${ }^{755}$ & N/A \\
\hline $\mathbf{1 9 8 0}$ & 943,935 & 901,641 & 2,716 & 10,521 & 5,948 & 23,109 & 36,615 & 886,187 \\
\hline $\mathbf{1 9 9 0}$ & $1,006,749$ & 950,451 & 3,370 & 13,780 & 9,365 & 29,783 & 52,927 & 928,661 \\
\hline Oregon & & & & & & & & \\
\hline $\mathbf{1 9 5 0}$ & $1,521,341$ & $1,497,128$ & 11,529 & 5,820 & 6,513 & 351 & N/A & N/A \\
\hline $\mathbf{1 9 6 0}$ & $1,768,687$ & $1,732,037$ & 18,133 & 8,026 & 9,120 & 1,371 & N/A & N/A \\
\hline $\mathbf{1 9 7 0}$ & $2,091,385$ & $2,032,079$ & 26,308 & 13,510 & 15,037 & 4,451 & N/A ${ }^{756}$ & N/A \\
\hline $\mathbf{1 9 8 0}$ & $2,633,105$ & $2,490,610$ & 37,060 & 27,314 & 34,775 & 43,346 & 65,847 & $2,456,012$ \\
\hline $\mathbf{1 9 9 0}$ & $2,842,321$ & $2,636,787$ & 46,178 & 38,496 & 69,269 & 51,591 & 112,707 & $2,579,732$ \\
\hline Washington & & & & & & & & \\
\hline $\mathbf{1 9 5 0}$ & $2,378,963$ & $2,316,496$ & 30,691 & 13,816 & 17,376 & 584 & /A & N/A \\
\hline $\mathbf{1 9 6 0}$ & $2,853,214$ & $2,751,675$ & 48,738 & 21,076 & 29,253 & 2,472 & & /A $/ A$ \\
\hline $\mathbf{1 9 7 0}$ & $3,409,169$ & $3,251,055$ & 71,308 & 33,386 & 44,060 & 9,360 & /A & N/A \\
\hline $\mathbf{1 9 8 0}$ & $4,132,156$ & $3,779,170$ & 105,574 & 60,804 & 102,537 & 84,071 & 120,016 & $3,725,878$ \\
\hline $\mathbf{1 9 9 0}$ & $4,866,692$ & $4,308,937$ & 149,801 & 81,483 & 210,958 & 115,513 & 214,570 & $4,221,622$ \\
\hline
\end{tabular}

754 Campbell Gibson and Kay Jung, "Historical Census Statistics on Population Totals By Race, 1790 to 1990, and By Hispanic Origin, 1970 to 1990, For The United States, Regions, Divisions, and States," Working Paper Series, No. 56, September 2002. Detailed Tables by state, available at http://www.census.gov/population/www/documentation/twps0056/twps0056.html [accessed June 21, 2014].

Census estimate for Hispanic origin during this year is 16,077 to 18,476. A more accurate count for Hispanics began in 1980.

756 Sample estimates range from 22,338 to 34,577 .

757 Sample estimates range from 57,358 to 70,734 . 


\section{Employment Statistics, 1960s-1980s}

Table C. 2: Forest Service Employment Statistics, 1965-1974

\begin{tabular}{|c|l|l|l|l|}
\hline Year & Total Paid & Perm. Full-Time & $\begin{array}{l}\text { Temp. Full- } \\
\text { Time }\end{array}$ & $\begin{array}{l}\text { Part-Time and } \\
\text { Intermittent }\end{array}$ \\
\hline $\mathbf{1 9 6 5}$ & 32,846 & 20,620 & 6,174 & 6,052 \\
\hline $\mathbf{1 9 6 6}$ & 33,454 & 21,832 & 5,143 & 6,479 \\
\hline $\mathbf{1 9 6 7}$ & 35,342 & 22,523 & 5,338 & 7,481 \\
\hline $\mathbf{1 9 6 8}$ & 31,628 & 21,520 & 2,961 & 7,147 \\
\hline $\mathbf{1 9 6 9}$ & 33,066 & 21,103 & 3,816 & 8,147 \\
\hline $\mathbf{1 9 7 0}$ & 34,166 & 20,737 & 4,872 & 8,557 \\
\hline $\mathbf{1 9 7 1}$ & 34,836 & 21,430 & 4,995 & 8,411 \\
\hline $\mathbf{1 9 7 2}$ & 36,564 & 20,225 & 6,742 & 9,597 \\
\hline $\mathbf{\%}$ Change, 1965-1972 & $\mathbf{+ 1 1}$ & $\mathbf{- 2}$ & $\mathbf{+ 9}$ & $\mathbf{+ 5 9}$ \\
\hline $\mathbf{1 9 7 3}$ & 36,200 & 19,321 & 6,967 & 9,912 \\
\hline $\mathbf{1 9 7 4}$ & 38,916 & 19,319 & 8,567 & 11,030 \\
\hline & & & & \\
\hline \% Change, 1965-1974 & $\mathbf{+ 1 8 . 5}$ & $\mathbf{- 6}$ & $\mathbf{+ 3 9}$ & $\mathbf{+ 8 2}$ \\
\hline
\end{tabular}

$758 \quad$ Ron Noland and Personnel Management Staff, “Manpower Planning,” November 4, 1974.

Washington Office Reports. 
Table C.3: Civilian Labor Force (CLF) and Forest Service -\% Women and Minorities, 1978-2005

\begin{tabular}{|l|l|l|l|l|l|l|l|l|l|l|l|l|}
\hline & $\mathbf{1 9 7 8}$ & $\mathbf{1 9 8 2}$ & $\mathbf{1 9 8 6}$ & $\mathbf{1 9 9 0}$ & $\mathbf{1 9 9 4}$ & $\mathbf{1 9 9 8}$ & $\mathbf{2 0 0 0}$ & $\mathbf{2 0 0 1}$ & $\mathbf{2 0 0 2}$ & $\mathbf{2 0 0 3}$ & $\mathbf{2 0 0 4}$ & $\mathbf{2 0 0 5}$ \\
\hline $\begin{array}{l}\text { Women } \\
\text { CLF }\end{array}$ & & & & 45.7 & 45.7 & 45.7 & 47 & 47 & 47 & 47 & 47 & 47 \\
\hline Women & 22 & 29.5 & 31.5 & 39 & 40 & 39.4 & 39.5 & 38.7 & 38.6 & 38.5 & 38.6 & 38.6 \\
\hline $\begin{array}{l}\text { Minority } \\
\text { CLF }\end{array}$ & & & & 22 & 22 & 22 & 27 & 27 & 27 & 27 & 27 & 27 \\
\hline $\begin{array}{l}\text { Minority } \\
\text { CLF }\end{array}$ & 9 & 10.5 & 12 & 15 & 15 & 16.3 & 16.2 & 16.2 & 16.1 & 16.1 & 15.9 & 16 \\
\hline
\end{tabular}

Table C.4: Minorities and Women: On Board Strength, 1976-1980 ${ }^{760}$

\begin{tabular}{|c|c|c|c|c|}
\hline Fiscal Year & \multicolumn{2}{|c|}{ Minorities } & \multicolumn{2}{c|}{ Women } \\
\hline & $\#$ & $\%$ & 6167 & 21.6 \\
\hline $\mathbf{1 9 7 6}$ & 2208 & 7.7 & 7013 & 23.6 \\
\hline $\mathbf{1 9 7 7}$ & 2448 & 8.2 & 8359 & 23.6 \\
\hline $\mathbf{1 9 7 8}$ & 2899 & 8.2 & 9424 & 27.6 \\
\hline $\mathbf{1 9 7 9}$ & 2831 & 8.3 & 10,540 & 28 \\
\hline $\mathbf{1 9 8 0}$ & 3638 & 9.7 & $\%$ \\
\hline
\end{tabular}

759 Table compiled from FS Diversity, 1976-2005, information from John Kusano in Human Resources/WO \& Monthly Labor Review, January 2012, http://www.bls.gov/opub/mlr/2012/01/art3full.pdf \& Cultural Transformation Report (CLF is based on ten-year census intervals. The data provided by J. Kusano showed numbers based only on the 1990 CLF. I have included 2000 and 2010 CLF from BLS report).

760 “Civil Rights Update December 10, 1980,” FHS Collection F5\&F5.2, file - Civil Rights Updates, 1980-1984. 
Employees by Occupation

Table C.5: Most Populous Permanent Full-time Jobs, 1972-1979 ${ }^{761}$

\begin{tabular}{|l|l|l|l|l|l|l|l|l|l|}
\hline Title & $\mathbf{1 9 7 2}$ & $\mathbf{1 9 7 3}$ & $\mathbf{1 9 7 4}$ & $\mathbf{1 9 7 5}$ & $\mathbf{1 9 7 6}$ & $\mathbf{1 9 7 7}$ & $\mathbf{1 9 7 8}$ & $\mathbf{1 9 7 9}$ & $\begin{array}{l}\mathbf{\%} \\
\text { change }\end{array}$ \\
\hline Social Services & 190 & 160 & 144 & 145 & 123 & 153 & 154 & 273 & +43 \\
\hline $\begin{array}{l}\text { Personnel } \\
\text { Management }\end{array}$ & 177 & 174 & 166 & 164 & 183 & 191 & 190 & 200 & +13 \\
\hline $\begin{array}{l}\text { Personnel } \\
\text { Clerical }\end{array}$ & 306 & 280 & 259 & 263 & 268 & 301 & 307 & 284 & -7 \\
\hline $\begin{array}{l}\text { Clerical \& } \\
\text { Admin. }\end{array}$ & 1,019 & 1,003 & 966 & 1,006 & 1,100 & 1197 & 1208 & 1107 & +.09 \\
\hline $\begin{array}{l}\text { Clerk Steno } \\
\text { Secretary }\end{array}$ & 197 & 158 & 121 & 94 & 65 & -- & -- & -- & $\begin{array}{l}\text { Elim- } \\
\text { inated }\end{array}$ \\
\hline Clerk Typist & 740 & 315 & 310 & 340 & 348 & 350 & 351 & 373 & +21 \\
\hline $\begin{array}{l}\text { Computer } \\
\text { Specialist }\end{array}$ & 92 & 112 & 111 & 126 & 161 & 187 & 187 & 212 & +130 \\
\hline $\begin{array}{l}\text { Administrative } \\
\text { Officer }\end{array}$ & 375 & 314 & 251 & 236 & 222 & 208 & 208 & 199 & +47 \\
\hline $\begin{array}{l}\text { Biological } \\
\text { Technician }\end{array}$ & 149 & 152 & 146 & 145 & 172 & 173 & 175 & 183 & +23 \\
\hline Entomology & 156 & 152 & 155 & 153 & 166 & 167 & 167 & 170 & +9 \\
\hline $\begin{array}{l}\text { Plant } \\
\text { Pathology }\end{array}$ & 96 & 95 & 92 & 97 & 97 & 95 & 95 & 95 & -1 \\
\hline $\begin{array}{l}\text { Range } \\
\text { Conservation }\end{array}$ & 262 & 259 & 254 & 260 & 278 & 262 & 263 & 294 & +12 \\
\hline Forestry & 5,021 & 4,875 & 4,726 & 4,616 & 4,664 & 4652 & 4659 & 4686 & -7 \\
\hline $\begin{array}{l}\text { Forestry } \\
\text { Technician }\end{array}$ & 2,351 & 2,611 & 3,005 & 3,182 & 3,306 & 3765 & 3800 & 3969 & +57 \\
\hline Soil Science & 151 & 156 & 155 & 173 & 186 & 196 & 195 & 210 & +39 \\
\hline $\begin{array}{l}\text { Wildlife } \\
\text { Biology }\end{array}$ & 108 & 109 & 112 & 119 & 149 & 176 & 180 & 214 & +98 \\
\hline Accounting & 138 & 125 & 113 & 108 & 109 & 111 & 111 & 99 & -.28 \\
\hline Accountant & 165 & 151 & 130 & 123 & 122 & 127 & 127 & 123 & -.5 \\
\hline $\begin{array}{l}\text { Accounts } \\
\text { Maintenance }\end{array}$ & 164 & 142 & 128 & 131 & 112 & -- & -- & -- & $\begin{array}{l}\text { Elim- } \\
\text { inated }\end{array}$ \\
\hline $\begin{array}{l}\text { Voucher } \\
\text { Examining }\end{array}$ & 192 & 170 & 137 & 124 & 119 & 114 & 116 & 103 & -46 \\
\hline $\begin{array}{l}\text { Engineering } \\
\text { Technician }\end{array}$ & 1,308 & 1,268 & 1,172 & 1,256 & 1,379 & 1404 & 1408 & 1444 & +10 \\
\hline
\end{tabular}

761 Table compiled from occupational statistics in the 1977, 1980 and 1982 Workforce Data Books produced by Ronald Nolan, Helen Weiler, and the Personnel Staff. The total number of full time employees varies slightly between reports; however, as personnel staff point out, the number of full time employees hovered slightly above twenty thousand from 1966 to 1980, while the number of total employees began to rise in 1973 so that by July 1980, the agency employed more than sixty thousand employees, the bulk in temporary positions. 


\begin{tabular}{|l|l|l|l|l|l|l|l|l|l|}
\hline $\begin{array}{l}\text { Landscape } \\
\text { Architecture }\end{array}$ & 181 & 185 & 182 & 170 & 168 & 172 & 172 & 188 & +04 \\
\hline $\begin{array}{l}\text { Construction } \\
\text { Inspection }\end{array}$ & 250 & 261 & 257 & 256 & 216 & 220 & 221 & 183 & +28 \\
\hline $\begin{array}{l}\text { Civil } \\
\text { Engineering }\end{array}$ & 1,081 & 1,060 & 976 & 966 & 924 & 935 & 936 & 946 & +125 \\
\hline $\begin{array}{l}\text { Surveying } \\
\text { Technician }\end{array}$ & 185 & 156 & 122 & 115 & 98 & 128 & 129 & 138 & 25 \\
\hline $\begin{array}{l}\text { Electronics } \\
\text { Technician }\end{array}$ & 165 & 155 & 148 & 148 & 143 & 139 & 132 & 181 & +10 \\
\hline $\begin{array}{l}\text { Contract and } \\
\text { Procurement }\end{array}$ & 239 & 234 & 229 & 225 & 228 & 242 & 242 & 285 & +18 \\
\hline Purchasing & 159 & 161 & 149 & 142 & 161 & 170 & 171 & 169 & -6 \\
\hline Geology & -- & -- & -- & -- & -- & -- & -- & 83 & +100 \\
\hline Hydrology & 104 & 104 & 103 & 107 & 129 & 133 & 133 & 154 & +30 \\
\hline $\begin{array}{l}\text { Cartographic } \\
\text { Technician }\end{array}$ & 136 & 131 & 126 & 116 & 120 & 141 & 142 & 156 & +15 \\
\hline $\begin{array}{l}\text { Forest } \\
\text { Products } \\
\text { Technology }\end{array}$ & 135 & 129 & 123 & 117 & 120 & 117 & 117 & 106 & -21.5 \\
\hline $\begin{array}{l}\text { Educ. \& Voc. } \\
\text { Training }\end{array}$ & 179 & 167 & 153 & 126 & 111 & 106 & 107 & 92 & -49 \\
\hline $\begin{array}{l}\text { Information } \\
\text { Officer }\end{array}$ & -- & -- & --- & -- & -- & -- & -- & 133 & + \\
\hline Instruction & 171 & 165 & 140 & 112 & 97 & 104 & 105 & 89 & -100 \\
\hline $\begin{array}{l}\text { Budget \& } \\
\text { Fiscal }\end{array}$ & -- & -- & --- & -- & -- & -- & -- & 132 & +100 \\
\hline $\begin{array}{l}\text { TOTAL } \\
\text { SERIES }\end{array}$ & 16,650 & 16,278 & 15,821 & 15,874 & 16,220 & 16,802 & 16,875 & 17,633 & +6 \\
\hline TOTAL PFT & 20,093 & 19,413 & 18,287 & 18,339 & 19,047 & 21,862 & 21,894 & 21,497 & \\
\hline
\end{tabular}




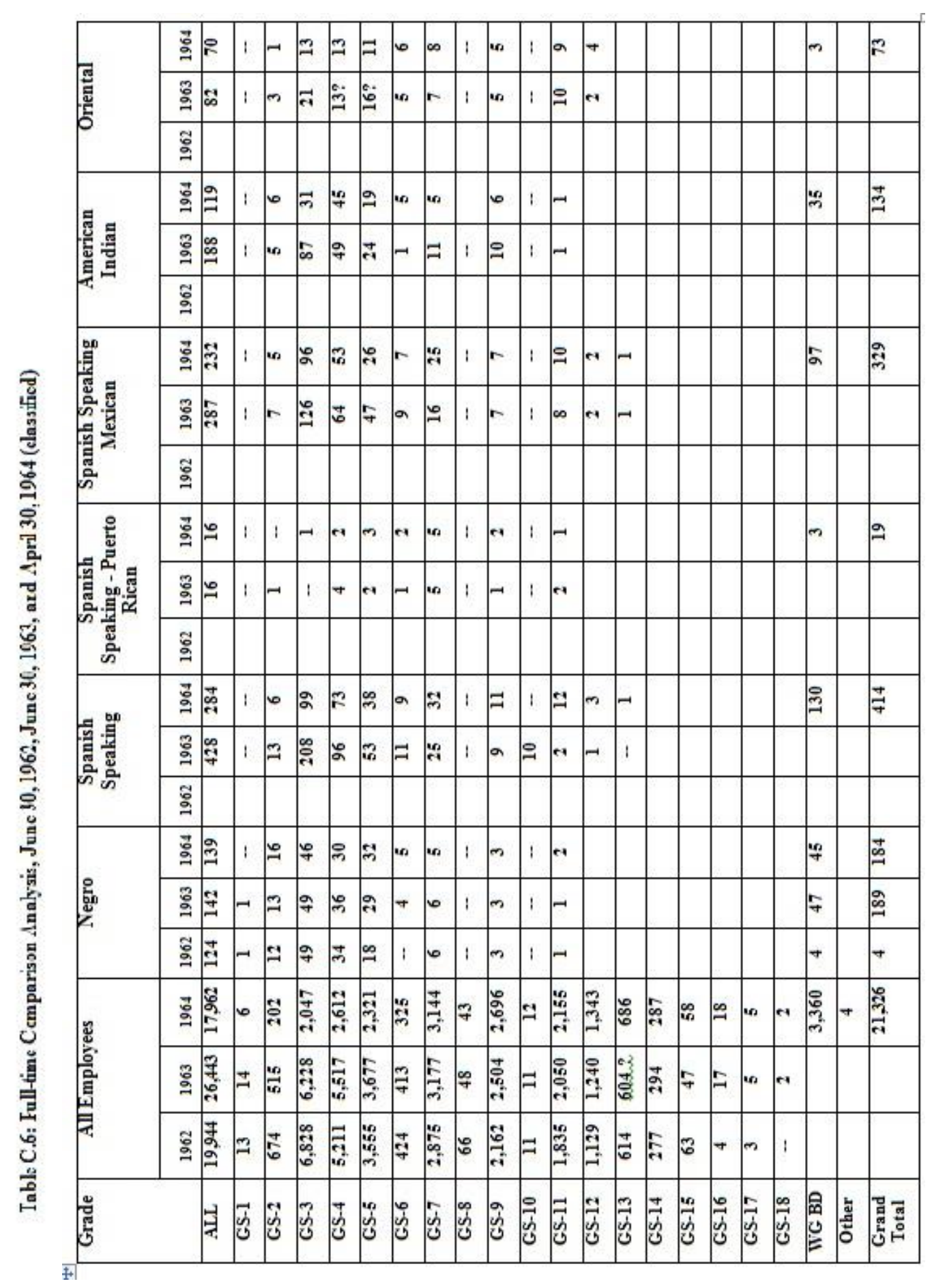


Table C.7: Employees Above GS-7 ${ }^{4}$

As of October 31, 1964

\# employees

Male 10,325

Female 348

Total 10,673 percent of total

96.74

$3.26 \%$

$100 \%$
As of October 31, 1965

\# of employees percent of total

11,185

392

11,577
96.61

$3.39 \%$

$100 \%$

\section{Women in the Labor Force}

Table C.8: 1984-2011 Women Employees by Race and \% of Workforce ${ }^{762}$

\begin{tabular}{|c|c|c|c|c|c|c|c|c|}
\hline EEO Groups & 1984 & $\%$ & 1988 & $\%$ & 1995 & $\%$ & 2011 & $\%$ \\
\hline White Women (WW) & 8,578 & $25 \%$ & 8,844 & $28 \%$ & 10,401 & $33 \%$ & $\mathbf{9 , 8 4 1}$ & $32 \%$ \\
\hline $\begin{array}{c}\text { African American Women } \\
\text { (AAW) }\end{array}$ & 505 & $1.5 \%$ & 565 & $1.8 \%$ & 711 & $2.3 \%$ & 624 & $2.01 \%$ \\
\hline Hispanic Women (HW) & 393 & $1.2 \%$ & 442 & $1.4 \%$ & 621 & $2 \%$ & 763 & $2.5 \%$ \\
\hline $\begin{array}{l}\text { Asian Pacific Islander Women } \\
\text { (APW) }\end{array}$ & 138 & $.4 \%$ & 185 & $.6 \%$ & 240 & $.8 \%$ & 240 & $.8 \%$ \\
\hline $\begin{array}{c}\text { American Indians/Alaska Native } \\
\text { Women (AIW) }\end{array}$ & 309 & $.91 \%$ & 415 & $1.3 \%$ & 596 & $1.9 \%$ & 422 & $1.4 \%$ \\
\hline Two or More Races Women & -- & & -- & & -- & & 74 & $.24 \%$ \\
\hline Minority Females - ALL & 1,345 & $4 \%$ & 1,607 & $5 \%$ & 2,168 & $7 \%$ & 2,123 & $7 \%$ \\
\hline Females ALL & 9,923 & $29 \%$ & $\mathbf{1 0 , 4 5 1}$ & $33 \%$ & 12,569 & $40 \%$ & 11,964 & $39 \%$ \\
\hline TOTAL EMPLOYEES & 34,129 & & 31,726 & & 31,240 & & $\mathbf{3 1 , 1 1 7}$ & \\
\hline
\end{tabular}

${ }^{762}$ Chart compiled from Civil Rights Updates, 1980-1984 and U.S. Department of Agriculture, "FY 2012-2015 Department-wide Diversity and Inclusion Plan" available at http://www.dm.usda.gov/employ/diversity/docs/DiversityandInclusionPlanFY11-15.pdf [accessed May 13, 2015]. 
Table C.9: Women in the Labor Force - Federal Employment, Civilian Employment and Forest Service - by Race $^{763}$

\begin{tabular}{|l|c|c|c|}
\hline & $\begin{array}{l}\text { Federal Workforce (FW) } \\
\mathbf{2 0 1 0}\end{array}$ & $\begin{array}{l}\text { Civilian Labor (CLF) } \\
\mathbf{2 0 1 0}\end{array}$ & $\begin{array}{l}\text { Forest Service } \\
\mathbf{2 0 1 1}\end{array}$ \\
\hline ALL Women & $\mathbf{4 3 . 9 \%}$ & $\mathbf{4 6 \%}$ & $\mathbf{3 8 . 5 \%}$ \\
\hline Black Women & $10.6 \%$ & $5.3 \%$ & $2.01 \%$ \\
\hline Hispanic Women & $3.3 \%$ & $5.6 \%$ & $2.45 \%$ \\
\hline $\begin{array}{l}\text { Asian Pacific American } \\
\text { Women }\end{array}$ & $2.5 \%$ & $2 \%$ & $.77 \%$ \\
\hline $\begin{array}{l}\text { Native American } \\
\text { Women }\end{array}$ & $1 \%$ & $.2 \%$ & $1.36 \%$ \\
\hline $\begin{array}{l}\text { Non-Hispanic } \\
\text { Multi-racial Women }\end{array}$ & $.3 \%$ & $.6 \%$ & .24 \\
\hline White Women & $26.2 \%$ & $32.3 \%$ & $33.7 \%$ \\
\hline Minority Women ALL & $\mathbf{1 7 . 7 \%}$ & $\mathbf{1 3 . 7 \%}$ & $\mathbf{6 . 8 \%}$ \\
\hline
\end{tabular}

Minorities in the Forest Service Labor Force

For Table C.10 and C.11 below (p. 524), bold percentages indicate higher than agency average. USDA Forest Service, "1978 Workforce Planning book," 248 and 1979 Workforce Planning book. Percentage of regional min. indicates the percentage of the overall minority population in the region. Percentage of regional pop indicates the percentage of overall population in the region. I have highlighted in bold those regional percentages that are equal to or higher than the agency totals.

${ }^{763}$ FY 2010 FEORP, U.S. Office of Personnel Management, p. 53 and CT report. 
Table C.10: Career and Career Conditional - Minorities by Region and Race/Ethnicity, as of April 22, 1978

\begin{tabular}{|c|c|c|c|c|c|c|c|c|c|c|c|c|}
\hline Race/Gender & R-1 & R-2 & R-3 & R-4 & R-5 & R-6 & $\mathbf{R - 8}$ & R-9 & $\begin{array}{l}\text { R- } \\
10\end{array}$ & WO & Other & ALL \\
\hline "Negro" & 7 & 22 & 25 & 6 & 46 & 113 & 398 & 71 & 3 & 78 & 290 & 1259 \\
\hline $\begin{array}{l}\% \text { of region } \\
\text { minority }\end{array}$ & 5 & 12.5 & 4 & 10 & 1.6 & 27.6 & 62 & 53 & 9 & 5 & 70 & 37 \\
\hline $\begin{array}{l}\text { \% of region } \\
\text { pop. }\end{array}$ & $<1$ & 1 & 1 & $<1$ & 2 & 1.5 & 9 & 3 & $<1$ & 6.5 & 8 & 3 \\
\hline $\begin{array}{l}\text { Spanish } \\
\text { American }\end{array}$ & 31 & 133 & 554 & 27 & 45 & 140 & 62 & 21 & 8 & 9 & 49 & 1289 \\
\hline$\%$ of min. & 23 & 76 & 84 & 46 & 6 & 34 & 12.5 & 16 & 23.5 & 9 & 12 & 38 \\
\hline$\%$ of region & 1 & 6.5 & 20 & 1 & 4 & 2 & 1 & 1 & 1 & 2 & 1 & 3 \\
\hline $\begin{array}{l}\text { American } \\
\text { Indian }\end{array}$ & 83 & 18 & 80 & 18 & 73 & 116 & 32 & 37 & 21 & 6 & 13 & 597 \\
\hline$\%$ of min. & 62 & 10 & 12 & 30.5 & 5.5 & 28 & 6.5 & 28 & 62 & 3 & 3 & 18 \\
\hline$\%$ of region & 2 & 1 & 3 & 1 & 3 & 1.5 & 1 & 1 & 3 & $<1$ & $<1$ & 1.5 \\
\hline "Oriental" & 11 & 2 & 2 & 8 & 12 & 35 & 2 & 3 & 1 & 6 & 61 & 24 \\
\hline$\%$ of min. & 8 & 1 & 1 & 13.5 & 6.5 & 8.5 & $<1$ & 2 & 3 & 3 & 1.5 & 1 \\
\hline$\%$ of region & $<1$ & $<1$ & $<1$ & $<1$ & 2 & $<1$ & $<1$ & $<1$ & $<1$ & $<1$ & 2 & 1 \\
\hline Aleut $</ 01$ & 0 & 0 & 1 & 0 & 0 & 1 & 0 & 1 & 1 & 0 & 0 & 4 \\
\hline Eskimo $</ 01$ & 1 & 0 & 0 & 0 & 1 & 4 & 0 & 0 & 0 & 0 & 0 & 6 \\
\hline $\begin{array}{l}\text { Total } \\
\text { Minorities }\end{array}$ & 133 & 175 & 662 & 59 & 77 & 409 & 494 & 133 & 34 & 209 & 413 & 3,398 \\
\hline & 4 & 5 & 19.5 & 2 & 0 & 12 & 14.5 & 4 & 1 & 1 & 12 & 100 \\
\hline $\begin{array}{l}\text { As \% of } \\
\text { ALL min. }\end{array}$ & 3 & 9 & 24 & 9 & 0.5 & 5 & 11 & 5 & 6 & 19 & 11 & 8.8 \\
\hline $\begin{array}{l}\text { As \% of } \\
\text { region }\end{array}$ & 4,192 & 1,858 & 2,078 & 2,444 & 5,782 & 7,411 & 4,007 & 2,564 & 576 & 871 & 3,260 & 35,043 \\
\hline $\begin{array}{l}\text { None of the } \\
\text { above }\end{array}$ & 4,325 & 2,033 & 2,740 & 2,503 & 6,459 & 7,820 & 4,501 & 2,697 & 610 & 1,080 & 3,673 & 38,441 \\
\hline & 1 & 5 & 7 & 6.5 & 17 & 20 & 12 & 7 & 2 & 3 & 9.5 & 100 \\
\hline $\begin{array}{l}\text { Total by } \\
\text { Region/Area }\end{array}$ & 4,325 & 2,033 & 2,740 & 2,503 & 6,459 & 7,820 & 4,501 & 2,697 & 610 & 1,080 & 3,673 & 38,441 \\
\hline$\%$ of total & 11 & 5 & 7 & 6.5 & 17 & 20 & 12 & 7 & 2 & 3 & 9.5 & 100 \\
\hline
\end{tabular}


Table C.11: Career and Career Conditional - Minorities by Region and Race/Ethnicity, as of July 14, 1979 ${ }^{764}$

\begin{tabular}{|c|c|c|c|c|c|c|c|c|c|c|c|c|}
\hline Race/Gender & R-1 & R-2 & R-3 & R-4 & R-5 & R-6 & R-8 & R-9 & $\begin{array}{l}\text { R- } \\
10\end{array}$ & WO & Other & ALL \\
\hline "Negro" & 9 & 30 & 26 & 11 & 126 & 88 & 299 & 59 & 6 & 170 & 145 & 969 \\
\hline $\begin{array}{l}\text { \% of region } \\
\text { minority }^{765}\end{array}$ & 9 & 23 & 5 & 18 & 23 & 24 & 82 & 53 & 16 & 83 & 57 & 35.45 \\
\hline $\begin{array}{l}\text { \% of region } \\
\text { pop. }\end{array}$ & $<1$ & 2 & 1 & .05 & 2 & 1 & 8 & 2 & 1 & 15 & 5 & 3 \\
\hline \begin{tabular}{|l|} 
Spanish \\
American
\end{tabular} & 29 & 85 & 476 & 24 & 193 & 116 & 41 & 15 & 10 & 19 & 43 & 1051 \\
\hline$\%$ of min. & 28 & 64 & 87 & 40 & 35 & 32 & 11 & 13.5 & 26 & 9 & 17 & 38.5 \\
\hline$\%$ of region & 1 & 5 & 21 & 1 & 3 & 2 & 1 & $<1$ & 1.5 & 2 & 1 & 3 \\
\hline $\begin{array}{l}\text { American } \\
\text { Indian }\end{array}$ & 61 & 11 & 43 & 21 & 142 & 117 & 25 & 34 & 20 & 9 & 14 & 497 \\
\hline$\%$ of min. & 58 & 8 & 8 & 35 & 26 & 31 & 7 & 31 & 53 & 4 & 5.5 & 18 \\
\hline$\%$ of region & 2 & $<1$ & 2 & 1 & 2 & 2 & $<1$ & 1 & 3 & $<1$ & $<1$ & 1.5 \\
\hline "Oriental" & 6 & 6 & 2 & 4 & 87 & 37 & 1 & 3 & 1 & 7 & 53 & 207 \\
\hline$\%$ of min. & 6 & 4.5 & $<1$ & .07 & 16 & 10 & $<.01$ & 3 & 3 & .03 & .21 & \\
\hline$\%$ of region & $<1$ & $<1$ & $<1$ & $<1$ & 1.5 & $<1$ & $<.01$ & $<1$ & $<1$ & $<1$ & 2 & 1 \\
\hline Aleut $</ 01$ & 0 & 0 & 1 & 0 & 0 & 2 & 0 & 0 & 1 & 0 & 0 & 4 \\
\hline Eskimo $</ 01$ & 0 & 0 & 0 & 0 & 1 & 4 & 0 & 0 & 0 & 0 & 0 & 5 \\
\hline Total & & & & & & & & & & & & 2,733 \\
\hline Minorities & 105 & 132 & 548 & 60 & 549 & 364 & 366 & 111 & 38 & 205 & 255 & 8.1 \\
\hline $\begin{array}{l}\text { As \% of ALL } \\
\text { min. }\end{array}$ & 3.8 & 4.8 & 20 & 2.2 & 20.1 & 13.3 & 13.4 & 4.1 & 1.4 & 7.5 & 9.3 & 100 \\
\hline $\begin{array}{l}\text { As \% of } \\
\text { region }\end{array}$ & 3 & 7 & 25 & 3 & 9 & 5 & 10 & 5 & 6 & 19 & 8 & \\
\hline $\begin{array}{l}\text { None of the } \\
\text { above }\end{array}$ & 3,392 & 1,654 & 1,677 & 2,191 & 5,345 & 6,559 & 3,358 & 2,313 & $\begin{array}{l}64 \\
4\end{array}$ & 899 & 2,876 & $\begin{array}{l}30,90 \\
8 \\
.92 \\
\end{array}$ \\
\hline $\begin{array}{l}\text { Total by } \\
\text { Region/Area }\end{array}$ & 3,497 & 1,786 & 2,225 & 2,251 & 5,894 & 6,923 & 3,724 & 2,424 & $\begin{array}{l}68 \\
2\end{array}$ & 1,104 & 3,131 & $\begin{array}{l}33,64 \\
1\end{array}$ \\
\hline$\%$ of total & 10.4 & 5.3 & 6.6 & 6.7 & 17.5 & 20.6 & 11.1 & 7.2 & 2 & 3.3 & 9.3 & 100 \\
\hline
\end{tabular}

\footnotetext{
7641979 Workforce Planning book, p. 248.

765 Indicates the percentage of the overall minority population in the region.

766 Indicates the percentage of overall population in the region. I have highlighted those regional percentages that are equal to or higher than the agency totals.
} 
Table C.12: Professionals on Board - from Civil Rights Update December 10, 1980

\begin{tabular}{|l|l|l|l|l|}
\hline Fiscal Year & \multicolumn{2}{|l|}{ Minorities } & \multicolumn{2}{l|}{ Women } \\
\hline & $\#$ & \% & $\#$ & \% \\
\hline $\mathbf{1 9 7 6}$ & 218 & 2.7 & 137 & 1.7 \\
\hline $\mathbf{1 9 7 7}$ & 321 & 3.6 & 282 & 3.1 \\
\hline $\mathbf{1 9 7 8}$ & 350 & 3.4 & 426 & 4.2 \\
\hline $\mathbf{1 9 7 9}$ & 395 & 3.7 & 562 & 5.2 \\
\hline $\mathbf{1 9 8 0}$ & 532 & 4.7 & 858 & 7.8 \\
\hline
\end{tabular}

Table C.13: Region 6 Employment (Permanent and Term) and Average grade by Sex and Race ${ }^{767}$

\begin{tabular}{|c|c|c|c|c|c|c|}
\hline & $\mathbf{1 9 8 7}$ & $\mathbf{1 9 9 0}$ & Avg. grade & $\mathbf{1 9 9 6}$ & $\begin{array}{c}\text { Avg. } \\
\text { grade }\end{array}$ & $\begin{array}{c}\text { CLF (1990 } \\
\text { census) }\end{array}$ \\
\hline Total & 6,586 & 7,983 & 7.9 & 5,679 & 8.8 & 54.3 \\
\hline Men & 4,396 & 4,919 & 9.0 & 3,437 & 9.3 & 45.7 \\
\hline Women & 2,190 & 3,064 & 6.9 & 2,242 & 8.0 & 77.9 \\
\hline Non-Minorities & 5,876 & 6,955 & 8.3 & 4,948 & 8.8 & 22.1 \\
\hline African Americans & 98 & 111 & 7.5 & 74 & 8.7 & 10.4 \\
\hline American Indian & 286 & 448 & 7.2 & 317 & 7.7 & 0.6 \\
\hline Asian & 107 & 138 & 8.0 & 104 & 8.8 & 2.8 \\
\hline Hispanic & 219 & 331 & 7.6 & 236 & 8.4 & 8.1 \\
\hline $\begin{array}{c}\text { People w/Targ. } \\
\text { Disabilities }\end{array}$ & $\begin{array}{c}\text { Not } \\
\text { available }\end{array}$ & 63 & $\begin{array}{c}\text { Not } \\
\text { available }\end{array}$ & 76 & 6.6 & $6.0^{768}$ \\
\hline
\end{tabular}

767 Data compiled from Region 6 Civil Rights Office (unnamed authors), "Pacific Northwest Civil Rights Assessment” (February 14, 1997): 24-25, Region 6 Civil Rights Collection.

$768 \quad$ EEOC figure, not CLF. 
Table C.14: Society of American Foresters Accredited Programs in Professional Forestry and Urban Forestry as of August 1, 2013 ${ }^{769}$

\begin{tabular}{|c|c|c|c|c|}
\hline Date & $\begin{array}{l}\text { West - degrees in } 11 \\
\text { states }\end{array}$ & Midwest - 11 states & North/East -8 states & $\begin{array}{l}\text { South }-15 \\
\text { states }\end{array}$ \\
\hline $\begin{array}{l}\text { Before } \\
1960\end{array}$ & $\begin{array}{l}\text { Forestry degrees in } 7 \\
\text { states }\end{array}$ & $\begin{array}{l}\text { Forestry degrees in } 5 \\
\text { states }\end{array}$ & $\begin{array}{l}\text { Forestry degrees in } 6 \\
\text { states }\end{array}$ & $\begin{array}{l}\text { Forestry } \\
\text { degrees in } 5 \\
\text { states }\end{array}$ \\
\hline 1935 & $\begin{array}{l}\text { University of California- } \\
\text { Berkeley; University of } \\
\text { Idaho; University of } \\
\text { Montana; Oregon State } \\
\text { University; University of } \\
\text { Washington }\end{array}$ & $\begin{array}{l}\text { Iowa State } \\
\text { University; ichigan } \\
\text { State University; } \\
\text { University of } \\
\text { Minnesota }\end{array}$ & $\begin{array}{l}\text { Yale University, } \\
\text { Connecticut; State } \\
\text { College of New York } \\
\text { College of } \\
\text { Environmental } \\
\text { Science and Forestry; } \\
\text { Pennsylvania State } \\
\text { University }\end{array}$ & \\
\hline 1937 & Utah State University & & University of Maine & $\begin{array}{l}\text { Louisiana } \\
\text { State } \\
\text { University; } \\
\text { North } \\
\text { Carolina State } \\
\text { University }\end{array}$ \\
\hline 1939 & $\begin{array}{l}\text { Colorado State } \\
\text { University }\end{array}$ & & & $\begin{array}{l}\text { Duke } \\
\text { University, } \\
\text { North } \\
\text { Carolina }\end{array}$ \\
\hline 1942 & & $\begin{array}{l}\text { Purdue University, } \\
\text { Indiana }\end{array}$ & & $\begin{array}{l}\text { University of } \\
\text { Florida }\end{array}$ \\
\hline 1947 & & & & $\begin{array}{l}\text { West Virginia } \\
\text { University }\end{array}$ \\
\hline 1950 & & $\begin{array}{l}\text { University of } \\
\text { Missouri }\end{array}$ & $\begin{array}{l}\text { University of } \\
\text { Massachusetts }\end{array}$ & $\begin{array}{l}\text { Auburn } \\
\text { University, } \\
\text { Alabama }\end{array}$ \\
\hline 1959 & & & $\begin{array}{l}\text { University of New } \\
\text { Hampshire }\end{array}$ & \\
\hline $\begin{array}{l}1960- \\
1980\end{array}$ & Added 2 states & Added 5 states & Added 0 states & Added 7 states \\
\hline 1962 & & & & $\begin{array}{l}\text { Clemson } \\
\text { University, } \\
\text { South } \\
\text { Carolina } \\
\end{array}$ \\
\hline 1963 & & University of Illinois & & \\
\hline 1965 & & & & $\begin{array}{l}\text { Stephen F. } \\
\text { Austin State } \\
\text { University, } \\
\text { Texas; }\end{array}$ \\
\hline
\end{tabular}

769 "Guide to Forestry and Natural Resource Programs," Society of American Foresters, 2013.

Available at http://www.nxtbook.com/nxtbooks/saf/2013collegeguide/\#/0n [Accessed May 19, 2014]. 


\begin{tabular}{|c|c|c|c|c|}
\hline & & & & $\begin{array}{l}\text { Virginia } \\
\text { Polytechnic } \\
\text { Institute and } \\
\text { State } \\
\text { University }\end{array}$ \\
\hline 1966 & & & & $\begin{array}{l}\text { Mississippi } \\
\text { State } \\
\text { University }\end{array}$ \\
\hline 1968 & $\begin{array}{l}\text { Northern Arizona } \\
\text { University }\end{array}$ & $\begin{array}{l}\text { Michigan } \\
\text { Technological } \\
\text { University }\end{array}$ & & \\
\hline 1969 & & & & $\begin{array}{l}\text { University of } \\
\text { Tennessee }\end{array}$ \\
\hline 1971 & & $\begin{array}{l}\text { University of } \\
\text { Wisconsin-Madison }\end{array}$ & & $\begin{array}{l}\text { Oklahoma } \\
\text { State } \\
\text { University }\end{array}$ \\
\hline 1974 & & & & $\begin{array}{l}\text { University of } \\
\text { Kentucky }\end{array}$ \\
\hline 1975 & & $\begin{array}{l}\text { Southern Illinois } \\
\text { University }\end{array}$ & & Texas A\&M \\
\hline 1976 & & $\begin{array}{l}\text { University of } \\
\text { Wisconsin-Stevens } \\
\text { Point }\end{array}$ & & \\
\hline 1979 & $\begin{array}{l}\text { Humboldt State } \\
\text { University, California }\end{array}$ & & & \\
\hline $\begin{array}{l}\text { After } \\
1980\end{array}$ & Added 3 states & Added 1 state & Added 2 states & Added 3 states \\
\hline 1984 & & & & $\begin{array}{l}\text { University of } \\
\text { Arkansas; } \\
\text { Louisiana } \\
\text { Tech } \\
\text { University }\end{array}$ \\
\hline 1993 & & $\begin{array}{l}\text { Ohio State } \\
\text { University }\end{array}$ & & \\
\hline 1994 & $\begin{array}{l}\text { California Polytechnic } \\
\text { State University }\end{array}$ & & & \\
\hline 1996 & $\begin{array}{l}\text { University of Alaska } \\
\text { Fairbanks }\end{array}$ & & & \\
\hline 2005 & & & $\begin{array}{l}\text { Paul Smith's College } \\
\text { of Arts and Sciences, } \\
\text { New York }\end{array}$ & \\
\hline 2008 & $\begin{array}{l}\text { New Mexico Highlands } \\
\text { University }\end{array}$ & & & $\begin{array}{l}\text { Alabama } \\
\text { A\&M }\end{array}$ \\
\hline \multirow[t]{2}{*}{2012} & & & $\begin{array}{l}\text { University of } \\
\text { Maryland }\end{array}$ & \\
\hline & $\begin{array}{l}\text { Only Nevada and } \\
\text { Wyoming do not have } \\
\text { forestry or natural } \\
\text { resources schools }\end{array}$ & & & \\
\hline
\end{tabular}




\section{Appendix D: TMO Goals and Strategies}

\section{Broad and Specific Goals Guiding the TMO National Diversity Task Force ${ }^{770}$}

\begin{tabular}{|l|l|}
\hline $\begin{array}{l}\text { Broad Goals - to consider all matters } \\
\text { pertaining to work force diversity, including } \\
\text { but not limited to: }\end{array}$ & \multicolumn{1}{c|}{ Specific Goals } \\
\hline Employment regulations and procedures. & To define work force diversity in operational terms. \\
\hline Administrative organization and staffing. & $\begin{array}{l}\text { To establish specific objectives for work force diversity } \\
\text { containing meaningful employment targets. }\end{array}$ \\
\hline Exemplary plans and programs. & $\begin{array}{l}\text { To prepare functional descriptions of work force } \\
\text { diversity which enhance and reinforce its definition. }\end{array}$ \\
\hline Utilization of non-Forest Service resources. & $\begin{array}{l}\text { To establish criteria of adequacy for all plans } \\
\text { formulated to achieve work force diversity. }\end{array}$ \\
\hline Appropriate recognition and encouragement. & $\begin{array}{l}\text { To recommend strategies to support the promotion and } \\
\text { achievement of work force diversity as outlined in } \\
\text { "Workforce 1995." }\end{array}$ \\
\hline $\begin{array}{l}\text { Suggestions and recommendations by } \\
\text { employees at all levels. }\end{array}$ & $\begin{array}{l}\text { To recommend activities that positively promote USFS } \\
\text { efforts to achieve work force diversity with the public. }\end{array}$ \\
\hline Recruitment. & $\begin{array}{l}\text { To establish appropriate recognition and } \\
\text { encouragement for all Forest Service units that achieve } \\
\text { diversity as defined and described. }\end{array}$ \\
\hline
\end{tabular}

770 U.S.D.A. Forest Service, Toward a Multicultural Organization: Report of the USDA Forest Service Task Force on Work Force Diversity (March 1991), v. 
Recommended Goals and Strategies in TMO Report ${ }^{711}$

\begin{tabular}{|c|c|c|}
\hline $\begin{array}{c}\text { Goals } \\
\end{array}$ & Situation & Strategies \\
\hline $\begin{array}{l}\text { Leadership: To elevate } \\
\text { the stature of leadership } \\
\text { devoted to human } \\
\text { resources and the } \\
\text { establishment of a } \\
\text { multicultural organization. }\end{array}$ & $\begin{array}{l}\text { Many agency leaders and } \\
\text { managers lack the } \\
\text { knowledge, skills, } \\
\text { commitment, and behavior to } \\
\text { effect multicultural change. }\end{array}$ & $\begin{array}{l}\text { The chief reaffirms his commitment to } \\
\text { diversity by changing the status of human } \\
\text { resources and incorporating diversity into } \\
\text { decision-making and staff appointments. }\end{array}$ \\
\hline $\begin{array}{l}\text { Outreach and } \\
\text { Recruitment: To } \\
\text { effectively recruit and } \\
\text { retain a multicultural work } \\
\text { force. }\end{array}$ & $\begin{array}{l}\text { Poorly coordinated and } \\
\text { inefficient outreach and } \\
\text { recruitment. Focused on } \\
\text { needs of individual units. } \\
\text { Potential of temps untapped. }\end{array}$ & $\begin{array}{l}\text { Chief commissions national strategic plan } \\
\text { for outreach and recruitment. Identify } \\
\text { diverse candidates for GS- } 13 \text { and higher } \\
\text { positions. Partner with other agencies and } \\
\text { organizations. }\end{array}$ \\
\hline $\begin{array}{l}\text { Work Environment: To } \\
\text { have an innovative, } \\
\text { creative, people-oriented } \\
\text { work environment for } \\
\text { Forest Service employees. }\end{array}$ & $\begin{array}{l}\text { Social and occupational } \\
\text { homogeneity shape } \\
\text { standardized values, } \\
\text { attitudes, skills, and } \\
\text { interpretations, i.e., } \\
\text { conformity. Most ( } 90 \% \text { ) of } \\
\text { professionals classified as } \\
\text { foresters. Non-forestry } \\
\text { professionals, administrative, } \\
\text { and clerical employees feel } \\
\text { like second-class citizens } \\
\text { because they do not fit the } \\
\text { "traditional mold." Increasing } \\
\text { numbers of employees do not } \\
\text { conform, i.e., FSEEE } \\
\text { example. }\end{array}$ & $\begin{array}{l}\text { Take immediate steps to create a } \\
\text { desirable work environment, which } \\
\text { includes a number of elements in relation } \\
\text { to creating and valuing an organization } \\
\text { that is "truly multicultural and not just } \\
\text { sensitive to cultural differences." } \\
\text { Set and enforce performance and } \\
\text { accountability standards for supervisors. } \\
\text { Track progress. }\end{array}$ \\
\hline $\begin{array}{l}\text { Community Acceptance: } \\
\text { To achieve community } \\
\text { acceptance of our } \\
\text { multicultural work force. }\end{array}$ & $\begin{array}{l}\text { Hostile attitudes in mono- } \\
\text { cultural communities toward } \\
\text { difference, i.e., beliefs, } \\
\text { lifestyle, race, sex, religion, } \\
\text { marital status, can affect } \\
\text { workplace productivity and } \\
\text { daily life through restrictions } \\
\text { on housing, loans, etc. }\end{array}$ & $\begin{array}{l}\text { Require agency officers to work with } \\
\text { community leaders to create a welcoming } \\
\text { environment; develop sponsorship } \\
\text { programs for new employees; encourage } \\
\text { support groups and seek outside } \\
\text { assistance when needed; seek regular } \\
\text { input from employees about community } \\
\text { situation. }\end{array}$ \\
\hline $\begin{array}{l}\text { Valuing Diversity: To } \\
\text { highly value, understand, } \\
\text { and effectively manage } \\
\text { diversity in the Forest } \\
\text { Service. }\end{array}$ & $\begin{array}{l}\text { Many employees do not } \\
\text { understand the difference } \\
\text { between workforce diversity } \\
\text { and affirmative action, nor do } \\
\text { most know how to move } \\
\text { from an organization that } \\
\text { accommodates cultural } \\
\text { differences to one that is } \\
\text { multicultural. }\end{array}$ & $\begin{array}{l}\text { Top management must send the message } \\
\text { that diversity is a high priority. Should } \\
\text { revise the agency vision statement to } \\
\text { incorporate valuing a multicultural } \\
\text { organization. Develop framework for } \\
\text { diversity training at the national level to } \\
\text { be attended by high level leaders, staff, } \\
\text { and line, who will develop } \\
\text { implementation processes. }\end{array}$ \\
\hline
\end{tabular}

$771 \quad$ TMO Report, 4.

772 Forest Service Employees for Environmental Ethics. 


\begin{tabular}{|c|c|c|}
\hline $\begin{array}{l}\text { Management and } \\
\text { Supervision: To provide } \\
\text { outstanding support and } \\
\text { first-line supervision to a } \\
\text { multicultural work force. }\end{array}$ & $\begin{array}{l}\text { Hudson Institute "Workforce } \\
2000 " \text { report indicates the } \\
\text { need for changing leadership } \\
\text { style to shared authority. } \\
\text { Supervisors are key to } \\
\text { employee retention. Exit } \\
\text { interviews indicate that } \\
\text { employees often leave due to } \\
\text { lack of appreciation, being } \\
\text { undervalued, plateauing in } \\
\text { one's career, supervisory } \\
\text { conflict, lack of meaningful } \\
\text { work or career development } \\
\text { plans. }\end{array}$ & $\begin{array}{l}\text { Develop national policy that places a } \\
\text { higher priority on first-line supervision } \\
\text { than nonsupervisory responsibilities. } \\
\text { Provide supervisory personnel with } \\
\text { human relations training in motivation, } \\
\text { cross-cultural communications, and } \\
\text { employee development techniques. Set } \\
\text { national standards for skill and } \\
\text { competencies to develop multicultural } \\
\text { leadership. Select leaders committed to } \\
\text { diversity and multicultural problem } \\
\text { solving processes. }\end{array}$ \\
\hline $\begin{array}{l}\text { Work and Family: To } \\
\text { establish a national Forest } \\
\text { Service policy that helps } \\
\text { employees balance career } \\
\text { and personal needs in an } \\
\text { increasingly complex } \\
\text { society. }\end{array}$ & $\begin{array}{l}\text { The typical American family } \\
\text { no longer consists of an } \\
\text { employee with a nonworking } \\
\text { spouse and children. The } \\
\text { agency has an array of } \\
\text { policies on dual careers, } \\
\text { family and parental leave, } \\
\text { flexible work schedules, and } \\
\text { a new policy on child care, } \\
\text { but has no coherent policy by } \\
\text { unit. Child care availability } \\
\text { varies by location, with } \\
\text { issues like elder care, job } \\
\text { sharing, family leave, and } \\
\text { flexible schedules also } \\
\text { increasingly important. }\end{array}$ & $\begin{array}{l}\text { Establish national family policy that } \\
\text { recognizes families as fundamental to the } \\
\text { health and strength of society and to } \\
\text { maintaining a productive workforce. } \\
\text { Require each region, station, and area to } \\
\text { outline clear, unambiguous policies } \\
\text { related to flexible schedules, permanent } \\
\text { and part-time employment, family leave, } \\
\text { dual career employment, elder care, care } \\
\text { for the severely disabled, child care, work } \\
\text { at home, children in the workplace, job } \\
\text { sharing, and wellness. Require } \\
\text { subordinate units to articulate policies. }\end{array}$ \\
\hline $\begin{array}{l}\text { Training and } \\
\text { Development: To achieve } \\
\text { a national vision and } \\
\text { focus for training and } \\
\text { development of the work } \\
\text { force. }\end{array}$ & $\begin{array}{l}\text { Decentralization of the } \\
\text { agency creates problems for } \\
\text { creating workforce diversity } \\
\text { due to regional variation in } \\
\text { training and leadership styles. } \\
\text { It is possible to create } \\
\text { consensus on agency-wide } \\
\text { initiatives without destroying } \\
\text { local autonomy. }\end{array}$ & $\begin{array}{l}\text { P\&CR works with Chief and Staff to } \\
\text { develop a national focus, vision, and } \\
\text { philosophy for training and development. } \\
\text { Reinforce management accountability to } \\
\text { provide training, career counseling, and } \\
\text { development opportunities to all } \\
\text { employees. P\&CR works with WO staff, } \\
\text { etc. to identify supervisory and } \\
\text { management competencies for a } \\
\text { multicultural environment, and to identify } \\
\text { and define core competencies for each } \\
\text { technical specialty. Make mentoring and } \\
\text { support groups available to all employees } \\
\text { who want them. }\end{array}$ \\
\hline $\begin{array}{l}\text { Accountability: To have } \\
\text { effective accountability } \\
\text { for managing a } \\
\text { multicultural organization } \\
\text { and for diversifying the } \\
\text { work force. }\end{array}$ & $\begin{array}{l}\text { Accountability for EEO and } \\
\text { civil rights activity comes } \\
\text { from the performance } \\
\text { appraisal system where it } \\
\text { should remain; however, } \\
\text { rarely do supervisors receive }\end{array}$ & $\begin{array}{l}\text { USFS is implementing USDA policy of } \\
\text { critical EEO/CR element for all } \\
\text { employees. Expand the element from } \\
\text { EEO/CR to include support for workforce } \\
\text { diversity and a multicultural organization } \\
\text { and fully implement policy change in FY }\end{array}$ \\
\hline
\end{tabular}




\begin{tabular}{|c|c|c|}
\hline & $\begin{array}{l}\text { less than satisfactory on this } \\
\text { performance element. The } \\
\text { USDA document, } \\
\text { "Framework for Change" } \\
\text { calls for consequences for } \\
\text { less than satisfactory marks, } \\
\text { i.e. to rank, bonuses, and cash } \\
\text { awards. Raters either lack } \\
\text { understanding or are } \\
\text { unwilling to mark down in } \\
\text { relation to EEO/CR. }\end{array}$ & $\begin{array}{l}\text { 1991. Line officers should know what } \\
\text { their goals are, how to achieve them, and } \\
\text { how their unit compares with their } \\
\text { Affirmative Employment Program Plan. } \\
\text { Develop user-friendly employee sensing } \\
\text { package to measure changes in } \\
\text { organizational climate, culture, and } \\
\text { individual performance. }\end{array}$ \\
\hline $\begin{array}{l}\text { Numerical Goals: To } \\
\text { clearly define Forest } \\
\text { Service numerical targets } \\
\text { for work force diversity in } \\
1995 \text { and to provide } \\
\text { overall direction for the } \\
\text { year } 2000 \text { and beyond. }\end{array}$ & $\begin{array}{l}\text { Agency workforce diversity } \\
\text { goals are poorly defined. The } \\
\text { task force does not } \\
\text { recommend heavy emphasis } \\
\text { on numerical goals, but does } \\
\text { recognize the need for such } \\
\text { goals to be fully defined and } \\
\text { universally understood. Legal } \\
\text { minimums must be } \\
\text { understood because certain } \\
\text { affirmative actions may be } \\
\text { taken only when legally } \\
\text { recognized deficiencies can } \\
\text { be demonstrated. }\end{array}$ & $\begin{array}{l}\text { Legal minimums to be identified in } \\
\text { relation to USDA statistics, National } \\
\text { Finance Center data by occupation, and } \\
\text { national CLF statistics. Create separate } \\
\text { plans for work force stratification in the } \\
\text { WO, regions, and at research stations. } \\
\text { Divide job categories into professional, } \\
\text { administrative, technical, clerical, and } \\
\text { blue collar (PATCOB) groups, with the } \\
20 \text { job series that comprise } 73 \% \text { of } \\
\text { employment analyzed in relation to } \\
\text { women, minorities, and people with } \\
\text { disabilities, i.e., identify representation by } \\
\text { occupation. Set a goal to attain } \\
\text { representation by the year } 2000 \text { and set an } \\
\text { example for the agency through high } \\
\text { level staffing. }\end{array}$ \\
\hline $\begin{array}{l}\text { Recognition: To fully and } \\
\text { appropriately recognize } \\
\text { individuals and } \\
\text { organizational units for } \\
\text { the full range of } \\
\text { multicultural } \\
\text { accomplishments. }\end{array}$ & $\begin{array}{l}\text { Workforce diversity } \\
\text { recognition awards presented } \\
\text { for the wrong reasons (flash } \\
\text { in the pan numbers), } \\
\text { minimally, and only to those } \\
\text { recognized in P\&CR without } \\
\text { recognition for employee } \\
\text { development. Many believe } \\
\text { that only those who make } \\
\text { hiring and promotion } \\
\text { decisions can help achieve } \\
\text { WFD. A broader concept of } \\
\text { WFD and greater recognition } \\
\text { by unit are needed. }\end{array}$ & $\begin{array}{l}\text { Enhance formal recognition for } \\
\text { multicultural accomplishments at all } \\
\text { levels and require special recognition for } \\
\text { multicultural accomplishments at the } \\
\text { local level for "exceeds fully successful" } \\
\text { ratings. Enhance recognition through } \\
\text { Chief's Special Awards by establishing } \\
\text { clear and uniform guidelines, creating a } \\
\text { nomination process, funding cash awards } \\
\text { through the chief's office, and } \\
\text { commemorating awards with plaques. }\end{array}$ \\
\hline
\end{tabular}

